\title{
PICTURES OF
}
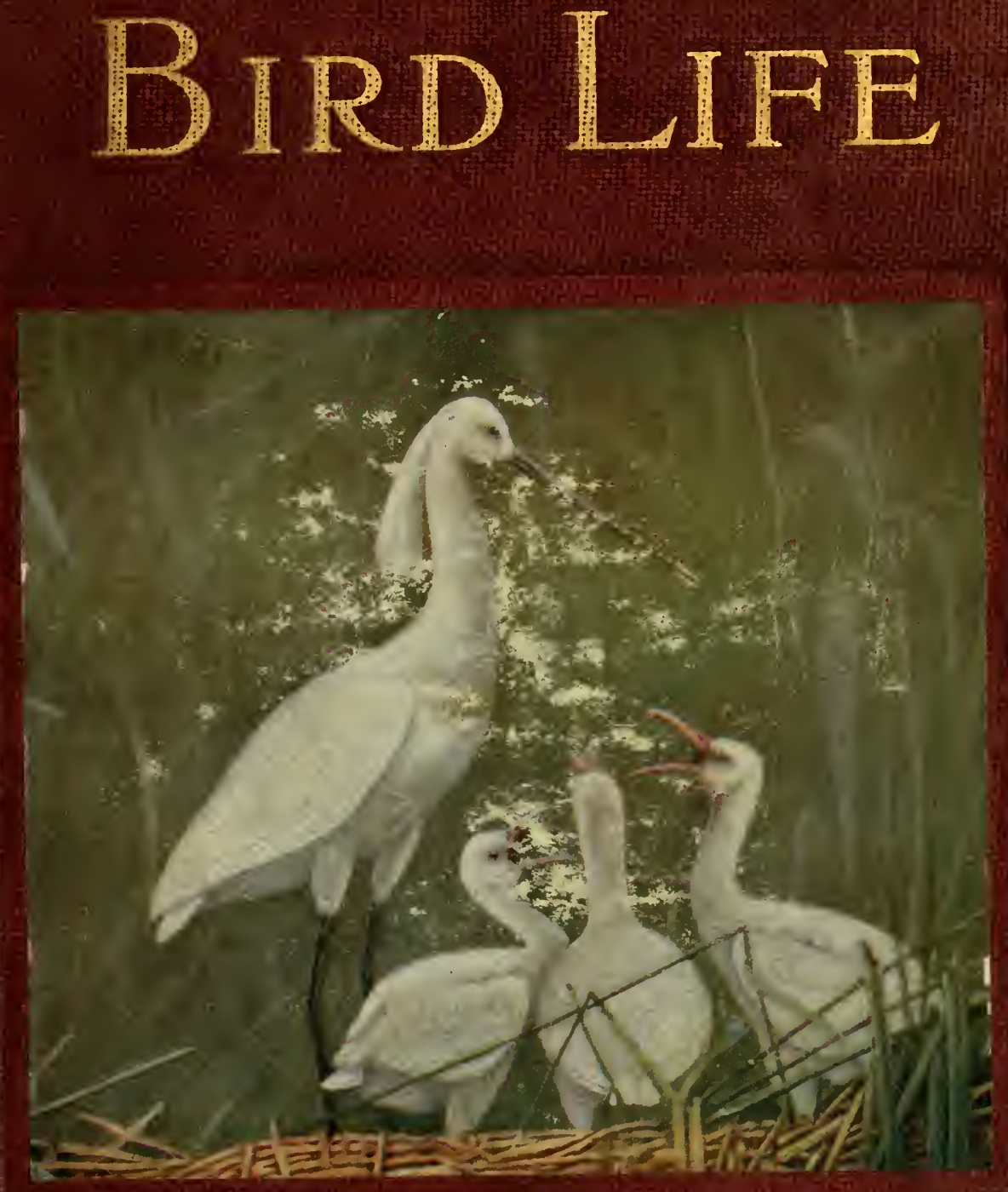

R. B. LODGE 


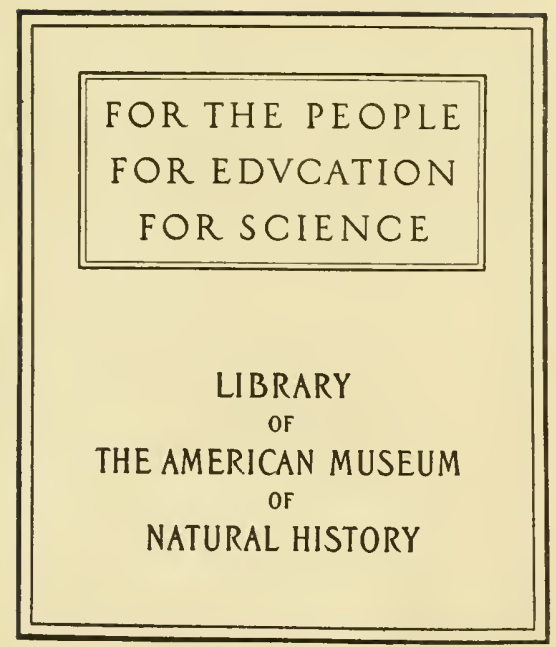




PICTURES OF BIRD LIFE 


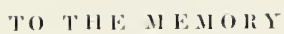

$\mathrm{OF}$

'I'H E I. I'T' F.

\section{THOMAS.J.M MN}

H Y DE: H I I I .

SAWBRITGEWOR'TH

WITHOTT WHOSE

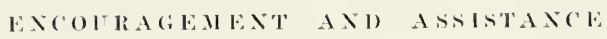

THIS WORK

WULLD XEVER HAVE BER BE(EX. 



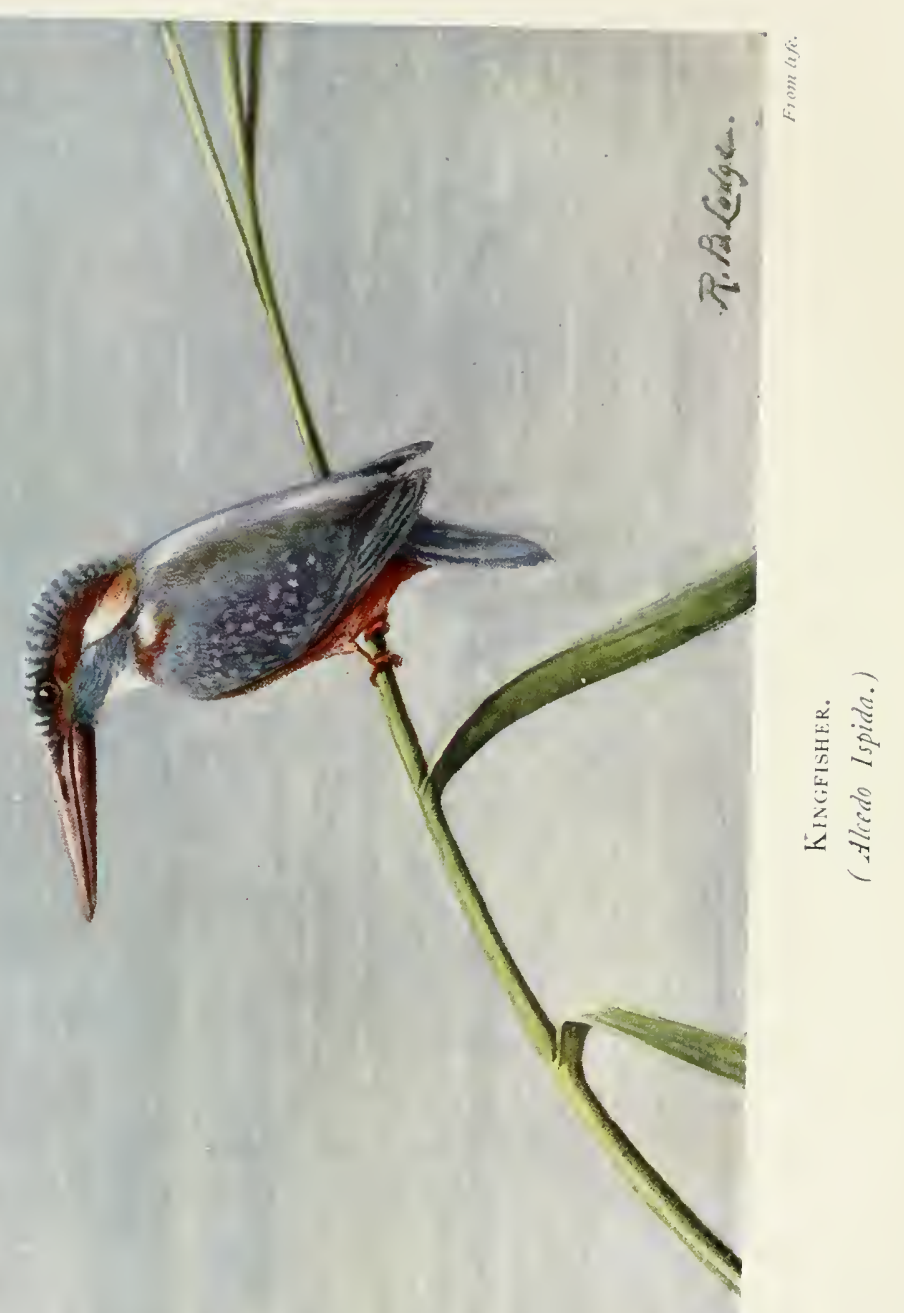




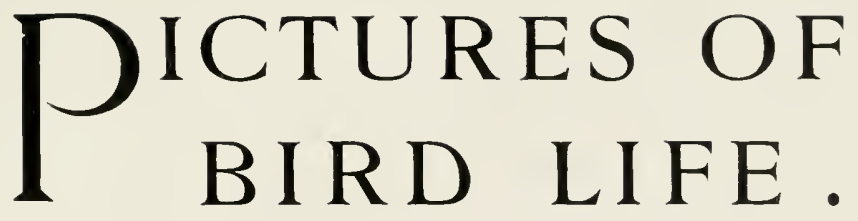

ON

\title{
WOODLAND, MEADOW, MOUNTAIN AND MARSH
}

\author{
$\mathrm{BY}$ \\ R. B. LODGE
}

MEDALLIST ROYAL PHOTOGRAPHIC SOCIETY

WITH

NUMEROUS COLOUR AND HALF-TONE ILLUSTRATIONS FROM PHOTOGRAPIS FROM LIFE BY THE AUTHOR

S. H. BOUSFIELD \& CO., LTD.

NORFOLK STREET

W.C. 


\section{$59.82: 08$ \\ C O N TE N T S \\ $45-158833-32 \ldots 11$}

CHAFTER PAl:E

I. PHOTOGRAPHY FOR NATLRALATS . . . . . . 9

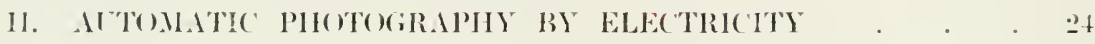

II. PHOTOGRAPHIC OLTFIT . . . . . . . . . 36

IV. BIRI) LHEE IN A STBRRAN PARISH . . . . . . 4:

V. I LINCOLASHHE ML1)-FLAT. . . . . . . . 174

V1. THE SEA-BIRIST OF THE FARNE ISLANISS . . . . I8G;

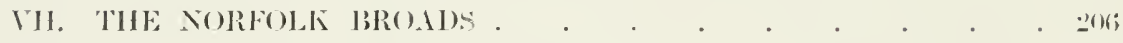

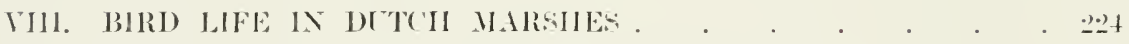

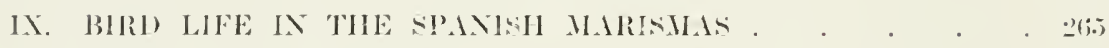

X. BIRI) LIFE IN DENMARK-ON THE FIORD . . . . :3:31

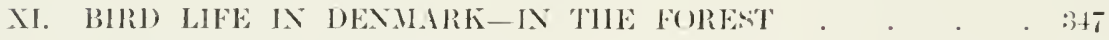

XI. A WEEL IN IERBYSIIRE . . . . . . . . . . . . . 


\section{IILUSTRATIONS IN COLOLR}

KINGFISHER . . . . . . . . . . . Frmutisprees WHINCHAT . . . . . . . . . . Fincing puge rit SPARROII-HAWK . . . . . . . . . . . . . . . . . . . . 144

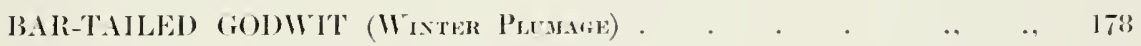

A PAIR OF KITPITAKE . . . . . . . . . . . . . . . I!4 SIPONBILL ANI) YOIXF . . . . . . . . . . . . . . . . A PAIR OF LITTLE EARETS NENTIN . . . . . . . . 310

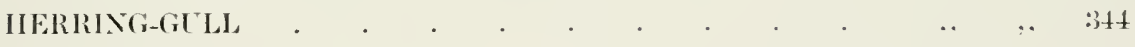




\section{ILIUSTRATIONS IN HALF-TONE}

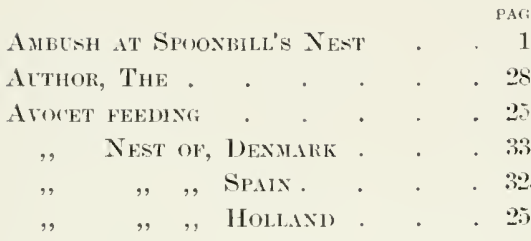

13EE-EATER, ENil of Nestivg Burrow . 208 " ox Topmost Twi _ 30 Blackbiri, Nkit of . . . . 4ti BLACKCAP, HEN, ON NEST . . 61

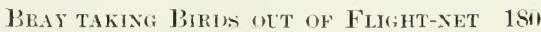
Buxtixg, Commos . • . • . 333 $"$ ReE1-, ANI Nest . . 105 $, \quad, \quad \operatorname{Cor} \mathrm{K} . \quad ., 2 ., 2$ ,, HEN . . . 10. BLzzard, NEST OH . . . . . $35 \%$

CAMERA HIDTEN IN HEDGEROW • . 27 CHAFFiNCh, COCK . . . . . , Hex, axh Nest . . Chiff-chlfF, Nest of • . . . $317 \%$ Climbing to Rook's Nest . . . 41 CoOt, Nest of . . . . . . 358 Совиовакт . . . . . . 2112 ConMoriNts sitTINA . . . 201, 2103 Crow, Carriox-, Nest of . . . 113 Crekoo, Yocxg, HEI BY HeIMiESPARROW - 13t, 135 IN HEDGE-KPARROW'S NEST \& 133

Cerlew . . . . . 18.

Diagram of Electric Trap Consectiose 28 DIPTER, NEsT OF . * . . 364, 36ij DLK, TLFTeN . . . . . . 360 $, \quad, \quad$ NEST OF . . . . 361 , WILD, NEST OF. . . 147 DiNuixs FEentNG . . . . 266

E.mily Morisg at the Nets . . 17t Egi-shello AS B.ATT . . . . 27 Egrets, Little, .NII Nest . . . .

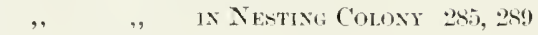
Ehier atTTiNG . . . . . . 199

Flamingoes, Dimtaxt View of . . 330 Feychtcher, Spottein, axi Nest . Si , NITTIN . . 84

GININ: \& B.YK UP A TREE . . . 351

Gomwt, Bar-talem, Wixter Plumate 175 ,, Blark-thlem, AxH Nest . 341 Golnfinch AND Nest . . . 101 GOSIIIWK, NEST OF. . . . . 3.5 Grebe, Great Ciested, Nest of. . 24! , LitTle. . . . 17:2 , ", FEDING Yocig . . 173 , ",$\quad$ ON Flodting Nest . 169 Greenftareh, Nest of . . . . 94

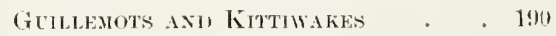
, ON THE PIXXAcles . . 191 GLle, Black-hehHeI, AND Nest . . 247 , Conmon, Nest of •. . . 345 Lesser Bugk-Bucket). 


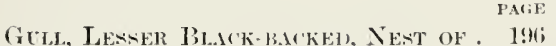
, , , , Vocxi, Cavillt 1. NET . $18: 3$

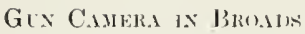

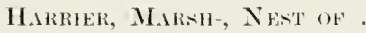
239

MONTsite's, Nest OF. 211 HAWFICH, NEST ()

HeRos, BLF-BA(KE)

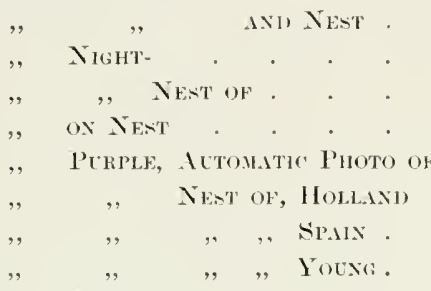

, Richoxil P'ikк.

His, Glossy, ANI NesT

$2 ! 31$

JACKIAW, NEST OF . 110

Kestrel ANI NEST. 143

Kixgrisher o. W.ITER-11Ex"' Nest . 130 Kite, Nest AN1 Voevi. . . . 271

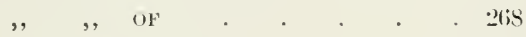
, BLACK, Xest OF. . . 273 KITTIWAKE OX NEST . . . . 193

LAPWING . . . . . . . 160 , Aetonatic Photo of . . 25 , NEST OF . . . . . 161

, Sitrixg . . . . 16:

, YotNG, CrocthING . . . 16;

M.RTIx, Hocsk-, AND NEst . . . 9'

Nightivgale axi Nest . AITTING

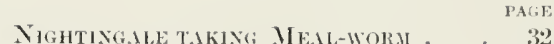

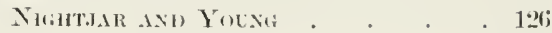
, Nestor of . . 125 , ON IPPER PBRANCH . . 123

Nightiars, Yotic: . . . . 129

OWL, B.11K- . . . . . . 138

,, , BoNes from CAstrixgs . 141

, " Cistexis . . . 14h

, , YolNi, 1X Dowx . . 137

., LiTTLE . . . . . .

, LON(i-EIREN . . . . . 21!

, SHORT-E.tREA . . . . . 213

, , HAR OF . . . 217

,. . NEST OF . . 215

, TAWXY . . . . . 142

OYSTER-ATTIIER . . . . . 293

NEST OH . . . 2910

Partriluge, Nest of . . . . 1.2

PHEANANT, 11EN, SITTINA • . . 153

154

Photographise: Nest UP Tree • . 10

Pixxirles, THE . . . . . 159

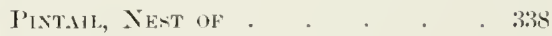

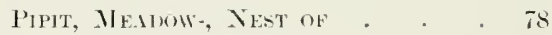

, TREe-, Nent of . . . . T9

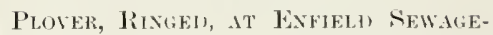

FARM. . . . 16.)

Plovers, GRFY . . . . . 275

P'RATIN(O), . . . . . . 30!9

Peffix, Nextlixi . . . . . 188

P’efrix's Burrow . . . . . 195

Pefrisis . . . . . 194

R.IVEX, NesT OF . . . . 304

ReDBREAST, ROBIN . . . . . $4 !$

, , NEST OF . . . 50

ReIntart aNo Nest . . . 45

ROOK AN1 NEST . . . . 117

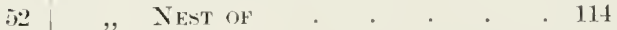

RufF . . . . . . 343 


\section{lllustrations in Half-tone}

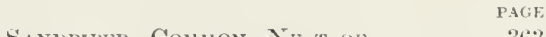

S.MTHPIPER, COMMON, NeAT (IF

SETTING PHOTO-TR.iP

Shrike, Grey

, Red-R.ACKED, Cock

, , HEX

, $\quad . . \quad$ NEST OH

Wоолснат-

SKYLARK, NEST OF .

Youx

Sparhow, Hedge-, Nest of .

SPOONBILL.

$$
\begin{aligned}
& , . \quad \text { Nrst of } \\
& , " \text { Nests. } \\
& ., \quad \text { YolNg. }
\end{aligned}
$$

SPOONBLLs, Yotyif.

ŚtARLiNg (2 Positios:s) .

.. NEST OF

STILT .

,$\quad$ (3 FEEDING)

, Nest is Water

$, \quad, \quad$ oN MLD

STORK, Black, Nest of .

, White, axu Yousi.

.. , GREeTINis

, "

,$\quad$,

, , ,

IN SETILLE

KL.IPPERING

ox Grocine

., ON NEST

STOWING Cayeras IN BOAT

SWALLOW .

, NEST of .

Ters, Black, Nest of, Hollasp

\section{SPIIN}

( Positiona) .

Coman, ANI Nest
363

34

326

80

80

83

265

118

$1: 1$

(i)

$\because 4$

233

2 ist

2:311

2.25

$101 \%$

119

27

312

315

318

34 ?. 350

- 25

ㅁ.51

331

$2 \pi$

251

332

2.).5

33.5

88

!1

214

323

243

- 245
Terx, Lerser, Nest of . . . . 2661

, SiNowich, Nests or . . . 337

,, Whiskereit. . . . . 321

Thrtsh, Missel-, Nest of . . . 13

, Sosi-, Nest of . . . 4

,. .. Yotra . . . . 4.

Tit, Besrdell, .Nil Nest . . . 209

, Blek, axe Stche With Nest - 69

„, LONG-TALED, NEST OF . . . 72

$\begin{array}{lllll}. . & . . & \text { HALF-M.ADE } & 73\end{array}$

, Mlarsh-, Nest of . . . . 70

TuRTLE-dOVF ANI NE:T . . . 151

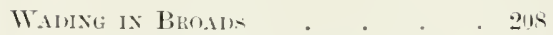

, IN SPATSH LAgion. . . 39

Whithl, Pieil . . . . . Tt

.. $\quad . \quad$ NEST AND Yotxi

"Yellow . . . . 76

, , ANI NEST . . . TI

Warblek, Giriex-, Nest of . . . 59

., .

., Greit Rikeil, ANI Nest . 202

, $\quad, \quad$ Yocxi . . 2031

., REED-, NEsT OF . . 2.21

..

, SEING-, AND NEST

" SEIRE-, AND NEST

WATER-HEX AXI NET . . . . 15 T̃

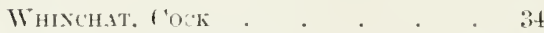

NEST OF . . 47

Whitethrolt, Gireater. . . . jh

., (3 Positiosis) . 56

,. NEST of . . .j.

LESSER, Yousg . . 57

Willow-Wrex AND Nest . . . 63

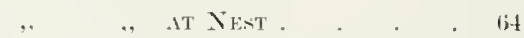

WOOD-P1GEON, NEST OF . . . 145 


\section{PICTURES OF BIRD LIFE}

\section{C'HAP'TER I}

\section{Photography for Naturalists}

There are -1 many gentlement who have leisure and means. that we beg to snggest that those who have the opportunity should make it their pleasure and

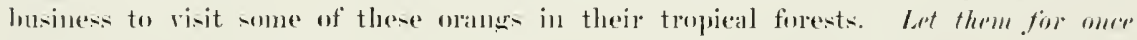

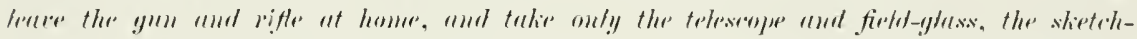
lumb and provit. Naturalists and anatomists know quite anough of the structure.

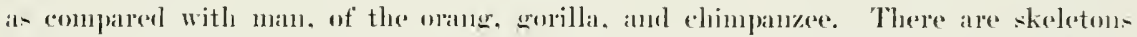
and skins in abmolanee of all these in Englant, but nobuly, nent even l'rofexor Owen

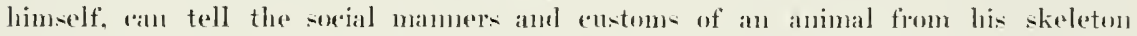
and the structure of his museles. What is wanted now to fill up this valuat salp

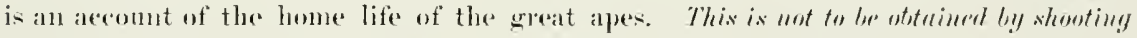

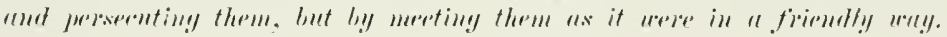

'TH's wrote Frank Buckland. now many years ago. respecting some specimen of orang-otang which had just reached England. If he had lived in these days of photography. I feel positive he would have inchuded the amera and tele-photographic lens in his suggesested outfit.

At any rate. his condemnation of mere killing is worthy of consideration. 'There is so much slaughter of wild animal life going on ail orer the world. that at the present rate of destruction there will seom be nothing left to kill.

But before the coning extermination the substitution 
of the camera for more deadly weapons opens up a novel form of sport to erery lorer of wild life, one no less fascinating and infinitely more difficult than that followed

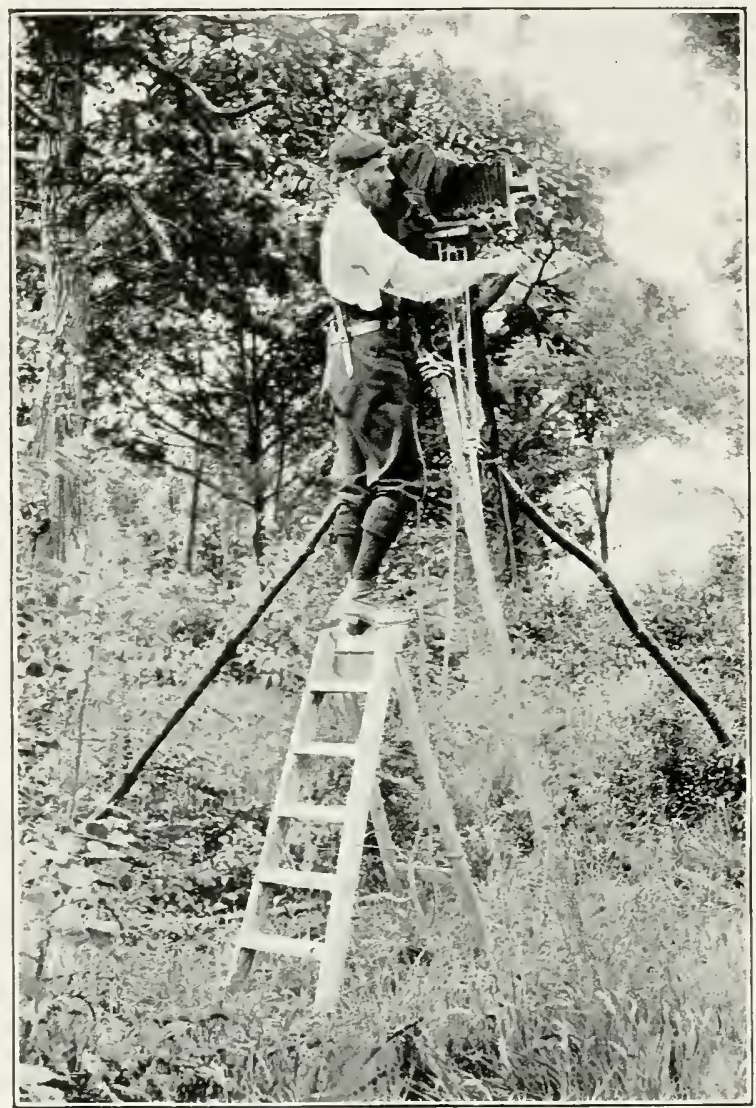

Photographixg Nest up a TREe with ax IMProvisel Tripod Made of loung Trees.

by the wielder of gom and rifle: a sport. too. which has the immense adrantage of in no way diminishing the fast dwindling number of our fere natwres. and one which at 
the same time produces permanent and truthful records of the comntless beantiful forms around us.

In the whole range of photographic possibilities. wióe as it is. where can any subject be found more worthy of one's best energies and keenest enthusiasm than the portrayal of the inner life. hamuts. and habits of the wild free inhabitants of woodland. meadow. mountain. and matrsh!

As Buckland says. there are so many men who have the time and the money. and there must be so many who badly want a new sensation. and some definite object in life. that I wonder it has never struck some of them what a good time they could have. Hundreds have yachits lying idle half the year. and find the time go slowly for want of an occupation. Most sportsmen have at least a liking for natural history and collecting. which only wants encouraging to turn them into enthusiasts. Iet them start an expedition photographic and collecting too. if they like with some definite object in riew: some long-debated point in matural history to clear up. or some newly discorered fact to prove more convincingly by means of photographs. or some fastdisappearing species to be photographed before it finally ramishes from off the fiace of the earth.

'The dwindling fimua of South Africa badly needs a photographic historian. 'That this would not be an impossible task Lord Delamere's interesting series of photographs is conclusire proof. It is a pity that there are not more such expeditions.

Iganda. from all accounts, would be a paradise for a 
photographic naturalist, if it could be worked at once. before the abundance of wild animal life is thinned down to the level of those parts which have been shot over for a longer period.

But going no farther than the confines of Europe though skins and specimens, both dead and alive, of almost every European speeies are a dring in the market-tinere is yet a grand opening for photographs of the most extreme interest.

We know now for certain that the Flamingo does not sit astride of a tall conical mud mound, as depicted in the old books: but a photograph from life of a Flaningo sitting would be worth some labour, and be more convincing than a drawing. The Lammergeyer on its native rocks, the Great Bustard. and the Crane would be fine prizes to strive for. The photographing these "at home" would be ten or twenty times as difficult and a hundred times more interesting than the mere feat of shooting them. and could only be done by the most enthusiastic perseverance and ingemity.

It would be no work for the ubiguitous hand amera. The whole apparatus, from lens to "anera and tripod, would need to be carefully designed for its special purpose, and difficulties, as far as possible, foreseen and guarded against. Some portable form of automatic release, electric or otherwise, night be contrived. combined perhaps on occasion by a flash-lighting contrivance.

The portability of the hand or folding pocket cameras is undoubtedly tempting to the trareller or sportsman already loaded with necessaries. and the facility with which 


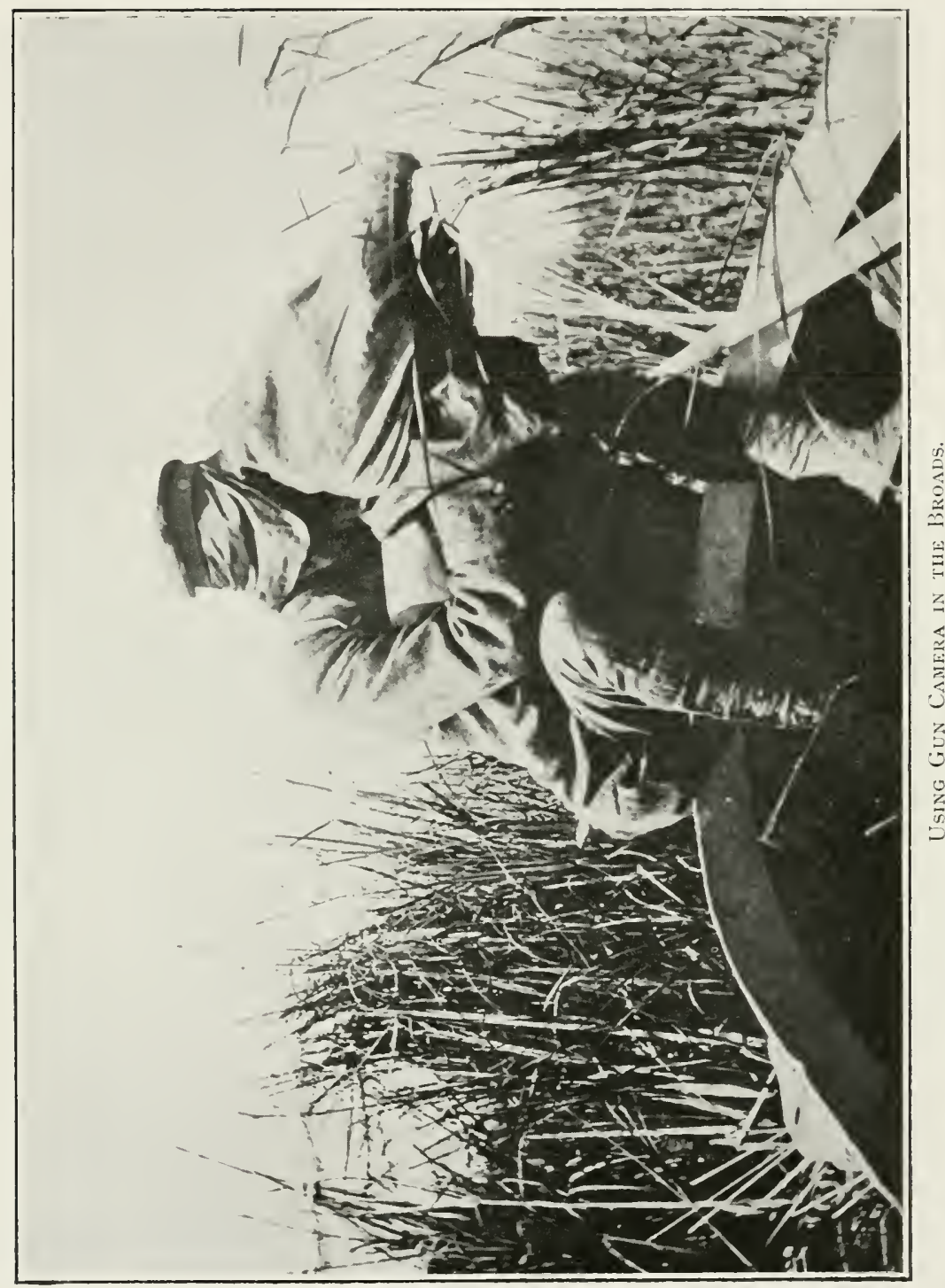


one can be carried about at the same time as a gun or rifte, or on horseback or amel-back, often leads to its being included in an outfit. and used for work for which it is absolutely useless. I wonder how many yards of film lave been exposed on objects rompletely out of their range, and dereloped after returning home, when it is too late to rectify the mistalie. It camnot be too strongly insisted on that serious work. such as Natural History work is. an only be accomplished by taking trouble and by using proper instruments, even though they are heary and extremely awkward to arry. I do not deny for a moment that good subjects have been obtained with a pocket camera. but I say unhesitatingly that for every chance of a successful shot the carrier of a pocket camera only misses a hundred for want of a longer focus lens. and in all probability the one solitary opportunity would have had more justice done to it with another instrument.

After ten years experience I only remember one occasion when a small camera would have been useful. and then, though I could have exposed more plates, I should certainly have been disappointed at the small size of the birds depicted by it.

Suppose for a moment that it had been possible for Messrs. Seebohm and Harvie-Brown's expedition to Siberia, Iard Lilford's yalding cruises after birds in the Mediterrancan, and the Crown Prince Rudolphis expeditions to the 1)ambe and Palestine to have been aceompanicd by a competent photographer provided with the modem appliances 
which have since been invented, there is no doubt that the ralue of these expeditions would have been much angmented.

How interesting to future generations of ornithologists to see permanent photographic records of the first recorded nests of the little Stint and Cirey Plorer, with the birds themselves photographed on or near the nests. as first discovered by Seciohm : or some of Wolley's I apland discoveries! What pictures of the great raptorial birds Prince Rudolph could have obtained if he had had a tele-photo lens while in ambush at their nests!

A most interesting expedition could be made now in pursuit of the Eagles and Vultures of Southern Europe. In Spain alone there are still to be found in the big pine-woods and rugged sierras fire different kinds of Eagles and four species of Vulture. Some of these are yearly decreasing in numbers. and in a few more years will be extremely rare. Hungary and the comntry round the Damube is also particularly rich in raptorial and marsh birds.

But enough has been said to show what a wide opening there is for the photographic naturalist, and what a scope for serious work in a new and practically untrodden field for research.

Infortunately the ficld is too big for any man of small means. I'nless backed by money. whether his own or provided by employers. no one can hope to do more than pick up a few crumbs here and there in the way of results.

The attempt to obtain photographs of wild and living animals is beset with many difficulties, not the least of which 
are the photographic and optical difficulties placed in his way by the linitations of his craft. though some of them are

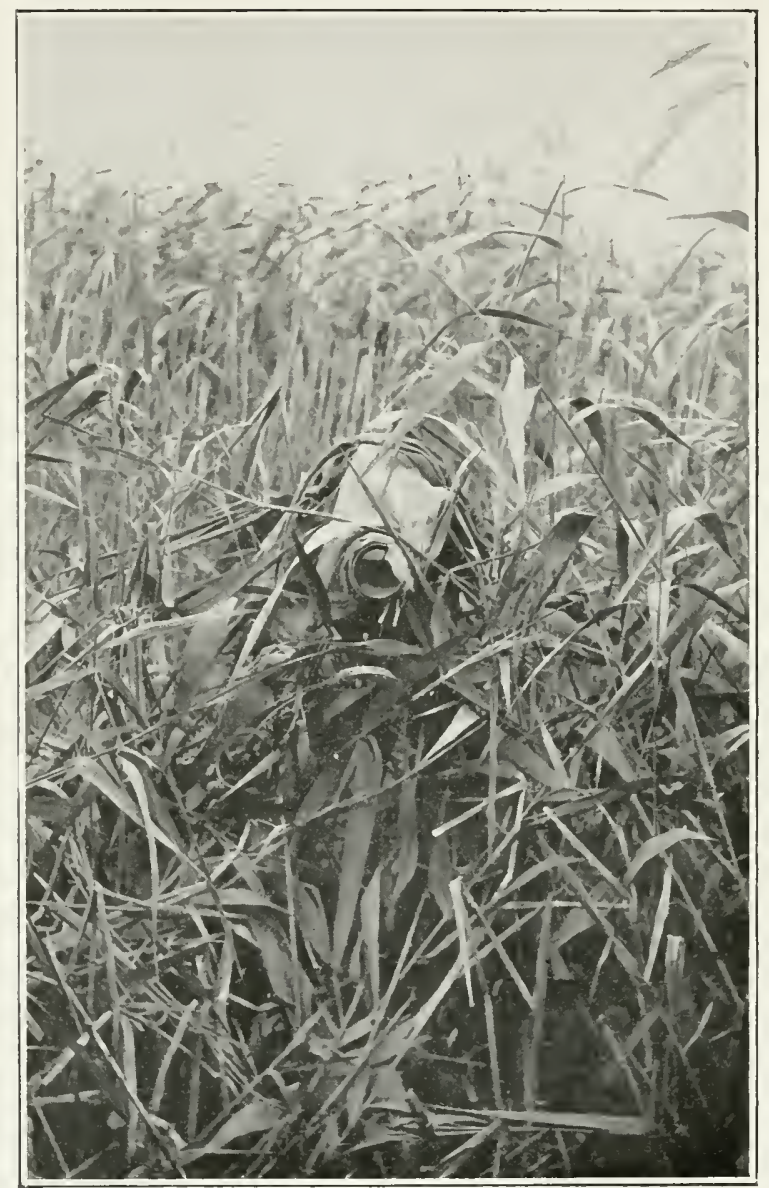

Ambtrsh NeAR Spoonbill's Nest, in which I REMAINEd iN Four FEet of WATER for Five Hours.

gradually being remored by fiesh discoveries and inventions. such as that of the tele-photo lens.

One of the difficulties is that the small size of most birds 
and of many animals renders necessary a very close approald in order to obtain a photograph of a practical si\%c. Against this close approach the extreme timidity of practically the whole animal creation is an almost insmperable barrier. 'Thus the use of very long-focus lenses beeonnes an absolute necessity. and eren with the most powerful a small object like a bird must be photographed from a rery few rards. or eren feet. and the necessary extemsion of cameral becomes cxrecdingly comblous and awkward at such close quarters. and requires, again, a rery heary and rigid tripod to support the weight. Photographing mall birds with a camera between three and four feet long on a big tripod resembles shooting Suipe with a Maxim-gun.

By using the tele-photo lens. invented a few yeals ano by Mr. Dallneyer, a long-focus lens and eomseguent large image may be obtained without the corresponding increase in the length of camera.

But this desirable result is mly arrived at by a great loss of rapidity. It is necessary to give a comparatively slow exposure eren with the fastest plates obtaninable. 'The longer the extension of eamera the bigger the magnification. but the greater the loss of rapidity. I find that a short cameral with a more moderate magnification gives a gain in rapidity. and improves the definition and depth of forus. and it is noticeable that my ameras by degrees get shorter and shorter.

'The latest step in this direction consists of' a hhort cameral (arrying a tele-photo lens, and provided with a reflecting focussing derice. which is momted on a light gun-stock, 
and can be used like a ritle by resting the elbows on the knees.

Another difficulty is the retiring nature of many birds. which prefer leafy retreats and shady corners embowered in foliage, where the quality of the light is not quick enough for the short exposmes which are needed for their actire movements and restless behavionr.

For some subjects. such as a bird on its nest. an ordinary lens may be used on a carefully hidden and previously focmsed camera, the shutter of which may be manipulated from a distance by means of a string. a long pneumatic tube. or even by electric current. Here great exactitude in focmssing is required, and eren with the most careful preparations many exposures will be wasted. It is impossible without much "stopping down" to get both sides of a nest in sharp focus on the plate: and unless the bird occupies the exact spot allowed for it. it will be more or less out of focus. It is generally safest to focus the nearest edge of the nest, as a bird will, as a rule, prefer to face any object of which she has any suspicion. She will also prefer to sit head to wind. 'Then, not only must the camera be most carefully concealed. but the operator himself must also be completely out of sight. 'Then. when, after many hours of waiting, the desired exposmre has been made, there is the necessity for him to show himself in order to change the plate if another chance is wanted, and it is never safe to trust to one plate in this work. 'This is not only a great drawback. but causes much loss of time. 
When hidden up with the camera, as when using the tele-photo lens, you may sometimes expose a dozen plates one after the other without having to alarm the bird by betraying your hiding-place, and there is besides more choice of pose, and the bird's morements an be followed without your being restricted to one particular spot. and when there is time the focus can be obtained with more certainty. Too often. howerer, the bird is on the move, and the time for consideration is of the shortest.

(On these orcasions self-effacement must be studied as a fine art. All animals do their best to shun the attention of mankind, for very excellent reasons of their own: and the photographic enthusiast, though he may orerflow with benerolence towards the whole animal creation, is viewed with just als much suspicion as the prowling gunner--with more, in fact. inasmuch as his weapon is so much more bulky and dangerous in appearance.

It is quite possible, however, to get gradually on familiar terms with birds individually. and to gain their confidence, if you can spare time to spend a day or two at their houseI should say, their nest. I have suceeeded in making friends with several pairs of Nightingales. Whinchats. Whitethroats, and other timid birds. By constantly risiting them and by moring quietly and gently, they soon lay aside all fear, and appear to recognise one as a friend of the family. who may safely be trusted not to betray the confidence placed in his good faith. When they have onee arrived at this satisfictory state of mind, the chief difficulties are remored, and work 
may be done at close quarters without the usual precantions as to hiding.

'The most portable disguise for general use among the greenery of hedges. woods. and reeds is a large piece of green fabrice. By having it lined with a yellowish brown. the reverse side would be useful on sand. shingle. and open moors. It may nearly alwaty be supplemented with adrantage by cut pieces of bracken. leafy branches. reeds. or whaterer is suitable and appropriate for the locality.

In such at difficult class of work the failures and disappointments are many and bitter. and success always rery uncertan.

I hare gone abroal for a week after a particular bird and succeeded in exposing two plates at short range. only to find on my retmm home that they were both hopelessly fogged. I have ridden miles. and carried a heary camera. only to find the nest deserted or pulled out by boys. or waded nearly up to my neck in stagnant water for half a day to no purpose.

()ne day I regcled thirty-fire miles. arrying a camerat. after a particular nest. and had the pleasure of riding the thirty-five miles home again without haring unpacked the camera serenty miles for nothing. not having surceeded in finding the wished-for object and have often and often been out every day for a fortuight and more without having exposed a plate. And here let me say that (arrying a whole-plate camera and spare lenses. and perhaps another camera as well. with tele-photo lens and all belongings. over hedge and ditch. plonghed field and marsh. 
varied perlatps by alimbing to the top of seven or eight big trees. is rery hard work nuder a hot smo such hatrd work that nobody but an enthusiast would erer tackle it twice.

'The long waiting at nests is generally supposed to be very tedions sort of work: but this is a great mistake. There is always something to be seen of exceeding interest. If it were possible to photograph birds as quickly and as eassily as it is to shoot them. the photographer would know no more about them and their habits than the man who shoots a bird the instant he sees it if he can. It is during this wating that one learns.

The nere pleasure of seeing a rare bird at close quarters is alone sufficient compensation for any amount of waiting. and there is the chance of a successful photograph thrown in. als it were: there is also a great probability of seeing all sorts of mexpected incidents and details of wild life. The fact is. the way to see Nature face to face is not to tramp) albont either with or without a gun. but to sit in a ditch or up a tree. or burrow into a thick hedge. and stop there half a day. or. better still. a whole day. You will see much more than when walking abont. and those birds you do see will be unconscious of danger instead of fleeing for their lives.

The great thing is not to more: it is the morement which frightens or perhaps aulls attention to your presence. By merely standing perfectly still. it is quite possible to hare birds and animals all round you. taking no more notice than if you were a post or tree. A good plan is to cover up 
your face and to wear dirty old dog-skin glores that have seen plenty of hard wear. You can then move your hands slowly and raise a ficld-glass to your eyes. when any morement of the bare hands would be fatal. If anything suddenly approaches close to you. half close the eyes and look through the half-closed lids. If you must move and after a time it becomes impossible to remain motionless do so slowly and cautionsly, watching for a suitable opportunity.

Conghing. sneering, and smoking must be strictly forbidden. I have myself given up smoking altogether. as being the easiest way out of the difficulty : otherwise. while waiting about. there was always present the longing for a smoke, all the stronger for being forbidden.

Also, and most important of all. go alone. whenerer practicable. One man working on the lines suggested will see four times as much as two. It is rery often impossible to do this. In strange localities. and especially abroad. it will often be necessary to hare a guide. or boatman. or keeper: and on such occasions the advantage of being taken straight to the birds sares so much time wandering about in a strange comitry as to outweigh any disadrantages.

Away firom home. too. much more weight has to be carried. so as to be prepared for anything that may turn up spare plates. lenses. etc.. generally more than it is possible to arry single-handed. Fren then it is as well, whenever after anything special. to leare your man at a little distance. and go on alone. I try always to plan ont beforelaund each day's work: but one must always be 
prepared to alter or modify. or even completely reverse, all one's plans at a moment's notice. for the least thing may render them all useless.

This branch of photography will be found of most absorbing interest, provided one has. to start with. the necessary enthusiasm. without which the many failures and the constant disappointments would soon prove orerwhelming.

'The worst of it is, that when a good photograph of any bird has been obtained as good. that is. as ean be reasonably expected or eren when it is the rery best that can be possibly done by photography. it falls so lamentably short of the beanty of the original. 


\section{CHAPTER II}

\section{Automatic Photography by Electricity}

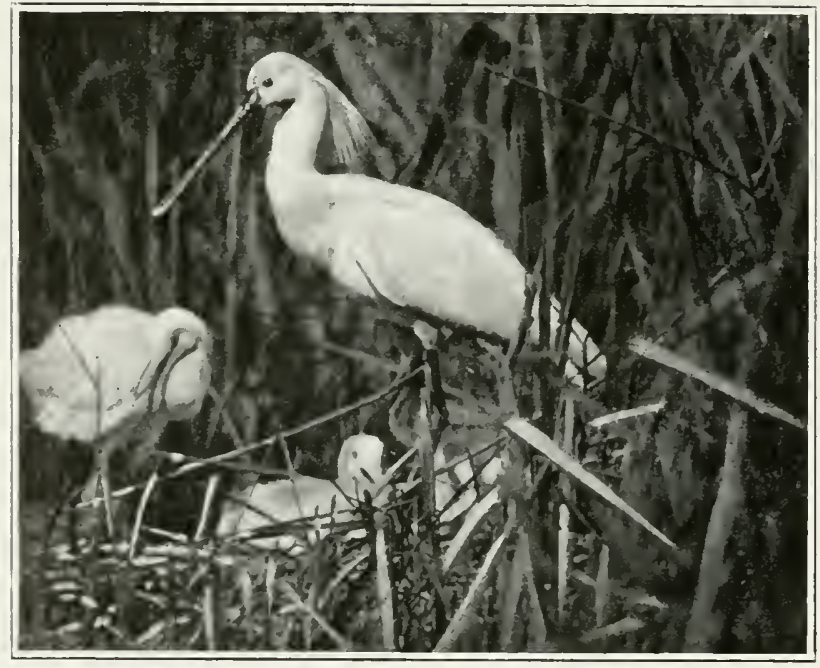

Spooxbill (Platalea leucorodur ).

Srser writing the foregoing chapter, the idea of the antomatic electric release therein sliggested has become all ac complished fact.

In $1901 \quad$ I devised an elertric shutter to be actuated automatically by the pressure of a bird's foot. and in the chapter dealing with Bird Life in Dutch Marshes will be found an accomut of how it was used successfully in portraying an uncomscious Purple Iteron in the rery act of stepping on to its nest. 'This was in the midst of a certain ". meer." which must remain nameless. where these Herons. so common on the Continent. but so extremely 
rare on our side of the Chammel, nest in great numbers. One advantage in this rery interesting method of phototrapping is that it cuables one to work with several cameras. as is evidenced by the fact that. at the very time the purple Heron was completing the electric circuit. and thereby antomatically photographing itself, I was hard at work a good mile away. making exposure after exposure at adult Spoonbills standing in their nest and surromeded by their halfHedged family.

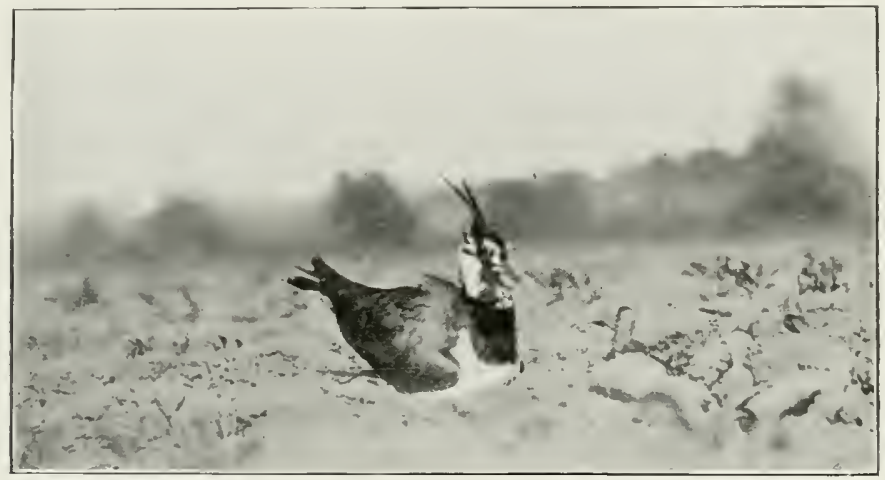

Lapwixg Sitting. Automaticaliy photographed by Electricity.

Truly this was a red-letter day. thus to obtain photographs of these two fine birds, so interesting and so desirable in erery way in the eyes of an ornithologist, and yet so extremely ditficult. owing to their excessive timidity as well as to their lore of remote and mapproachable localities!

Many have been the attempts. carefinly plammed and paticntly carried out. but all in vain. to circumvent this timidity and photograph them “"at home "-attempts hegum in 189.5. and only successfully ended in 1901. 
It would, howerer, have been the height of rashness to rush orer to Holland to use an untried and untested apparatus. especially one so delicate in manipulation. A whole week was first spent at a Lapwing s nest not far from my house. 1)ay after day the trap was carefully set, and watched throughout the whole day from the shelter of a thick hedge half-way across the next field. Squatting in this prickly retreat, the birds could be watched through the field-glass, and their actions and behariour noted. Fach day one or other of the birds went on to the eggs, and, duly setting the current in action, exposed the plate: but it was not until the end of the week that a successful photograph was obtained. First one slight alteration or modification became necessary, and then another. 'The shutter' made for some time a slight noise--rery slight it was, but quite enough to cause the mother bird to spring up and completely blur the photograph before the exposure was completed. Since then some considerable improvements have been effected, and to complete the circuit a bird now has only to touch an inrisible silk thread. 'This can be made to match the placegreen orer grass, yellow orer sand, and so on and can be so delicately set that a Butterfyy, settling on it. would set the battery at work. I have released the shutter by dropping a piece of thin newspaper an inch square on to this thread. Another difficulty had to be got over at the last moment. 'The Iapwing sat on the release so long that the battery. kept in action all the time. ran out. It then became necessary to work out an antomatic ". ent off," which would prevent this waste of battery action. howerer long the pressure was maintained. 


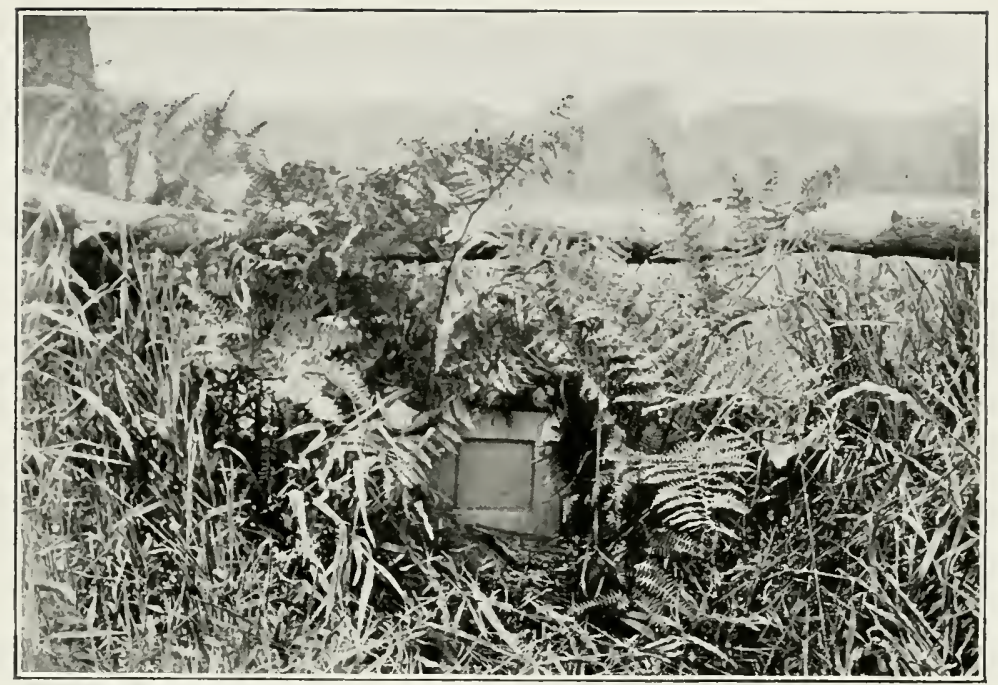

Canera hidden in Hedgerow. Trap set for a JaCkDaw, baited With Eggs. (Froxt of CaMera axd Shutter painted Grass-greex.)

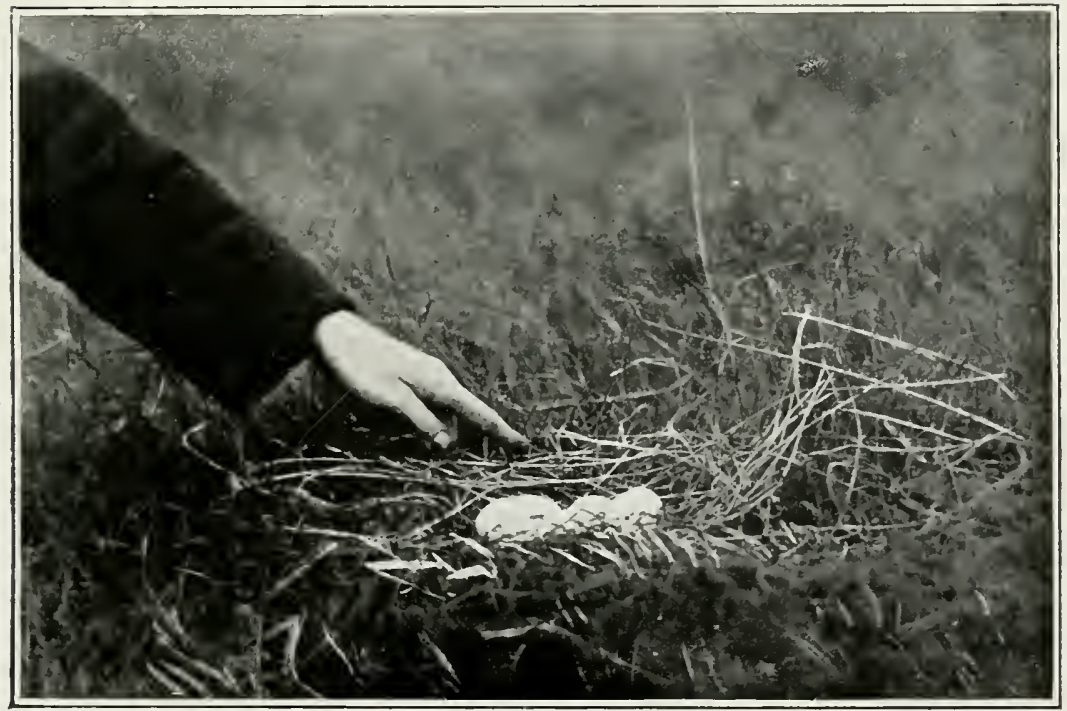

Egg-shells set as Bait for Crows or JACKdalis. Plate exposed by Finger tolching Green Silk stretched over Eggs. 


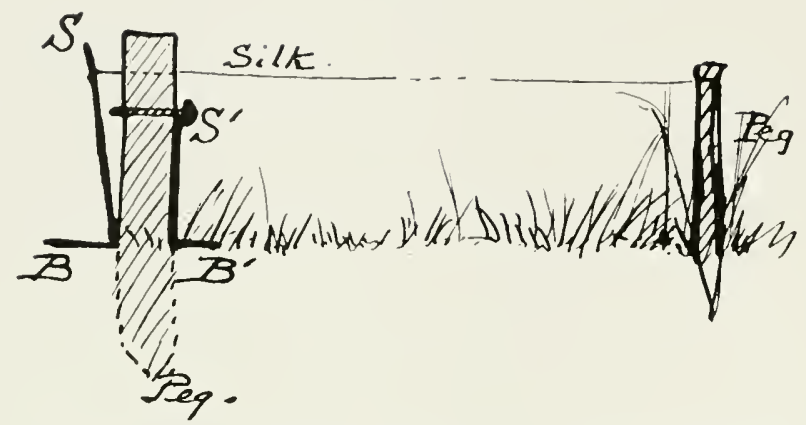

S, Spring; $S$, Screw,-both connected with insulated wires to battery and electro-magnet of shutter. The slightest touch on silk causes $S$ to touch S', which completes the electric circuit, and causes the shutter to open and shut, whereby the plate is exposed.

The camnera, it is needless to say, must be most carcfully ronccaled : it is, in fact. mpon the thorough concealnent that erentual suceess depends, for very many birds will not approach their nest if their suspicions are too much aroused, but will desert their egos altogether, and some birds will eren desert their young ones. I have known 'Turtle-dores to do so : but this is. I imagine, a very extreme case.

When a nest is, like a Iapwing's, placed in the middle of a field on the bare ground, it is not an easy task to so disguise the canncra as not to alarm the parent birds. It is impossible of course to so conceal it as to leare nothing suspicions: there must be some lump which did not exist before. howerer you maly attempt to do away with it. And it is just here that human ingenuity comes into play. It is. for instance. a capital plan to gradually accustom the birds to this necessary lump before they begin to sit, by piling up two or three clods of earth sone yalds away. and gradually decreasing the distance, so that they become familiarised with its appearance. 


\section{Automatic Photography by Electricity}

'Then, when you actually commence operations, place the cancrat in position at the right distance. taking advantage, if possible. of any natural mound or rise of gromd. but kecping the light behind the camcra. As you may take it for granted that a I alpwing will never come on at first under two hours (it will much more likely be four). it becomes necessaly to make a mental calculation as to the position of the sum in two or four hours time. and allow accordingly. 'This is really an important point. Then focussing must be most calrefully done: and those who have never experienced the delights of lying down flat in at muddy field. and formssing a camera on the ground, will be considerably surprised at the difficulty involved and the time taken up by this essential operation. 'The lower the "amera is. the more difficult it becomes to focus sharply the foreground grass as well as the cxact spot where the bird is expected. and the swing-back must be used to the rery fullest possible extent. Then the shutter is set. and the wires connected with the dry battery, a proper circuit being arranged with the two terminals of the shutter and the release on the nest. which only wants completion by the pressure of the bird itsclf. 'The wires. insulated with green silk or gutta-perelat. must be hidden in the grass or buried. the battery hidden with the amera by being covered with a brown or green cloth. and then artistically disguised with earth. stones, thistles, dry cow-dumg. or anything there happens to be alround. and at the last moment. not before. the slide withdrawn. It is a good plan to shicld the lens with a cap until everything is completed : for on sereral oceasions I have gone through all these operations. generally an hours 


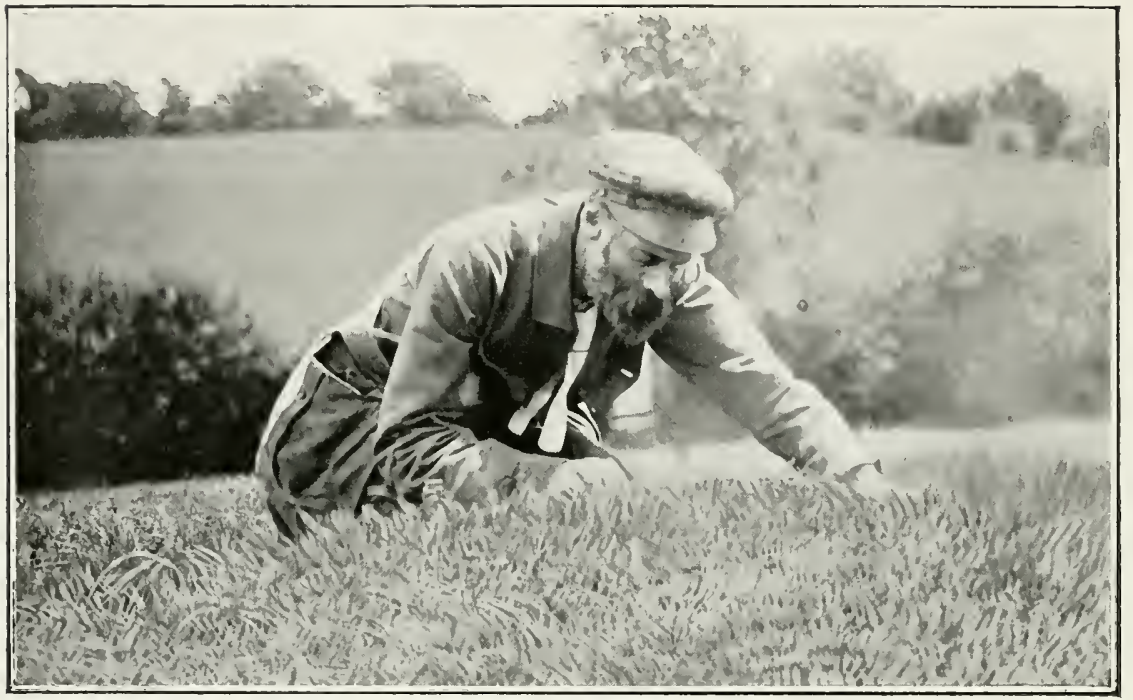

SETTING PHOTO-TRAP. Exposere made by touchiNg Silk THREAd.

work, and then, inadrertently releasing the shutter, have wasted a plate, and had to commence again de nozo. If tall grasses or plants come into undue prominence. cut them down at an early stage of the proceedings. and make sure that none of your disguisements come in front of the lens, and that no wind which may spring up (an blow grasses or leares in front of it after you have gone.

Whaterer you do, aroid. if possible, any field tenanted by sheep, horses, or eattle. I have had a pony come smelling around my carefully arranged wires, with a pair of Iapwings dancing about in front of its nose, until I have had to jump up and drive it off to save a wasted plate. Once, when depending upon a string from a hiding-place, a cow swallowed several yards of it. in spite of my fiantic efforts to frighten her away. 
and sheep have broken it and wasted plates no end. On another oceasion. when baiting for Hooded Crows with a dead rabbit, my bait was diseorered by a big black dog : and though. being pegged clown, he could not take it away, he released the shutter and left a photograph of his mongrel carcass instead of the desired Hoodie. All of which things are aggravating to one's patience and waste a lot of raluable time.

The best place for the shutter is behind the lens. for many reasons: but some birds cammot stand the mucamny look of the single eye looking at them. I have watehed a I apwing go up to the camera, look into the lens, give a bob or two, as if to bow to it, and then settle on her eggs. But it seems fatal to suceess with any of the Crow family. Jackdaws I lave tried, as well as Hoodie Crows, with rabbits, eggs, and a variety of attractions for the corvine taste. When the camera has been perfectly invisible, but the lens looking out (although on one oceasion I made a tummel about a foot long in fiont of it) was always detected sooner or later. I watched a Jackdaw once walk round with every precaution, then hurry forward, and raise his beak to dig at two hen's eggs temptingly displayed, when the tail of his eye eanght sight of the lens, and that was quite sufficient. 'That Jack departed eggless, but un-photographed, leaving me very wroth. but at the same time ammsed at his hurricd and undignified departure.

'There is a good deal of interest in this ploto-trapping. and not a little uncertainty. You may find you have anught nothing. or that you have got something you never expected, more especially when depending upon a bait to attract to 
the desired spot. Meal-worms are the great bomme-bonche for Nightingales: but Rohins are equally fond of them: and as these latter are much more muncerss and twice as bold. the chances are that some humgry Robin will discorer the attractive morsel first and promptly ammex it. And if a Robin once finds out that you are putting out racal-worms. it will come again and again. and seize them as fast as you can put them ont. without waiting till your back is turned: so that. muless you want to be rumed in plates. you will have to gire it up and select another place. Fiven at a nest you may perhaps get another than the rightful owner thereof. and the result may possibly be more valuable: for the negative of an egre-stealing Crow caught in flagerante delicto, or of a cuckoo visiting some small bird's nest with felonions intent. would be of extreme interest and value. 'There is. in fact. all the mocertainty of regular trapping without the element of aruelty which

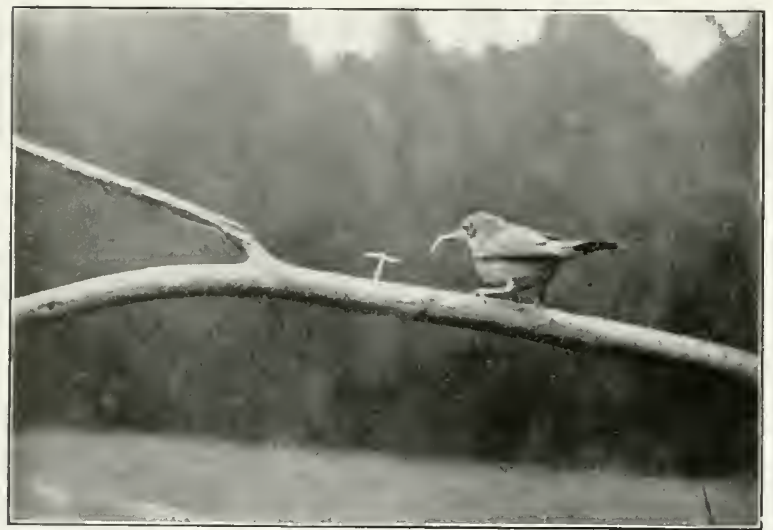

Nightivgale Taking Meal-Worm. is almost maroidable.

Instead of the longh homits of hopeless suffering and intolerable agony. only to end in a cruel death. the bired or animal. by simply touching a thread. has re- 
corded its presence and appearance on a semsitive plate without knowing that anything has happened. A permanent record of the bird's apparance has been obtained without any sacrifice of life or the suffering of any pain.

The varied nature of the positions selected by birds makes it impossible to depend upon any one particular method of using or releasing the automatic photo-trap. What is possible on the ground, for instance. is not by any means practicable up a tree: and there is plenty of occasion for all one's resonree and ingenuity. In the case of water-birds it should be possible, on a small and narrow stream, to stretch a silk thread from bank to bank just above the surface of the water, so that any swimming bird would touch it in passing and complete the electric circuit. 'There is. in fact. no end to the devices which may be made use of in this branch of work. It is hardly necessary to say that the greater one's knowledge of the habits of birds the greater chance there is of success.

It is quite possible to induce some birds to pereh upon any twig you may select, or to put a twig or branch on purpose for them to sit on. with every chance of their acceptance of your invitation. Whinchats. Butcher-birds. and Spotted Flycatchers, for instance, are fairly easy to manage in this respect. and I have succeeded in persuading Xightingales to settle where I wished. Some species seem to be gifted with abnormal acuteness of sense. Water-hens are as difficult as any birds I know to circumvent. When you are expecting them to approale by water, they are in 


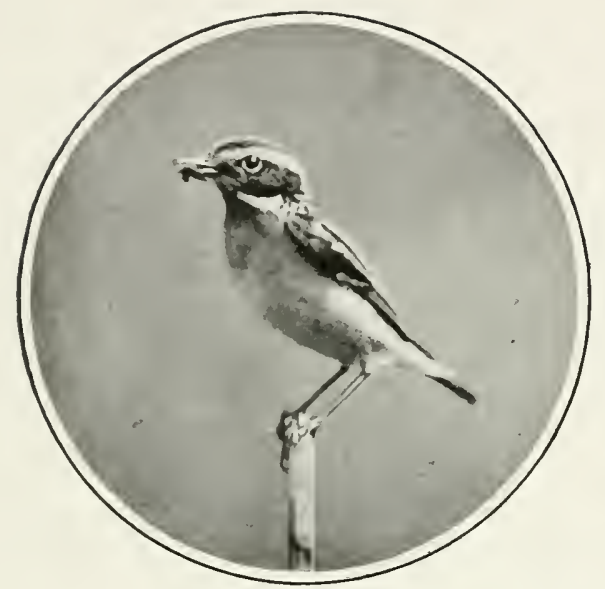

Cock Whixchat (Pratincola metra).

all probability on the gromen somewhere bchind your hidingplace. perfectly aware of your presence, and taking stock of all your proceedings.

There are few scenes in bird life more satisfying in an artistic sense than the picture of a $\mathbf{W}$ aterhen lazily paddling among the reeds. nodding its head and fiirting its tail at every stroke. so as to display the white under-tail corerts.

bird and reeds reflected in the glassy surface. and the reflections just broken by the ripple caused by its morements. What hours I have spent in the rain endearour to portray such a simple and common scene as this. which may be enjoyed in almost every pond in the kingdom ! It is necessary for success to get the bird in a patch of water reflecting the sky and it is such a skulker that it seens to know what you want, and to be persistent in kecping to the reflection of the bank and trees, where its dusky plumage does not get the contrast necessary for a good photograph in the short exposure which alone you are enabled to give.

In watching the ways of Nature's children, the artistic beanty of the unconscious pictures they make anid the scenes of their daily life is, I think, the greatest inducement to the desire of obtaining pictorial records of their 


\section{Automatic Photography by Electricity}

actions. 'The artist will, in fact, derive as much pleasure as the naturalist. and the sensations of each will be so blended as to make any attempt to analyse then or to differentiate one from the other a matter of impossibility. 


\section{CHAP'TER III}

\section{Photographic Outfit}

As to the photographic outfit, it may perhaps be useful if I describe my own kit. which is now the result of about ten years experience.

The lenses are the most important as well als the most expensive items, several of them being necessaly. First comes the 'Tele-photo lens before mentioned. This is a difficult - in fact. a very difficult - lens to work with: but it is an absolute necessity for an ornithologist. Mine is the simple form. als first brought out by the inventor. Mr. Dallmeyer, now. I believe. not made, as it has been superseded by the later form with a l'ortrait lens and a Negative lens attached to the back. With this lens the majority of the birds as depicted in this rolume have been photographed. Then I use two Optimus lenses. a R.R. of $10 \frac{1}{2}$-inch focus and a Furyscope of $8 \frac{1}{2}$ inch: with these two nearly all the nests have been photographed. Lately 1 have procured a I)allmeyer Stigmatic of 7 -inch focus. This is a most useful lens, and I wish I had had it sooner: in confined situations a short-focus lens is often a necessity, and in dozens of cases would have saved me much trouble and given a better result. 
The emmeras consist of a whole-plate Optimus camerar. on an Isliford stand the best, the lightest, and the strongest of all stands. (I have stood on mine before now.)

I have also a quarter-plate reflecting camera, provided with a focussing eye-piece and mirror, through which I can look horizontally on to the focussing-glass. which gires the exact image seen throngh the lens itself: This takes the Tele-photo lens. and also the Eurysope and the Stignatic. Here, I may say, all my things are interehangeable - all the ameras go on the same stand. all the lenses go in all the "ameras, ete.. etc. Instead of slides or changing-boxes there is a single slide, with a leather changing-slecre attached thereto. which holds a box of plates, and when they are used any number of fiesh boxes can be used one by one. This camera, besides fixing on to the Ashford stand, also screws on to a gun-stock made of willow. so that I cam use it from the shoulder like a gun, or rest it on my knee like a rifle, or with the Euryseope lens it can be used as an ordinary reflecting hand eamera.

Then there is the electric camera described in Chapter II. This is a half-plate, rather solidly made, which takes all lenses. and is provided with metal dark-slides and the electric shutter behind lens of my own design. made by Mlessis. Dallmeyer.

('This camera has since become unusable. having suffered too much from exposure to dimp by being left in wet ditches and similar places all night, so as to be ready for the proverbial early bird in the morning. I now use at 
$5 \times 4$ camera, fitted with an old focal plane shutter. which, howerer. works now before the lens. It takes a single lens of 1t-inch focus, besides the R.R.. Euryscope, and Stigmatic. and has a changing-box with twelve plates.)

As for plates. they are all good, and I firmly believe in everybody sticking to one brand and knowing what it will do by experience. For tele-photo work the rery fastest plates are hardly fist enough sometimes. Cadett Iighting and Spectrum and Imperial flash-light plates have been used, and are all of them rery good. For nests I prefer a plate of ordinary speed. and hare found Imperial ordinary plates most excellent. Except for working in a rery high wind, I would not ask for anything better: but on such occasions their special-rapid plate is perhaps to be preferred. Another beantifully clean and brilliant plate for nest work is the Warwick instantaneons plate. For developers I believe in old-fashioned pyro, with soda as accelerator. But in these matters we all have our own opinions and prejudices, and there is plenty of room for difference of opinion.

'Then. besides the purely photographic outfit, a good field-glass is a sime quâ $n 0 m$. With such a load of necessary tools to be carried about, every ounce of weight is a matter of importance, and before the introduction of the prismatic glasses a powerfiul glass was a serious addition to the kit, already over-heary. Now a glass as powerful as a telescope weighs so little as to be mmoticed. The innate timidity and incessant watchfolness displayed by each and every member of the animal creation make some 


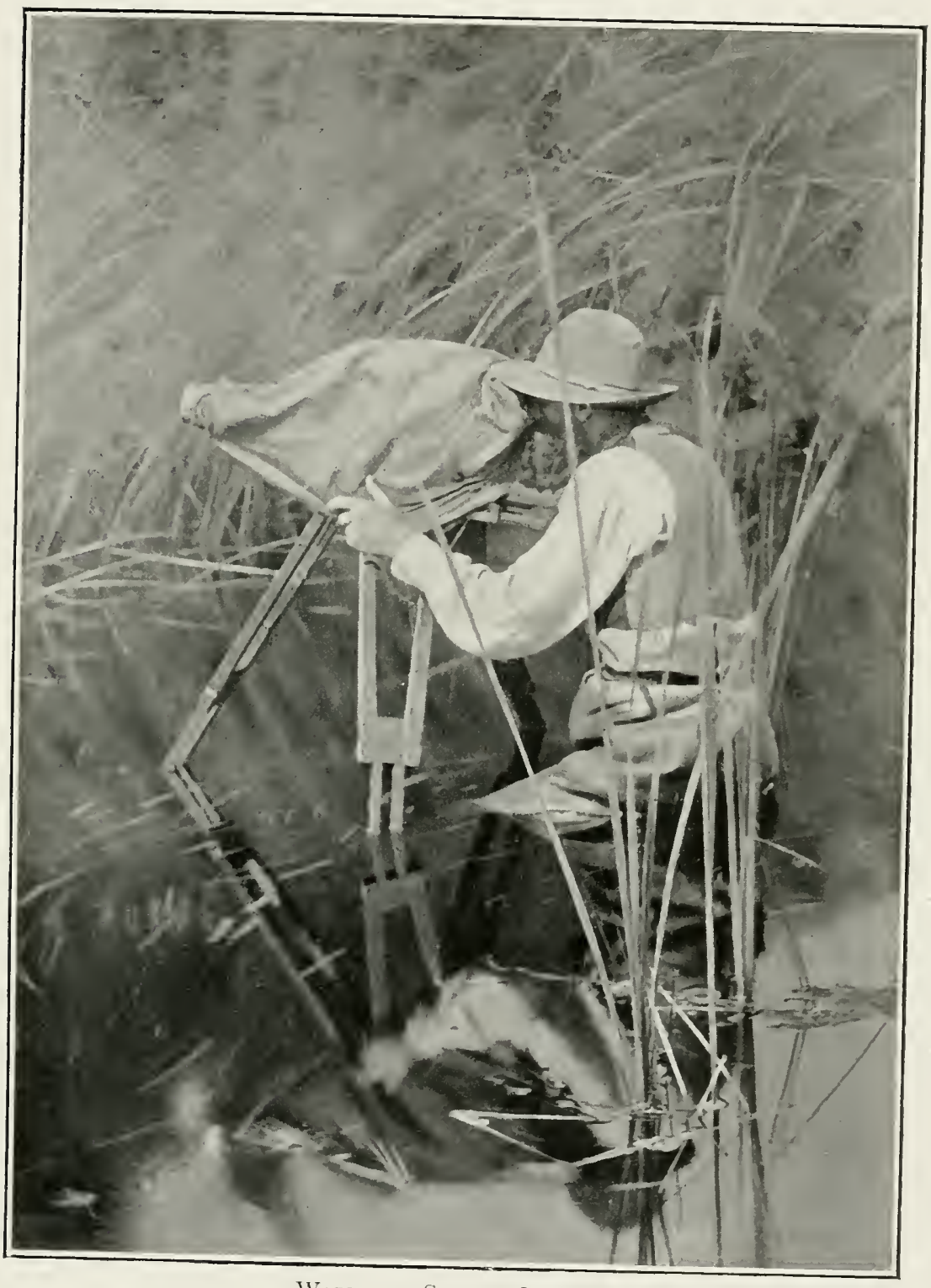

WADING IN SPANiSH LagooN. 
assistance to the sight absolutely necessary. and an ordinary ficld-glass is an immense improrement on the naked eve: but the new prismatic glasses present the object with such cleamess and rivid distinctness that they are as superior to the old-fashioned glass as that was to the massisted eyesight. While being half the size and half the weight. 'They also give a much latger ficld of riew. Looking at a bird forty or fifty yards away with a Goerz glass. medium power. I have been fairly astonished at the brilliancy and microscopic sharpmess rendered by it. Not only can yon distinguish clearly the delicate markings of the plumage. but the very fibre of its feathers and the twinkle of its eye can be seen as distinctly as if you were watching a bird in a rage close at hand. In fact. you can see it much more distinctly. for the glass appears to give a strong stereoscopic effect. so that the bird seems to stand out from its surroundings in a most wonderful manner.

If much of marsh work be attempted and it is. I think. the most fascinating then wading-trousers are necessal'y. 'They should come well up to the shoulders. like those which ale worn by salmon-fishers, as the water is nearly always very deep and the bottom soft. The amera then can be manipulated in four and fire feet of water. Nothing is more aggravating than the attempt to use a camera on its tripod on a small boat or narrow punt. As a rule it is absolutely impossible to give anything but an instantaneous cxposure. and for photographing nests instantaneous exposures are no good. I small stop. a moderately fast plate. and 


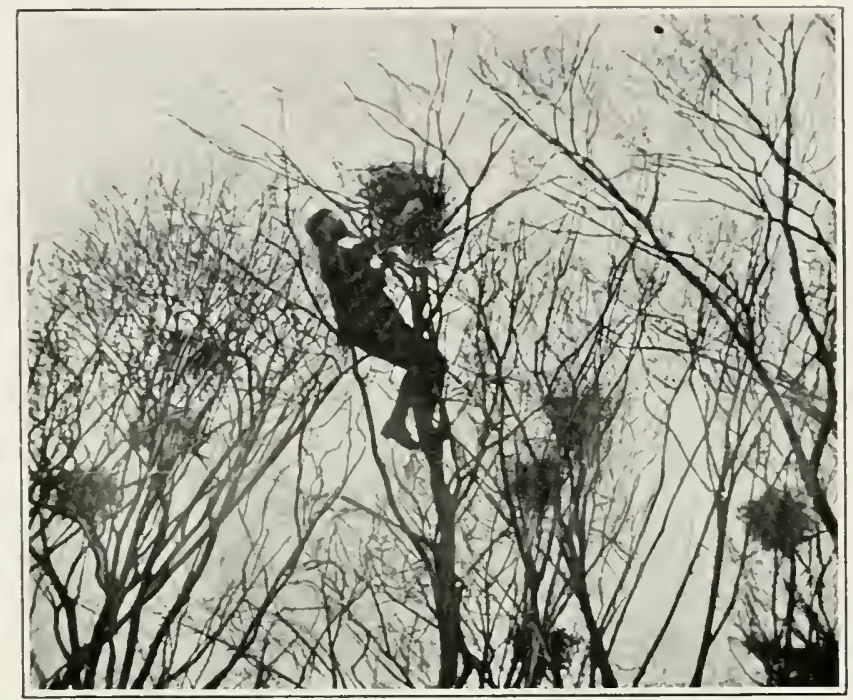

Climbing to a Rook's Nest.

a prolonged exposure is the rule. except in al very few exceptional instances.

If I had been born a bird. I should have liked to have been web-footed and to hare lived in a marsh. Nothing grives me greater pleasme than working in such situations. surromded on all sides by a waring sea of fresh green reeds. As I sit trying to collect my scattered thoughts, distracted by the usual uncouth noises of a suburban street. I long for the silent reed-hed and the pleasant days I have spent wading in remote and watery wildernesses alone with the birds. and wonder whether I shall erer enjoy the like again.

For rock work ropes and a crowbar will be wanted. It is one thing. however, going down a rope, and another to get a decent photograph when you are down. 
For tree-climbing a short length of rope is sometimes rery useful, and so are. on occasions. climbing-irons. They want some practice, howerer. and are awkward things, and. in finet, rather dangerous, until you are used to them. when they will no doubt enable you to climb trees otherwise impracticabie. I am not a good climber. but I have generally managed to do without their assistance. They and considerably to the load to be carried. and are best left at home in reserve. unless you know ther are likely to be wanted. 


\section{CIAP'TER IV}

\section{Bird Life in a Suburban Parish}

ForTexite indeed it is for Einglish naturalists that the migratory impulse among birds induces so many species to risit this country. (Orr resident birds are but few. and are in too many instances dwindling in numbers, or

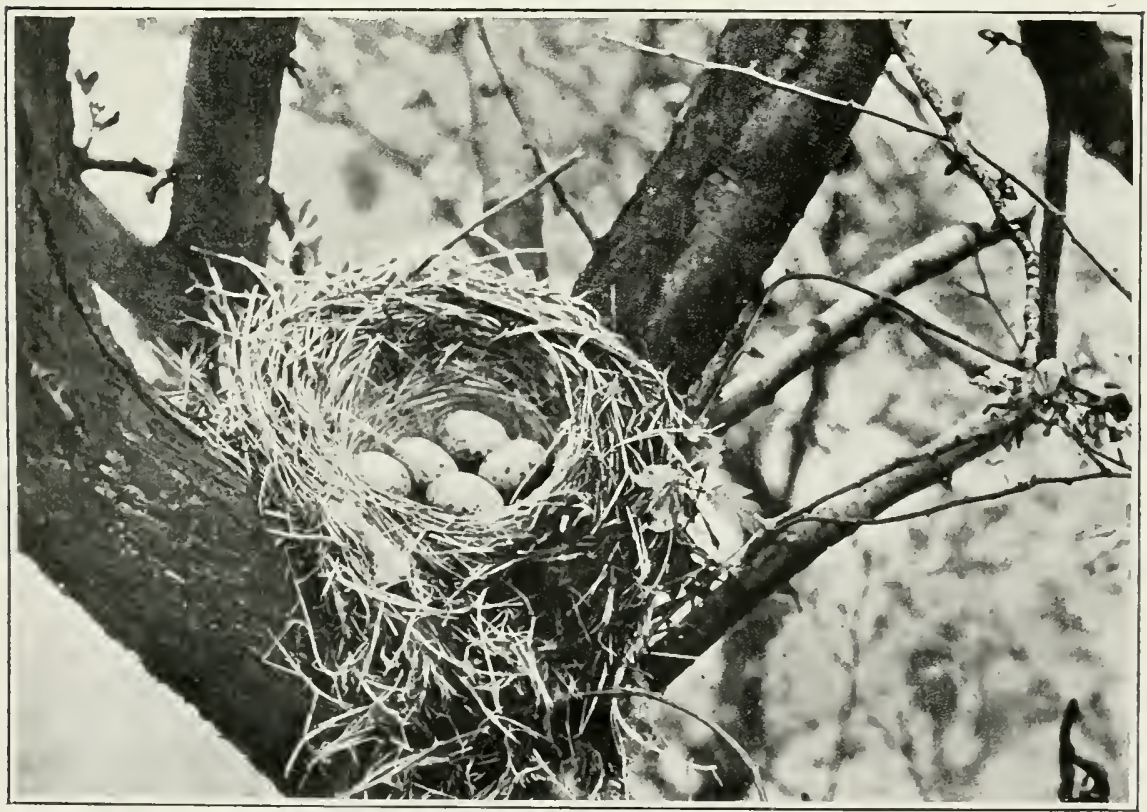

Nest of Missel-thresh (Turdus a'iscivorus). 


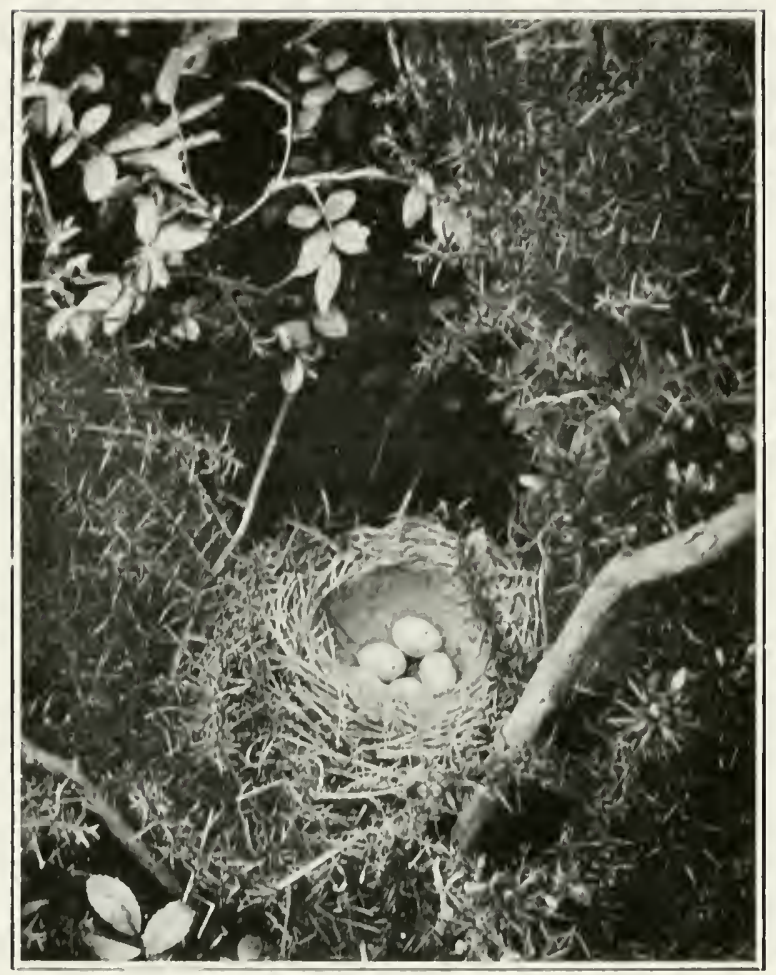

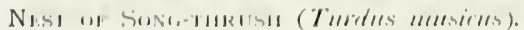

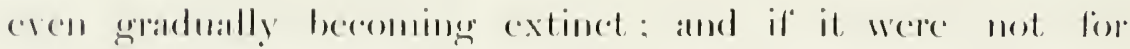

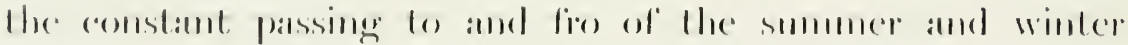

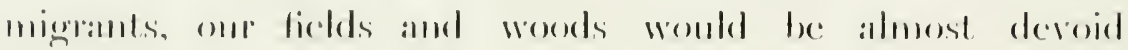
(i) lilie.

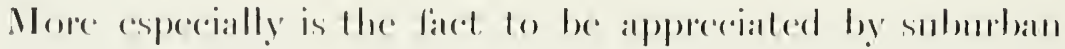

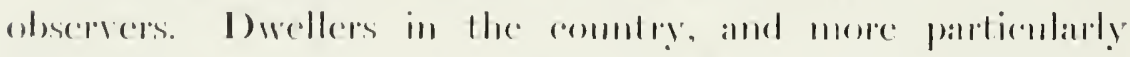

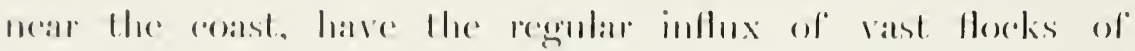

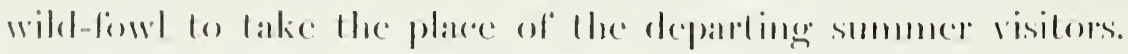

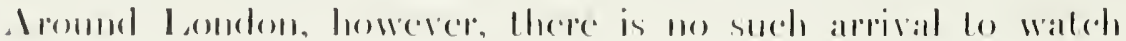




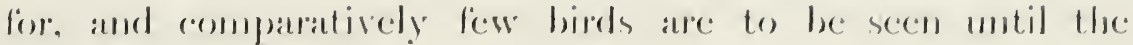
adrent of springs.

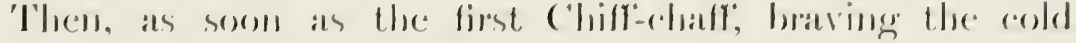

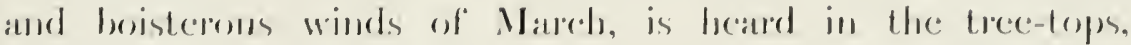
there is the rectainty that onte weleome sumner friends will

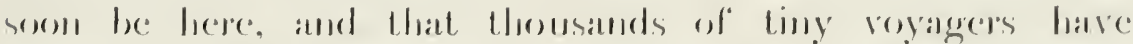

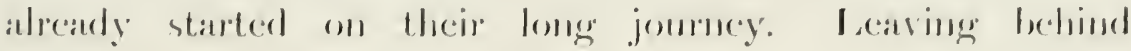

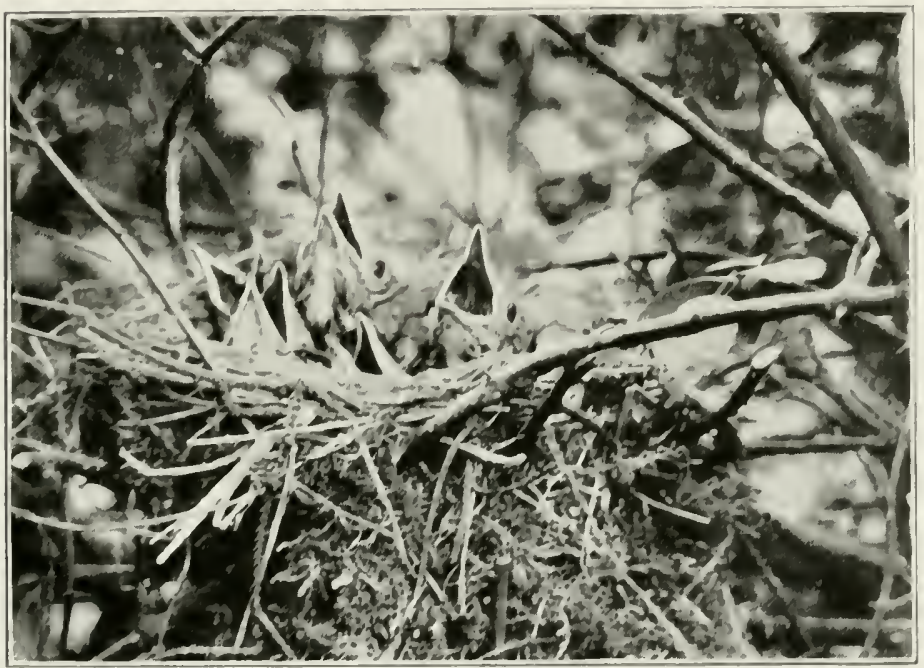

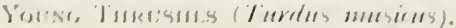

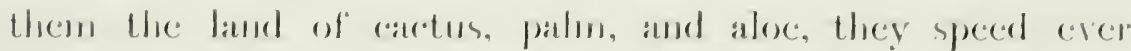

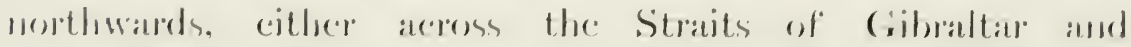
through Sprin and France, or through Italy riô Malta.

l'lying mostly by night, and feceling by day, they press forward, oser plain and sierra, vincyard and monmtano. losing mombers in nets and traps, and preyed mpont by Hawks and predatory leasts, at last, lanving the bitter ardel 
of the momintan-passes and the dangers of the sea-passage. they reach the hedgerow in old England where they were born: and all the summer through the quict fields and leafy lanes, even close up to the great city itsclf. are

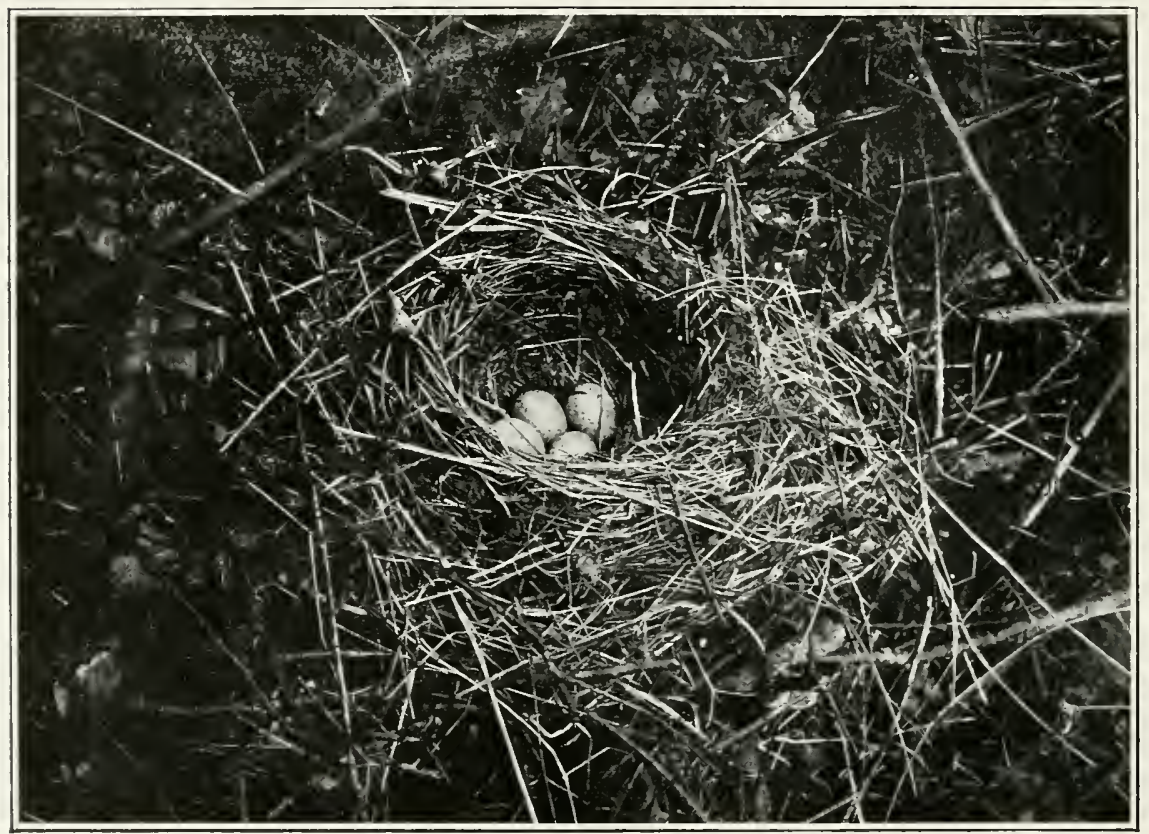

Nest of Blackitidd (Turdus marula).

enlivened by a diversity of feathered life, and graceful forms and joyous sounds greet us on every side.

A suburban parish, only partly outside the Isondon postal district. and on the firinge of a dense population, is not the most likely neighbourhood for observing the life habits of wild birds, and yet it is surprising what a number of species are to be met with as more or less 
regular visitors at one season or the other, withont taking into account those accidental occurrences which happen from time to time. For such an erent as the picking up) of an exhausted Petrel or other pelagic species in an inland locality seems to me to be quite devoid of any more than a passing interest. and to have no ornithological importance whatever. The particular comty in which the stom-driven wanderer happened to fall has no real claim to consider it as an inhabitant, althongh our British and county lists of species are, als a matter of fact. artificially swelled by the inclusion of many such atses.

My idea in compiling these notes is not so much to

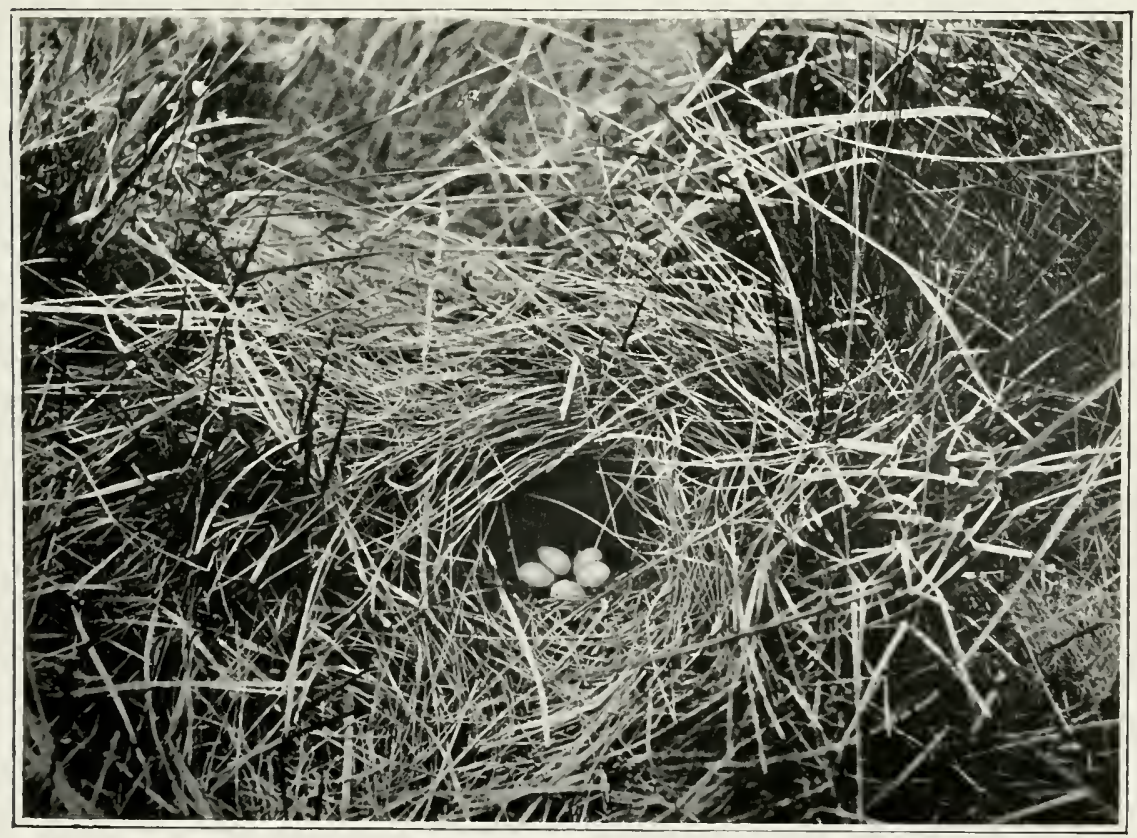

Nest of IVhixchat (Pratincola rubetra). 
gather together records of such rare and unusual events. but rather to describe what I have myself seen of the abundance of suburban bird life, to emunerate the different species (ninety-one) observed during the rears $189+$ to $190: 3$ in the parish of Enfield, and to illustrate, as far as pos

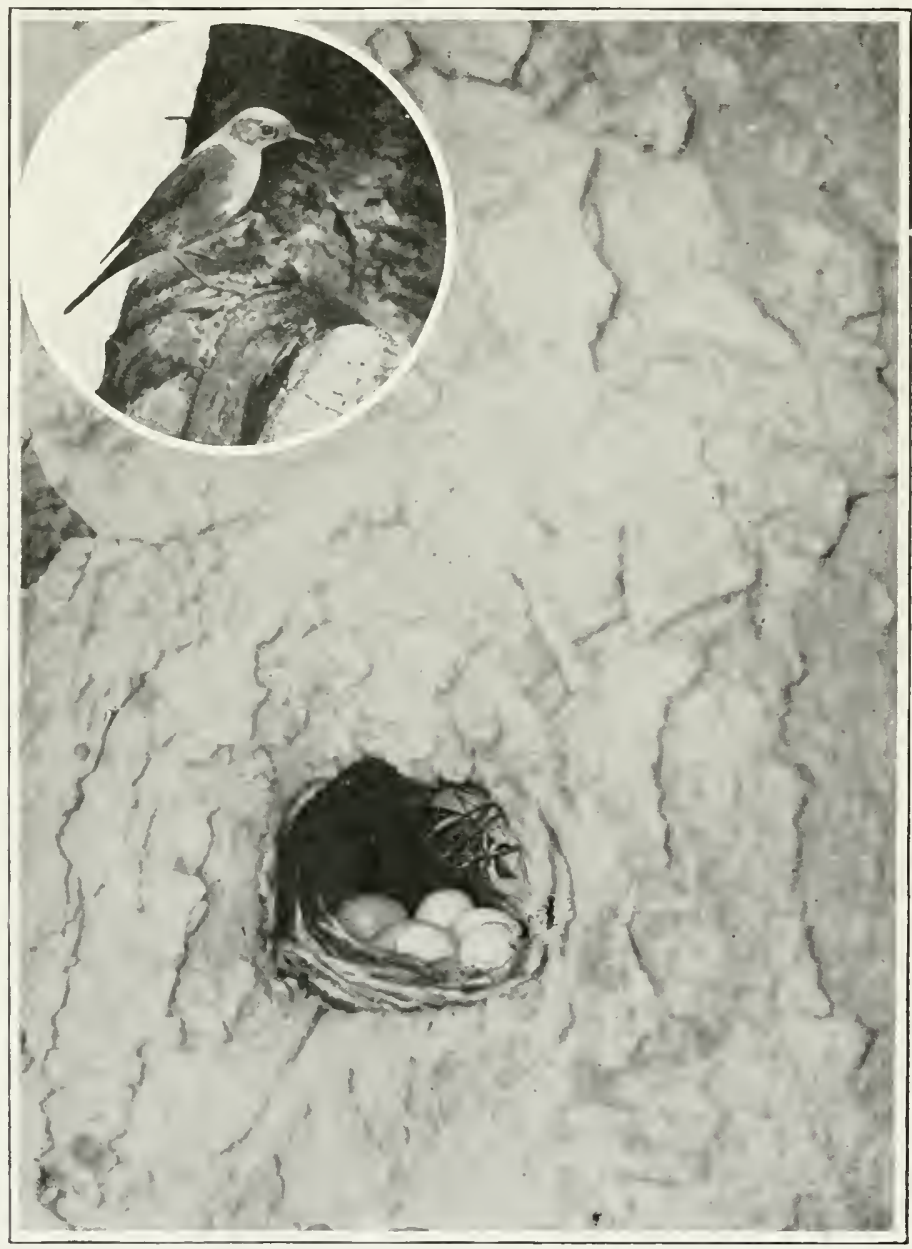

Redstart AND NEST (Ruticilla phanicumus). 
sible by photographs, their nests. their egess and young, and abore all, the birds themselves. feeding. sitting on their nests, tending their young ones, and, in fact, engaged in their ordinary pursuits. and the scenes of their daily life.

Enfield parish. one of the largest in England, is very nearly connected with the outskirts of I condon. only a few open spaces now intervening between 'Totten-

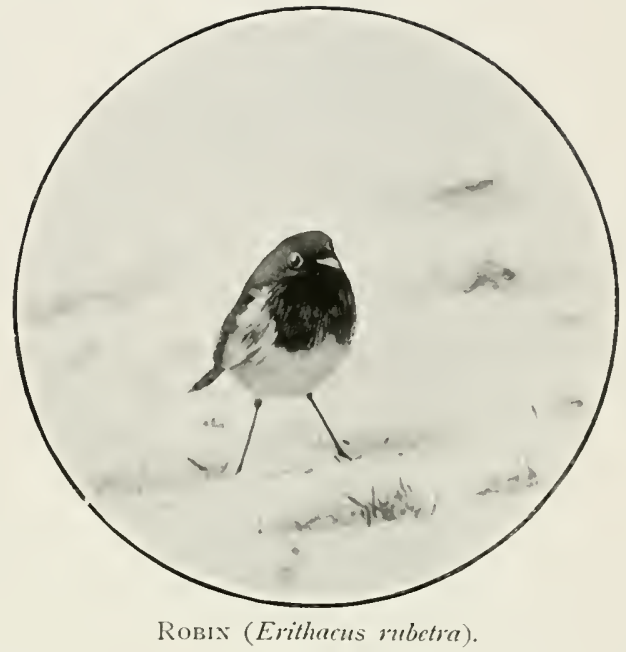
ham and other dense centres of population: and year by year these few spaces are gradually being absorbed and swallowed up by the rapidly adrancing tide of bricks and mortar. Rows of mean-looking houses now cover what were but a few years ago pleasant orchards and green ficlds, and places where the Iark sang and Blackbird and 'Thrush piped from the tree-tops now resomind with the vells of the costernonger and the hideous jangle of the piano-organ.

Old historic mansions and spacions gardens are giving place to strects of small houses, to accommodate the thousands of workmen brought backwards and forwards daily by the cheap workmen's trains, which are the most potent factors in the transformation which is rapidly altering the aspect and character of the place. It is quite right and proper that this should be so--better far that the thousands of working men and women and the little children should 
be enabled to live annid wholesomer surroundings than pent up in the squalid courts and alleys of I condon: but at the same time it is impossible to aroid looking back with some pardonable regret to the old state of things.

'To the northward. howerer. the houses become fewer. and a large expanse of fine open country stretches for some miles between Barnet and P'otter's l'ar. while to the castward Fpping Forest and the marshes of the Icea afford shelter and food

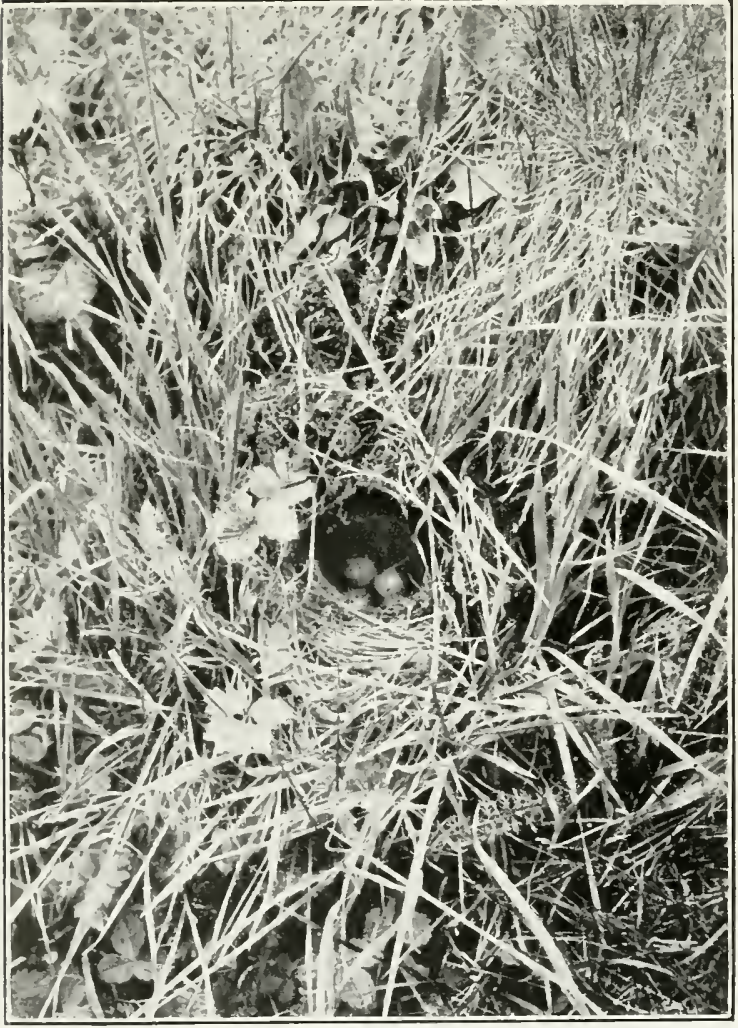

Nest of Robix (Erithacus rubetra). for matly of the feathered tribes.

I a lige woods and game preserves, and the estates of latrge landed proprietors. interspersed with farms of pastoral land. ensure an abundance of bird life which (oompares repr farourably with many a more remote locality. Besides the ordinary species which might be expected in an 
inland place, several maritime species have found that the pools and filter-beds and flooded fields of the sewagefarm afford them suitable food and congenial surroundings. approximating closely to the mud-flats and banks of tidal ooze, so beloved by many of the waders and kindred species. Here, at certain seasons especially, they may be observed in numbers wading in the shallow water and busily feeding. just as if they were in some tidal estuary.

The adjacent marshes afford sport to the Cockney gumner during the winter months. When snow lies on the ground. and the pools in the forest and elsewhere are covered with ice. many Snipe and I nocks and a few 'Teal frequent the banks of the old River Leal, as it wanders in devions course beside the navigable canal. To get these, however, it is necessary to be up betimes. The first gun over the ground after the grey dawn has broken and the first rays of light have begun feebly to penetrate the fog. which hangs thickly orer the low-lying marshlands on each side of the river. may hare good sport in suitable weather: but it is not rery cucouraging. for one who has three or four miles to tramp oxer frozen snow on a foggy December moming before daybreak, to find, when he arrives at the river, footsteps in the snow. which prove conchusively that somebody. perhaps one who lives close to the spot. has got the start of him. Such has been my experience before now. in the dayss when the gum was more familiar to me than the cameral. At other times, wating for the dawn. I have heard all round me the big 
Hocks of I a apwing feeding. and the swish of wings as a lot of Crolden Plover havedashed past in their impetuous flight. and have discerned through the mist the grey and ghostly figure of at motionless Heron. intent on procuring some fish for breakfiast. In such weather many Fieldfares. Redwings, and I arks are shot by a colass of men who do not consider. or (are, that by the

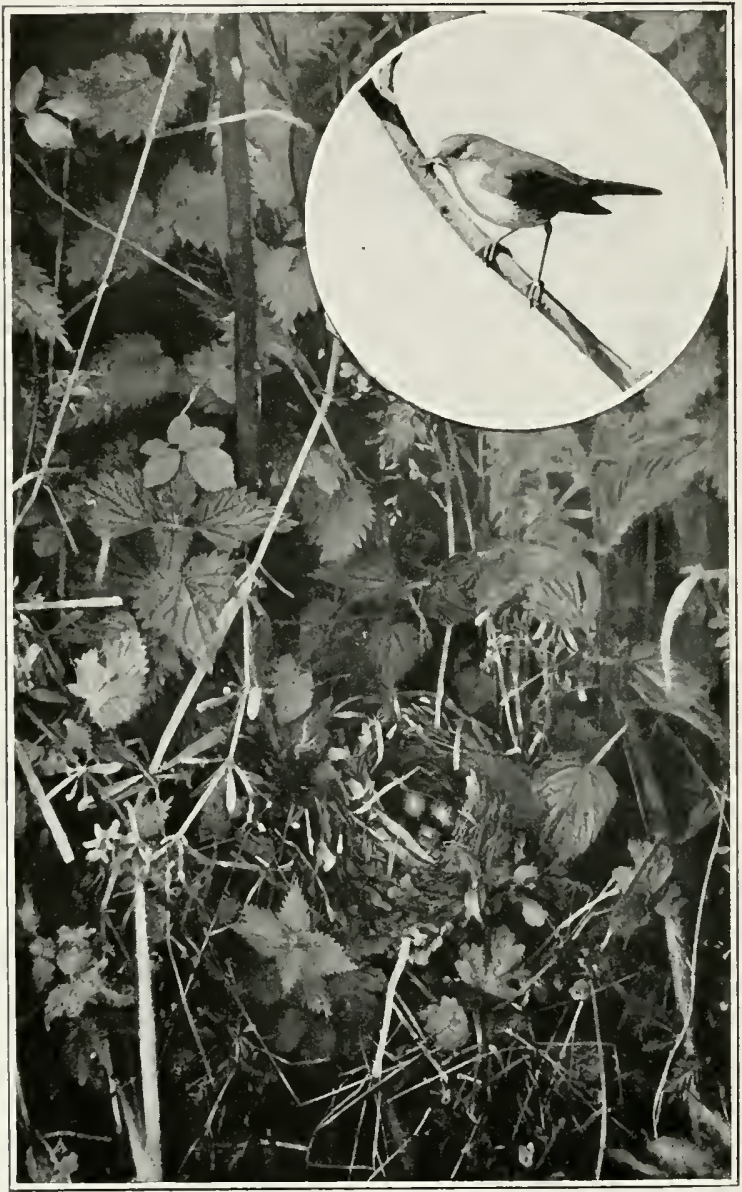

Nightingale (Daulias luscinia) and Nest. constant popping at such small game the more desirable birds are driven away to quieter retreats.

Most of my observations and work have been done on a small farm of poor land, chiefly pastoral. quite close to the inhabited part of the parish. But one or two important characteristics help to make it a very good hunting-ground 
for the ornithologist. One is that it is bordered on one side by a large wood. strictly preserved : and the other consists in the fact that it is watered by a small stream. which (arries off' the surface-water of the valley throngh which it runs. This strean through much of its length is covered over with an almost impenetrable thicket of bramble, wild rose, sloe, and other prickly shrubs and bushes, the home of many Water-hens, Wild Ducks. Nightingales, Sedge-warblers. Bullfinches. 'Turtle-doves, and many other kinds which delight in similar situations. Some of these strongholds are only to be explored with great difficulty. and at the imminent risk of damage to both person and elothing. the only method being to crawl in on all fours, or even, prone on one's stomach, to wriggle in like a lizard.

The farm, too, abounds in large, old-fashioned hedges, high

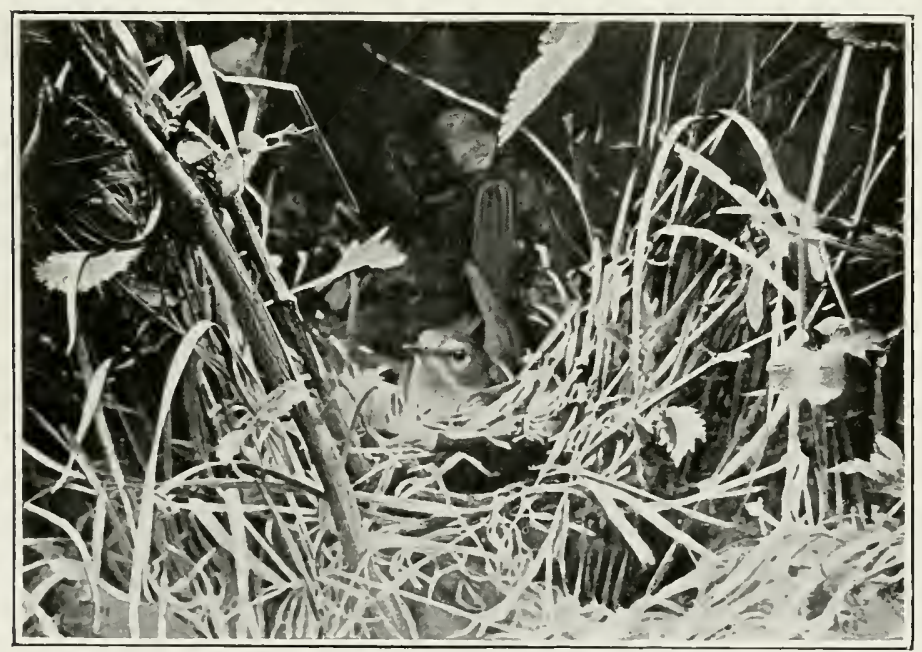

Nigitingale (Daulias luscinia) sittixg. 
enough to provide nesting-sites for many $\mathbf{W o o d - p i g e o n s , ~ a n d ~}$ thick enough to shelter myriads of Nightingales and small binds. These hedges are, howerer, gradually being reduced and " plashed," to the noticeable diminution of the number of birds to be seen: and the recent introduction of sheep seems to tend to drive away the Nightjars. which formerly nested annually among the bracken at the edge of many

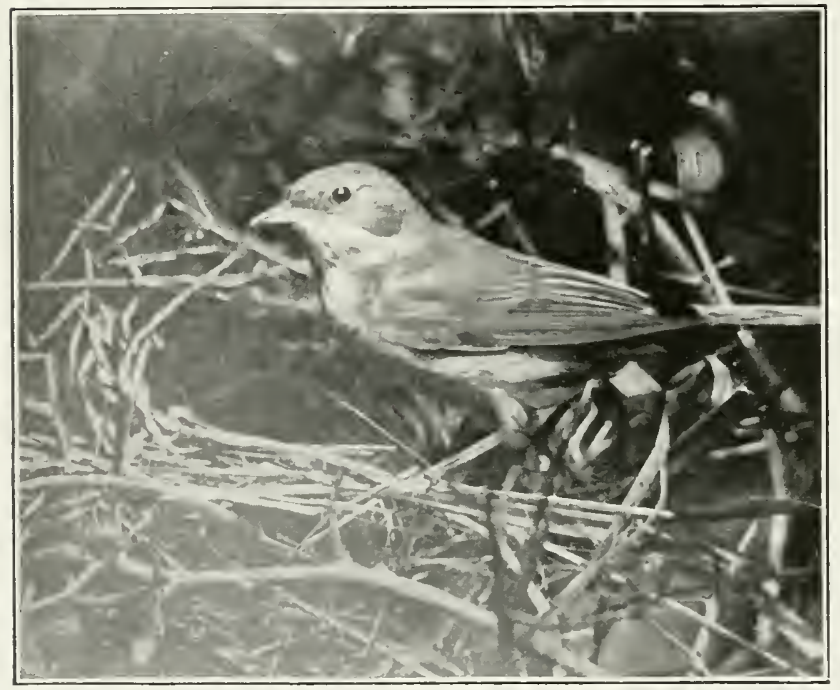

Greater Whitethroat (Silita cincra). hedges bordering on the rood.

The Missel-thrush is a nost abundant species throughout the year. It may be noticed more particularly perhaps at the end of the summer, when great numbers of them frequent the grassfields, hopping about orer the parched turf: apparently finding food of sone kind but what I hare never been ahle to discover. It this season of the rear the ground is sometimes as hard as iron. and the short turf almost burnt up. dry and yellow. on which these fine. bold-looking birds are extremely conspicuous, and look very light in colour. 
At other times they are not so much in evidence, and the first intination of their presence is generally the harsh. cackling alamn-mote as they leare some high hedge or bush.

'The nest is built rery early in the year: and though there is generally no attempt at any concealment. the nests

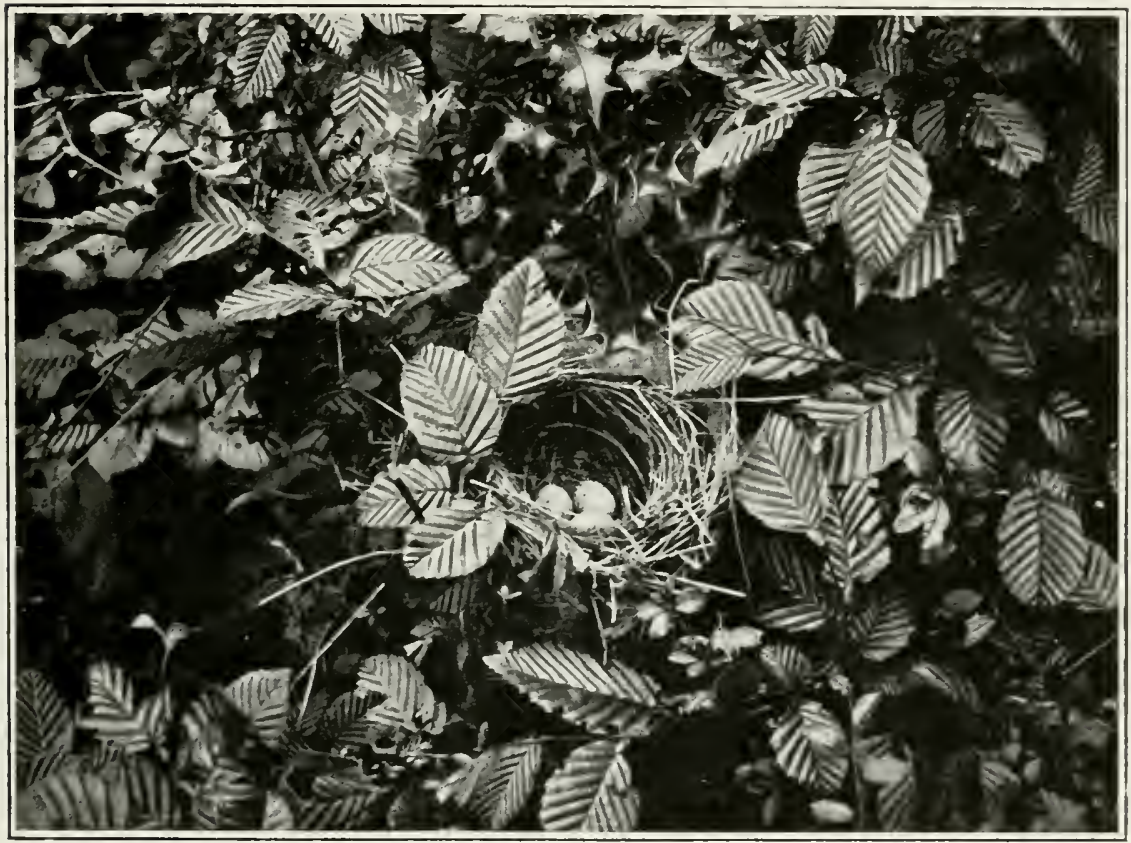

Nest of Greater Whitethroat (Syluia cinerea).

do escape notice more often than those of the Blackbird and 'Thrush, partly perhaps because the situation is rather higher-generally about seren or eight feet from the ground. and occasionally on the extreme summit of a small larchtree. 'They are more usually firmly fixed in the main fork of a hawthorn- or fruit-tree. never among the smaller twigs. 


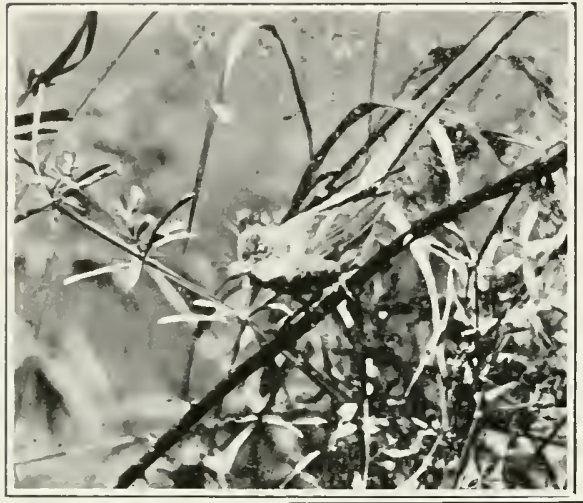

a $11 \mathrm{~d}$ a re

st rollg g a I 11100 s ro $11 \mathrm{~g} \mathrm{hl} \mathrm{l}$. III a d e a most applopriate and fitting lome
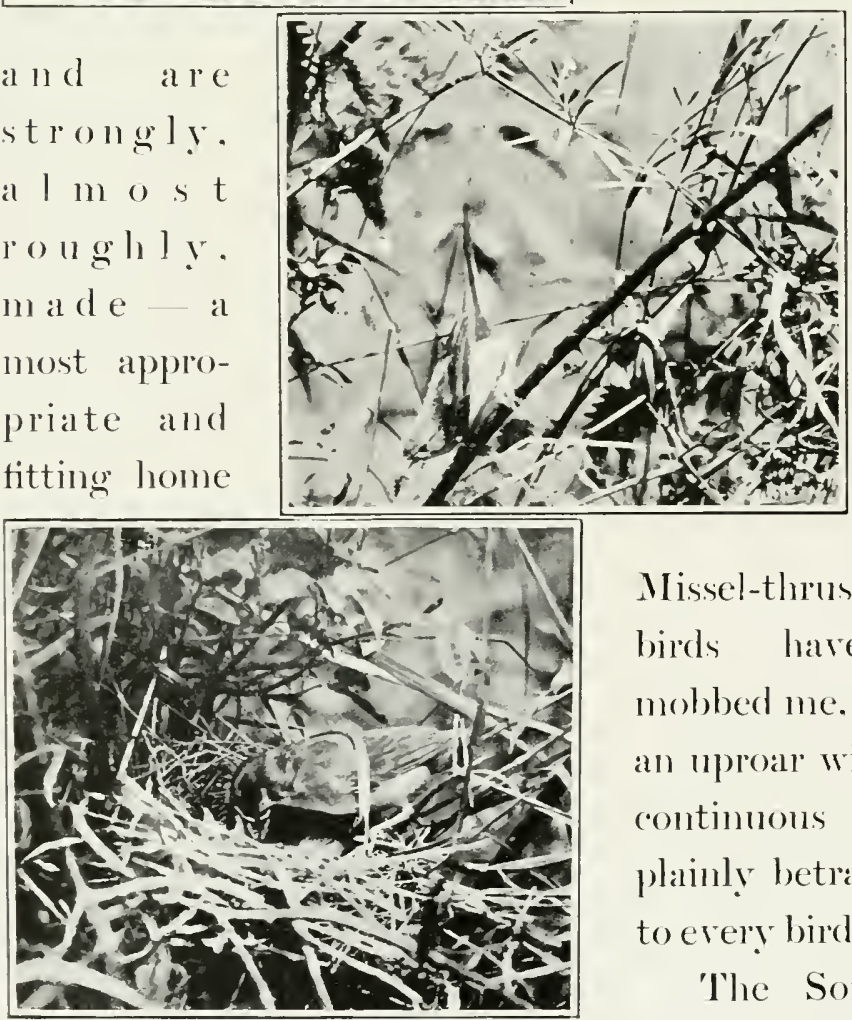

Greater Whitethroat (Sylvia cinerca). for such a bold. hatedy songster. which braves the wildest weatler with its cheery songe.

'The Missel-thrush appears to have no fear when nesting, and will drive away any bird. whatever its sizc. if it rentures too near. I

have sereral times been batulked of photographing solnc other species when I have i nadrert ently hidden up near a Missel-thrush's nest. Both birds have persistent!y mobbed me, and made such an uproal with their harsh. continnous scolding as to plainly betray my presence to every bind within hearing.

'The Song - thrush, in spite of the enomous 
number of its nests which are destroyed by boys and remin (one is almost tempted to write "boys and other vermin") in the early part of the year, is still one of the commonest of our native birds. In the early hours of the morning. and again in the evening. it momts to the topmost spray of some tree and pours forth its pleasant song. 'This is but a simple melody, mostly made up of repetitions of single notes. in which traces of almost articulate speech can be detected.

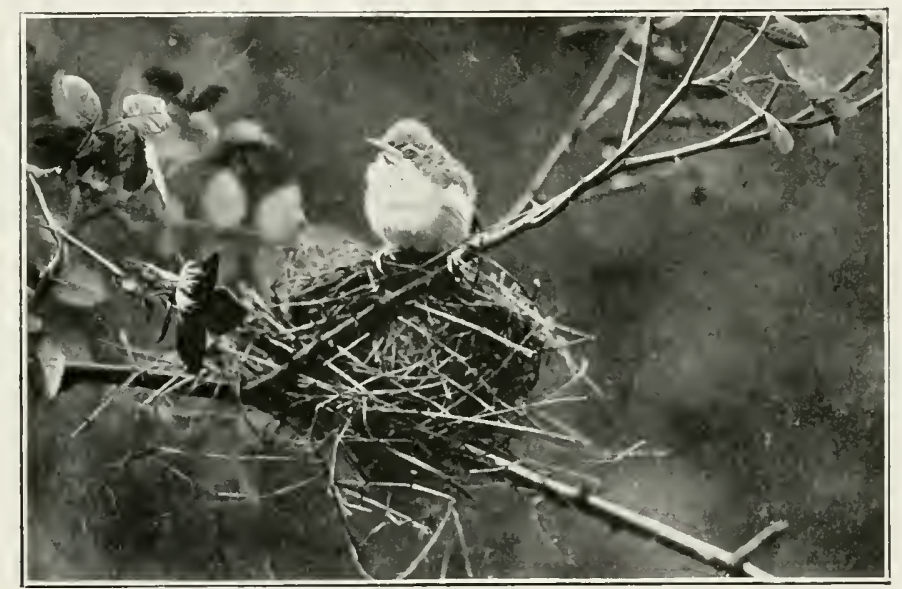

Young Lesser Whitethroat (Sylvia curruca).

One bird repeats, "Did he do it! did he do it?" and another, "Cup of tea. cup of tea." over and over again. But so pure and fresh is its roice, and so clear and melodious are its notes. as to earn for it the admiration of all. Its rank as a musician is so fully recognised, even by science. as to be shown in its scientifie name-T'urdus musicus: and not only so, but it has earned for its fimily the foremost place in the scientific order of birds. as embodying the highest 


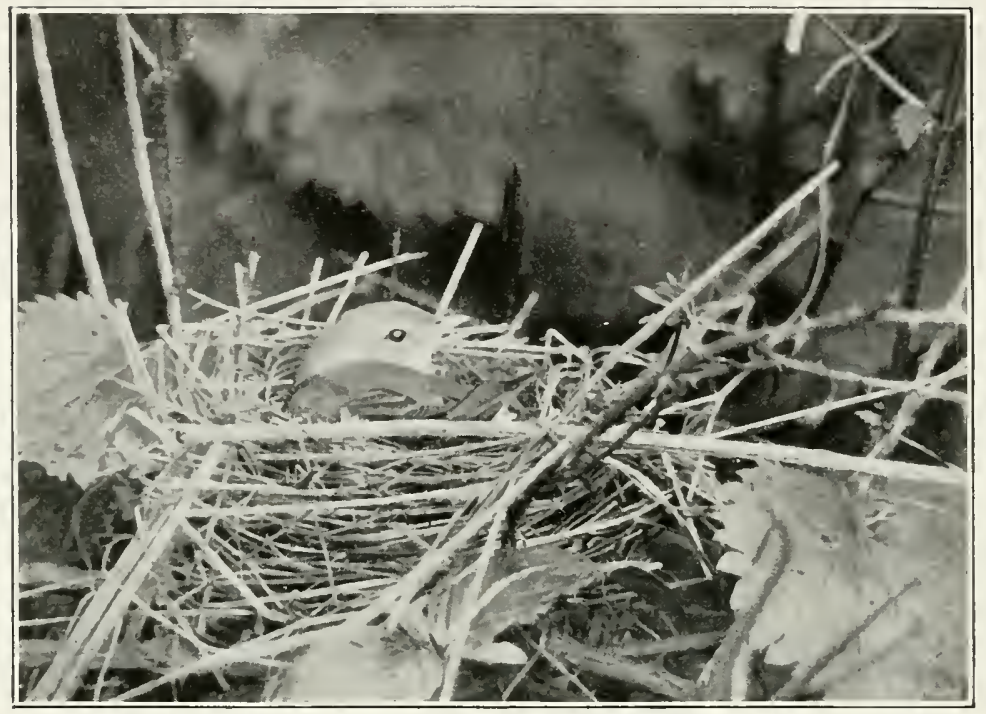

GARDEN-WARBLER (Syluia hortensis).

type of arian derelopment. 'The family of 'Thrushes now heads the list of birds. arie Eagles deposed. Art has trimmphed orer strength.

The nest is so well known as to be familiar to everybody : and in the earlier months of the rear-for no bird begins to nest earlier than the 'Thrush - it is frequently made as though the bird rather conrted observation than desired to conceal it: and the lovely blue eggs spotted with black are ruthlessly taken by the first boy who passes that way too often only to be smashed at once. out of sheer mischief and love of destruction. Only a rery small proportion of the first clutches of eggrs can ever be hatched: but luckily the birds have several broods. and the later nests. made after the hedges are in full leaf. have a better chance of being unobserved. 
Like so many other timid birds, it shows considerable courage in defence of its young. (One day last year. passing along a hedge-side. I heard a 'Thrush in distress. and found the motherbird doing her best mavailingly of course - to drive away a pair of marauding Jackdaws, which were bent on derouring her half-fledged young. One youmg bird hat to be killed to put it out of its pain. the black robbers having pecked large holes in its plump and tender body. (On returning some bours later. the empty and bloodstained nest showed that the villainous Jackdaws, undeterred at being driven off; had retumed as soon as my back was turned. and had completed their nefarious banquet.

On another occasion. while waiting for a Nightjar to

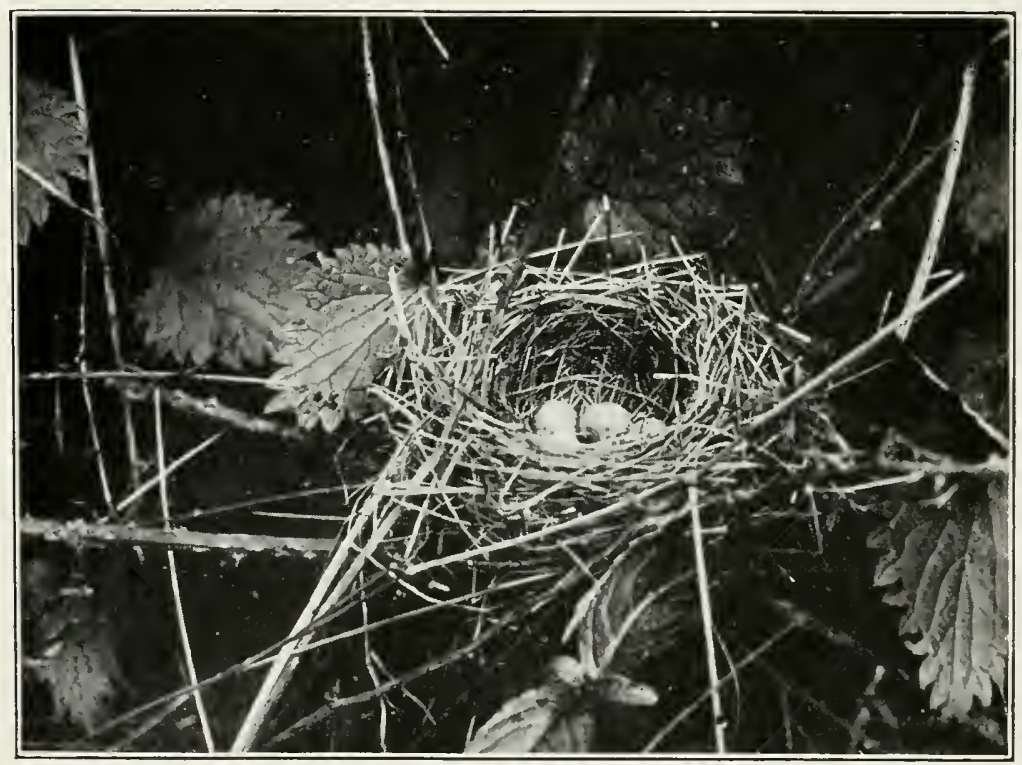

Nest of GARDEx-WARbLeR (Sylvia hortensts) 
return to her two eggs. a Thrush. Which had a nest in al neighbouring bush. saw the Nightjar Hitting about. and so hustled and drove it about that it took refuge almost between my feet. and remained there quite a comsiderabie tinle.

The nest is arefully and curiously made, being finished off' with a lining of mud and cow-dung. monlded by the bird's breast into a deep. ('np-like form. and then rubbed orer with powdered rotten wood. Why the birds should take the pains to make such a watertight nest cannot be explained. One would suppose that a looser comstruction. which would allow the rain to drain through. would he much more practically useful. 'Two or three days are allowed for this lining to set and harden before the egas are laid.

'The Thrush is essentially a bird which follows cultivation: fields and gardens are more to its liking than moors and wild. barren situations, where the Ring-ourel takes its place. Its faromite locality is a large garden. with a good expanse of well-kept lawn. and plenty of shelter in the form of lamel and evergreen bushes and shrubberies. Hours before the gardener is up and about the 'Thrushes are hopping orer the lawns, and scratching the fallen leaves and damp places for worms. slugss, and smails: the shell of these last are eracked by being banged riolently against a stone. For these useful services, carried on most industriously all the year round. and for the chorus of bird music daily for a great part of the rear. it is surely entitled not only to protection and safety. but to a share of the finit in 
due season. If it takes a few strawberries when they are ripe. surely it has fully earned them by keeping the beds clear of slugs and caterpillars and other insect pests throughout the year. 'Too many of us accept their services. and enjoy their presence and sweet minstrelsy. but grudge them their fair share of the produce they have helped to

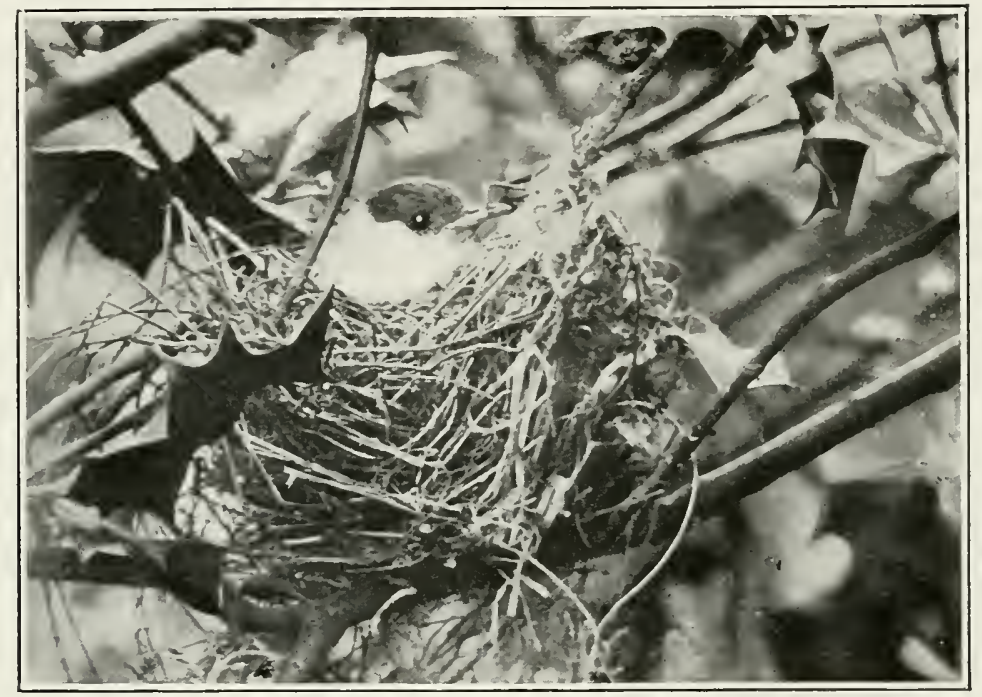

Hen BlackCap (Sylira atricapilla) on Nest.

raise. It would be just as reasonable to expect the gardener to work without wages.

Though a resident with us throughout the year. the 'Thrush appears to be subject to migratory impulses from one part of the country to another, and immense numbers aross the sea.

The Redwing and the Fieldfare are only winter risitors. arriving regularly every autumn from their Scandinavian 
homes, and remaining with us well into the summer. long after our resident 'Thrushes have begun their nesting operations. Iike all hirds which breed in northern latitudes, they appear to know perfectly well the difference in the seasons in their summer and winter resorts. and are nerer deluded by warm weather here to take a too early departure. only to find themsclves without food in a region still covered with snow and ice.

Enlike some birds which visit us from wild and nuinhabitated districts. these birds are remarkably shy and wary - the Fieldfare particularly so- and do not readily allow a nearer approach than about a hundred yards. When this limit is reached, the whole Hock. which has been clustered on the topmost branches of some high tree. fly off to another. about fifty or a humdred yards farther on. each bird uttering its lond alam note-."Chack. chack!"- as it takes wing. 'This note can be heard high overhead when large flocks are on the move from one part to another. and dombtless serves to keep the flock together. as each bird proclaims its whereabouts, and stragglers can trace the progress of the main body.

'The Blackbird is another frequenter of gardens and cultivated fielas. and there are few lawns where the *- Ouzel cock so black of hue " may not be seen. before the morning" dew is off the grass. hunting for worms and slugs. With what intentness it listens, its head on one side. and the bright. lustrous, orange-rimmed eyes eagerly scanning the grass! 'Then with a spring it hops forward. and the 


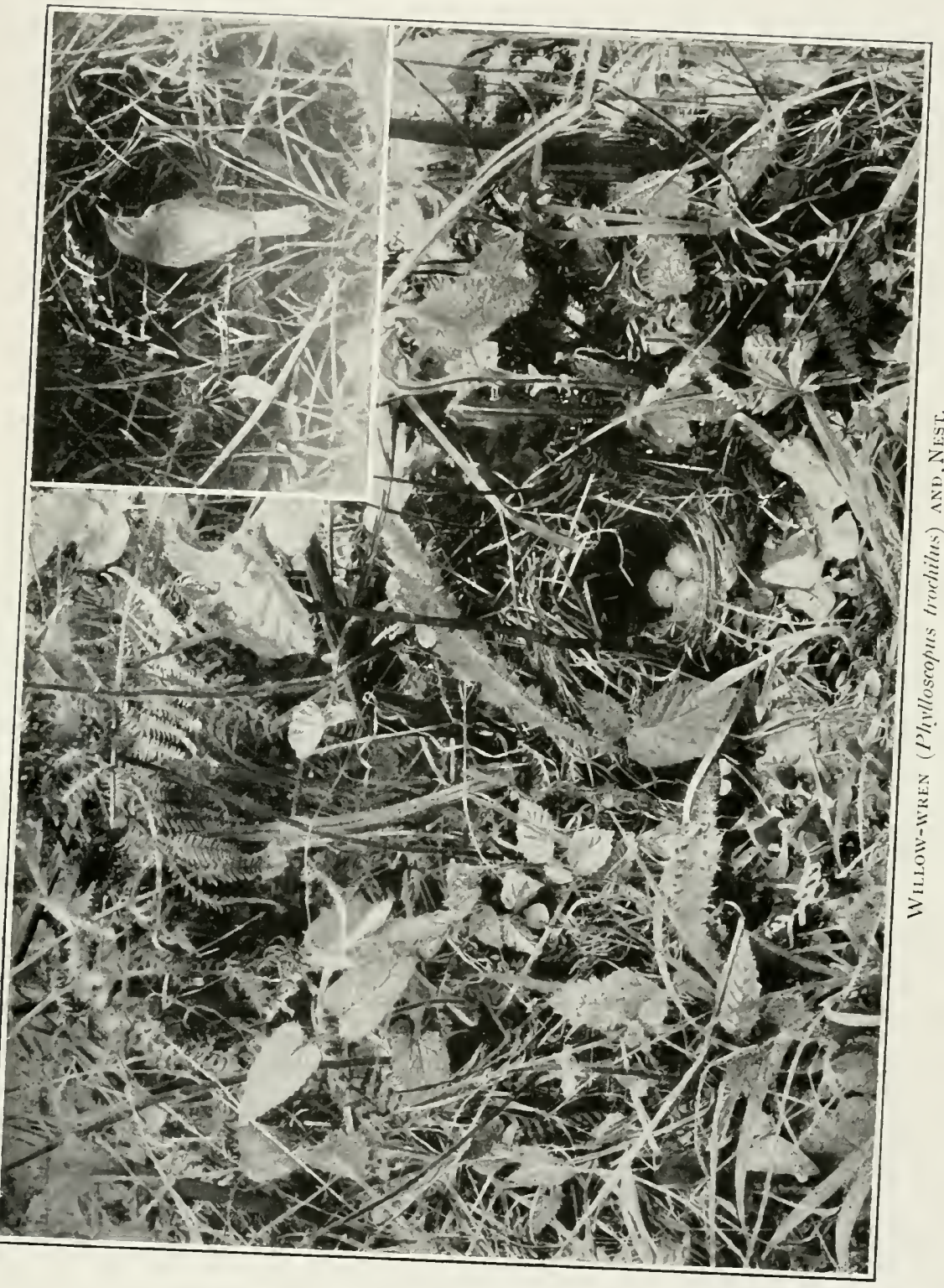


(it

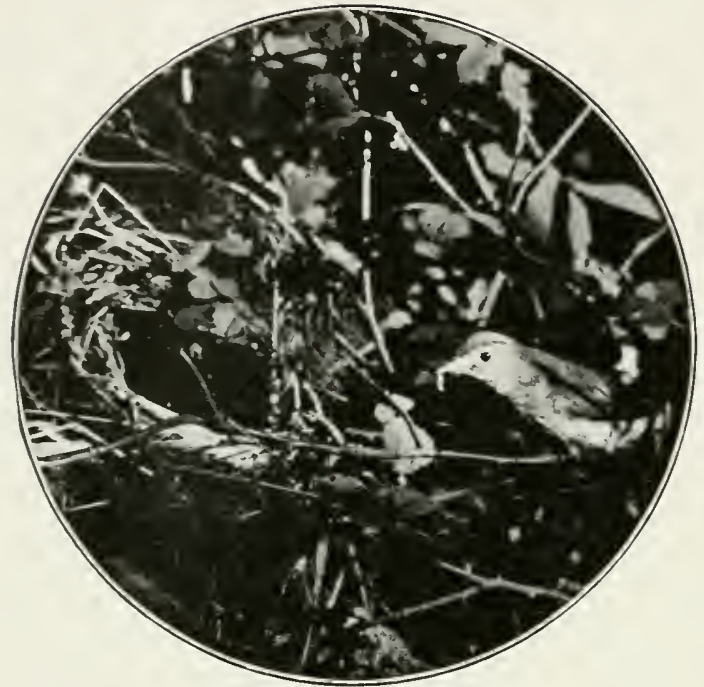

Willow-I Rex at Nest.

\section{Pictures of Bird Life}

luckless worm is seized by the orange beak, dragged out. and promptly swallowed, despite its convulsive wriggles and squirmings.

Sharing the labours of the 'Thrush, it also shares the rewards. taking its tithe of ripe strawberries and (cherries. 'To me the fairest and bestkept garden in the world would secm but a barren wilderness witlout such glimpses of bird life.--the Blackbird and 'Thrush on the dewr grass: the Robin. with its bold and sprightly familiarity: the sober Flycatcher. performing its quiet but useful services throughout the long summer day: the burnished Swallow. on tireless wings. sweeping to and fro so unceasingly : and the lovely Martin, twittering happily in its mud nest under the eares. 'The presence so near our houses of such graceful visitors as these ought to be looked upon as a privilege and a constant enjoyment. without taking any account of the undoubted good they do in devouring grubs and insects.

The Blackbird is. too. a most accomplished musician. and its mellow flutings are by some preferred to the song of the 'Thrush. By its constant vigilance, and its loud. rattling alarm-note. which gives waming to all within hearing that danger is approaching. it merits the title of 


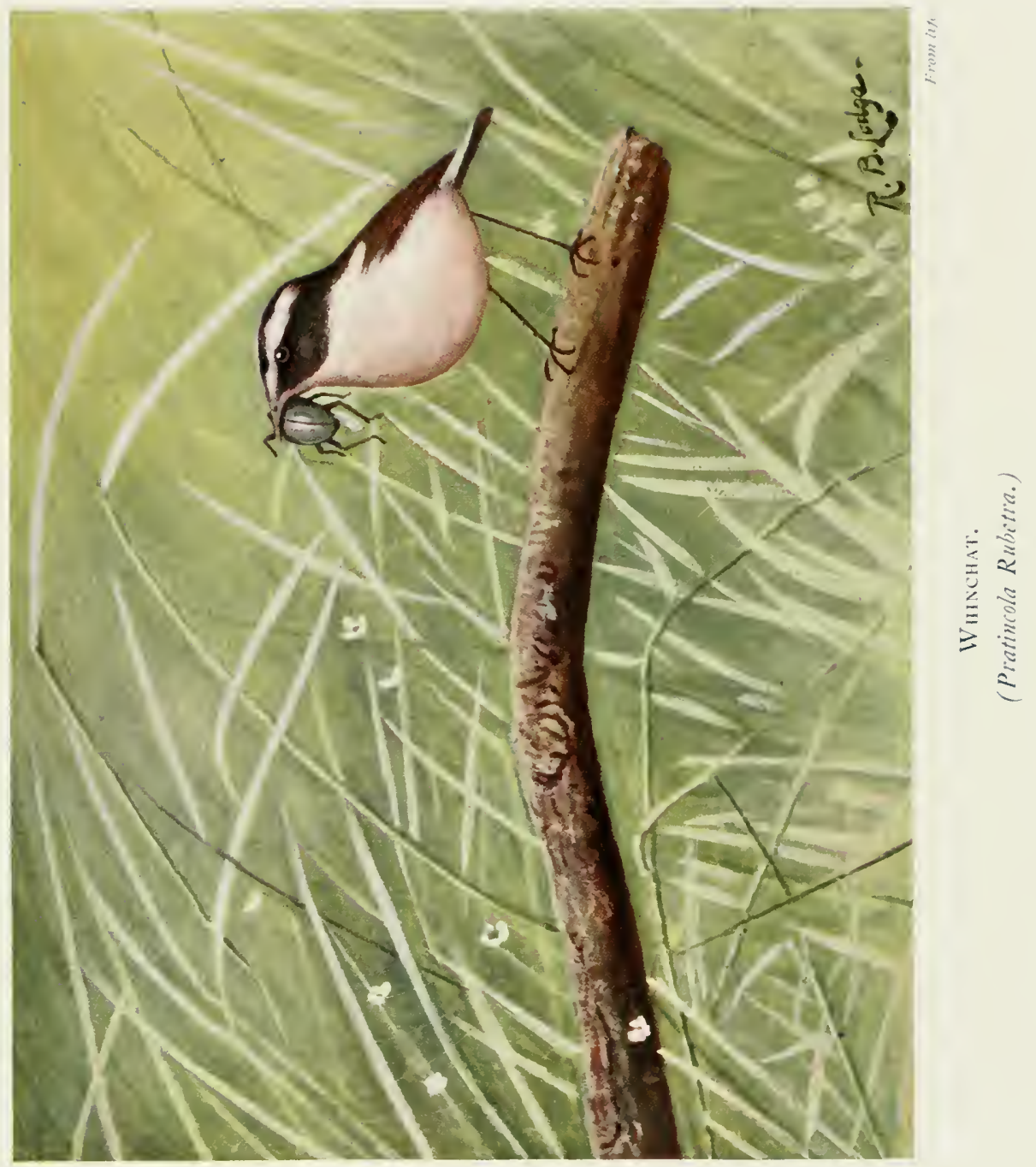



the "scutinel" of the ficlds. Many a promising ".stalk." with both gun and ameral, lass been baulked by its timidity and unceasing rigilance.

The Stoncellat is very scarce and local. and I only remember secing two or three about. and have never yet succeeded in finding a nest. In the next parish, however. of Edmonton. it is a common bird. Numbers may be seen

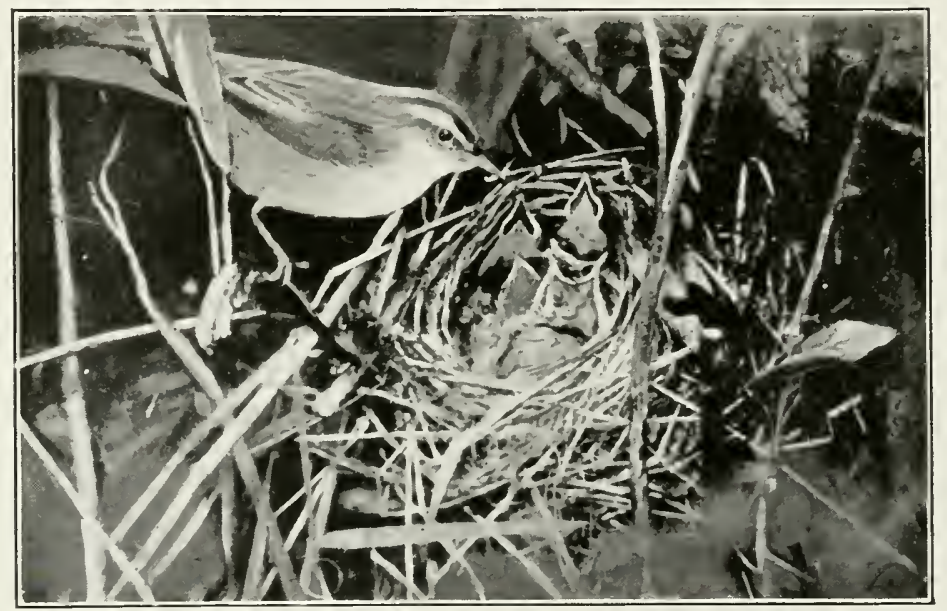

SEDGE-WARLLER FEenixg Yousg (Acrocephalus phragmitis).

in the cemetery there any day throughout the smmmer. and I feel sure that they nest in the long grass at the sides of the graves. 'The birds themselves are fond of sitting on the grarestones. This cemetery is quite a firourite resort for birds: the following species breeding there to my knowledge - Lark. Meadow-pipit. Blackbird. Thrush. Pautridge. Red-legged Partridge. Cirrion-crow, Martin. Swallow. Hedge-sparrow. and Cuckoo. 


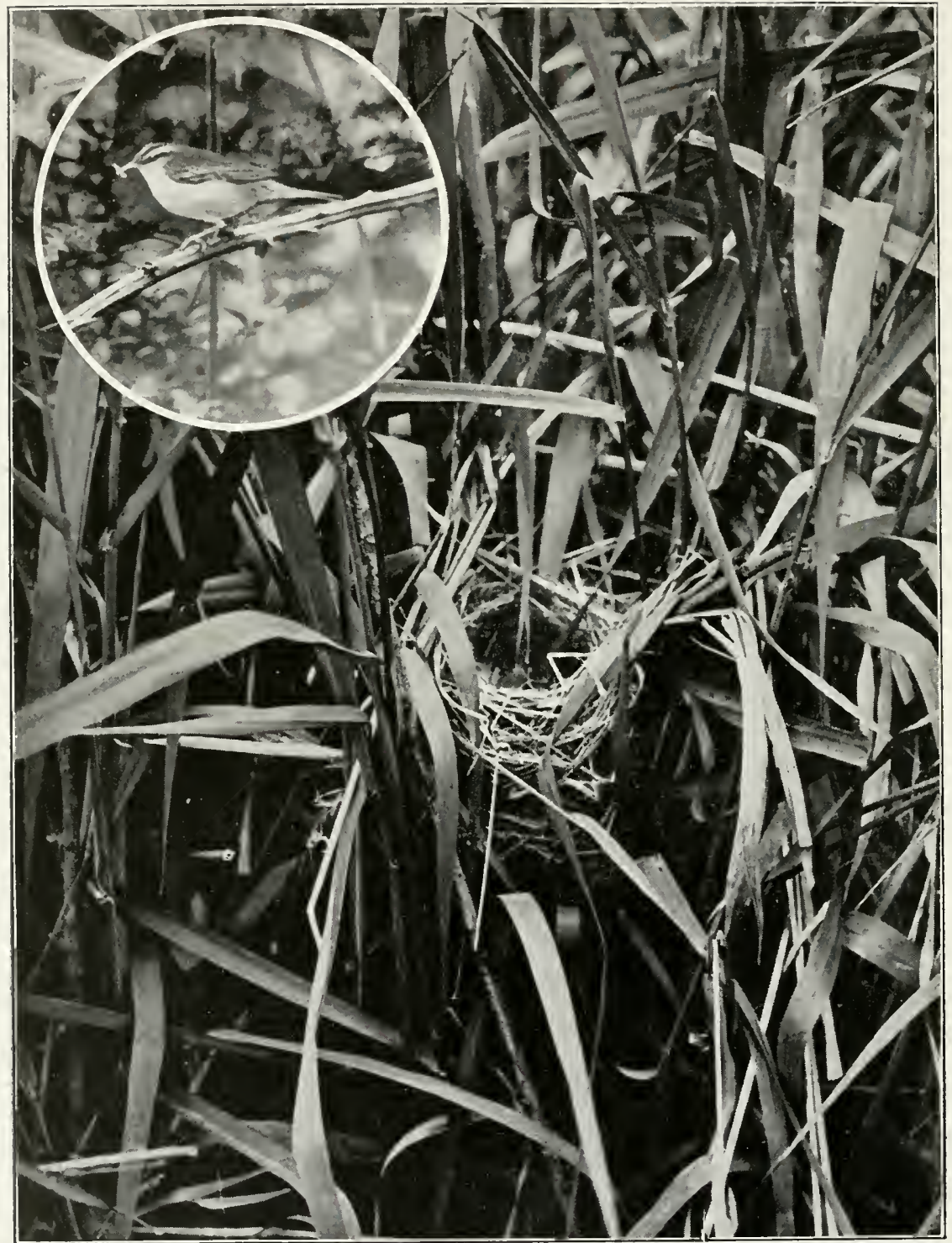

Sedge-WARBLer (Acrocephalus phragmitis) ANd Nest. 
'The W'hinchat, on the contrary, is excecedingly abmondant infict, quite one of the ('ommonest birds. In crery ficld and meadow a pair or two of these sprightly and handsome little birds maty be seen Hitting fiom the top of some low plant or spray to another. The note solunds like - I tick-utick. utick - tick - tick, incessantly re-

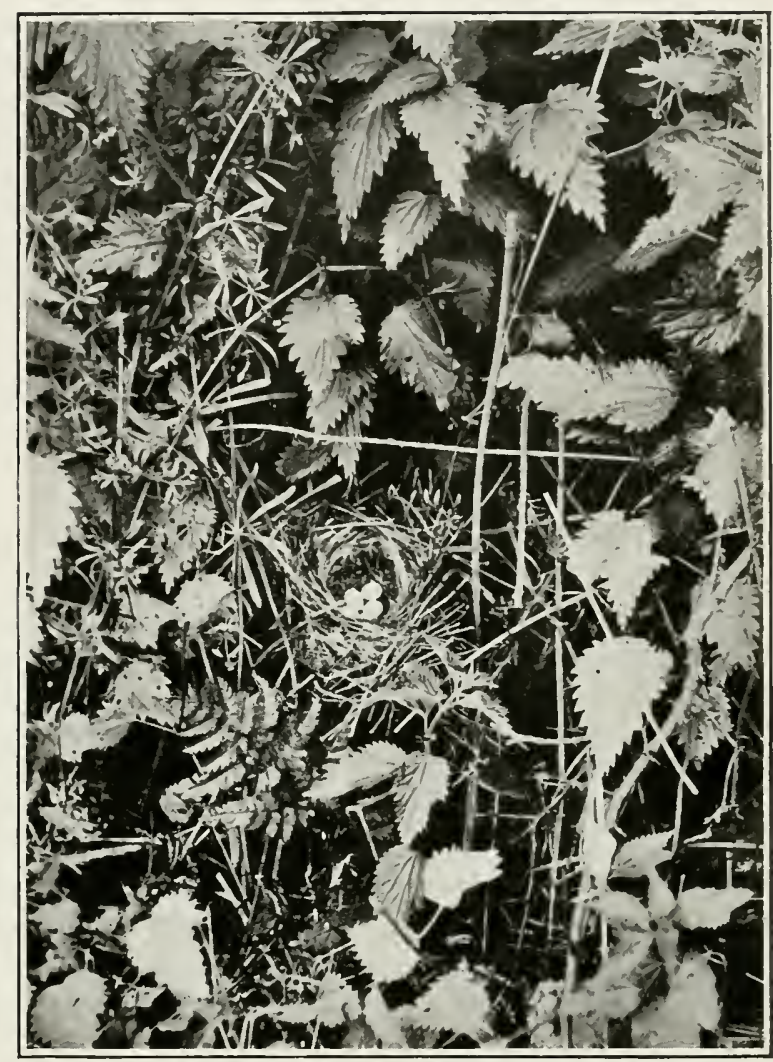

NEST OF HEDGE-SPARROW (Accentor modularis).

peated, and that of the young just after leaving the nest is just like - Egypt-ligypt." 'Their nest is one of the most difficult to find. so well hidden is it anong the long grass. It is generally, or at all events rery often. placed at the foot of some little sapling or upright plant, which serves as a perch for the birds.

One pair. which had a nest of young underneath a fallen branch, always perched on one end of it every time 
they came with food. This fact once ascertained, it was comparatively easy to photograph them firom the shelter of a bush not many yards away. (On one such occasion an extra large mouthfinl was plainly visible in the beak of the bird. but not until the plate was dereloped did I guess the nature of it. It proved to be a large beetle-a most indigestible-looking morsel for nestlings: but I suppose the bird might be trusted to know its own business best.

Another pair became very tame. finding by experience that I was not dangerous, and I made a series of exposmes eventually at a distance of not more than two yards in the open. without any attempt at conecalment. 'The cock was in this ease much the bolder, contrary to my usual experienee. So tame did he get. that eventually he would come and sit, just in front of the camera, on different twigs stuck in the ground for the purpose: and I finished up by photographing him as he sat on the handle-bar of my bicycle.

For these photographs I used the latest development of camera for this work-ivis a tele-photo lens and a short reflecting cameral, mounted on a gun-stoek. 'This is a much handier weapon than a camerar on a tripod in following a bird about in its movements from place to place and from twig to twig. When using the tripod in photographing a moving objeet at short distance, the readiest way is to place the point of one tripod leg-the back one- on the toe of your boot. 'Ihen. by moving your foot backwards and forwands, the camera can be raised and 


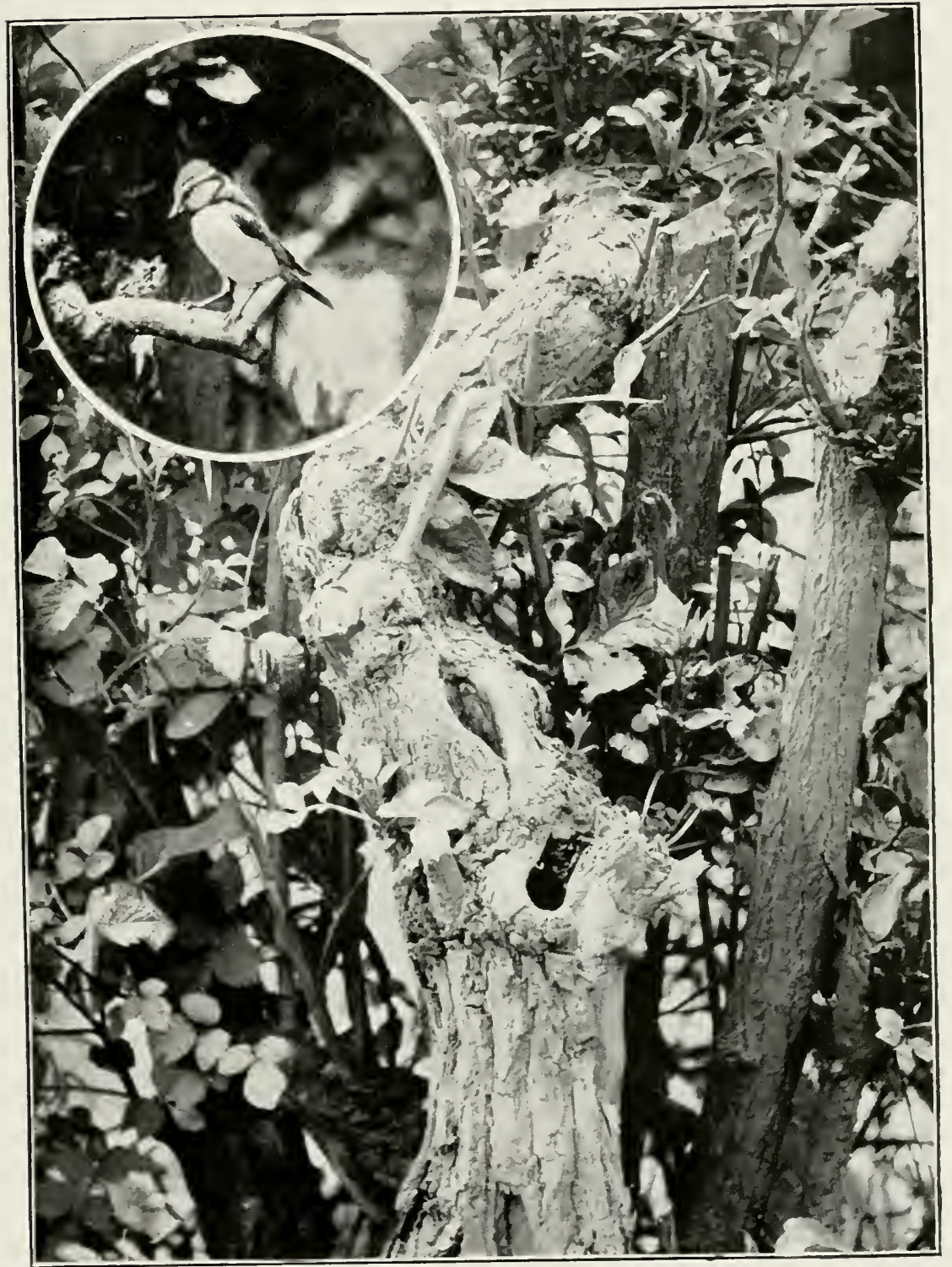

Blue Iit (Parus camleus) and Elder-stump Contaning Nest 
lowered with greater ease and speed. and with less noise and risk of slipping. and it leares you a hand free. 'This

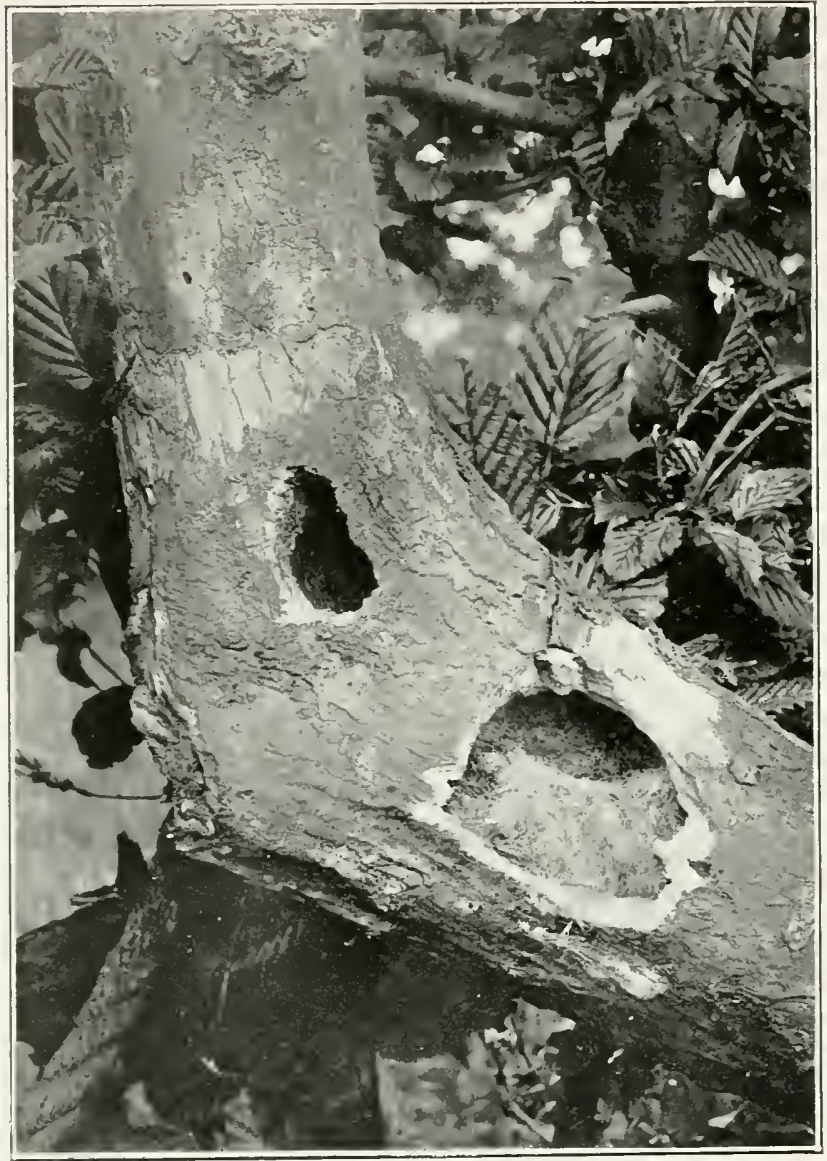

Nest of Marsh-tit (Parus pulustris). Hole excavated by Bird Clt OPEN to SHOW Nest. alone is a great adrantage. I could often find a use for three or four hands. and a spare eye or tro would be usefinl.

II anipulating a wholeplate camera up a tree. for instance. $\mathrm{Or}$ O 11 a $1011 \mathrm{~g}$ ladder. is very often an awkward bit of work, a $11 \mathrm{~d}$. single-handed. maly very well take orer an

hour's hard labour before you can get satisfactorily focussed. 'I'o obtain the photograph of the spotted Flycatcher's nest on page $8 \%$, the spike of one leg of the tripod rested on 
the topmost rung of the ladder. and was there lashed with string. the remaining two legs being lashed to orerhanging boughs of the tree-an oak. As these boughs were thin, and mored firecly with the slightest motion. focussing was no easy job, especially as I had to stand on the ladder and lean backwards to look into the focussing-glass. The only hold within reach being the same thin boughs which held the legs. the operation was somewhat of a shaky onc, and the subsequent work of putting in the double back and withdrawing the slide had to be performed with no hold at all, both hands being occupied. Ender the eircumstances I was rather surprised that the negative was any good, especially as the f.:32 stop necessitated an exposure of ten seconds. And this was only an ordinary case, with no special difficulties about it. A more difficult as well as a more dangerous work was the photographing of a Barnowl's nest at the top of a thirty-foot ladder. Idcaning backwards to focus, my weight was entirely supported by the extrene tips of two fingers on the edge of the hole (I could not reach with the other fingers). while the other hand worked the focussing-screw. 'To cusure getting at least one good negative, I tried to expose both plates, and, owing to the difficulty of the situation, only exposed the same plate twice orer. thereby spoiling both!

'The Redstant is often met with. though it can hardly be described as common. It is a comspicuously beantiful bird. and the nest is sufficiently scalce to be worth finding. Holes in old apple- and pear-trees are farourite plances: the one shown 
was in a sycamore-tree, at a most convenient height from the ground. 'The six eggs were exactly as they appear in the photograph, plainly risible from the outside, which is not

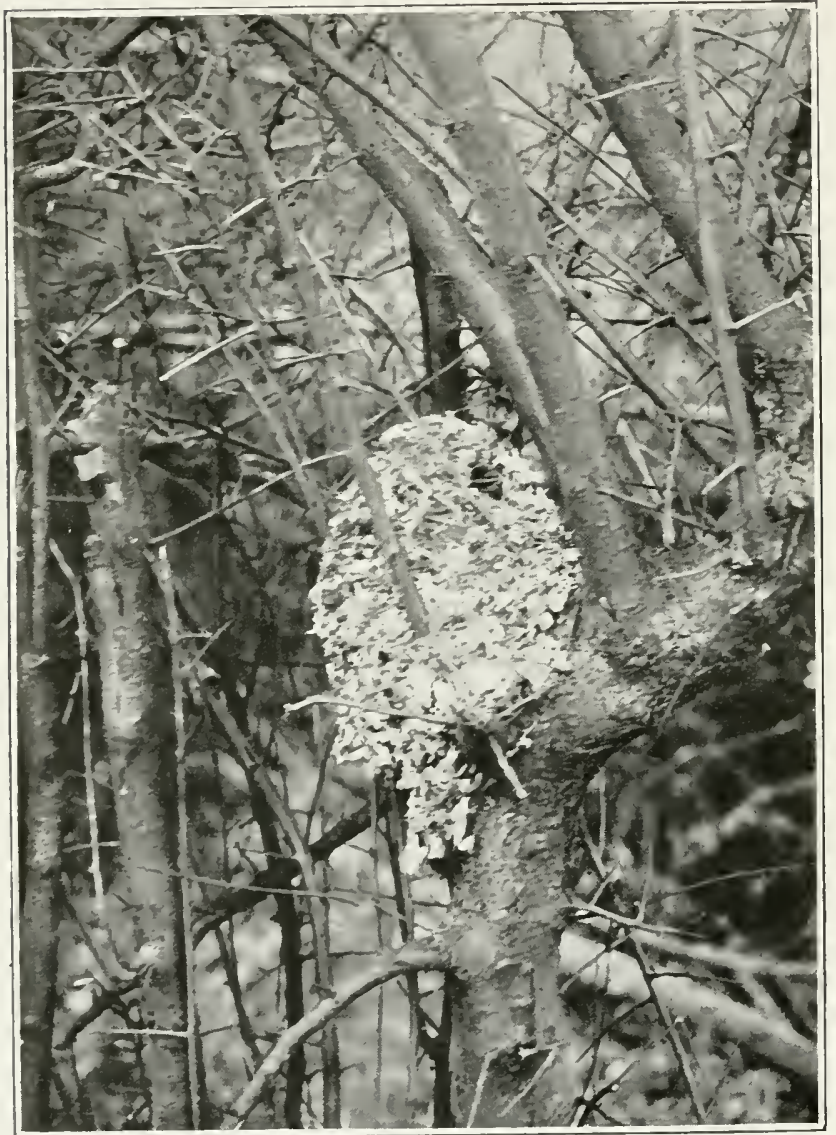

NEST OE Long-Tailed Tit (Acredula.caudata).

usually the calse.

'The Redbreast is without doubt Tre bird of the suburbs - the universal and favoured firequenter of every garden. Its cheery song during the winter, when other songsters are silent, and its familiar boldness, make it a welcome guest with everybody, and one pardons it for its greediness and pugnacity. 'Two rival Robins will fight with a fierce disregard of consequences almost incredible in a bird of such small size. 
'The Robin may, with a little perseverance, be induced to feed from one's hand, and to enter a room through the open window, and its ways are then very engaging. It is always a mystery to me how it escapes the claws of the prowling art. While nesting operations are in progress, howerer,

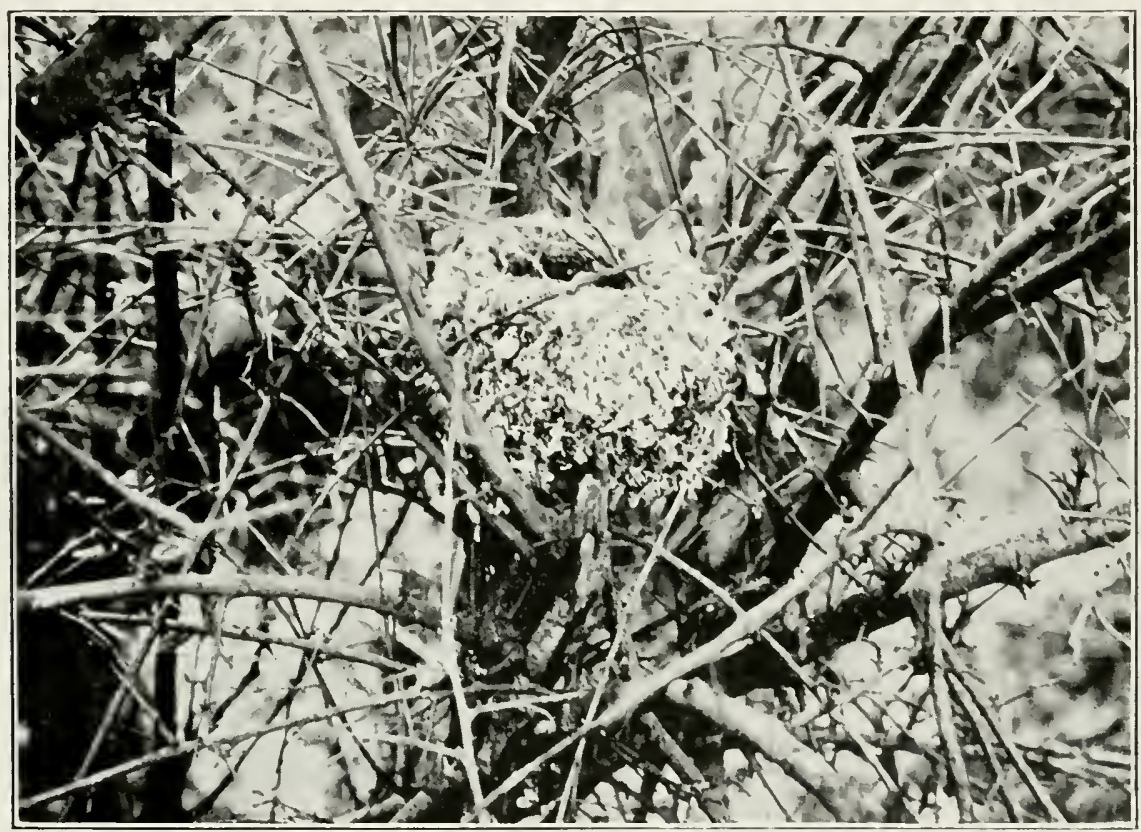

Half-made Nest of Long-talled Tit (Acredula caudata).

it is, like many other birds, much quicter and less conspic'uous.

Gardening operations, and especially digging, interest Robins not a little. An infallible way to bring one within reach is to take a spade and dig a few spadefuls of earth. 'Then leare the spade sticking up and retire a little. If there is a Robin anywhere near, it will certainly (‘ome and search orer 
the up-turned earth for worms, and afterwards it will as certainly sit on the handle of the spade. If a camera be left. focussed on the handle. and a long string or tube be fitted to the shutter. you may get a photograph of it. provided the shutter is a noiseless one. otherwise the result will be failure. 'The first time I tried it, the Robin did all I expected of it : but although the shutter was set abont the twentieth or thirtieth part of a second. fire exposures only secured me five photoglaphs of an empty spade-handle. This will give an idea of the lightning quickness of a bird's morements: at the click of the shutter it had hopped off quickly enough to aroid being taken.

The Nightingale is a very abundant species. much more so than people in general seem to imagine. (On their first arrival. before pairing. and also after the young are hatched. these birds make a curions croaking noise, like so many

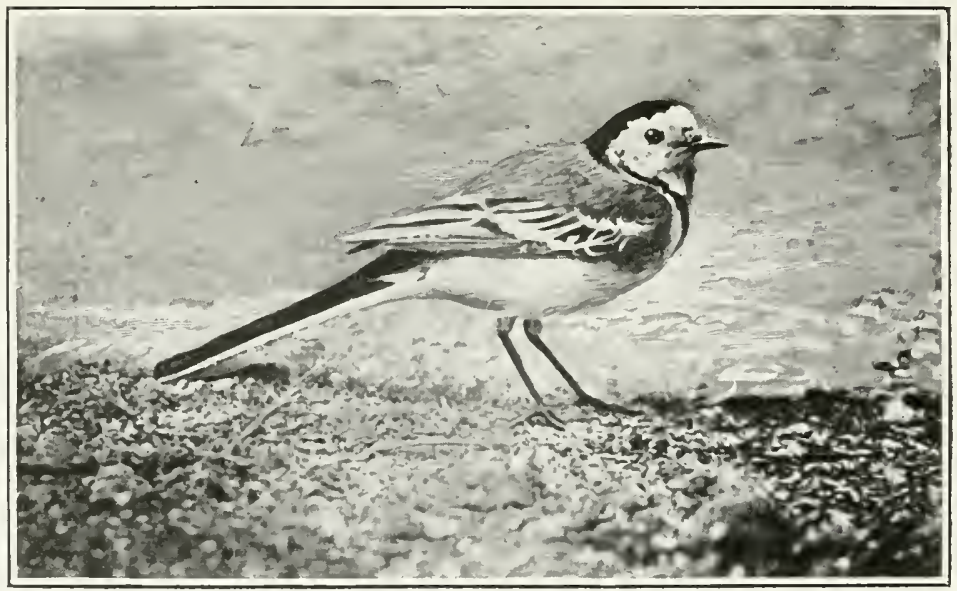

Pied Wagtail (.Motacilla lugubris). 


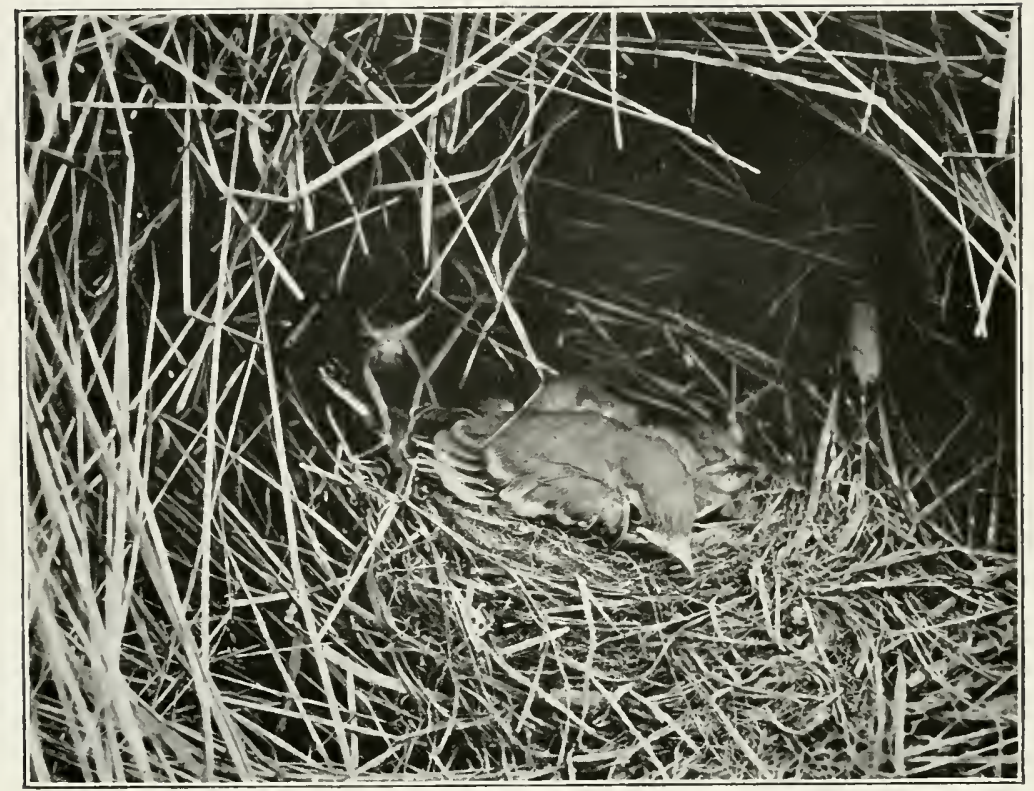

Pied Wagtallos Nest with Young (Molacilla lugubris).

frogs. 'Their song may be heard in every direction in the fields and in many of the gardens, not only in the evening. but at all hours of the day. The quite mistaken notion that it only sings at night is probably traceable to the poets, who are also responsible for the idea that the song is of a melancholy nature. This maty be perceptible perhalps to the poetic mind. which may be and probably is. more sensitive to minute shades of expression than that of ordinary folk : to me the song seems the result of intense joy.

Poets are, in finct. not to be trusted. however much they may be admired. The truth is not in them and eoncerns them not. $A$ good rlyme or a well-rounded sequence of 
words is more important to them than the mere truth of any faet.

I think it is Mrs. Hemans who writes of the sky-blue eggs of the Iark! 'Temyson is more poetic, and also more correct, when he writes:

\section{As the music of the moon}

Sleeps in the plain eggs of the Nightingale.

And even 'Temnyson is not altogether perfect. Some of his

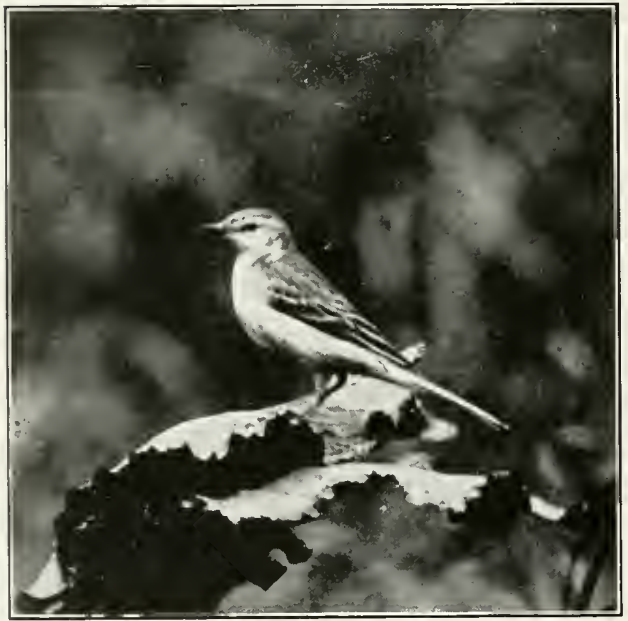

Y'FLlow W Wagtail (Notacille raii). allusions to birds are, however, particularly happy. What, for instance, call be more true than the line

As careful Rolins eye the delver's toil?

You can almost see the redbreasted firourite of rhildhood, Cock - robin. watching with sidelong glance and bright black eyes the spadefuls of earth thrown up by the gardener, and pouncing eagerly on luckless worm or earwig as soon as meorered.

Or, as a forecast of spring, what could be more fitting than The building Rook 'ill caw from the windy tall elm-tree, And the tufted Plover pipe along the fallow lea, And the Swallow ill come back again with snmmer o'el the wave?

Nightingales, though shy and retiring, may be easily 


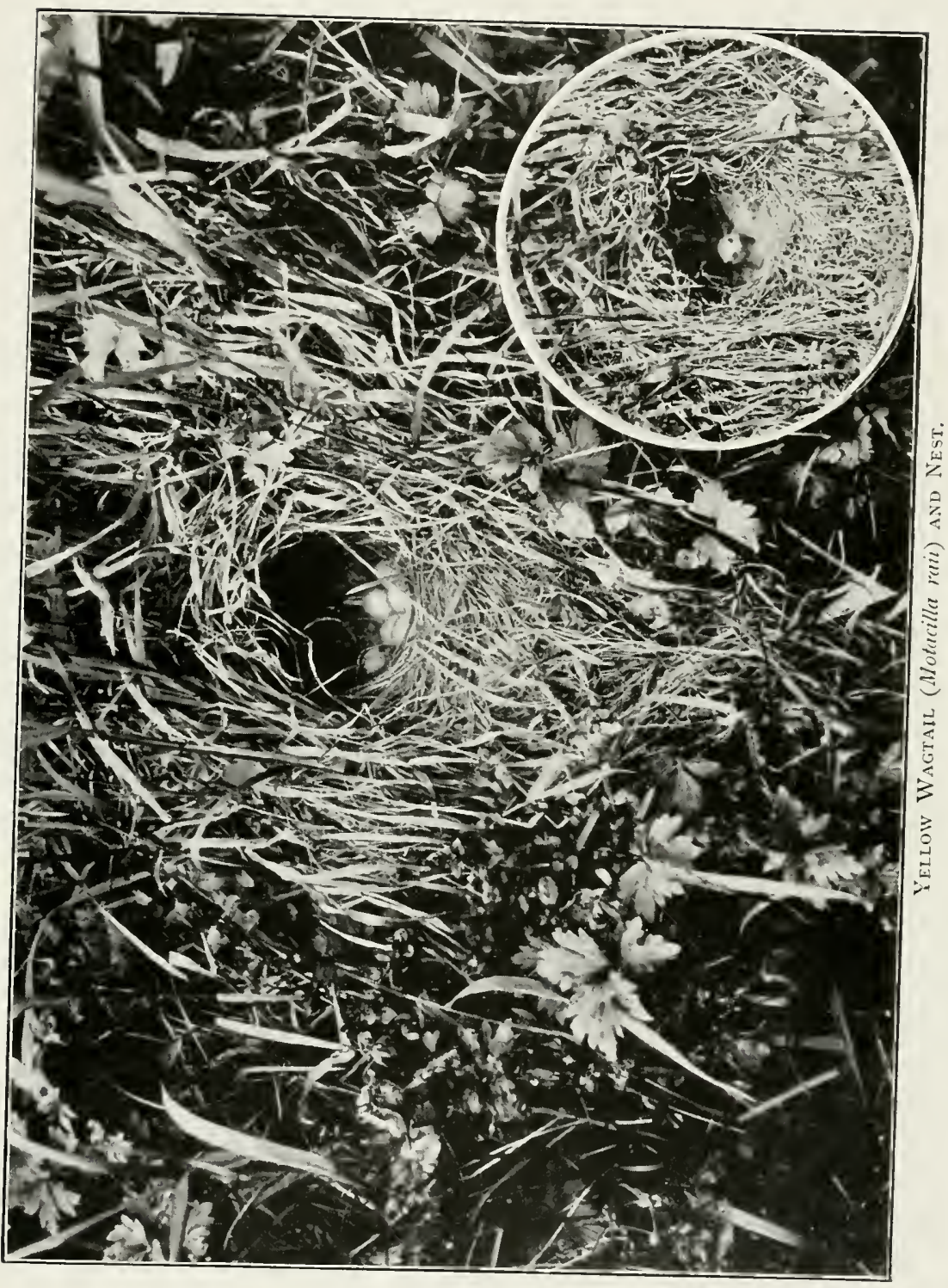




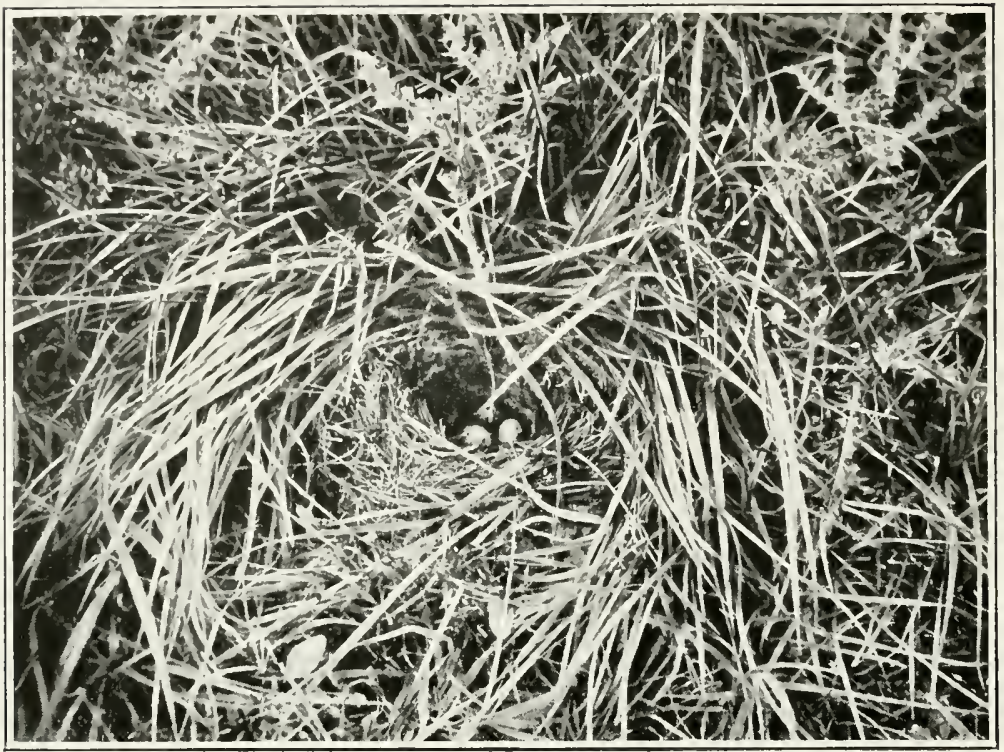

Nest of Meadow-pipit (Anthus pratensis).

watched. especially when the young are hatched and the parent birds are busy supplying them with insect food. I have had a close and friendly aequaintance with more than one pair. and have photographed what I have some reasons for supposing to be the same pair for two suecessive summers. 'The second nest was situated a few yards away from the spot where they had successfiully reared a brood the previous year. On the first attempt. I had to wait in a ditch eorered over with a green cloth for seren hours before the motherhird appeared at the nest. On their second visit they appeared to recognise me as a friend of the family, and laid aside so much of their usual timidity that I did not go through the formality of the usual careful concealment. Though equipped 
with a most alamming-looking (:ancra, they visited their nest to feed their yomng quite openly and fearlessly, and enabled me to get several photographs within half an hour.

It is a delightful expericnce to thus watch at close quarters the whole domestic economy of such interesting birds, and to see the mother-bird flit from spray to spray in her search for caterpillars and insects. 'They are most particular in keeping the nest clean. searching it after every risit, and remoring in their beak the refuse of the young birds. Hying right off and dropping it many yards away.

'The distribution of the Nightingale in Fingland is anrious. 'Though so common in many parts, it fails to penetrate

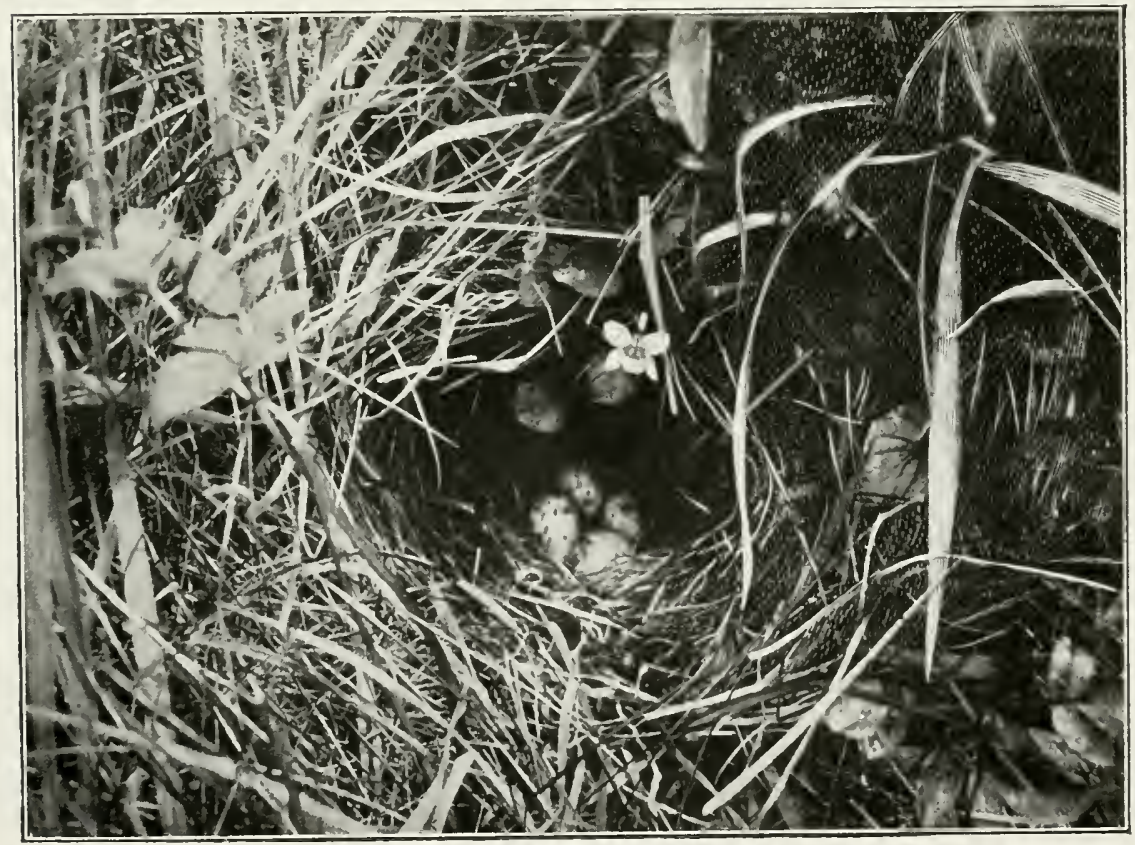

NEST of TREe-PIPIT (Anthus trivialis). 


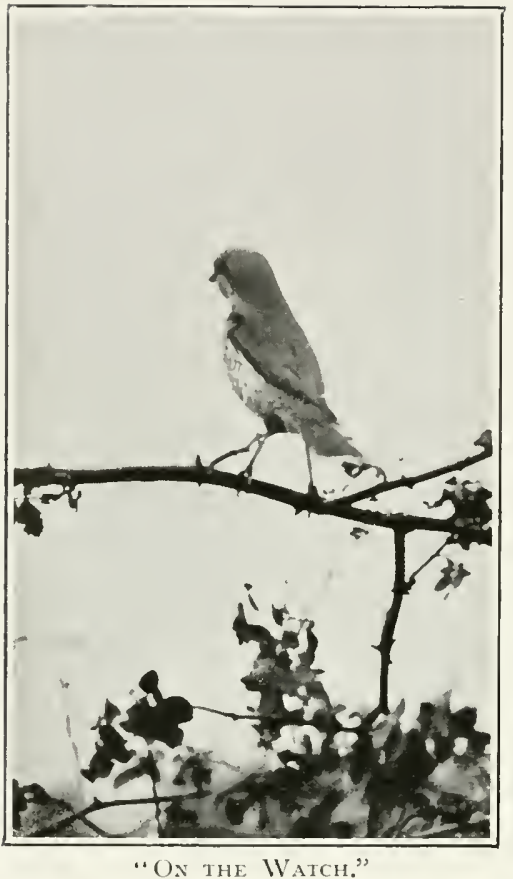

HEN RED-BACKED SHRIKE (Lanius collurio). rery far westwards and northwards. It is only quite recently that it has been recorded fiom Deromshire and Vorkshire. and in one Inincolnshire locality where formerly it was nuknown it now nests sparingly every year. 'The increased range of such a fannous songster is an interesting fact, especially in these days of extermination.

The first thing that strikes one on seeing a Nightingale is its large size and ruddy colour. especially about the tail. In its general appearance and attitudes it is a

tỵpical Robin. 'The same sprightly morements, large bright eyes, drooping wings. and long legs are at once noticeable. 'The roung birds in theil first plumage are also exceedingly like young Robins. and maỵ easily be taken for them.

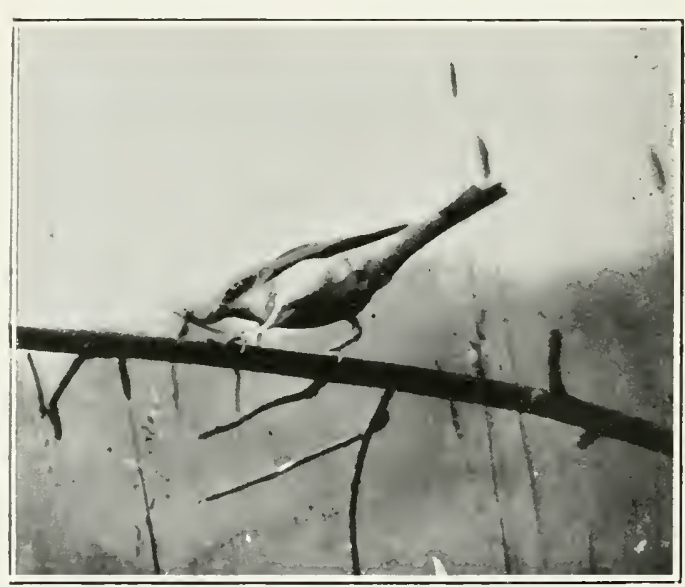

Cock Red-backed SHRIKE (Lamius colluio) SEIZING AN INSECT. 
The nest is really a wonderful construction of dead oakleaves a most intractable building-material, one would think. The rery deep hollow is lined with hair. In such a setting the olive-brown eggs have a unique appearance - in fact. neither nest nor eggrs can possibly be mistaken or confounded with those of any other British bird. It is invariably placed on the ground, and whether in a ditch at the foot of some sapling. or amid the stalks of a dense bed of nettles, it is always well concealed, and only found after a careful search.

'Their song, about which so much has been written in prose and verse, is matchless in its purity and quality. In passionate intensity it is morivalled, and its characteristics are so monistakable that once heard it an never again be mistaken. It ceases after the young are batched, after which the croaking note is the only somnd uttered.

'The most common of all the Warblers, and the one which has the widest distribution, is the Greater Whitethroat. From its partiality to nettle-beds it is often known as the "Nettle-creeper." and in some parts as the "Ilaybird " or "Hay-chat." It is an unobtrusive little bird both in appearance and habits. and one not often seen in the open, preferring. as it does, the shelter of thick hedges and bushes. Here it reeps about all day, finding abundance of food in the minute caterpillars and other insects so numerous during the summer. So persistently shy and skulking is it that for some years I tried in rain to obtain a photograph : erery attempt. howerer patient. always resulted in failure. But erentually a pair was found nesting 
in a thick bed of nettles. and by visiting them daily for some time they became so familiarised to my presence that I had no difficulty in getting a series of photographs in different positions.

Most hirds. it will be fomnd. approach their nest in the sanne direction. Snall birds like the 11 arblers generally (reep through the thickest of the sumounding regetation in monselike fashion. and slip quietly and silently into the nest from the back. Very often the first intination of the approach of the parent comes from the young birds. which suddenly pop up their heads and open their beaks suggestively. Sometimes from your hiding-place you cam see a leaf or spray quirer as the bird noisclessly makes her way along. Some, again. Hy openly fiom the top of one bush to another. like Whinchats. and other's keep up a constant wailing, querulous note like 11 illow-wrens. But after a little watching you will nearly always find there is some particular branch on which the birds perch every time. The ammera can then be pointed and formsed on the place. all ready for the next opportunity.

'This particular pair of Whitethroats invariably used a bramble-stalk which grew up diagonally. and at the foot of which the nest was placed. Starting at the top. they always arept domn the stalk. gradually assmunge a more perpendicular position till the nest was reached. when. stooping down to feed the young birds. their tails pointed straight upwards. By focussing different parts of this bramble. I obtained a variety of interesting positions, including one 


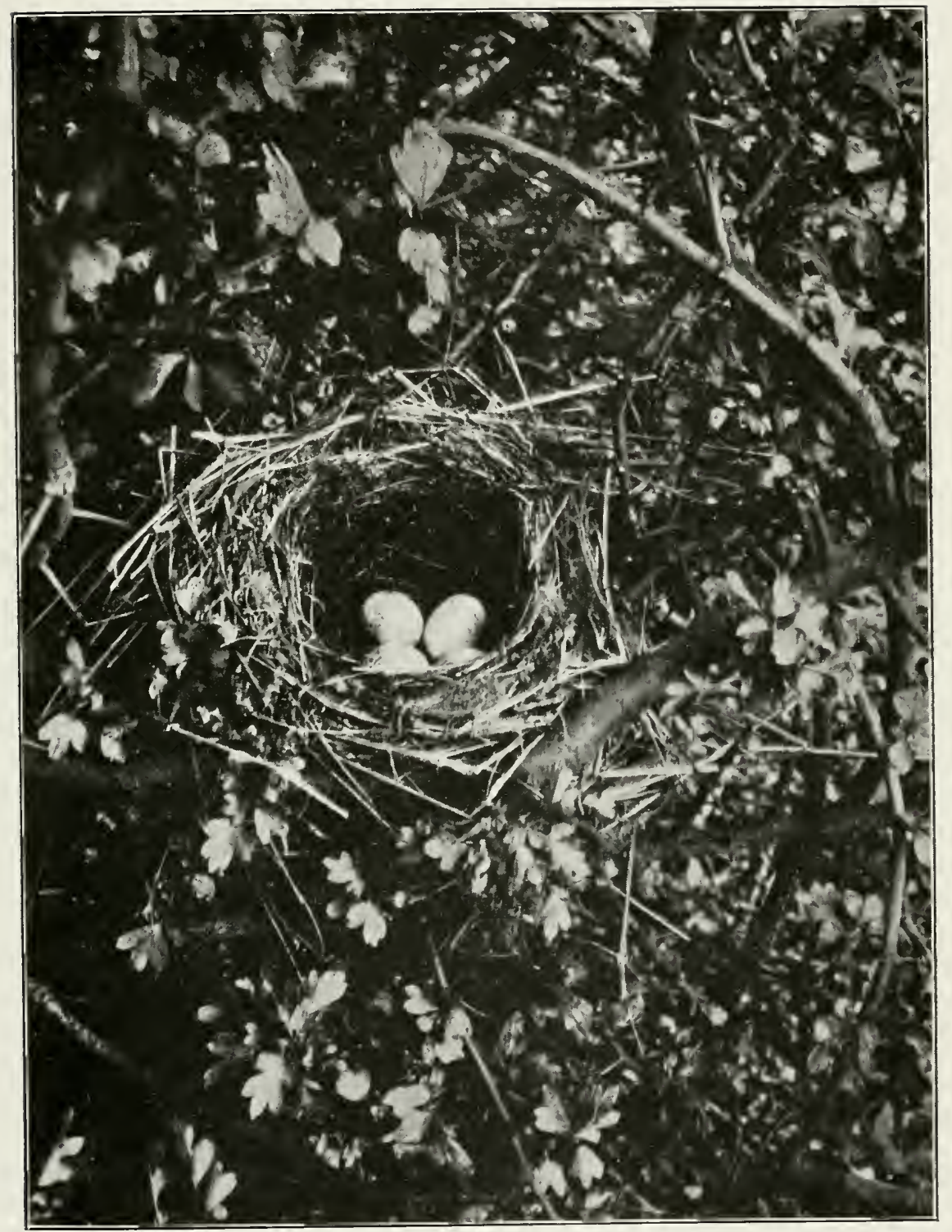

NEST OF RED-BACKED SHRIKE (Lamills collumio). 
showing the old bird's beak and part of her head inserted down the young bird's gapping throat.

'The Isesser 11 hitethroat is distinctly more uncommon than the last species, though several nests are found each ycar. 'They are very similar in construction to the last, but a little smaller, and are very often much higher up, sometimes almost at the top of a high hedge. In such a situation you very seldom find a nest of the Greater Whitethroat, which prefers a more lowy nesting-site among brambles and low bushes. 'The eggs are rounder and smaller, and of two quite distinct types: one, except in size, closely resembles the ego of the Greater Whitethroat, and is of a freckled greenish white: the other is always very round, and the spots are distributed in a zone round the larger end, leaving the rest of the egg almost colourless.

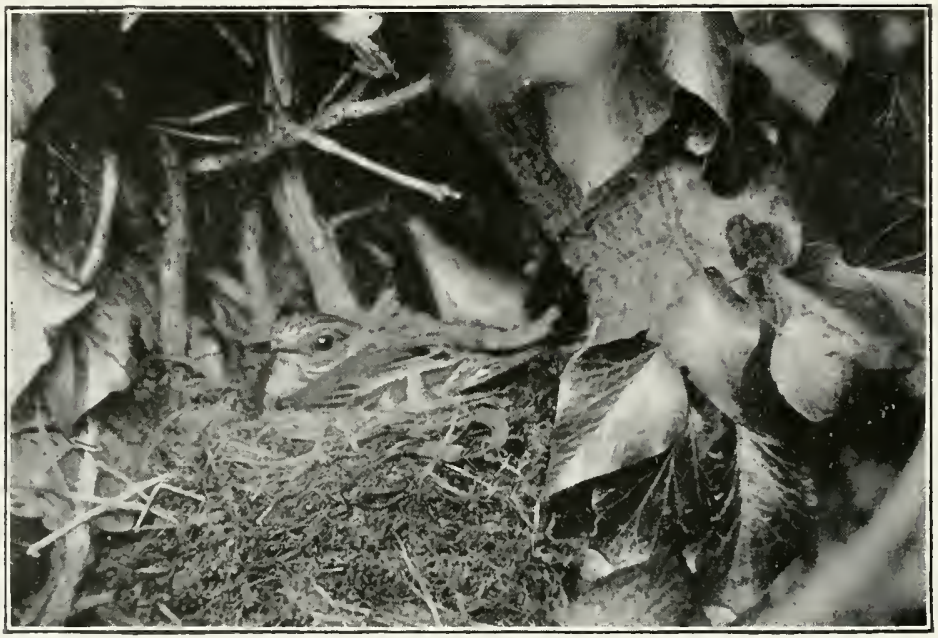

Spotted Flycatcher (Muscicupa grisula). 
'The birds are slighter and more elegant in appearance, and not quite such persistent skulkers. Any close approach to their nest is much resented: the little birds. with erected rests and excited actions, will follow an intruder, vigorously scolding the while with harsh and chiding note.

The Garden-warbler in some seasons almost rivals in numbers the Greater Whitethroat, 1898 bringing an unusual number of these birds to our neighbourhood. 'The nest much resembles those of the two former species, but is perhaps a little more shallow. A favourite locality is among the bare, leatless stems of bramble, below the thick cover of green leares which clothes the outside of the bush, and roofs in, as it were, the space below. The eggs, howerer, are much more like those of the Blackcap-in fact, it is sometimes impossible to distinguish them. I have seen it somewhere stated that the Garden-warbler and the Blackeap are never found in equal abundance in the sime place. Here, at all events, facets seem to bear out the statement, for the Blackeap) is much less commonly met with than the other. I have found a few nests, on one of which I photographed the russet-headed hen-bird, and have seen the cock Blackcap take his share of domestic duties.

From its diminutive size and feeble flight the Goldcrest is not a species one would expect to find in the habit of migrating. It does so, however, in considerable numbers, and occasionally remarkably large flocks arrive on the eastem coast during autumm, some years being noted as bringing umusual numbers. 
Howard Saunders says: "An umusual spring rush took place in March and April. 1882. On such occasions bushes in gardens on the coast are covered with birds as with a swarm of bees: crowds flutter round the lanterns of lighthouses. and the rigging of fishing-smateks in the North Sea is thronged with weary travellers."

'The following graphic aceount fiom the pen of the late Mr. Cordeanx appears in the Zoologist for Deeember, 189:2: "During this time the immigration was inmense: greatest in number were Golden-erested Wrens. . . Golderests everywhere in hedges and gardens, dead thoms and hedgetrimmings, rubbish-heaps, beds of nettles and dead Lmbellifera, the reeds in ditches, side of haystacks, and the thom fences of sheds and yards. 'The sallow thorns were denscly croaded. Many fomd shelter in the long sea-grass, and others, again. cronched on the bare, rain-swept sands between the sea and the domes. Many might have been taken with a butterfy-net. (On this day I saw a very handsome Firecrest. I was standing in shelter of a big fence. watching the Golderests working inland up the hedge and flitting close to my face. when one tried first to alight on the stick of an umbrella which I held horizontally orer ny shoulder. and then perched on a twig within a foot of my nose."

'The date of this great "mush" of Goldcrests was October 14 th. 1892.

'These exceedingly restless little birds are more readily observed in the winter and early spring. when their minute forms are more easily seen in the leatless hedges. 


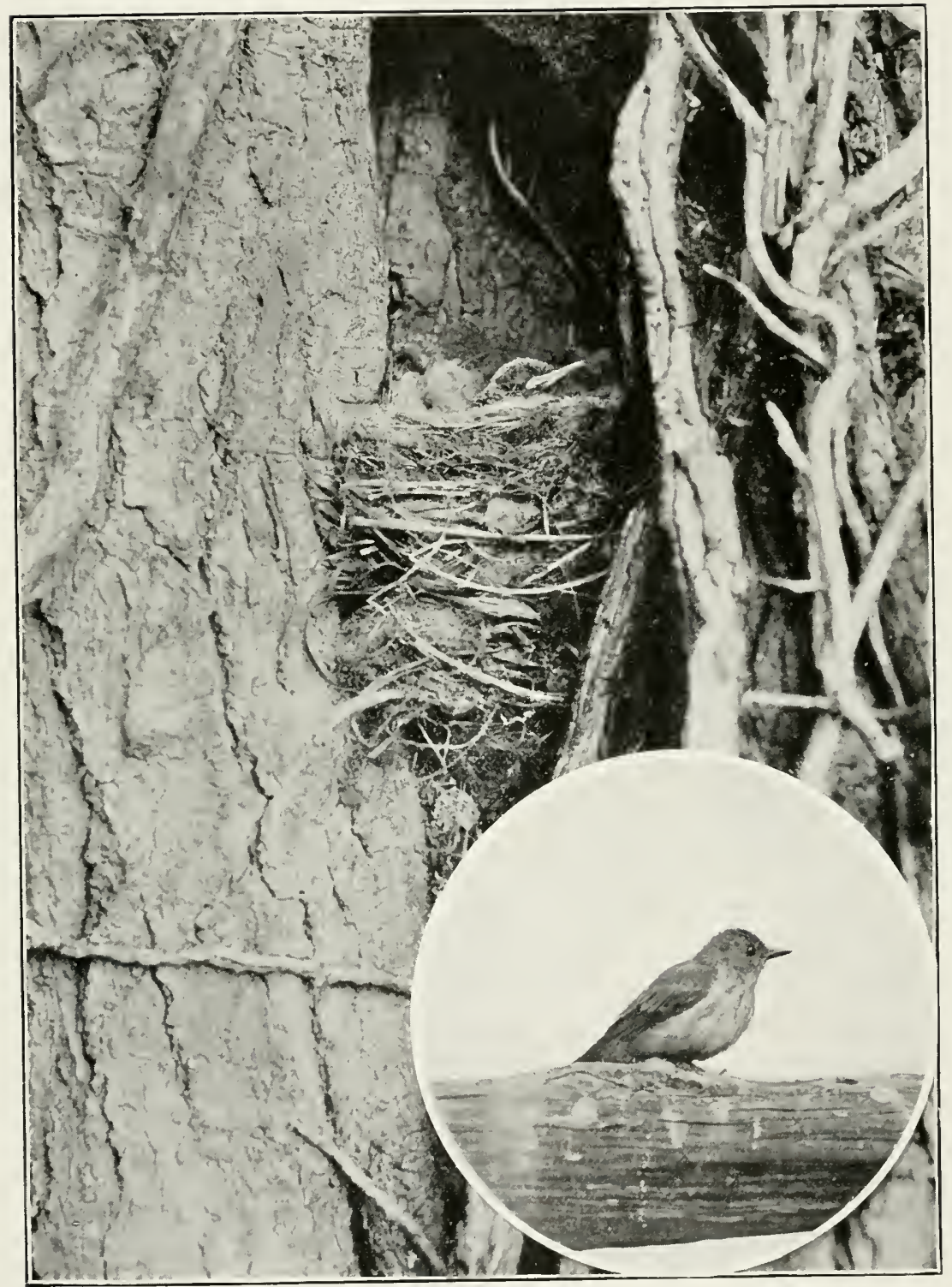

Spotted Flycatcher (Muscicapa grisola) and Nest of loung. 
Probably the first intination of its presence will be the sound of a shrill succession of highpitched notes like " '/Ai-zi-zi," as a small party of Croldcrests explore a small wayside bush. How in(essantly they flit from branch to branch, sometimes head downwards like a 'lit. sometimes horering like a moth. until. after having finished a rapid examination of the bush. they all dart off

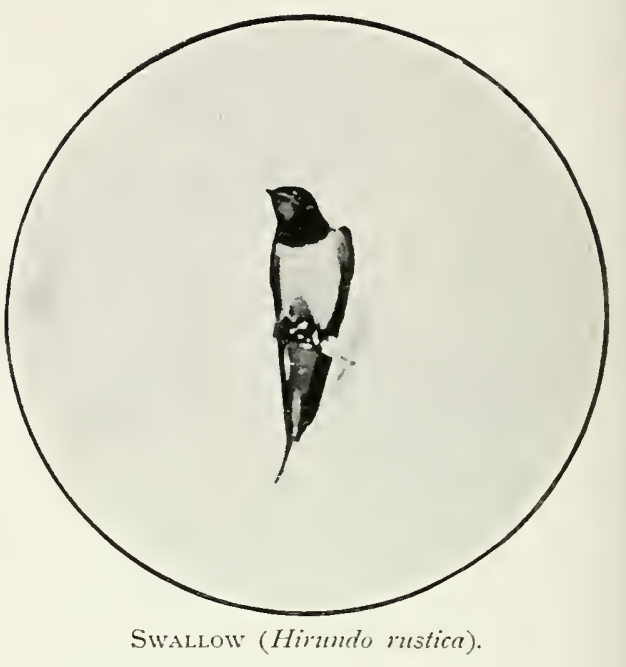
with undulating Hight one after the other to the next! 'They are often to be seen in company with 'Tits of several kinds. During the smmmer they are not so readily seen anong the heary and sombre foliage of the firs and erergreens in which they build their nest. 'This nest. one of the most beautiful examples of bird architecture we have, is always suspended from the underside of a spreading horizontal bough of some fir. larch. or yew. and. being compactly made of green moss. very easily escapes notice. Even when found. it is not an easy nest to photograph. owing to the deep shadow cast by orerhanging branches. especially if of spruce or yew. 'Two attempts have been failures. owing to the utter impossibility of seeing anything on the focussing-glass.

If the Swallow be the harbinger of summer. the Chiffchaff is that of spring. While hedges and trees are still bare and leafless. its note may be heard in the tree-tops like 
"Chip-chip-chip," at such a height that the minute form is barely visible. 'The bird is smaller than the Willow-wren. and has darker legs. The nest is domed like the Willowwren is nest: but the eggrs. instead of being spotted with red. have dark purple spots. It is rery fond of frequenting large gardens with plenty of undergrowth and low bushes.

The Wood-wren is more local. and I have not net with it nearer than Broxbourne and Lpping Forest.

By far the commonest of the three is the Willow-wren. which abounds in every direction. Perhaps the place of all others to look for it with certainty is in the outskirts of a wood or plantation. where the trees are more open, and where bushes. sallow. and such-like predominate anid bracken and coarse grass. Here its slender, yellowish-brown form may surely be seen searching the twigs and foliage with graceful actions. Here its nest may be found carefully hidden among the coarse grass and bracken, domed at the top, and comfortably lined with feathers. On the ground is the usual place, but I have seen one quite three feet high, and there is no doubt that it does occasionally depart from its usual custom.

The nests are generally found by the bird flying out. for they are by no means easy to discover. (On two occasions I have. while waiting near a Nightjar's eggs to photograph the old bird. found a Willow-wren's in close proximity by seeing the birds go in and out. 'They will feign lameness in order to entice you away from the vicinity of their eggs or young. 
'The Reed-warbler I hare not yet identified with eertainty ; it is not unlikely that it may have occured once or twice, as I have been told, on the I.ea, and I am almost sure I saw one in a small patch of reeds one day ealy in May.

'The Sedge-warbler is exceedingly abundant. 'The mame of this bird is. howerer. I think. very misleading. It is not particularly fond of sedge, nor is it at all restricted to marshy places. Any thick hedge and rough. prickly bank will afford it a suitable home, and it is rather partial to railway embankments. It is certainly very fond of asierbeds and marshes, but in the latter it occurs in the drier parts. In either of them its characteristically loud song may be heard all day and well into the night.

It is perfectly surprising to see with what frequency and regularity the young of these insect-eating birds are supplied with food by their parents. No sooner has the mother-bird distributed a fat grub or luscious. juicy caterpillar to each of her four or fire young ones than she is back again with a fresh supply. in what always seems to me an incredibly short space of time. 'Their prying eyes and nimble actions search out so thoroughly erery leat and stem that it seems wonderful that any insects at all escape. What their numbers would be without this check upon their increase is impossible to estimate.

()n one or two occasions the curious reeling note of the Grasshopper-warbler has been noticed in spring. probably from birds fireshly amived and simply passing through, for 
on a second risit to the spot on the next day nothing finther has been seen or heard of them. I have heard of onc nest, however. being fomnd, which, I am ghad to say. was left momolested.

'The Hedge-sparmow is, of comese, alumeant. Its beantifiul nest and egges are annong the filst to be found in early

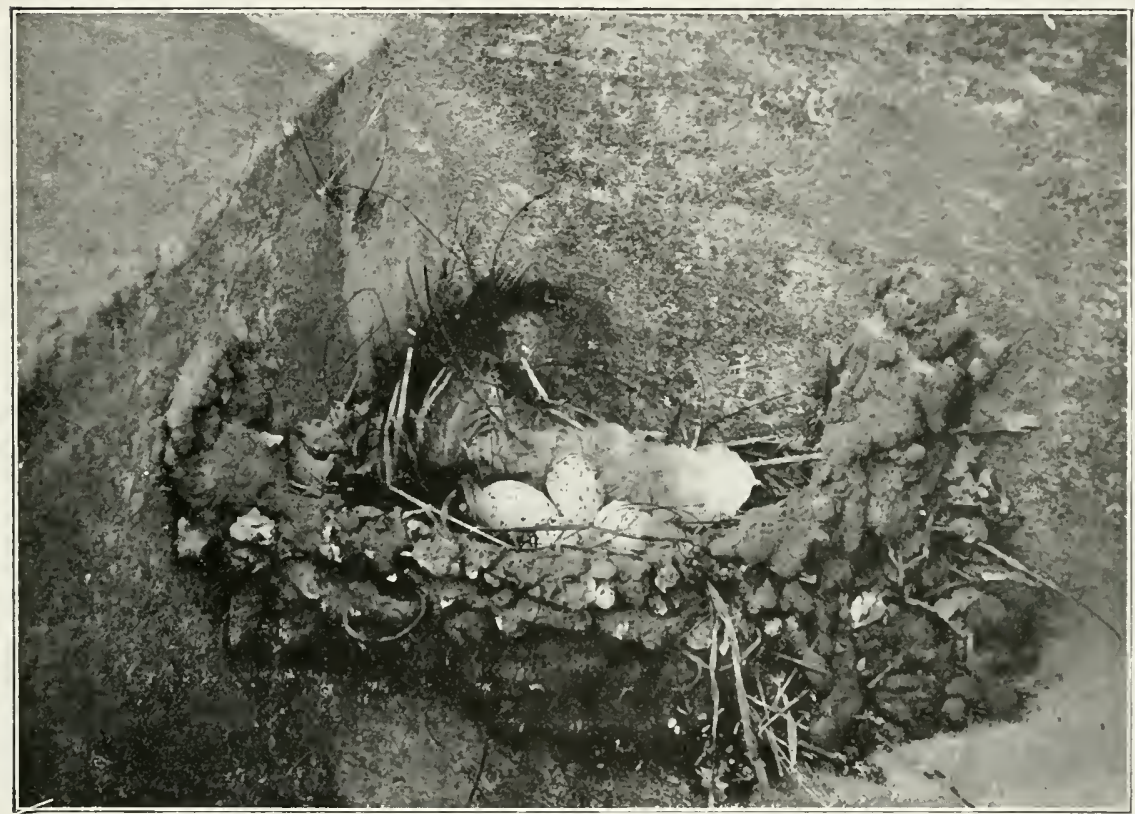

Nest of Swallow (Himundo rustica).

spring. 'This bird is a frequent, if mowilling, host for the Cuckoos eggs. For two reals I have attempted, by uncovering all the Hedge-sparmows nests I could find, to induce a Cuckoo to lay. but so far without success. 'These birds perhaps prefer to find nests for themselves.

Five species of 'Titmice are represented on my list- 
the Great 'Iit. the Blue 'Iit, the Coal-tit, the Marsh-tit, and the I,ong-tailed 'Tit.

The first four I have fiequently seen in my small garden in the autumm. They are all very fond of sumHower seeds, and are rery quick to find out where they are grown. I have often been interested in watching them fly

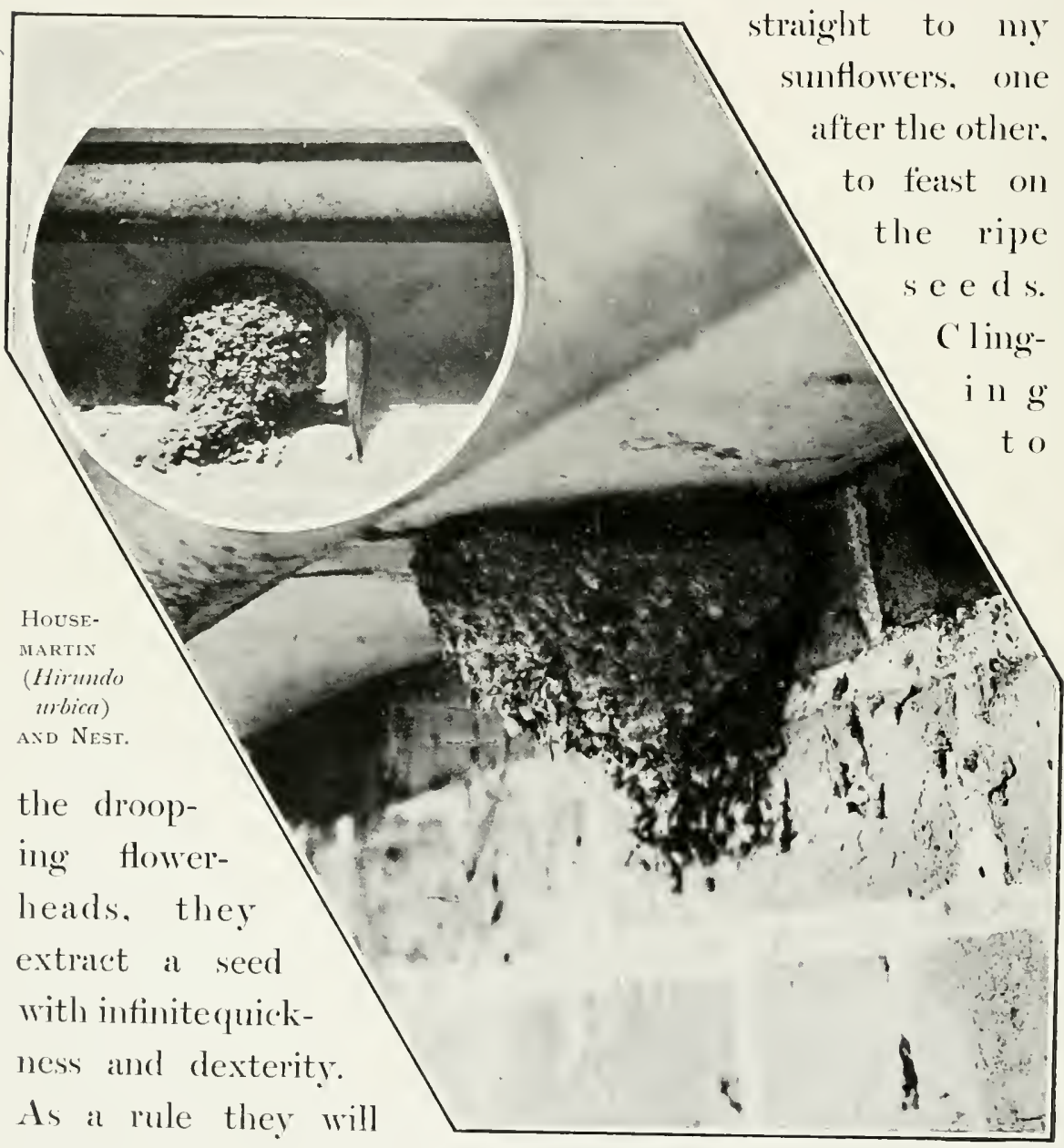


Hy off' with each one, and return presently for another : but sometines I have seen them eat one on the fence. (irasping the seed with one foot, they hammer it with the beak two or three times very quickly, and soon get at the nutty kernel. In the winter we fisten bacon-rind to a tree for their benctit. 'They soon find out and risit regularly any titbit put out for them, such as fat. cocoa-nut, a bone, or a limily of suet.

Both Great 'lits and Blue 'Tits are well known to be fond of curious nesting-sites ; many of the lamp-posts around are regularly used by them. and I have seen pumps and gateposts also used. On one occasion I was just in time to rescue a pair of Marsh-tits which had been alught by two boys firom their nest in a hollow gate-post. 'They were going to kill them, till I persuaded them to release them, for the sake of their family, plainly audible but out of reach, in the centre of the post.

'The Bhe 'Tit in the photograph had a nest of young in the hollow elder-stump. but popped in so quickly that it was impossible to photograph it. The hole was accordingly stopped up with brown paper. 'This gave me a chance, as the bird pondered as to the best means of getting in to its humgry brood, which were clanoming for food.

'The I cong-tailed 'Tit varies in many particulars from the rest of the fimily. Instead of a loosely constructed heap) of feathers and moss in a hole, it builds for itself a beantiful domed nest in the almost bare hedges of early April. How the numerous long-tailed family. numbering from six to 
eight. (an live in such a small abode is a mystery I have never been able to solve. After the brood are fledged. instead of being sent off' to do for themselves as best they may. the whole family of young and old keep together throughout the autumn and winter months. Often in company with numbers of other 'Tits and coldcrests. the

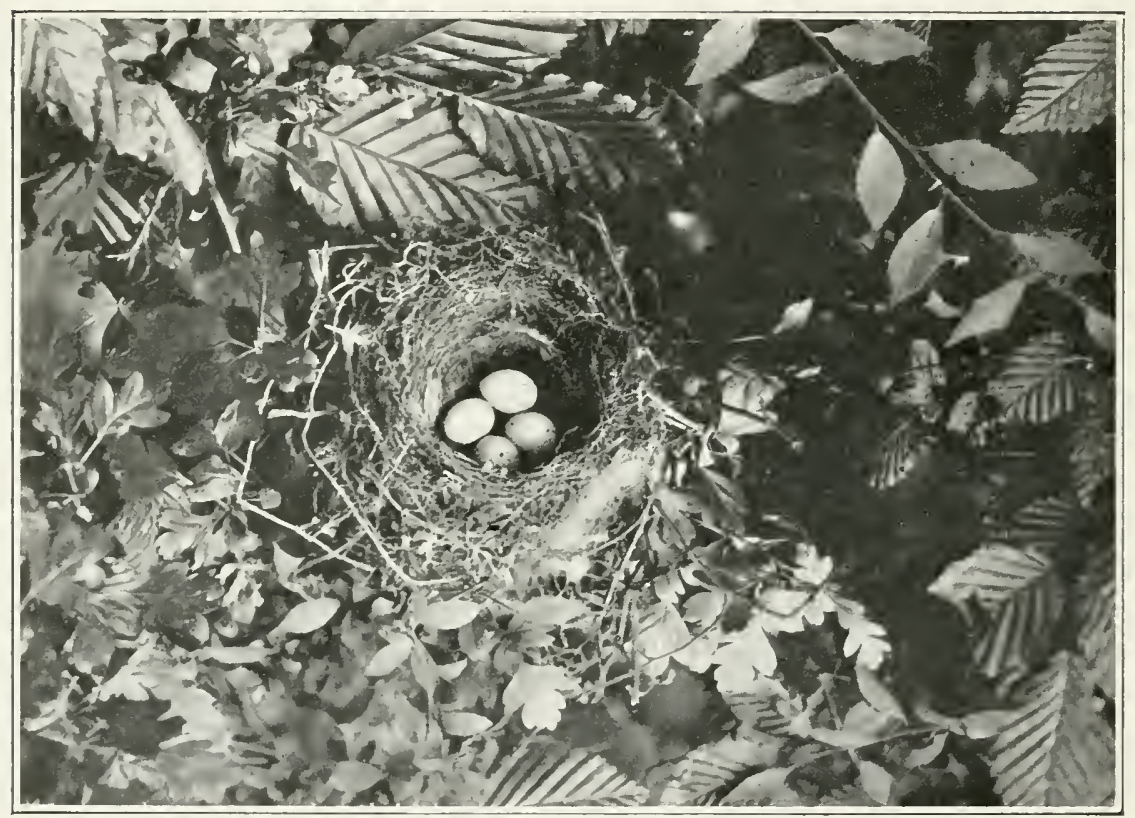

Nest of Greexfinch (Fringilla chloris).

merry party flits along from tree to tree and from bush to bush. always busy. aud incessantly uttering their shrill all-note to tell their companions of the whereabouts of each nember.

'This bird suffers much from boys. 'The nest in a leat'less hedge is rery comspicuous. and the first boy who 
passes pulls it out as a matter of course. But the birds. in spite of this treatment. stick to the same hedge and make another close to the same place. which gencrally sufters a similar fate. I knew this spring one pair of I song-tailed 'Tits which built fom nests before they were able to rear a brood in saffety. 'They did suceeced at last. for after my return from Demmark I saw the whole fimily party. 'They built in the sane hedge year after year. and I always know where to find two nests erery season. one at each end of the farm I mostly frequent.

'This year I found a half-finished nest. which shows the method of construction. It exactly resembled a Chaflinchis nest, but one of the Isomg-tails entered it while I was in the act of focmssing with the lens not more than an foot away. It was pulled out the next day before it was finisherl, being the third of those just mentioned as made by the same pair of birch.

'The Nuthatch is common conough. and may be often heard by those who know its liquid note. Its whole life being spent among the lofty branches and rugged trunks of large trees, it is not a hird which is often seen. Its climbing powers are wonderfinl, eren rivalling those of the Woodpeckers, and excelling them in one particular. Although minprovided with the stiff tail or the climbing foot of these birds. it am run down a perpendicular trunk. whereas they, with the assistance of the fulcrum of their tail feathers. (an only rum up. As is well known. they have the curioms habit of filling up the aperture of the 
hole in which they nest with rlay and mud, so as to reduce the size of the opening.

'The Wren, though not much bigger than the Goldcrest, and like it of short and feeble flight, is also in the habit of migrating, though more irregularly. Both on the west and east coasts of Seotland and the east coast of Fingland it has been recorded in the returns furnished by the lighthousekeepers as arriving generally in small numbers. Once, however. mention was made of " great numbers seen in the Isle of May."

Its nest is well known, but is none the less a wonderful (onstruction for such a tiny being. It is rery much addieted to building a number of nests which are never used. 'The materials of these nests are cleverly adapted to their surroundings. If among ivy or green leaves. they are cosily made of green moss. A very farourite situation is in the side of a haystack, and then the material used is invariably hay: while, should it be in dead iry or dried plants. it is made of dead and withered leaves.

A well-known firequenter of the farmyard, as well as the stream-side and meadow, is the l'ied Wagtail. 'This bird, though only clad in sober black and white, is exceptionally danty and elegant in appearance and ways. It trips along so lightly. constantly flinting its tail-feathers up and down: then running a fer paces, it stops suddenly and darts off in another direction or Hies to some stone or post. 'The flight is rely undulating. and the note, constantly uttered on the 


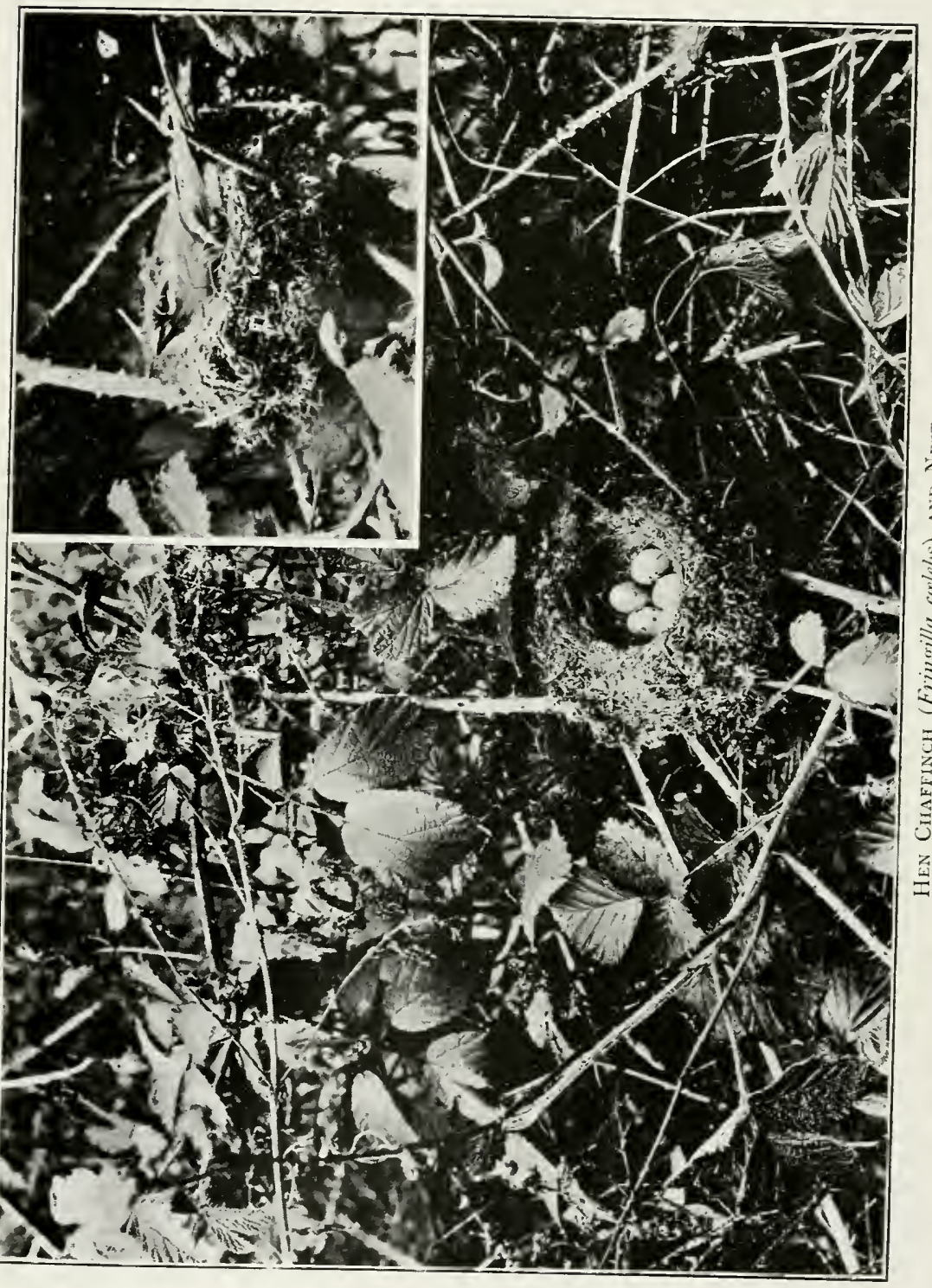




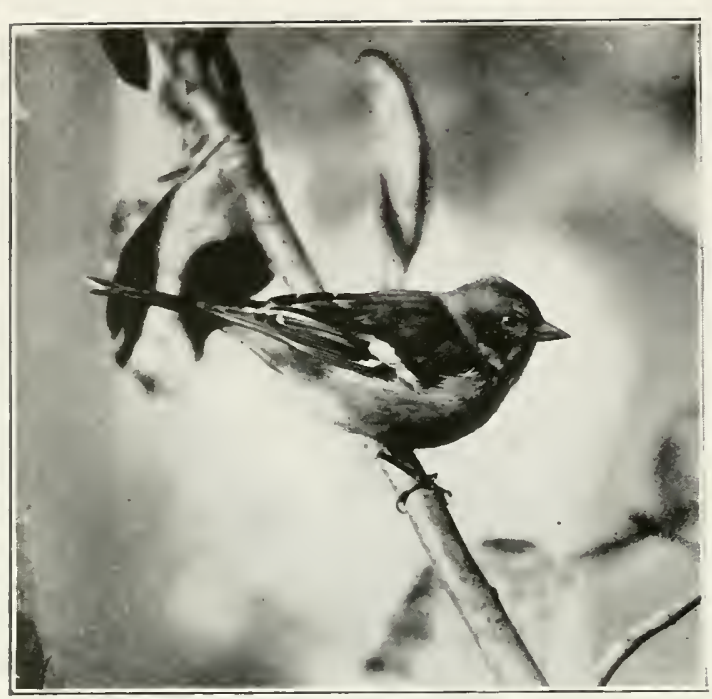

Cock Chaffinch (Fringille crelebs).

wing. sounds exactly like ".Chis-wick. chis-wick." ()n the sewage-farm it is exreedingly numerous all the year round.

'The beatutiful Yellow Matgtail is found in some numbers in the same place.

I nest photographed two or three vears ago was in a ditch-side. and con-

tained six eggs. rery like Sedge-warbler's in appearance. 'The birds were rery shy and it took me two days to photograph the hen on her nest. and I had almost giren up the idea of getting them off the nest. when at last I noticed that before Hring across the ditch they always settled on a tall dock just opposite. This gave me a chance of obtaining some good positions. in spite of a very strong wind which was blowing at the time.

In the same locality are also inmense numbers of Meadowpipits, which feed all the rear round about the little pools on the numerous insects so abundant in such places. Here you can see them to adrantage when they are busily engaged feeding or chasing one another, which they are so fond of doing. 
'The 'Tree-pipit is more frequently fonnd in the fields. and seems to be particularly addicted to railway cmbankments, where its nest may fiequently be foll 11 d. Inlike the Meadow-pipit. which is resident. the 'l'reepipit migrates before the ap)proach of winter.

'The Redbacked Shrike is a common species all round the north of I I OHdon. On the topmost twigs of the tall hedge in which the nest is placed it sits

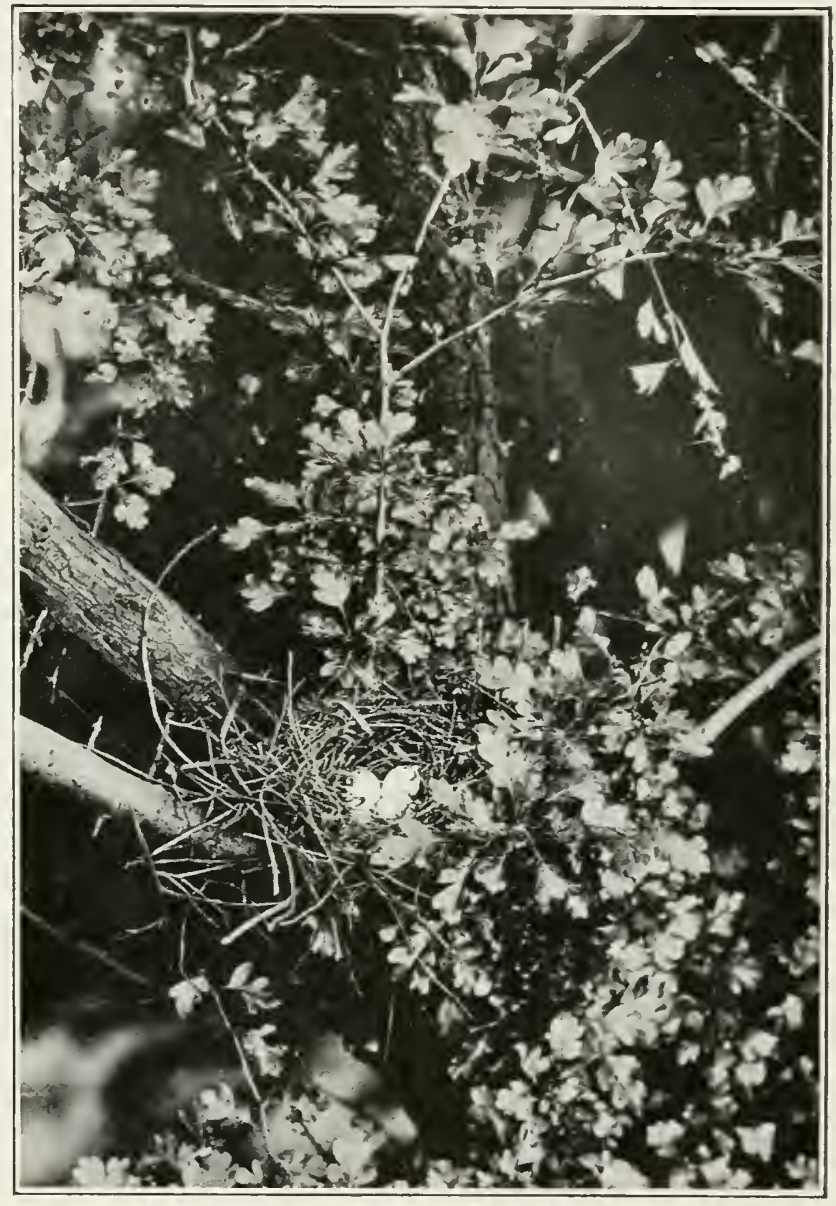

Nest of Hawfinch (Coccothranstes vulgaris). on the watch for insect prey: for though it will kill small birds and mice, by far the greater part of its food is composed of beetles and other insects. 'The castings show 
abundance of beetle wing-cases. These are generally caught by the bird pouncing down on them on the gromend. 1)uring haynaking operations it is keenly olservant of insects disturbed by the machines. swooping down on whatever it may see and carrying it to the romg. which are fed long after they have left the nest. All the Shrikes have a curious and characteristic habit of moving the tail round and round in a circular fashion. quite unlike the usual upand-down motion in rogue with most birds.

Every garden of any size round I condon contains a pair or more of Spotted Flycatchers. 'These. from the rantagepoint of croquet-hoop. dahlia-stick. or temmis-net. spend the whole long summer's day in aatching Hies. Itere they sit on the watch. repeatedly Hying off to catch passing inserts with an andible snap) of the beak, returning generally to the same place to wait for another. 'The Spotted Flycatcher is one of the latest to arrive of the smmmer migrants, and one of the most silent. It appears to have no song. but often utters its short. shrill note.

'Three species of Hirundines are found. but the Sandmartin only in small numbers. For some time the nearest rolony of these birds I could find was at Broxboume. but in a grarel-pit near the I andon Road there are a few burrows which the men working there declare to have been used this summer. Numbers can be seen at the end of summer passing along southwards and hawking orer the New River, and the pools at the sewage-farm are frequented by immense numbers just before their final departure. 


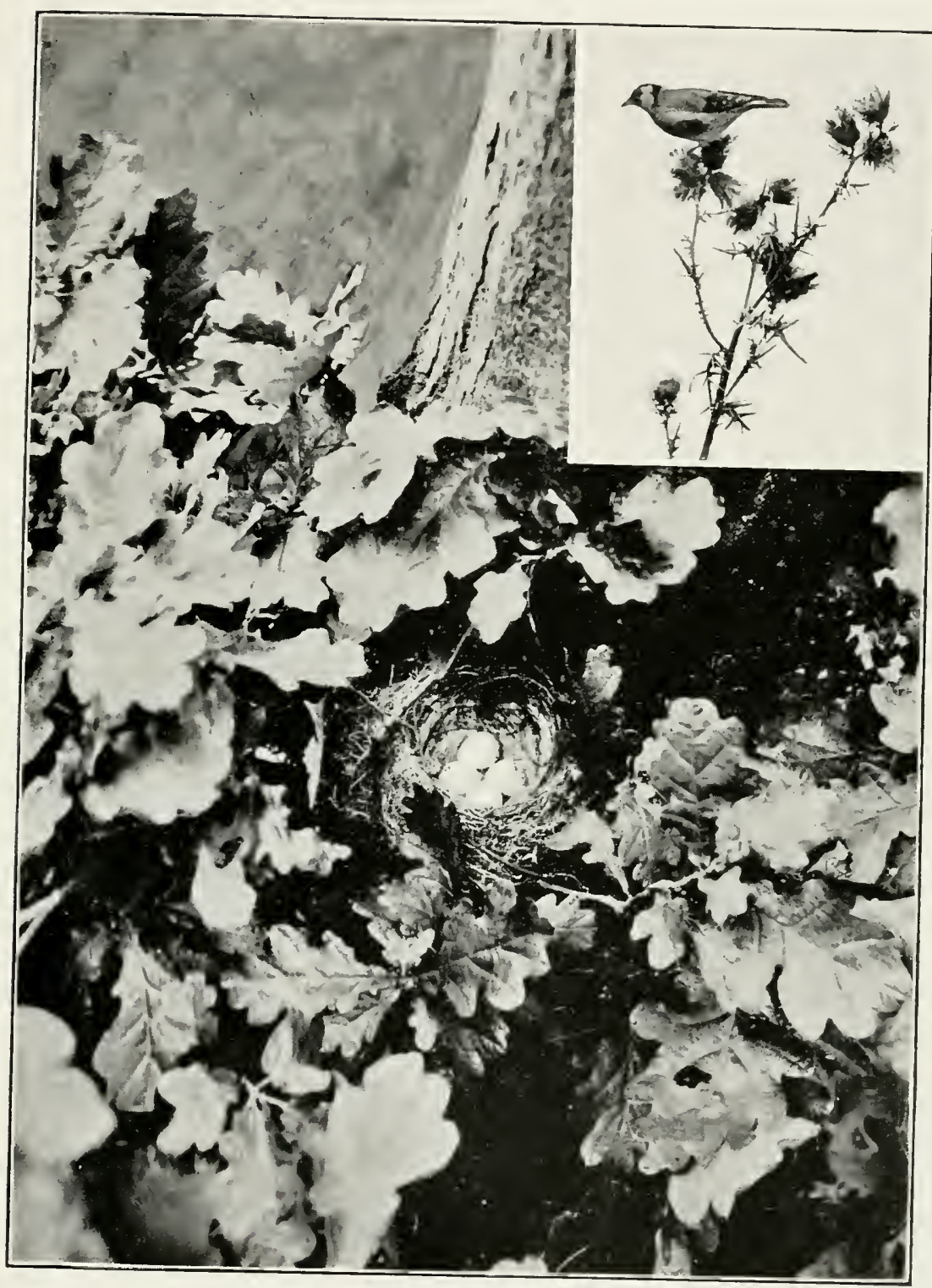

Goldeinch (Curduelis elegans) and Nest. 
The Swallows nest in every comshed and barn alound, and also under all the New River bridges. where they are particularly safe firom molestation.

In Spain the Swallows nest freely in the rafter's of the rooms. instead of outside and in the chimmeys. ats with us. Entering one day an Andalusian " posada." or wayside imm, several Swallows were quietly sitting on their nests just orer the head of the brown and smo-dried host. I photographed one perching on a nail projecting from the whitewashed wall of the " patio" of the British Consul's house at Bonanza, the small port at the mouth of the Guadalquivir.

In this comntry it is the Martins which chiefly fiequent human habitations. but always outside under the eaves. Here they build up. pellet by pellet. a curious. oren-like abode of mud, and line it profisely with feathers and a few straws.

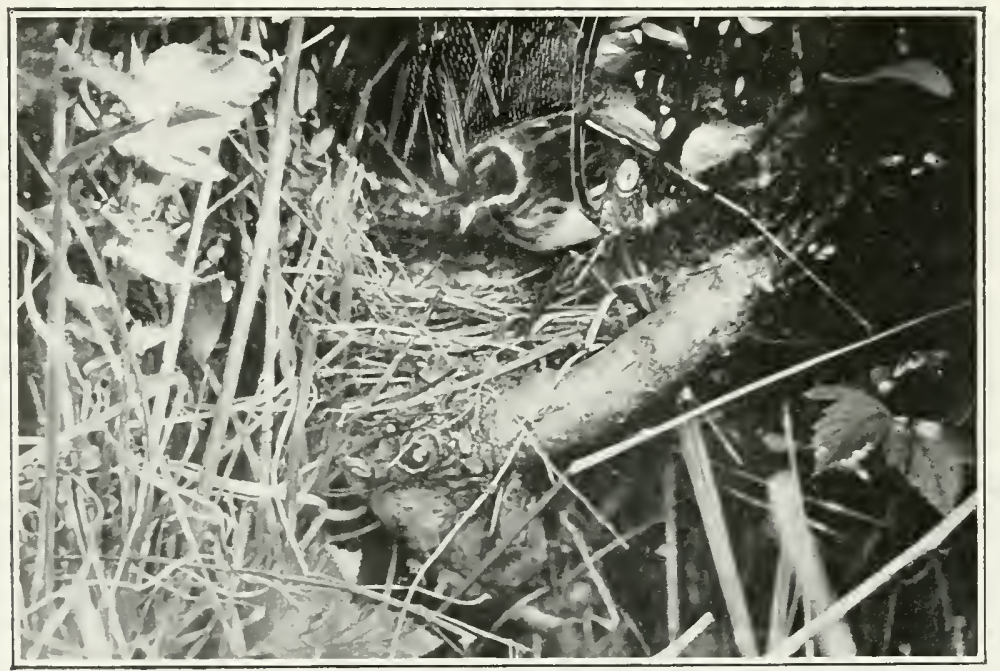

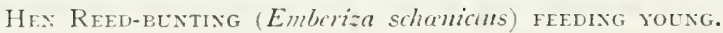


The nest is chietly built in the carly pant of the day, and then left to dry before the work is resmed the following morning. The birds may be seen collecting mud from puddles in the road and in farmyards and ponds, and I have even watched them picking it up from the metals of a tram-line after rain. A pretty sight it is to see a Housemartin dhasing a big white feather as it is carried hither and thither by the gusts of wind. and finally carrying it off to line its newly finished nest.

Both Swallows and Martins, though not arcounted songsters, have a remarkably sweet but slort song. uttered both on the wing and while perched on a roof or bare branch of a tree, as they so often do on first arrival. After the yomng have left the nest, they are often to be seen perching in small companies on a leafless branch: young Swallows may readily be distinguished fiom the adults by the absence of the two long pin-feathers in the tail.

The whole question of bird migration is a curions one; and while we know more about it than in the days of Gilbert White. there are many points which have yet to be cleared up. One of the most curious facts abont it is the departure of the young Swallows and other birds before that of their parents.

Mr. Dixon writes in one of his books. "The Migration of Birds" (pp. 178-9): ". The young birds are the greatest blunderers the birds which have practically no knowledge whatever of the road: and have to depend entirely on the guidance of older birds. That this is the case is abundantly 
proved by the faret that nearly all the birds that accidentally wander to the British Islands. from nore or less remote countries, are birds of the year."

'This would seem at first sight to account for the frequent arrivals. on the east coast especially, of birds which do not risit us habitualy. occasionally eren of those which have never before been met with in any part of Furope.

For instance, the Asiatic species Lusciniola solicarai (Radde's Bush-warbler). a young bird. was recorded in Kmocledge as shot in Iincolnshive on February 1st. 1899. 'There is no other record of this bird in Europe.

A specimen of the Siberian Meadow-bunting (Emberian (cioides) was shot at Flamborough in Norember. 1896. and has also never been obtained in any part of Furope before. not even in Heligoland.

It would be interesting. if such a thing were possible. to find out what cause led these wanderers from the north of Asia to risit this country. For the true home of the latter speeies seens to be in ". Turkestan. Siberia, Mongolia, Manchuria. and Korea. and orer a great part of China (Saunders).

'Three specinnens of the I)esert-wheatear (Saricola descrti). a native of North African deserts. have been obtained in Fingland. ( )ne of these is described as a young bird (Samnders). But if other competent observers are correct. Dixon is wrong. both in his fincts and in his deductions firom them. For the late IJerr (ratke, who studied the migratory movements of birds for fifty years at Heligoland, that wonderful natural observatory of bird life. altogrether denies that the majority 


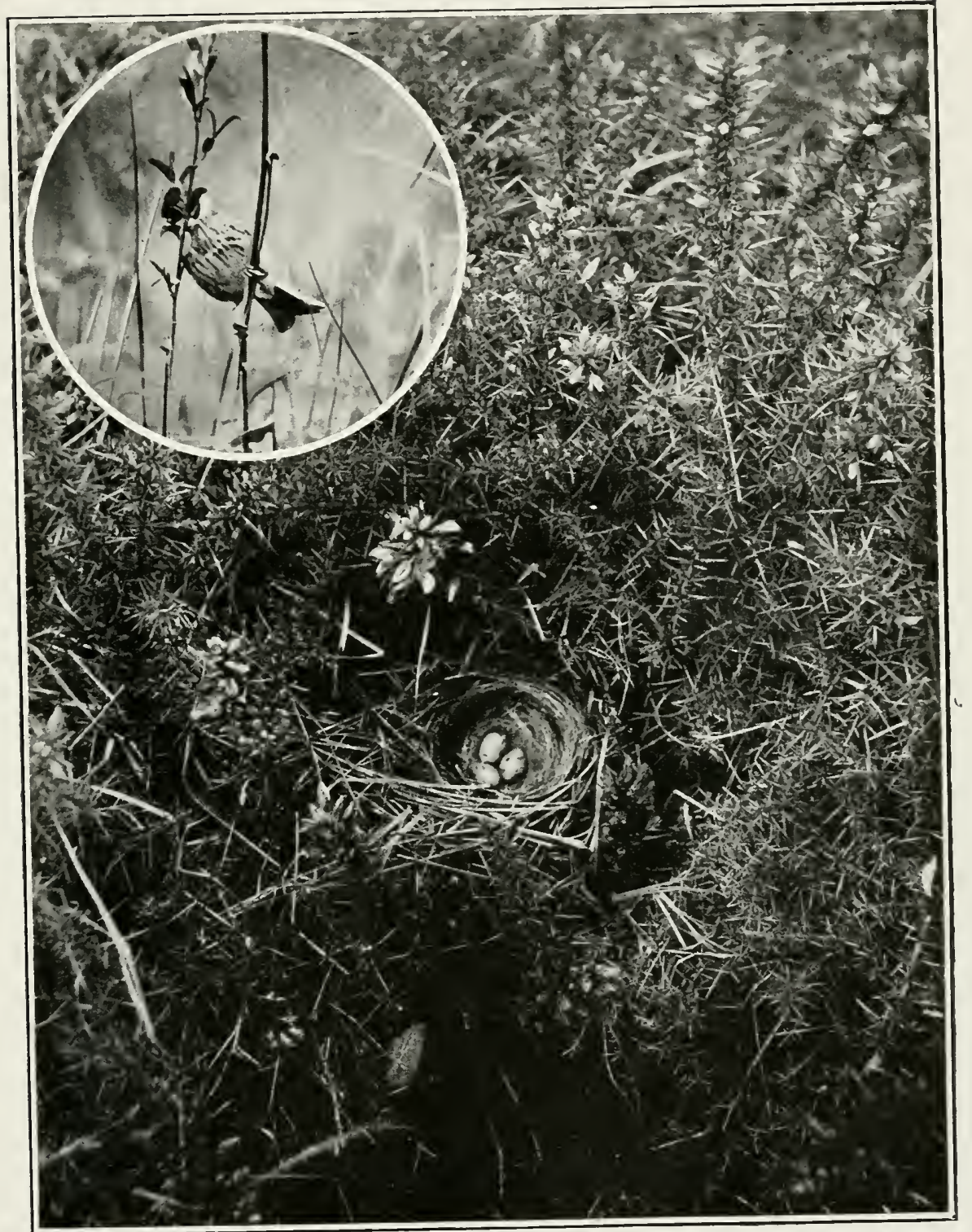

LiRen-BUNtixg (Emberiza schanichus) AND NeST. 
of " accidental" visitors are inmalturc: in fact, firom a list furmished by him to Mr. Cordeaux, an orerwhelning majority were adults, and in a letter to the Zoologerst. May, 189:3. he writes: ".(Ornithologists ought to give up the worn-out myth of inexperienced young birds dependent on the teathing and gruidance of their experienced parents: for the moment the young are tolerably well

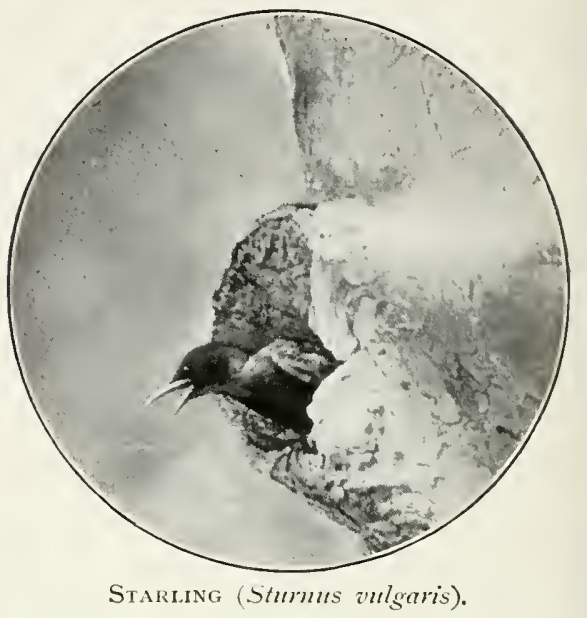
able to take care of themselves parents and young separate. and become total strangers to each other. 'The first perfect plumage of the latter being completed, in a few weeks they start of their own accord, and entirely by themselves, on

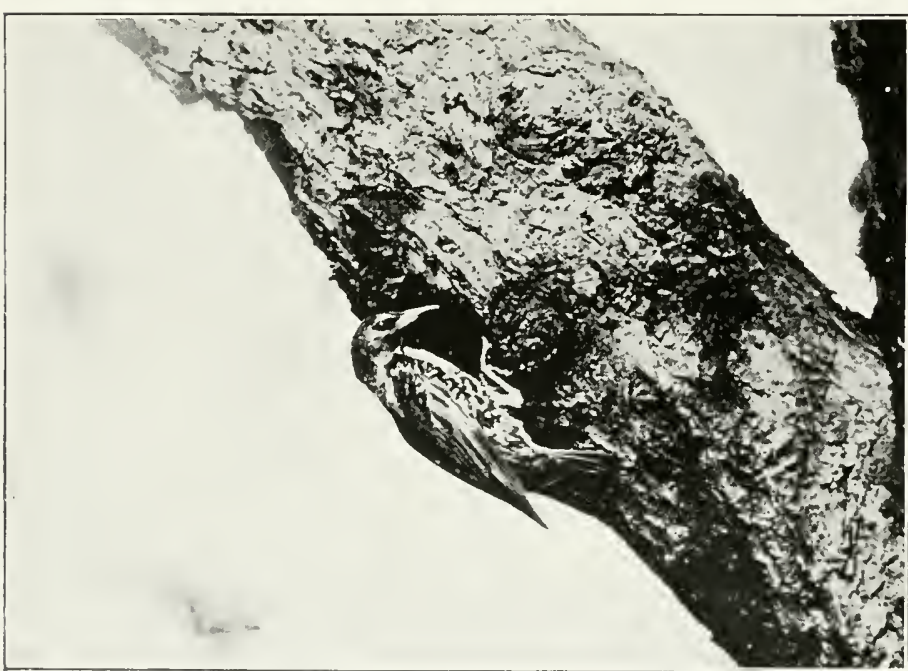

Starling visiting Nest in Old Woodpecker's Hol.e. their first nigratory excursion : wh i l s $t$ $111 \mathrm{a} 11 \mathrm{y}^{\mathrm{O}} \mathrm{of}$ the parent birds devote themselves to al second brood,orat all erents have to go 
through the tedions process of change by moult of their entire plumage being thus detained for one or two nonths firon following their off'spring into winter quarters. This holds grood for nearly all regular passengers in Heligoland, the sole exception being the Cuckoo. which. learing the are of hatching its egg and rearing its young to kind-hearted fosterparents. is free to go south whenever it pleases. The most striking instance of young birds preceding their parents by a month or two is furnished by Starlingss (Sturmus iulgaris) : young grey birds appearing here by hundreds and thousands at the latter end of June, without in any case being accompanied by a single old one. the antumnal morement of the latter commencing about the end of September, lasting through October, and occasionally till late in November."

These are the opinions of an ornithologist who has had far more opportunity for the observation of the mysteries of bird migration than any other naturalist. For fifty years he systematically noted every arrival to the island of Heligoland, where there are actually no resident birds to cause confusion. and which has a list of feathered visitors greater tham the whole list of the birds of the British Islands. Nearly the whole population of Heligoland has been trained by him to observe and catch the feathered visitors to this island rock on their passage. and every important capture hats passed through his hands. and a record has been kept of its age. plumage, sex, date, and the prevailing wind and weather. The late Mr. Sechohn disputed the acenracy of Ierr Gatke's list, alleging the difficulty of distinguishing 
the minute differences between the plumage of many birds (especially 'Turdinas) in their first spring dress and adults. But the fact that young birds do migrate half across the surface of the globe without any assistance from their parents is sufficiently astonishing. and the wonder is. not that one or two go astray. but that so many thousands suceed in finding their way alone and with no previous experience to guide them.

It is known also that birds which are bond to the extreme northern latitudes. instead of starting early on account of the longer distance. actually start some months later. They know in some mysterious way that if they arrive at their destination too som they will find the country thickly covered with snow and the rivers still ice-bound.

Chapman notes that in Spain "there is a distinct arrival of Swallows in Februaly (early in March many already have eggs). yet the "through transit' of rast bodies-destined perhaps to populate Iapland and Siberia is conspicuous throughout April and even into May."

Wherever trees are fond. there the Tree-creeper may be seen. (reeping spirally up the trunks and branches. When stationary the sharpest eye would with difficulty detect it at all. and when moring upwards in jerks it might be taken for a mouse. The back is mottleci with different shades of brown. making it ahnost invisible against the weather-stained branches. Watching its progress. it suddenly disalppears round the farther side. and after an interral its silvery breast and long curved beak (one into view again higher up. With its 
stiff tail-feathers it supports its weight while it searches the interstices of the rough bark for small insects. 'Tlue nest may be found squeezed between the trunk and the bark where it has becone loose, as it often is in old willow-trees. From the nature of the situation it is most curiously compressed.

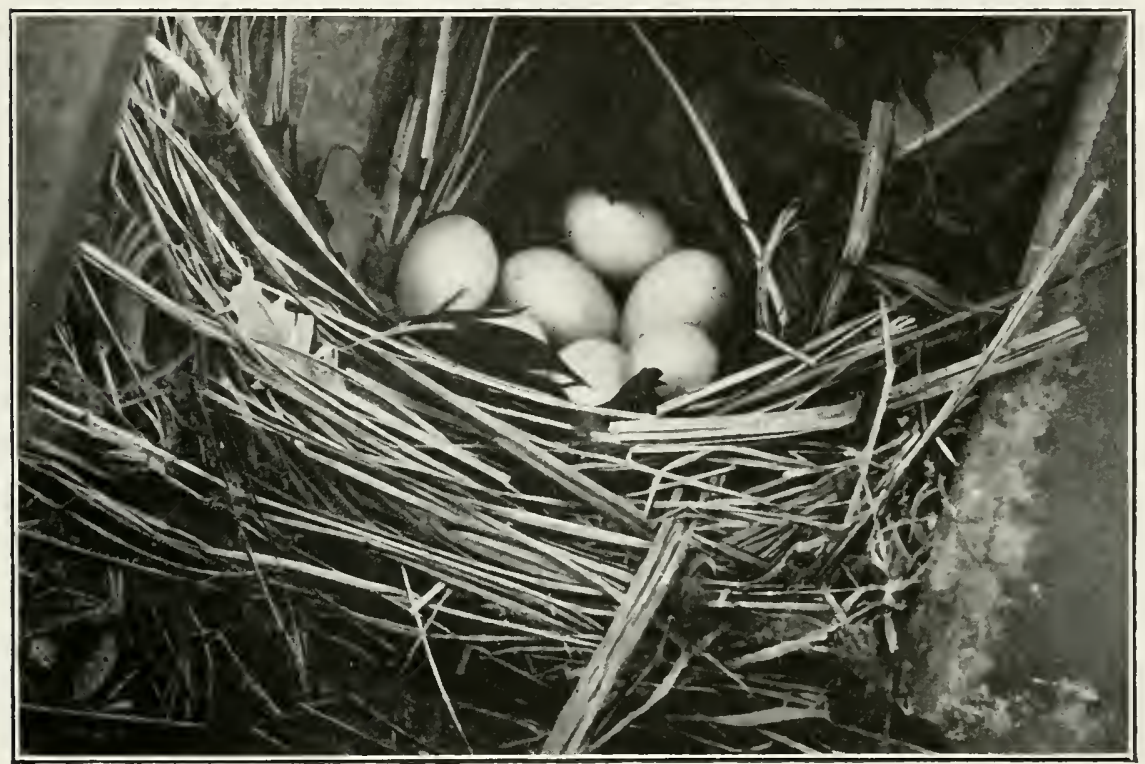

Nest of Starling (Sturmus vulgaris).

eren for such minute and slender forms as the T'ree-creepers and their young family.

The Greentinch is a really handsome bird. though so common and little esteemed. It is a hardy and ornamental bird for the ariary (it is too big and elumsy to show to adrantage in a cage). but the worst of him is his dreadfully monotonous voice. 'The long-drawn and constantly repeated "(he-e-ep" in early spring is the most angravating bird- 
note I know of. the only one anongst British birds I really dislike. When nesting has fairly begun. howerer. the birds are very silent. and the nest in ronsequence escapes notice. though gardens and shrubberies are very favourite places for them to choose. The nests are well and romfortably made. and have a charm of their own. without having the special beauty of the Chaffinch's nest.

For thehome of the Chaffinch is distinctly the work of an artist. Without in any way losing any

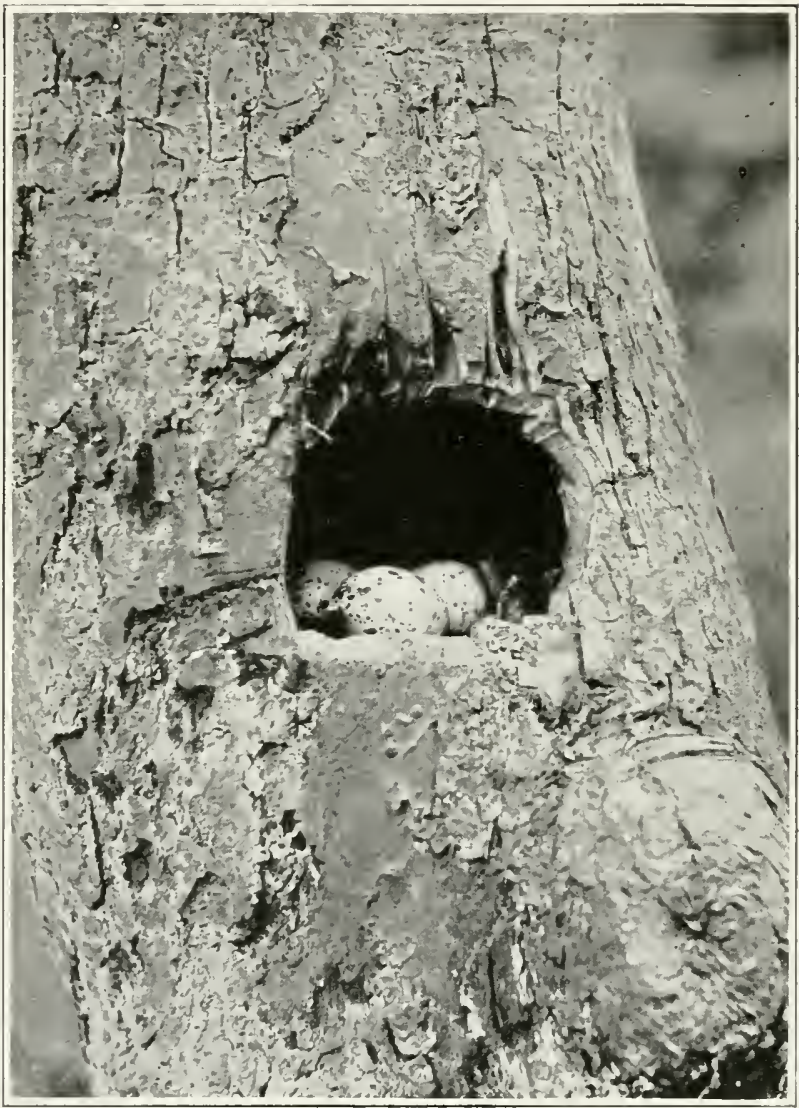

Nest OF JACKDAW (Corius monedula) CUT OLTT. useful quality

for in warmth. confort, and durability it is second to none in decorative effect and tasteful situation and appearance it is entitled to rank among the highest efforts of 
bird architecture. Whether placed in the guarled and rugged branches of the elder. or hidden anong the delicate white spangles of "may" or blackthorn, it is always worth stopping" to admire: still more so if the mother-bird remains on her egass. looking at you with quict and fearless eyes. als she will do if you move discreetly. The picture then is perfecet in every way. Do not spoil it hy disturbing her and robloing her of her treasures.

'The northern suburbs of I.ondon and the adjacent country is the chosen home of the IIawfinch. In the numerons orchards and market-gardens in this neighbourhood it is a fairly abundant species. Unfortunately their fondness for green peas leads them into trouble, and makes them very unpopular with gardeners. In spite of the numbers which suffer from their misdeeds in this direction, it is one of the few birds which appear to be increasing in numbers and spreading into localities where it has been previously looked upon as a ralrity.

I have seen numbers of the nests both in the appleand pear-trees of orchatrds and in hawthorns in parks and fields. The birds are rery silent and unobtrusive, but are sometimes seen while lying in wait for other birds. The enormous beak is their chief chatracteristic. and one by which they may be readily known. Another feature. which is only seen when in the hand, is the eurious notching of the primary feathers.

The Goldfinch is too much in demand among bird-atchers ever to be a common bird neal I London or any other large 
town. Still, a good many may be scen at times if one knows where to look for them. In one field, chicfly remarkable for its fine crop of thistles, and where the bird-catcher is not a persome erenta. large flocks of young Goldfinches and I imnets may be seen during autumm. And there are not many sights in Nature preitier than a small flock of these elegant birds clinging to the bending thistles with expanded whings. and flying from one to another. If the time is winter. and there is a covering of snow on the ground, the beanty of the sight is still further increased. When one patch of thistles is exhausted, they Hy off to another with a joyous twitter. learing the downy seed-feathers floating in the air and strewn on the surface of the snow.

The only nest I have seen was about ten feet up the trunk of a small oak in a wood, placed between the trunk and the small leafy twigs growing out of it. In such a place they are much safer than when nesting in hedges and orchard trees. I have some reason for thinking that they nest more often than is thought at considerable heights in lare trees.

'The House-sparrow is, as a matter of course, abundantextremely abundant: where is it not! In towns its presence may be tolerated. and eren welcomed, but there is no doubt that in the comntry it does much damage. While the corn is yet green in the ear, and after it is ripe. Spanrows in Hocks may be seen on their way to feast on the precious grain. Clinging to the bending ears, they strip them speedily. and break down as much as they derour. 'They also let the 
damp and rain into the thatched roofs of stacks and cottages by pulling out the straws. Wherever food is to be found Sparrows are certain to be there, eager for their share.

Is there a good rise of May-fly on the trout stream?

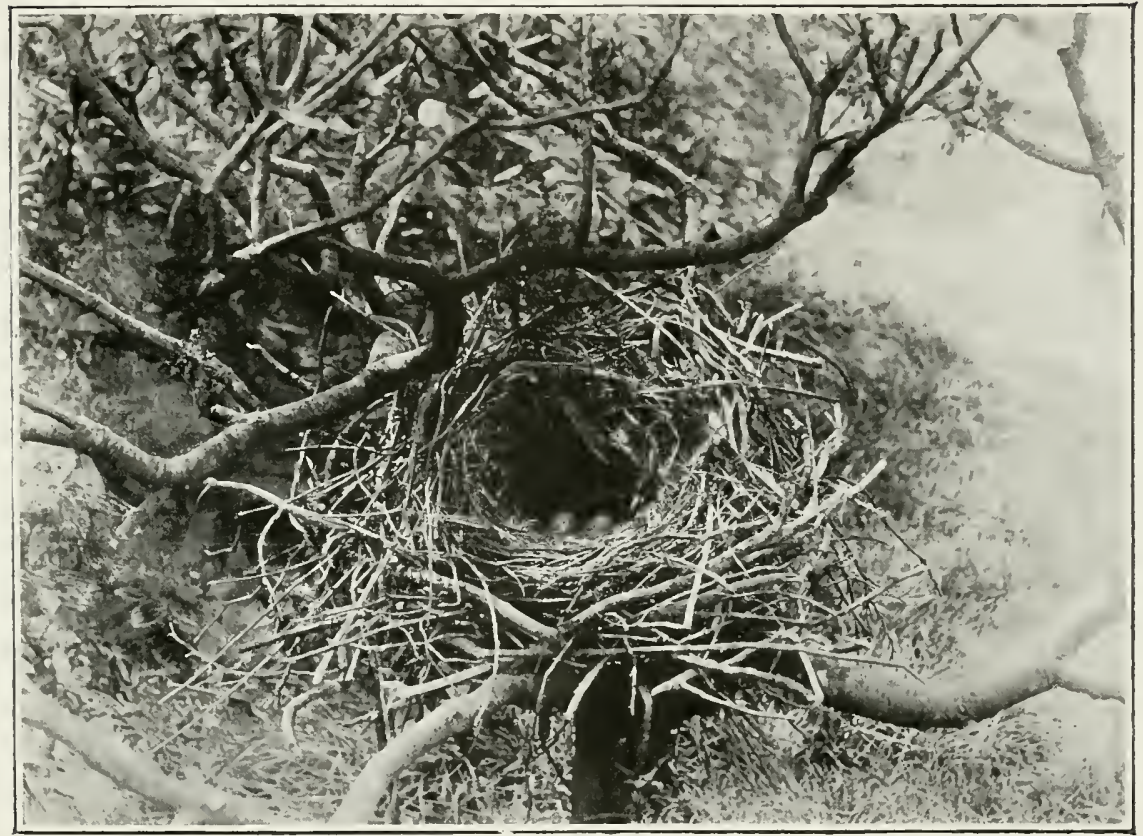

Nest of Carrion-Crow (Coriuts corone).

In competition with the Swifts and Swallows, which grate on untiring wings. and sweep so gracefilly to neet the gauzy flutterers above the water they have so recently left, are numerous Sparrows; despite their thick-set clumsy bodies and short wings, they too attempt the difficult feat, and eren try awkwardly to pick them from the 
surface. In spite of many failures they do succeed by persererance in obtaining a share. and pick those up which are drowned and washed agamst the grassy banks.

Drop a crust of bread, or spill the contents of a nosebag in the strect! Before a minute has passed a group of watchful Sparrows are squabbling excitedly over the find, and chasing the first coners in the hope of their dropping a bit. 'latk about the struggle for existence! Each mouthful a Sparrow eats seems to be obtained by the exercise of unrivalled energy and watchfulness. No wonder they thrive and increase and multiply! 'There is one period of their existence, howerer, during which they do some good.

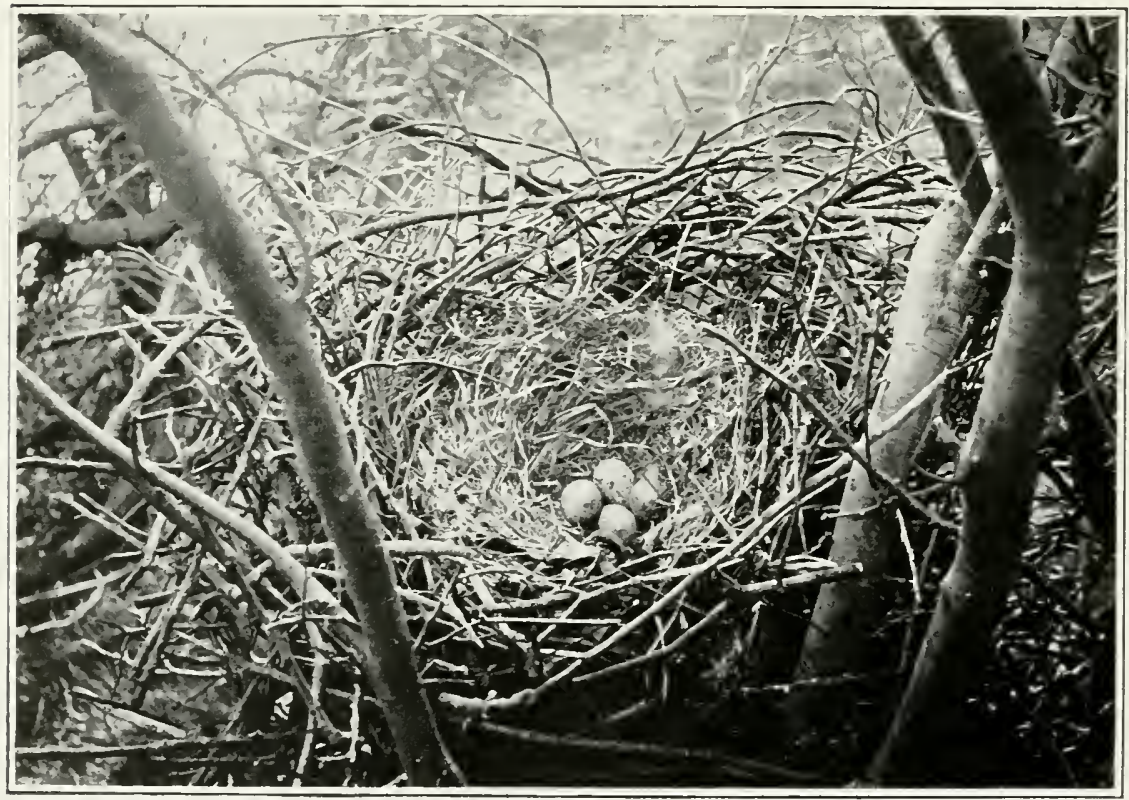

Nest of Rook (Coraus frugilegus). 
While rearing their young and they have at least two. if not four, broods every year they feed them on grubs and insects. It is only fair that this should be put to their redit, for it is apt to be orerlooked.

One of their worst habits is that of ousting the Housemartins from their nests, and appropriating them to their own use. 'The theft is invariably betrayed by the untidy ends of straws and rubbish left sticking out of the entrancehole in straggling disorder.

I have often watched a Sparrow sitting on a roof. intently observing a pair of Martins building up their mud nest under the eaves. With the greatest interest it watches all their proceedings, chirping impudently now and then, as if to hurry up the patient builders. Presently the nest is finished, and the lining nearly in, and the Martins go off' for one more feather. On coming back, they find the Sparrow has taken possession of the home they have made for their own use with so much skill and labour.

As for the ancient fable of the Martins building up the robbers by blocking up the hole with mud and learing them to die of starration. I simply camnot believe it. What would the Sparrows be doing while the building up was in progress and afterwards. if it was ever completed! With their strong beaks they could, with the greatest ease. demolish the mud as fast as it was brought, and break up the whole nest from inside. The nests are so fragile that a elumsy finger roughly inserted is enough to bring the whole structure to the ground. No: the story is of 
a class with many others very popular a few years ago, which get repeated orer and orer again as gospel "Anecdotes of Natural History," which should be taken, most of them, ('lum grano salis.

'The 'Tree-sparrow is common, building a much neater nest in holes in apple-, willow-, and other trees. Its smaller. romder, and browner eggs may be easily distinguished from those of the commoner species. 'The bird itself' is somewhat of a handsone one.

Patches of furze-grown common-land around are not of great extent or very numerous. Wherever they exist there are plenty of I innets; but these birds are not found in any abundance away firom their farourite haunts, though they do nest sometines in the hedges. In the antumn they Hock to the thistles in company with croldfinches.

'The I cesser Redpole, with the Bramblefinch. is only known as a winter visitor. when flocks of these sprightly. active, restless little birds wander sonthwards.

'The Bullfinch is abundantly found, though it is more in evidence in the autumn and winter. In the nesting season it keeps rery quict. and chooses the thickest hedges and the most retired places in the woods. and shms notice as much as possible. In walking along the bare hedges in winter, great numbers of their nests may be seen, which have escaped observation during the leafy months of summer.

'The Com-bunting is scarce, the reason probably being. as Samnders remarks in his " Manual of British Birds," that " it is principally to be found where grain of some 


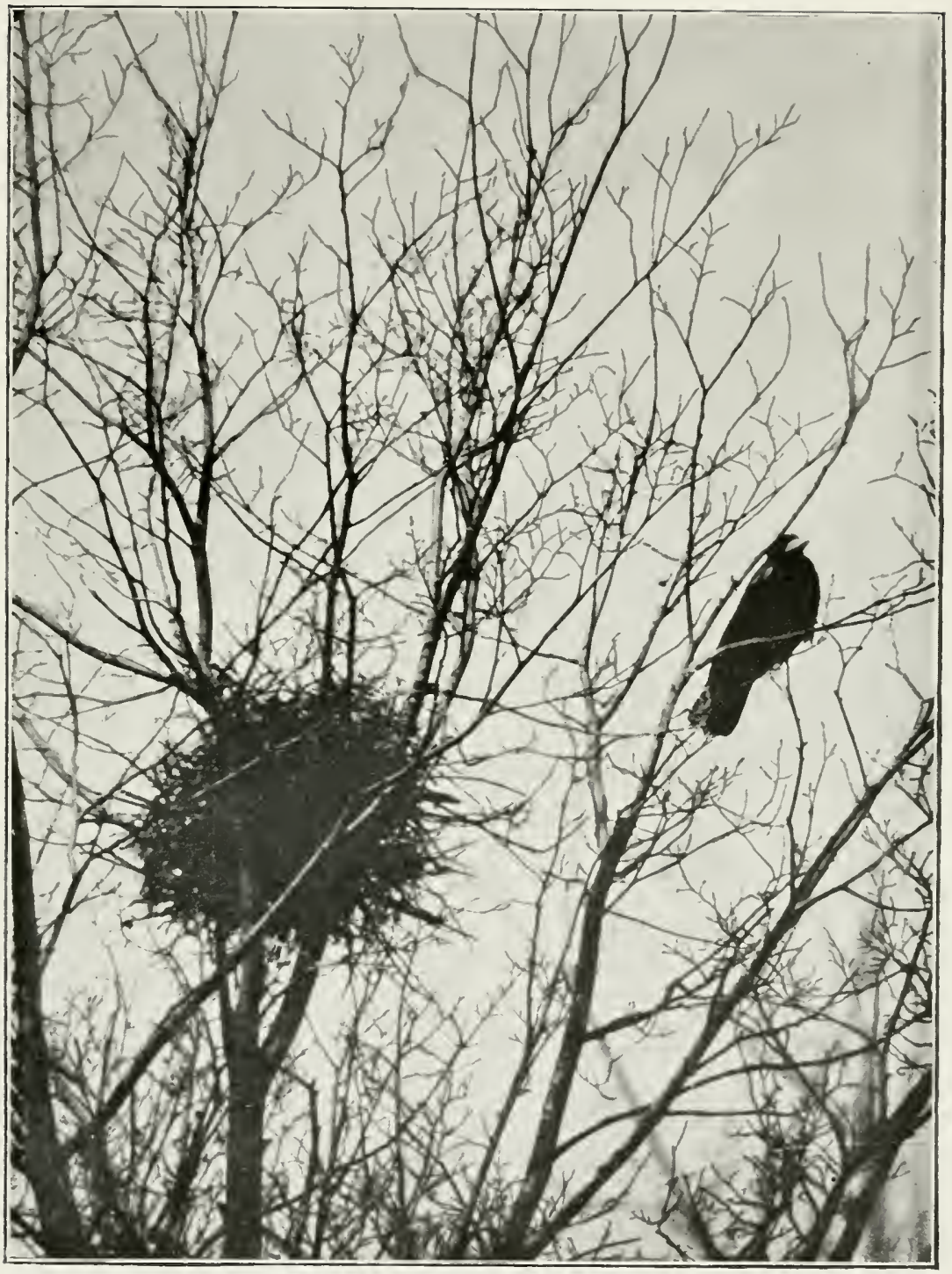

Rook (Coruls frugilegus) AND Nest. 
kind is grown, and where arable land is turned into grazing ground the Corn-bunting is scarce or even disalppears."

'The Yellow-hammer, or Yellow Bunting, is common cnongh at all seasons. Its somewhat monotonous song, which is supposed to somnd like "A little bit of bread and no cheese," is very familiar, for it is somewhat of a

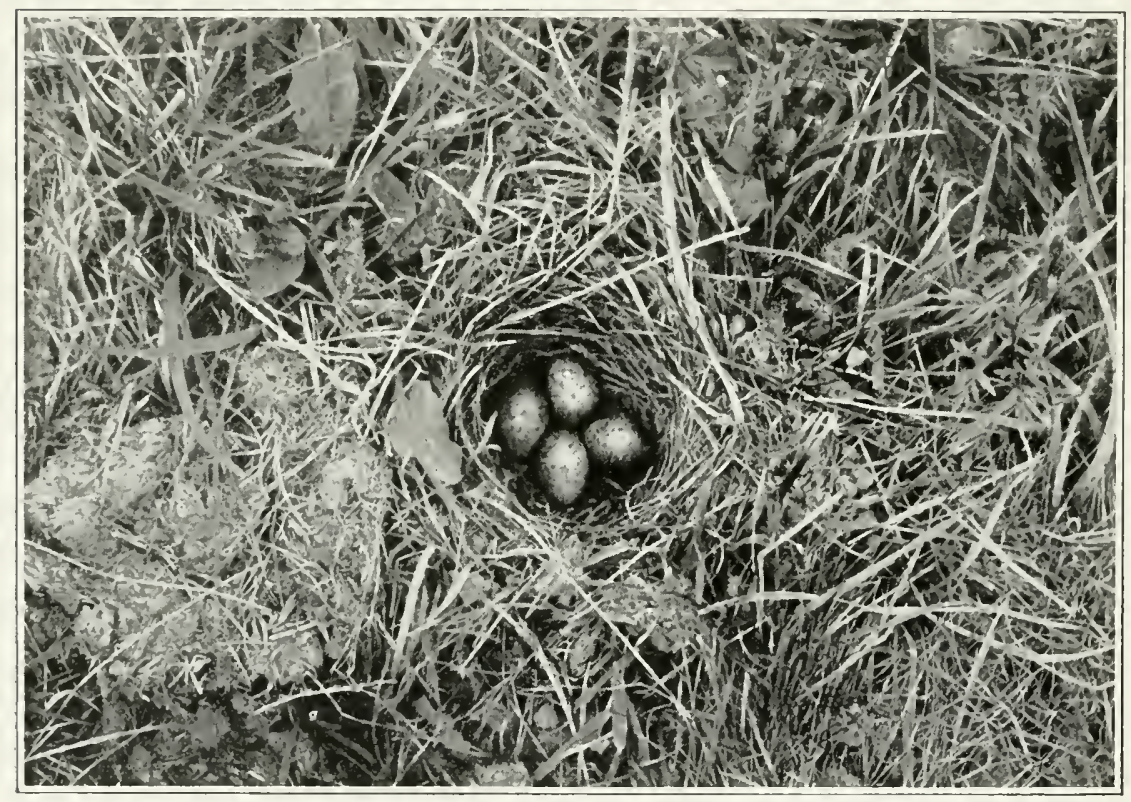

Nest of SkYlark (Alauda ariensis).

roadside bird, where it may frequently be seen on the top of some small tree or bush. The dusty herbage of the roadside bank is quite as often chosen as a site for its nest as the greener and fresher field bank. It is, too, nearly as fond of furme as the limnet.

'The Reed-bunting (or Reed-sparrow) is given to 
marshes and damp situations, though it is by no means restricted to reeds. In one small osier-bed (since drained) I always found one pair of birds nesting. 'The birds. I have thought sometimes. try to delude you as to the true position of their nest by great pretended anxiety when you alre searching in quite the wrong direction. 'This may be only fancy on my part: but be that as it may. the nest is by no means an easy one to find.

The cock is one of our handsomest mative birds. 'Though its colours camnot compete with the brilliance of the Kingfisher, yet it makes in its way quite as effective a picture. In its farourite and characteristic attitude. clinging to an upright stalk of reed or rush, its strongly contrasted plumage shows up so well against the riverside background. whether of green reeds rustling crisply in the summers breeze, which rocks the bird backwards and forwards. or anainst the sere and yellow tints of autumn, or the cold glare of fieshly fallen snow. For it is a resident, and does not Hy fiom us at the approach of winter to warmer climes. The hen is not so boldly marked, and, as she creeps cantionsly through the tangled undergrowth to feed her young. is not nearly so conspicuous.

The Starling is a typical suburban bird, where it is nearly als great a hanger-on to mankind as the common Sparrow. It finds by experience that houses and buildings are provided with all sorts of holes and corners, in chimmeys. under tiles, and in gutter-pipes, which make very convenient places for nests. Here they are really quite as safe. if not 
safer. than in the fields, where large numbers of them nest in holes in trees. The Starling has a bad habit of taking possession of the holes which the Woodpeckers have industrionsly hewn out for themselves in trees, and have also been known to oust the Swifts firom their nestingholes in buildings ('/oologist, June, 1899). In either case the theft is betrayed by the straws sticking untidily out of the entrance, which tell the tale to erery passer-by. The young Starlings, too, in the nest have a peculiarly strong and pungent odour, which may be readily detected from a short distance by anybody familiar with the birds. On several occasions this smell, so well known, has called my attention to the nest in places which I should have passed umnoticed. 'The young in first phumage congregate together in small flocks, and as the summer adrances these flocks join forces, till in antumn their numbers are prodigious. In the Norfolk reed-beds the damage done by their roosting in the reeds and breaking them down by their combined weight necessitates the regular employment of men to scare them off at the approach of evening.

'This first plumage is unspotted, and the young birds used to be described and known as "Solitary Thrushes." Why Solitary it is difficult to imagine: it is the most inappropriate title that could possibly be given them. 'The Starling is not liked by fruit-growers, as it is undoubtedly fond of cherries: but against this must be set the inmense amomnt of good it does all the remainder of the year in clearing the land of noxious insects. 'The grubs of the Cockchafer and Crane- 
Hy, or I anddy-long-legs, which do so much mischief in devouring the roots of grasses, are the farourite food. Watch a dozen Starlings ruming orer the grass. their lustrous plumage shining in the sum, and see how busy they are in searching for these pests.

Once, while waiting at a Starling's nest in an appletree, a Wryneck settled on the edge of the hole and

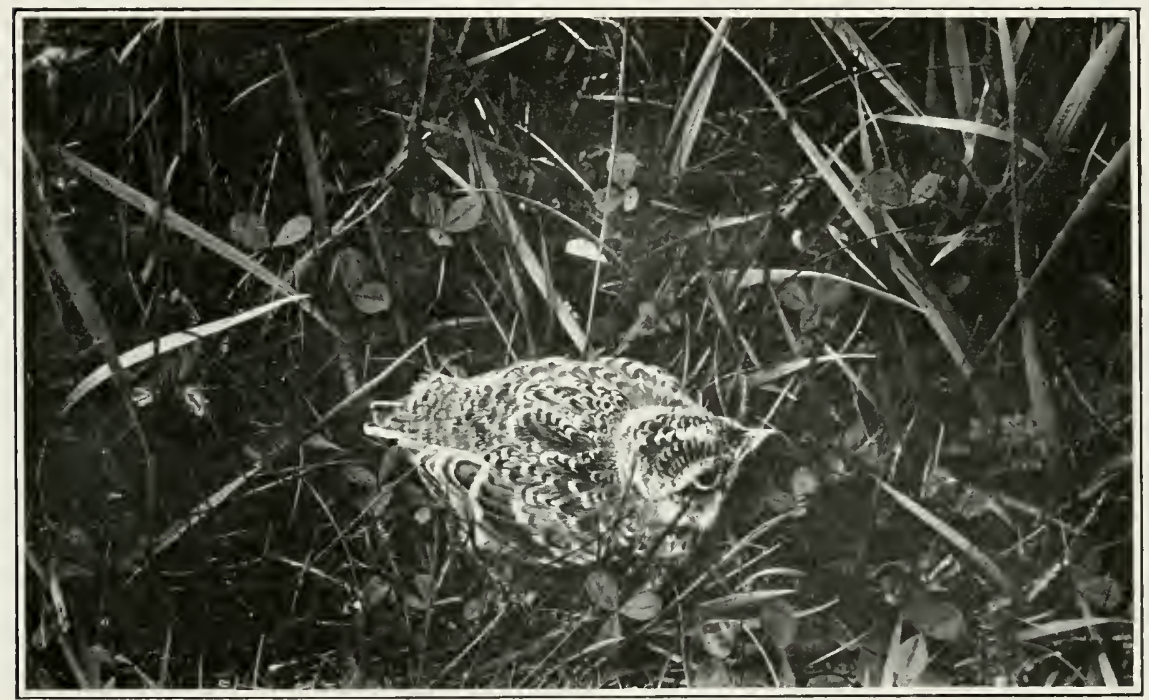

loung SkYLARK (Alamia atensis).

looked in, evidently house-hunting. Before I could press the shutter the Starling. which larppened to be inside. lumstled her away in a great hurry. and thus lost me a chance I shall probably not get again.

'The harsh scream of the Jay may be heard, and oceasionally a glimpse of this fine bird maly be seen: but I have not yet found a nest. It is rery common in the forest. and 


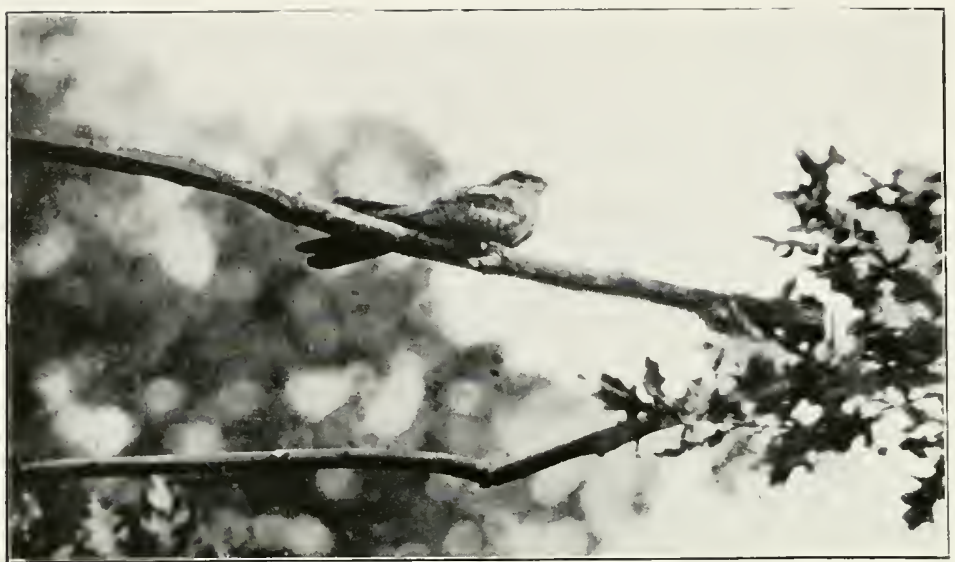

Nightjar (Cuprimulgus europans) ox LPper Branch of OAK-tree.

in the autmonn numbers of Jays spread into the surrounding country, and fill the places of those shot and trapped by keepers. 'The .Jay, no doubt, is rery fond of eggs: but I faney that the Blackbirds and 'Thrushes suffer more from their depredations than any of the game birds. Keepers. howerer, invariably destroy all they can. 'The Magpie also suffers for similar misdeeds. and is in consequence generally a scarce bird where game is preserved. I have seen them sometimes even close to the town. and heard of their nesting in an orchard. But nowhere in Fngland is the Magpie the abundant and familiar species it is in Ireland. Sweden. France, or Spain. where sometimes it seems to be the most common bird, and also the tamest.

Jackdaws are, in my opinion. more mischierous than the Jay or Magpie. I hare caught them in the act of devouring young 'Thrushes pieceneal. and eggs of all groundbreeding birds are regular objects of food. Ialpwings. when 
nesting, know perfectly well what the Jackdaws are after. and if they see one quartering a field containing their nests they will drive it off. Water-hens also will mob any prowling Jackdaw, and attempt to drive it away fiom the neighbourhood of their nest. Last year every Iark's nest known on one fam was destroyed by Rooks, Crows. and Jackdaws.

Jackdaws are generally strictly ecclesiastical birds: but Fnfield has some dissenters, for the Jarkdaws here have made a gallant attempt to fill up the spire of the Iresleyan chapel by dropping sticks through the round holes near the top. When I saw the accumulation, there must have been a comple of cartloads, for the base of the spire, ten feet each way. was filled up to the height of between four and fire feet. I beliere it had been cleared out once before. 'There were no egrs.s. only a few dead Sparrows. I suppose. by the time they have filled up the interior level with the holes, they will think about laying.

The Carrion-crow is another maranding species, and one which is decidedly on the increase round London. where game-preserving is not rery strictly carried out. I have to-day (March 12 th, 1900) been up to a typical nest in a big hedgerow oak, which is to all appearance ready for eggss. (Two eggs were erentually found in this nest. and at that time there were two Crows nests in the same tree, belonging to two pairs of birds which I have seen in the tree at the same time-a most umusual erent.) 
Many Water-hens and Mild Ducks' nests have been robbed by the crows before I eould get up to photograph them. 'The Crow' nest is, in fact. like one of the castles of old, commanding from a height a rich lowland district, the crows themselres being worthy representatives of the robber barons. Like them, they live by harrying periodically their weaker neighbours. From then nothing is safe. Egges and young birds are a regular article of diet: young rabbits, partridges. pheasants, and hares are all carried off: toll is taken of all the chickens and young ducklings within reach: and. failing these. carrion and insects of various sorts are deroured.

'The Hooded Crow I do not remember seeing so far south.

'The Rook. of course. abounds in all suburban districts, though unfortunately it now seems to be on the rerge of extinction as a nesting species in London itself. the ciray's Inn rookery being the only one left.

A pleasant thing it is in spring-tine to hear the familiar caws and to see the birds busily at work. repairing the old nests. damaged by the winds of winter. and making them ready for another season's tenancy. Very deep and cosy are these nests in reality. wamly lined and comfortable. thomgh they look so rough from below.

When the bitter cast winds are howling through the leafless branches, and the tapering twigs are bending in the gale like a ship's topmasts. this depth is necessary to prevent their squab roung from being thrown out. Is it is. some- 
times after a stiff gale many young birds will be found dead on the ground below.

'The Rook is a bird which is gradually deteriorating in character. For long he has been considered a most respectable member of society. a friend to the farmer during the greater part of the year. whose only fault was a liking for seed-corn, and a propensity for stealing sticks from his neighbour's nest when his back was turned, instead of honestly collecting them for himself: But of late years there has been a constant growl from game-preservers that he is acquiring an ever-increasing taste for eggs-mot only for Ialpwings eggs and such-like. which would be forgiven

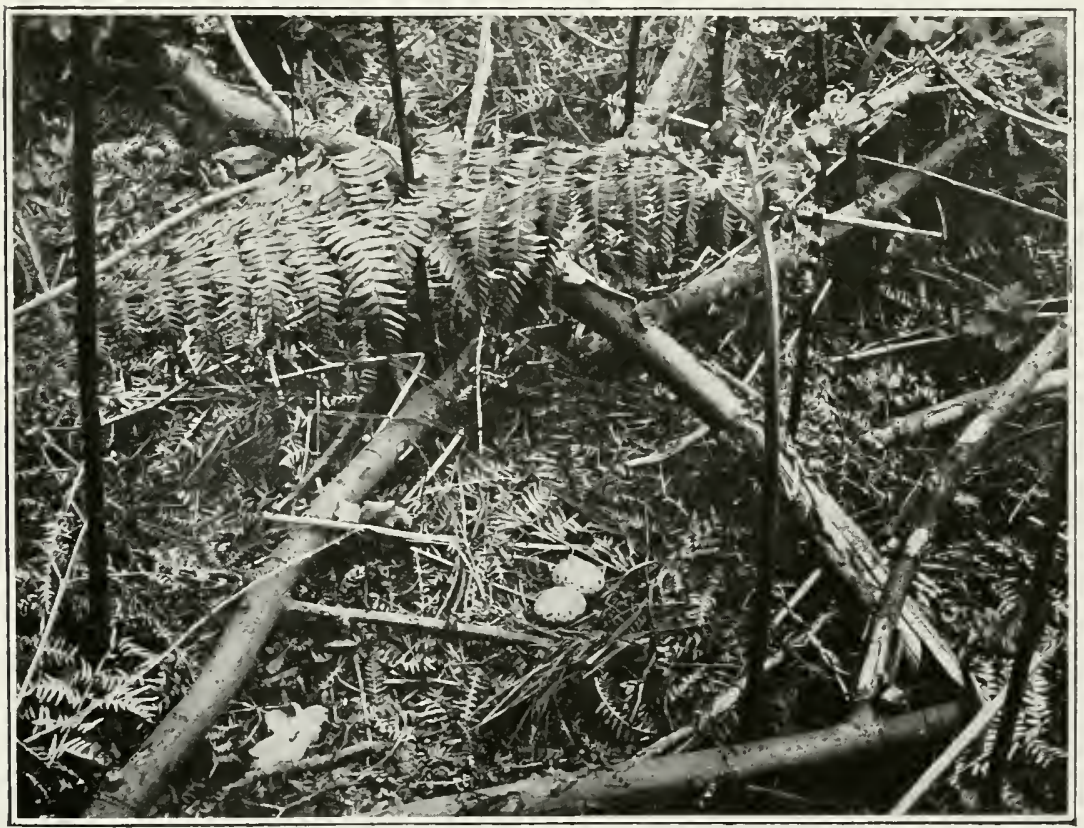

NEST of NightjaR (Caprimulgus emropaus). 


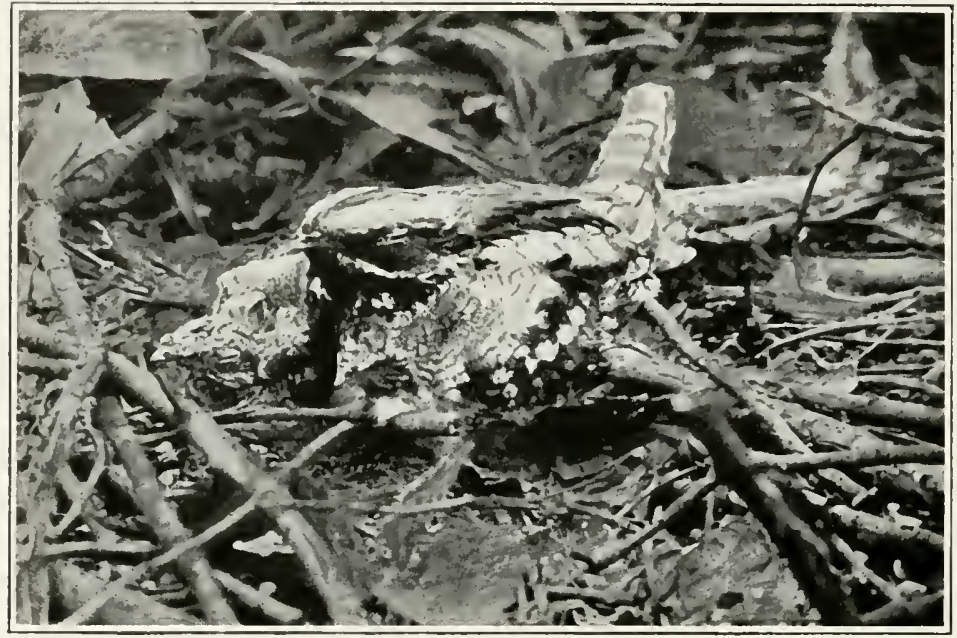

Nightjar (Caprimulgus curopaus) and Young One.

him, but he must have Partridges' eggs, and for such a heinous arime there is no forgiveness.

Now, the worst of it all is that it is too true: and a pity it is, for he is a great ornament to the fields. He is the largest common bird we have left, and his presence in the rookery of ancient elms gives an added dignity to many an ancestral estate. His familiar figure would be missed. and his absence would be mouned as a personal loss by many, if sentence of death or banishment were passed upon him. That Rooks are not arerse to animal food eren is shown by an extraordinary account of the systematic hunting of Field-roles by Rooks in 'I'huringia Wald. It will be found in the October number of the Zorlogist for 1892 .

From a letter in the Zoologist of .January, 1900. by W. Wilson. it wonld seem that some injustice has been done 
this bird. An examination of the contents of the stomardus of dead Rooks by the Highland Agricultural Society appeared to demonstrate that the birds had lived by eating grain instead of noxions grubs and insects, and in consequence many rookeries have been destroyed. Mr. Wilson. however. goes on to say that "another point of general interest to ornithologists has been brought out here by Mr. 'Turnbull, B.Sc., who has examined dead Rooks where a rookery was being ' cleared out.' and found grubs and wire-worms in the birds when dissected shortly after they were killed, but grain only in those examined a day or two after being destroyed, his contention being that digestion went on after death, and that this accounted for little but grain being found in those the subject of the Highland Agricultural Society's Report. 'This digestion after death is worthy of attention, and tends to bring out the views most commonly held on the food of the Rook. Those forwarded to the Highland Agricultural Society were driven by rail to Edinburgh from Montrose, and time must have elapsed before they were examined."

The Raven is no longer to be found, having been for many a year driven away from most inland localities in England. Persecution has been too much for it, and it now betakes itself to the overhanging ledges of the precipitous eliff's round the coast. where it still nests in comparative safety. Enfield, however, can boast of being the last locality in Middlesex frequented by these fine birds, and (an show the tree still standing on which they used to 
nest. 'This is one of a gromp of magnificent elms known as the .. "Three Sisters." close to the New River. In comntries where game preserration is not thought so much of: and where the population is more santy. the Raren still nests in trees. 'l'wo nests I took in the sonth of Spain in 1897 were placed on the top of tall pine-trees. and contained five eggs apiece. This was in May: with us nidification is begm in January. and eggs are laid while snow is thick on the glound.

Among our native songsters, the Skylark ranks with the best. and abound, ererywhere. on either pasture or arable land. A little later than the 'Thrush to begin. it eren rivals that fine musician in the superb quality of its song. Rising higher and higher orer the fields. it pours forth its joyous melody with a rigour and zest perfectly marvellous, until. its highest pitch being reached. it descends still singing, till. nearing the gromel, it folds its wings and drops back to earth. Ocaasionally I have both heard and seen the Iark sing on the gromnd. Once in particular I well remember one singing lustily while perched on a clod of earth within a few yards of where I was hiding. It has even been known to sing at night ( $/$ onglogist. Octoher, 1892).

'The nest. like most of those placed on the gromnd, is exceedingly difficult to find. Fren on almost bare gromid it makes the most of some small inequality, perhaps only sheltered by one small. low plant. so that it takes a sharp eye to discover its whereabouts. IIundreds of nests are destroyed ammually by Rooks. Crows, and Jackdaws, which 
cither find them accidentally while picking up worms or grubs, or else they systematically look for them as a regular article of diet.

'The next bird on my list is of an entircly different character. 'The Swift practically lives in the air. wheeling round in immense circles at great heights. and dashing in erratic and never-tiring Hight throughout the hours of daylight. It never seems to rest. or to alight. except to roost and to nest, for which purposes it resorts to holes in the roof's of thatched cottages, under tiles. and in holes and crevices of church towers and large buildings. Its harsh scream has earned for it in some places the name of ".Jackyscreamer " or "Deviling." It is quite one of the latest to arrive of our summer visitors, and the first one to depart.

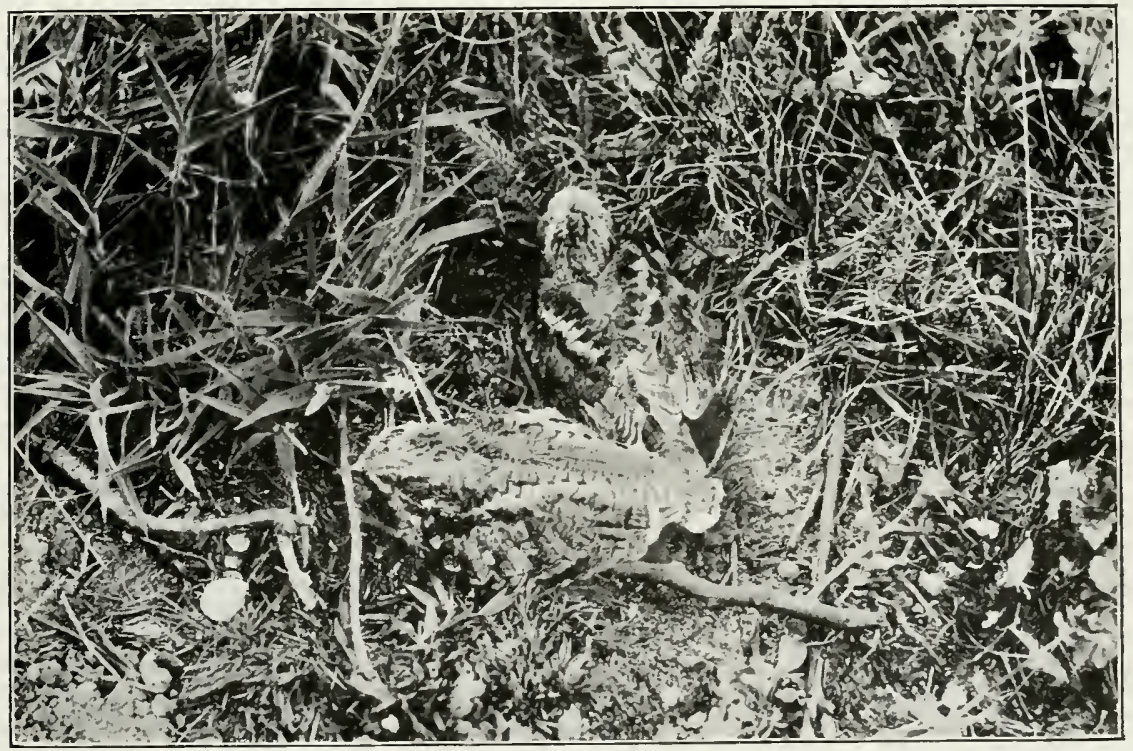

Young Nightjars. 
'They nest in some of the houses in the I condon Road. One in particular. Whose gable-end faces the street in a narrow part. seems to accommodate several pairs on the end of the beams which support the gable. 'The egers are two, sometimes three in number. and are deposited among a few straws. cemented together by the viscid salira of the birds.

'The country here is not generally favourable to the habits

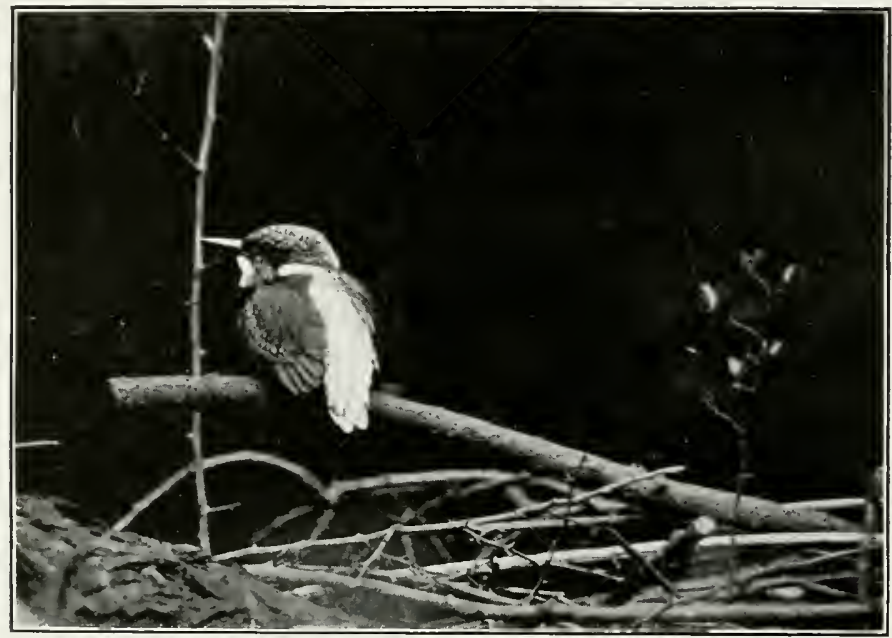

Young KingFisher (Alcedo ispida) sitting on Water-hen's Nest.

of the Nightjar: but wherever bracken is found at the edges of some of the woods a few pairs may be found nesting or rather laying. for nest-making troubles them not.

'The two egg's, cmiously resembling round pieces of chalk or mottled pebbles, are simply deposited on the bare ground. In such places, anid dead leaves and sticks and loose stones, they are not casily seen ; and the bird herself, while incubating. is absolutely invisible to the keenest eyes. muless they knew 
beforchand exactly where to look. As she sits. with puffed out and nearly closed eyclids, she resembles nothing so much as a short bit of dead lichen-corered stick. On two occasions at least I have noticed similar pieces of stick lying close to the egges, as though the hird relied on the protective resemblance they bore to her mottled, russet-coloured plumage.

'The young birds exactly resemble two lumps of dry earth or mud. Fren when in the hand they appear as if they had becn dipped in wet mud, which had dried on them. So much is this the case that I have felt inclined before now to dust them, to try to get some of it oft. A roung Nightjar in the attitude of being fed has a most extraordinary appearance, owing to the immense size of its open mouth.

'The flight of the Nightjar is indescribably light and noiseless, though sometimes it has a curious habit of clapping its wings behind its back.

Quite one of the prettiest experiences with birds I have had was to see one fly up, hover over her eggs, and finally settle down on them. while I was hiding moder my concealed amera not much more than a yard away. I had already photographed her four times. after carefully crawling up to her and climbing over a fence with the camera in full view and very near to the nest. She eventually hatched her roung ones, and, I believe, brought them off all right. But from two other nests the birds deserted on my trying to hide up for them. 'They return to the same place to nest year after year not necessarily to the same spot: but a patch 
of bracken or bit of open ground in a wood is often tenanted regularly by Nightjars. I can generally find a nest, whenerer I want one, by knowing where to look.

A Nightjar. when perched on a thick branch, always sits lengthwise; when on a thinner branch, howerer, it adapts itself to altered circumstances, and then sits across like other birds. 'The lengthwise attitude. howerer. seems to be preferred; for I notice that, if the branch be of a medimn thickness. it will sit diagonally across it - that is, as near to the lengthwise position as possible. 'The eurious cluming noise only made towards evening seems to be akin to the reeling of the Grasshopper-warbler, a vibratory sort of sound, difficult to locate. It has a weird sound as the darkness deepens and the songs of other birds are hushed. It now rises and falls, sometimes appearing to be close at hand. sometimes far away. Presently the bird may be seen on the wing, skimming across the glades of the wood, over which the branches cast fantastie and grotesque shadows in the light of the moon. If by chance the bird should settle near at hand, you will be astonished at the strength and power of the note. howerer it may be produced. The same thing is very apparent with the Cuckoo's note. I have been sometimes perfectly astonished at the powerful vibrations made by a Cuckoo which has settled close to me one I remember seemed to shake the tree in which it sat, a rery large oak.

As Howard Saunders remarks, the Nightjar is known in every country in which it is found "by some name equivalent 
to Croatsucker:" 'This is due to one of those mistaken and utterly exploded ideas which used to be so common in matural history. fit only to rank with the metanorphosis of Barnaclegeese from barnacles. and other ridiculous fables. which have been grarely described and eren illustrated by professed eyewitnesses.

In the delicate markings and general colour of its plumage the Wryneck rescmbles the Nightjar. It is. however, a bird of very different habits, being arboreal. like the Woodpeckers, though not provided with the climbing foot of those birds, or the powerful beak and stiff. pointed tail-feathers. Its habits are somewhat different. Inable to hew out for itself

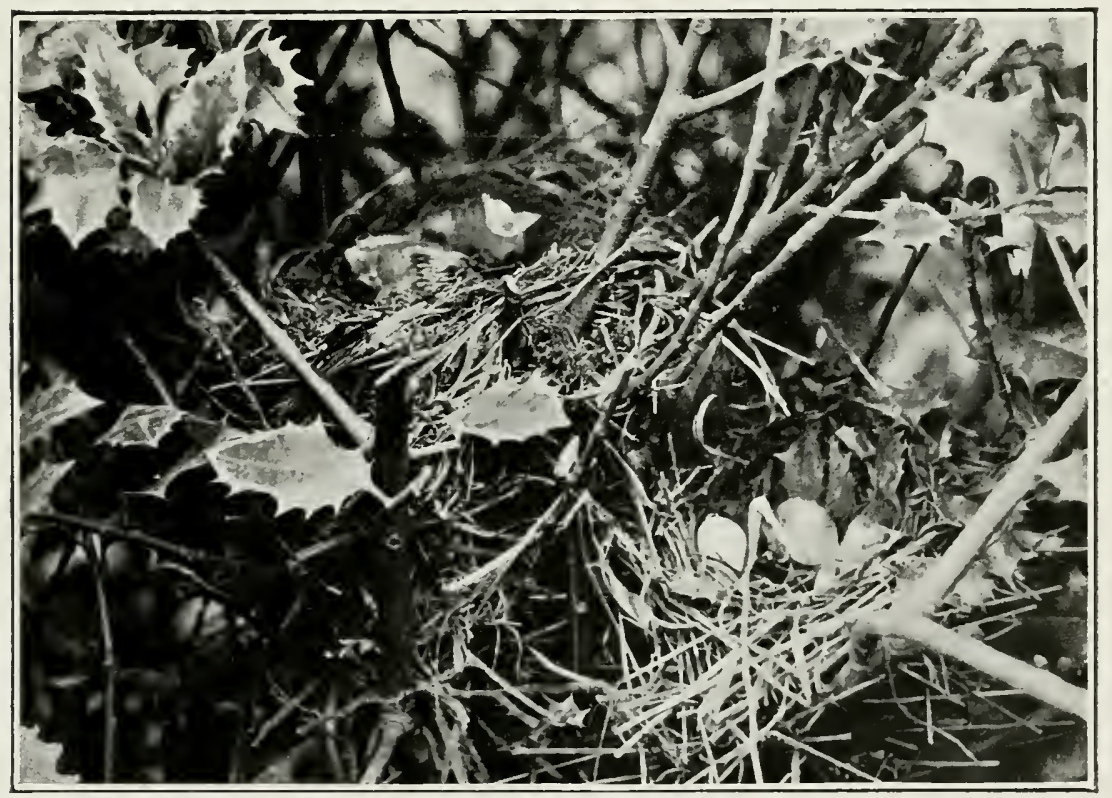

Young Cuckoo (Cuculus canorus) in Hedge-sparrow's Nest.

(Below in an old nest is an egg and dead nestling, presumably ejected by the young Cuckoo). 


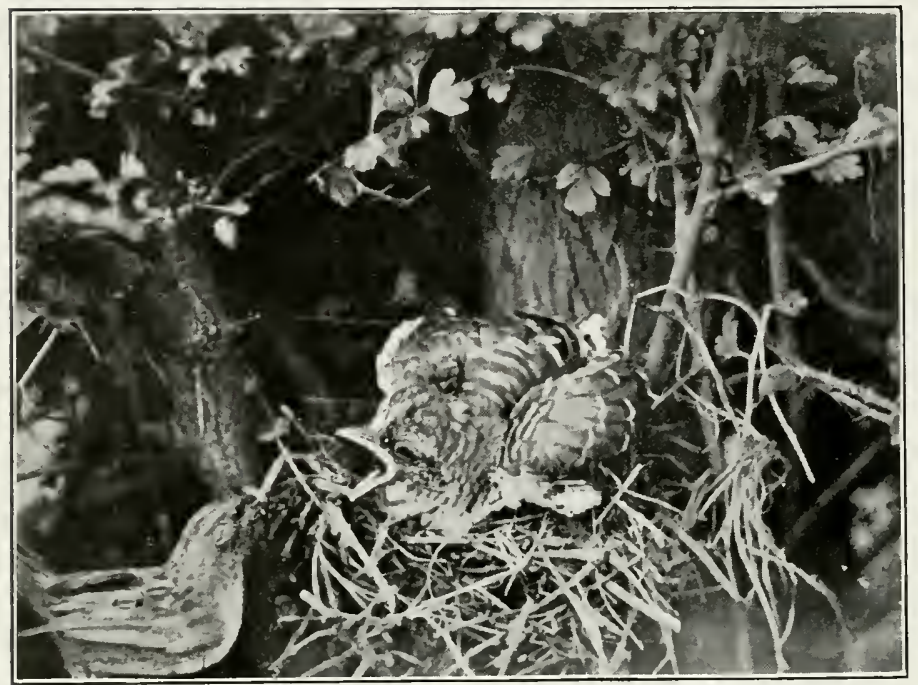

Young Cuckoo fed by Hedge-sparrow.

a hole for its nest, it has to fall back upon some natural hollow in which to deposit its white eggs.

'The Grecn 1 roodpecker is the largest representative of at class of birds extraordinarily well fitted in every detail for the life they are destined to lead. They are, in fact. rery highly specialised, eren among birds. which show peculiar proof's of adaptability to all sorts and conditions of life.

'There is not a condition in the life of Nature's beings that some bird camnot adapt itself to. even to burrowing holes under the cartl. and. more wonderful still. to boring tumnels in the hard and solid wood of large trees in which the sitting female can incubate her eggs free from danger and molestation. In almost every case of birds nesting in holes two facts are rery apparent. (One is, that the egges are almost invariably white. or white inconspicuously spotted 
with red. the exceptions being the blue eggs of Starling and Jackdaw: and the other is, that the birds themselves are generally of brilliant plumage in both sexes. A bird sitting on egges, if brilliantly coloured or conspicuously marked. is of course much safer out of sight down a hole;

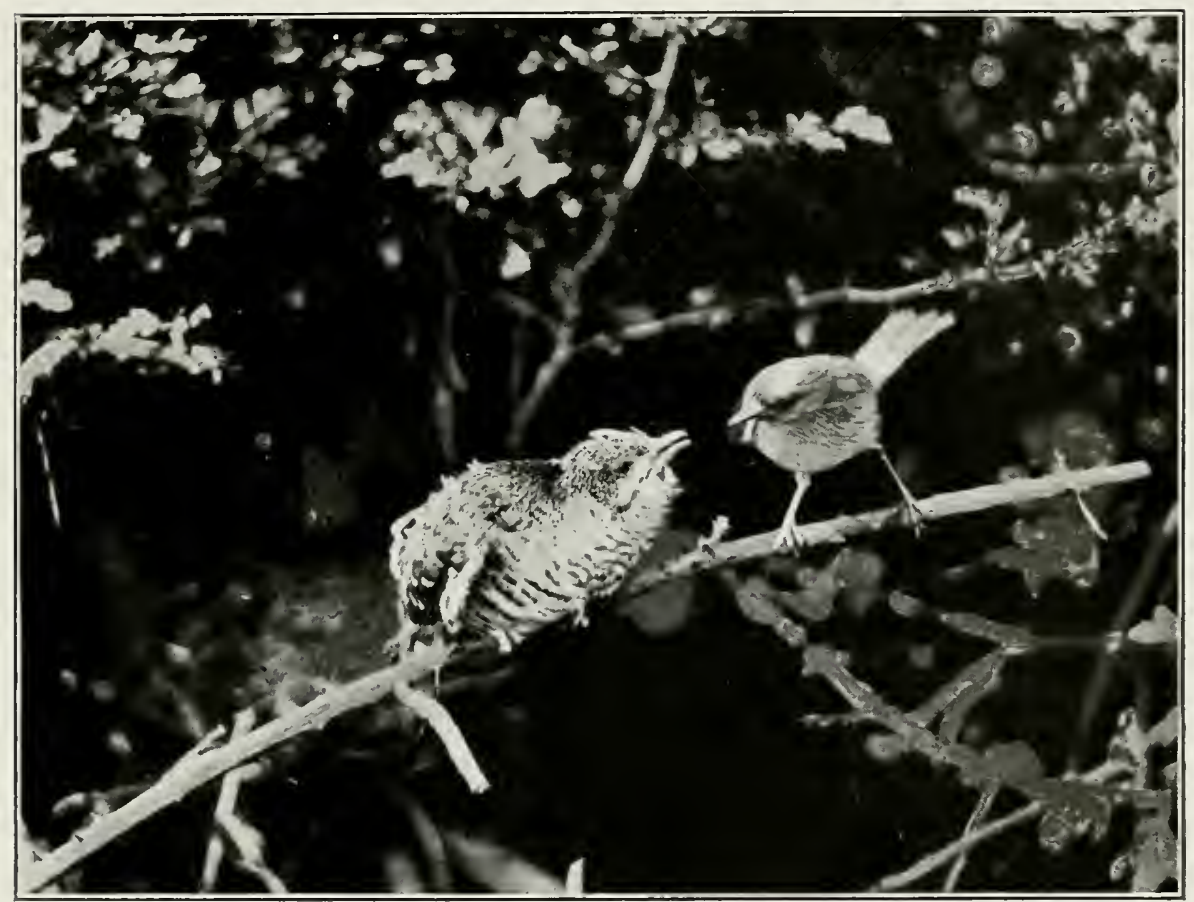

Joung Cuckoo fed by Hedge-sparrow.

and the farct that all the brilliantly plumaged hen-birds on the British I ist nest in covered situations, with a few exceptions anong the gromud-building birds, seems to indicate that they are perfectly aware of the fact. 'The exceptions to this rule take other steps to the same end. 
Knowing that they ane conspicuous, instead of sitting close, they leare their egges at th slightest suspicion of danger, wamed hy their mates. which keep watch orer them. But their eggs. which would be in danger if white. like those of birds nesting in holes, are invariably exceedingly diflicult to see, being in colour and marings so like the surounding ground as to be indistinguishable. Birds which sit closely on an open nest are always so protectively coloured as to be rery inconspicuous.

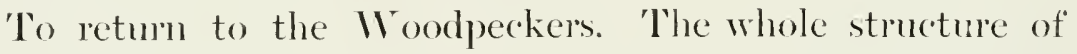
their bodies in erery particular is admirably adalpted to their peculiar way of life. 'The feet are rery powerful: and in place of the toes in front and one behind. as is usual with birds which merely grasp their perch, they have two hind toes and two front ones. This gires the birds a better purchase in grasping the inequalities of the rough bark. and in supporting themselves in an upright attitude. Additional support is further provided by the long, stiff. incurved tailfeathers. which serre as a fulcrum. The beak is like a natural pickaxe, with which the bird. while grasping firmly with its strong feet, can give the nost tremendous blows. sufficient not only to dislodge large pieces of bark in searching after insects. but to dig grubs and caterpillars out of the solid wood. The nest-lole is constructed by boring a perfectly circular hole into the tree. which turns at right angles to a depth of several inches. 'The hollow is then slightly enlarged, and the glossy white eggs la:d on the chips at the bottom.

'The tongue is perhaps the nost extraordinary feature 
in the 11 oodpecker. heing (aupalble of protrusion to the extent of four inches. 'The tip is sharply pointed and barbed, and covered with a glutinous secretion. The anatomical peculiarities of this curious tongue are worth describing.

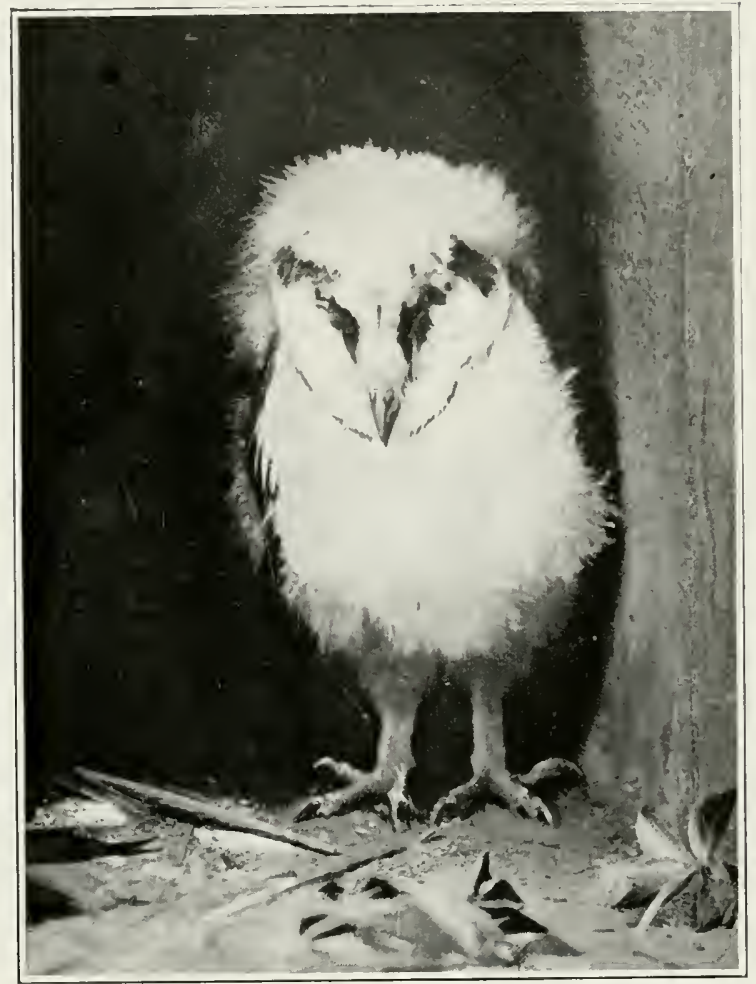

Young BARN-OWL (Stryix flammea) IN DOWn.

Instead of the root of the tongue being fixed to the throat. the tongue itself goes some distance down the throat, and then divides into two tendinous processes, which rise again and coure round the head, one on each side, and are firmly attached to the frontal bone, near the base of the upper 
mandible of the beak. 'The length of a specimen which I have had in spirits for twenty years is 8 inches, including the tendinous processes, the tongue proper being $4 \frac{1}{2}$ inches.

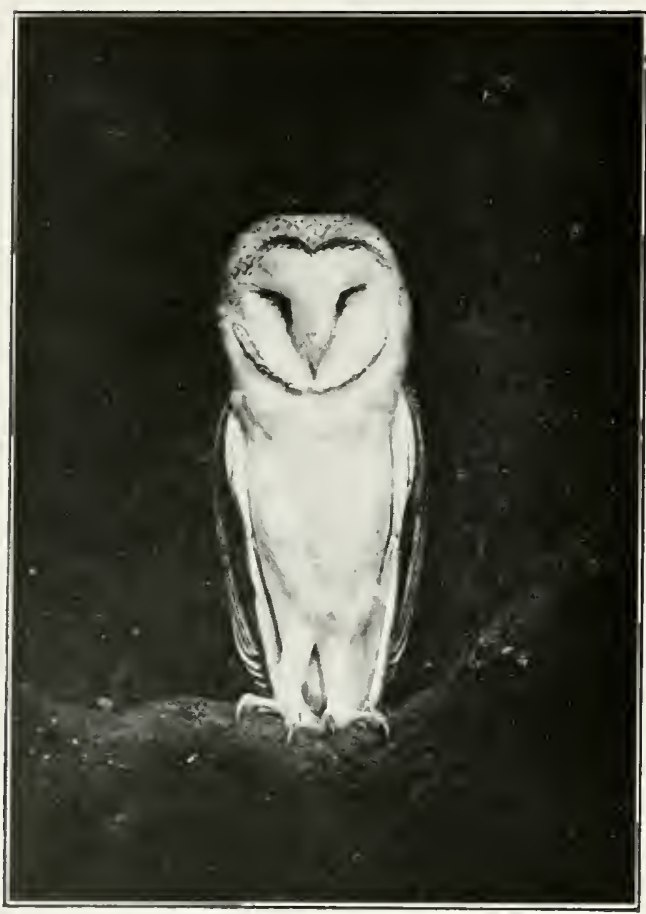

BARN Owe, (Stryir flammia).

'The length of the whole bird from beak to tail is only $1.2 \cdot 5$ inches.

All three Wroodpeckers are fairly common romend I andon, the I esser Spotted being on the whole the most abundant. 'The curious drumming noise made by Woodpeckers in spring-time may be often heard, as they sit on a dead bough and hammer it with their beak with inconceivable rapidity. The effect is a curious drumming. vibratory noise, which may be heard for a long distance. and is rely difficult to localise. I once followed the sound for a long way. thinking at every step the bird was in the next tree, and then the next. At last it Hew out quite fifty yards fiom where I had thought it to be. It is supposed to be a call-note between the sexes before pairing, and is only heard in spring-time. 
Young Woodpeckers, before leaving the nest for good, rum in and out of their hole and climb the trunk as nimbly as the old birds.

In spite of the persecution it undergoes, in consequence of its brilliant plumage, the Kingfisher still holds its own, and is. I firmly believe, as common as it was thirty years ago. Hundreds are shot, in spite of the Bird Protection Acts, and more still are netted in the antumn, when there seems to be a decided migratory movement among them. Kingfishers then are frequently met with in places where at other seasons you never expect to see them. Bird-catchers aatch them when netting the ditches and small streams for Blackbirds and Thrushes: I have had four bronght to me alive in the course of one week. Some I have bought, and after keeping them a few days have released them at the bottom of my garden, along which passes the New River. One of these birds took Sticklebacks out of a soup-plate after the first day, but they never live long in aptivity.

They nest here regularly in certain places. In the bank of some small brook the Kingfisher makes a hole. or finds a rat-hole ready made, at the end of which it enlarges a small cavity. Ifere the minute bones of the small fish on which she feeds are disgorged, and on these she lays her shining white eggs. almost globular in form. I have occasionally seen the bird hover like a little Kestrel and plunge into the water after its food: but its usual tactics are to sit motionless on some orerhanging spray or protruding stump, on the watch for any small fish or aquatic insect. On these it drops suddenly. 


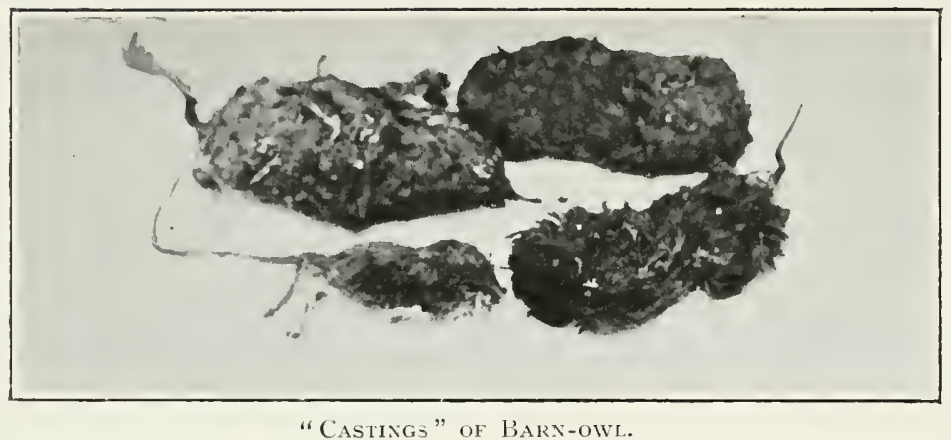

and generally succeeds in making a capture. It then resumes its perch, or sometimes another one near at hand, with the prey - if a fish-crosswise in its beak, and it is only swallowed after being repeatedly banged violently against its perch.

By watching these lovely birds, it is possible to find out their farourite perches along a length of stream. 'To these they Hy regularly, and visit one after the other. At one such perch, a thin rootlet sticking out from a bank. I watched at close quarters an adult Kingfisher this year for a long time. He had in his beak a small fish, apparently from the shape a very young .Jack. Just above the bank was a hole, from which apparently a brood of young Kingfishers had recently flown, and I was doubtfinl if they were nesting again. either in the same place or elsewhere near at hand. Momentarily I expected to see it fly into some hole or other, and watched it closely. hoping thereby to discover its nest. Finally howerer, after waiting a considerable time, it swallowed the fish itself, head foremost, after first taking it by the tail-end in its beak and swinging its head round viciously 
against the twig it sat on. Every bone in the fish's body must have been smashed by the repeated blows. The movements of this bird, as of others I have watched, were very jerky, and its attitude the reverse of graceful.

A regular perch in another strean was a tree-stump lying across the water, with sereral projecting arms. In the middle was a $W$ ater-hen's extra nest. This made an excellent station for a pair of Kingfishers-or perhaps I should saly two Kingfishers, young birds of the year, fully fledged and quite capable of looking after themselves. Repeatedly, during a day spent in ambush squatting in a small elder-bush, concealed by twigs and nettles, these two birds returned to the place. sometimes sitting on the stump, sometimes on the outer sticks of the W'ater-hen's nest. Sometimes one only

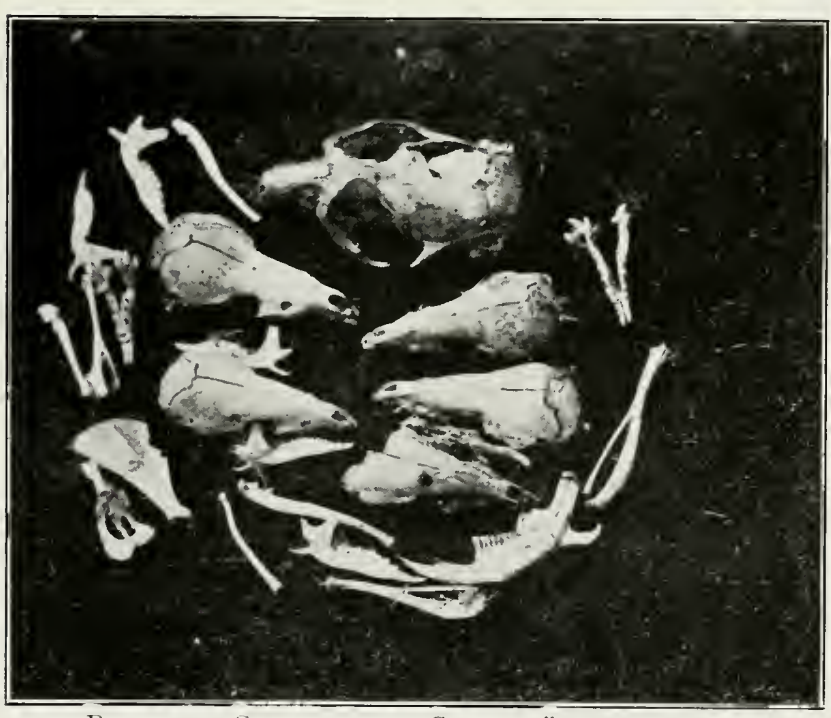

Bones AND SKulls From "CASTINGS" OF BARN-OWL. (The five shrews' skulls were from one "casting.") could be seen, but generally both of them were in view at the same time. Many plunges were made after sticklebacks while we watched, and nerer once did they miss their prey. 


\section{Pictures of Bird Life}

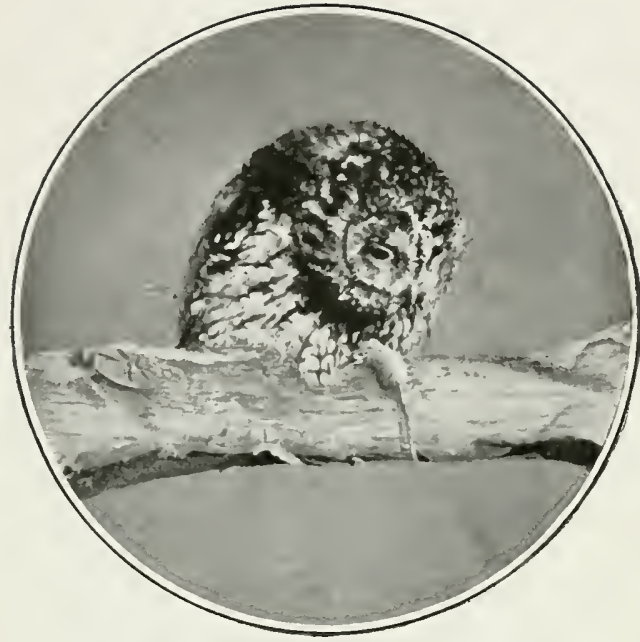

TAWNy OWL (Symimm aluco).

I once saw a Kingtisher hotly pursued by a Sparrow-hawk. Both birds flashed past me at topmost speed while fly-fishing in a small Lincolnshire stream. There was but a small space between them, and I could mark the bright yellow eyes of the Hawk. and the feet among the breast-feathers ready to strike, but a thick and high liedge prerented me from seeing the end of the chase. 'There is no doubt, howerer, that, unless the Kingtisher could take shelter under a bank or drop into the water, it must have been taken. 'They are not birds capable of prolonged effort in flight. though for a short distance they travel rery quickly.

One of the most curious habits among birds must surcly be that which characterises the Cuckoo, of laying its eggs in the nests of other birds, and thereby ridding itself of the burden of bringing up its off'spring. (Other birds show such derotion to their young lore of offspring being so predominant in their natures that life itself is freely sacrificed in their defence that this callonsness on the part of the Cuckoo is rery abnormal and rery difficult to account for.

The South European form, the Greater Spotted cuckoo, also practises the same parasitical custom, but restricts 


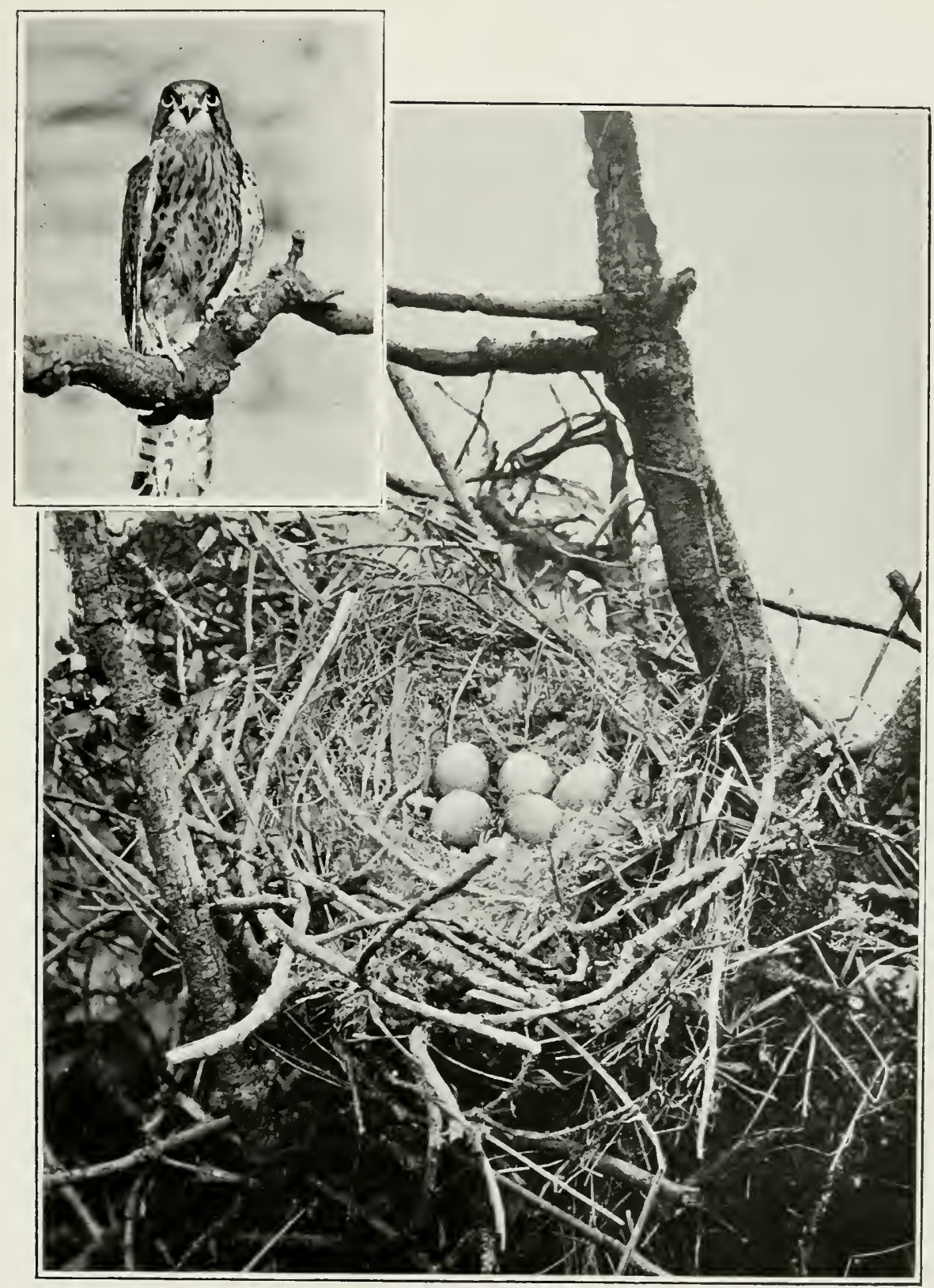

Kestrfi (Falco timmunculus) AND NEst. 
itself almost exclusively to laying in the nest of the Mangie. The Imerican Cuckoo, howerer, builds a nest and rears its own progeny like other hirds.

'The sound of the well-known and familiar note of our bird is always eagrerly expected, as a welcome harbinger of spring. It sometimes happens that numbers of Cuckoos arrive simultaneously, as if they travelled in large flocks. and that their mocking cry of "Cuckoo" is heard in all directions, and the birds conspicuously seen in numbers about the fields and hedgerow trees. where the day before there was not one to be heard or seen.

The nests particularly faroured by them seem to be those of the Hedge-sparrow. Meadow-pipit, Pied Wagtail, and Robin, and I have seen the egg in nests of the Willowwren and Redstart. 'The latter nest was, as usual with the Redstart, in a very small hole in a cherry-tree. into which it was perfectly impossible for the Cuckoo herself to have entered. In such cases it is supposed that the egg is deposited on the ground and then placed in position by the beak.

Young Cuckoos are gifted with most inordinate and insatiable appetites, and grow apace. 'To make room for their Inwieldy bodies. they have a most objectionable habit of ejecting the other and rightful ocmunts of the nest. 'The illustration on p. 1:3:3 shows the details of one sueh tragedy. in a more complete way than would be possible, as a rule. Here. however, the accidental circumstance of a second old nest immediately helow having arught the ejected nestling and an egg enables me to show a complete record. The 


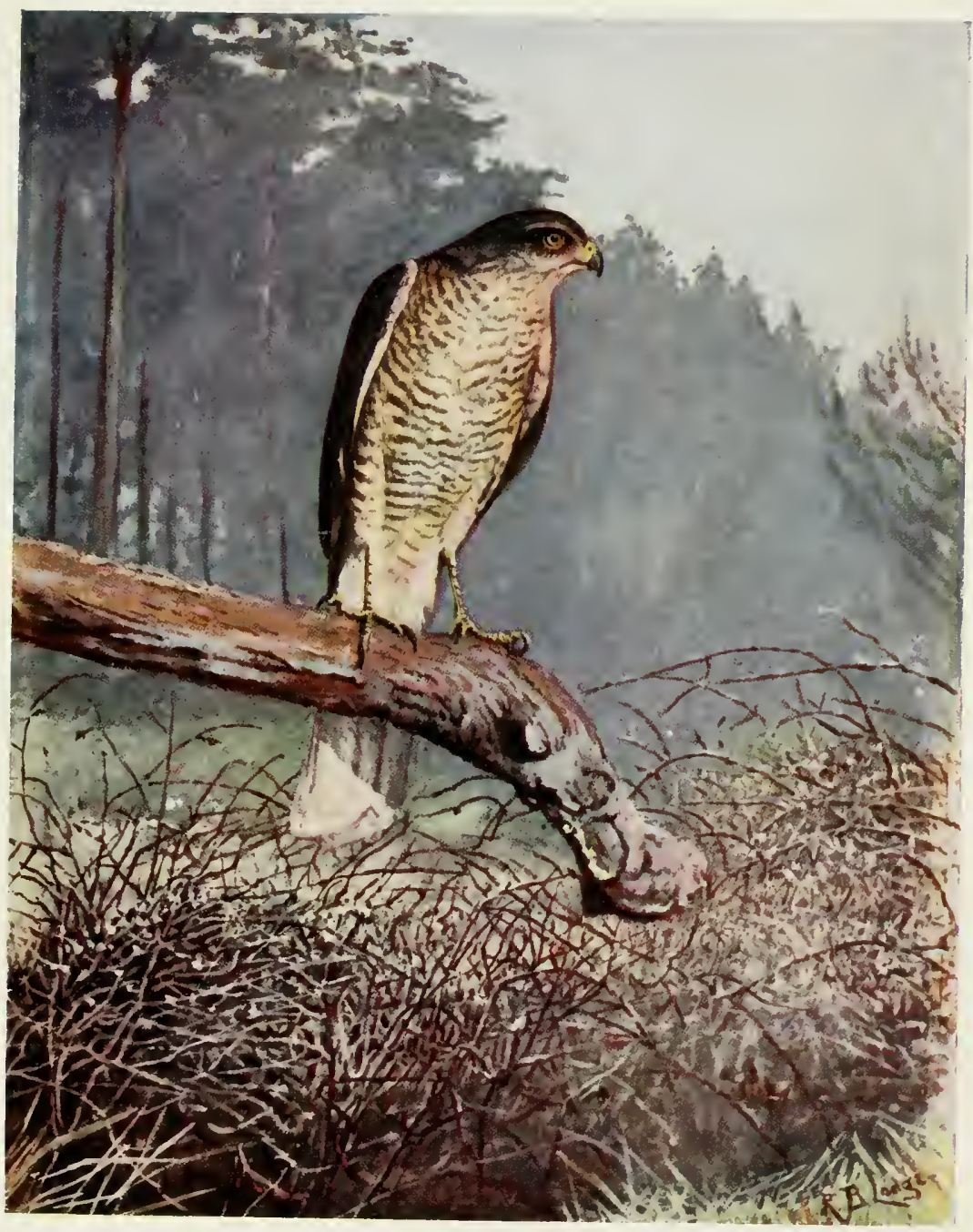

fromline.

SPARROW HaWK.

(Accipiter Nisus.) 

little monster above. characteristically enough. has its mouth wide open, screeching for mole food. 'The nest was that of a IIedge-sparrow. placed in the very centre of a variegated hollybush.

'The fosterparents show the greatest attention to the usurper long after it has left the nest. and may sometimes be seen busily feeding it

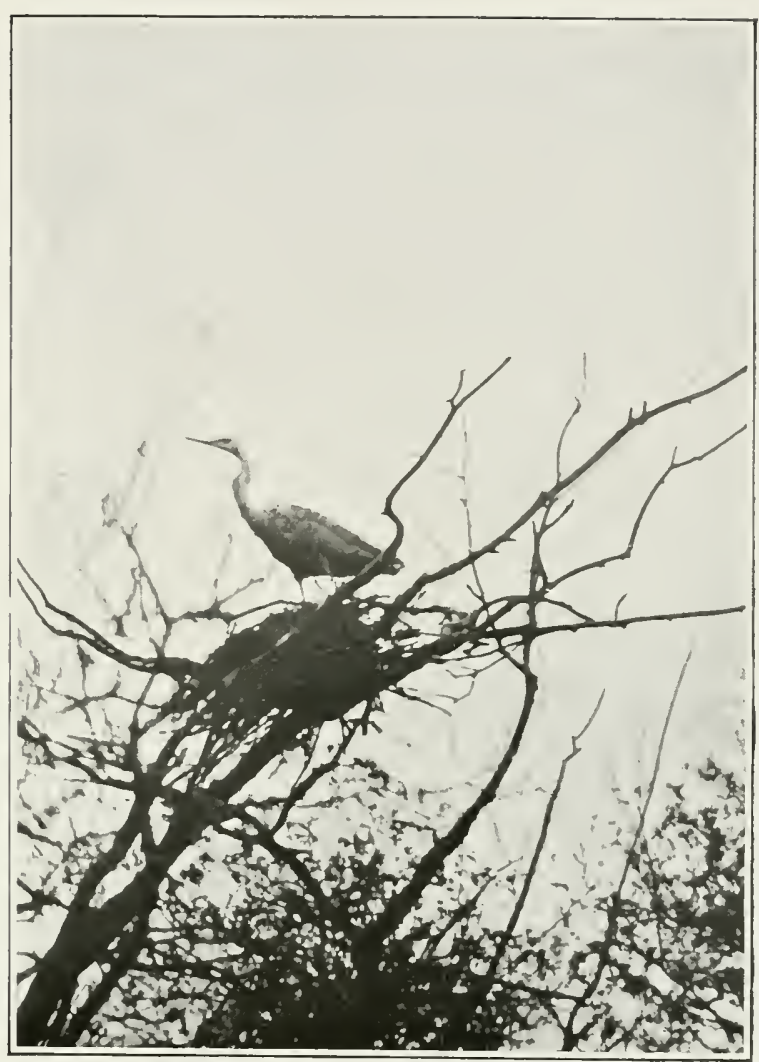

Heron (Ardea cinciea) AND Nest. when it is apable of Hight. and is many times bigger than the two of them put together.

'The Barn-owl, though one of a persecuted race. still holds its own. In 1901 a pair built in the eaves of an moocoupied house in a side street. Though the united hissings and snorings attracted attention of a hostile character fiom some persons who should have known better, the nocturnal family were luckily protected by the inhabitants of the neighbouring 


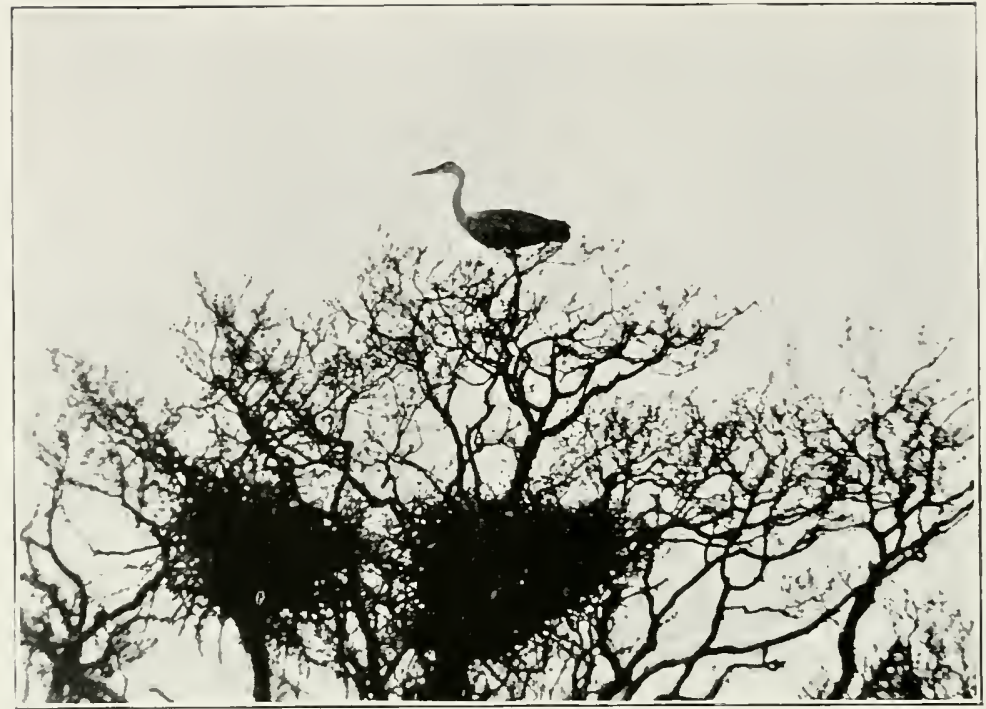

Heron (Ardea cinerca), Richmond PARK Heronry.

house, and with the exception of two. which fell from the nest, the brood got off' safely. 'The house has since been unfortumately let, and the hole carefully boarded up by the new tenant, because of his children, as he told me! I never myself knew of an (Owl eating children, but I suppose he thought he would be on the safe side. On another occasion I was smmmoned by a breathless choir-boy one Sunday evening to eome at once to the church, as some Owls were in the roof. There I found parson, organist. and choir gazing up at a small hole in the oak panelling of the chancel roof, at the imminent risk of a crick in the neck. From this hole it appeared that an Owl had appeared during the service. Frentually it was agreed, on my suggestion. that as they had taken sanctuary in the church 
they should be allowed to remain ummolested. 'There, accordingly, I hope they still abide in safety.

Occasionally, when riding home in the gloaming, I have seen a ghostly form fly orer the fields on silent wing, and the "Whoo-whoo" of the Tarny (Owl may be often heard after nightfall. Sometimes I find one resting in the

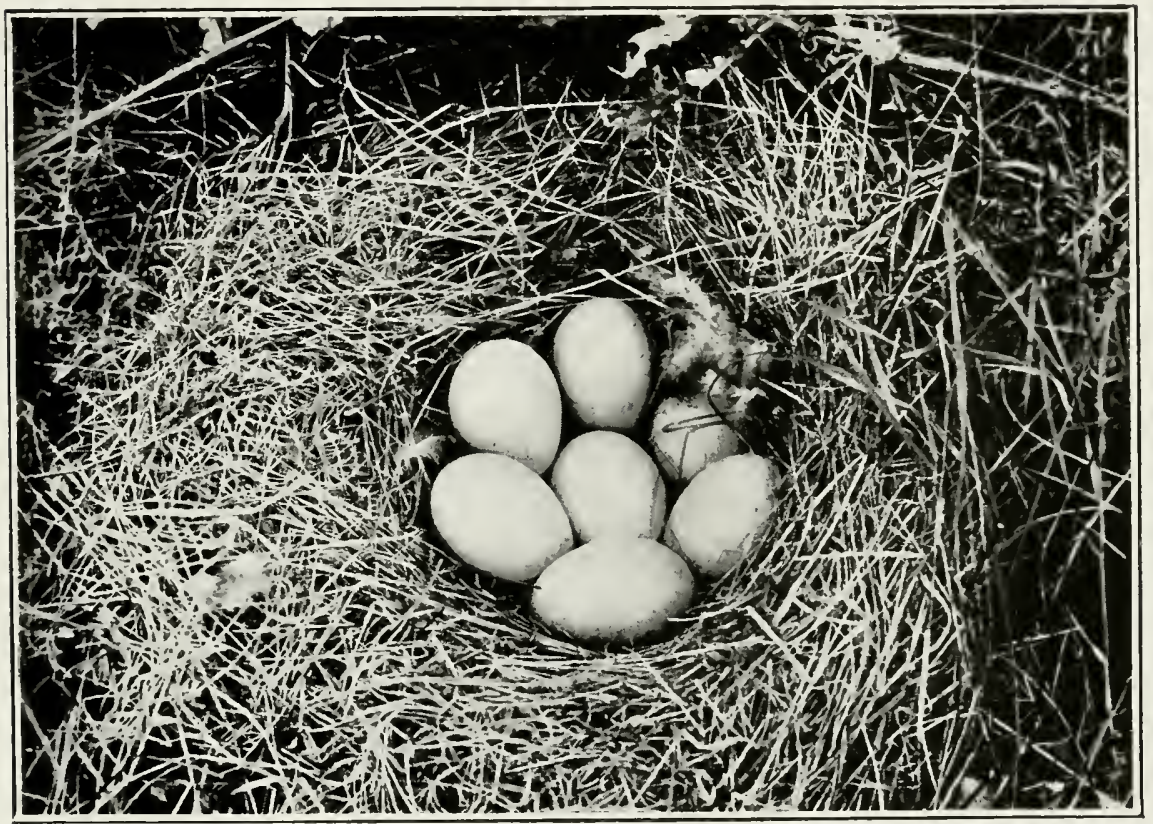

Nest of Wild Duck (Anas boscas).

cavity of an ancient oak, up whose trunk I have scrambled inside like a chimmey-sweep. Some castings taken from the hollow were full of the glittering wing-eases of beetles. 'The 'Tawny Owl breeds here regularly in some numbers, but this particular hole seems to be only used for resting in during the day, and I have never found more than one 
bird in it. 'There is no doubt that there would be more of these two species if it were not for that most iniquitous of traps the pole-trap.

On a keeper's gallows near here are nailed up three Bann-owls, one 'lawny (Owl, and two Kestrels, all of

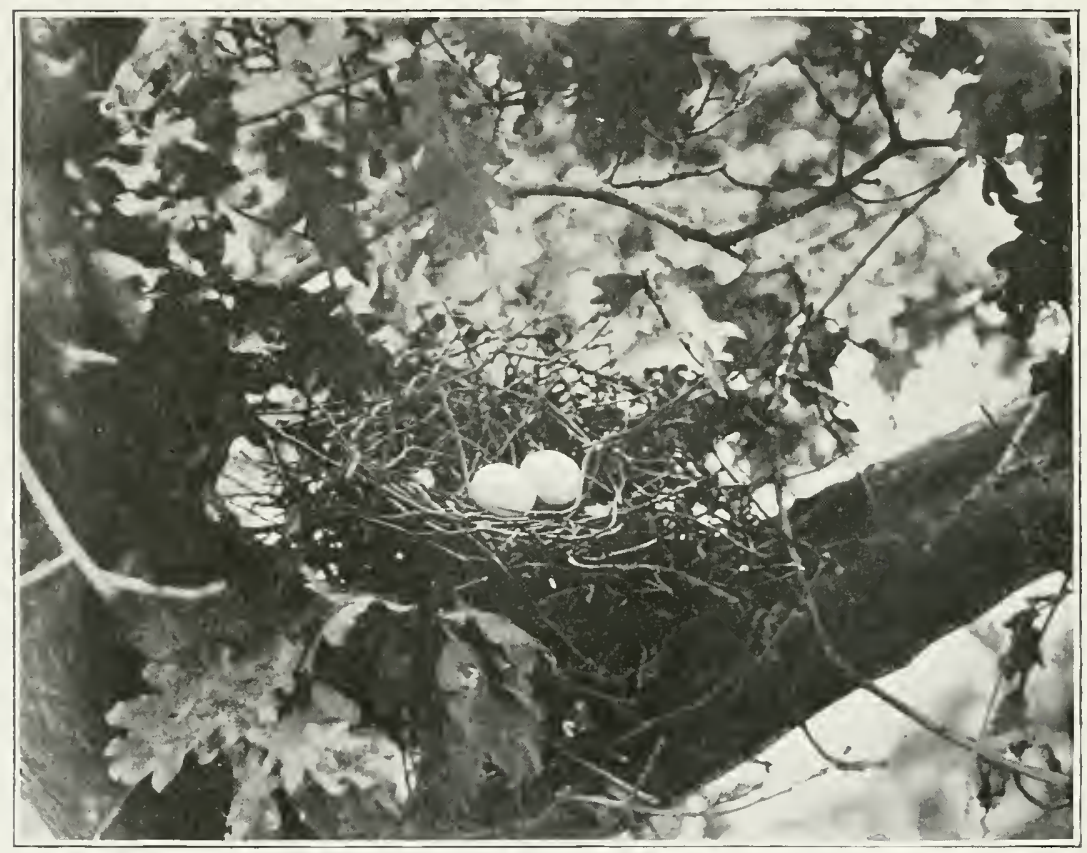

Nest- of - Wood-PIGEON-(Columba-palumbus).

them victims of a pole-trap erected outside between two large woods. Now, all of these birds are absolutely harmless to game, and of the greatest possible use to the farmer.

The late Mr. Cordeamx describes the barbarity of the pole-trap) with such rivid eloquence that I should like to 
bring his words before every game-preserver in the kingdom: ." The (Owls (Short-eared (Owls) have been exterminated by the keepers with their deadly pole-traps a cruel form of bird murder which no humane person would tolerate or adopt. . . The useful barn-owl, too. has been ruthlessly destroyed whenerer opportunities offered in this same cruel fashion. Noiselessly across the waste in the twilight. like a flitting phantom, comes the soft - winged ()wl, and secing, as if placed ready for his use, a post of rantage from which be may mak cach stealthy morement of the mischierous Field-role, stays his flight to settle on the treacherous perch: and then during all the long sad night-and too often, we fear, through the succeeding day-with splintered bone protruding through smashed Hesh and torn tendon, hangs suspended in supreme agony, gibbeted head downwards till death puts an end to his sufferings. Well may we ask, Cam all the game-preserving in the world justify this ignorant and needless wrollg !"

()wls and other raptorial birds eject the indigestible parts of their prey in the form of pellets, so that it is perfectly easy to show exactly on what they feed. On putting the castings of a Barn-owl into warm water, you find bones of mice with their skulls embedded in the skin. Out of bushels of these castings taken from hollow trees inhabited by (Owls for many years, not the slightest trace of the remains of any game bird is to be found. The few bird-remains will be Sparrows skulls. The Isong- 
eared (Owl is the only species which may perhaps be suspected of occasionally taking young Pheasants, but I (annot help thinking that its opportunities in this direction are very few and far between.

The Kestrel, hanging on suspended wings over the fields mouse-hunting, is not at all an uncommon sight. and is one which I fiequently enjoy. 'These birds make no nest for themselves, but make use of an old Woodpigeon's. Crow's or Squirrel's nest. One found two years ago was on the top of an ash-tree. and the five eggs reposed on a comfortable bed of broken-up castings of mouse fur and bones, among which I detected only one bird's wing. that of a hen Blackbird. And yet this bird is killed as rermin by nine keepers out of ten.

Another nest was found immediately outside the town, in an old Crow's nest high up in an immense elm. It was only found the day before the young left it. For four days a friend and myself lay in wait with cameras pointed at two young chickens tethered within sight of the nest. On the first day the hen Kestrel hovered immediately orer the mconscious chickens: but just as she appeared ready for the fatal stoop, she detected me rouching behind a big tree and sheered off. 'Though we tried different places for the bait and changed our hiding-places. it was all to no arail. One whole day we spent on an overhanging branch of a neighbouring tree, well hidden, as we thought, by the surrounding leares. helped out by cut-down branches. But though we were unsuccessful in these attempts to photograph. we were 


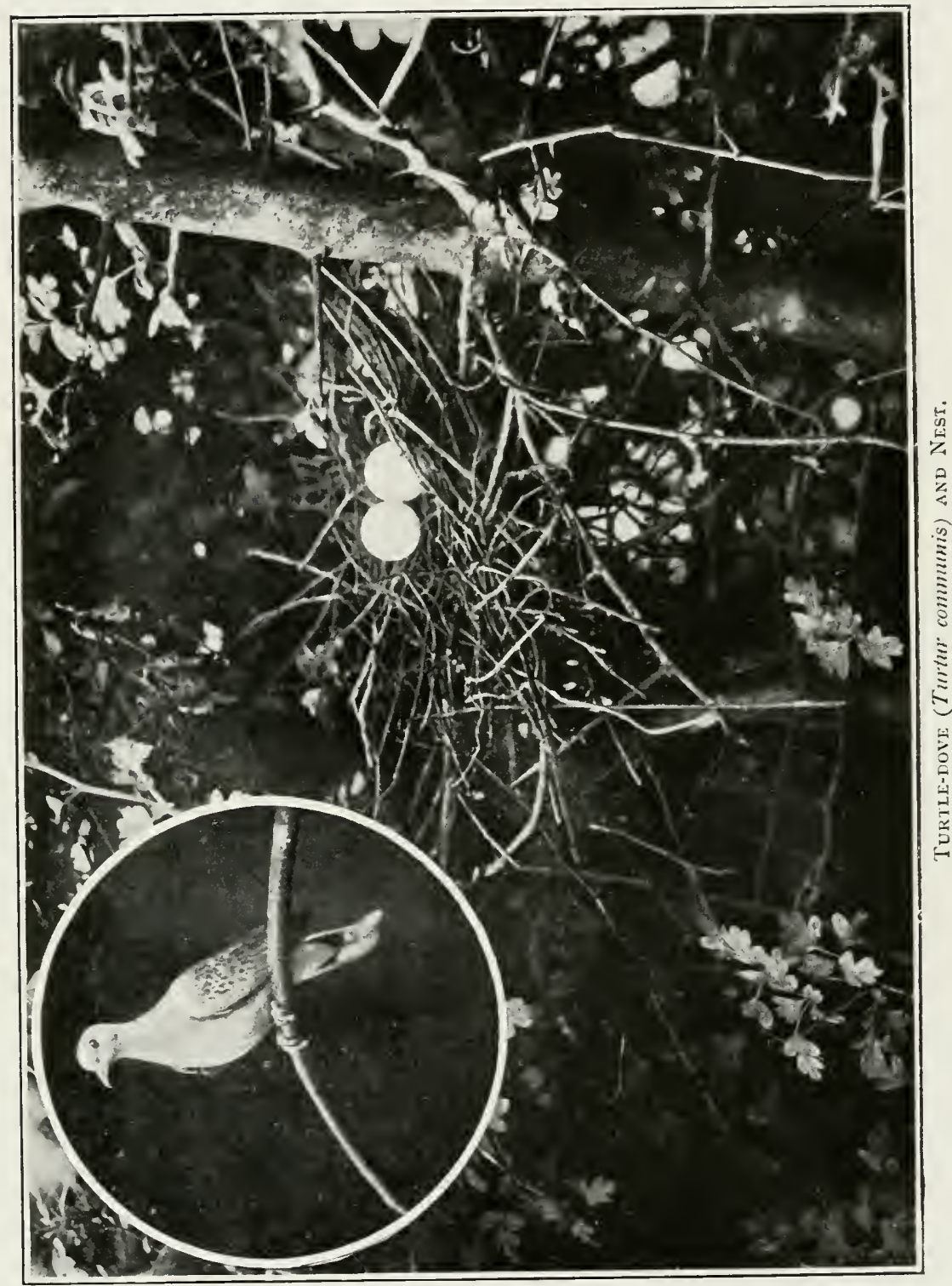


able to see a good deal of the birds. watching then through our glasses. both on trees and on the ground.

Once I saw two of the young birds perched on the goal-posts of a foothall ground. one at each end. In the same field were also a family of yomng 'lawny ()wls with

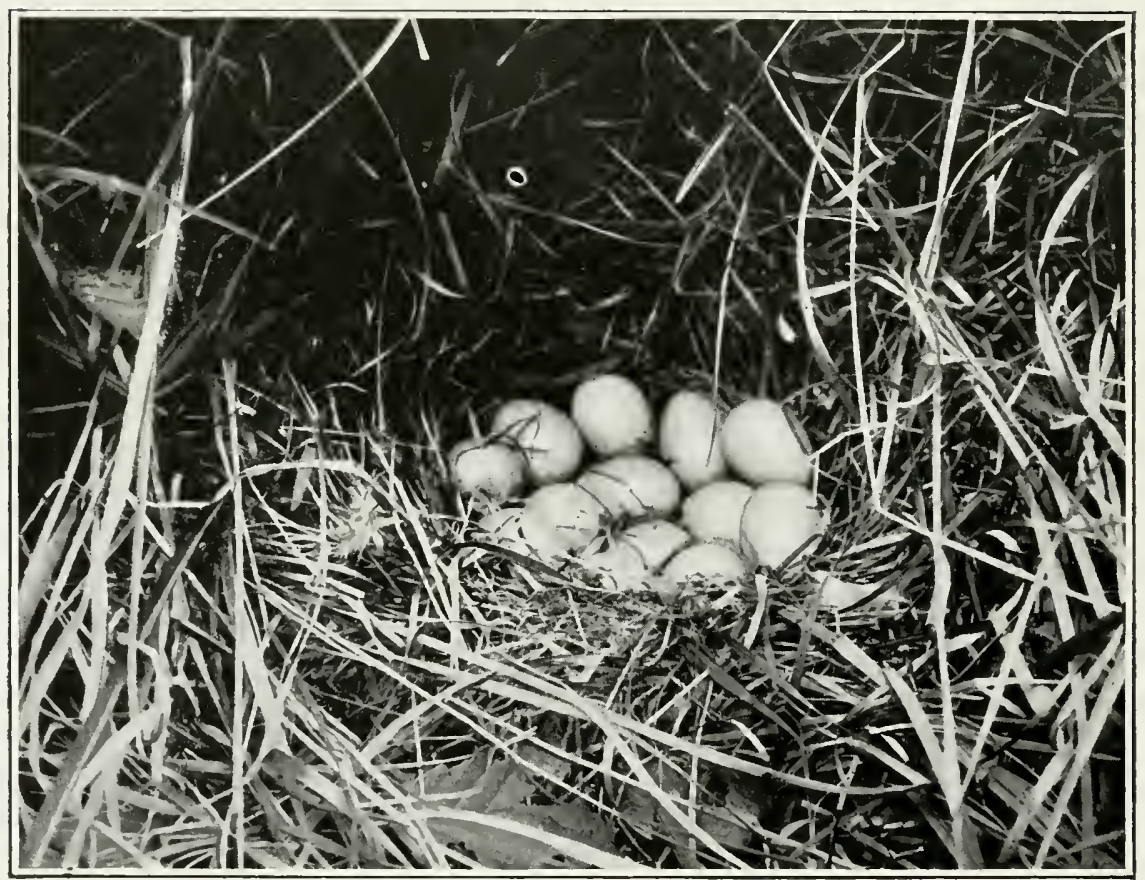

Nest of Partridge (Perdiv cinerer).

their parents. One erening the whole fire were Hying round us, as my companion, crouching with me behind a tree-trunk. gare a capital initation of the note. I am myself no good at initating the notes of birds: but he. by blowing into his clasped and hollowed hands between the thumbs. "an prodace the " Whoo-whoo" to perfection. 
'The first attempt brought them from a distant tree, till they settled just orer our heads, where we could see their forms by the moonlight against the sky.

'The gallant little Sparrow-hawk is not nearly so commmon as the Kestrel, and i have not seen a nest nearer than Epping Forest. Many are brought to ne in the autumm by hird-catchers, which have been caught-in the act of attacking their call-birds. I think the majority of them are taken in the neighbourhood of Northaw. Ocomsionaliy the bird-aatchers take Kestrels in the same way. One day I had a beautifiul little cock Kestrel bromght to me. 'To sare it from the fate of being killed and set up in a public-honse bar, which is what its eaptor pmposed to do with it, if I

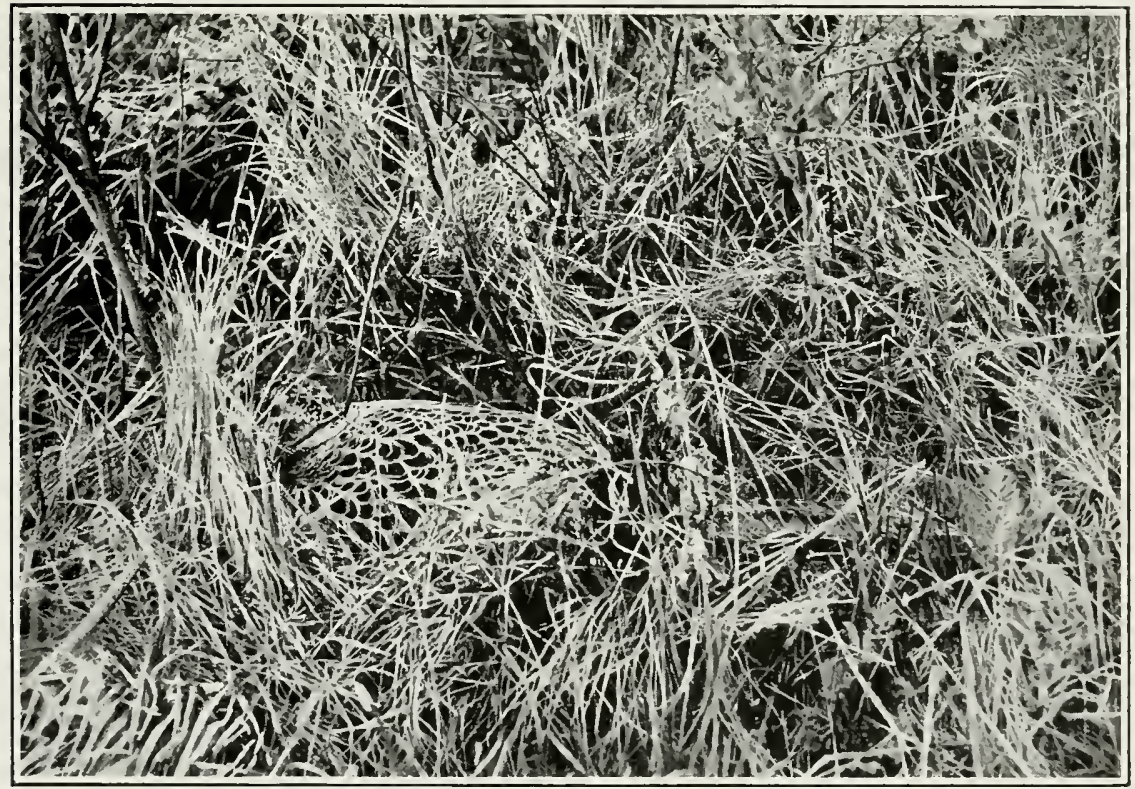

Hex Pheasant (Phasianms colchicus) on Nest. 
did not buy it, I gave him what he asked, took it to the door, and released it before his eyes, to his great indignation and disgust. 'That was the second I had restored to liberty. and gladly I watched its Hight, and rejoiced at its narrow eseatpe from the hideous fate in store for it.

Herons, within the memory of at least one inhabitant,

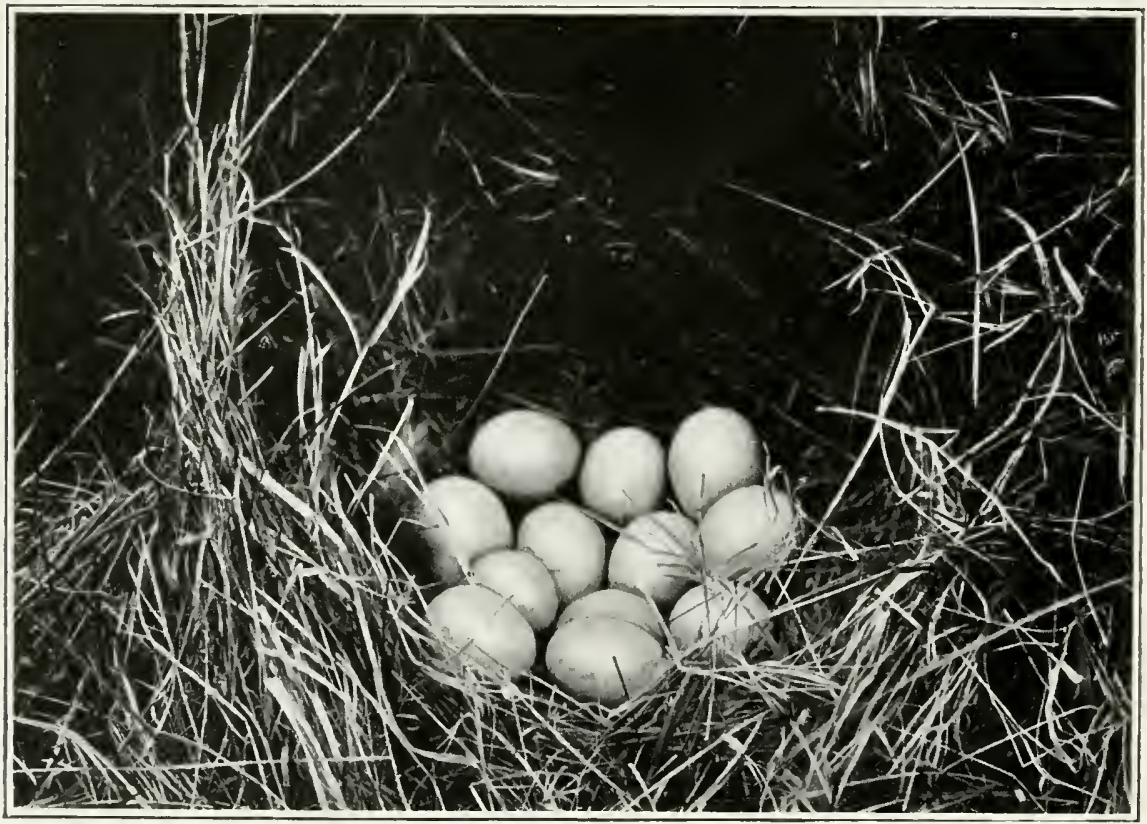

Nest of Pheasant (Phasianus colchicus).

used to nest on the island at Bush Hill Park. Nowadays the nearest heronries are the well-known ones at Wanstead l'ark and Richmond Park. At the former there are at least sixty pairs of these birds nesting on the island in the lake, in company with Rooks. It Richmond there are about a dozen nests on some large oaks in one of the enclosmes. 
'The Heron does not always, howerer, nest on trees, where, to tell the truth. he scems somewhat out of place: for in Ifolland I have seen it nesting among the reeds, in just the same sort of a place as that chosen by Purple II erons. except that. if possible. it was more difficult of access. For, in spite of every effort, I failed in my attempts to photograph the nests which contained young birds. 'The water was rery deep. almost up to my neck, and the bottom exceedingly soft and treacherous. and the six exposures I made. after an infinity of exertion and trouble, were all failures.

But though the Heron no longer nests with us, it may frequently be seen following its rocation as a fisher along the brooks and ponds. or flying orer to some more distant feeding-place with slow and dignified flaps of its great rounded wings.

Once. while hidden under a spreading tree waiting for Water-hens, a Heron unexpectedly perched on the extreme summit of a dead tree, exactly opposite my hiding-place. Creeping forth to clear the branches orerheald. I just sucreeded in focussing the bird in a splendid position, when its keen sight detected my presence. 'The suddenness with which it took its departure before I could secure the photograph left the branch on which it had perched in violent ribration for some time afterwards. (On nu next risit to the place the branch was missing. as though the bird had perched once again and broken it. As the spot was. I knew, a regular resort for Herons. I paid sereral early visits before daybreak. hoping that this particular tree was 
used regularly as a look-out station before descending to the water. which is rery shut in by trees all round. Never again. howerer. was I faroured with another chance.

'Thongh the 'Teal may occasionally be met with in winter, the Wild Inck is the only representative of the family which nests. In the summer months it is a common thing to find its nest. or to see the old duck. followed two and two by her mumerous family. 'To these she is a deroted mother. In the event of danger the roung ones scatter. hiding in any cranny or hole. while she flutters. apparently wounded and helpless. in the heroic attempt to distract attention from her brood.

The nest is sometimes a considerable distance from water. I have seen one in the middle of a field, quite a hundred yards away from the water: another was hidden under a firze-bush, and contained eleven eggs. These were safely hatched. and the resulting ducklings afterwards seen on sereral occasions with their mother on a small brook about eighty yards from the nest. Many nests. though carefully and artfully hidden under orerhanging brambles and luxuriant nettles and long grass. have been nevertheless discorered by the Carrion-crows and robbed of erery egan.

The Wood-pigeon flomishes exceedingly in all the woods around. and nests abundantly not only in the trees. but less often in the tall hedgerows. It has even within this last ten years invaded Icondon itself: numbers nesting in all the parks and in many of the squares and gardens. In 


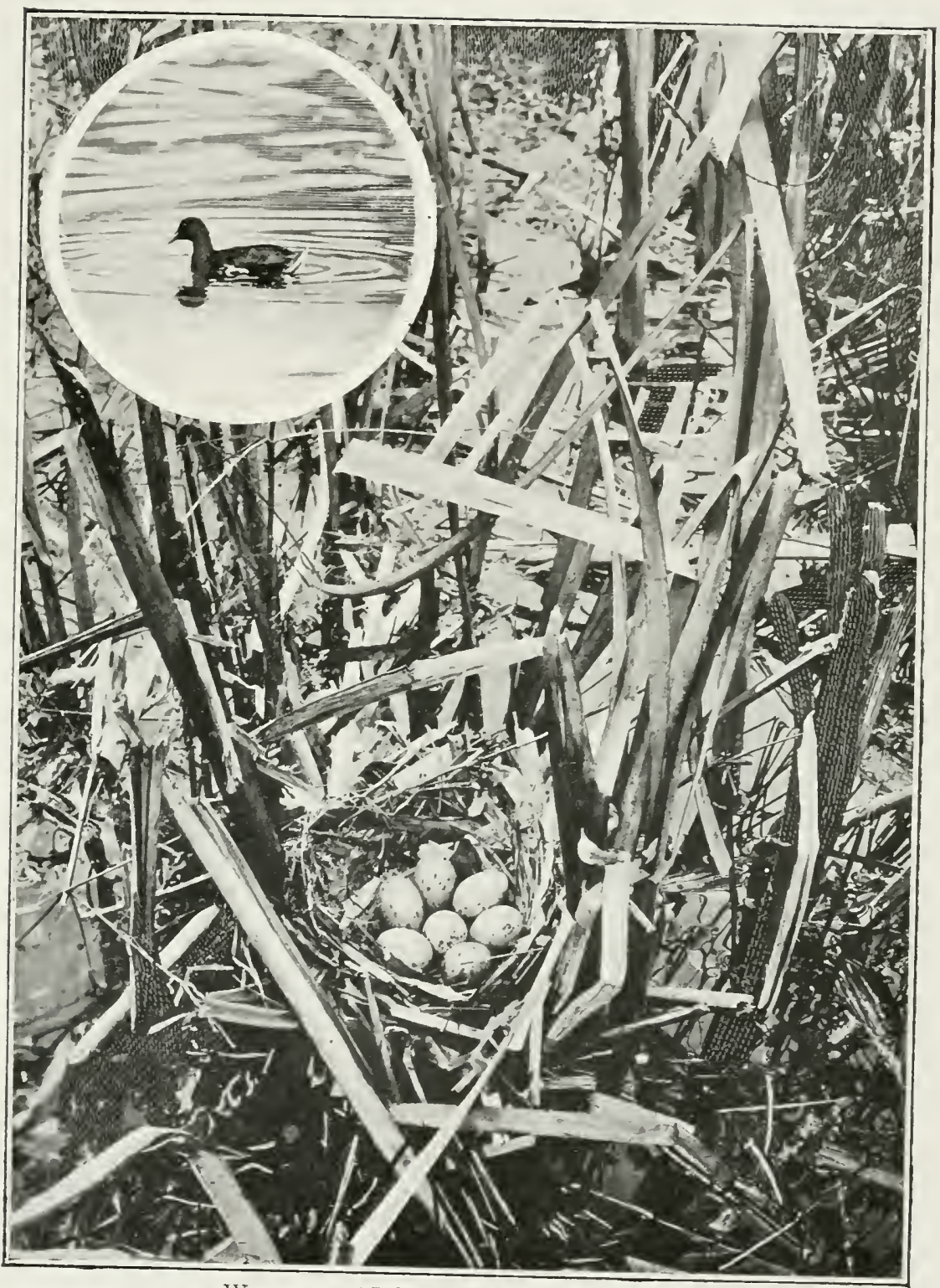

WATER-HEN (Gallimula chlcropus) AND NEST. 
these unlikely localities it may often be seen sitting on its scanty nest, only a few feet above the passing throng. of whom it takes not the slightest notice. It is very extraordinary, for one who knows the wary habits of this bird in more sechuded places, to watch it boldly feeding with tame Pigeons and Sparrows, and rivalling these habitués of Cockneydom in audacity. It will come readily within a foot or two if you throw food to it. 'The nest does not rank very high as a specimen of bird architecture. A rude and open platform of sticks, through which the eggs may be readily seen from below, suffices for the purpose. I have found Wood-pigeons rery shy at the nest. and, howerer arefully hidden. hare not succeeded in photographing the sitting bird. 'l'wo attempts this year failed, and in both ares the birds deserted their eggs.

One nest was on the top of a tall rose-brier in a small wood, and the camera was fastened to the branches of an adjacent oak-tree and well hidden with leares, while I retired with a long tube to the shelter of some thick bushes, where I was perfectly concealed from view. Here I waited nearly the whole day: and though several times the birds could be heard in the surrounding trees, sometimes rery near to the nest. yet they nerer visited it again.

While waiting, the excited clucking of a hen l'artridge attracted my attention, and presently, while lying motionless full length on the ground, a large brood of young lartridges, only about a day old, (anne ruming up two and two, followed by their mother, a Red-legged Partridge, in a great state of 
agitation. 'They never saw me, though the whole family' almost ran orer my feet. 'They had evidently been alamed by some haymakels in the next field, just orer the hedge. None of these, either, had the slightest idea of my presence. though they were working for hours only a few yards away. In the same clump of bushes behind the Wood-pigeon's nest was also a 'Turtle-dore's nest and a Bullfinch's nest, both with young, while a little farther down was a Goldfinch's nest with four eggs, and a Nightjar brooding over two young ones.

After the departure of the Partridges a friendly Robin came and inspected me, and accepted an invitation to share my lunch. Perching on the camera-ease, it hopped down and ate all the crumbs thrown to it, constantly coming back for more throughout the day. A 'Turtle-dore preened its feathers hard by, while 'Thrushes and Bullfinches flitted in and out of the bushes and hopped all round me. Besides all these, a family party of little brown Wrens busily searched the bushes immediately in front of my face, till I expected them to perch on my head and search my pockets for food. One of them was reltainly within six inches of my nose, and a Thrush ame almost as near. The Wrens simply ignored me altogether, treating me as a piece of a tree or an inanimate log.

But though the Wood-pigeon is shy, the 'Turtle-dore is still more so. and is the only bird I have known to desert her nest, and abandon her helpless young ones to die miserably of starvation, because I have hidden myself near in order 


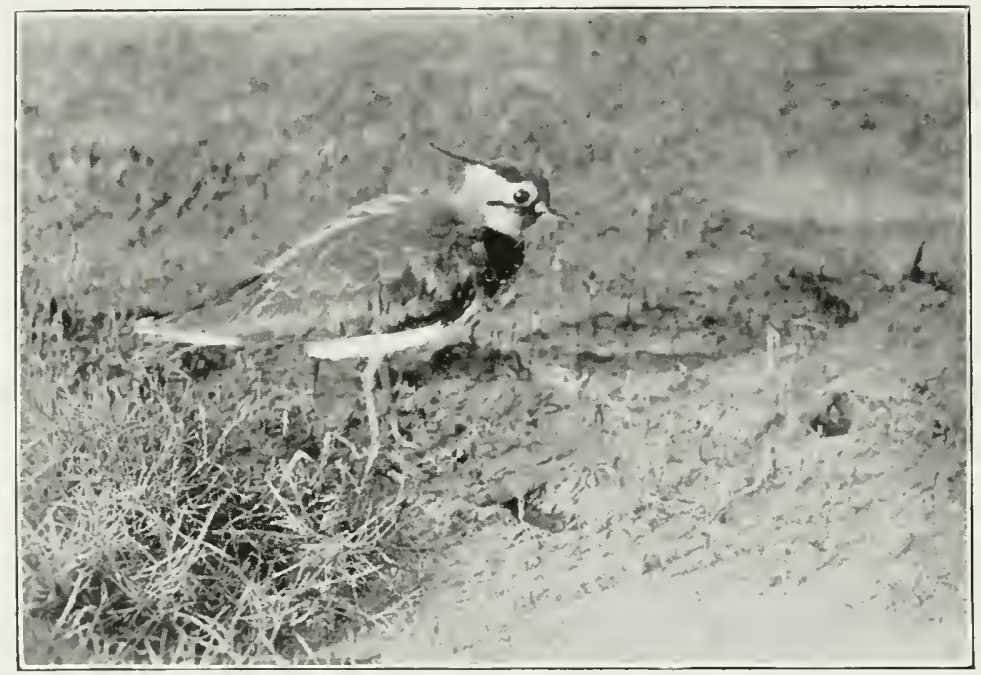

LAPWIXG (Vanellus cistatus).

to photograph them. 'Turtle-dores are very abundant. and after the spring arrival their deep ". 'Tur-tur" may be heard in every direction. 'They nest in all the tall old-fashioned hedges so common about here. 'The nest is eren slighter and ruder: and of conse much smaller, than the Woodpigeon's. But this rery rudeness of construction only serves to enhance the beauty of the two pearly white egos reposing side by side on the network of brown sticks. It is a nest which has a great cham about it. somehow.

The Stock-dore is the most morommon representative of the family, but may be seen here and there. Inlike the others, it nests in hollow trees.

'The Partridge is fairly plentiful for so near to Irondon. In some roadside fields it may be heard or seen almost at any time. It seems. in fact. like the Iapwing. to lave a 
strong predilection for certain firoured localities, thongh perhaps not to the extent that those birds undoubtedly have. Some peculiarity of food procurable is probably the secret of it, and in connection with this I have been told that Intch clorer has a great attraction for l'artridges, and that fields containing any are always sure finds for then.

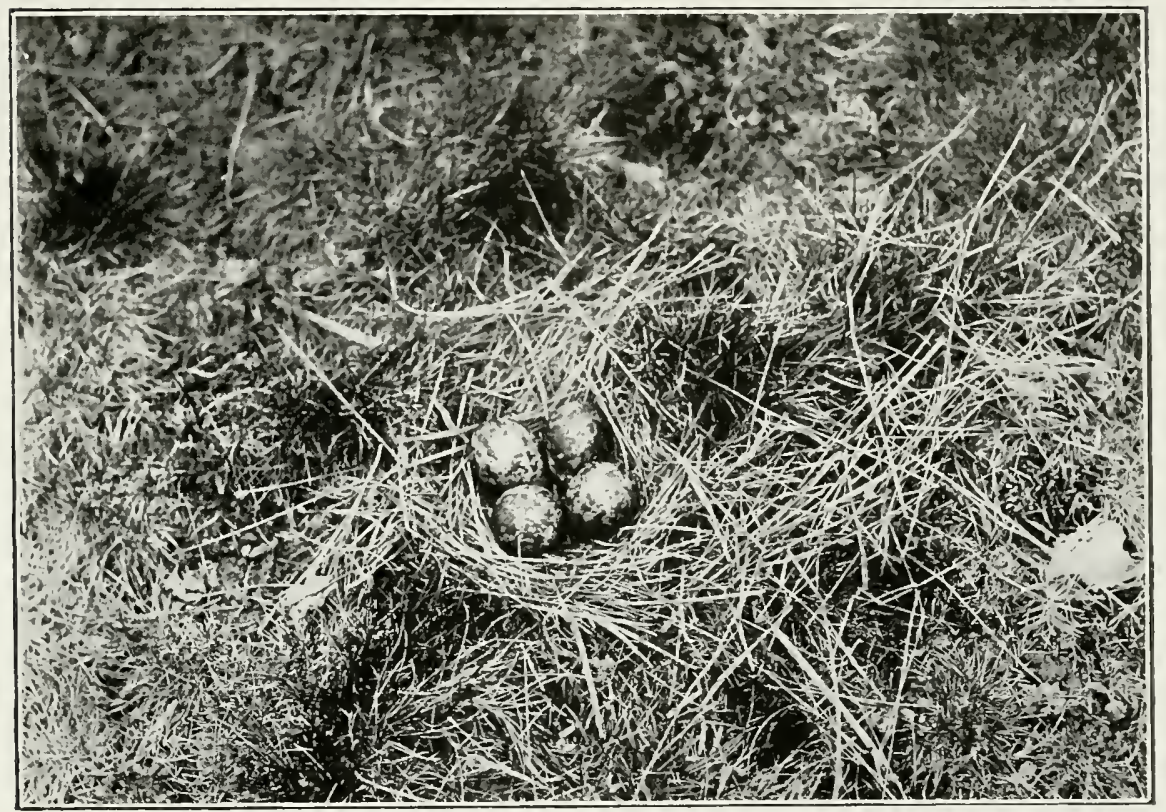

NEST OF LApwing (l'anellus cristatus).

A hen Partridge, while sitting, is a good example of protective coloration. It is almost inpossible to distinguish her crouching form amidst the thick growth of grass and hedgeside regetation. She seems to burrow into the rery heart of a clump of grass or dead bracken. without learing a trace or mark of her presence. If approached quietly, she 


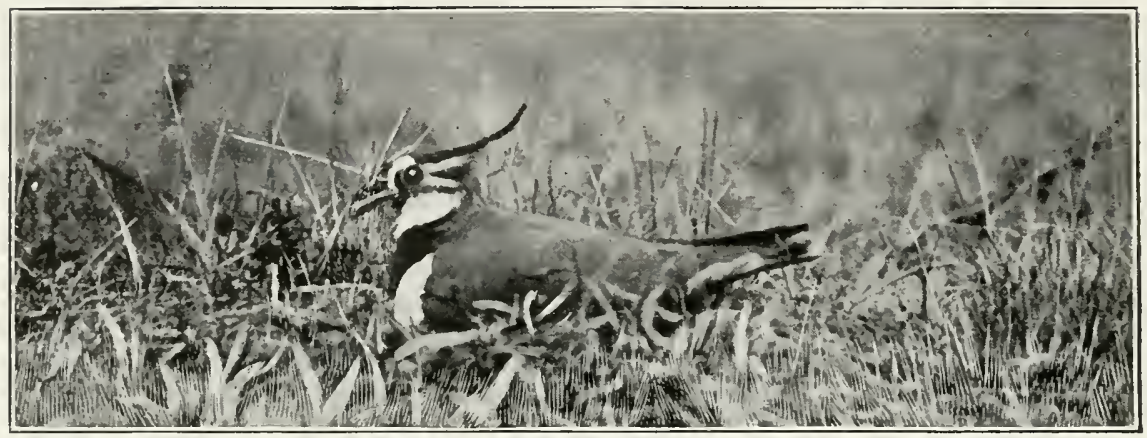

LAPWING (Vancllus cristatus) sitTixg.

will only crouch closer and remain motionless, though keenly observant all the while of every movement on your part.

The quiet heroism shown by birds while incubating or brooding over their young is very touching. The slightest noise or rustle may mean some cruel and ruthless eneny: yet they never move. though it is so easy for them to spring up and fly away. But unless you blunder on to them with sudden noise and crash of broken branches, they will remain sooner than betray the whereabouts of their nest.

The hen Pheasant is another example of the protectively coloured and elose-sitting bird. One was almost trodden on before I saw the markings on her russet plumage hidden among the dried grasses under my feet. After photographing her from four different positions, she only left her eggrs eventually on my attempting to pull up by the roots some of the grass which hid her from riew: and even then, instead of flying off. she ran towards me with all her feathers fluffed ont, hissing like an angry goose. The Pheasant will 
sometimes cover her eggs orer on learing them, as if she knew that they would be readily seen by their numerous enemies without some concealment.

All these gallinaceous birds show great pugnacity in the paring season. On the Continent, where ideas of sport differ from ours, advantage is taken of this in shooting them to a decoy-bird.

The Corn-crake, though numerous in the Ica Valley, does not commonly occur elsewhere, and I do not often hear it. except in the marshes. A pair frequented a meadow at Winchmore Hill in 1901, but no nest was found. Nor have I myself seen the Wrater-rail.

The Coot firequents a pond in the neighbourhood, and nests there sometimes, but irregularly. In 1901 a thorough search was made by wading all orer the pond among the

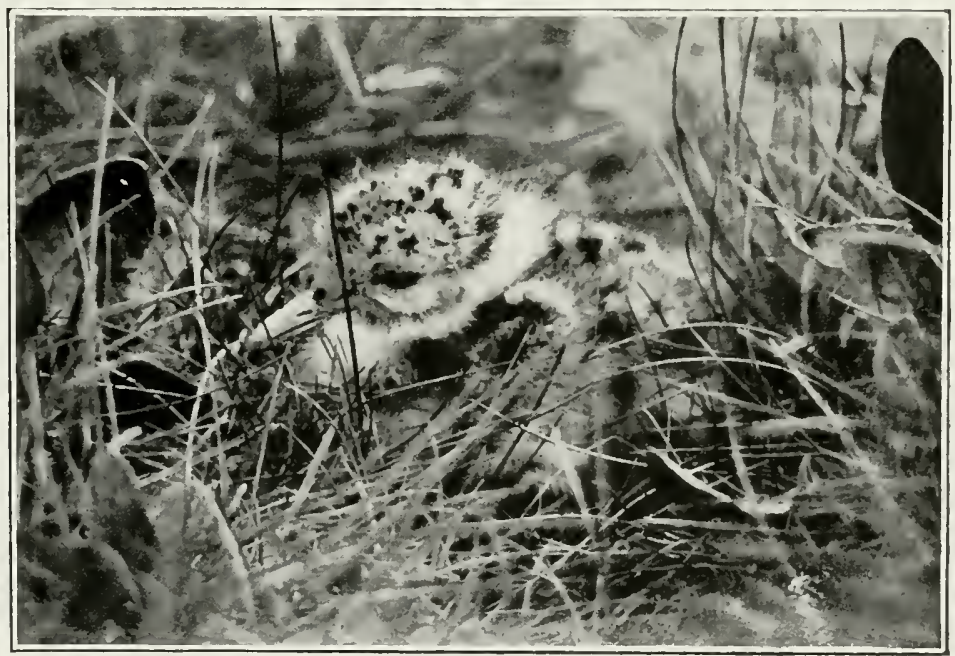

Young Lapwing (Vanellus cristatus) crovching. 
reeds. but no trace of the birds could be seen, nor any nests but $W^{2}$ ater-hens" nests found.

'The Water-hen a name whieh always seems to be so much more appropriate than Moor-hen is a miversally conmon suburban species. It is even found abundantly in a perfectly wild state in most of the Icondon parks. In such localities. like the Wrood-pigeon, it lays aside its usual timidity. and feeds boldly with the other wildtow when fed by visitors. and by its presence adds very much to the interest of the many lakes like the one in St. James's lauk, the Serpentine, and others.

'Though such an aquatic species, its feet are not webbed, and it always appears to swim, not exactly with difficulty. but with more or less exertion. 'The long toes secm to be better adapted for rumning orer the broad surface of Hoating lily-leaves than for swimming. Much of its time is spent on land, exploring ditches and threading the long herbage which grows in rank abundance in damp and marshy situations.

In its habits there is a curious mingling of boldness and extreme timidity. It will build its nest perfectly openly in a roadside pond, and yet its presence is often mosuspected by the great majority of the passers-by. At the approach of a footstep it slips noiselessly from the nest, barely making a ripple, and either hides muder the bank or anong the reeds or rushes. Failing any hiding-place of this kind. it will dive and hold on to the weeds at the bottom. only putting up the tip of its beak to breathe till the danger is 
past. Its young are equally adepts at hiding from the moment they are well out of the egg. They will crouch and hide in any hole and ammy, and remain perfectly motionless mutil told by the parent-bird that the coast is clear. One I caught. not more than a day or two old. on being released, dived under some crowfoot in shallow water. keeping its head muder so long that to save its life I fished it out again. 'Then. replaring it in the water. I took out

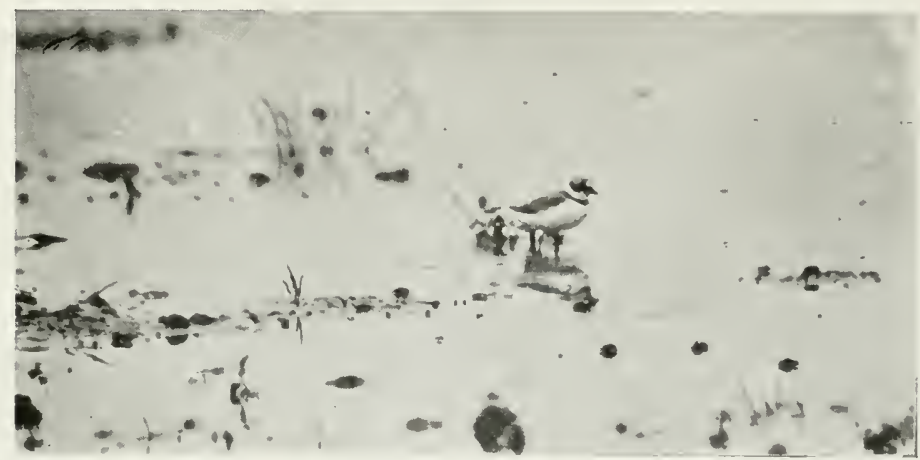

Ringed Plover (.Egalilis haticula), photographed at ExField SEWAGE-FARM.

my watch and timed it while it dived again. and fomm it conld remain perfectly submerged for sixty seconds. It the end of this time it came up. gaspoing for breath. but dived again directly afterwards.

Several broods are hatched during the summer. and the half-grown young of the first will assist in feeding the freshly hatched youmg of the second brood. 'To accommodate the youmg birds, the parents generally make a second nest. 'This is often composed of green weeds, built up in shallow water 
and perfectly exposed to view: and on this they will brood orer their roung. Sometimes the second nest is made of sticks, placed athwart a fallen branch or tree: and these are often of such a length and thickness as to cause surprise at the birds being able to manipulate them.

'The bours I hare spent trying to photograph Waterhens have been generally wasted. Hiding up at one which seemed to be well placed for the purpose. though I was carefully hidden under a thick bush, one of the birds quickly found me out. Hearing a slight rustle behind me. I tumed cautiously, and she flew away from close behind me. As there was no other hiding-place within reach. I climbed a tree. and sat there. After a time comparatively short. perhaps an hour one of them swam out from round the corner. and proceeded straight to the nest. immediately below me. This should have resulted in a successful photograph. but for some stupid mistake in arranging the camera. On trving the same plan again. howerer. the birds must have seen me descending. for they refused to approach a second time, though I waited patiently for hours. Finally I was obliged to give up any further attempt. for my hiding-place was discorered by some boys. Lufortunately the road was near. and one of them on their way home from school "spotted" me up the tree while they were all looking orer the fence for some mischicf to do. I heard one say. "'There's a rabbit!" and another, ". There's a man up a tree!" . I (an see his ears nore!" - that must have been the rabbit's. I presume. 'Then they saw my bicycle on the ground. and 
proceeded to shout and throw stones at me, and finally climbed orer the fence to meddle with the bicycle. I was erentually obliged to show myself and descend to drive them away : and after all the uproar it was not worth while starting again. I had already been up the tree about fire hours. It was probably as well that I could not catch any of the young rascals.

'The Golden Plover is only a winter visitor to the marshes in hard weather - wildfowl weather-and seems to be decreasing in numbers: but the Lapwing is a resident all the year round. Large flocks of these birds may be seen during the winter in the marshes and cabbage-fields, but rery early in the year they pair, and resort to certain fields in which they are accustomed to nest. 'Their characteristic Hight, as, with rounded wings, they now rise in the air and now swoop down almost to the ground, uttering their wild, plaintive cry. " Pee-weet. weet-a-weet," adds a great charm to the landscape, and enlivens many a bare expanse of fallow and moor. From the note is derived not only the English name "Peewit." but the I)utch name ". Kievit." and also the French "- Dix-huit."

'The eggs may be readily found with a little practice. but an maccustomed eye has some difficulty in seeing them. eren when pointed out. Both sexes being of rery conspicuous plumage, and the nests being on open ground. they are very shy while breeding, and leare their nests as soon as a stranger approaches within two hundred or three hundred yards. Farm-labourers. howerer, do not excite 
much alarm as they go about their daily work. 'The male birds keep strict watch. and give the alarm to the sitting females. These nerer rise direct from the eggs. but run some distance before taking Hight.

If at your approach both birds wheel around with loud outcries. and perhaps tumble to the ground as though injured. or fly immediately orer rour head. you may depend upon it that they have young ones hiding anong the grass. If they have eggs. they Hy right away. If now you hide mp in some ditch or convenient bush and watch. the bird which first appears with wailing cries and tumbling Hight is the cock. It is no use watching him: his duty is to humbug you: and if you do not know his tricks. he will do it rery cleverly.

If you pay too much attention to him. you may miss seeing the hen. which will Hy silently and quietly low down. and settle in the farther corner of the ficla. standing at first perfectly motionless for some time. I think that generally for the first few rards the direction in which she rums will be likely to point to the nest. but it is rery difficult to say with certainty. Anyway, after a yard or two she will stop and pretend to feed and preen herself. and then stant off' in another direction. She will then rum about in an apparently aimless fashion. as if thinking of anything rather than sitting on eggs: but always. in the long-run, she will approach the nest by slow degrees.

It is rery pretty to see her daintily tripping orer the rough ground. now stopping to pick up an insect. now 


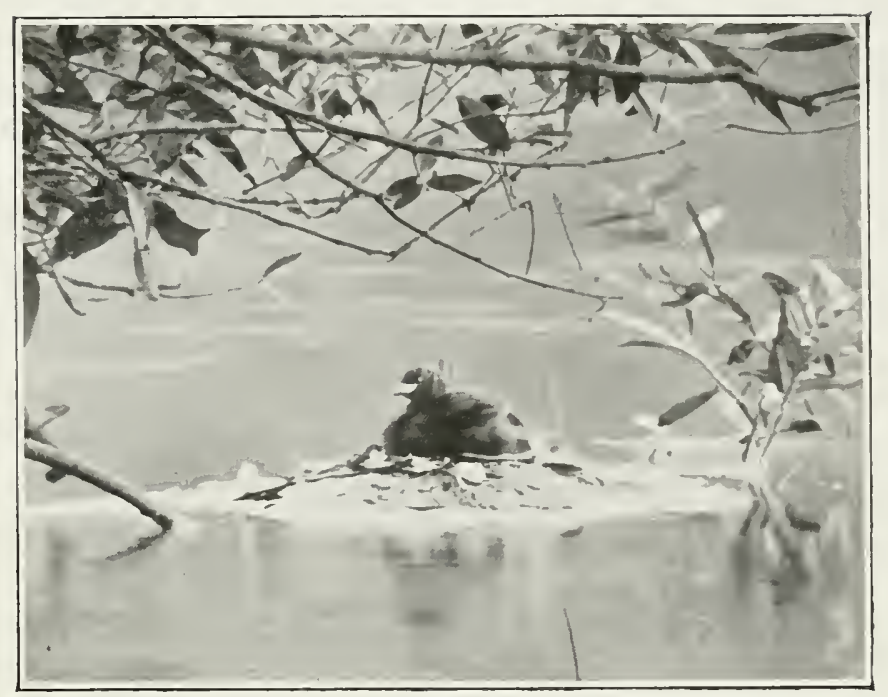

Little Grebe (Podiceps fluitiatilis) on Floatisg Nest in St. James's Park.

standing motionless, as if listening: then, stretching her wings. rmming nimbly in the opposite direction. Sometimes she will be almost hidden from sight in the furrows. and her movements an only be traced by her erect crest. 'Then perhaps she will fly off' to another part of the field. and repeat the whole performance over again. Now and then she will stand on some molehill or little elevation facing your hiding-place: then the snow-white breast and black collar are rery conspicuous against the grass. ('This black collar in the hen has a white patch in the centre.) Even when. after endless deviations and precautions, she does erentually reach the nest, she wiil rum up and down and round and round, as if nothing was there. many times before actually settling on her eggss. 
'Then, if you have cumningly arranged your camera, and covered it up carefully with clods of earth and tufts of grass. and set the shutter, you can pull the long string provided to release it: and you ma!y get your photograph. or you may not. I have known the bird time after time spring up at the click of the shutter, either in time to escape altogether or to give only a blur and flash of wings.

The freshly hatched young birds seem to leave the nest as soon as they are dry. and do not return to it. They can not only run nimbly after their nother, and hide when danger threatens, but they can swim. like young Water-hens. without any doubt or hesitation. I fancy they must drink a good deal. A young Lapwing crouching in the grass is curiously inconspicuous. I have often found one, and then. haring taken my eyes off it for a monent. have been unable to see it again for a considerable time.

Mention has already been made of the sewage-farm as attracting wading-birds to its tanks and filter-beds. Doubtless on migration these birds. when passing orer at night. have been attracted by the gleaming pools, and on alighting have found plenty of food and shelter, until they have regularly risited such a congenial spot. No doubt a similar state of things would be found to exist in other sewagefarms: but it is rery interesting to find such birds at all so near I andon - in fact, within the London postal district: and more interesting still to find them nesting. In 1901 I was able to of the nesting of the Ringed Plorer at the Enfield sewage-finm. 
I had sereral times watched small numbers of Dunlins and Ringed Plovers through the winter, but a few of the latter lingered on until the summer. At last, one day a pair were noticed which, by their behariour, were mmistakably nesting: but unable to find anything. I feared that the eggs had been destroyed by a harrow, which was at work over the ground chiefly haunted by them. Being about to go abroad. I was mable to continue the search, but the superintendent. a good naturalist. kindly undertook to keep his eye on them. On my return he told me he had eaught and handled two young Ringed Plovers in down. which had got into one of his carriers, and were unable to extricate themselves until he came to the rescue. 'This places the fact of their haring nested beyond a doubt.

The sight of these daintiest of birds tripping orer the oozy margins of the pools and wading in seareh of food was a great treat. and one day I was actually able to photograph them while so employed. With them were sometimes a few Redshanks, which also remained on the farm throughout the summer. but apparently, from their actions, did not nest: but I often enjoyed their wild note and the sight of them feeding. Knots. Curlews, and Green Sandpipers may also be frequently observed.

Snipe are extremely common here during the winter months, and in 1901 a pair nested. For daily one of them used to "drum" overhead: but hours of searching up to my knees in liquid sewage failed to discorer the nest-- the coarse, rank regetation was too thick. 
I) ming a short spell of firost and snow one January. I spent five days in the attenpt to photograph a Snipe on the glomond. For five hours each day I sat on the snow covered over with a sheet. in the middle of a flooded ficld. Iapwings were rery numerous. and sometines came rather close, and Snipe were constantly seen flying orer. Several were on the ground in front of me for a considerable time: but the dim light of a winter's day was not enough to

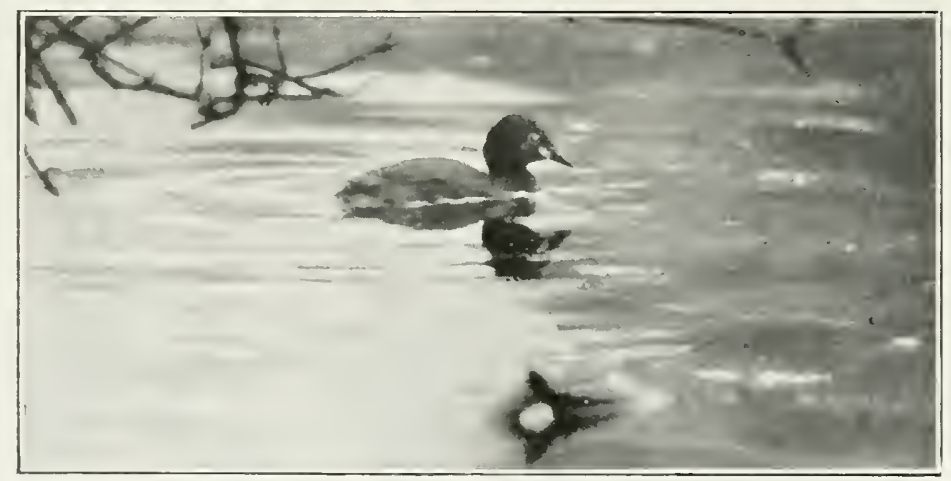

Litile Grebe (Podiceps fluzitulis).

distinguish them in the photograph from the muddy ground on which they sat, and the photographs were of no practical use.

Wild Geese may often be seen flying orer in their accustomed V'-shaped formation during the winter months.

Black-headed Gimls frequent occasionally not only the sewage-farm, but alıo an artificially flooded pond made for skating. One day I saw a Hock of quite a hundred birds Hying about and settling on the ice. Erery now and then the (ruils were driven off by a Carrion-crow which seemed to resent their presence. but after wheeling round they soon returned to the spot. 
'The Dabchick, or Little Grebe, nests occasionally in the varions ponds. and I have been interested in watching the quaint actions of this diminutive direr, which, like the Wood-pigeon and the Water-hen. has taken to nesting regularly in the London parks. It is really a great deal more safe in the heart of I condon than anywhere else: for these birds are carefully protected. and a great deal of interest is taken in them. so that they do not stand much chance

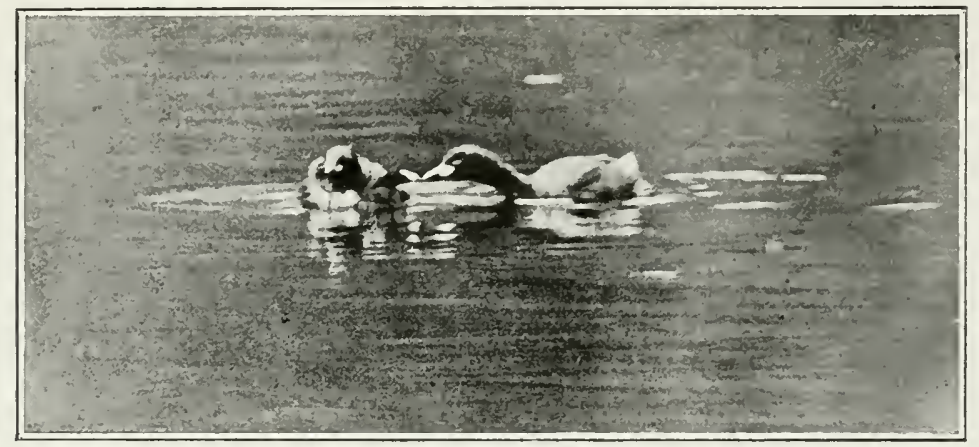

little Grebe (Podiceps fluviathis) heeding its louxg.

of coming to harm. 'Two whole days spent opposite their nest in St. James's Park were rery enjoyable. and resulted in some good photographs.

Now that the Great Crested Grebe nests in Richmond Park. perhalps we may indulge in the hope that these most stately and ornamental of all water-birds will also establish themselves in one of the London parks, where they would be heartily welcomed, and would give as mueh pleasure to Londoners as the yearly visits of the Black-headed Gulls which are now so regularly expected. 


\section{CHAP'TER V}

\section{A Lincolnshire Mud-flat}

Mro, miles and miles of mud. and tidal ooze are the chief characteristic features of the shores of the Wash. A little farther north. where the sand predominates, the shallow sea is full of innumerable shrimps. which are caught, not from boats, but in nets trailed astern from a cart: but below Skegness the mud begins. The Friskney Flat, for instance. is three miles wide and nearly ten miles in length. At low tide the sea is invisible from the sea-wall, save as a narrow streak midway between the Lincolnshire and Norfolk coasts.

'This rast expanse of mud, as antumn approaches, is peopled by immense numbers of birds. chiefly waders, which appear with unfailing regularity every year. Many of them hail from the mysterious solitudes of the frozen north, never yet trodden by the foot of man : others from Scandinavian fells and the desolate "tundras" of Siberia.

In those far-distant shores they have spent the short summer nesting and rearing their young broods. until the signs of quickly approaching winter began to be perceptible. warning them to start on their southward jomrney to warmer climes. Gradually they are working down. stopping to rest. 
and feed in suitable places. As they travel onwards their places are constantly taken by fresh arrivals, while they pass along our coasts, and through the rast marshy plains of Southern Europe, until they are lost in the great African Continent, the winter quarters of so many millions of the feathered race. In the spring they begin their return journey with equal regularity.

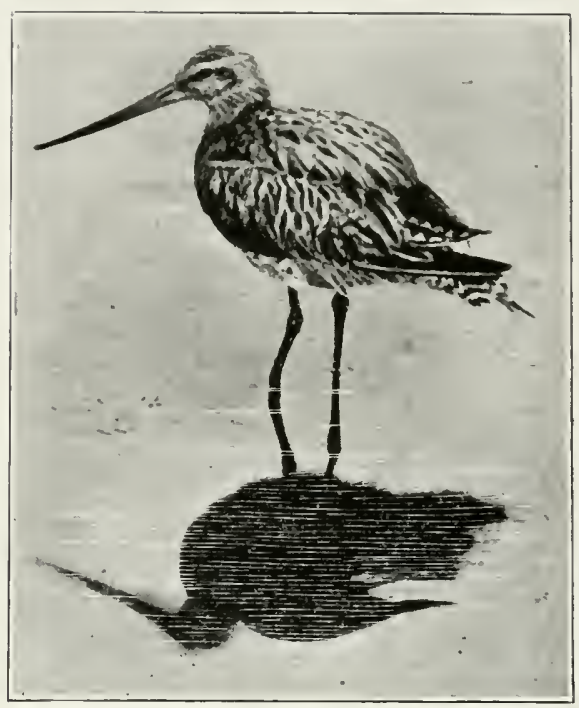

BAR-TAILED GODWIT (Limosa lapponica), Winter Plumage.

Hence it is that the mud-flats of the Wash, which all the summer through have been almost devoid of bird life. are now alive with immense flocks, busily running orer the shimmering surface. and flying along the water's edge as the encroaching tide restricts their feeding-grounds and drives them along before it.

White flocks of Culls, like drifting sea-foam dot the distant margin. Curlews, Godwits. Redshanks. Knots. and Oyster-catchers explore the shallow pools tufted with samphire. Ever and anon eircling flocks of Dunlins, now dark against the sky, now gleaming white against the moist muddy surface. dash past in search of fresh feeding'grounds: while others trip nimbly over the shining sands, or with half-expanded wings, like tiny pleasure-boats, run before the 
wind. By day the scene is one of great animation, and the constant arrival of comntless thousandis fills the silent watches of the night with the beatings of immmerable wings and the mysterious sound of their cries to one another. We see the Hocks which safely reach our shores: but who can estimate the numbers of weary wanderers which fall utterly spent and exhansted into the pitiless sea, or dash themselves against the lanterns of lightships and lighthouses, attracted to their death by the glaring rays?

On first arrival many of them are ridiculously tame, and show by tineir boldness how marcustomed they are to the presence of man. Dunlins. instead of fying off at one's approach, will often run behind a tuft of grass. and continue feeding in the most fearless and muconcerned manner. and Codwits also show little fear. Danger, howerer, besets them on every side, and they soon leam caution and how to take care of themselves. Shore-shooter's and gumners take toll of them, and they are caught wholesale in the flightnets. which at this season are stretched orer the flats at right angles to the incoming tide. During the night the treacherous meshes entangle numbers of them while flying from one feeding-ground to another, six or seren dozen Knots taken out of one net being a not mucommon experience.

At Friskney lives old Bray, the most skilful Hight-netter on the coast: and three or four days were spent with him a few years ago in watching his methods of eiremmenting wildfowl.

'Tuming out of our lodgings before daybreak one cold, 
raw morning, we walked half a mile in drizzling rain to Bray's cottage, finding the old man struggling into his big sea-boots. 'Then shouldering a lot of empty bags, destined to receive the bodies, alive and dead, of the night's eatch, we proceeded together to the fiats. (On reaching the sea-

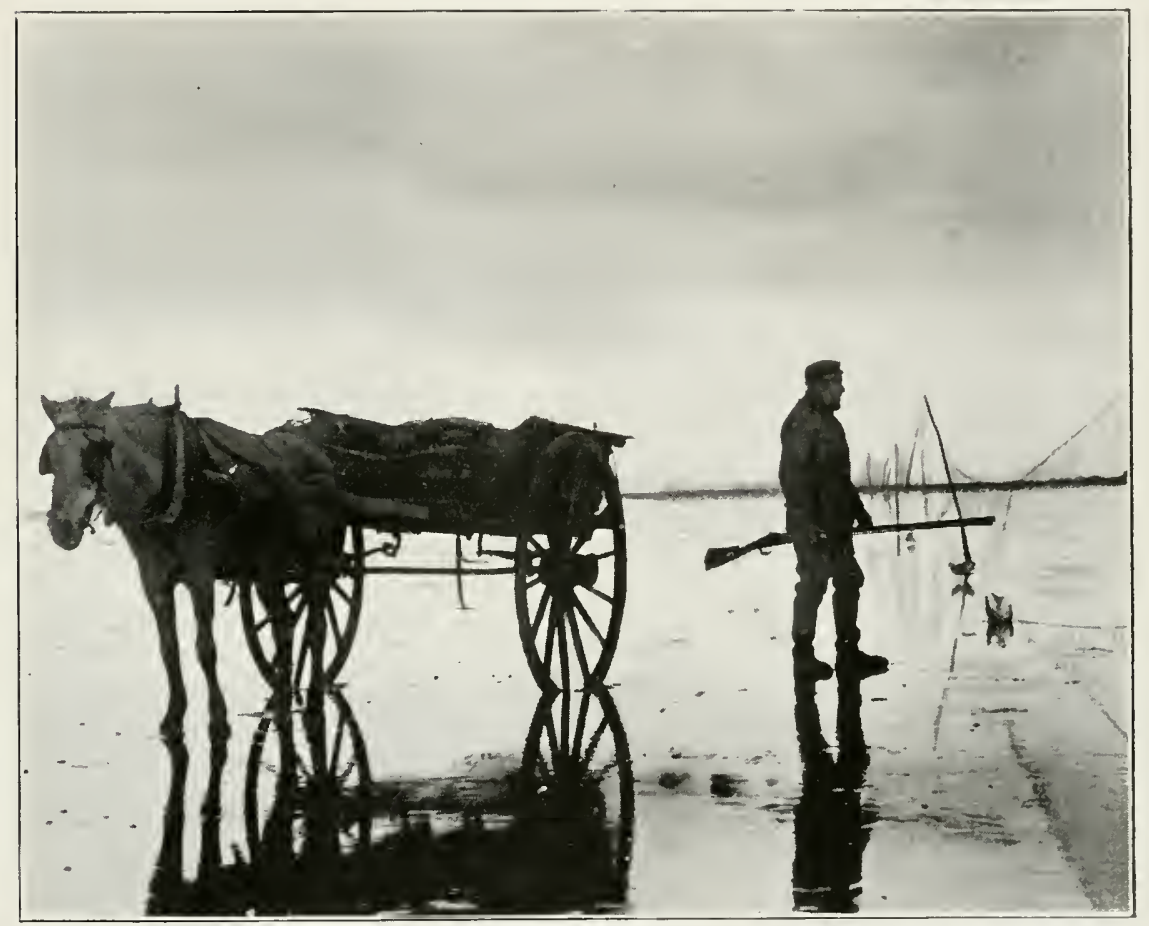

Early Morning at the Nets.

wall. we turned off along it to the left for some distance, in order to aroid a rreek which winds in a devions direction towards the sea.

'These creeks are quite invisible a few yards away, and help to make this coast a very dangerous one for strangers; 
for the tide adrances so rapidly on the flat shores, that any shooter rash enough to renture alone. without knowing all the creeks and inequalities behind him. may suddenly find himself cut off by half a mile or so of deep water, and will be lucky if he escapes with his life.

Picking our way along in the grey morning light over the slippery mud. and splashing through the pools, we begin at last to be able to see in the distance the long line of the nearest net. and can soon distinguish various birds suspended in the meshes. On one of the upright stakes sits a fine Peregrine Falcon, evidently attracted by the fluttering of the captured hirds. but too knowing to renture to strike at them. As we advance. she soars into the air and soon disalppears. We had heard rumours of a large Hawk about the shore a day or two before.

The nets are from two hundred to three humdred feet in length. each piece six feet high and thinty-five vards long. suspended between upright stakes driven into the mud. As soon as a bird strikes the net. which is made of rery fine twine. and with a large mesh, it is entangled, and the more it struggles the more hopelessly it becomes bound. Sometimes. indeed, it is no easy task eren for a practised hand to free it from the toils. 'The nets must be risited at daybreak: for if left, the Grey Crows will find them. and help themselves to the smaller birds, and to those which have been aught in the lower meshes and drowned by the adrancing tide.

After risiting four or five nets, the round tiking us 


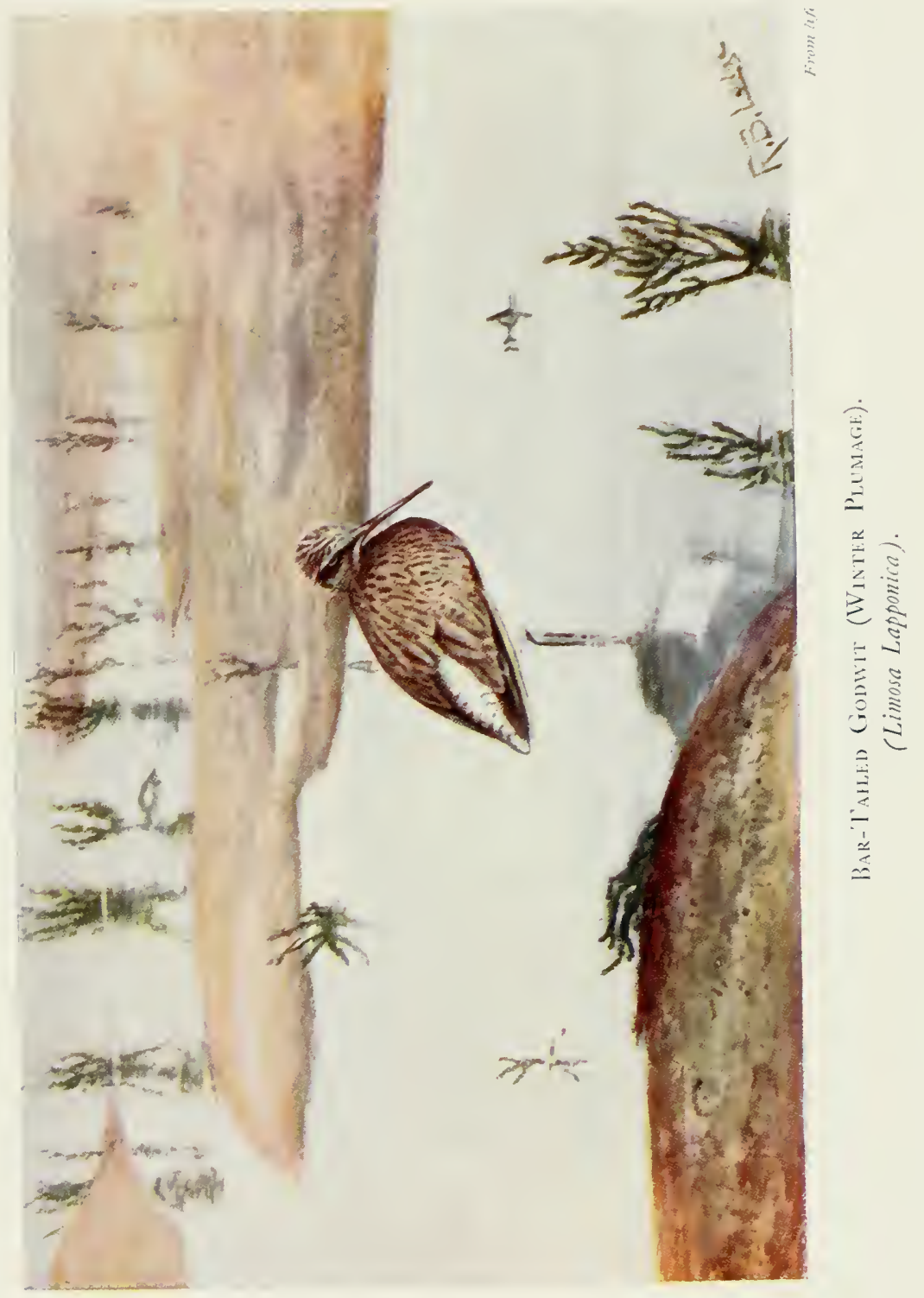



five or six miles orer very bad ground. the bags getting heavier and heavier as we proced, we are by no means sorry to get back to the rillage and a good breakfast.

The take has not been anything rery great the bulk of the birds being Black-headed and Common Giuls. one immature Great Black-baeked Gull, and some Lapwings. Godwits, Stints, Dunlins, Knots, and a Curlew, the greater number alive and uninjured. These are turned out into pens awaiting their disposal, and the dead ones put aside.

They eat the Crulls here, the market-price being one pemy each: and the orthodox mamner of cooking them is to make what they all a "pot-pie." I believe they are skinned and boiled as a preliminary, and was assured that they were very good. Howerer, I did not feel tempted to try, so camnot say from experience whether they are to be recommended as a dish for epicures. They are cheap enough, at any rate.

But wading- and sea-birds are not the only ones which come ashore here. The Grey Crows, which haunt the shores all the winter, as well as the fields more inland, come over from the Scandinavian Peninsula, and also Woodcoeks and Short-eared Owls. The former of these are seldom caunght, presumably because they fly too high; but the latter are often taken in the nets.

I saw myself one day the arrival of a Short-eared Owl, hustled and mobbed by a lot of Rooks. It is often flushed from turnip-fields by Partridge-shooters, and, coming about the same time as the Wroodeock. is known sometimes as 
the Woodcock-owl, and in Norfolk as the Marsh- (or Mash-) owl. It eren nests on the gromed among sedges and coarse grass. but is now better known and nore common as a winter visitor than a resident breeding species. Howerer, whenerer the comntry is derastated by a plague of voles -

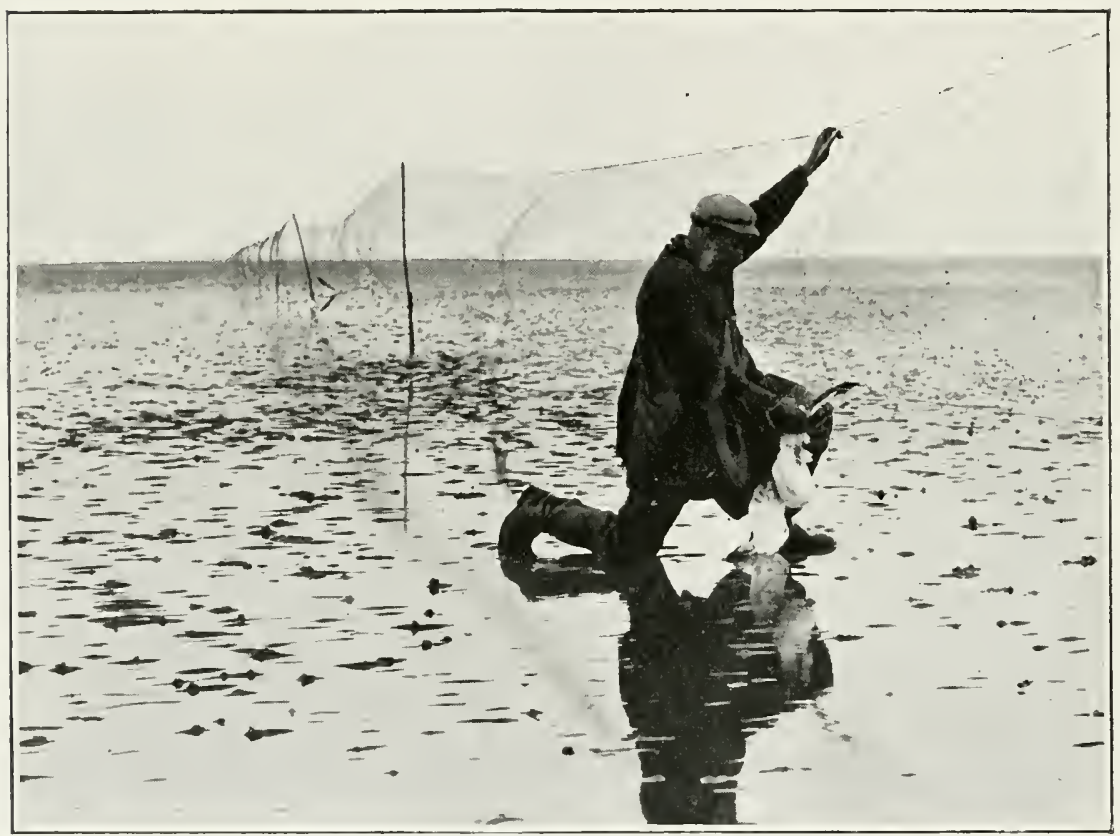

Bray tAKING Birds out of Flight.Net.

such as took place in Scotland in 189:3-the Short-cared Owls flock to the infected spot and do good service, as is shown by the report of the Committee appointed by the Board of Agriculture, published in the Zuslogist for April, $18: 3: 3:$

- In consequence of the vast multiplication of their 


\section{A Lincolnshire Mud=flat}

farourite food, the vole, these Owls have not only arrived in unusual numbers, but have renained and bred all over the district affected. laying from eight to thirteen egges (though Prof. Newton, in his edition of " Yarrell's British Birds, mentions seven as an unusual mumber), and rearing more than one brood. The shepherd on crooked Stone counted fourteen nests on his ground. The small wood behind the farmsteading of Howpasley presented a remarkable appearance. the ground being densely corered with the 'pellets' or ' 'astings' of Owls. being composed of the fur and bones of voles."

Some years bring a remarkable invasion of Goldencrested Wrens, and with them generally may be found a specimen or two of the rarer Fire-crest. ()n these occasions the hedges and bushes in the neighbourhood are thickly covered with tiny wanderers, sometimes too fatigued with their journey to proceed until refreshed by rest. Snowbuntings also come over more or less regularly. if not in such large numbers.

Occasionally there will be a sudden invasion of some umusual species in great numbers to the castern shores of England. The winter of 1893-4 will be remembered for the numbers of Lapland Buntings, which before the previous year had only been known as rery occasional stragglers. In 1888 there was the extranordinary passage of Pallas's Sand-grouse. not only to the eastern counties, but all orer knghand and Scotland. and the whole of Europe. In 189\%2 large numbers of Ruddy Sheldrakes invaded Britain: and early in 1895. 
and again in 1900, the shores of Lincolnshire and Norfolk were strewn with little Auks, either dead or dying.

It is fortumate, seeing so many rare wanderers turn up on our eastem coasts, that there have been competent observers ever on the watch to detect them in both I.incolnshire and Norfolk. For years Mr. Caton-Haigh and the late Mr. Cordeaux in I incolnshire, and Messrs. Gurney and Southwell and the late Mr. Sterenson in Norfolk, have watched the arrivals ammally, and have recorded not a few occurrences of most extreme interest: for among crowds of the common migrants there is always a chance of a rarity : and following the rush of small birds, for the purpose of preving upon them, are often large birds of prey-such as Falcons and Buzzards.

'The Great Grey Shrike is a tolerably common winter risitor on our east coast while in attendance on flocks of little birds.

But while birds which breed in Scandinaria, Iatpland. and Siberia may be expected to risit us on their southward passage, it is less easy to account for the occasional occurrence of American and Asiatic speeies. How is it that hardly a year passes without a few such occurrences? inong the order of limicole there are no less than twelve Ameriean species which have been recorded from our roasts, and some of these on several occasions.

It is inconceivable that these birds, which are none of them noted for very strong and long-sustained flight. should have crossed the Atlantic in defiance of all known habits 
of their class. It is more reasonable. surely. to suppose that. returning southwards from their circumpolar breeding-grounds (and it seems customary for all this class of birds to nest at the farthest northem limit of their range), they lost their way or became mixed with fiocks of similar habits which were bound for the European route instead of that through the Anerican Continent.

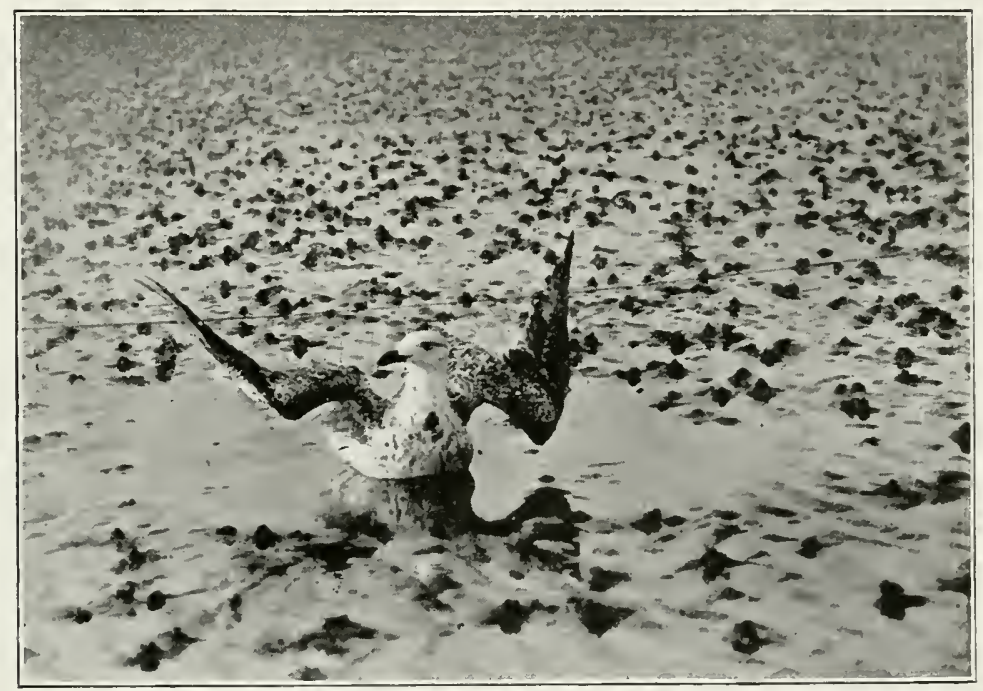

Lesser Black-Backed GUll (imature) CaUght in Flight-Net.

How else can the presence be accounted for of so many of this kind of bird? - the Solitary and Spotted Sandpipers. the Pectoral Sandpiper. Bartram is Sandpiper. Bonaparte's Sandpiper, the Buff-breasted Sandpiper. Eskimo Curlew. Red-breasted Snipe. Yellowshank. American Stint. Kill-deer Plover, and Lesser Golden Plover-birds which usually range through the entire length of the great American 
Continent, from the Aretic ('ircle to Patagonia and Chili.

'The extent of the world's surface covered by birds in the course of the vear. many of them of minute size and feeble flight. is really a most interesting and fascinating part of the study of bird life. and one too often neglected by naturalists.

We are too insular even in our ornithology. and rather too much inclined to rank all birds not on the " British" list as ontsiders, morthy of any consideration at all. It really adds very much to the interest of any particular bird seen to know where it has come from and whither it is bound.

These Knots just taken out of Bray's nets. for instance. have come recently from the farthest north. Various Arctic explorers have found them and their romg in lat. $81^{\circ}$ and $82^{\circ}$ : but no eggs are known to exist in any collections. national or private. though the birds in their grey winter plumage are so abundant in the autumm. 'Those which escape the dangers from nets. shore-shooters. and birds of prey will work their way south. passing. many of them. through the Spanish marismas, where ther are extremely eommon on passage, and, according to Saunders. down the west coast of Africal ats far as Damaraland: and the return jomrney brings them back again. passing up our eastern shores. in the red breeding-plumage. the following May. Truly a wonderful ammual performance.

What a pleasure it is to be able to follow to their 
foreign breeding-grounds birds which have only been known as winter risitors. or perhaps only as stuffed specimens or skins in a museum! A little experience like this does more to broaden one's riews and open one's mind than anything I know of.

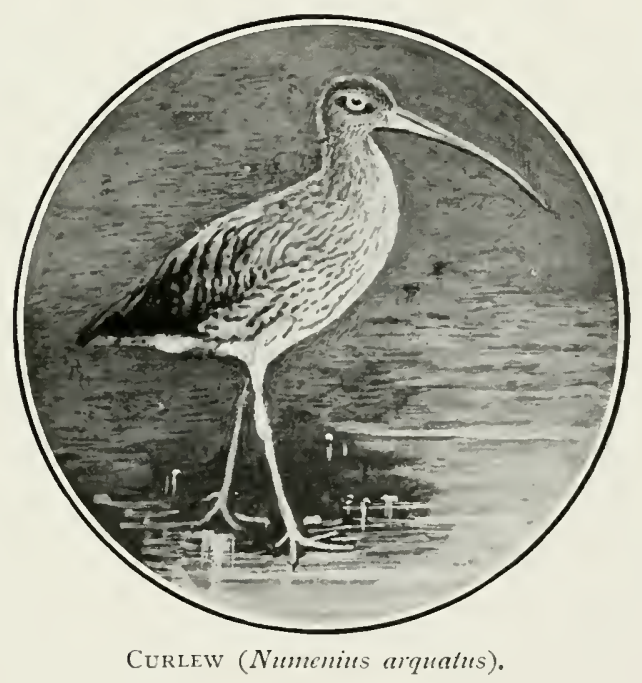




\section{CHAP'TER VI}

\section{The Sea-birds of the Farne Islands}

Arvmon desirous of seeing sea-fowl "at home." and of watching their habits and customs, should make a point of risiting the Farne Islands. 'This group of little rocky islets, set in the North Sea five or six miles from the coast of Northmmberland, has been known for ages past as the summer resort of countless numbers of sea-birds. Frer since the days of $\mathrm{St}$. Cuthbert. and probably for centuries before that, they have flocked in myriads to these remote rocks for nesting purposes.

I atterly, howerer, the continued existence of this interesting breeding-station being imperilled by the greed of the fishemen, and by the thomghtless cruelty of the tomists from the neighbouring towns, the islands have been leased by an association of naturalists. who employ. during the season. four watchers to live on the islands for the protection of their feathered tenants. 'This has resulted in a most satisfactory increase in the numbers of the birds. which have been in some danger of extemnination. and also in the remarkable tameness displayed by them.

Haring arrived at North Sunderland or Bamborough, it 
is necessary to engage a fishing-" eoble," as the boats of this Iocality are ealled. They are fine seaworthy boats, huggerrigged. and manned by a crew of three.

After leaving the small fishing-harbour, I found no indication of the existence in the immediate neighbourhood of any latrge number of breeding sea-birds. A few 'lerns were to be seen hovering with graceful flight and swooping down on the scraps of fish from the herring-boats, with some stray Crulls and a few Gammets engaged in their micque mammer of fishing. As the boat rushes forwards over the hearing waves, a few P'uffins and Guillemots may be passed, riding buovantly orer the billows. These, as the boat approaches, suddenly dire, to come up again far away on the other side. 'The water is so clear and transparent that the brilliant colour of the Puffins' legs may be distinctly seen ats they scull themselves along under water. Exreedingly comical they look, with their trim, squat figures and immense. aaily coloured beaks. Every now and then one will pop up from below with a little silvery fish hanging from its beak, and fly off with it to its solitary young one, anxiously awaiting its arrival at the month of the nestingburrow. Both they and the Guillemots are as much at home below the surface as they are above it. and are most expert in eatching such slippery customers as sand-eels and the firy of valrious fishes.

'The sight of the islands to which a visitor is always taken first is the "l'muacles," where the Guillemots breed. An extraordinary scene it is too, and one well worth the 


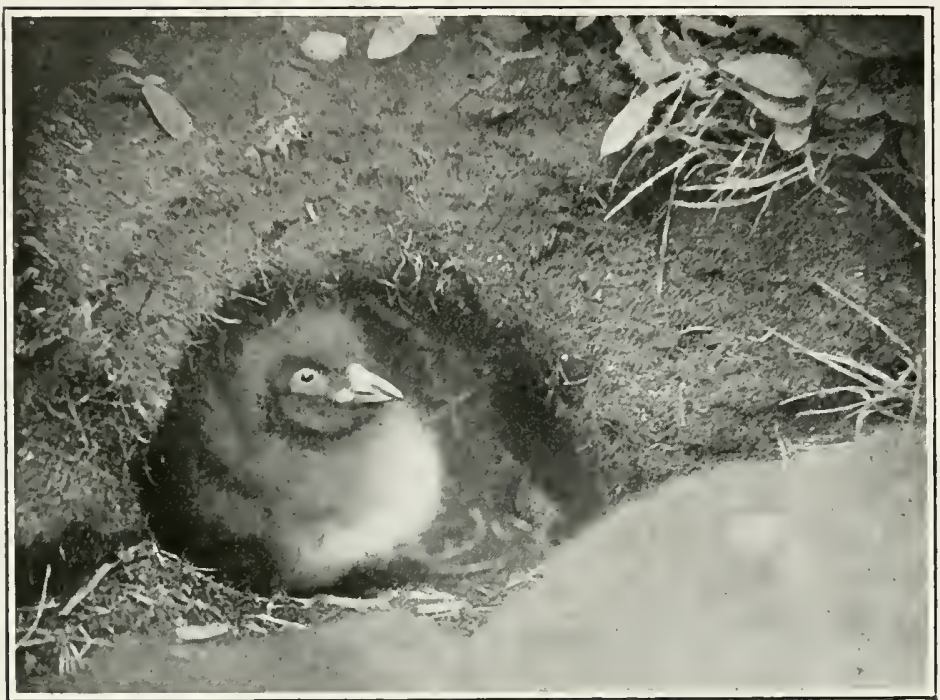

Nestling Puffin (Fratercula arctica) in Down at Mouth of Burrow.

journey alone. Off one end of the largest island-ralled, I think, Staple Island-are four detached, Hat-topped rocks or stacks, rising straight up firom the sea to the height of forty or fifty feet, so that the top of them is exactly level with the end of the adjacent island. of which at one time they doubtless formed a part. 'The whole of the upper surface of these stacks is yellow-washed from the droppings of the birds, which crowd together in such numbers as to completely rover the flat tops. Nothing is to be seen but a dense mass of Guillemots, so closely parked together that a fiesh bird coming up from the sea has some difficulty in finding standing-room: and it is quite a common thing to see sereral birds standing on the top of their companions. struggling to squeeze in. 
Each of these birds is engaged in incubating its single egg. Like the Puffins, they only lay one, and, like these birds also. the egg is disproportionately large for the size of the bird. so much so that it would not be calpable of rovering two.

'Their eggs, as is well known, show an extranddinary diversity in colour and markings. 'The ground-colour of some is quite white. others are bright green. and every conceivable shade of yellow and brown, and sometimes blue, is to be seen. The markings are generally striking and bold in character; but these, too, vary as much as the groundcolour, so that out of hundreds of eggs no two will be found alike. It may be that this diversity serves a useful

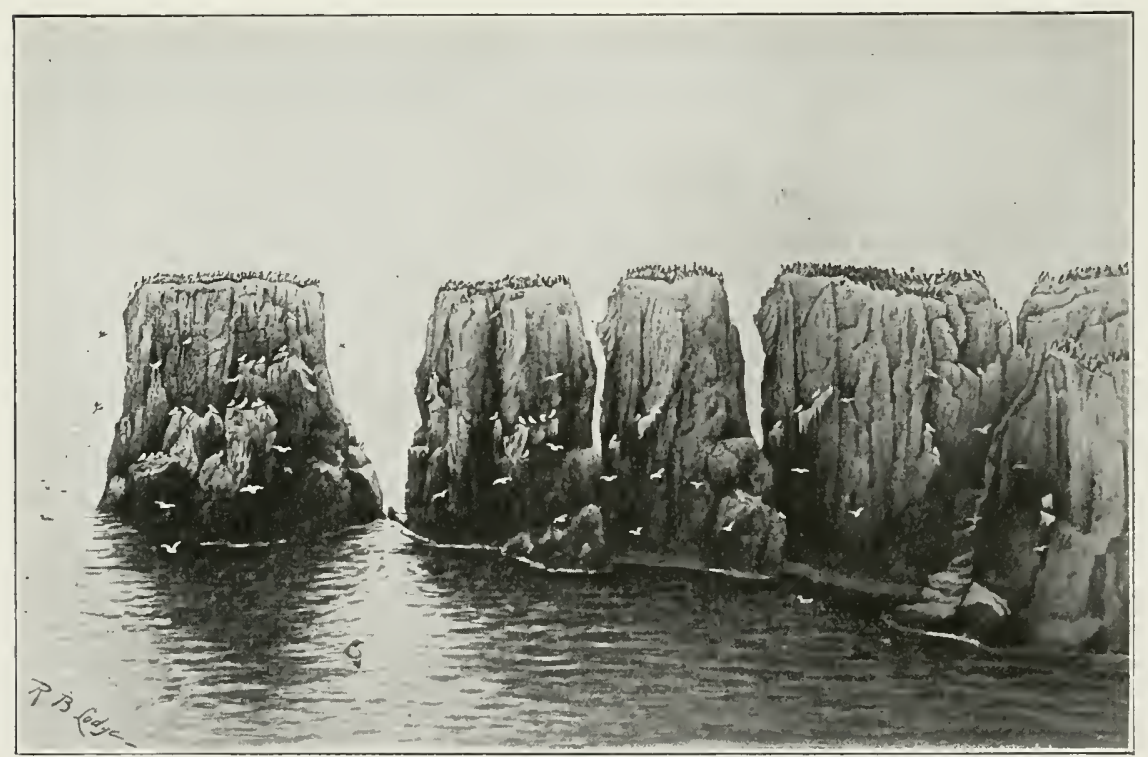

The Phinacies. Drawn fron Photugraphs. 
purpose in enabling each bird to identify its own egg. which wonld, if the egas resembled one another, be a matter of some difficulty. 'Their renarkably pointed shape has been

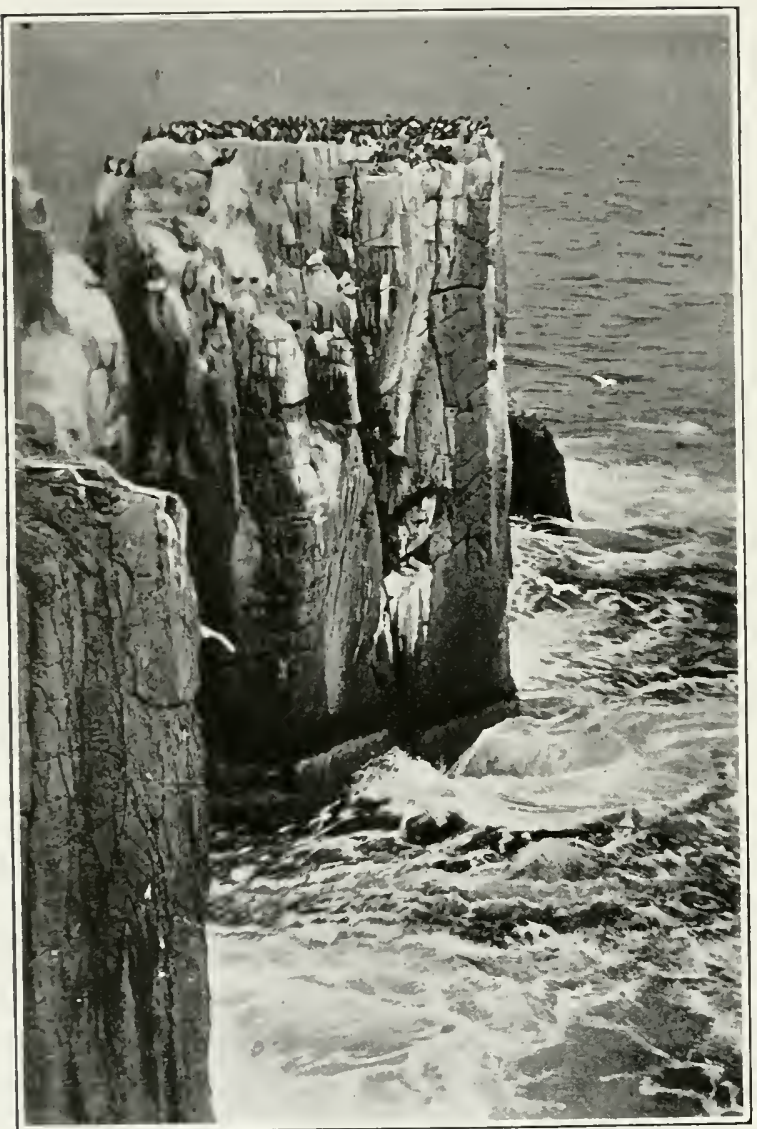

Gillennots aid Kittiwakes oN the Pinnacles. supposed to be for the purpose of lessening the risk of their rolling orer the edge of the rock - a risk to which they are peculiarly liable. being simply deposited on the bare surface withont the slightest restige of nest to keep them in position. It must be admitted that their shape does make them less likely to roll. the tendency being for them to revolve on their own axis.

All the birds are in eonstant motion, continually bowing their heads up and down in a particularly grotesque fashion. and engaged in preening their feathers and quarrelling with 
one another. Numbers are constantly ieaving the rocks for the sea below, and others as constantly ariving. The surface of the sea is also thickly dotted with birds. It is perfectly easy to watch them from the edge of the main island. which is only separated from the nearest stack by a galp of ten or

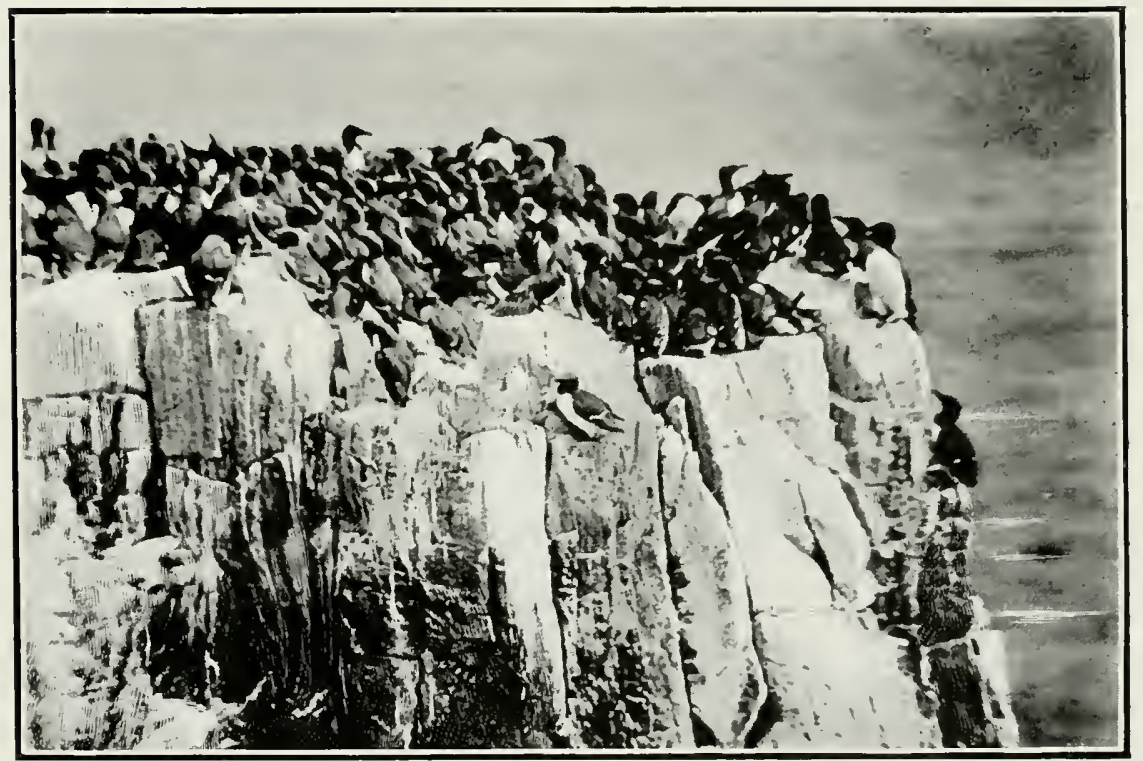

Guillemots on the Pinnacles.

fifteen yards. All the narrow ledges of rock near the top are also occupied by the Guillemots.

The lower cramnies and holes in the precipitous sides of the staeks, as well as of the island itself. are occupied by the Kittiwakes. Some of their nests are so near to the restless waves, which constantly bieak oier the base of the rocks, that many eggs and young hirds must be washed 
out of them in rough weather. 'The nests are fairly large and well made, apparently of seaweed and turf, wedged into the cliff-face wherever there is a hole or erack large enough to hold it.

'The pure and spotless plumage of these beautiful Gulls looks of a dazzling white against the dark and rugged rocks, and the seene is one of great beauty. 'The sea below, bathed in the glorious rays of the midday sm, glitters as if composed of molten jewels, and is fretted into a network of creamy foam as the everlasting surge beats incessantly against the opposing cliffs. Fresh birds are constantly arriving with food for their young. or Hying off for supplies, and their shrill cry of " Kitty-kea, kitty-kea," resounds from all sides.

'The Kittiwakes, though nesting in such numbers on the same rocks, are never so crowded together as the Guillemots. Fach pair of birds build their nest just wherever they can find a snitable place in the perpendicular face of the cliff: 'They never build on a that surface like the larger Gulls. If two or three suitable crannies happen to be close together, there will be a nest in each : if not, they will be correspondingly farther apart.

'They present the most charming little pictures of bird life. Standing on the extreme edge of one of the numerous rifts and chasms, or on a jutting promontory of rock, your can look across a few feet of space right into the nests. At the time of my risit, the first week in July, the nests for the most part eontained freshly hatched birds, sometines 


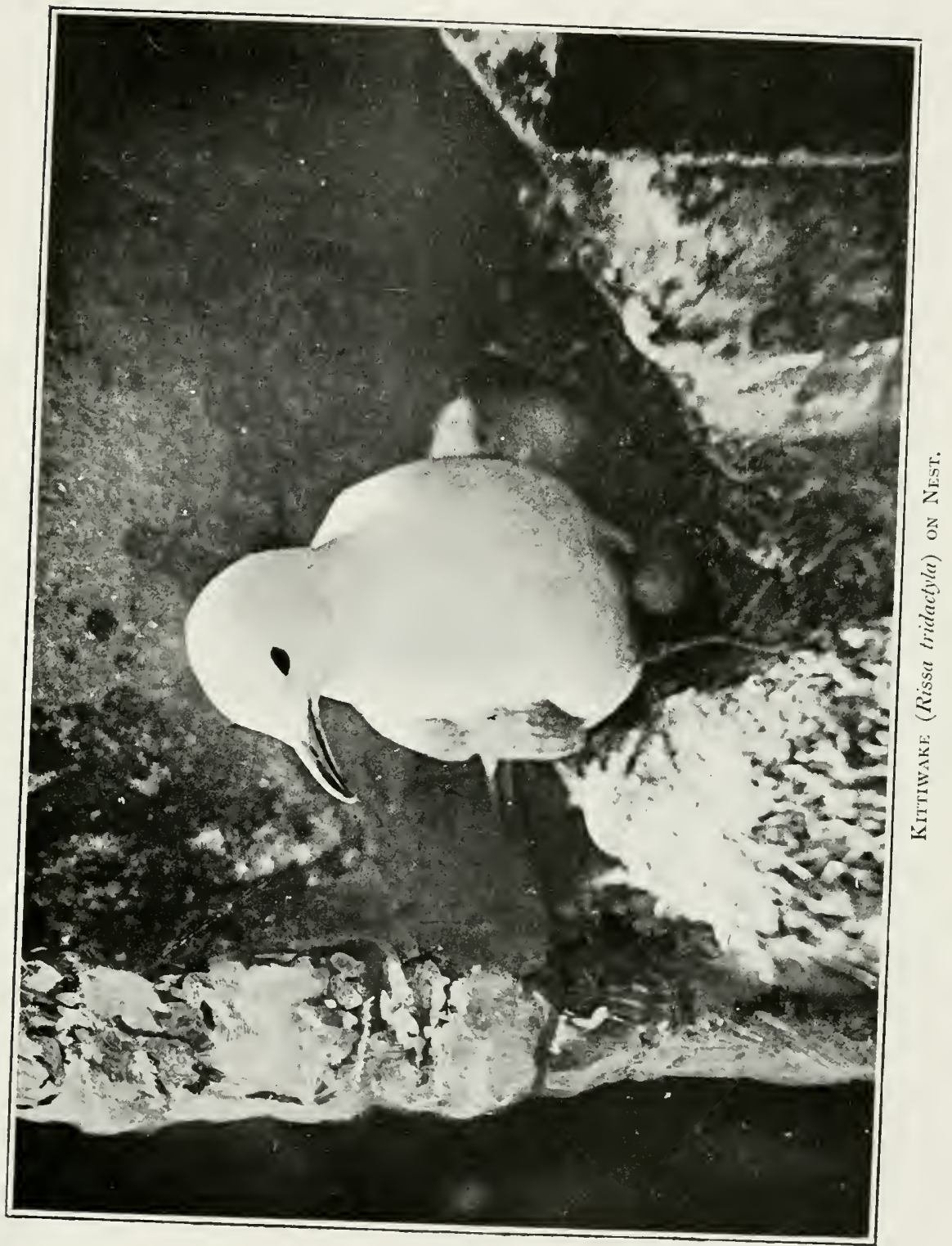


one egg and one young one. In many eases one or both of the parents remained standing on or about the nest withont displaying the slightest fear or timidity.

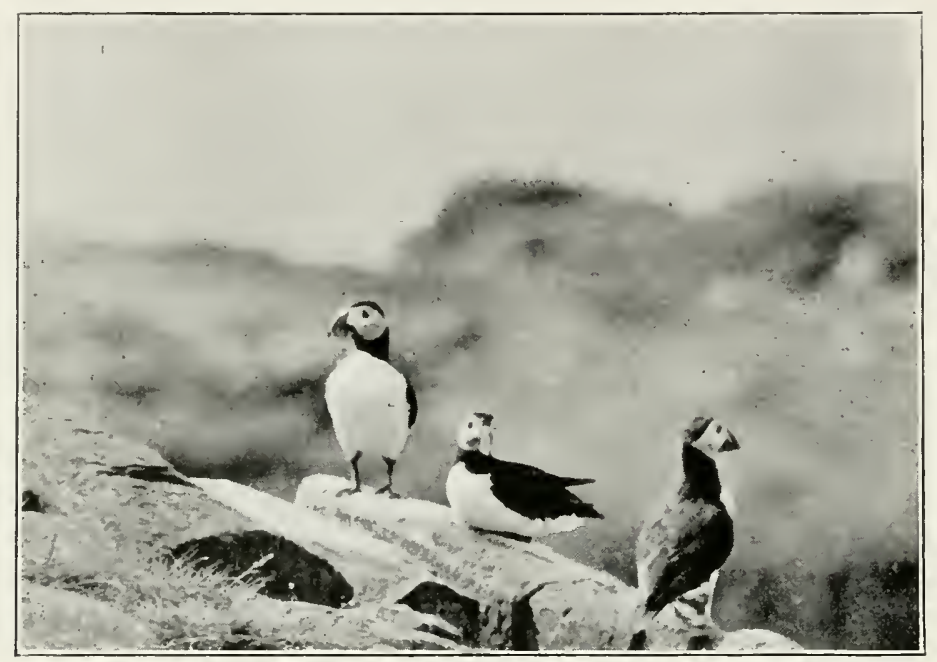

Puffins (Fratercula arctica).

Most of the islands appear to be of the same formation. sloping gradually at one end into the sea, and at the other rising abruptly to the height of about forty feet. 'This higher part is worn into fantastic pinnacles and jutting crags by the action of the wares. In some parts there is a depth of peaty soil covered with short turf, and sometimes with a luxuriant growth of bladder eampion and dock.

'This peaty soil is completely honeycombed by the l'uffins for their nesting-burrows; whether these holes, which exactly resemble rabbit-holes, are made by the l'uffins 


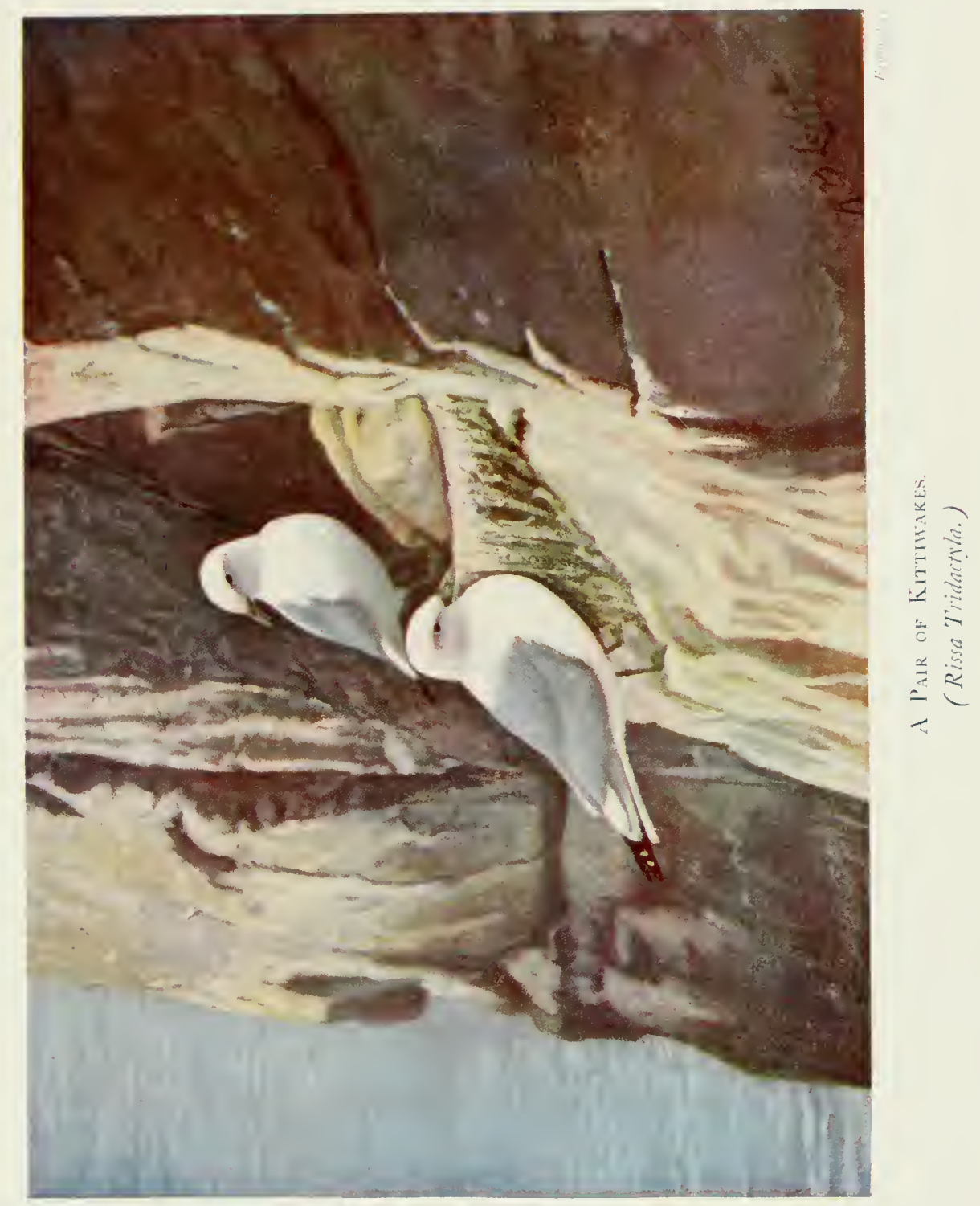





\section{The Sea=birds of the Farne Islands}

themselves, or by the rabbits which are also found here. I do not quite know. At any rate, the Puffin is well equipped with his big beak for excarating a hole for himself, or equally well fitted, by means of the same weapon, for ousting the rabbits in at armis from their habitations.

At the end of these burrows the Puffins lay one large white egg. They may be readily caught in the holes, which are not as a rule beyond arms-length. But before going Puffin-catching it is adrisable to put on a stont glove; for the first intimation that the bird is at home will be a sharp nip. and you realise that the Puffin has

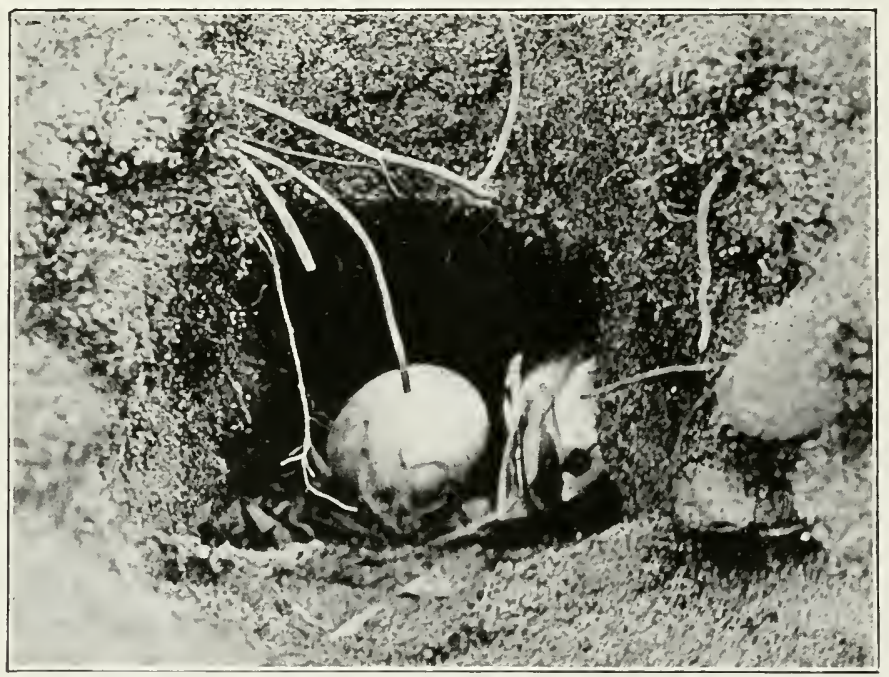

PufFix's Burrow, SHowixg EgG and HeAd of Bird.

canght you first. It can bite hard-nearly hard enough to take a piece out of your glore-and luang on vindictively. its little black eyes seeming to twinkle with anger and 
resentment at being disturbed. On putting one down on the ground, it is at first mable to rise, but flutters along

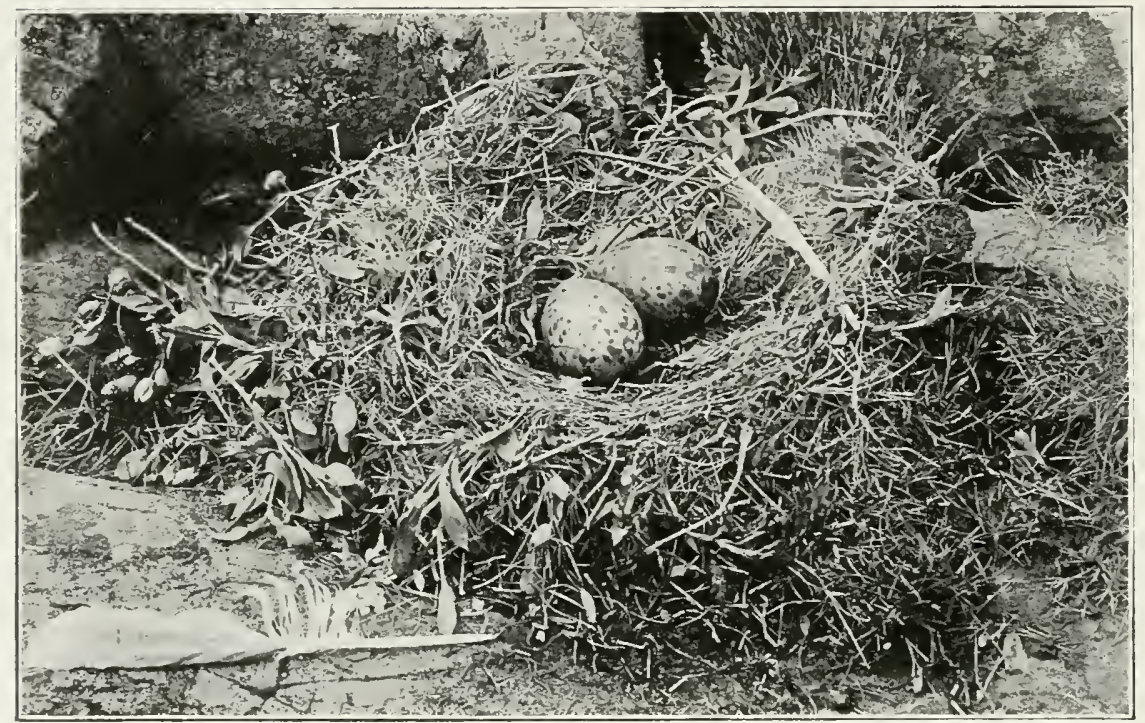

Nest of Lesser Black-Backed Gull (Larus fuscus).

to the edge of the cliff' in order to launch itself into the air: once started, howerer. it is quite at home.

The young Puffins in their downy dress are eurious little objects, sooty brown or dull black in colour, with white chests. 'Their beaks have neither the size nor the brilliant colours of the old ones. 'The old Puffins are fond of sitting' in small groups on elevated points of rock. discussing, I presume, the weather and the state of the fish-market. 'The postures of these birds are very comical, some bolt upright, others sitting or squatting. and others Happing their little short wings as if to dry them. 
Each island hats its own special inhahitants. The Guillemots are entirely restricted to the pinnacles. while the chief stronghold of the Comorants is on the Megstone. The 'Terns in 1895 were nesting in large numbers in the ". Wideopens." The Lesser Black-backed Gulls and the IIerringgulls nest all orer the islands, making their untidy nests indiscriminately anywhere on the flat surfice. never on the perpendicular sides of the cliffs. Many are in the corners of the bare rocks, and others are placed amid the tall docks and ampion. One nest was particularly well constructed of bladder campion pulled up by the roots, with the white Howers still fresh.

The eggs are very variable in colour. from dirty white to a dark olive-brown, and the eggs of the two species so much resemble one another that it is impossible toidentify them moless you see the birds. The Herring-gulls, however. are much in the minority, not much more than five per cent. being of this species. Young birds of both species, in

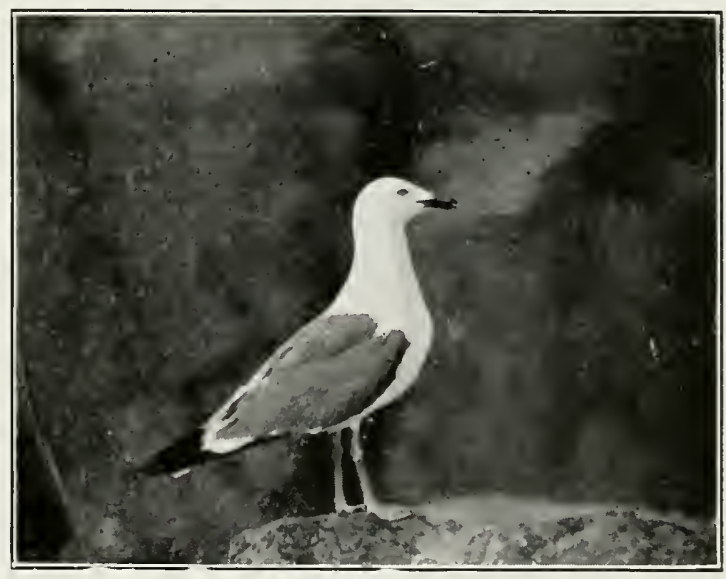

Lesser Black•Backed Gull (Larus fuscus). dirty yellow down mottled with brown. are to be seen rumning about the rocks and paddling in the pools of rain-water. As 
you approach them they crouch into a corner, and so much do they resemble the rock on which they are squatting that when motionless it is difficult to aroid treading on them.

The adult Gulls wheel round to the spot in hundreds. the moment the boat touches their island domain. anid great excitement and loud and angry eries. On landing. you are greeted with many unsaroury salutes as the birds soar overhead. every step being accompanied by splashes on the rocks on every side. It is like being under fire. Before I had landed two minutes. both my coat and hat were plentifully besprinkled. while the birds langhed derisively. - Ha. ha. ha." 'They are most bold-looking and handsome birds. but are great robbers. living chiefly by plundering their weaker neighbours, devouring both eggs and young. if left umprotected for a moment.

When trying to approach the other birds. I found their inquisitive behaviour a great muisance. Just when I was most anxious not to attract attention, they would wheel around me with much clamour and outcry.

On the island known as the " Wide-opens" there were large colonies of both the Aretie and Sandrich 'Terns. 'There used to be a settlement of the Isesser 'Terns. which some years ago died out, and I do not know whether the attempt to re-establish them by placing eggs from other localities in the nests of the larger species has been successful or not. 'The Common 'Tem used to nest also, though I saw none. Since the better protection of the birds a few pairs of the rare Roseate 'lems hare nested ammually, and seem 
to be increasing again. It is not so easy. however, for an incxperienced eye to distinguish an isolated pair or two of any particular species, mingled with so many hundreds of the common kinds.

On landing, the numbers of white forms flying in wild confiusion give one the idea of a snowstom, and the invasion

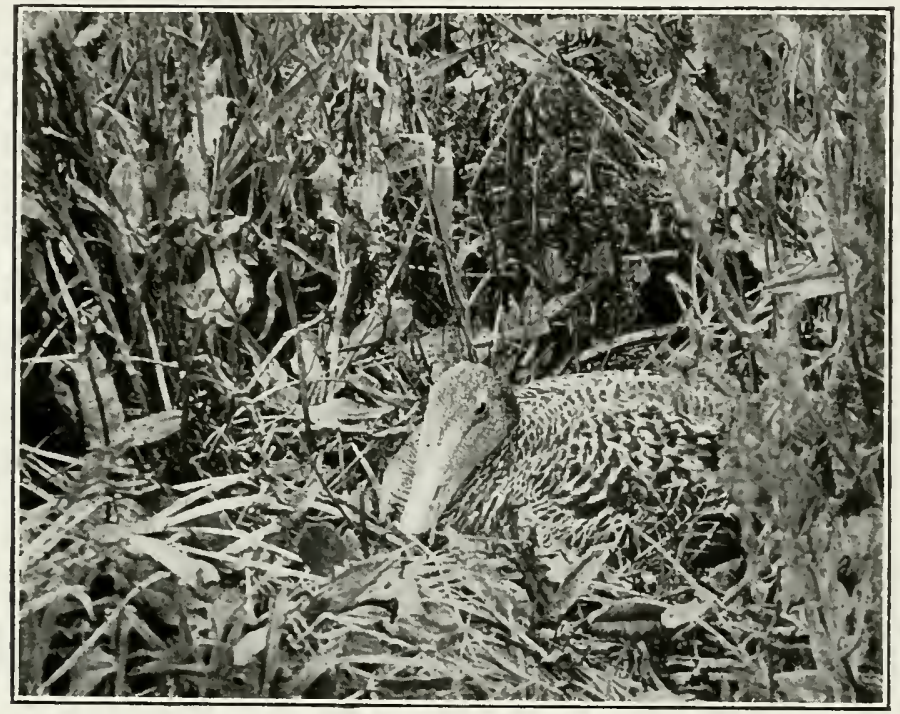

EIDER-DUCK (Somateril mollissma) SITTING.

of their nesting-ground is greeted by a babel of incessant outcry. 'The note is a repetition of " Kreee-kr-ee."

'The Arctic 'Tems were mostly nesting in the shingly shores, some anong the stones, and others among the driftwood and seaweed above high-water mark. Not much of a nest is made in these situations. 'The Sandwich 'Terns' nests were generally higher up, among the bladder campion; and here the nests were simple hollows in the ground. 
sometimes rery close together. 'Two and three eggs is the full chutch. Many young birds had been hatched, and dozens of them were dead in the nests, killed by a heary storm of wind and rain on the previons day. The egas of the Sandwich 'Tems ane rery richly coloured and matied. and are much more handsone than those of the Aretic 'lerms. as well as much larger. 'They appear shy at the nest. and when sitting the long swallow-like wings are crossed high orer the back, and the head is rery upright.

After photographing the nest of a Sandwich 'Tem containing an egg. a young hird, and the empty shell from which it had just emerged. the other egg also hatched

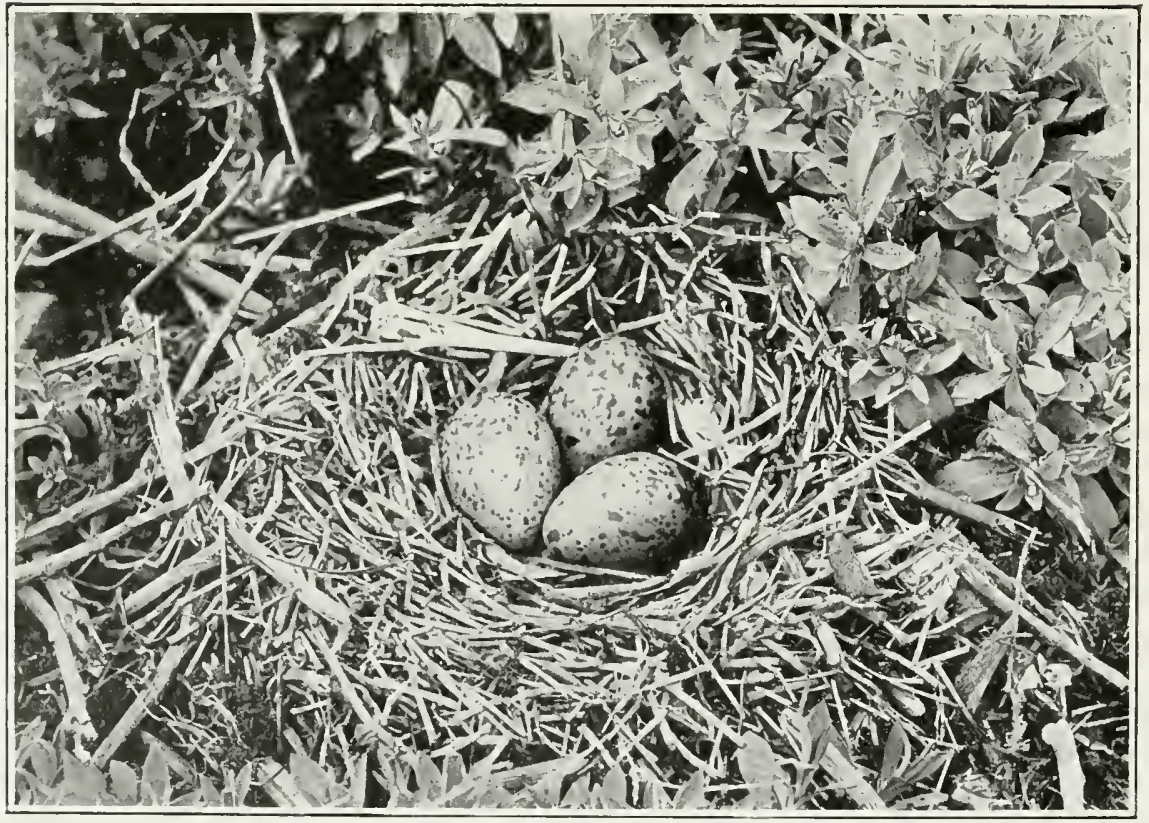

Nest of Orster-catcher (Hamatopus ostralegus). 


\section{The Sea=birds of the Farne Islands}

before I had taken the camera away. Young in down are yellowish grey. 'lerns ale very plucky in defence of their nests. and I salw one pursue a I esser lilack-barcked crull

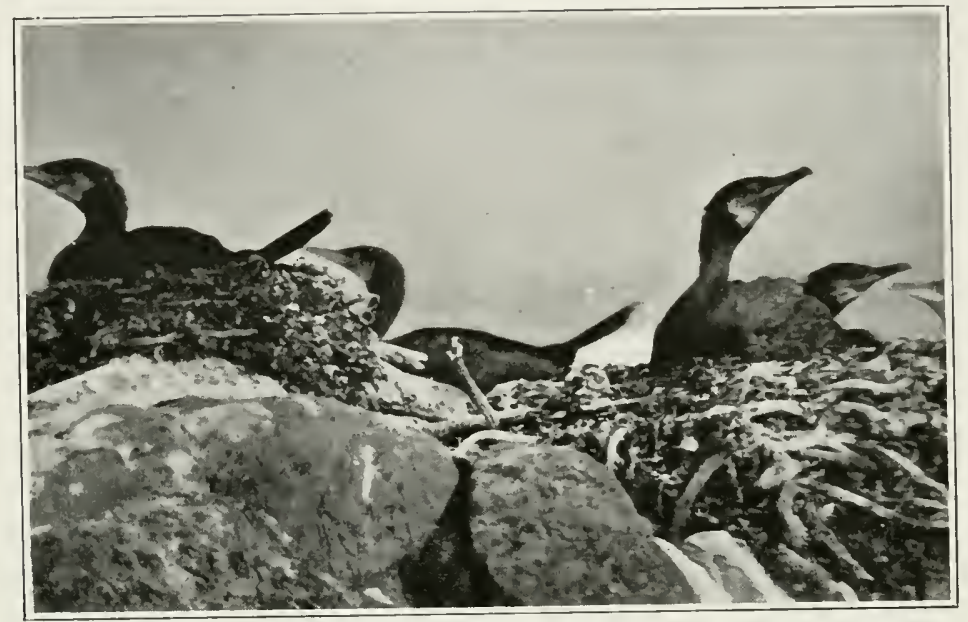

Cormorants (Phalacrocorax carbo).

which had approached too near, striking at it repeatedly, and following it resolutely for a considerable distance. (One of the watchers had been struck on the head the previous day by one of them.

Near to the Tem colony were two nests of Eiders. ()n one the duck was sitting hard, and our photographic operations did not disturb her. There is no bird which its closer than the Eider. 'This one allowed us to stroke her on the nest. 'The other nest only held three eggrs and a small quantity of the famous down, which is not deposited in any quantity until the full clutch of eggs is laid. The nests are sometimes on the bare rocks. often 
among the campion. where they are perfectly hidden, and at the foot of the rumed buildings or inside the roofless walls.

()n the rocks at the water's edge was a flock of about

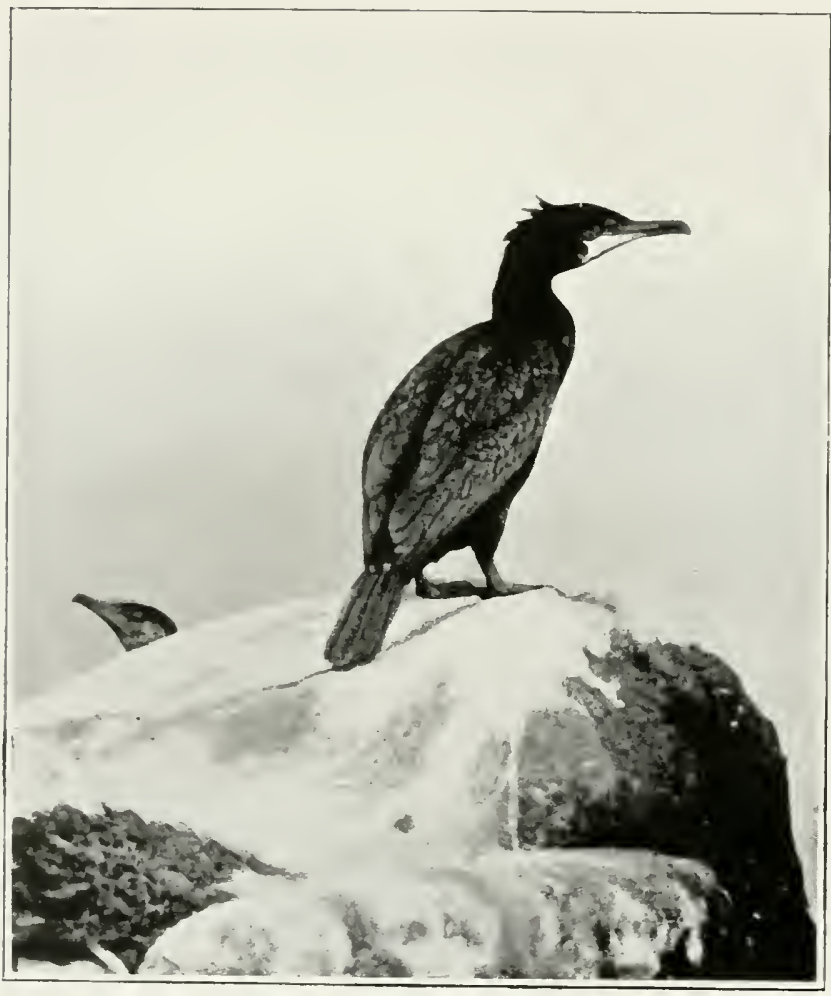

Cormorant (Phalacrocorav carbo). thinty Eiders. mostly ducks. but allong them were a few drakes. Only one of these was in the beatiful male plumage -the others had begun to assume the duckplumage. and were in - eclipse", dress. a rery interesting sight.

Farther on was a small flock of five or six Oyster-catchers, uttering their somewhat plaintive pipe as they searched the seaweedcorered rocks, uncorered by the falling tide. Close to an old wreck. cast up high and dry by the fierce gales of winter, was a nest belonging to some of them. 'This 
was better made than is usmal with these birds. being a fairly substantial structure of stalks, in which were three eggs and two labbit bones by way of ornament.

( ) a a patch of wet sand, reflecting the colours of sky and clonds, and on which the long billowy swell broke larily in little ripples, a large flock of 'Terns had settled. while others soared and hovered above them, their white

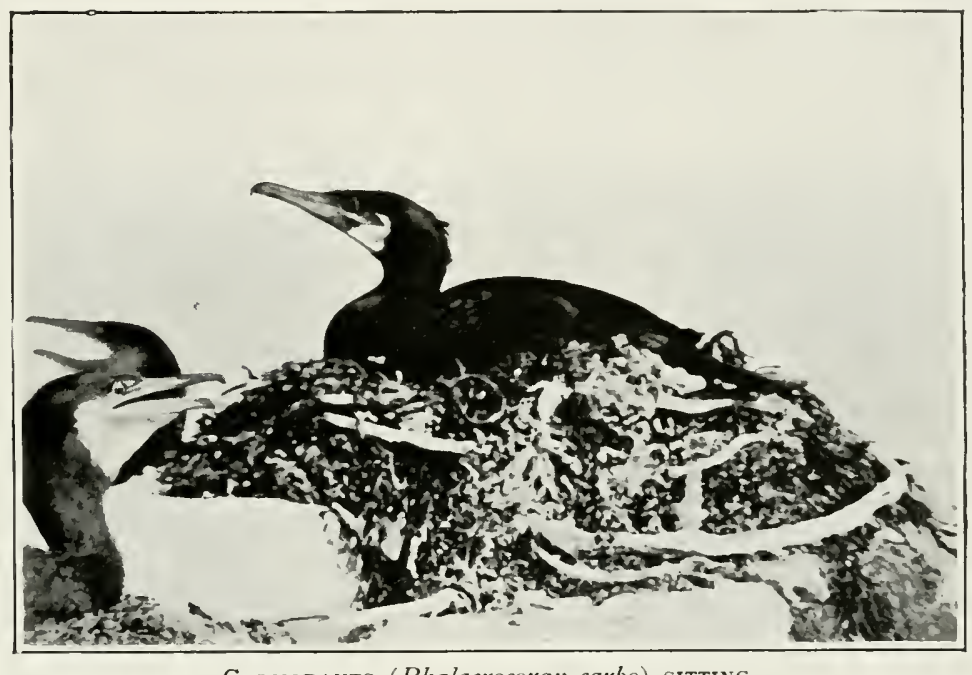

Cormorants (Phalacrocorar carbo) siting.

wings and snowy plumage looking very brilliant against the sunlit seat.

( )n the highest point of rock of the neighbonring island were a number of Cormorants on their nests. 'These I detemined to photograph, if it were possible-though I must say I hardly expected that they would allow of a close enough approach.

When landed, it took some time to climb up to the 
top of their rocky islet. necessitating sereral journeys to get up the camera and belongings. 'The climbing was easy and simple enough. merely clambering up luge boulders. one on the top of the other: but liden with cameras and breakables it took some time. especially as they were rery slippery. Howerer. at last I got everything up. and there. forty yards away. were fifteen or sixteen Comorants sitting. Corering the camera with a large green bag. and getting inside nurself. I started crawling on ny knees in their direction. until slowly and laboriously I reached the rocks on which the nests are placed.

All this time the Gulls were wheeling overhead. and screaming their hatrdest. and the Cormorants began to show serious alarm. one bird in particular standing up in the nest. as though meditating flight. As the flight of one would probably lead to the departure of the whole lot, I thought it better to halt until their confidence was regained a little. While waiting I exposed a plate or two on them in case of failure in getting any nearer, and when they appeared to have settled down I proceeded. It was now necessary to more rery cautiously indeed, an inch at a time. over the rough surface. through pools of stagnant rain-water, nearly squashing on my way sereral young Gulls. until I was within five rards of the nearest birds. and could see the close scaly nature of their plumage and their emerald-green eyes. 'Though they looked curiously in my direction. I was enabled to obtain sereral good photographs before they finally took alarm and Hew off. 
'The nests were large structures of seaweed and large stalks of some kind, piled up on the rocks, sometimes so close together as to touch. 'The nests were very flat. and the majority held two chalky-white eggs, though some had three, and one nest contaned four. 'The smell in their immediate proximity was rery strong. and the rocks around were plentifully whitewashed.

At the time of my visit I had secm some small birds fitting about the rocks: but being then maware that the Rock-pipit was one of the species to be met with. I did not take particular notice of them: nor did I see any nest of the Ringed Plovers on the little shingly beaches to be found on some of the islands.

The Gamnets, which may be seen fishing around, are visitors from the Bass lack. which is only about forty miles farther north, a mere trifle for these grand birds when in search of food. To see them plunge from the clouds is nearly as fine a sight as to watch an Osprey catch its fimmy prey.

Permission to risit this sea-birds' paradise is necessary: and when that is procured. you are allowed to land in company with one of the watchers, who never leares you, and is responsible for your discreet behaviour. No eggs must be taken. cxcept perhaps a few of the I-esser Black-backed Gull, which predatory species has to be kept rather in check, as any undue increase in their numbers would mean danger to their weaker neighbours. 


\section{CHAP'TER V'II \\ The Norfolk Broads}

Anove all the counties of England. Norfolk easily comes out first for its list of birds, and a very large pereentage of rare occurrenees are recorded by Norfolk naturalists.

For this there are several reasons,--the chief, perhaps, being its position, right in the track of migration. where so many migrants from northern latitudes first strike our coast: and secondly, the large extent of marsh and water still remaining in what is known as the Broad district, where wading and water-birds, driven away from the rest of England by drainage and cultivation of their former haunts, may still find a congenial refuge. Here they linger in ever-dwindling numbers. but they are very reluetant to be driven away. Again and angain do they attempt to nest and establish themselves more firmly - only to have their eggs taken, their young broods destroyed, and themselves shot without merey.

'The naturalist desirous of seeing some of these ramishing species on English soil must hasten before it is too late. Some have already ceased to nest even in the most secluded spots in this mique and semi-aquatic district, and to read the yearly Norfolk notes in the Zoologist is sald work. 
Year by year the record is rather of disappearances than oecurrences of dwindling numbers in the place of abundance. It is true that a few species added to the list of British birds are mostly from Norfolk: but these are without exception accidental visitors-strays of migration, which may never be seen again on our coast. Poor consolation for the steady diminution which is taking place of regular breeding species, many of which are already extinguished, and others, too many others, on the very verge of amnihilation.

The Great Bustard, Little Bustard, Hen-harrier. Ruff, Spoonbill, Bittern, Aroeet, Blaek 'Tern, Sari's Warbler, and Black-tailed Godwit have ranished as nesting species, never, I fear, to return as such a sad list of submerged species once plentiful as regular summer visitors, and now victims not so much of over-population, or eren cultivation (for there is plenty of room to spare for them still). as of senseless persecution and the greed of collectors.

Most of these may still be met with haunting the scenes where formerly they were so abundant, but only as straggling individuals on migration, and are too often recorded in the local papers as "shot and added to the collection of Mr. So-and-so." Luckily a local association has taken in hand the protection of the birds on Breydon Broad. or there is no doubt whatever that the number of bird murders would be far higher tham it is.

It this famous resort for rarities Black 'Terns and Godwits may often be seen, and every year Spoonbills spend some 
days not more than a few miles from the spot where, two hundred years ago. they were accustomed to nest. In 1895, in May, a small flock of twelve Spoonbills risited Breydon. and were so effectually protected by the watcher employed by the association as to escape the usual fate of such rare birds in Fngland, and in 1899 six risited the same place.

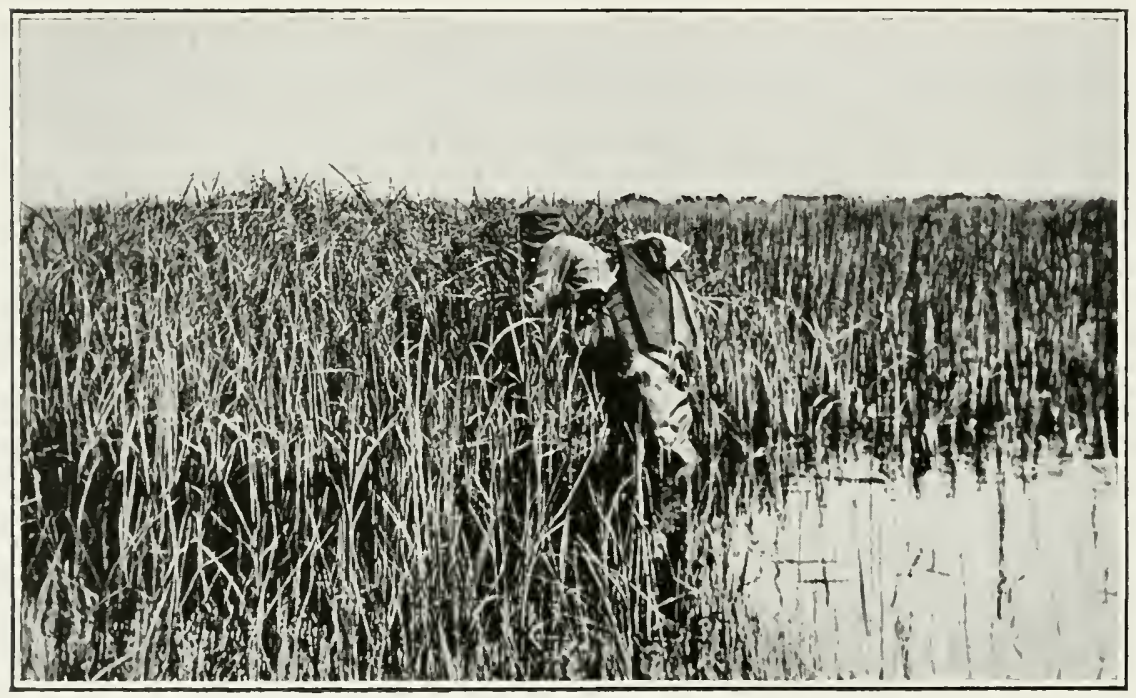

Wading after Bearded Tits, etc., in the Broads.

In 1901 twelve Spoonbills came, and again they escaped molestation. Mr. Cimmey, who records the fact, mentions that they were sufficiently well known to have acquired the nickname of "* Banjo-bills," not an inappropriate designation.

'The Short-cared Owl. the Marsh-harrier, Montague's Harrier, the Gargency 'Teal and Shoveller, and the lovely Bearded 'Tit are all fast-disappearing species, and every year sees their numbers still further diminishing. 


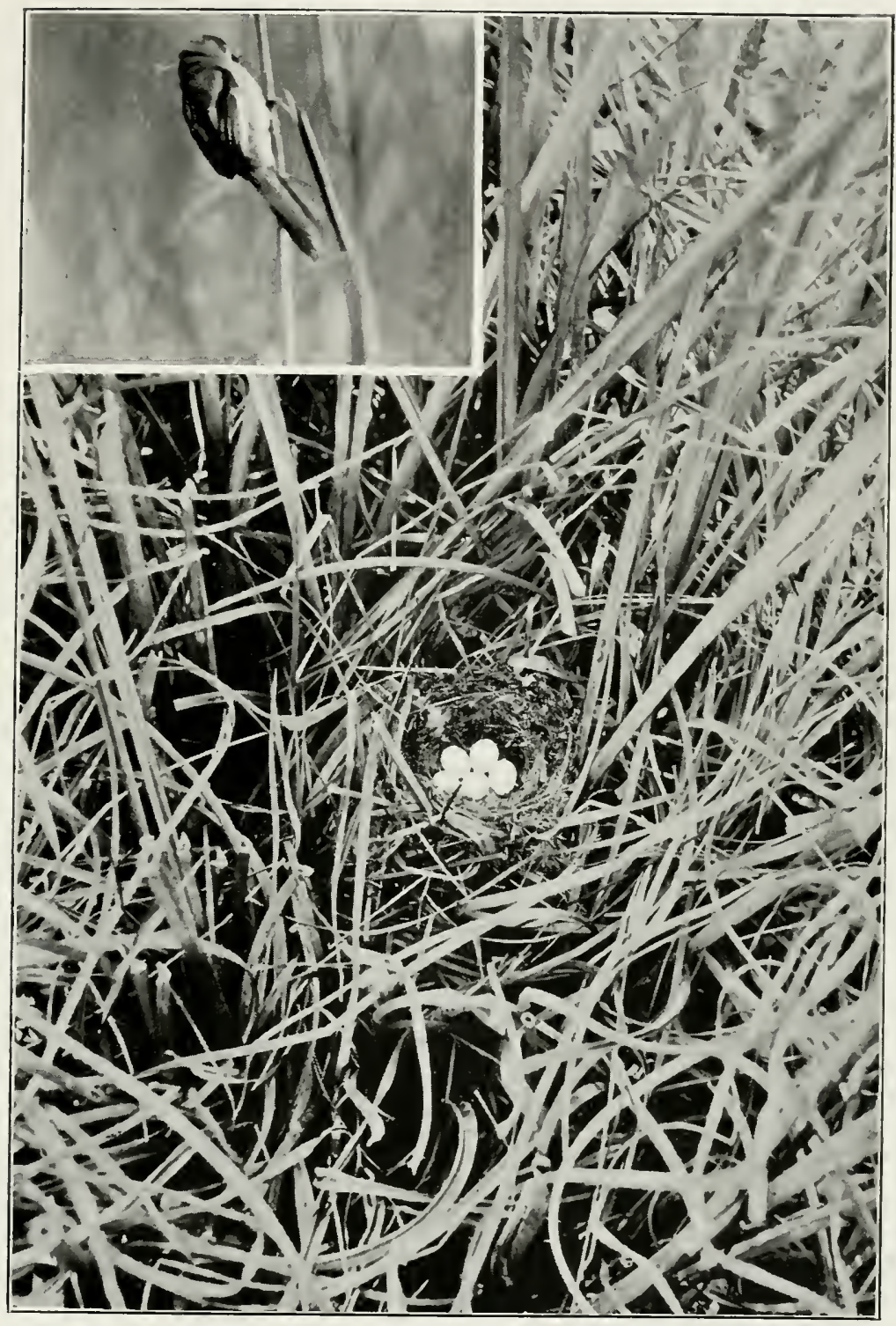

Bearded Tit (Panumes biarmicus) axd Nest. 
The best way to investigate the bird life of this most interesting district is to live on board a small yacht or wherry with accommodation for sleeping: and if two or three men with similar tastes join in an expedition of this sort. it is by far the cheapest as well as the most enjoyable way. 'There is the great advantage of being always on the spot. and haring a temporary home close to your days work. instead of having to trudge long distances daily to and firom the nearest inn.

A party of four spent ten days in such al yacht in May. 1899, living in the midst of our feathered friends. and a most enjoyable time we had. Our evening meals under the awning orer the boom. while we discussed the erents of the day and our plans for the morrow, were enlivened by the drumming of a Snipe across the river: and the latest sounds as we turned in for the night were the ripple of the water past on hows. the reeling of the Grasshopper-warblers. and the Sedge-wamblers chattering in the reeds.

In the immediate neighbourhood of our boat we found several nests of the Bearded 'Tit, and saw every day some of the birds. Most beautiful and most distinguishedlooking of all our mative birds they seem to me. and it is a thousand pities they are getting so scarce. I am glad to saly our party had, before starting, resolred not to take a single egg of the Bearded 'Tit during our stay.

It is easy enough to find the nests if you know how and where to look: but you must be prepared to wade. 


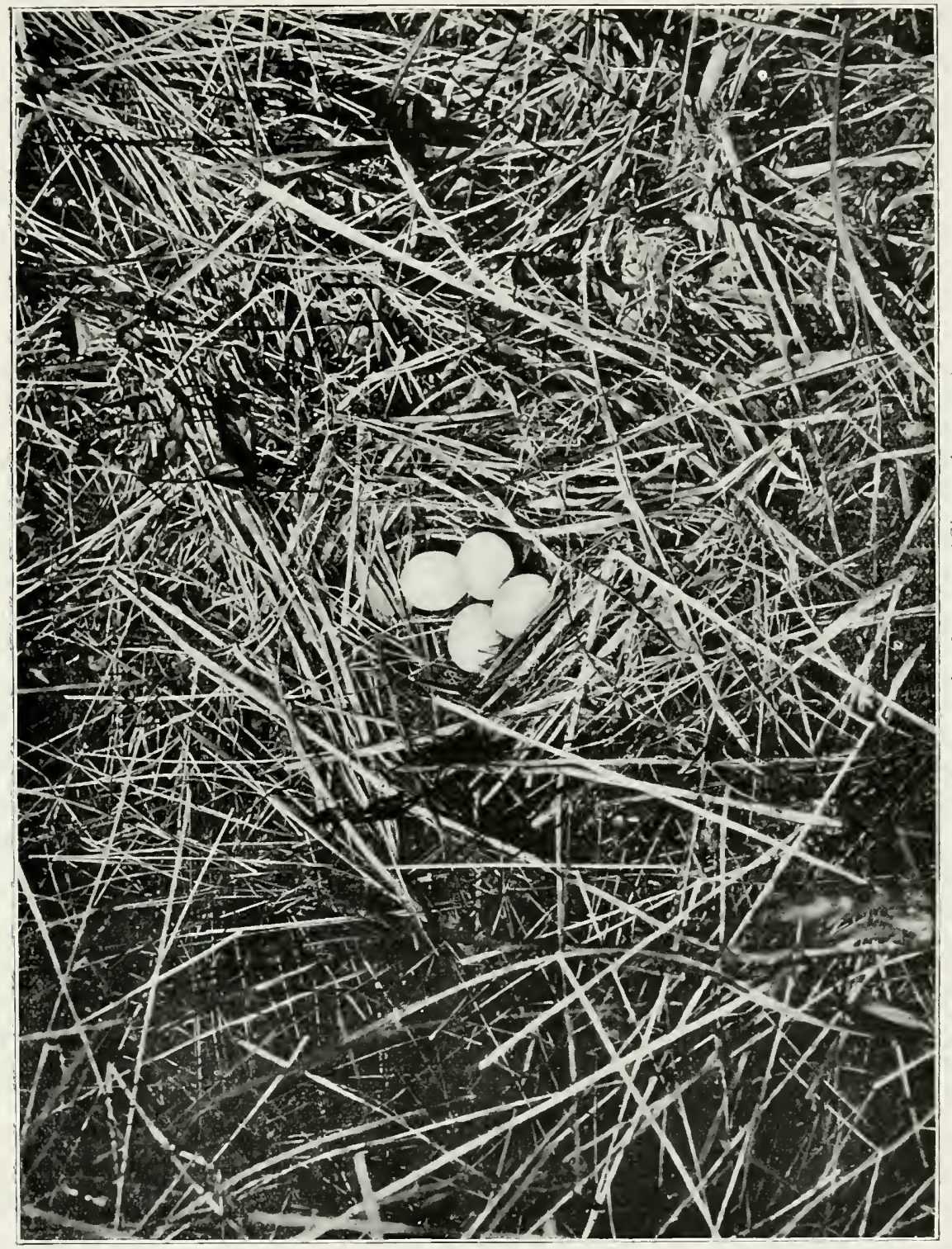


and to wade deep. For. with a long experience in wading in rarious ont-of-the-way parts of the world, I must say that wading in the Broads is abont the trickiest of any. Many a time, while wading with a good fim bottom in about three feet of water. I have suddenly. and without the slightest waming, gone plump through a deep hole in the floor. so to say. up to my shoulders. and then have been mable to touch the bottom. For this reason it is necessary to carry an oar, or a " quant" (as a punt-pole is called in the Broads). The edges of these holes are luckily firm, and. with the help of an oar. you can get your knee over and struggle up again: but they are exceedingly dangerous.

A "quant" is also a most useful tool with which to poke about anong the reeds and sedge, and in searching for Bearded 'Tits' and Reed-warblers' nests it is almost indispensable. By parting the reeds in front of you as you advance slowly, and as quietly as possible, you can see the nests of the latter suspended botween the reed-stems: and for the former you ean hear the rustle of the bird as it silently slips off its nest and creeps through the thick growth. 'Then you know exactly where to look for the nest. and will probably find it a few feet in front of you among the confused tangle of dead regetation. where otherwise it would most probably escape observation altogether. For its construction is of the roughest, as far as the outside appearance. 'The inside. howerer, is beantifully lined witl the Hower of the reed the "fine," as the marshmen call it - and sometimes a feather or two. 


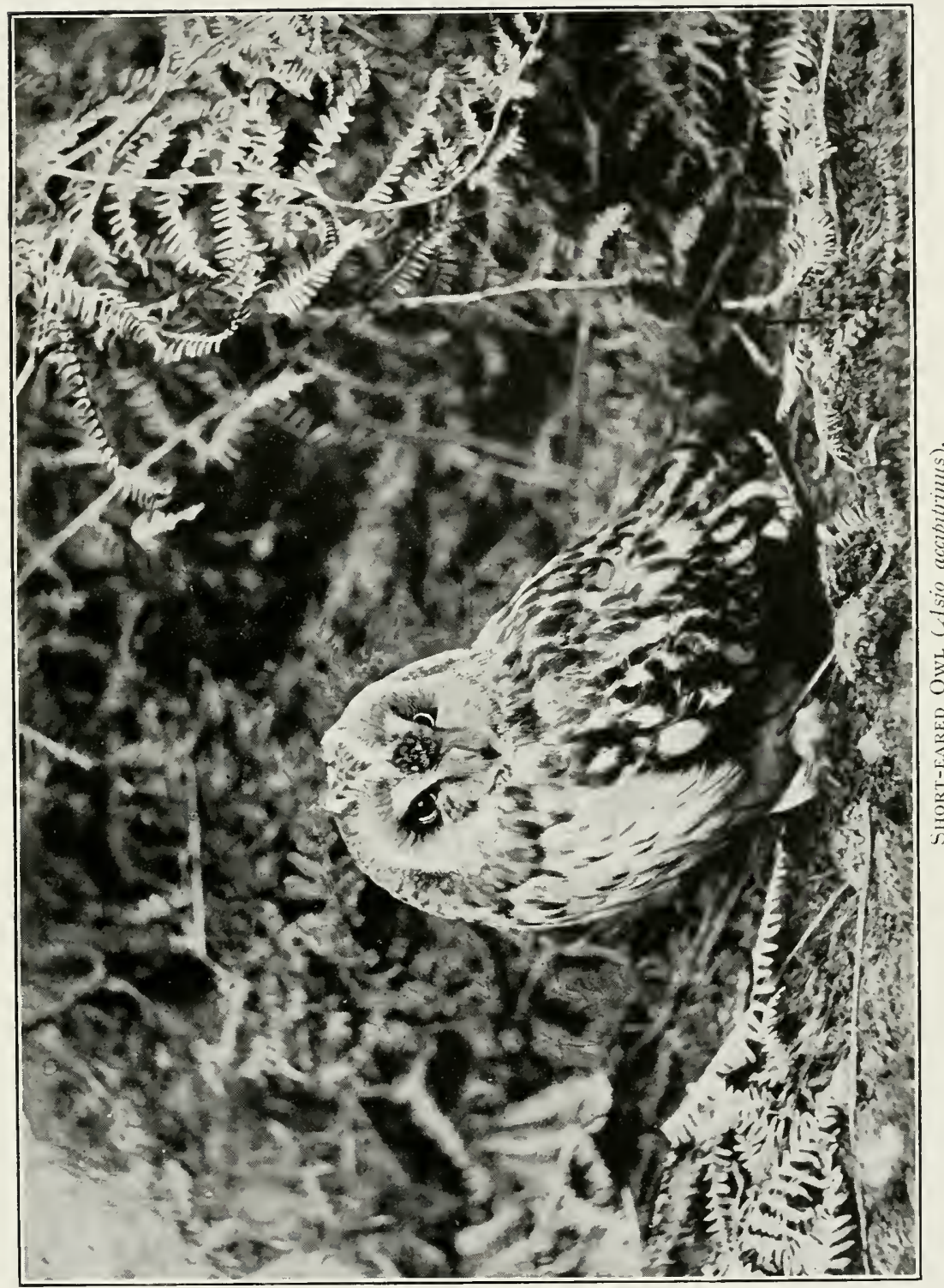


All the nests I have secn have been in a sedge-bushi.c. a thick, tangled mass of sedge, which conts like a knife. I hare nerer seen one among reeds proper: they are generally on the edge of a little pool. and within a foot of the water. Only one has been fomd orer dry land, and this was but a few feet from a pathway leading to a boathouse, and contained young.

'The nestlings have the most extraordinary palates I ever saw. When they open their months as all young birds do when any one approaches them - they may be seen to be most brilliantly coloured and spotted.-far more so than any other with which I ann acquainted.

'The parent-birds. after the young are hatehed, are particularly bold and tame, taking repry little notice of anybody watching them. It was, in fact, a matter of some difficulty to keep them off' the nest when I wanted to photograph them on the surrounding reeds. 'Though standing' but a yard or two away. I have had to quite drive them out of it.

Nearly the whole of one day was spent squatting in the same clump of sedge in which was a nest of six eggs. Here most of the sitting was done by the eock. It was most interesting to watch these chaming little birds hunting round a small reed-encireled pool for insects, and to see their graceful postures and elegant morements. Their coloration matches admirably the localities in which they delight, and in which alone they are to be seen. 'The musical note, " Ching-ching," just like a sharply struck banjo- 


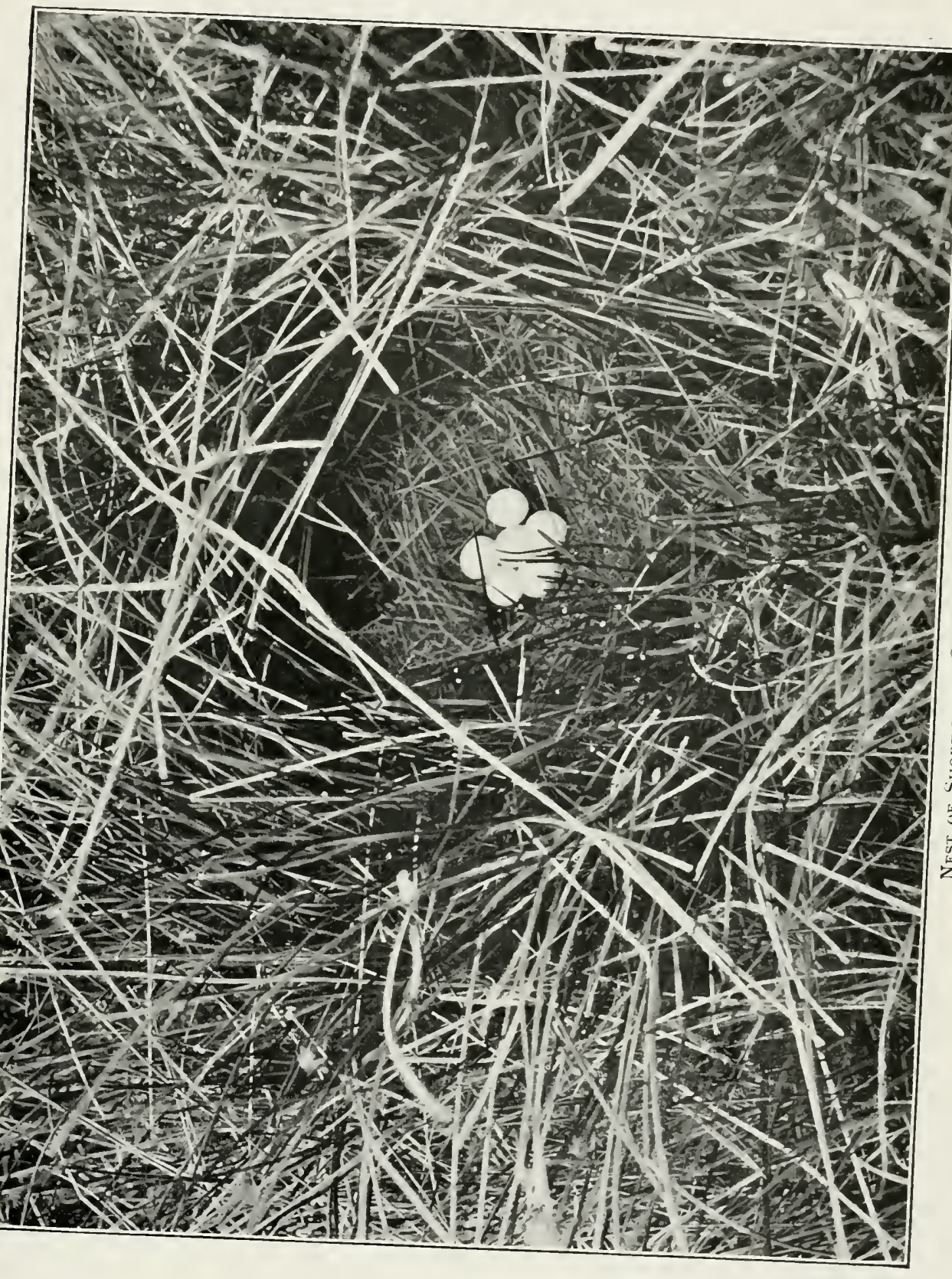


string, is quite unique and characteristic, and. once heard. (am never be mistaken. The eggs are rery faintly streaked with fine lines instead of spots. and are thus different in appearance from the egges of the other 'l'its.

These birds have suffered so much from the marshmen, in the interest of collectors and dealers, that it is to be hoped they will be accorded a more effectual protection in the near future, before they are quite wiped out. (I wonder how many clutches have been taken by Joshua Nudd alone!) 'The present laws are a complete failure, simply because nobody takes the slightest notice of them. The areal orer which the Bearded 'Tit is to be found is so restricted that the species is in imminent danger of speedy extinction. 'The wonder is, not that there are so few left. but that there are any at all. eonsidering how unmercifully the eggs have been taken, and how perfectly easy it is for anybody to shoot them.

But the Harriers are in a much worse plight than the Bearded 'Tits. 'The Hen-harrier has quite gone. none having nested now for many years: the Marsh-harrier has almost gone (the last nest was in 1899. but both birds were trapped): Montague's Harrier still lingers, and on rare occasions a brood of young are hatched, but seldom reach maturity: and in a few years this fine species will be numbered with those of other days, and no more will the sight of it quartering the marsh delight the bird-lover.

It was therefore a great pleasure to be able to photograph a nest of four eggs. though the pleasure was discounted 


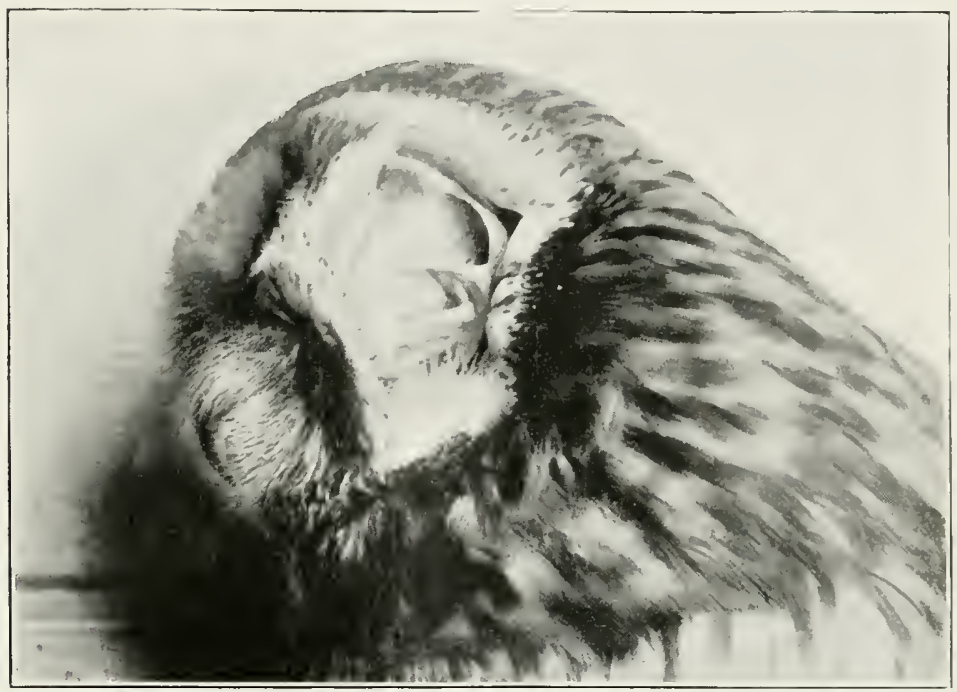

Head of dead Short-eared Owl. Facial Disk lifted to show True Ear.

by the knowledge that the nest was a deserted one. The situation was a small open space on the ground in the midst of a perfect sea of sedge the height of a man. Such a nest in such a spot can only be found by the most patient watching of the old birds. Not far away we picked up some half-deroured remains of a leveret, for which. I fear, the Harriers were responsible.

'This day wals a memorable one, for we had that same morning photographed a nest of another rarity -that of a Short-eared Owl. This was also among sedge and rushes, the mowing of which had disturbed the sitting bird from her six eggs, causing her to desert them. Though a circle had been left uncut all round her. she never returned to them. 
'This Owl is known as the Marsh-owl in this district. and often elsewhere as the Woodcock-owl. It is a migratory species. arriving from Scandinaria about the same time as the Moodcock. But in suitable localities. such as this. it nests in small numbers. It is much more dimmal in its habits than any of our other owls : and instead of nesting in hollow trees and ruins. always does so on the ground among sedge or heather. 'Though comparatively scarce as a general rule. whenerer any part of the country is derastated by a plague of roles, then these Owhs. with the wonderful instinct of most birds in discovering any unusual abundance of food. Hock to the affected spot in great numbers. and remain there as long as the supply of food is sufficient for them. when they disappear as mysteriously as they arrived.

The so-called " ears" of the Short-eared Owl and the I song-eared Owl alre, of comse, not " ears" at all. being merely tufts of feathers. in no way connected with the oroan of hearing. 'The true ear is an inmense and complicated carity. occupying nearly the whole side of the head, and concealed by the short feathers of the faeial disk. 'The illustration shows the ear-cavity of a Short-eared Owl, taken. of course. from a dead specimen. By lifting up the morable mask. or facial disk, and pinning it back, the large extent of the true organs of hearing may be plainly seen. 'This bird is a particularly silent one. Beyond a hissing and a elapping or snapping of the beak, it appears to make no sound whatever. 


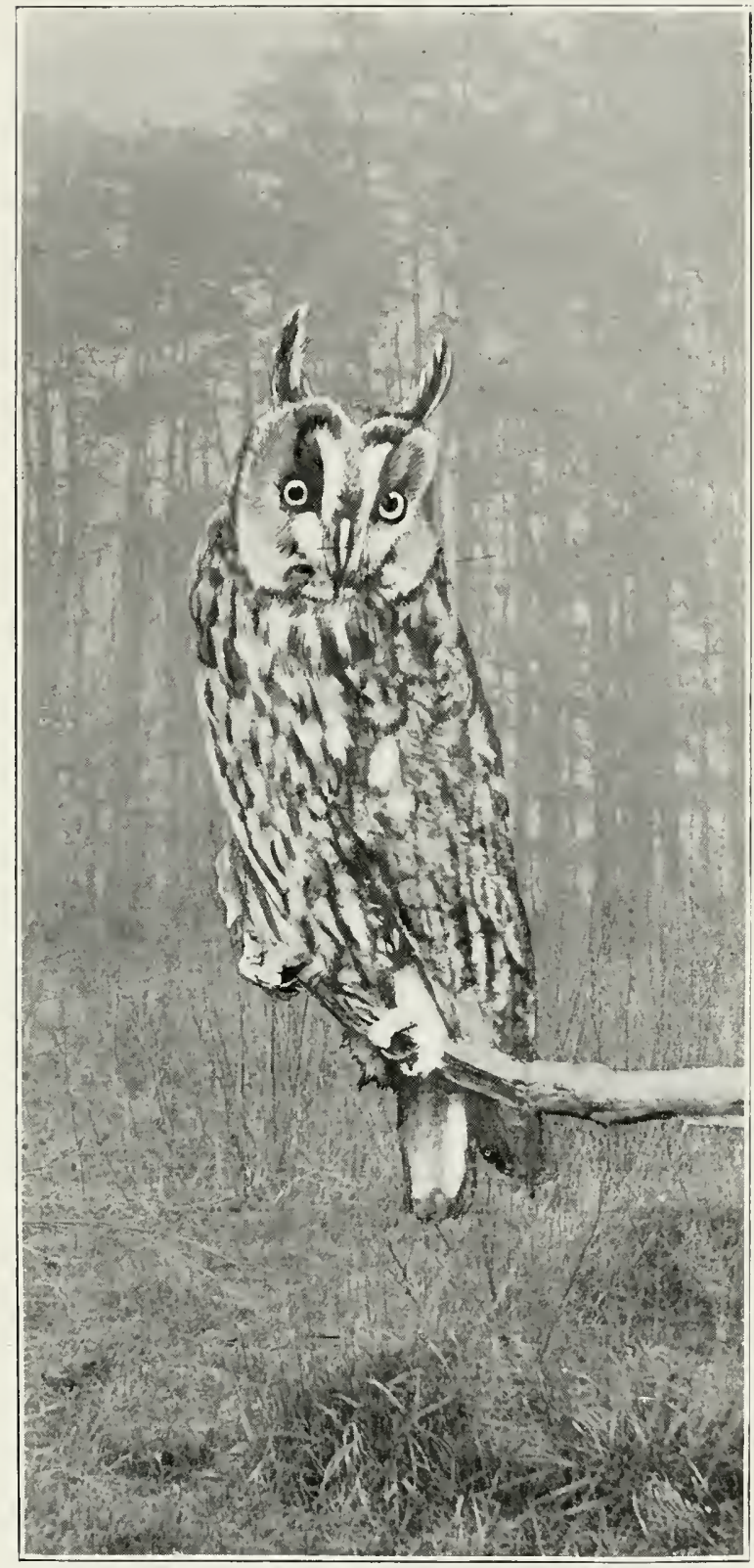

Long-EARED OWL (Asio otus).
Iarge numbers of these Owls atre taken in the flightnets of the I.incolnshire and Norfolk coasts on their arrival in this country. I once saw one come orer in the early morning mobbed by a lot of Rooks.

'The fir-woods are inhabited by the Long-eared Owl, which nests very early in the year in old squirrels' nests and Wood - pigeons' nests - sometimes eren on the ground, but this is exceptional.

Daily we saw a Shoreller-duck. which must have been breeding 
somewhere not far from our anchorage: but no amount of searching enabled us to discover its nest. Every moming and evening we could see a Great Crested Grebe. accompanied by its single young onc. and many a time watched the mother Grebe bring up a small eel. and. after banging and shaking it about. present it to the roung bird.

In these days of extemmation, it is a relief to tum to one bird which is increasing in numbers and extending its

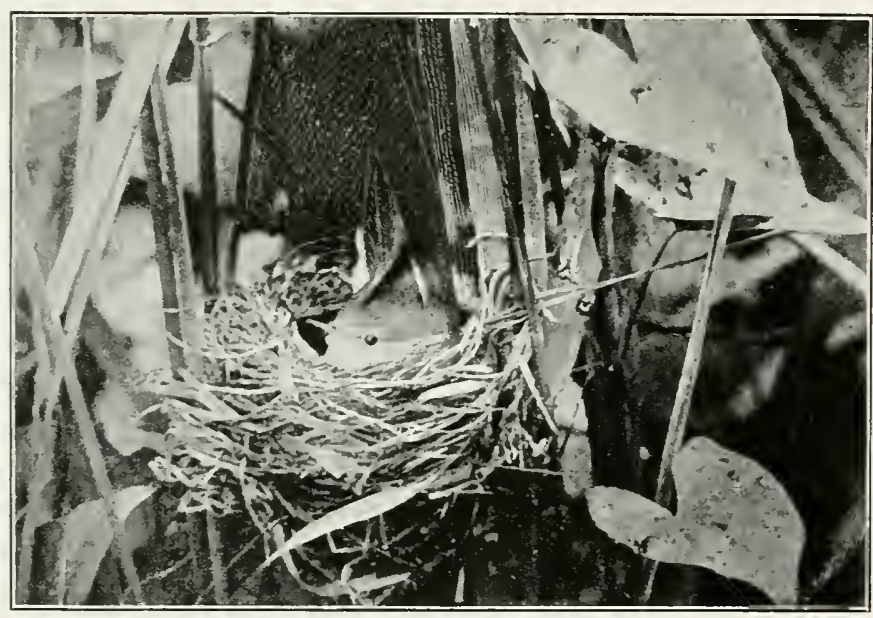

REED-WARBLER (Acrocephalus streperus) sITTING.

lallge. as seens really to be the ('ase with the crieat C rested Grebe. On some of the Broads in Norfolk. especially where indiscrinninate shooting is not allowed. it is quite abmomant. and in many parts it is beeoming established where formerly it was not known. A pair of these most stately waterbirds have these last fer years nested in the Penn Ponds in Richmond Park. and appear to have laid aside some of their usual timidity.

The 'Tufted I)uck is another bird which seems to be on the increase. 'The chief stronghold of this expert diver 


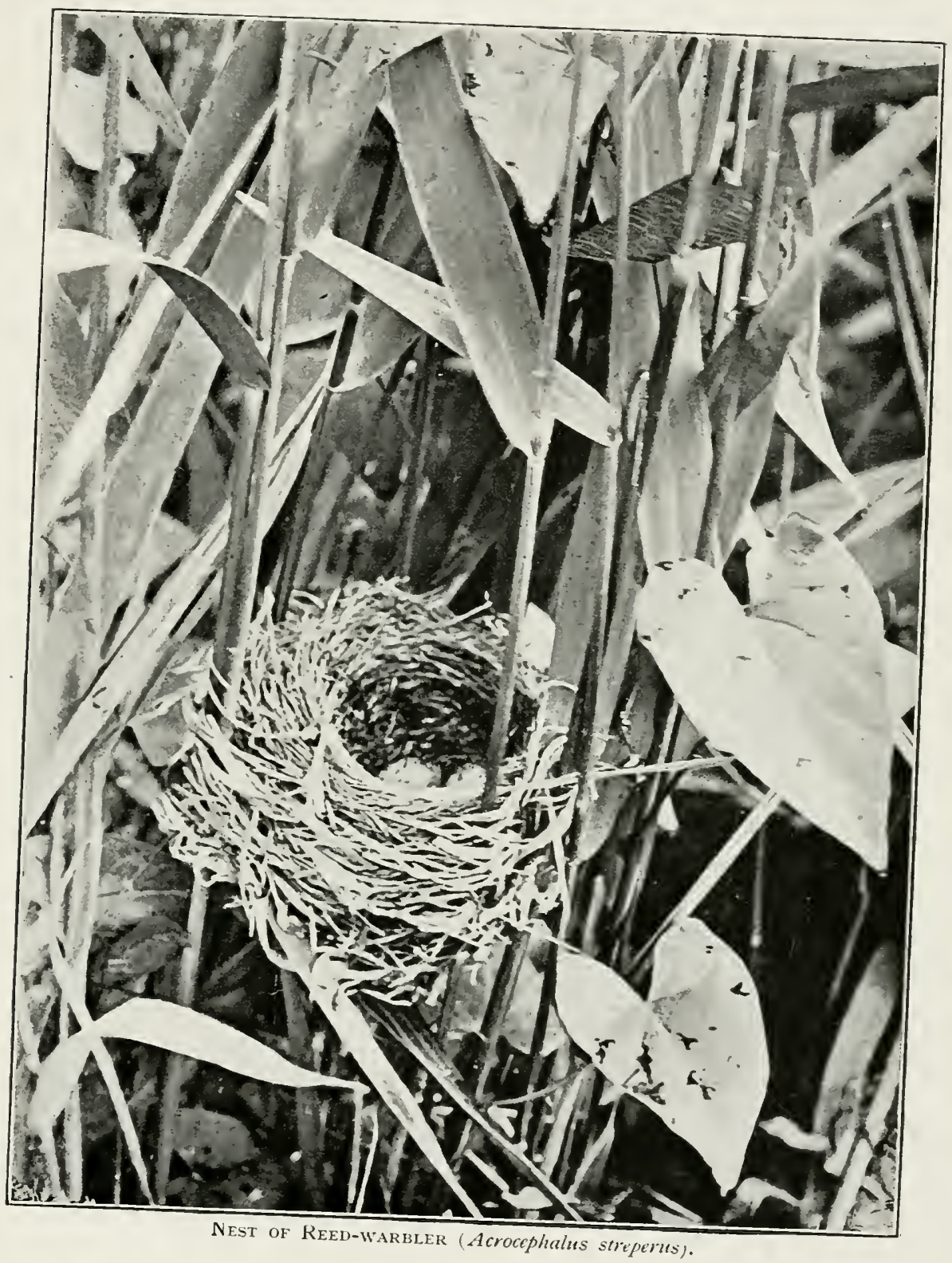


seems to be in Northamptonshire, but it nests in the south of Norfolk with the Pochard. Shoreller, 'T'al, Gargeney, Wild Darck. and Gadwall.

At the time of om visit-May-the reeds in erery direction were alive with young Coots and Water-hens, and their curious cries were ineessant. 'That of the young Water-hens sounds just like "Joey-joey." We were also, I think, late for Water-rails, and also for Redshanks and

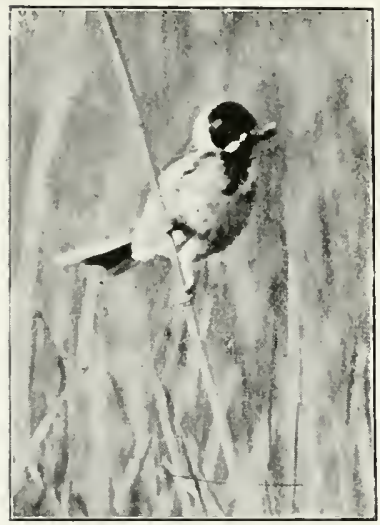

ReEd-BUnting

(Emberiza schaniches). Ialpwings, both of which had halfglown young ones.

Of smaller birds, the Reed-warblers had hardly begun to nest. 'They are always late, appearing to wait until the reeds have grown up to a fair height. Jume and .July are more likely months for their nests, and 1 have found fresh eggs in August. 'The nests are very easy to find. and are generally orer water, but occasionally on dry gromnd, anong meadow-sweet, and eren in lilac and willow. The unique method of suspension between upright stems makes them rery interesting objects. In Norfolk they are made of dry grasses, lined with reedHower: but in Canrey Island, where there are sheep. the nests are made almost entirely of wool. in which the greenish eggs look rery pretty indeed.

l'erhaps the commonest hird is the Reed-bunting-locally called the Blackcap. Its short and somewhat monotonous 
song is constantly to be heard in every direction: and the black-headed male bird, flirting its white tail-feathers while clinging to the dried and yellow reed-stems, is a very common sight in all the drier parts of the marsh and on the reed-ronds.

Many Sedge-warblers, Yellow Wagtails, Meadow-pipits, Winchats, and other common birds, all ald by their presence to the bcauty and interest of the scene.

'The botanist, too, may find many rare plants peculiar to the district, and the entomologist comes to capture rare and beantiful insects procurable nowhere else. The sight of that splendid butterfly the swallow-tail, Hying in hundreds from flower to flower, is alone worth the journey to see, especially as, with the exception of one small fen in Canbridgeshire, the sight can be enjoyed nowhere else in Fugland.

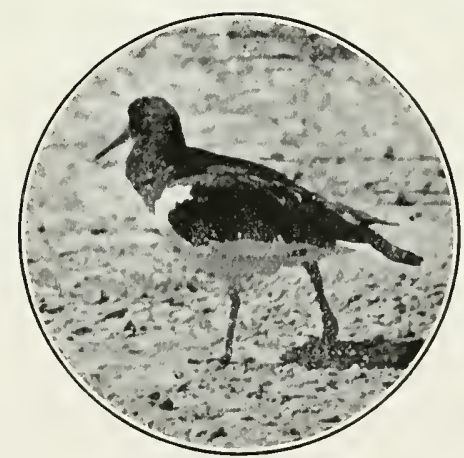

OrSter-CATCHER (Homatopus ostralegus). 


\section{CHAP'TER VIII \\ Bird Life in Dutch Marshes}

They are all arone now : no longer do the Ruffs trample the sedge into a hard floor in their fighting-rings. while the sober Reeves stand romel. admiring the tomonment of their lover-gay with and and tippets. no two of them alike. (rome alre Ruti- and Reeres. Spombills. Bitterns. Arosets.

'TH's Kingsley wrote in his eloquent lament over the disappearance of the old fen country and its wild inhabitants and their picturesque associations. And gone they truly are ats regular and common risitors.

But fortunately the memory of places seems to linger strangely in the minds of birds. Ther are very reluctant to forsake altogether any locality frequented by them through many generations: and for years they or their descendants, impelled by we know not what inherited instinct or ghost of a memory. will revisit the once-familiar spots. in spite of persecution. and in spite of sadly altered circumstances.

(of the Lincolnshire fen country barely a trace remains. to such an extent has it been drained and cultivated. growing roots and corn where formerly the " Coot danked and the Bittem boomed. and the Sedge-bird. not content with its own sweet song. mocked the notes of all the birds around: while high overhead hung motionless Hawk beyond Hawk. 


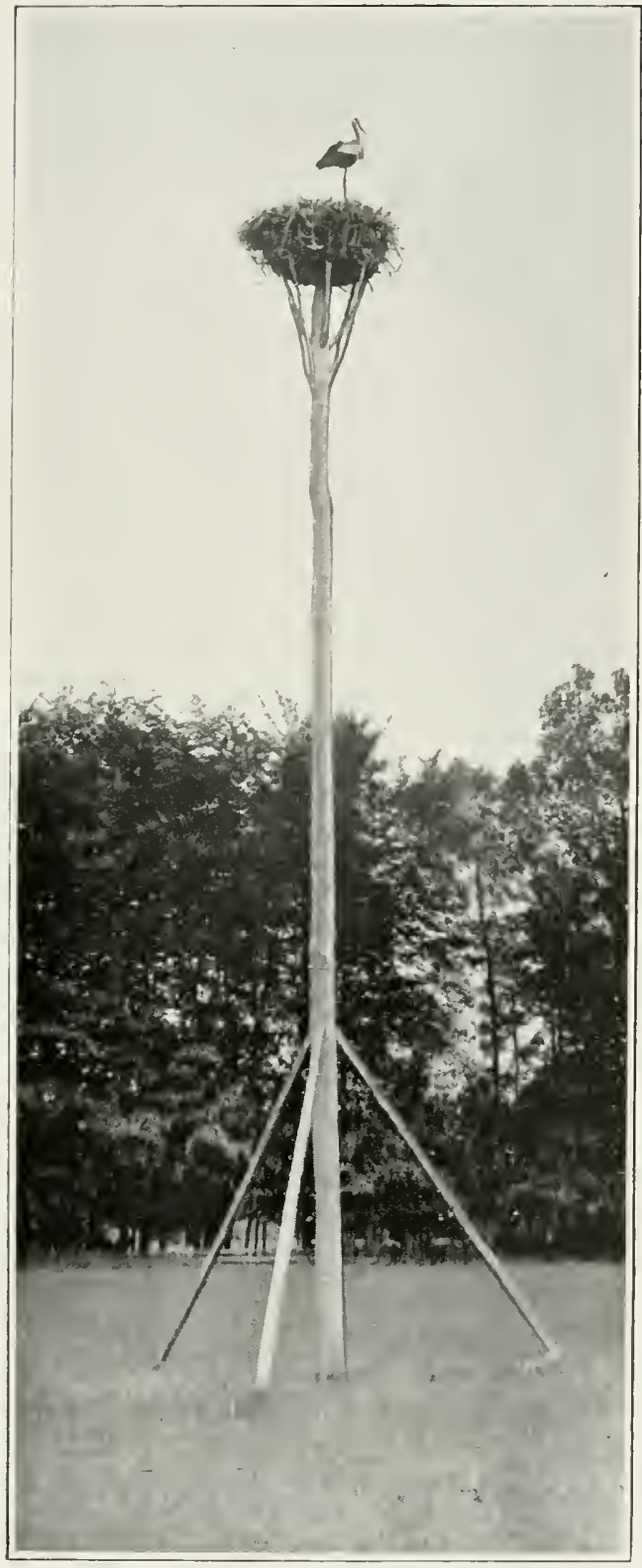

White Stork (Ciconia alba) oN Nest.

Buzard bevond Buzzalld, Kite beyond Kite. as far as the eye could see."

In Norfolk the fen famna is making a last stand. much as the English did after the Conquest in the old Ely fen, and. like them, they are year by year dwindling down and being orerwhelmed by a new order of things : so that the ornithologist desirons of observing their habits, being mable to find them with any degree of certainty, is compelled to cross the North Seal and follow them to their haunts in Danish marshes, and in the "meers" and "polders" of Holland, while there is yet time. Eren there the greed of mankind is pressing hearily on them. 
- so much so that it is only a question of time a few more years and they will have to be followed still farther afield. to conntries where they can find more fiee and

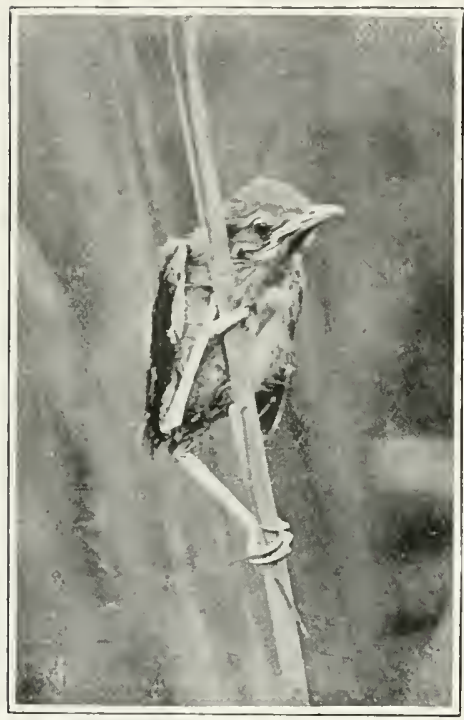

Young Great Reed-warbler (Acrocephalus turdoides). unocoupied space and less human persecuntion.

Iolland is the nearest and most easily accessible, and it was there that I first experienced the delights of working in a fresh country, where birds which had hitherto only been seen in books and muscums were to be met with at home. full of living grace and beauty.

I seaving London at eight in the evening by the comfortable Hook of Holland route. ivi Harwich, one finds oneself on Dutch soil about fire o'clock the next morning, almost without knowing that there has been any sea passage at all. 'I'hen about four hours jommey brings one to the house of a Dutch friend, to whom I am indebted for my first introduction to a large fresh-water "meer," inhabited by many of the birds whose extinction and diminution we have just been deploring in Fingland.

'The exact loeality of this place I prefer to keep to myself. for there are now but two localities in the whole of Northwestern Enope where the Spoonbill still nests, and this is 


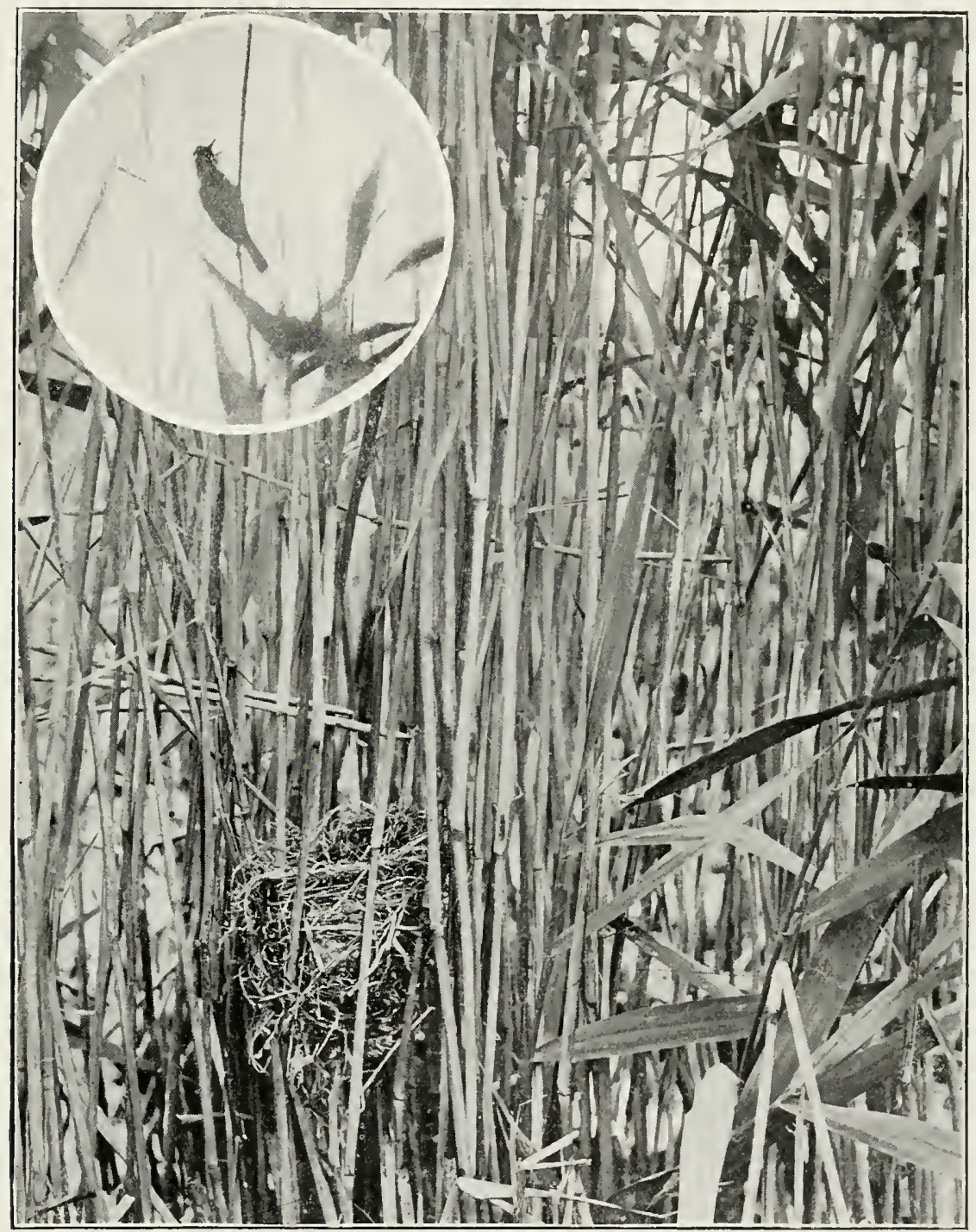

Great Reed-warbler (Acrocephalus turdoides) ANd Nest. 


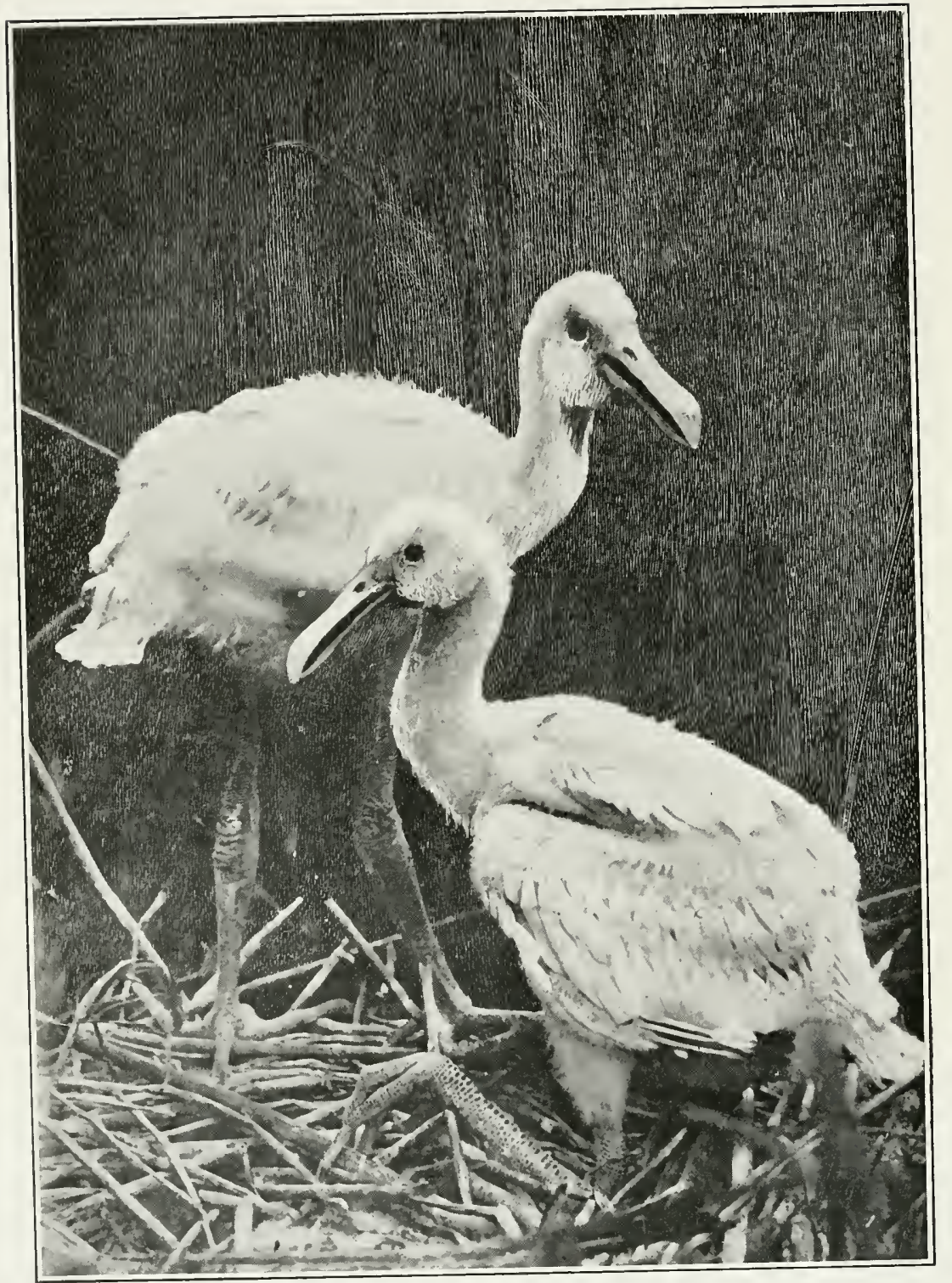

Young SPOONBIlls (Platulca lencorodia). 
one of them. I am indeed bound by promise as well as by inclination not to reveal the place to any one. or in any way to endanger the retreat of these fine birds.

A few years ago a colony of them used to frequent another marsh in the neighbourhood. which was subsequently drained, and is now cultivated land. 'They then betook themselves to their present resort, and in a few years this was also drained. Fortunately, howerer, the expense of pumping exceeded the value of the recorered land, which was indeed almost worthless, and after sereral thousand pounds had been spent the place was allowed to revert into its original state, and the Spoonbills and other feathered inhabitants returned to find shelter and safety onee more in the reed-beds of this most interesting " meer."

It is indeed a most eharming place for an ornithologist full of lasting interest and delight, where he can revel in the sight of many banished birds nesting in large numbers undisturbed and ummolested. 'Three visits made to this spot have each been more enjoyable than the one before, and I hope to be able to revisit at some future day the seenes of so much pleasure.

The birds are not by any means the only inhabitants of this place. It is full of fish. Immense pike, great, fat, slimy tench, red-finned roach, and eels abound in its deep waters, and eonstitute a source of profit to the lessee, who employs a fisherman to protect his rights. and to net and bring to market his captures.

The fish are eaught mostly in drum-nets placed in 


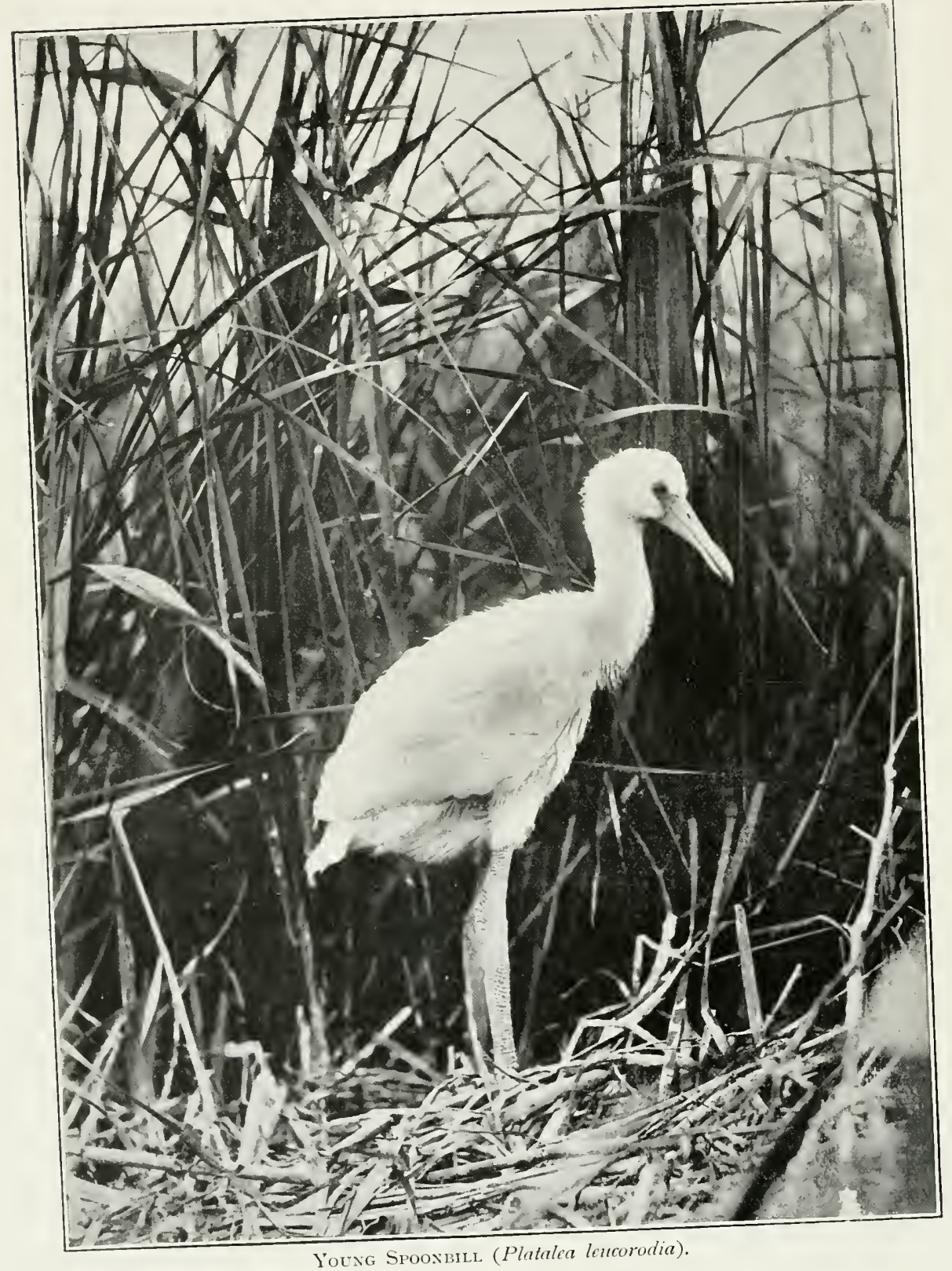




\section{Bird Life in Dutch Marshes}

narrow chammels cut in the reeds, and as soon as camght they are all placed in a stew-pond at the back of the keeper's house. It is a sight, on the ere of market day, to see this stew emptied by means of an immense net raised by the muted efforts of fom or fire stout Dutchmen. As it nears the surface, it is seen to contain a solid mass of fish struggling and kicking. 'Then they are picked out by large landingenets, and placed in various reeptacles according to kind.

'The first bird to be seen, as one leares the keeper's cottage for the " meer" in a flat-bottomed punt, is probably a Black 'Term, sitting on one of the stakes of the drum-nets, or skimming orer the surface of the water after dragon-flies. 'This bird takes the place of the Swallows, which are scarce, and. so they say, decreasing in numbers every year. Then as one progresses Coots are heard, plunging and clanking amid the reeds on each side, and presently a brown bird about the size of a 'Thrush darts across and dives into the thickest part of the reeds. 'This is abont all one sees of' the Great Reed-warbler, though its harsh, grating song may be heard in erery direction. By standing still and motionless, you may see the bird, as it sings. gradually mounting the upright reed-stem until it reaches the top: but at the slightest morement it will drop into the thick molergrowth, still singing, though invisible. It is a great skulker.

'The song is ummistakable, when once heard, and somnds like " Kara-kara-karra," etc., fiom which the Dutch name " Karakeite" is derived. Groote Karakeite and Kleine Kara- 
keite serve respectively for the Great Reed-warbler and the smaller species.

The nests are suspended between the upright reed-stems in exactly the same fashion as those of our Reed-warbler. but are of course much larger. A nest in my possession measures $2 \frac{1}{2}$ inches across the hollow. and 5 inches deep outside, against $1 \frac{1}{2}$ and 4 inches respectively. In the deep hollow. lined with the flower of the reed, the four eggrs look rery handsome, being very boldly spotted and marked with rich purplish spots at the larger end. 'The birds are rery common, and the last time I was there we saw hundreds of their nests.

It is rery eurious that this bird, so common in Holland and North France, only separated from our coast by a narrow twenty miles of sea, should be so exceedingly rare with us. Barely half-a-dozen cases are known of the bird being seen in England. and I believe that there is not one authenticated instance of its laving nested.

Howerer, the Spoonbills are the chief objects of interest. and we push on for their haunts in the far corner of the " meer," passing many interesting sights, but stopping for nothing.

A Great Crested Grebe, accompanied by a single roung one. passes ahead of us, and is soon lost to sight: Coots and Ducks get up on each side: and we pull past the edge of a large colony of Black-headed Gulls. whose harsh sereams accompany us until they consider we are off' their particular domain, when they leare us and retum to their nests. 


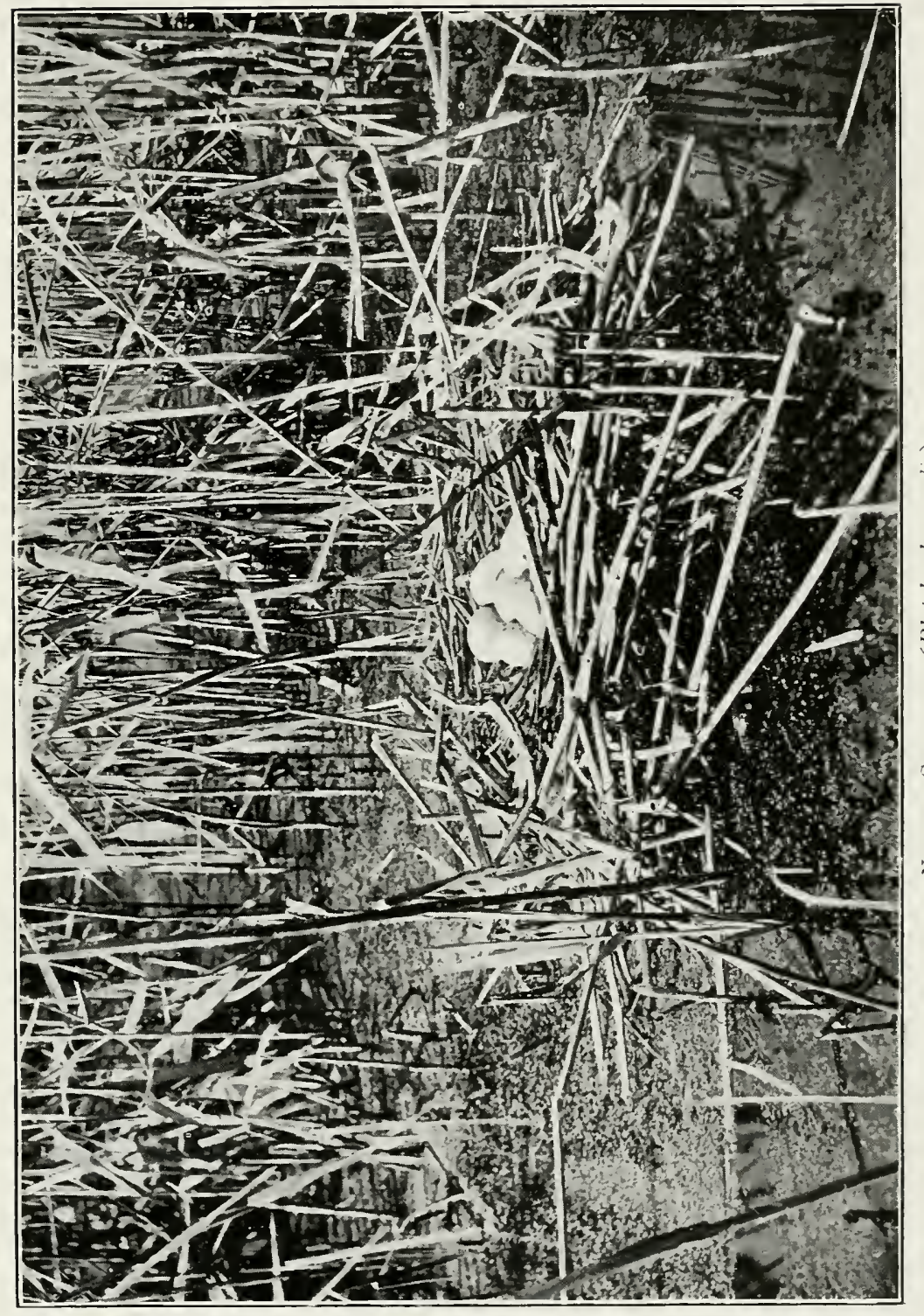




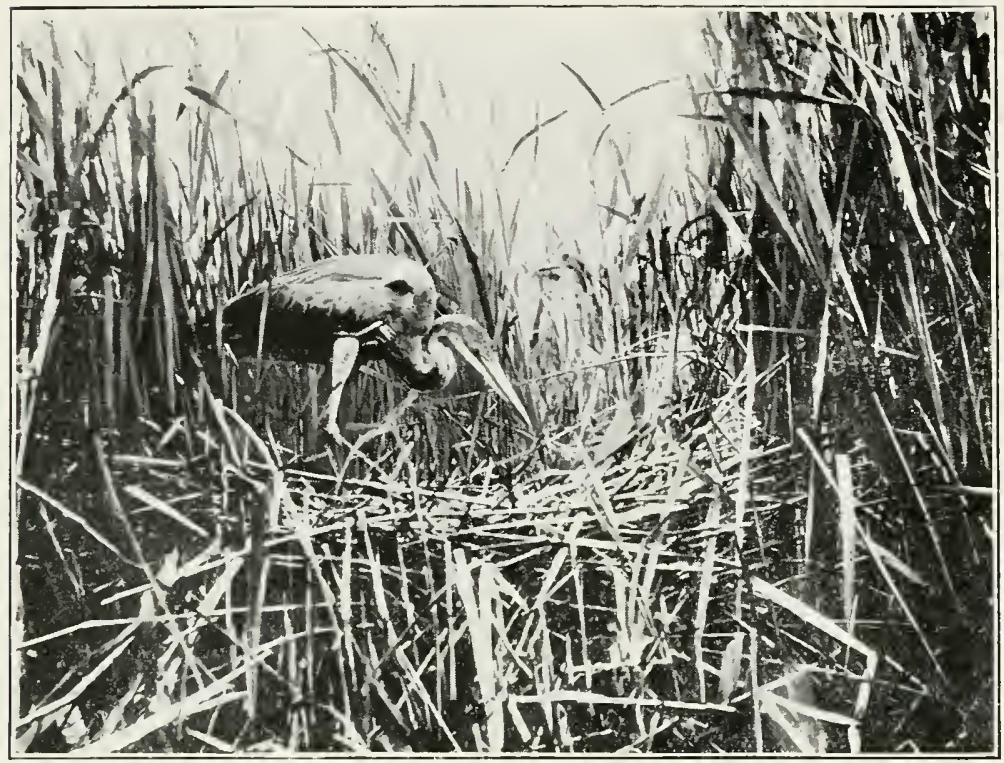

Purple Heron (Ardea purpurea), automatically photographed by the Bird itself treading on an Electric Trap conNected with Hidden CAMIERA.

Presently the rising of sereral Spoonbills from the recds shows that their nesting-place is not far away : and ats the punt leares the channel. and is forced through the thick reedbed. Spoonbills are getting up all around us in every direction. Presently, after much exertion, the first nest becomes visible through the reeds.

On a large and bulky platform of sticks and dead reeds we can make out three nearly fledged young birds standing up. Inufortunately, howerer, the noise necessarily made in foreing our clumsy raft along has alarmed them so much that two out of the three. after hesitating on the brink. scramble out, and, plunging through the water. finally dis- 
appear. Sereral others from neighbouring nests do the same, but eventually we find one nest whose occupants are not quite so fully dereloped.

The scene is a most striking one. (On the rude platform of sere and yellow stalks are two young Spoonbills, whose snow-white phumage in the bright sunshine is in strong

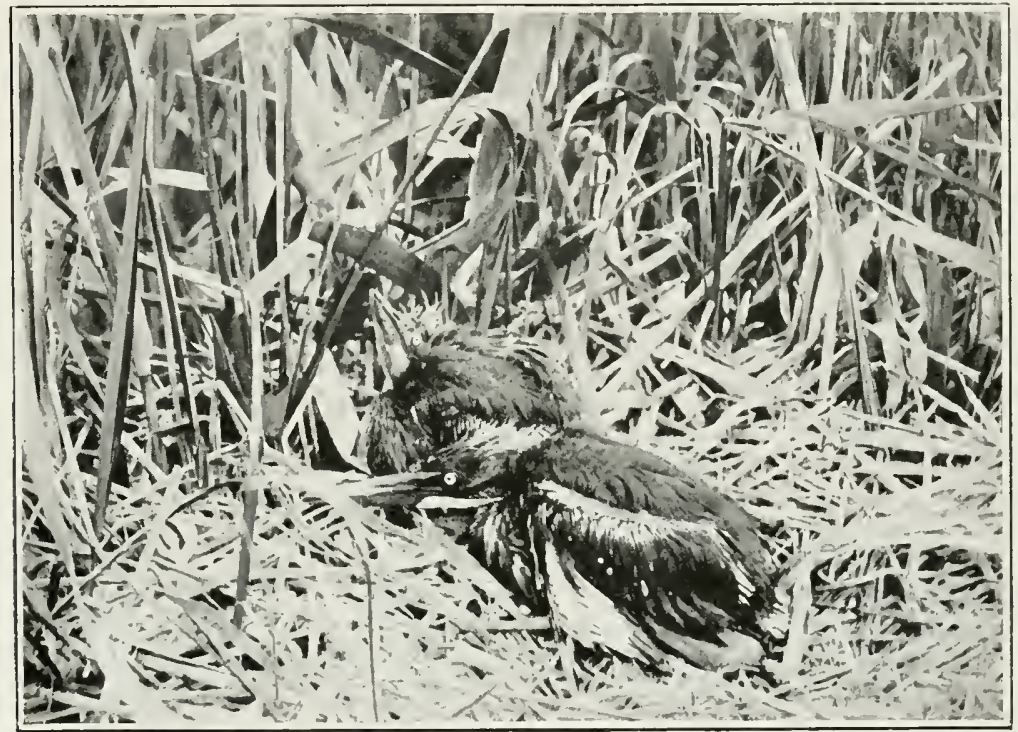

Young Purple Herons in Nest.

contrast to the green background. Their legs look swollen and rather limp, and one of them prefers to squat, as if its legs were hardly equal to supporting its heary body. 'The other stands tottering on the edge, desiring to see the last of our company and wishing to depart.

Finding them, however, is one thing, but photographing them is not quite so easy as we expected. The punt is 
too narrow and too unstable for the tripod, which has to be put overboard into deep water with a soft muddy botton. At last. after many struggles, and nearly falling headfirst out of the punt in the act of focussing. the exposure is made. 'This first attempt, however, proves conclusively that wadingtrousers are an absolute necessity for this marsh work. and my second and other visits found me better provided in this respect: I could then accompany the camera orerboard into nearly five feet of water, and if neeessary remain hidden up for hours while waiting for the return of the old birds.

An attempt to photograph the old birds on this occasion was a failure. as was also another more determined one the following year in the south of Spain. where, though I could see a dozen Spoonbills all round my hiding-place, the intervening reeds made any photograph of them impractieable.

On a second risit to this same I)utch locality the Spoonbills had been disturbed by poachers. who had taken a number of their eggs, and in consequence, while the birds which had escaped molestation had half-grown young, many others were still sitting on eggs. The curious part of it was that the clutches were unusually large. especially for second layings; in one nest were six eggs. and in another sevell.

At one of these nests I hid up with a camera, orer waistdeep in water, and covered over with reeds, for five hours. For nearly the whole of this time the Spoonbills were 


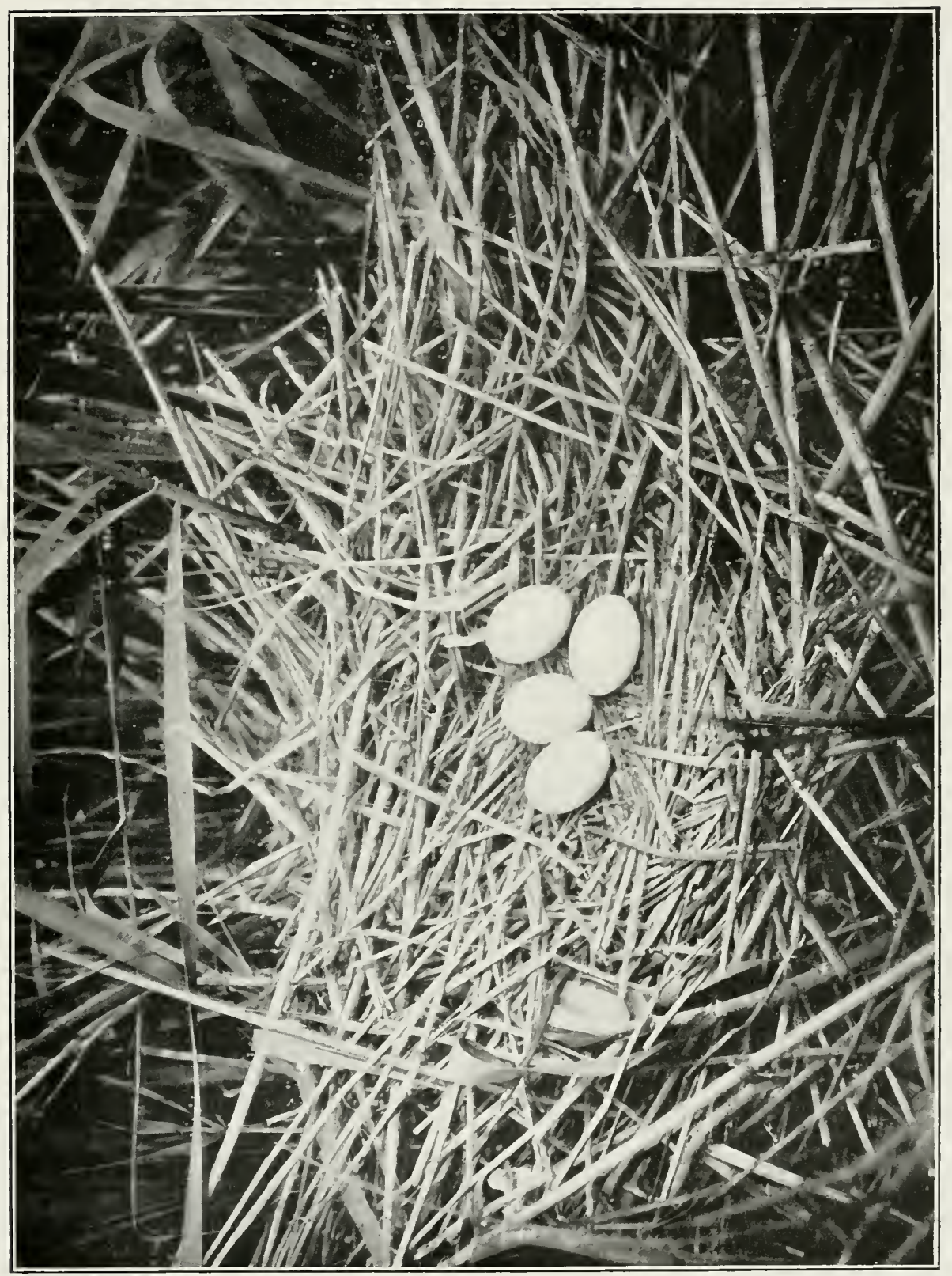


(ircling round and round my ambush, sometimes looking as if they meant to alight, until by degrees they dropped down to their nests hidden in the reeds. At last I heard a tremendous flapping. and, on looking out of my peephole, had the gratification of sceing one of these magnificent birds alighting on its nest. not seren yards away. As bad luck would have it, I had left one reed between us, and a leaf of this dangled in front of the bird, and I had to wait, watching the musual sight for several minutes, mutil it departed. 'Then I crept out of my ambush and cut down the offending reed, and retired again under cover. It was not long before it returned: and while on the point of making the exposure its mate alighted also on the nest, and I had the pair of them in full view, standing up just in front of me. I was able to expose two plates without disturbing them, and naturally thought that success had at last been achieved. However, on developing them, after my return home, both plates, from whieh I had expected so much, were hopelessly fogged and quite uselessa typical example of the uncertainty of photographic work among birds.

Four years later, in 1901, I was more fortunate, and succeeded in obtaining several photographs of these interesting and beantiful birds with their half-grown young ones. 'They are peculiarly silent: only once have I heard them utter a low sort of croaking noise whilst fying round me. 'They $\mathrm{H}$ y with their neck outstretched in front and their legs behind. and look very white against the blue sky. 'The budding 


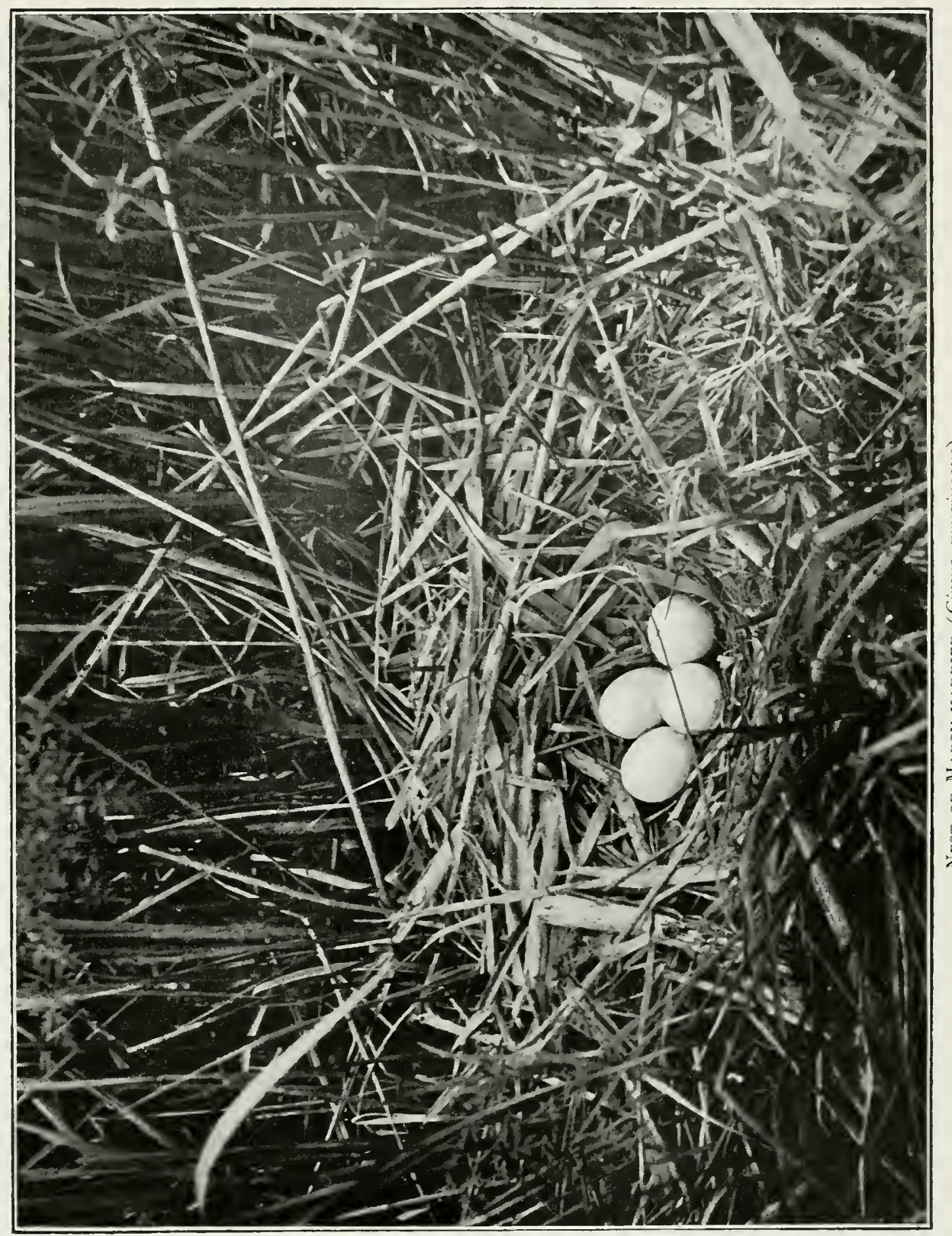


primaries of the yomng birds, while in the nest, are of a jetty blackness, and the beaks at the same age are flesh-coloured.

I have always found, in close proximity to the nesting-place of Spoonbills, whether in IIolland or Spain. nests also of the Purple IIeron. At times these nests are exceedingly difficult to approash. though now and then one may meet with them

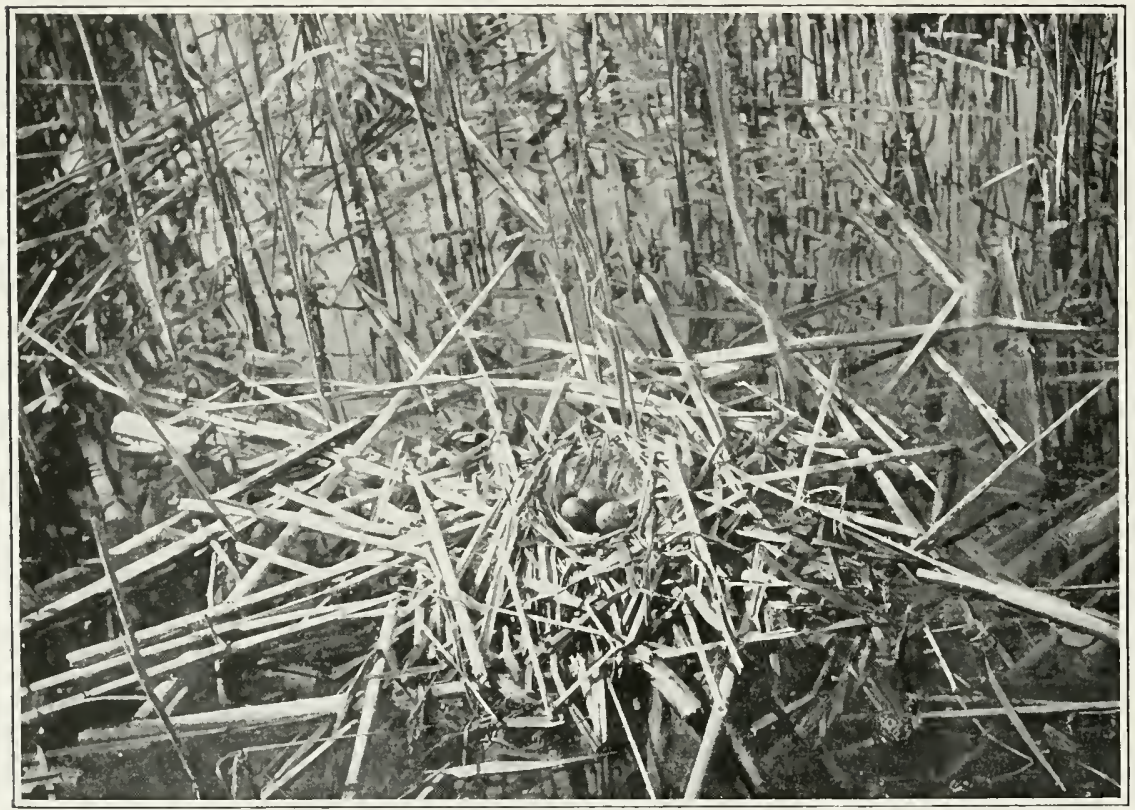

Nesi of Black Tern (Hydrochelidon migra).

on fairly solid ground, but always well surrounded and hidden by a thick growth of tall reeds. In such places, where they cann find the solitude and quietness they desire, they lay fire beantiful pale blue eggss on a romgh nest of dead reeds and sedge. The birds are particularly and excessively shy and retiring. It one nest, which held three freshly latched birds 


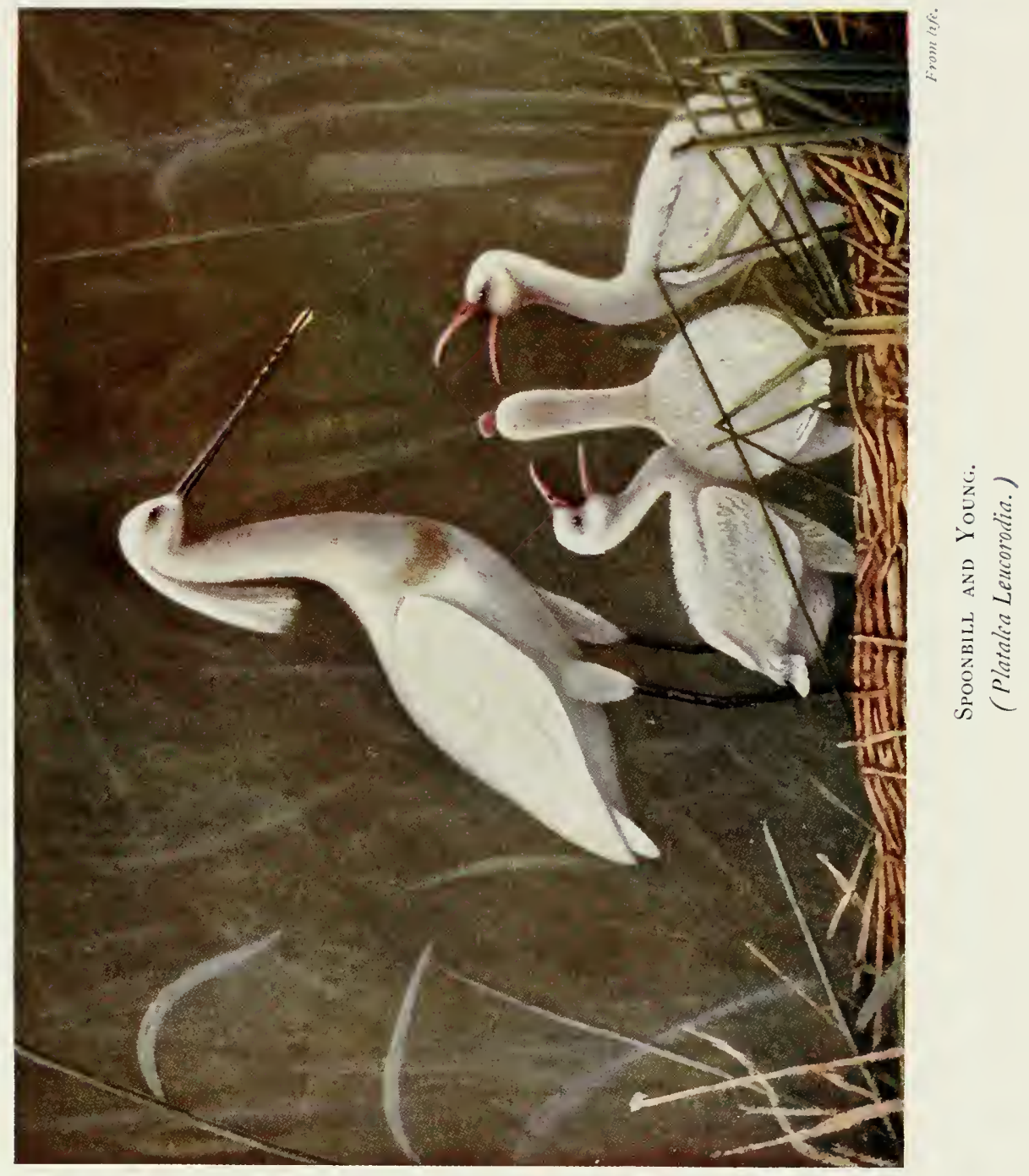



not an hour old, and two eggs where the young chicks had the tips of their beaks through the shell and were vigorously ramouring to be let out, I waited hidden the whole day in the hope of a photograph. But no: the parent birds obstinately refinsed to return, though it was impossible for them to see me. One l'urple Heron. probably one of the pair to which the nest belonged, alighted not five yards away from me, a little to one side of the nest on which the camera was focussed. But so suspiciously did the bird watch my hiding-place that it was impossible for me to turn the camera in its direction, and I conld only watch it myself. Just in front of it. in a great state of excitement, was a Reed-warbler vigorously scolding the great long-legged Heron, and plainly betraying the nearness of its own nest, which, sure enough. I afterwards found close at hand with four eggs. If this Pmple Heron had not been seen alighting, it is rery doubtful whether it would lave been recognised as a bird at all. The long. thin reddish-coloured neck and head exactly resembled a reed-stem. while the yellow beak looked like a dead leat.

'The smell round all the nests of Herons and Spoonbills is rery strong and mupleasant, rivalling in evil odours a nestingplace of Cormorants. One colony of Purple Herons was strewn about with small pereh in a state of decay. and the stench was horrible.

In this "meer" the Common Heroms also habitually nest among the reeds exactly in the same way as the Purple Herons. 'They are generally located in a far-awaly corner, where the growth of reeds is thickest and the depth of 
water greatest. The bottom is so soft and treacherous that six attempts to photograph the young birds in their nest utterly failed. Frery moment I expected to disappear from sight. camela and all. In the water around these nests were floating numbers of small roach. and others were lying on the nests rotting in the sum. putrid and flyblown. each one contributing its share to the usual perfime of a heronry. A strong stomach and plenty of enthusiasm are wanted for this work. Besides the strong smell from the nests. each step in the deep stagnant water and each prod with the punt-pole stirs up bubbles of evil-smelling gas evolved fiom the rotting regetation. and after a prolonged stay in such unsavoury quarters one's elothes become saturated with evil odouls.

()n one occasion all the nests of some Pruple Herons appeared to be empty when. after some struggling. I had reached the spot, though standing up in the punt we had seen young birds in every nest. After a lot of hunting about in rain. it occurred to me to look moler the nests. which. for a wonder. were built on dry ground. or at any rate eomparatively dry for Purple Herons. 'There in a space of a few inches between the nests and the ground all the roung Herons were crouching motionless. hoping. no doubt, that the enemy would depart withont detecting them. One luckless individual had allowed ne to tread on it sooner than move. and on retranging my steps to retum to the punt its body was found crushed by my heary nailed brognes.

The colouring of these nestling Purple Herons is very 
striking. 'Their reddish phmage shows ofl the yellow eves and beak, green legs, and bright blue primary quills. so that

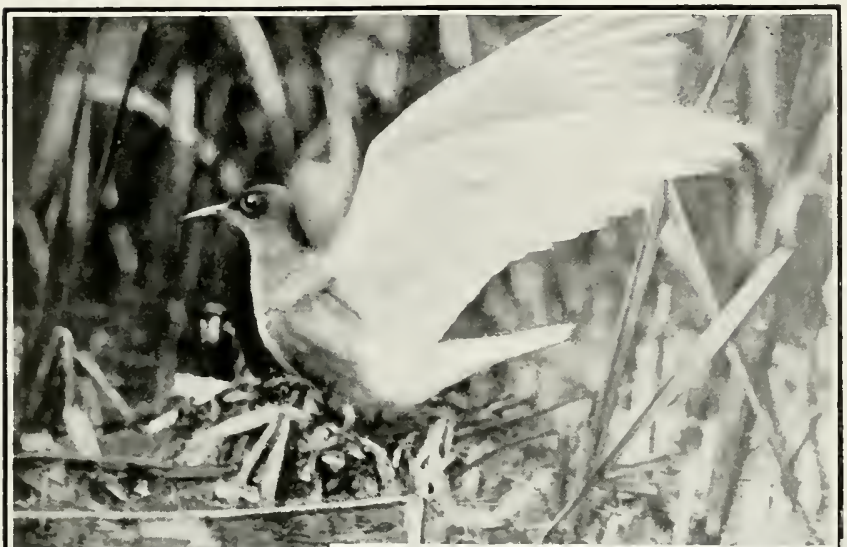

three or four of these bizarre - looking young birds standing in their nest make a most effective picture. 'T'he advilt birds

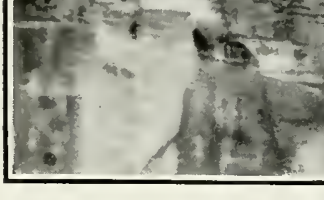

are a trifle smaller than the Common Herons, and look darker in colour.

I $t$ was a common sight in our progress in the punt along the canal-

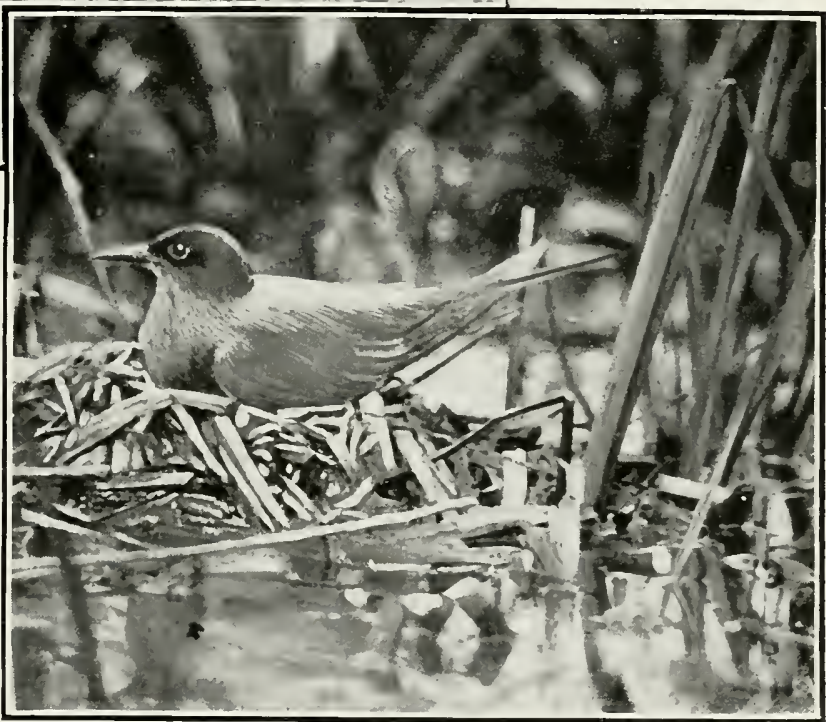

BLACK TERN (Hydrochelidon migra).

like chamnels cut in the reeds to see these birds. disturbed by our presence, rising from the reeds with flapping wings and 
drooping legs. and to surprise them on theip way home. (On seeing us they wonld pull up in their Hight. and sheer off' in another direction with much convulsive and laborious energy. At their nests they are rery noisy. making the most extraordinary grunting and groaning.

The difficulty in photographing these wary birds, so striking in their appearance and so interesting in their habits, and the picturesque mature of their haunts. only made me more anxious to make another attempt on different lines.

Aceordingly, in 1901, a special expedition to the same place was made in order to photograph the Spoonbills and Purple Herons by means of an antomatic electric trap arangement. which had been derised for their especial benefit. 'The idea was that. by placing this arrangement on the nest, the bird, on its return. would, by treading on it. depress the lerer of an electric switch, and so put the current of a dry battery in action, which would operate a shutter worked by an electromagnet on a concealed camera. By this plan there would not be so much to alam the birds, so quick to detect the presence of any hidden photographer, who would be firee to work in another direction with a spare camera. Howerer, on amival at the colony of Spoonbills' nests, it was at once evident that this plan was impracticable for them ; for the yomng birds were more than half grown, and ceaselessly wandered up and down their nest. and would ineritably have sprung the trap long before the parent birds returned. A modification of the plan had to be adopted, and a string was fixed to the switch to be pulled from a hiding-place in the reeds a little distance 


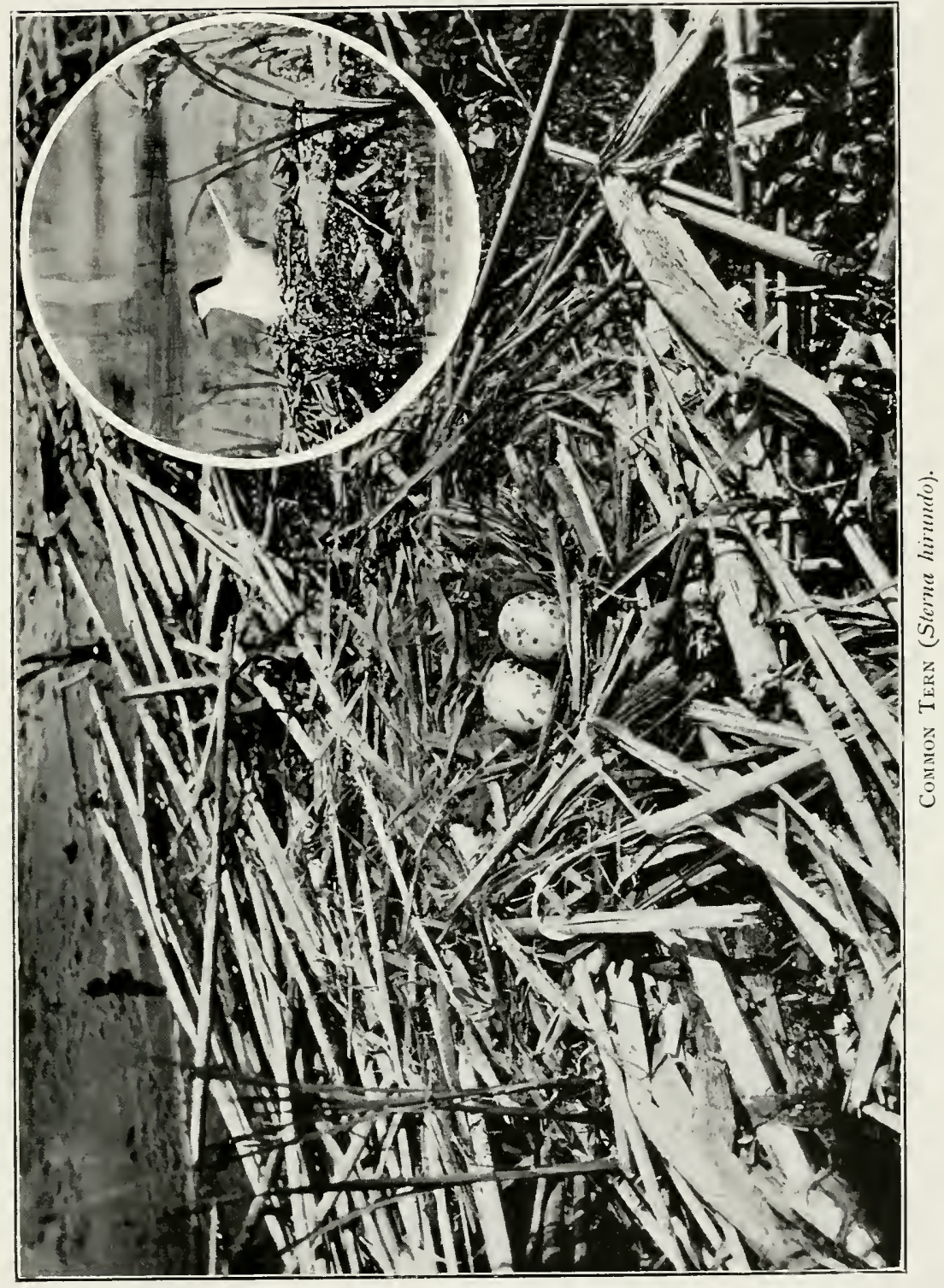


away. Howerer. the adult Spoonbills ame so much more readily than ever before that this was given up as mmecessary. and mamy exposmes were made from a distance of only about five varchs.

Here, sitting in the water and covered over with reeds for several hours, the mmusual treat was enjoyed of watching both the parent Spoombills accompanied by their half-grown young ones. As soon as the old birds had settled. after much Happing of great white wings. the young birds would tease them for food. uttering a whining. chipping noise. mutil the parent would open its curious beak. and allow the young birds to insert their beaks as far as the erop and feed like young pigeons. 'This I watched repeatedly.

Another very noticeable fact was that the orange mank on the throat. described simply in the Mammal of British Birds. as " gular region orange." gave them exactly the appearance of having had their throats cut: for the colom is just that of dried blood. and the shape and position resemble a gash with a knife across the throat.

After leaving them, the trap was set at a Purple Heron's nest not far off. which held four eggs. But the water was deep. and the difficulty in hiding the camela rery great. Ifter wasting half a day. we failed to score any success : and. to make it worse. my large sheath-knife fell out into five feet of water. and I failed to recover it. 'That made the second knife lost in the depths of this " meer." A pair of spectacles wals also dropped. but these I fished up again: and a box full of exposed plates also fell orerboard-these. of course. 


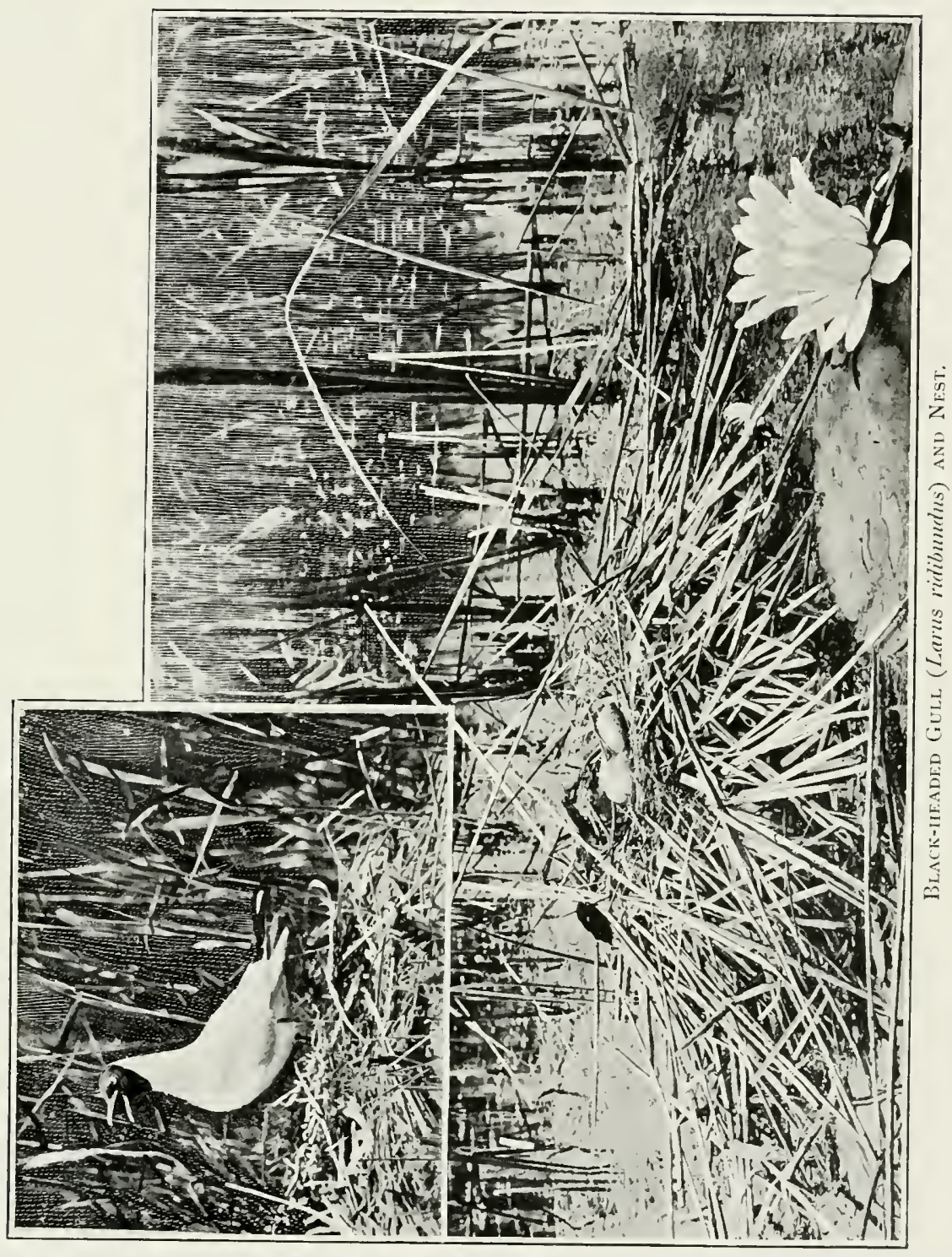


were not worth any attempt at recovery, as the water would have utterly spoilt them.

After this another nest was found better situated for our purpose, where the cannera conld be effectually hidden on a heap of piled-up reeds level with the water and rovered orer with wet sedge and rubbish. 'The nest being made of' reeds. a dry reed-stem was used as the lever of the switch, and was placed across the nest. After learing this for a few hours, we were delighted to find, on our first risit to it. that the bird had returned and had sprume the shutter.

'The first impression was that, instead of the Heron herself being recorded on the plate, we had succeeded in photographing a Marsh-harrier in the act of stealing egas: for we had left four egrgs in the nest, and found but three, while the reed-stem serving as a switch was broken short off; and the nest itself smeared with blood. In eonnection with these marks of disorder, the sight of a Marsh-harrier rising fiom the reeds as we approached appeared to be rather suspicious. Fiurther investigation, howerer, showed us that the Heron herself must have hroken the reed and her own egg at the same time, for we found it eventually in the water below the nest. The plate, too, on derelopment. showed the P'urple Heron in the atet of stepping on to her nest in a most typical and characteristic attitude, the reed-stem planily visible under one uplifted foot.

'Two other exposures were subsequently made by this same bird. to my great satisfaction, as proving that for particularly shy birds this method is really practicable in 


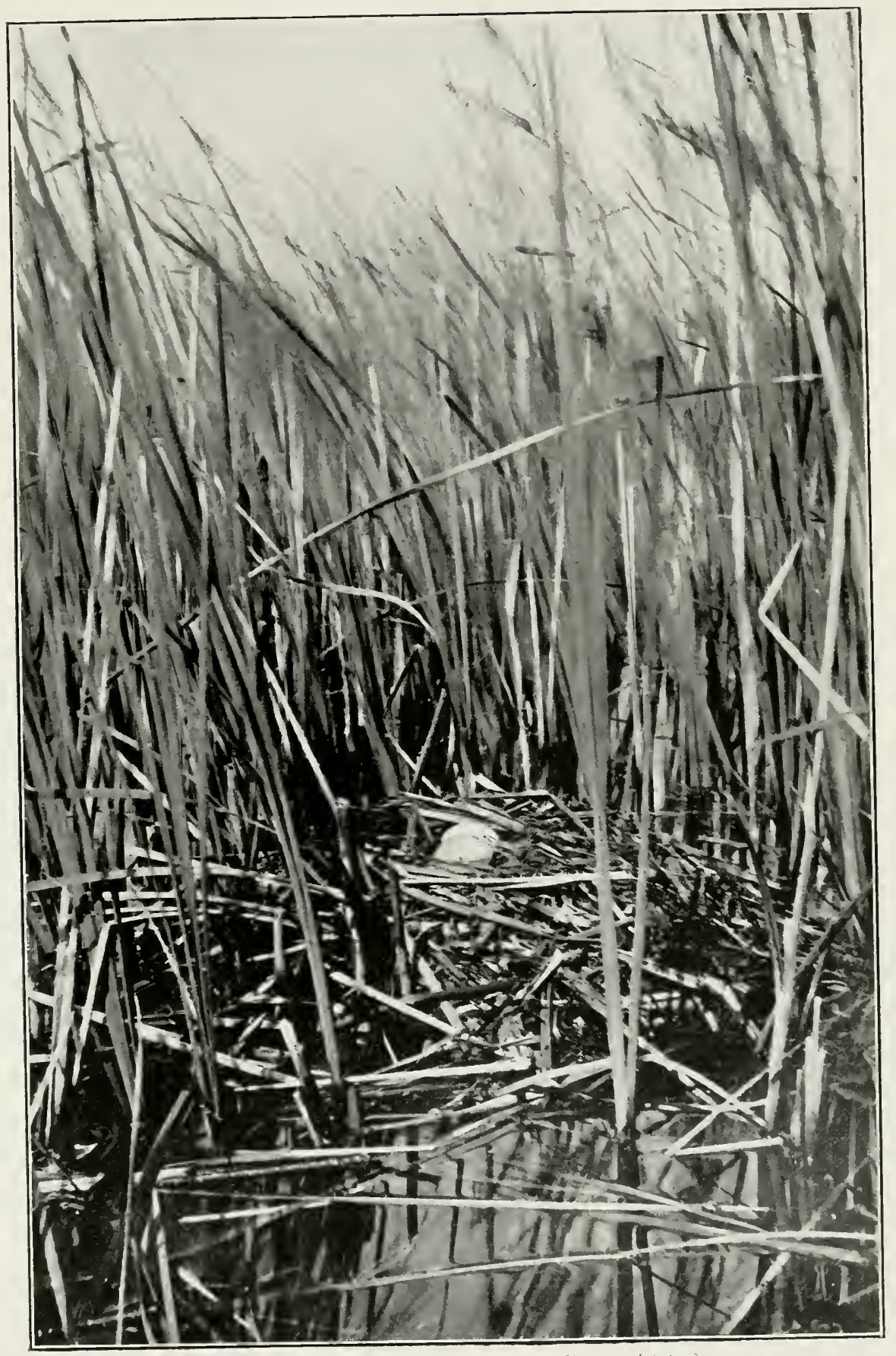

Nest of Great Crested Grebe (Podiceps cristatus). 
obtaining photographs, while they are perfectly unconscious of any danger. Hiding the camera successfully is the chief

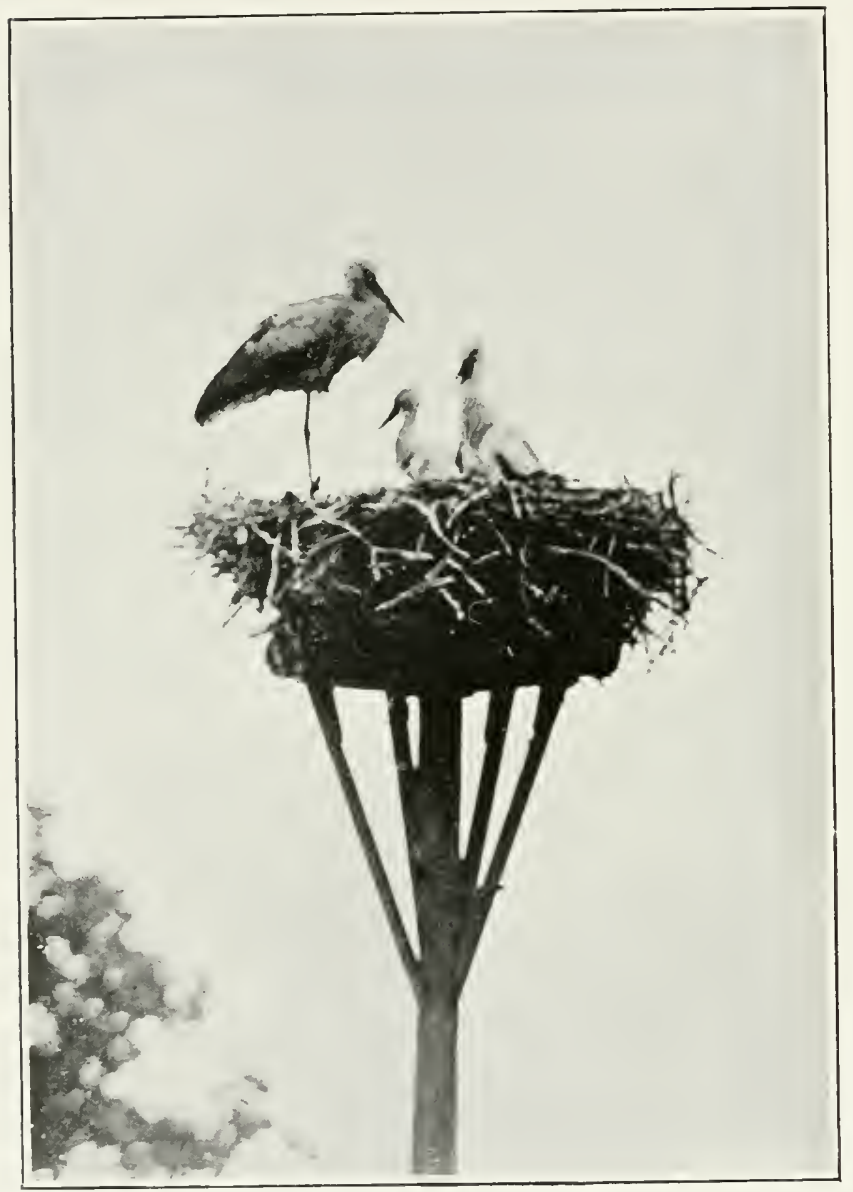

White Stork And Young (Ciconia alba). difriculty. If this can be done at the llest of ally bired, it is almost a certainty : but if its suspicions are aroused by any very unusual appearance, it will probablydesert itseggs.instead of returning to them as usual.

Me liad proof of this. unfortumately : for a whole day was given to the nest of a Marsh-harrier,

where the mistake was made of attempting to hide the camera on its tripod by corering it with reeds, instead of placing it on a heap of reeds and then corering it orer. 


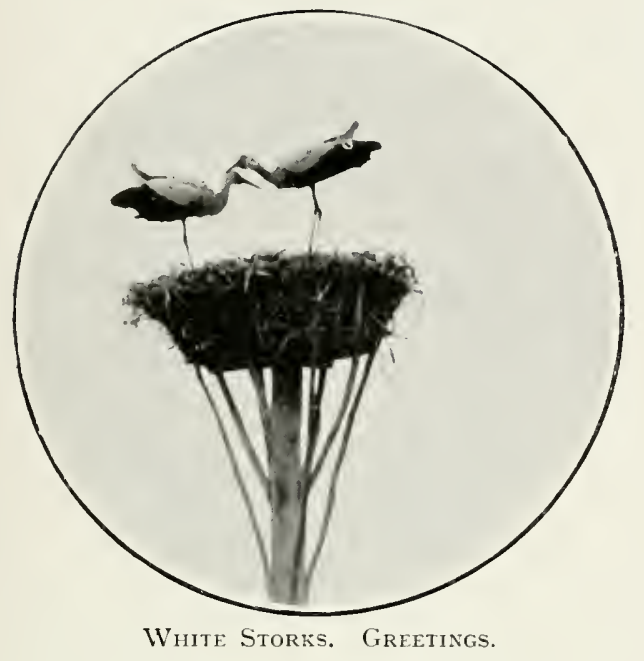

The bird, though its four eggs were hard sat on, deserted sooner than approach such a suspiciouslooking object, and they were eventually sucked by Crows.

It was a great treat to be able to watch the fine flight of these IIarriers, an they soared in great circles, hardly seeming to move their broad wings, while they sailed round against the blue sky. Every now and then they would settle on some low bushes near their nest. which was situated on a dry part of the marsh, and placed on a small mound anid the sedge. The nest itself' was carrefully made of́ sedge. This failure was a great disappointment: but had the camera been hidden as at the Purple Heron's nest. I am confident that a successful photograph would have been obtained. 'There would have been a better chance, perhaps, if the eggs had been hatched and the young birds waiting to be fed. This is the only Harrier's nest I have seen here, though in former years an odd bird or two have been observed. From the train window. in $189 \%$. I watched one flying orer

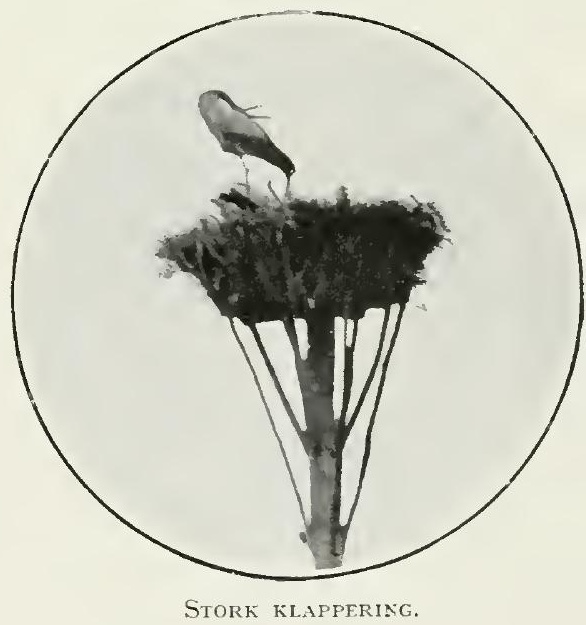


the "meer" in which I had worked for a whole weck withont seeing one. (n my first risit two, I think. were noticed in the immediate neighbomhood. One of these was quartering orer some meadows. which were being mownon the look ont. probably. for Godwit's eggss, or else young Godwits. laid bare by the mowers. At any rate. several Godwits were flying in an excited and alarmed state. One of them I noticed perching on a gate-post, as a Redshank will sometimes do in similar circumstances. Doubtless the Marsh-harrier would nest much more often in a place so suitable for its habits: but too many Harriers would probably mean too few Ducks - at any rate. that is the opinion of the old keeper. who. I miderstood. had killed no less than serenteen in one season. Inder the circumstances their (omparative scarcity is easily accounted for.

'Though Coots and Wild I)ncks are to be nuet with in numbers indiscriminately all orer the ". meer," the other birds breeding there keep very much to the neighbourhood of the particular part selected by thems, any intrusion into which (amses a great commotion and excitement. 'The Spoonbills and Herons fly off' at once, and when sitting hard leave their nests with some reluctance: but the Gulls and 'Tems. with harsh aries and angry protests. Hock ronud the trespasser as soon as he approaches their nesting-place: nor do they cease their scolding for a moment as long as he remains. He is made to moderstand mmistakably that he has no business there. and that his presence is deeply resented. I have been sometines fairly mobbed by Black 'Terms in 
their angry excitement at my presence so near their fireshly hatched roung. Sometimes their nests are substantially built in shallow water, similar to those seen in the south of Spain. But in the deeper waters which generally prevail they adopt other methods. and lay their rery dark, pointed eggs, without any attenpt at a nest. On

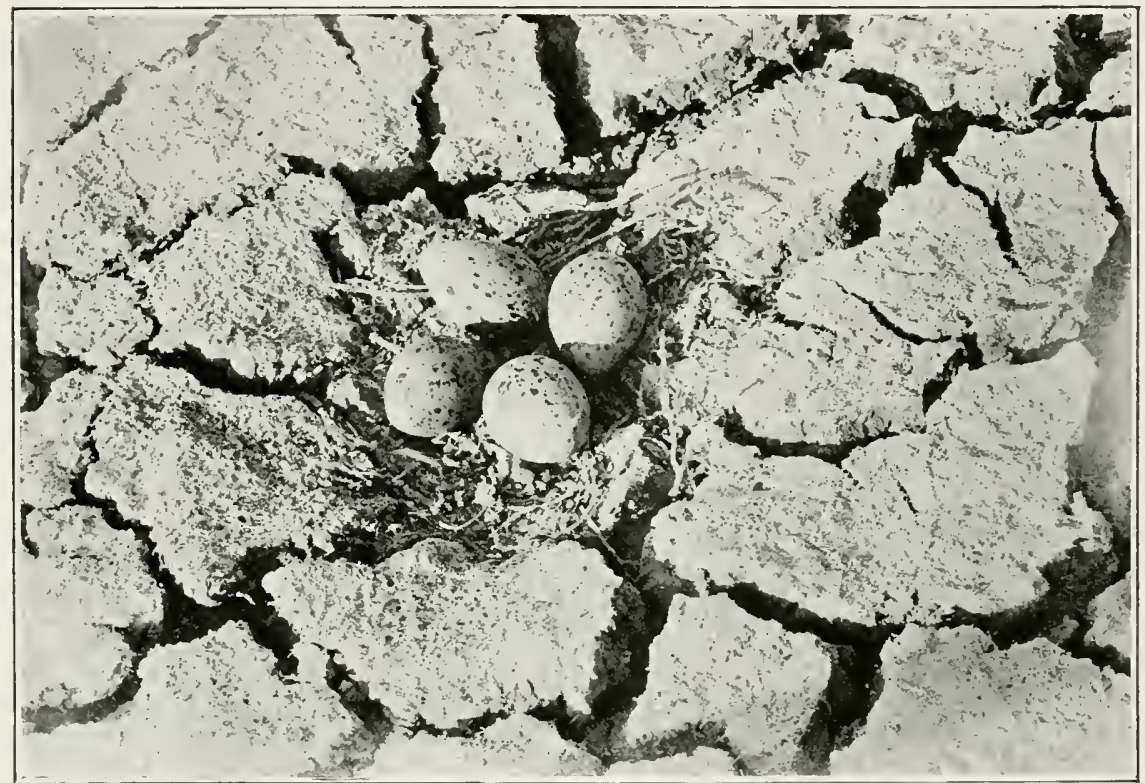

Nest of Arocer (Recurivestra azucetta).

the floating masses of reed-stems, scomm, and rubbish of all kinds which accommlates, and gradually forms a kind of floating island, in which seeds of various marsh plants and flowers spring up and grow luxuriantly. In such places perhaps a dozen nests may be seen, sometines alone, but often in company with Common 'Terms'. At 
other times they will lay on the heaps of cut reeds at the edges of the channels.

On returning to their nests. which they will do when sitting while you are watching them from a rery short distance. they lave a pretty way of remaining for a second or two with their fully expanded wings in an upright position before finally closing them. In this attitude they have a particularly dainty and fascinating appearance. They appear to feed their young on dragon-flies. which naturally. in such an expanse of marsh, are exceedingly abundant.

Black 'Terns are regular Marsh-terns, and nest habitually in fresh-water situations: but I must say I was surprised to find the Common 'Tern breeding in such a locality. looking upon it as a maritime species. It scems, however, that this 'Term. while nesting in many places round our coasts. and on islands off the coast. is also addicted in some parts to nesting on the shores of fresh-water lochs: and this appears to be its more usual habit in Ireland. where it is common. On the island of 'Texel I have seen their nests on short turf in company with Oyster-catchers'. I have eren fancied that their egges in such a place are more inclined to a greenish coloration than when laid on shingle.

While waiting to photograph a common 'Tern at the extremity of a long floating island, a Redshank pitched close to the nest. Although engagred in changing a plate at the moment. I managed to get it in in time to make an exposure: but before it was possible to repeat it. the 'Tern Hew up and hustled the Redshank away. 


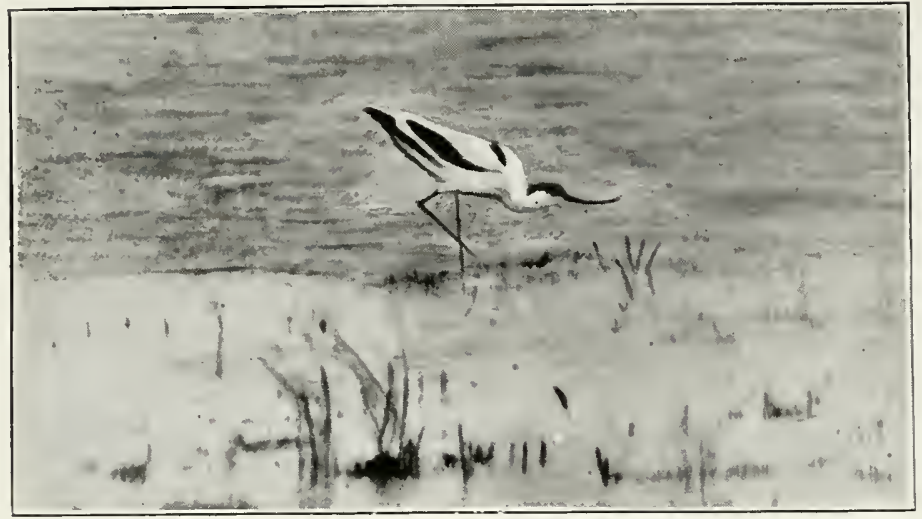

Avocet (Recurvirostra aüocetta) FEEDING.

The young Black 'Terns are adepts at paddling along the surface of the water, when disturbed. in the endearour to escape. They are clad in down of a rich mottled chocolate colour, and the bare patch of skin round the eyes is pale blue. The young of the Common 'Tern are also diffieult to photograph for the same reason : they are most persistent in their attempts to swim away fiom any intruder. Very much larger than the Black Terns, and of a dirty yellow mottled colour: they rery much resemble young Black-headed Gulls in general appearance.

A colony of Black-headed culls is a most interesting and picturesque sight. The birds themselves are perfect pictures of srace and beanty. 'Their black, or rather dark brown. hoods, red legs and feet, and snowy plumage, with jet-black primaries, are in such striking contrast. and their easy and buoyant Hight is a treat to behold. as the birds float past and poise overhead, each one scolding its hardest. 
'Their chosen retreat. too. is perhaps the prettiest bit of the whole " meer." 'Their nests are placed in an open space surpounded by reeds, and spangled with the floating leares and white flowers of the water-lily, rivalling their own spotless phumage in purity and beanty. 'Though the water is deep quite three or four feet the nests are solid structures of reeds. apparently built up from the bottom. In a small hollow in the top the three olive-brown egess lie on a lining of smaller and finer material. ()ther nests are made on the edge of a small island, and many are hidden from sight in the midst of the smroming reeds.

On a long heap or stack of cut-down reed-bundles rows of the Gulls maty be seen perching. and there are generally two or three preening themselves on the top of a noticeboard close to their nesting-place. 'They may be seen hunting for food over the hxmiant meadows which surromnd the "-meer," and scarching the dykes and ditches.

Coots are exceedingly numerous: but. curiously enough. the Water-hen seems to be quite a scarce bird in Holland, where one would naturally expect it to abound. 'The country seems to be made on purpose for it, and yet I do not remember erer seemg more than one.

On my last risit I had the pleasme of listening daily to the "boom" of a Bittem: and a weird somed it is certainly not what anybody would commect in any way with a bird. The Dutch name, "Roer-dump)," expresses the somnd very well. 'The first part resembles a big indrawn sigh, and the second a hollow "dump." The keeper 
declared that the bird did not nest there, which I doubt: but in June the young birds would have probably flown. I should think the Bittern would be very difficult to locate from its "boom," which appears to have a ventriloquial effect.

The Bearded 'Tit seems to be only a rare winter visitor. Nor could I hear anything of the Short-eared Owl.

A Iagpie was nesting in a poplar just opposite the keeper's cottage.

The Great Crested (irebe is fairly common, and I fincy the pike must take toll of the young ones. I have never seen more than one young bird following the parent. The keeper talks of another (rrebe, or "I Loem." breeding hereprobably the Earred Grebe. We saw in the distance one day a Grebe, not a Great Crested, and too big for a Little Grebe: but I could not understand what he said abont it, and it was too far off to make it out.

'The reeling note of the Grasshopper-warbler may be constantly heard. It is known here as the "Schneider." which means, I presume, "T'ailor." If this is because of the resemblance of its note to a sewing-machine. it would seem to point to the bird's comparatively recent occurrence.

The Stork. though popularly supposed to be a welcome guest in every Dutch village, if not in every house, is not by any means so widely distributed, and it is quite possible to travel a rery long way and never see a sign of one.

In the beatiful and extensive grounds of the gentleman before mentioned, there is a nest on the top of the usual 
pole erected on their behalf: but he has improved on the cart-wheel ordinarily placed in position on the top throughont Holland, by having made an iron cage arrangement to receive and hold the sticks of which the great nest is composed. 'This is within sight of his library window. looking across the comer of the garden and carriage-drive, and from his easy-chair he can watch their morements, and see the parent Storks standing in their contemplative attitude at the edge of the nest. or watch them arriving with food for their young ones. After the young are hatched, they nerer appear to be left mguarded. but one or other of the old birds stands sentry until relieved by the arrival of its mate. 'Then it will spread its wide black wings and lannch itself into the air from its lofty perch. Any strange Stork passing over. eren though so high in the air as to be wellnigh invisible. is always watched with every sign of alarm and suspicion by the sentry: while the approach of its mate is greeted with * klappering." that mode of language peculiar to the Stork family. The nest is gained by a gradual rise after skimming low down close to the gromend and when it is finally reached by the returning bird. the sight of the meeting between the pair is most grotesque. Falch bird politely bows to its partner, and then. throwing back their great red beaks until they rest on their backs. they each “klapper" vigorously.

'To see them. one would suppose they were congratulating themselres on meeting once more after a long and perilous jommey. In reality, the jommer has been to the distance 
of some adjoining meadow in search of frogs. 'Their power of flight is superb, and it is a fine sight to see half-adozen Storks soaring easily upwards till lost to sight among the clouds.

There are two other Storks nests not far away-one at my friend's old house, where he lived up to three years ago, and one in the grounds of his father-in-law. The only other nest I know of was to be seen a few years ago from the railway near The Hague: but I have missed it lately. though I have looked for it when passing.

In the tall trees at one end of the meadow, and quite close to the house. is a heronry and from my bedroom window in the early morning I could listen to the extritordinary noises made by the birds when feeding their young. At the side of the house is a long arenue of magnificent lime-trees. and in the holes in these trees were many Owls nests. One hole was pointed out as having held Barnowls for several years, and the ground below was strewn with aastings. One of these yielded the skulls of no less than five shrew-mice. besides other bones: another one contained the skull of a small rat. 'The grounds of this fine specimen of a Dutch country house consist of eight hundred acres, and the trees contained therein are worth a special risit. The lime-trees in particular are exceptionally fine. Besides Bamowls. both the Tawny Owls and Little Owls nest near the house. The latter, I was told, are frequently seen in the daytime. and are very tame.

Golden Orioles were rery numerons, their liquid note 
being constantly heard in the lofty tree-tops. 'They are seldon seen. howerer: I saw but a passing glimpse of one, and my host told me that he had only once seen a nest. 'They are invariably suspended from the pendent extremity of a topmost branch of a high tree, and in consequence are seldom found. and can only be reached by cutting off' the branch.

The Icterine 11 arbler is another species which nests in the garden and grounds, but I have nerer seen it.

Desirous of seeing some of the rarer waders. particularly Arocets. a journey was made to a more northern locality. where they still may be found. 'Though late in the season. several Arocets' nests were seen still with eggs. 'The nests were on the caked mud of a dried-up creek. and consisted of a few stalks such as are usually to be found in a Ialpwing's nest. and each nest contained four eggs. These beautiful and mique birds are perhaps the most graceful and elegant of all the waders. and have always excited the utmost admiration wherever I have met with them. whether on the sandy creeks of the Zuyder Zee. or on the mud-flats of the tawny Guadalquivir and the marismas below Seville. or the fjords and marshes of West Jutland. Whether daintily tripping over dry mud or the shining surface of tidal ooze, wading in shallow pools. swimming. or Hying. all their actions are full of grace and beauty. and by moving quietly they are fairly easy to approach. In fact, we were able. on the Guadalquivir. to run close enough to them in the electric launch to have touched them with a boat-hook as they ran about 


\section{Bird Life in Dutch Marshes}

the mud-flats along the shore at low tide. We found then, in this 1)utch island. with the same preference for the company of Redshanks which had been noticed in Spain.

Many Redshamks nests were carefully hidden in the tufts of long grass: Ciodwits were also numerous, but we were too late for egres. By their excited demeanour they had evidently young birds hidden in the luxuriant grass

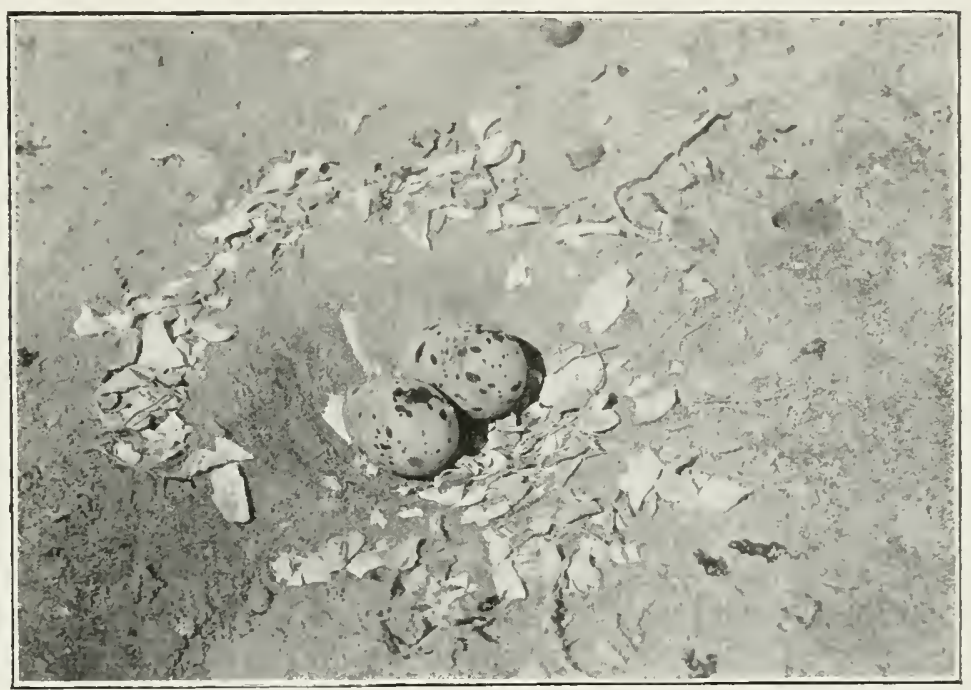

Nest of Lesser Terx (Stcrna minuta).

in the meadows, in which they breed. This grass was far too thick and high to permit of anything like a successful search being made for them. 'They are the Black-tailed Godwits, which, at the begimning of the nineteenth century, were accustomed to nest in the eastern counties of England. The Bar-tailed Godwits, so common along our coasts in the antumn and winter. do not nest any where south of Lapland. 
Oyster-atchers and Common 'lems were nesting on the short turf. and Ixesser 'Tems on the shingly patches, while the little pools were inhabited by numerous Blackheaded Giulls.

'The Ruffs. or rather the Reeres, were presumably tending their young in the meadows. where they also nest. like the Godwits, and we saw very little of them.

In this place I had the advantage of a guide who could speak very good English, and had, besides, a knowledge of the different birds, and where they were to be met with. In most Dnteh towns there is very little difficulty with the language, as almost everybody with any education speaks English perfectly well. The upper elasses invariably speak it with amazing fluency and correctness. In my three visits to the "meer," however, I have failed to find a soul who could understand or speak one single word of English. 'Twice have I spent a week there-onee in a large farmhouse, and again at the keeper's cottage-without being able to communicate with anybody, save by signs.

The whole of each day was spent with a young Dutchman. the son of the keeper, who punted me about from one nest to another. and acted as guide among the intricate chammels of the "meer." Here. again, all commmieation was by signs. helped by a few Dutch words left by my Dutch friends in my pocket-book when they drove me orer and made all arrangements for my stay. Above all, the Dutch names of all the birds to be met with were prorided: and with these I got on very well, especially as my 
boatman rery quickly got into my ways and understood what was wanted.

The chief difficulty at first was to make him understand, when it was necessary for me to wait in concealment at a nest in order to photograph the bird itself, that he was wanted to go right away, and to stop away until he was called. Nothing is more annoying, when engaged in this work, after waiting for hours, half broiled by the sum, orel waist-deep in stagnant water, and covered over with wet reeds, just at a critical moment, when you are expecting the bird you have waited so long for, to hear your boatman pottering about close to and preparing to come to you. 'These are the occasions when the ignorance of the language makes itself felt, and when you feel as if you would like to know some of the stronger adjectives in local use in order to do full justice to your feelings.

On one occasion he failed to come when I did want him. 'Though I shouted till I was hoarse, he did not appear, and I hegan to wonder what had become of him. 'The water was generally so deep, and the bottom so soft and meren, that I hardly liked being left alone: and if anything had happened to my boatman when in such a situation, mable to more a yard without getting orer my head, and encumbered with a heary camera and wading-trousers, the result might have been decidedly mopleasant. If I stopped there for a week, there would be no chance of anybody coming within hail. In this case I was able, huckily, after a time to wade in the direction in which I thonght he had gone. and 
presently saw him. or läther his punt. some distance off. ()f the boatman himself the only visible sign was one leg. with a wooden shoe on the end of it. sticking up in the air. Shouting and yelling had no effect whaterer. and doabts (ame into my mind as to the cause of his silence. Mas he drunk, or in a fit. or dead? After some difficulty I managed to wade out to him. and found him lying on his back fant asleep in the sun. Even then he only woke up when I tipped the punt to one side and nearly rolled him out of it.

Howerel, we got on very well together, and he was invariably rery obliging and intelligent. His people. too. did everything in their power to make me comfortable. and to help ne in nuy work: and the hours I spent with him exploring all the immermost recesses of this fimnous resort of rare birds are among the most enjoyable I have crer experienced anywhere. 


\section{CHAP'TER IX}

\section{Bird Life in the Spanish Marismas}

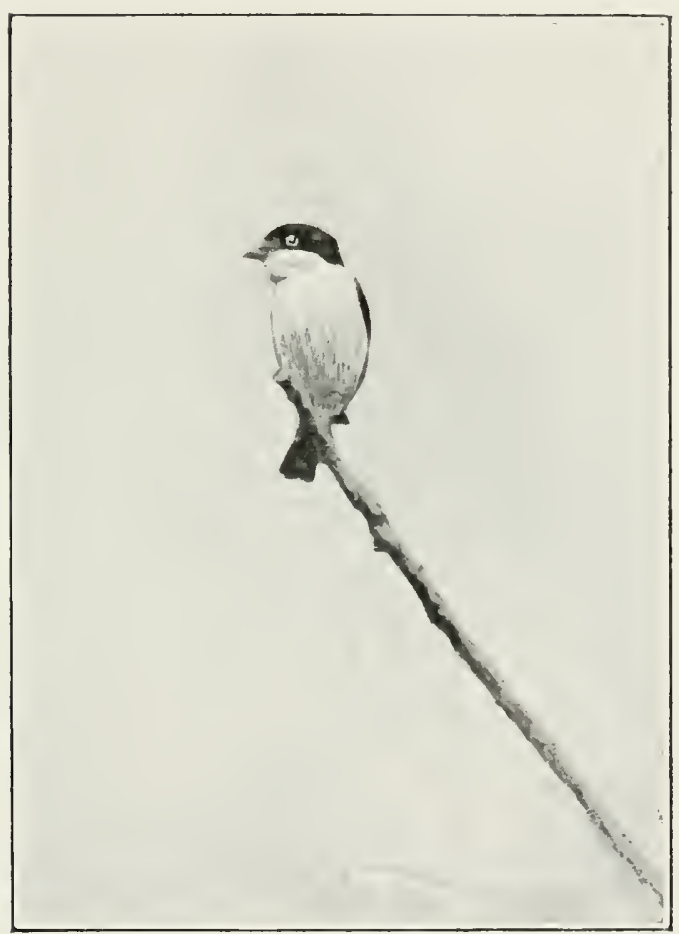

WOODCHAT-SHRIKE (Lanius pomeramus).
Spary is moloubtedly the countly which offer's most attractions to the ornithologist at the present day. First of all. the comntry itself has many natural adrantages in the inmense range of climate and temperature, owing to its physical peculiarities. 'lhe snowclad heights of the sierras look down on summy vineyards and olive-groves twelre thousand feet below, where the orange. banana, and other sub-tropical finits and plants grow freely and abundantly. The soil, too, is of as diverse a character 
as the rest of this paradoxical comntry, the barren and metalliferous provinces of Northern Spain cuhninating in the fertile gardens of Andalucia and the swampy rice-fields of Vialencia. 'Then, too, the greater part of the country is

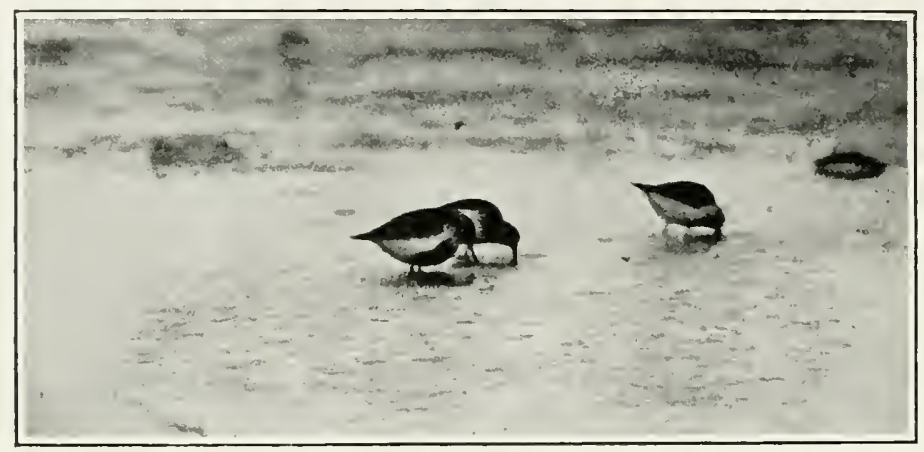

DUNLINS (Tringa alpina) FEEDING.

minhabited. Fiven in the cultivated parts the population is confined to the towns and villages, and the vast spaces of barren sand-dunes, the flooded marismas of the south, and the pine- and cork-woods are absolutely withont a human habitation, save the temporary shelter of reeds and branches used by the few herdsmen and charcoalburners. And, above all, the propinquity of Gibraltar and the southem apex of Andalucia to the great Afriem Continent, the winter resort of so many migratory birds. is taken adrantage of by them as the shortest and easiest route to follow. So that a very large proportion of the birds which migrate to and from the northern comtries of Europe pass through Spain twice erery year. Besides these. there are many others which cross over from Africa, and nest 
in the sonth of that comtry, as their farthest northern limit in an ordinary way. though most of them are represented in our list of British birds by a few stragglers which have, at long intervals, reached our shores.

The larger raptorial birds, which are almost exterminated in more populous and civilised countries, are here found in great abundance. 'The amrion-cating Vultures nest in numbers in the inaccessible heights of the sierras, and range over the open country in search of food. 'The carcases of drowned oxen and sheep, and those of the luckless horses, vietims of the brutal bull-ring, are cleared away in an incredibly short space of time by these scavengers, which throng to the feast from far and wide. Even the very bones disappear, the "Quebrantahuesos," the Bone-smashers, as the Egyptian Vulture and the Lammergeyer are called, carrying them one by one high in the air, and then dropping them on to the roeks in order to get at the marrow. The Golden Eagle and Imperial Eagle. Bonelli's and the Shorttoed Eagle, and the Booted Eagle are all to be found, some of them preying on the rabbits and the smaller quadrupeds, and others on the innumerable snakes and lizards which abound in every direction.

Of the larger Hawks, the Kites, partly carrion- and partly reptile-eaters, are excedingly mumerous. The Eggeating Harriers are to be seen daily quartering the lower grounds and reed-beds for what egges and young birds they can find. The knightly Peregrine and the more humble Kestrel are also numerous. But perhaps it is that extraordinary 
and mique region known as the "marisma" which affords the greatest diversity of bird life. Here come. either at one time of the year or the other, alnost erery species of mansh. aquatic. and wading birds on on list of British binds. with many others monown to us. 'The Gieat Bustard

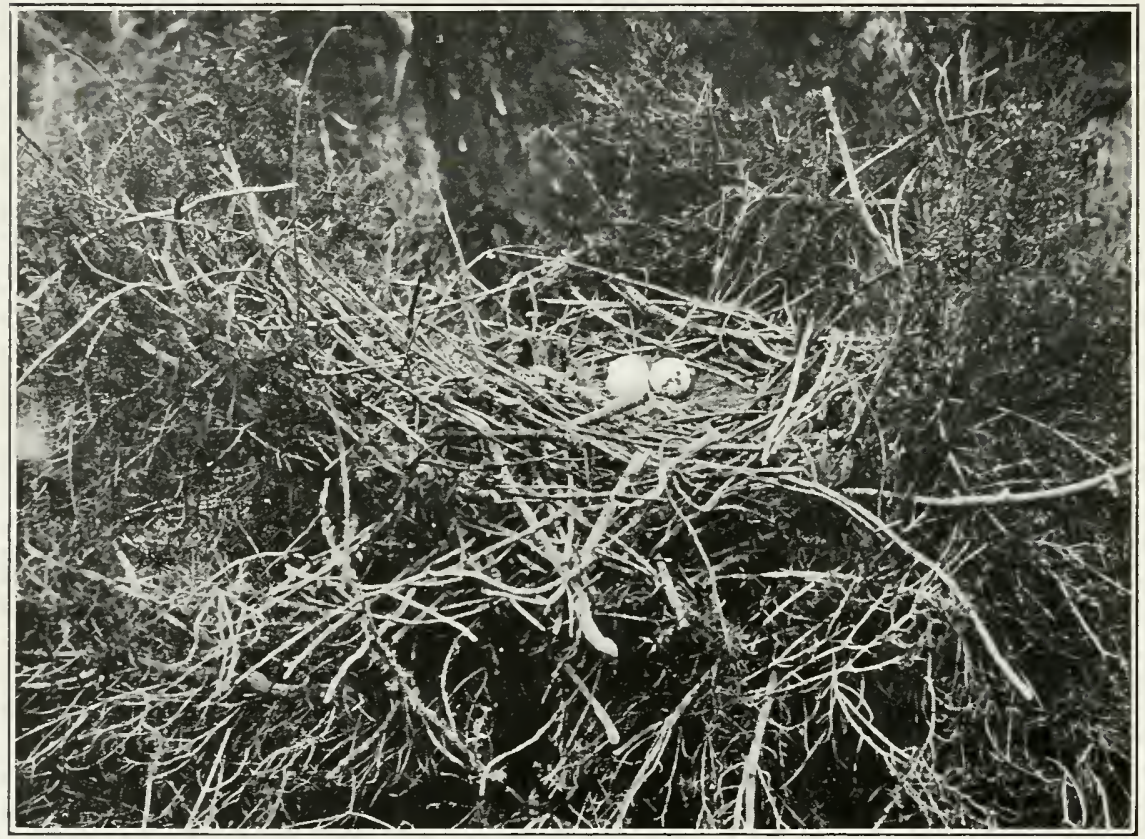

Nest of Kite (Milins regalis).

still frequents the rolling plains and tawny corn-fields of the south, and the stately Crane nests amid the reed-grown lagoons.

So that. when I received an invitation to join a rachting party at Gibraltar. for the purpose of exploring the mouth of the cruadalquivir and the famous malrismats of that dis- 
trict in search of birds, it is needless to say that it was accepted with alacrity. It was the very thing I had been longing to do for years: all needful preparations were made with the greatest enthmsiasm, and a start was made with anticipations which were more than fulfilled. 'Travelling overland through France--for I had been mable to cateh the steamer did not present anything worthy of notice. Birds. indeed. appeared, as far as one could judge from the passing train, conspicuous by their absence, with the exception of Magpies, which were more plentiful than I laad ever seen them before. 'Their nests were to be seen by the dozen, sometimes two, and even three, in one leafless tree.

Railway travelling was not altogether so comfortable as it might have been, though it was partly or altogether my own fault that the joumey from London was so long and tedions. Starting on Sunday evening, I did not land on the quay at Cribraltar until Friday erening. Still, the journey was an experience I am glad not to have missed. It gave me an opportunity of seeing something, howerer eursory, of the whole length of Spain, from north to south, and many typieal glimpses of an extremely interesting and picturesque people. and of noting the effects of climate on the various races.

'The comtry south of the P'yrenees is rery picturesque: rocky valleys, corered with oak and chestnut, generally had a small stream rippling along over the shallows, and looking very " trouty" - as I beliere they are. Here the people are frugal and industrious. the soil not being very productive, and labour being absolutely necessary to get a living. 
It was a common sight to see a couple of men, one on each side of a scarlet petticoated woman, digging on a steep hillside. keeping step and time together. All six brown arms would raise their spades above the head. down would go the blades all together. like clockwork, heing pressed farther down by their bare feet. At erery station and there was one every few miles-the train would wait while many kegs and boxes of produce of some kind or other were leisurely packed on board: and when we did at last get under waỵ again. the children would mu alongside, jumping on and off the footboard for some little distance with familiar contempt. On every train travel a couple of the ubiquitous "guardas civiles." in their neat black-andwhite miform. and armed with rifle and sword-bayonet. One of these men would, every time he wanted a smoke, open the breech of his rifle, give it a tap, and out would come a cigarette. 'They are a long way the best-set-up and most soldierly troops in Spain. Every station was also occupied by a " carabinero," in shabby miform of most atrocious cut and colour or combination of colours. ()ne I remember had a blue coat. red trousers, and bright green worsted gloves !

Magpies again are very mumerous: they appear to be the commonest bird throughout both France and Spain. As the train climbed higher and higher up into the sierras north of Madrid, the snow-corered peaks began to be visible on each side. and the nights were bitterly cold. 'The people here were wrapped in their long Spanish cloaks, a most service- 
able garment for such a climate, where the winds are of an icy coldness.

At one of the mountain stations a party of sportsmen alighted, and I watched them momnting their horses, which were waiting outside in charge of two or three keepers. ()ne of the "guns" camied a large Parrot's cage, in which

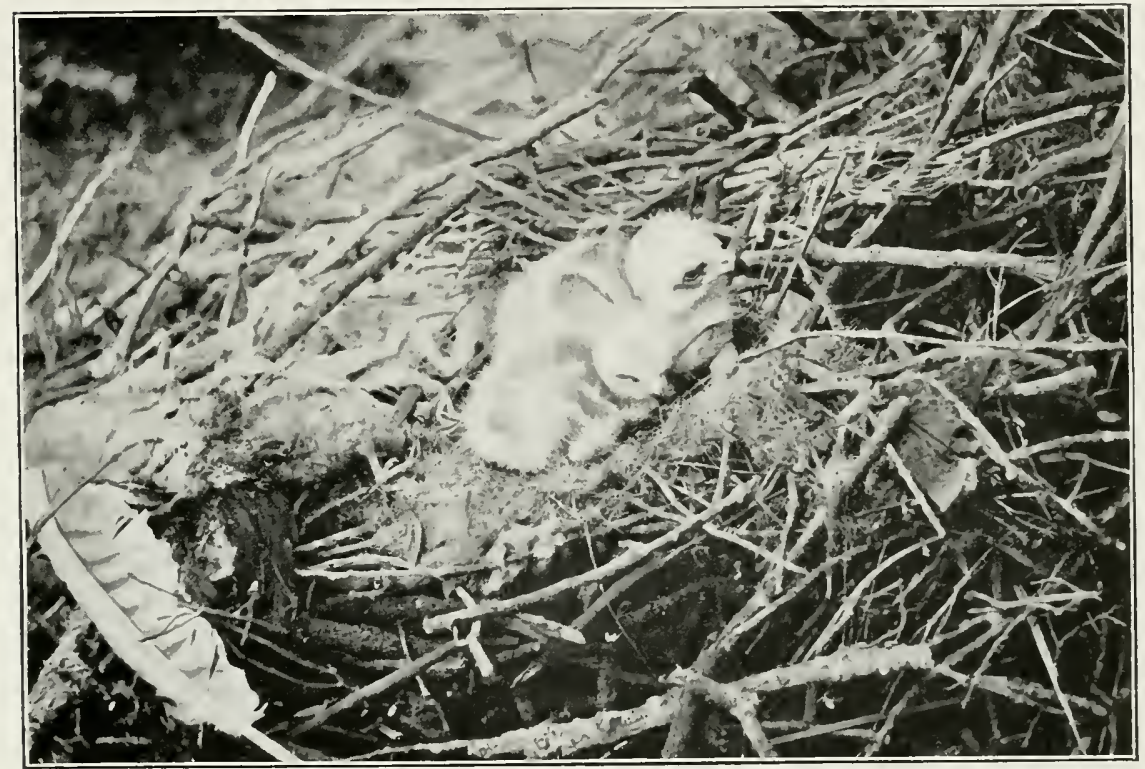

Kite's Nest with Youvg (Miluns regalis).

was a "Reclammo," a tame cock Partridge, a Red-leg (our Partridge being unknown south of the Pyrenees), whose call was to be used to attract his kith and kin within reach of the ambushed guns. 'This is the usual Spanish fashion of shooting Partridges !

'Through a galp in the mountains the line passed close to the Esemial, and brilliant uniforms and many ladies 
were on the platform of the little station, not far from Madrid.

South of Madrid the country is monotonous in the extreme at this time of year (March): a barren-looking platean appeared to stretch to the horizon. unbroken by tree or shrub. The rines had not yet begun to sprout. and appeared to be so many rows of dead and lifeless stumps.

A few small parties of Swallows and Kestrels now began to be seen. all of them working northwards: and the farther south the more numerous they became, until by the time Andalucia was reached many Swallows and Martins were noticed perching on the stations and telegraph-wires. Now and then a Bee-eater might be seen. and cactus hedges and aloes bordered the line.

Beggars infest all the stations. which are quite open to all comers. cripples of all sorts and descriptions, and pedlars shout their appeals and call attention to their wares. Some of them sell water - - Agua, agua" ; others oranges. which are (heap) and delicious : and boys run about with trays of fearsomelooking cakes and eatables, of whose composition I know nothing, nor want to most unholy-looking compounds, which would, I should imagine, make very excellent fly-traps.

'The herdsmen and shepherds are invariably armed with long rusty guns shmg on their backs, and mostly clad in leather from head to foot. looking much more like brigands than honest men. Appearances are. howerer. deceptive: for further experience showed that this class of men were invariably very polite and obliging. 


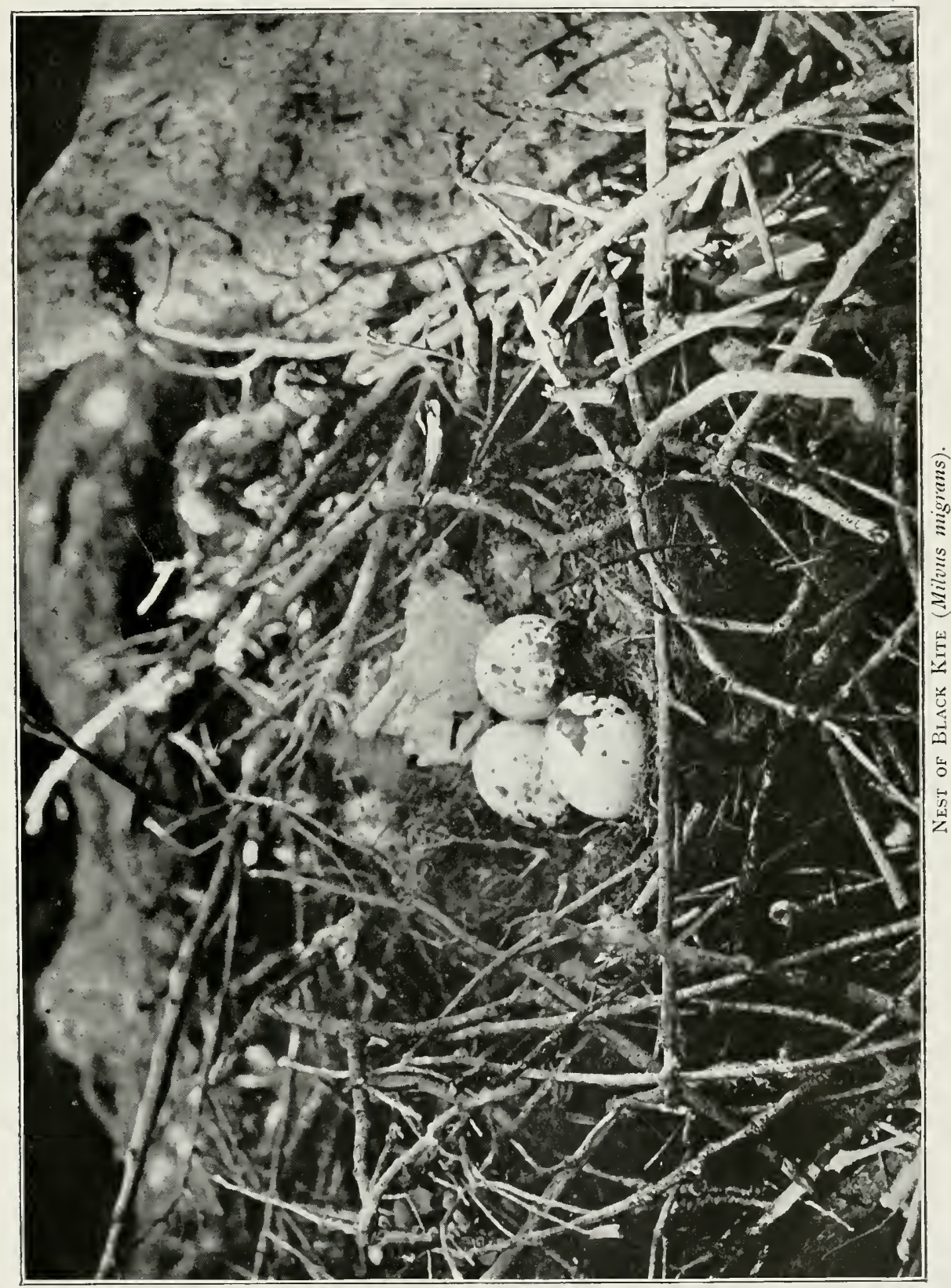


At Gibraltar I waited ten days before the yacht arrived, being delayed by bad weather coming from Cyprus. During the whole of this time I applied in rain for permission to photograph at the adjutant's office. In spite of repeated promises I never got it. and had to leare without having had a chance of doing many things that I wanted to.

Swarms of Kestrels clustered like bees up and down the rugged face of the stupendons cliff of the north front. I was nerer tired of watching them soaring overhead and listening to their wild, chattering eries. It is possible to climb up the sloping foot of the cliff: and there I conld sit and see them horering or perching on the ledges and crevices of the perpendicular Rock above. In the holes and cramnies were many pigeons, and towards evening the Swifts would come tumbling out, to wheel aromd the narrow streets, uttering their weird screams. 'The Kestrels, I imagine, must feed largely on beetles, no other food being plentiful enongh to support such immense numbers of them.

In the beantifinl public gardens on the south side were many familiar English birds, whose notes came at first as a surprise fiom and the luxuriant tangle of semi-tropical foliage-fiom date-palms, oranges, bamanas. pepper-trees, and many others, festooned with strange climbing plants, whose brilliant flowers fill the air with sweet perfume and attract numbers of butterflies.

From the parade-gromend above these gardens the great bare Rock rears its imposing height from the belt of pines and low brushwood which rlothes the lower slopes. Below 
lie at anchor the stately warships and large passengersteamers, which are ever arriving and departing : and across the narrow straits ean be plainly seen Centa and the African nomintains.

Between the north front and the neutral ground there is a wide moat. on which are nmmbers of Coots and Mallards. feeding and swimming about in the most nnoncerned manner within a few fect of the noisy and busy traffic constantly

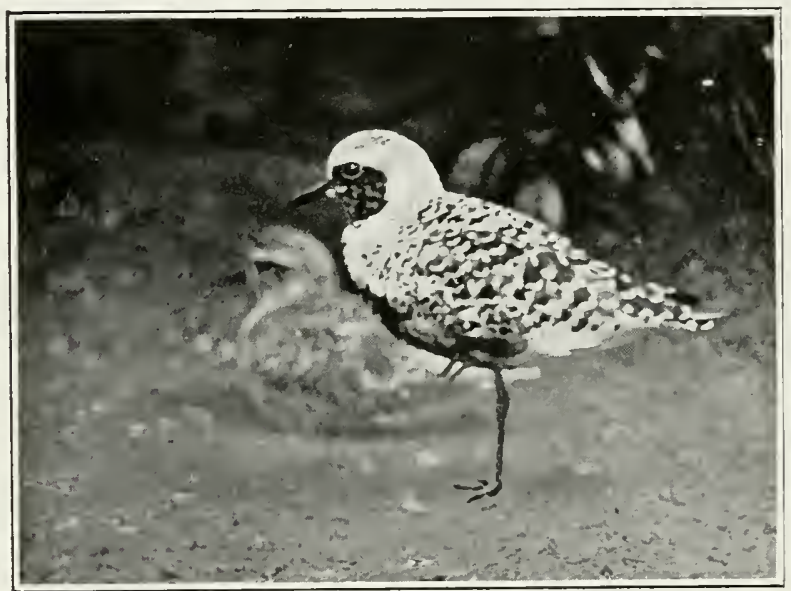

Grey Plovers (Squatarola helvetica).

passing along the dusty roads leading to the Spanish lines. Though so tame, these are perfectly wild birds. fiee to come and go as they like: and they may be seen towards ercning Hying in from seawards. and. after wheeling round, pitching down on the water.

It was reported in the hotel that an Egyptian Vulture was in the habit of daily risiting the offieers mess of the South Wales Borderers, where food was regularly provided 
for it. Not having the necessary permit to photograph from the military anthorities. I arranged to go 11 ) with the local photographer, as he had a commission for some work there, and. passing myself off" as his assistant. intended to derote myself to the Vulture. Unfortunately he was prevented firom going, and the opportunity was missed.

'The fact is, the ordinary civilian in (ibraltar, especially when making a short and temporary stay, is soon made to realise that he is only there on sufferance, which indeed is the case : and unless he has introductions. or is known to the powers that be, he does not stand much chance of doing anything, beyond going orer the galleries in change of at sergeant and inspecting the lighthouse. I could have forgone these sights with much equanimity if I could have seen the Bonelli's Eagles which have nested for many years within sight of one of the signal stations. or the Osprey's nest. or the celebrated apes.

As it was. these were forbidden pleasures; and being unable to do anything on the Rock. I arossed orer to Mgerciras, and went inland a short distance by train to some cork-woods. at a place called Almorama.

I seaving the little station. I found myself in rery English-looking country: the light, sandy soil was covered with bracken. here and there were small reed-grown lagoons and swamps, and from the oak- and rook-trees could be heard the " l'ink-pink" of chaffinches and the notes of many 'Titmice and Blackbirds. From yonder rose-spangled thicket entwined with honeysuckle ame the joyous melody of a Nightingale, 


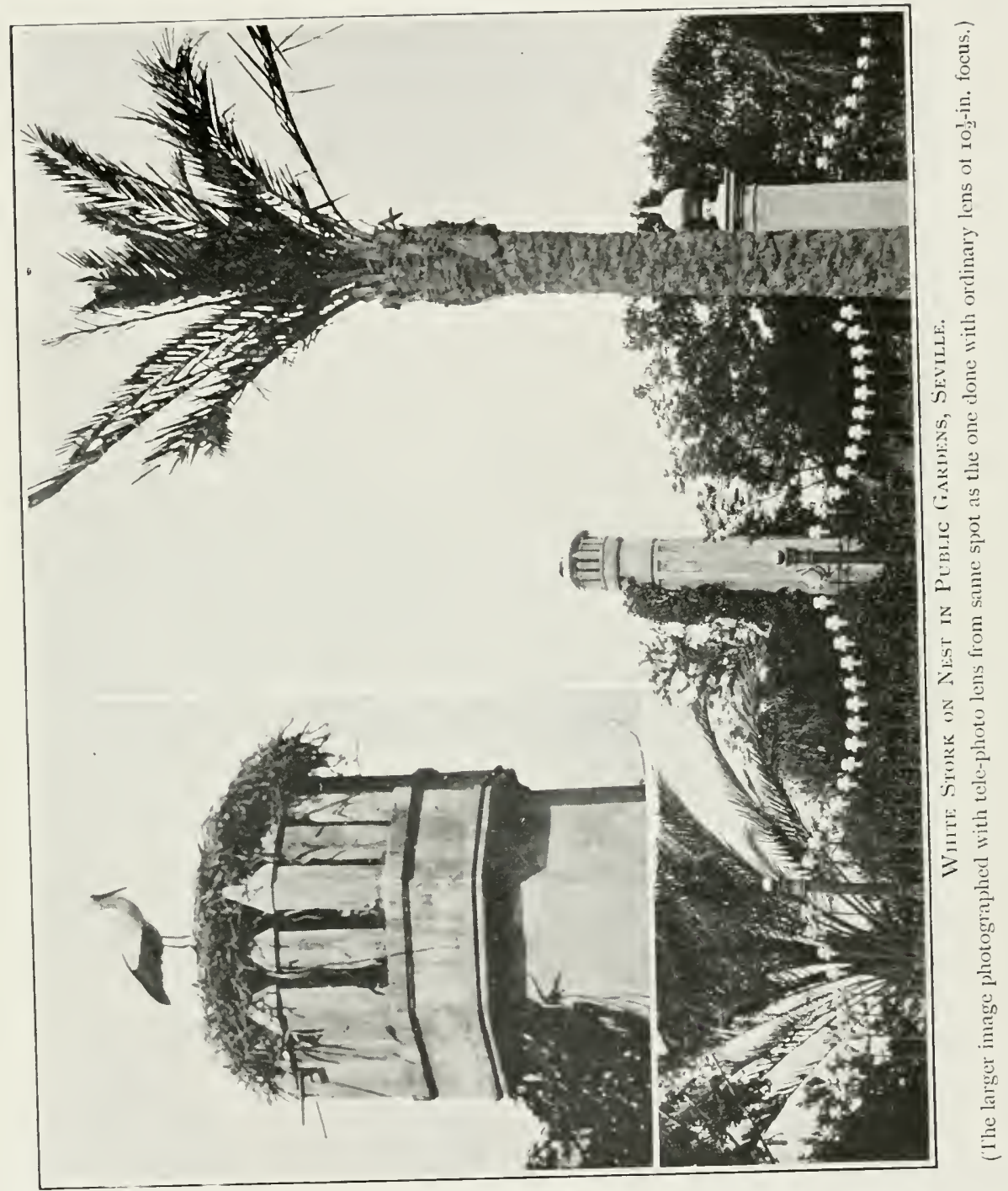


and cuckoos amounced their arrival in erery direction. But among these somnds were mingled the liquid notes of the Bee-eaters. as they poised in mid-air or perched on some bare trig on the watch for passing insects.

More complicuous still on the bare branches of the lower bushes were the $\mathbf{W}$ oodchat Shrikes. their white breasts shining in the sum. and showing off the rich chestunt of head and back. 'They are rery bold and familiar. much more so than

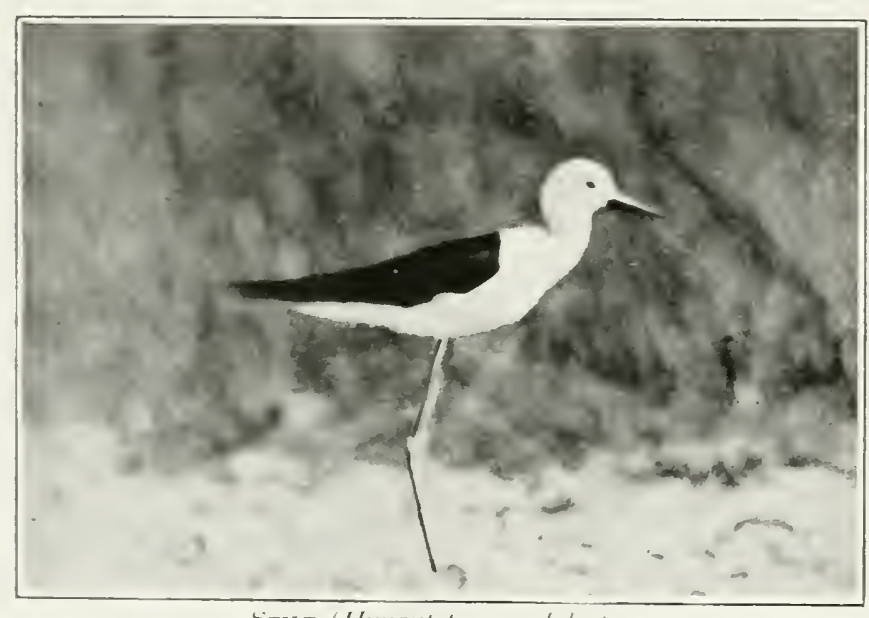

STILT (Hunantopus candudus). the Beeeaters. which dash off at the slightest attempt at a n e a $\mathrm{r}^{\mathrm{a}} \mathrm{p}$ proach. Sereral of these gracefiul and brightly coloured birds were hovering in front of some holes in a high bank: but so early in the season-mid-April it did not seem worth while to try to dig out the holes. While watching to find out if the birds were entering them at all. I saw the tail of a big lizard sticking out of one of them.

Lizards and snakes are exceedingly numerous, and run to a very large size. Both are credited with deroning birds and their egoss. and eren rabbits: and in their turn they 
are deroured by many of the raptorial birds. Very soon after learing the station a rushing sound behind made me turn quickly. and I saw an Fangle closely pursuing another one. which had firmly gripped in its claws a large lizard. In their excitement they had approached quite close to me. From their white-barred breasts. they were seen to be the Snake-eagle. or Short-toed Fagle-a migratory species which crosses into Spain in the summer to feed on the numerous snakes and lizards. and nests in the cork- and pine-trees.

Passing on the way a roadside "renta." I went in for something to eat and drink. The accommodation in these places is of the roughest. though I had some capital eggs and some sour wine. "Huevos fritos" (fried eggs) are the only things eatable. so far as my experience goes. in Spain.

()n entering. I found the host. sun-dried and lean. sitting on a rough bench on the earthen floor of the public room. In one comer stood sundry mules and donkeys. and cocks and hens ran in and out of the open doorway. Just over his head many Swallows were risiting their nests in the rude rafters. perfectly tame and unconcerned. I heard afterwards that only the day before a man had been dangerously stabbed in this same. "renta" in a quarrel with a rival orer the old man's daughter. probably the same girl who waited on me. Howerer. I knew nothing then of all this. and enjoyed my meal and rest: for carrying a camera orer rough comntry under an Andalucian sum. even in April. is trying work.

On one side of the line a small stream runs. full of 
fish. apparently dace. and water-turtles appeared to be very common. Here I saw a Marsh-harrier for the first time, disturbing it from a dead and withered tree which orerhmug the stream.

I Sandpiper was also seen. which I took to be the Green Sandpiper: and a Kingtisher- the only one I saw in Spain

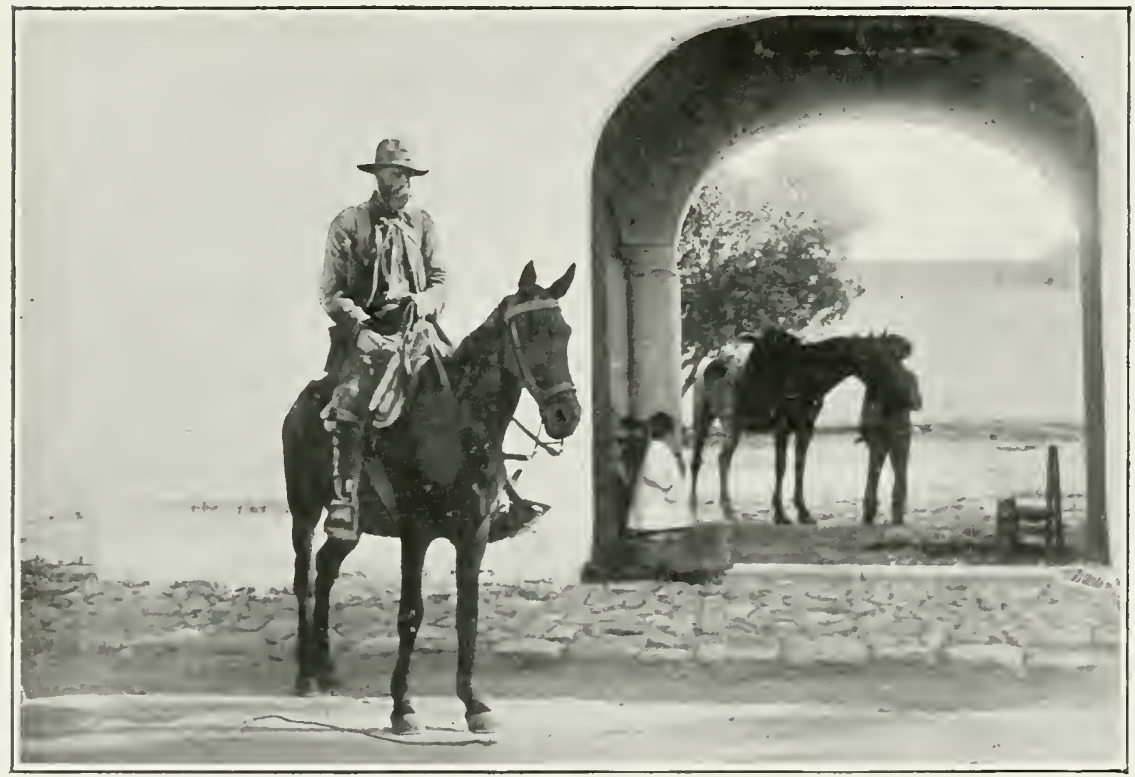

THE AĽthor.

throughout my risit. According to Chapman. it is ". most numerous in winter." I Blue 'Tit was noticed nesting in al birch-tree at the watemide. Cnfortunately I did not see the crested 'Tit. which is to be found in the neighbourhood.

laoking into a small bush for nests, a green tree-frog was espied a few inches from my fiace. clinging to one of 
the upright stalks. It was perfectly motionless, and the curious. compressed form, of a most vivid and brilliant green, was wonderfully inconspicuous anid the leares. After watching and photographing it. I gave it a slight touch-up, and the thing vanished into the next bush with a flying leap. nor could a close search detert it again.

A pair of the inevitable "guardas" were occupants of my carriage on the way back: and on arriving at the terminus I was requested to move, and then saw for the first time that my next-door neighbour was a prisoner. chained hand and foot. so that he had to be half lifted out of the "arriage. He was most likely bound for the comvict prison on a small rock-island in the bay.

It last the welcome amrival of the vacht released me from waiting in idleness. and I went on board at once. as ghlad to leave cribraltar as I had been to see it on first arrival.

Rumning round to the Guadalguivir under steam just took up one day, and we made for San Lancall de Barrameda after dark, anchoring off the town. on which we turned the search-light from the bridge. in order to see what sort of al place it appeared.

Early the next morning bronght the British Vice-('onsul and a letter from friends to whom we had introductions. griving us permission to risit and collect over a celebrated preserve on the property of the Duke of Medinal Sidonia: and, acording to instructions. we proceeded farther up the river. and brought up again off" a rude and rickety landing- 
shelter as a big cabbage-stalk, with my waterproof orer his alm. It was no good to me, as I was already soaked to the skin, and was, besides, too busy to go for it, so I shouted to him to put it on himself: but when we finally returned to the yacht, he shivered and shook and looked such a picture of utter misery that 1 had to get him

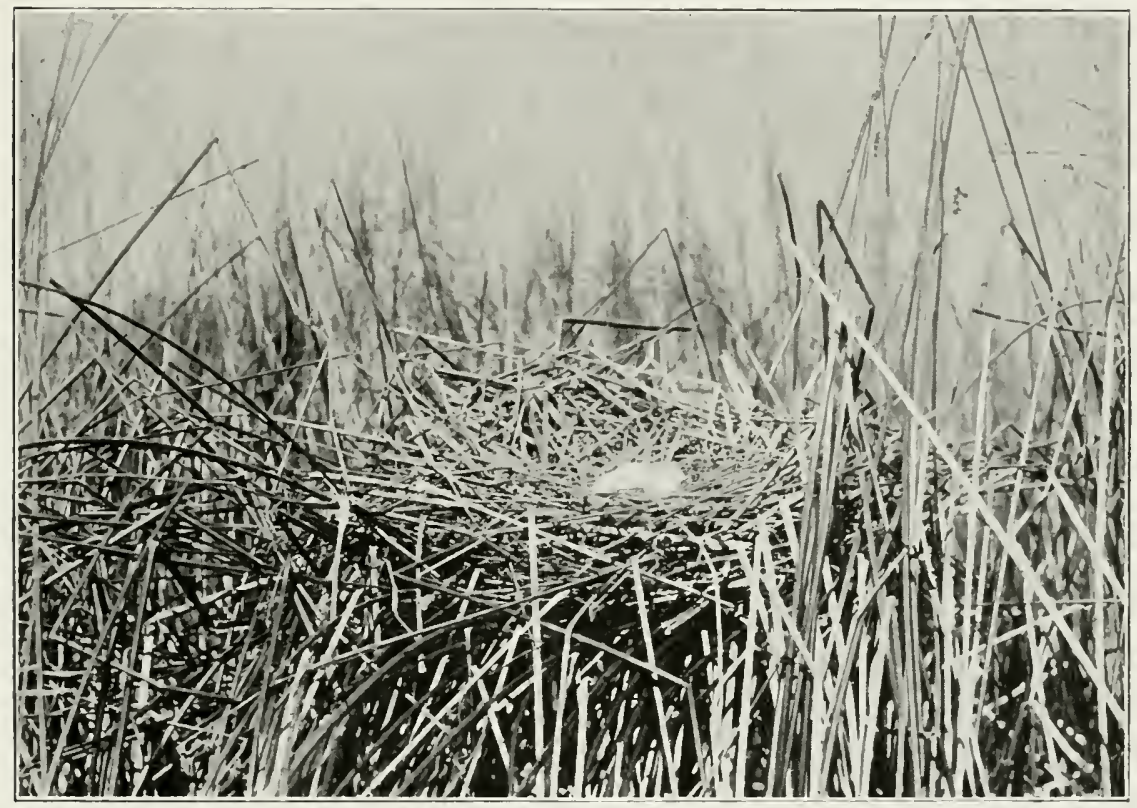

Nest of Purple Heron (Ardea parpuca).

a stiff "go" of brandy to put a little life into him again. While engaged in the thick of this storm. I was surprised and disgusted to find myself hailed fiom behind, and. turning, saw two momnted keepers with g'ms shouting to me. On showing them. howerer, a letter from their employers. they said no more-though, as it 
was in Fuglish. they could not have understood a single word of its contents.

On first landing here among the pine-trees not many birds were seen. only a few Kites and an Eagle. and accordingly we turned along the shore. where were some Arocets and

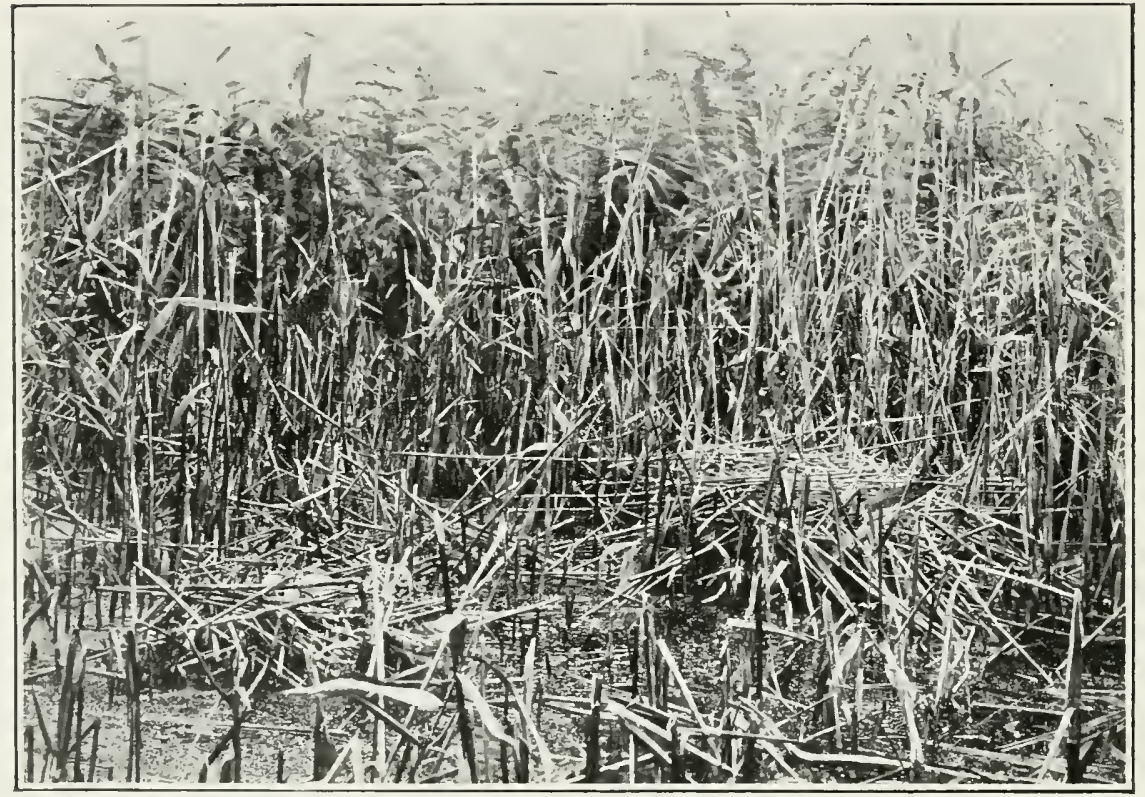

Two Nests of SPoonbills (Platalea lacorodia).

Redshanks. 'They were, however, very wild. and there was no appearance of their having begm to nest.

Following the muddy banks of a small areek led us to some marshy ground grown over with immense rushes. from which we disturbed some half-wild pigs. Presently small waders. like Innlins. Knots, and Ringed Plorers. began to be more numerous. and large flocks of birds could be seen in 
the distance, orer what appeared to he al large sheet of water : and we soon fomnd ourselves standing on the shores of a valst inland lake. divided at the horizon from the sky by low pine-trees. 'The nearer shores were alive with flocks of birds busily feeding, the Dunlins especially almost regardless of our presence as they ran about over the mad and explored all the

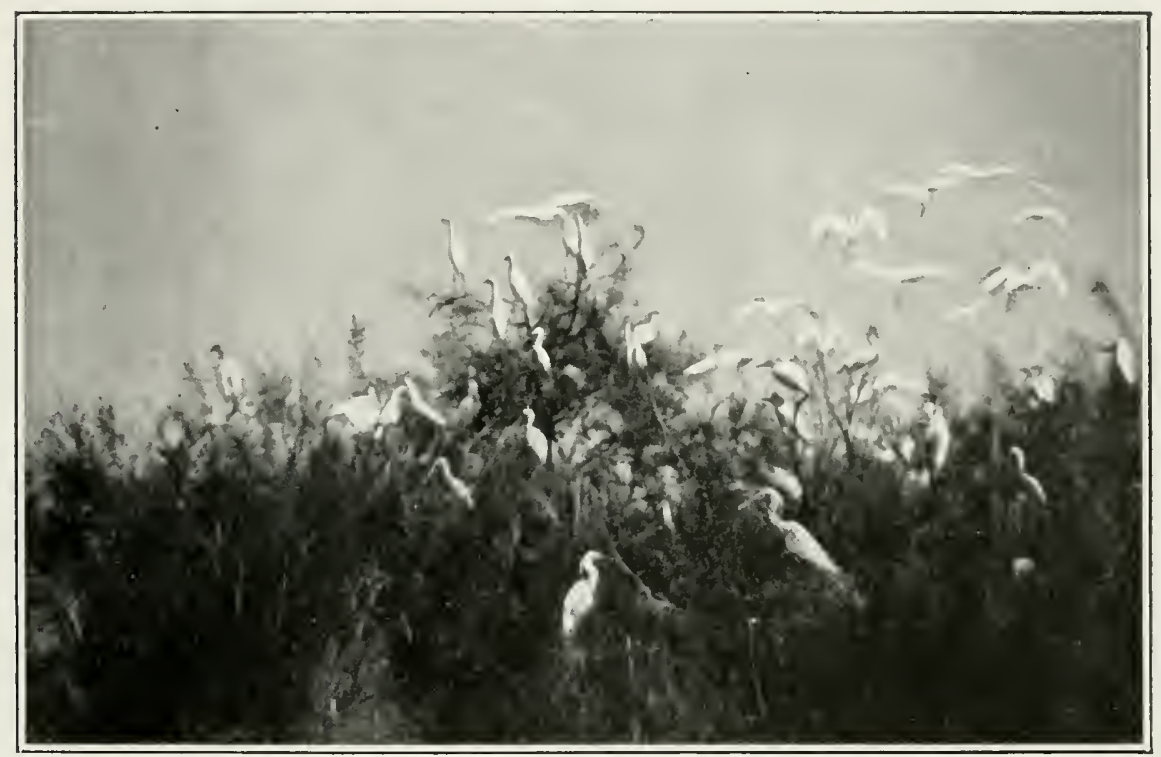

Little Egrets (Ardea gelrzetta) IN Nesting Coloni.

little creeks. Crodwits and larger birds waded in the farther shallows, while (inlls and 'Terns flew overhead: but the chief interest was centred on the Flamingoes. which stood in long lines along the fiuther shore exactly like regiments of soldiers.

Then it was realised that we were really in the marisma which we had come to see, and that all we had read and heard about the wealth of bird life was more than true. 
'The scene was one full of interest and animation. and I enjoyed it to the utmost. I was soom hard at work, and found that after a while the birds were too busy to take much notice of me crouching behind the camera enveloped in my green cloth. 'The weather, howerer, got so bad, and the wind and rain so heary, that it was impossible to work, and we returned to our ship in a rough kind of punt. exeedingly leaky and rickety, pulled by two natives, arriving in a rery dripping condition.

On board we found a Spanish "shikari," sent by the friend to whom we owed the privilege of working in this paradise for naturalists, as guide, factotum, and assistant generally: and a first-rate fellow I found him, always obliging and willing, and with a good knowledge of the local birds and beasts. He could also skin hirds and blow eggs. and altogether was a great acquisition. Not one word of Finglish, however, could he speak: it is. in fact. musual to find any Spaniard outside the large towns able to speak anything except his own language, and not very usual there.

'The next day we had a long round through the pinales and over the sand-dunes. and after a while came to a Kite's nest up at the top of a big pine-tree. As I was very much out of condition, and it was a stiff' climb, all swaming to the top. I suggested he should tackle it. and gave him a back till he was standing on my shoulders. and then I pushed his feet up as far as I could reach; but as soon als this support was withdrawn he eame tumbling down again. As a climber he was a dead failure, though it is only fair to say that he laad a nasty cut on one hand. 


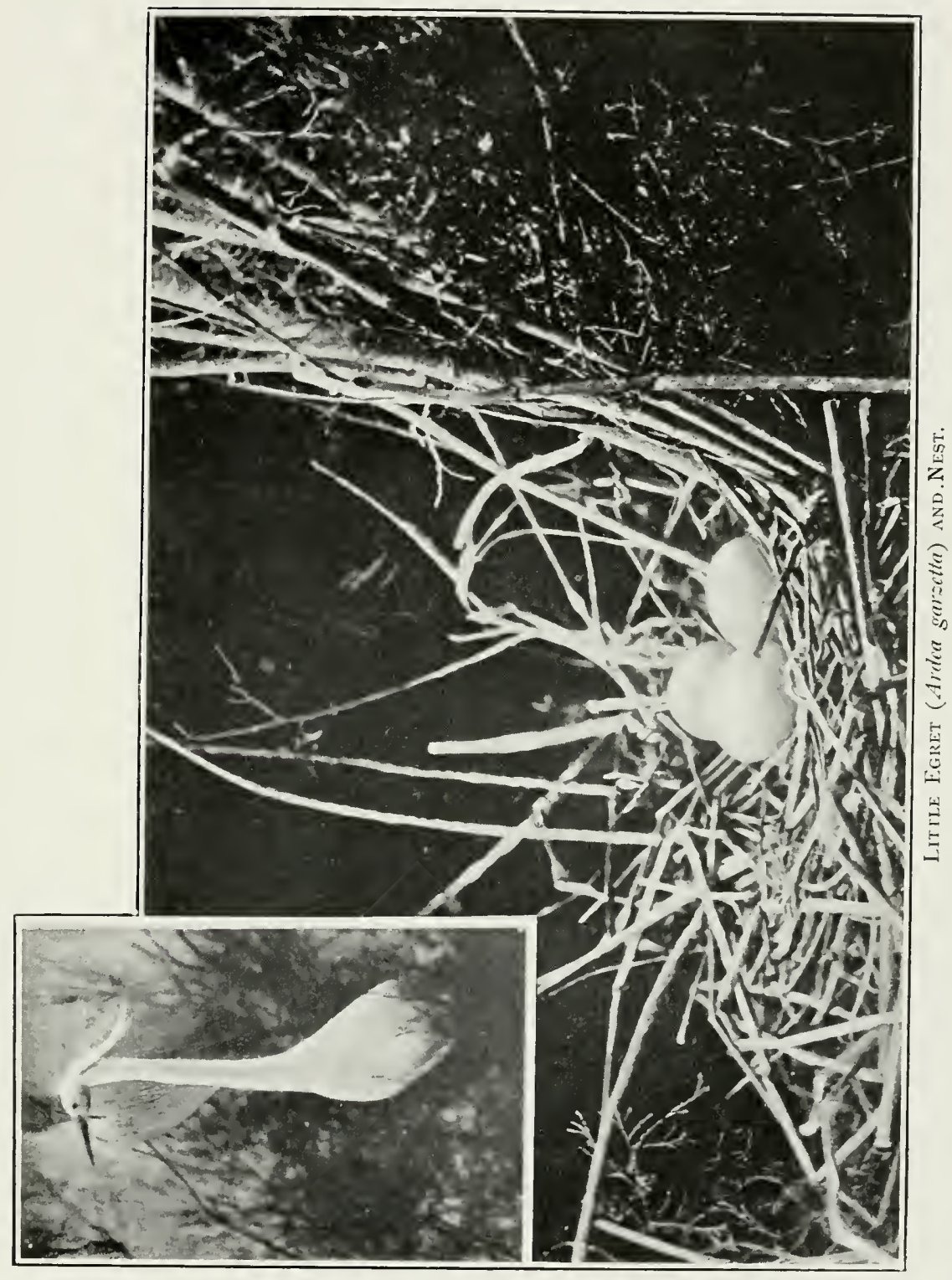


His failure made me determined to get up somelnow. whaterer happened. and I got him to give me a back. Finally. atter a hard struggle. I reached the nest. somewhat to my own surprise. Unfortunately it was empty: but we soon found more nests, and that afternoon I successfully tackled nine pine-trees, taking altogether three clutches of Kites eggs.

I shall not soon forget the pleasure experienced on looking into my first Kite's nest, and seeing the three great round eggs. so richly spotted and marked. All the nests were lined with horse-dung, and without exception contained a bit of lag of some description and a piece of newspaper. One such piece I still have. containing an account of the Cretan War, which was going on at the time.

'There are two species of Kites the resident Common Kite, . Milano real " of the Spaniards, and " Milano negro," the Black Kite. a migratory species. The eggs of these two are indistinguishable, and in order to identify them it is necessary to make sure of the birds. 'The flight of both is magnificently easy and graceful. as they glide along. steering themselves by their long forked tail, which is in the Black Kite less deeply cleft: and the bird is somewhat smaller and more dusky-looking, as seen from below.

()n one nest. in a large cork-tree. the bird remained while I was climbing up to it. and I did not know she was there. (On getting my head abore it and looking in, I was considerably astonished at seeing the nest. as I thought. unfold a big pair of wings and fly away. My eyes. in fact. 
were so close to it that I hardly realised at first what I was looking at. 'There were two young birds, clad in dirty white down, one much larger than the other. 'I'he interior of the nest - or rather the surface, for it was only a rough, flat platform of sticks was covered with horse-dung. which was perfectly alive with maggots. Tlue young birds crops were very full, as also their larder: for the nest continined an

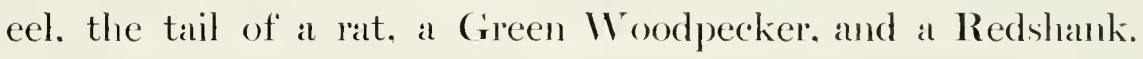

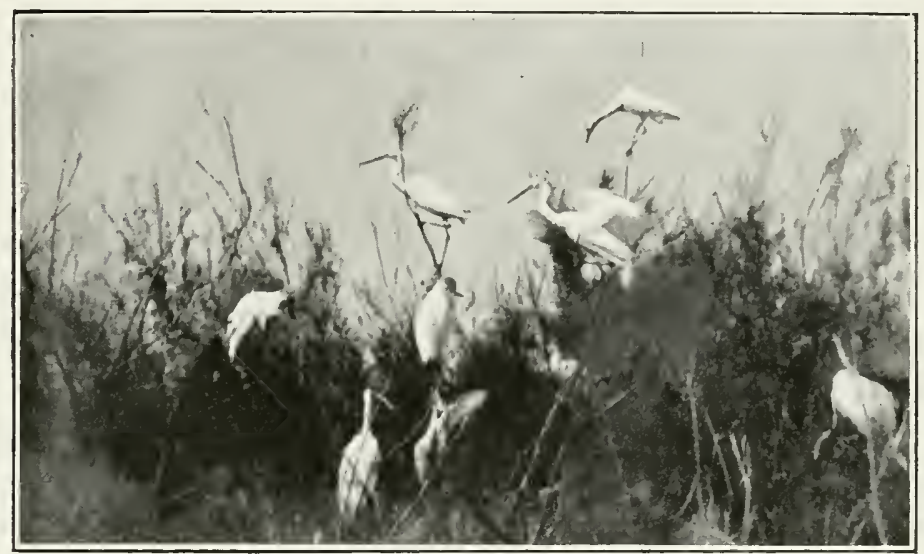

LitTLE EGRETS (Ardea garacttı).

'This cuts a sorry figure, howerer, with the larder in a 11 elsh Kite's nest, as found by Iard Aberdare, and recorded in the Zoologist. A drowned puppy, a rabbit. and the hindquarters of a small pig indicate a liberal scale of homsekeeping. compared with which the Spanish lander appears quite mean and porerty-stricken, as befits, perhaps, a poor and porertystricken country.

(It was from a Spanish newspaper found in a Kite's nest 
that I Lord Lilford first learnt the news of the assassination of' President I incoln.)

Descending the smooth, branchless trumk of one of these pine-trees, with three Black Kite's eggs in my roat-pocket. I had the misfortune to slip, and landed on my back. Howerer, there was no damage done, except the breakage of one of the eggs, which made a great mess in my pocket. It might have been worse, though.

'These egg's of the Black Kite and Common Kite, together with two clutches of Magpies' eggs, were all we found on this day: but I was perfectly satisfied and well content.

We found on our return that one of the sailors had brought in two large round white eggs from a nest in a pine, which he described as lined with grass and containing a rabbit. These were subsequently submitted to a great authority on Spanish ornithology-Mr. Howard Samndersand were by him pronouneed to be those of the Booted Eagle (Aquila penmata).

The Imperial Faghle is found also among these pine-trees, and we saw sereral. They were described by Benitez as "Aquila real." We came across an immense nest on the extreme summit of the largest pine-tree I erer saw. I was too tired eren to attempt it: and without rope or climbingirons it would have been impossible to ascend, as the tree was much too large to elasp. 'The nest was, besides, probably empty, as these birds breed rery early, beginning in January. An immense primary feather was lying on the ground below. the only evidence seen of the birds. 


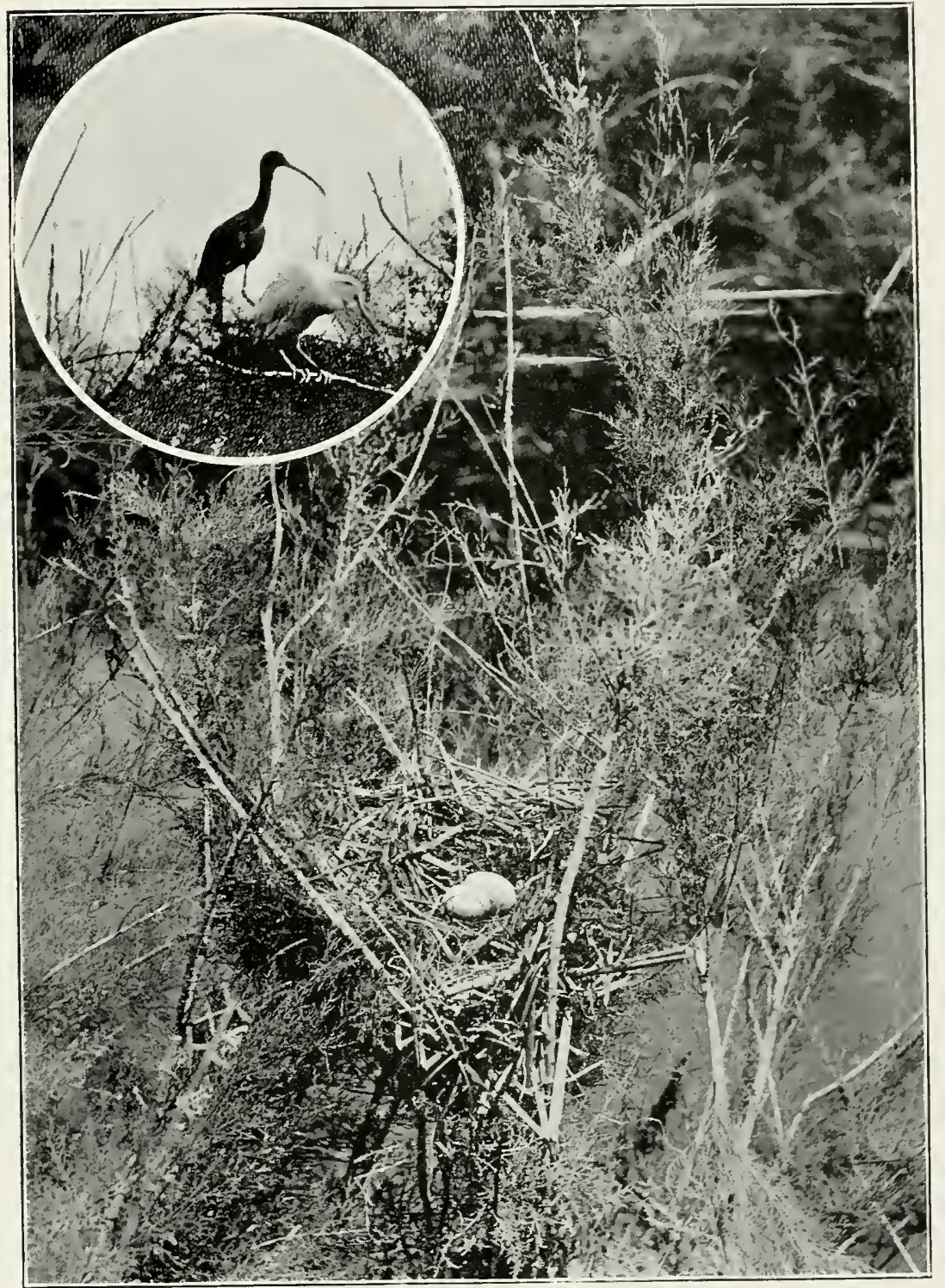

Glossy IbIs (Plegadis falcinellus) aNd Nest.

(The bird in front is a Buff-backed Heron.) 
The Golden Fangle and Bonellis Eagle are confined to the sierras during the nesting season, and nothing was seen of either of them.

'The next day was spent steaming up the river to Serille, where a stay was made of several days. The scenery. als seen from the Gratalquivir, cam hardly be described as

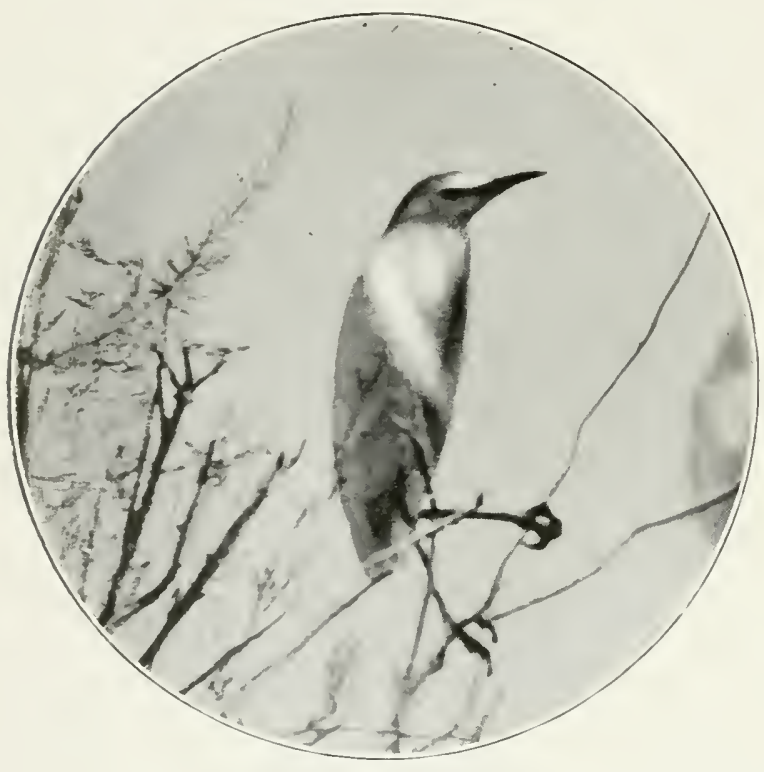

Buff-backed Heron (Ardea bubulcus). interesting or picturesque to anybody but all ornithologist. 'To us, however, there was much to wateh for and plenty to interest.

Where the river divides and forms the Isla Mayor we could from the bridge look across a flat expanse of malrsh and shallow water. in which were standing whole battalions of Flamingoes in flocks of hundreds. Here and there on stacks and buildings conld be seen Storks standing by and sitting on their nests. Sometimes the shores and the edge of the water. when shallow enough. were black with hundreds of cattle drinking. for this is a famous grazing-ground for the bulls destined for the national sport of the bull-fight. In one place we saw thousands of Sand-martins resting on their passage north. and several large flocks of Starlings were noticed. 
On the muddy banks in the lower reaches were muncrous Arocets. Curlews. Crodwits, Redshanks. Grey l'lovers, and other waders. 'These appeared to be mostly on passage: for on one day a particular species may be very prominent. and on the next there will be none of it to be seen. and some other will be equally numerous. Flying past were Pratincoles and Whiskered 'Teins. with Marsh and Montagne's Harricrs and mumerous kites. Where the river narrowed as we advanced farther up, the banks were corered with thick reedbeds. from which came the well-known harsh and grating song of the Great Reed-warblers: while from the bushes we heard a strange and unfamiliar song. which, while it reminded us of the Nightingale. was evidently from some other and muknown musician.

At last we reached our destination, and moored in midstream near to sereral English cargo-steamers.

Seville and its attractions I must leare to abler pens to do justice to.

". Quien no ha visto Serilla. no ha visto maravilla." says a well-known Spanish proverb, and a rery true one. For he who has not seen Serille has indeed missed a marvel. It is. I think. the most picturesque place I ever saw, and contains some gems of Moorish architecture. Storks were nesting on one at least of the churches. and there is another nest on the summit of a tower in the publie gardens. 'There was also one on the top of a dead tree a few miles below Seville. A strong migration of $M r y-$ necks appeared to be passing through Seville: the gardens 
in every direction were full of them, and their note resounded on all sides.

() April 30th, 1897, the yacht left the Guadalquivir, bound for Gibraltar, Malaga, and 'Tangiers.

Benitez had a few days previously been sent to make arrangements for food, wine, bedding, and other necessaries for a fortnight's stay up in the Coto, and accordingly he and I were landed on the quaty at Bonanza on the way down. Here we found a large open cargo-boat, into which we stowed away our luggage and ourselves, and were soon rumning up against the strong tide under an immense lateen sail, and in a short time landed again higher up the river. While our goods and chattels were being landed by the Spanish crew Benitez ranished among the pines, presently returning with a pack-mule for the luggage and himself, and a horse for me.

'Then I had my first experience of the carrying capacity of the Spanish mule. It seemed almost impossible for any one beast, short of an elephant, to have carried all our packages,--some large and cumbrous, bedding and such things: others exceptionally heary, full of photographic materials, plates, and so on. But one by one they were all stowed away in the two lugge pack-saddles, and, when these were full, piled on the top and made fast with ropes. As each package was hoisted up. the beast only straddled his legs out a little farther apart to support the weight; and then, when all was securely fastened, Benitez was hoisted up by the boatmen, and perched himself on top of everything. 'The load was one which far exceeded the mule itself' 
in bulk. and would have been a tremendous load for an English road.

But how can I describe the track along which we journeyed for four or five hours? Actual road there was none. but a barely risible track wandered along through pineforests and thick prickly serub, skirting round inpenetrable thickets and morasses of unknown depth. (often the heather (ame over our heads: sometimes we ploughed along painfully orer an endless succession of sand-dunes. through whose

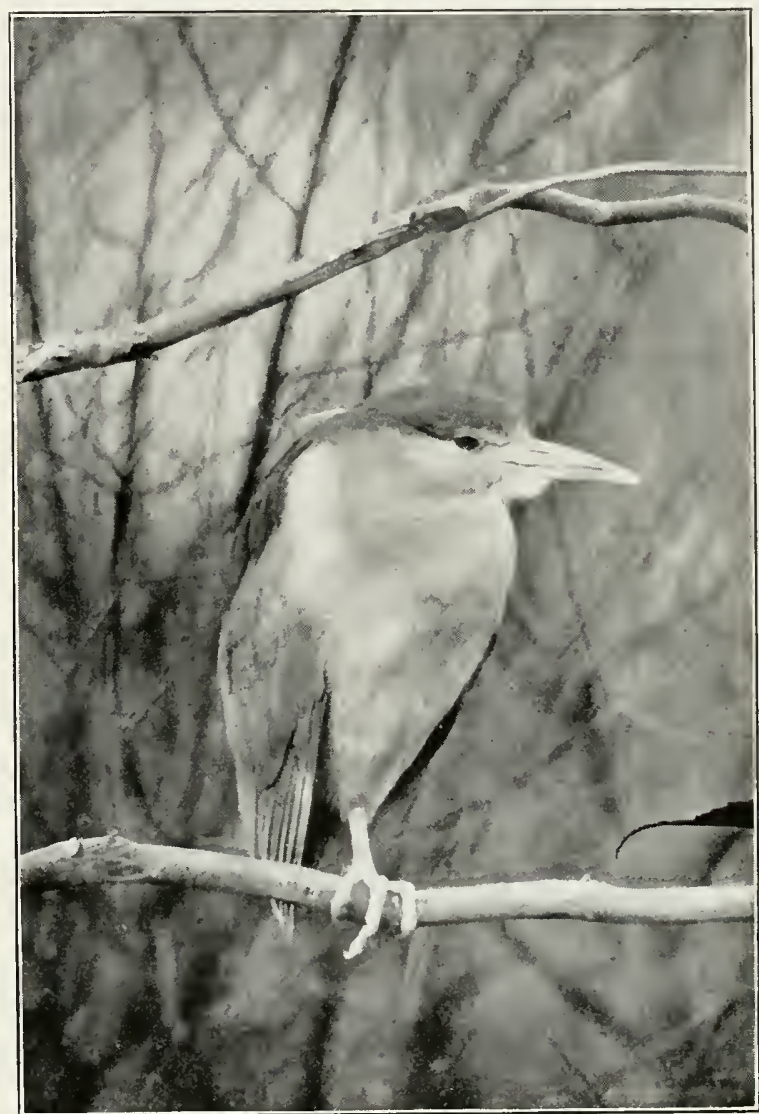

Night-heron (Nycticorax grisells). loose surface our animals sank fetlock-deep. Many miles of the way were through thick and most tenacions mud, whose surface was not yet dried into the brick-like hardness of those parts from which the water had earlier receded. There the 
surface was split up into countless cracks and reticulations: but here every footstep sank deeply. and it was with difficulty the beasts were able to drag their feet out again. Sometimes. again. we waded through shallow water or deeper reeks. where it was as much as we could do to cross without swimming. And this was what Benite\% had described to me as a good road-.. m bueno camino"! I beliere he really in this case lost his way. for we returned afterwards in much less time. and the going was certainly better.

I do not believe that there is a decent road in the whole of Andalucia. If there is. I never saw one: even in the large towns the streets are bad enough. 'There is no wheeled traffic possible from place to place. Frerything is carried by pack-mule. or " borrico." strings of donkeys being often met with in the most ont-of-the-way places. laden with goods: and all trarelling is done on horsebatck.

()ur progress. as we plodaled along. was sometimes anid the familiar cries of I alpwings and Redshanks, mingled with those of stranger birds. We now passed for the first time numbers of Stilts wading in the shallow water. 'They allowed us to ride within a few yards. and when they flew their extrat ordinary long red legs were stretched out straight behind. pratincoles flew round. looking on the wing like huge Swallows. Eangles and Kites soared orer the pine- and corktrees, and in the more mansly spots we were accompanied by Black and Whiskered 'Terns. Around every gromp of cattle and half-wild horses. feeding on the succulent waterplants. and ofters perched on their backs. were numbers of 


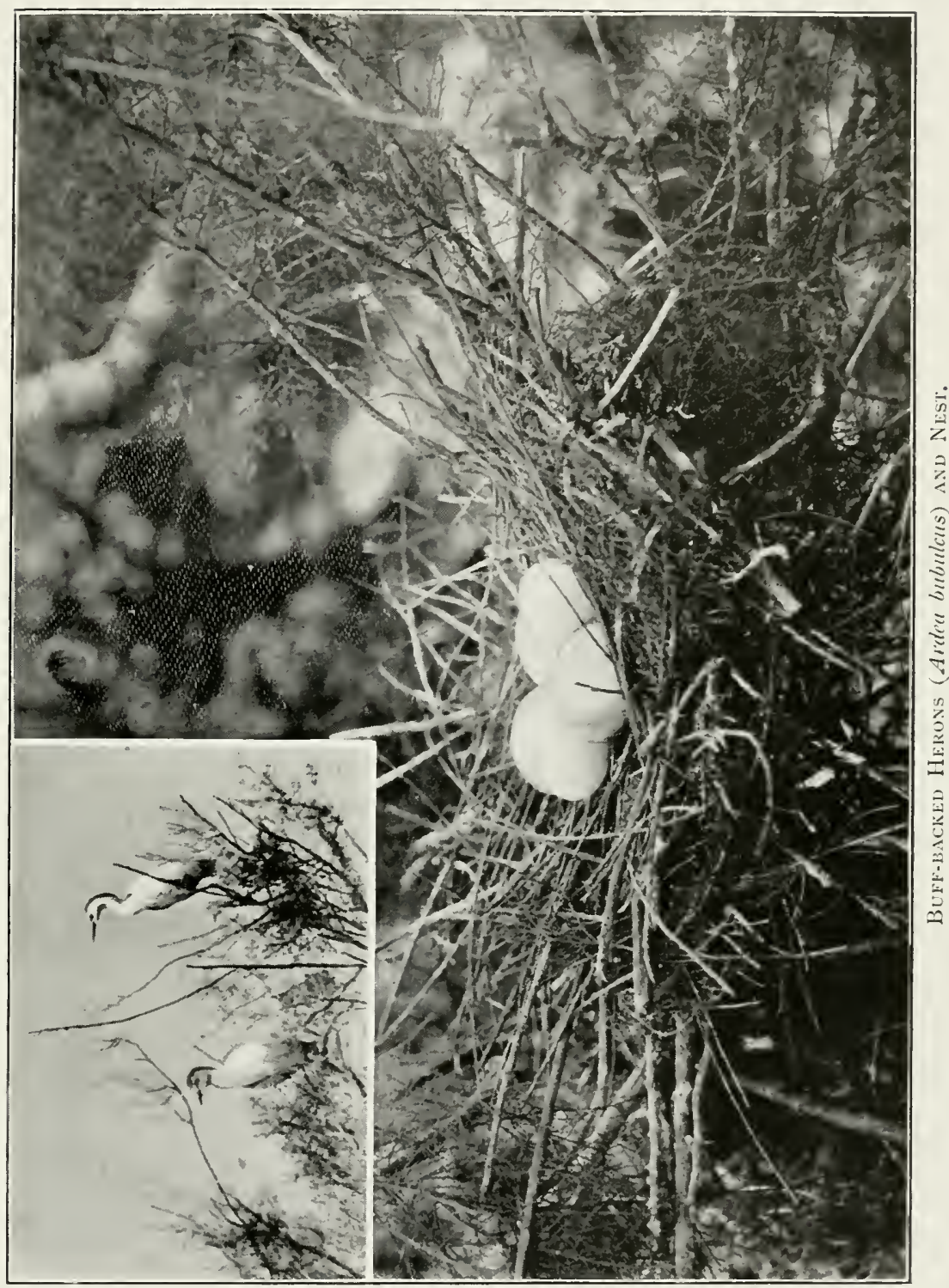


the pretty Buff-backed Herons. 'They feed on ticks and other insect parasites. from which their Spanish name is derived -. Agarrapatosos" ('Tick-eaters). Besides these. we saw plenty of Storks. Ibises. I ittle Egrets. and Purple Herons.

For the last hour or so of our jommey we had seen in firont of us orer the marsh a large white house, surrounded by a few trees. This prored to be our destination. The house, like all Spanish houses. is built in a square. enclosing a large open space. or ". patio." 'The entrance was a large arched doorway, high enough and wide enough, when the thick and massive double doors, studded with iron bolts. are thrown back. to allow three mounted men to ride in abreast without stooping. A camp-bed was soon umpacked from the long-suffering mule, and rigged up in an upper room, and the baggage (amried up), and presently a hot meal and a wash made things seem comfortable.

'The house is in an ideal position for ornithological work. on the rery edge of the " matrisma." where it first begins inperceptibly to merge into dry land. Behind are sanddunes, pine- and rork-woods, and vast heather-covered wastes. From my window erely erening I could see the flocks of Egrets and Herons wend their homeward Hight, followed by strings of (ilossy Ibis. looking intensely black against the glow of the sunset sky. Erery night I was sercuaded by a pair of Bam-owls, which often sat on the balcony outside my window. Their mucamy cries could be heard far into the night. together with the cat-like mew of one 
of the smaller Owls I think a Scops-owl. In the early mornings the first sound to greet my ears was the fimilial (hatter of Starlings. 'These. howerer, are not our English Starling (Stmrmus rolgaris), but the unspotted Sardinian Starling (S. unicolor). which have a very glossy appearance in the bright sunshine: otherwise their habits. nest, and eggs seem to be identical with those of our well-known bird.

Each morning we used to start off" at about eight o'clock: myself. the guarda-mayor. Augustin, and another guarda. Mamucle. on horseback. with Benitez on the mule "el mulo maldito," als he used to call it-in whose capacious packs were stored away cameras, plates. water-bottles. wine. food, and wading-trousers, together with two large baskets for eggrs.

It is impossible to get along without horses, and it was a novel and not unpleasant experience to go birdnesting thus mounted. Sometimes for miles we rode through water from six inches to three feet deep. In the dry plains the bushes were too thick and high to permit of our penetrating far afoot. The bracken and heather grow to a height unknown in England, and the numerous muddy reeks and swamps would have been impassable without horses. These are small. wiry. and unkempt-looking beasts, on which one sits perched up high on a peaked Spanish saddle corered with sheepskin. and provided with stirmps like huge triangular iron boxes. The bits are anel and very powerful. and have to be carefully used by strangers. My horse would always go off' full gallop every time the slightest 
pressure was put on the bridle. 'The rery first time of mounting him. on taking up the reins he stanted buck-jumping. and tearing round as hard as he could go: and the harder I pulled the faster he went. Benite\%, perched on his mule. shouted to nue in Spanish: but I was too murch occupied to understand him. until presently I began to realise that he meant me to slack off the pressure on the bit. On my doing so the beast quieted down directly and went anl right. But if ever he stmmbled orer the rough smm-baked mud, and I tried to pick him up with the bridle an instinctive habit I could never break myself of he would invariably go off' at full gallop as hard as he could pelt; and I daily expected to get my neck broken in one of these wild outbursts orer hard mud, punched into inmumerable decp holes, where the artle had trodden it when wet and soft. lint all Spanish horses are wonderfully surefooted, and we never (anne to grief', howerer dangerous the ground. 'The finish up of every day's work was a race home with Augustin, as soon as the house became visible and the ground fairly lerel. In these races my horse invariably came in first, and the pace he could go over any description of ground was astonishing.

For tree work being mounted is a decided adrantage. Standing on the saddle enables one to investigate many holes which would otherwise only hare been reached by climbing, and would often bring one within reach of a branch if the tree had to be ascended. and eren if there were no branch the height thus gained made a good start. On 


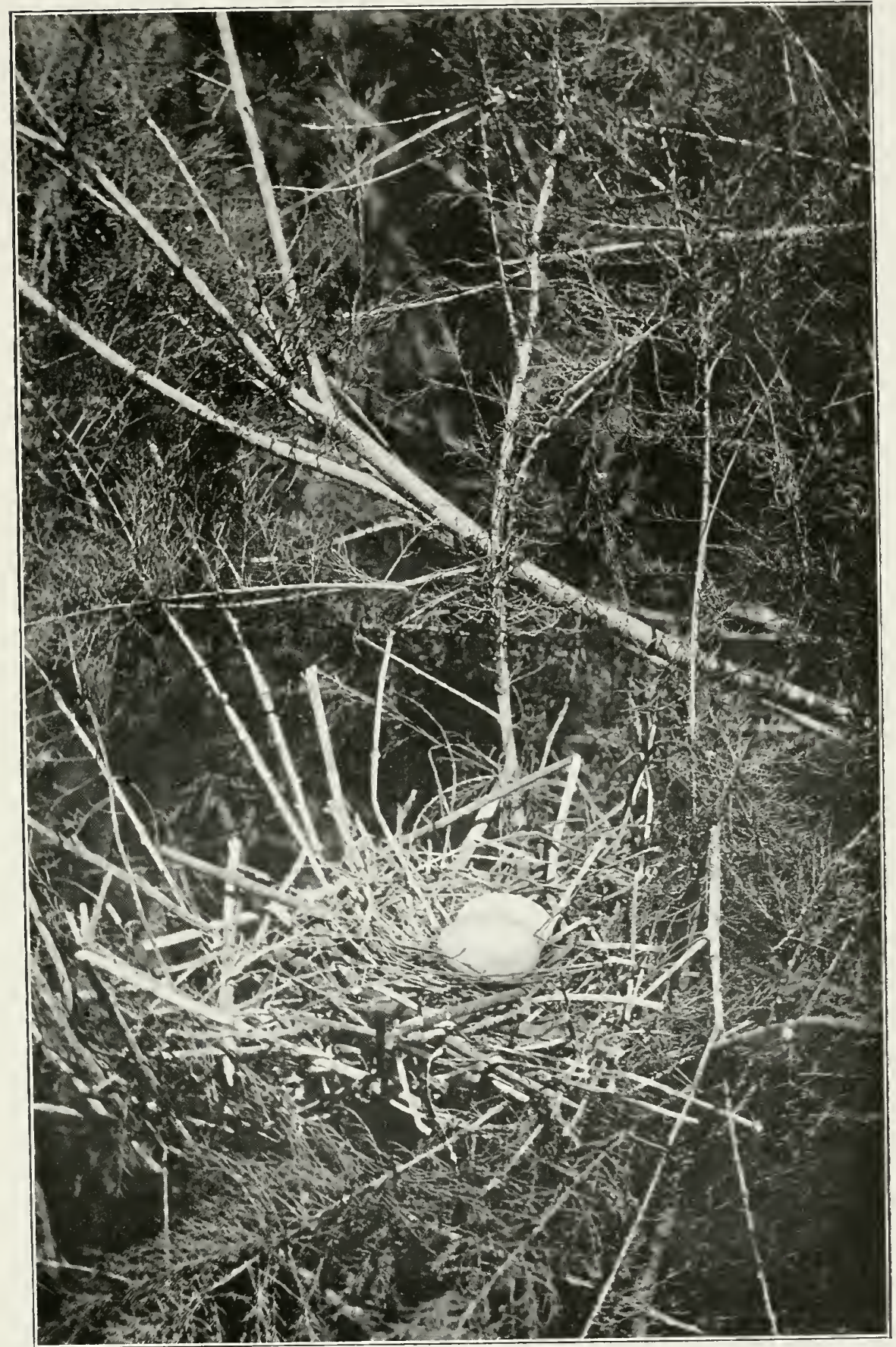

Nest of Night-heron (Nycticorar griseus). 
coming down I always found the horse where I had left him. so that I could slip into the saddle and ride off to the next one: while eggs eould be picked up from shallow water, and even fiom level ground. without the trouble of dismounting.

On one occasion, while standing on my saddle to peer into a large hole in a cork-tree, I saw in it two Bamowls. which were standing side by side in their usual sedate and contemplative attitudes. One of them Happed out in my face, and the other was grabbed before it could make its escape. 'There was no nest. nor any sign of eggs. and ny captive was soon released. Soon afterwards another Barn-owl flew firom a hole at the end of a broken branch. in which we found freshly hatched youmg, clad in pure white down. The Barn-owl (*Isechuza") is very much disliked by Spaniards. who view it with the same superstitious alarm with which it is regarded by the ignorant of most European mations.

'The old cork-trees were nearly always full of holes. which serve as comrenient nesting-places for numerous Jackdaws. Rollers, and three different speeies of Owl. Enderneath the soft spongr bark the wood is intensely lard, but in spite of this the Spanish Green Woodpecker (Gecimus sharpii) bores large holes down into the interior.

IVe never succeeded in getting eggs of this $1{ }^{\prime}$ oodpecker. though they are exceedingly common. hut twice found their holes occupied by Little Owls. In one were four egg's, and in the other we caught the old bird. which was reluctant 
to leave her freshly hatched young. After replacing the youngsters and releasing her, she at once scrambled in after them again. I have since often wished I had kept these quaint-looking little objects - the whole fimily, in fact. Owls are rery easily reared and kept in confinement, and I have had several kinds at different times, and found them rery amusing. The odd contortions and grotesque poses of the Little Owl are above all irresistibly fumny.

Soon afterwards a Roller was seen to leave a hole in another cork-tree; but we were quite mable to make any impression with any tools in our possession, and were in consequence unable to reach the eggs. 'These birds tumble about in the air and behave in a most extraordinary manner. making the whole time an indescribable racket. 'The first one I saw puzzled me: to all appearance the bird was stark staring mad.

Birds of all sorts are always to be found in numbers round these old cork-trees. One group of magnificent trees, under whose welcome shade we had stopped to lunch. was. I remember, fairly alive with birds. Many Little Owls Hew from the numerous holes and carities: Woodpeckers were to be seen, as we rode up, climbing nimbly all orer the great gnarled and twisted branches: and a large colony of Jackdaws were busy nesting. We found many nests full of eggs: one of them being among the roots underground. Among these trees the only Hoopoe and the only Great Spotted Cuckoo seen during my risit were observed. The former appeared to have left a small round hole about 
thinty feet up one of the smaller trees. but on climbing to it there was no appearance of any nest.

Soon after starting on our first day a colony of Spoonbills were seen nesting among the reeds about fifty yards fiom the shore in a lagoon. 'The white plumage of the

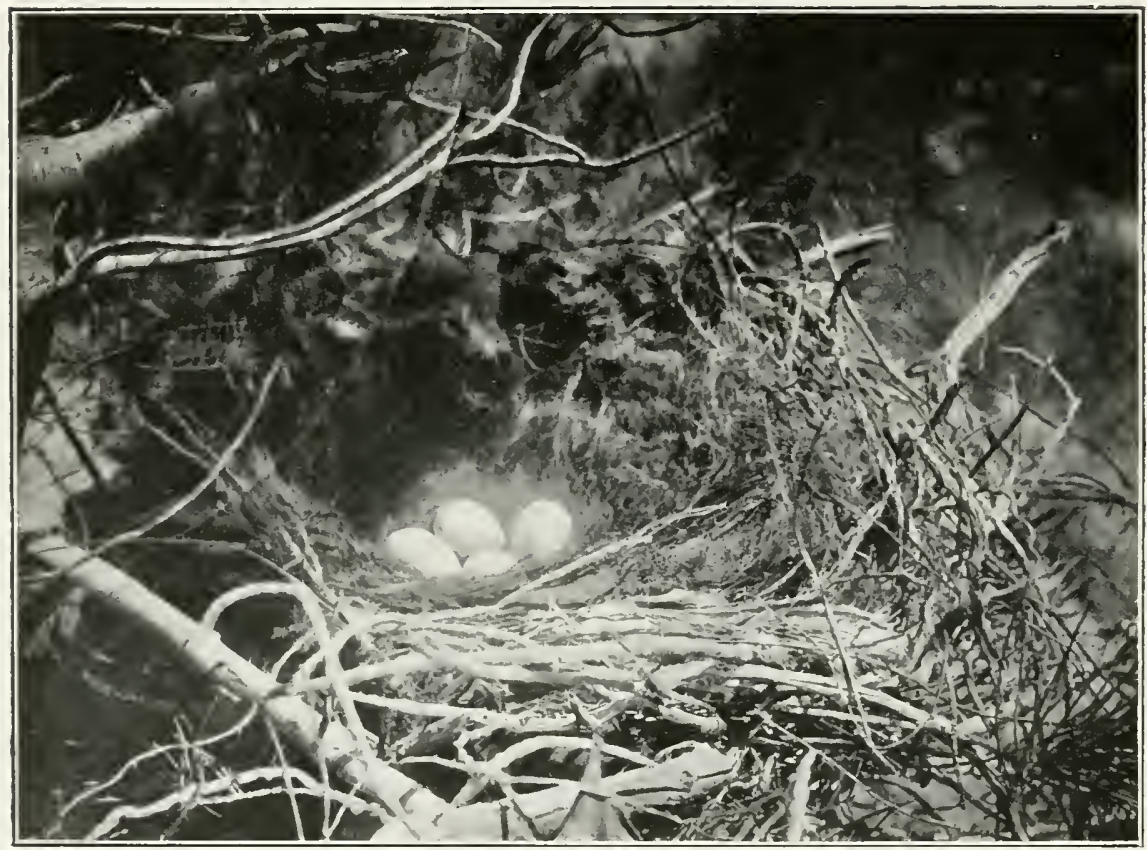

Nest of Ravex (Corints corarr).

birds could be seen through the thick growth. as we rode along the edge of the water. One of the men was sent round for a punt not far away, while we dismomnted and hobbled the horses. By the time the amera had been got ready and wading-trousers got into. Mammele had arrived with a rickety. flat-bottomed affair. called a . lancha." in which 
I was paddled orer to the nests with some difficulty. 'There were about a dozen, of exactly similar appearance and construction to those I had seen in Holland, Hat, rough platforms of dry yellow recds and sticks, just raised above the surface of the water, which was rather deep quite four feet. Fach nest contained egges. two. therec or four in number, which varied considerably in shape, some being very rounded, and others. again. remarkably elongated.

I was soon orerboard, and astonished Manuele considerably by telling him in Spanish.

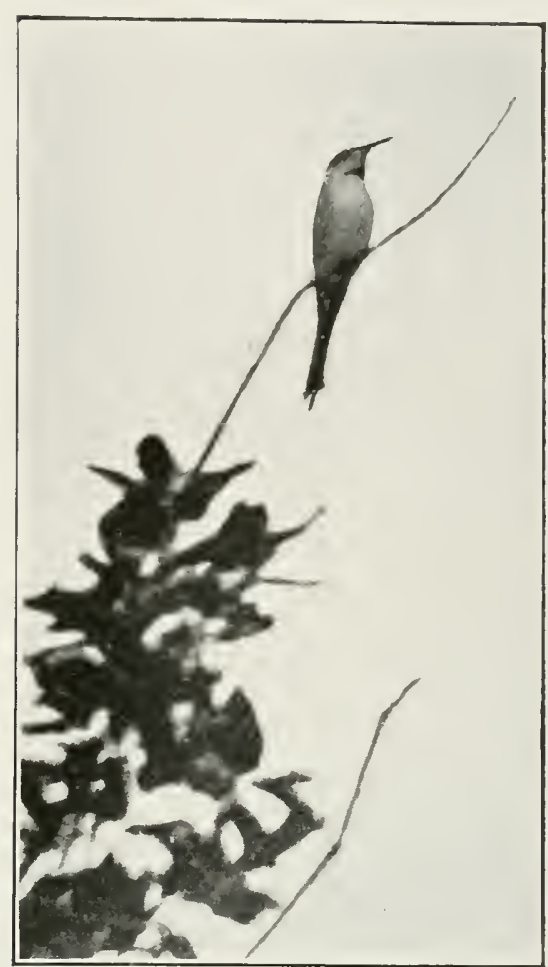

BeE-EATER (.herups apiaster) ON TOPMOST TWIG OF A CORK-TREF. as well as I was able, to go away. but had the usual difficulty in making him understand that I wanted him to go right away out of sight and hearing. I was most anxious to photograph one of these birds at its nest. and it was obviously useless for me to hide up while he was pottering about in a punt within sight of them all. Howerer. at last he was made to understand what I really wanted. and he departed, very unwillingly. being, I dare say, very doubtful of my intentions. 
As soon as he had really gone. after cutting down some of the reeds round the most exposed nests. which were utilised in making a screen to hide myself and the camera. I waited as patiently as I could. standing in the water and crouching behind my improvised shelter for about three or four hours. All this time the Spoonbills flew round and round orerhead. At first their circles were rery wide and high in the air: but gradually they came closer and closer. and lower and lower still. till presently they were skimming along just oree the reeds. and. when passing their nests, would drop their legs. as if going to alight. But their minds would misgive them. and round they would go once more.

At last. howerer. first one and then another actually alighted, until I could see seren or eight Spoonbills standing on their nests all round me. their arests waring in the wind. and their orange gorgets plainly visible. Between us. howerer. were too many reeds waring about in the wind to make a successful photograph possible. 'The birds which belonged to the nest I was waiting for obstinately refiused to alight. being evidently suspicious of the clearing I had made: and. after waiting so long. part of the time in a heary rainstorm. I was eventually obliged to give it up and signal for the punt.

IThile waiting in ambush here. a P'uple Heron had been noticed in an isolated (Chmp) of tall rushes at a little distance. The water was too deep to permit of approaching it until the ampival of the " lancha." when we found there a nest and five egors. 
On returning to dry land, we found Benite and Augustin hard at work blowing a large basketful of l'urple Herons' and Coots" egges.

Leaving the Spoonbills, an hour's further ride orer an endless succession of sand-dunes brought us in sight of another lagoon. surrounded on all sides by sand. which appeared to be gradually filling up the water. As our cavalcade rode up, some low tamarisk-bushes, growing thickly massed together in the water, were seen to be crowded with immense numbers of white birds, which, as we approached. rose into the air in dense clouds. circling round with a great deal of noisy clanour and confusion. It was a most extraordinary and interesting sight: and I realised that in front of us was a breeding colony of the Southern Herons. which are such a characteristic feature in the bird life of this aquatic region.

There were Buff-backed Herons in thousands. These alone were well worth the journey to see. for they breed nowhere else in Europe: and with them were countless numbers of the lovely and graceful I ittle Egrets. which have suffered so much persecution on aceount of their beautiful plumes, the demand for which has almost exterminated them in more accessible localities.

Squacero Herons were not so numerous, though I did see a few of these beautiful little birds: and there was quite a goodly number of Night-herons and Glossy Ibis.

Seebohm's most graphic description of a somewhat similar nesting colony on the Danube came into my mind as I gazed on the anmated scene before me. and I appreciated then, 
more eren than I had before, the truth and power of his descriptions.

'The horses were off'-saddled, and I was soon in the wader's

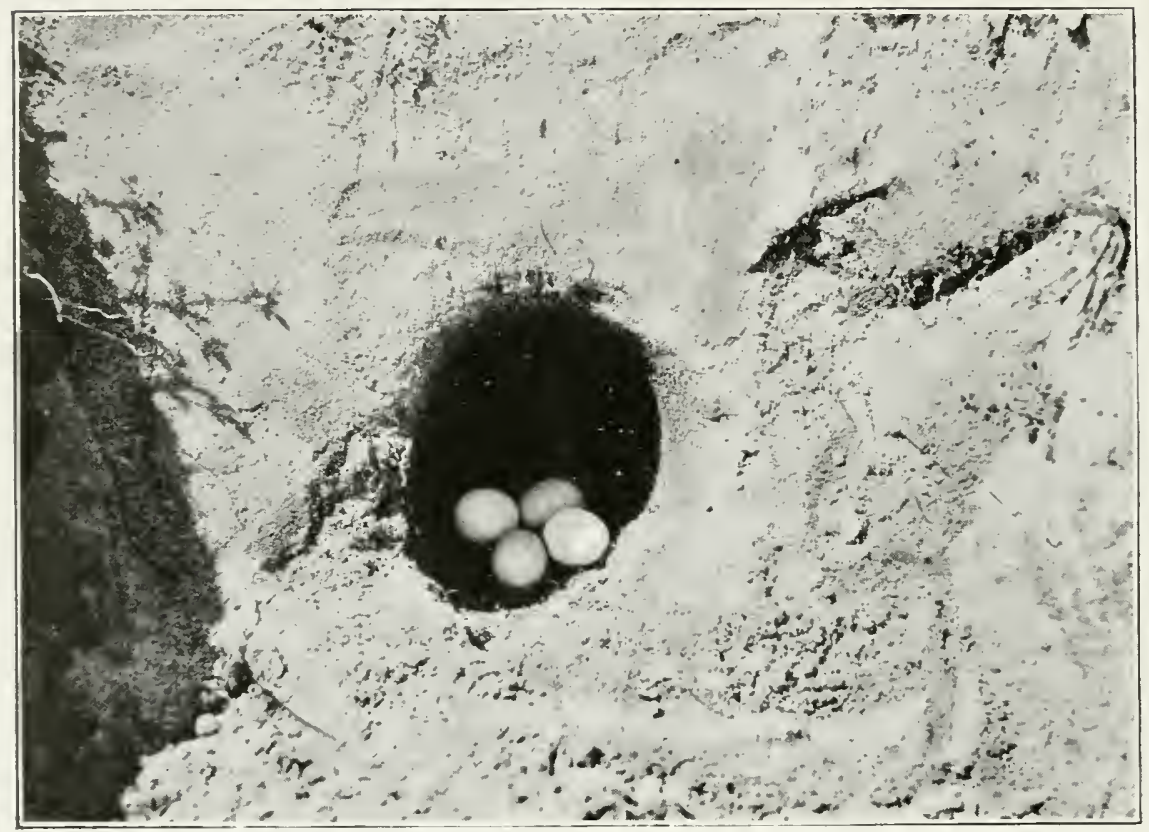

Exd of Bee-ejter's Nestixg Burrow (Merops apiaster).

and hard at work photographing the birds, as they elustered thickly on the topmost twigs of the bushes in all sorts of grotesque and curious attitudes. As soon as one bird lad grasped a slendel twig in its awkward-looking teet, and while still struggling to preserve its balance in the high wind, another one would fly up and knock it off. only itself to be ousted by a third a moment afterwards. ()thers were constantly flying round and attempting to settle, and 
each individual bird added its quota to the unceasing babel of extraordinary croaks, grunts, and groans with which all the IIeron family express themselves. The sand-dunes around were also thickly covered with masses of birds, which would every now and then again rise and circle round and round, protesting with all their might aganinst our intrusion into their own particular domain. 'The bushes were full of their nests-mere slight platforms of sticksbut there were as yet no eggrs.

My work on this first day came to a most mintimely end: for learing the camera on its tripod in the water, while I went ashore for a fresh supply of plates, during my

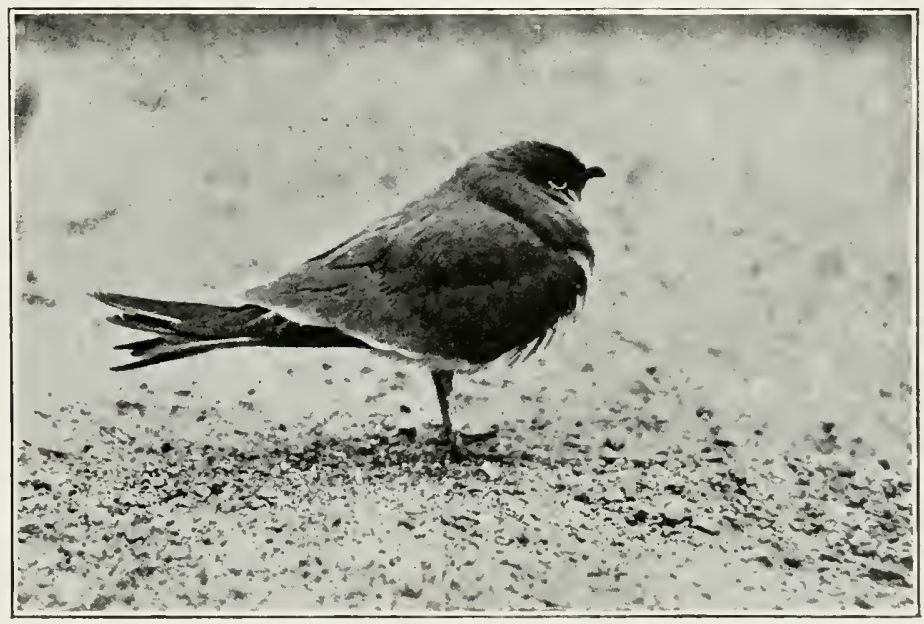

PRAtincole (Glareolet pratincola).

absence it blew over into nearly four feet of water. Trying to raise it. I got my bag of dark-slides wet: and. in consequence. every plate I had exposed was wasted. 'T'he gelatine 
films swelled with the wet, so that I had to smash the plates into pieees before I could get them out of the slides. Wre had a long ride home that day in a complete state of saturation.

However, I had two more days work in this lagoon, and obtained photographs of most of the birds and their nests.

On May 5th we took plenty of eggs of the Buff-backed IIerons and Furets. and by the sth the Night-herons, Squaccos, and Gilossy Ibises had laid.

These last birds had an intensely black and fimereal aspect annid the throngs of whiter birds. I do not know whether their Spanish name, ". Morito," has anything to do with this idea. It always struck me as being possibly derived from mor (death). It would certainly be appropriate, though in reality there is no black at all in their plumage, which is altogether glossy green and brown. 'They are birds of extremely powerful Hight; the noise made by the wings of quite a small party of them when flying past is perfectly astonishing. 'They lay eggs of a very dark greenish-blue colour, which have a somewhat pointed shape.

'The eggs of all this group are easily distinguishable one from another, though they are all of different shades of blue. 'Those of the Buff-backed Heroms are pale in colour, and rounded, while the I ittle Egrets lay eggs pointed at both ends. They are, besides, smaller and somewhat darker. 'The Night-heron's are also elongated and rery pointed, more so even than the Egret's, but are much larger in size, and as pale in colour as the first named. 'The 


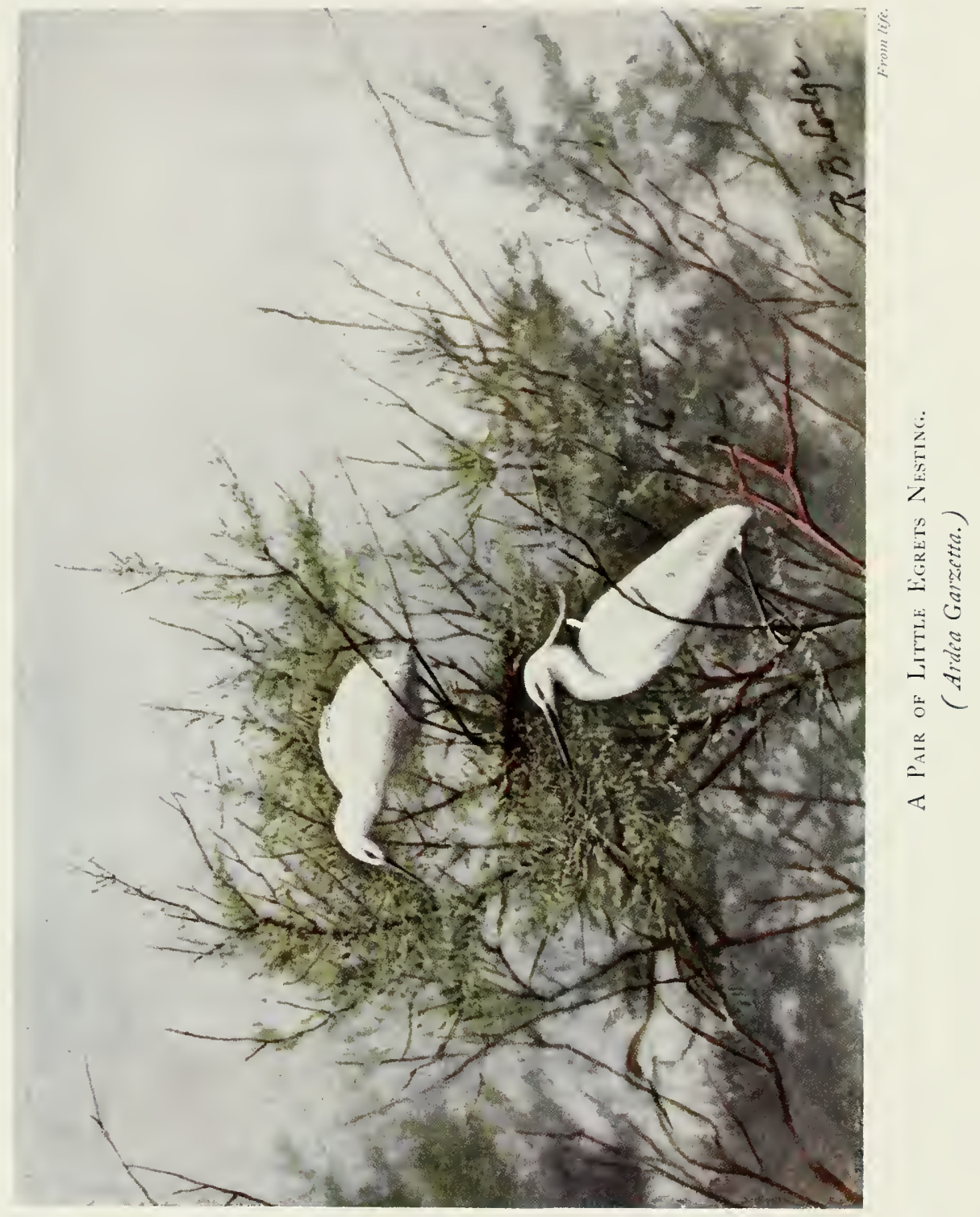



Squacco's eggs are pale. rery round, and by far the smallest of them all.

We were not fortunate enough to find any nests of the Bittern ("Ave toro") or the Little lBittern, both of which are common enough. Plenty of Mallards and coots were observed while we were at this heronry, and a Little Grebe wals also seen. The loud song of a Great Reed-warbler also claimed our attention, but a thorough search among the reeds failed to find any nests. In fact. nowhere in Spain did we find a nest of this common $\mathbf{W}$ arbler. the reason probably being that they nest later. They are certainly late breeders in Holland, and our own Reed-warbler always seems to me to wait until the reeds have well grown up before it begins to make its beantiful home.

No account of this district would be complete without a mention of the sand-dunes, which are such a striking feature of the country. They appear to be encroaching fast on the forests and lagoons, the fine particles carried by the wind filling up the latter and burying the former.

On the dazzling surface only broken by tall tufts of seapinks and the yellow-spangled cistus-bushes. are many tracks of various birds and animals. The curious footprints of the Stone-plorer, or Thick-knee. are very numerous. and sereral clutches of eggs were found on the bare sand. Here is the slot of a passing red deer, and the curions track of the lizard, and there the serpentine trail of a snake. One mark puzrled us for a long time, until an accident revealed its origin. It looked as if some animal with many fect 
had passed orer the loose surface: but the sight one day of a large pine-cone being rolled along by the wind plainly revealed the anuse of the mysterious track.

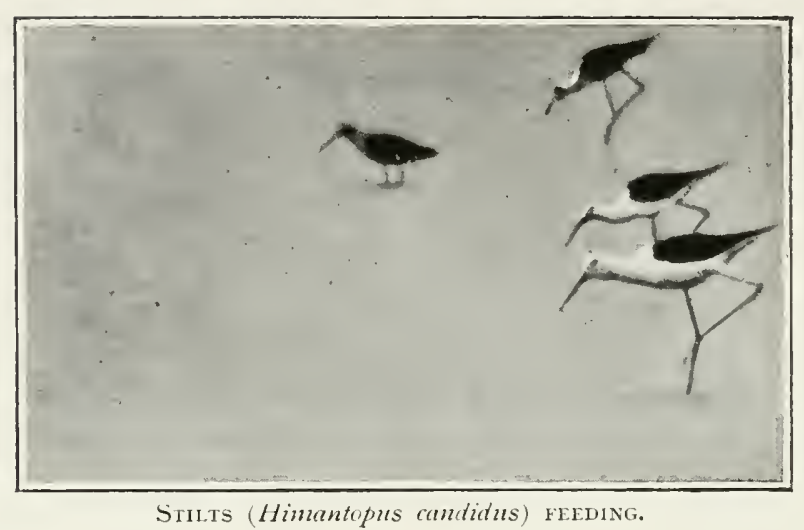

These pine-cones, by-the-bye, are largely used as fuel in some parts. Large piles of them may be seen exposed for sale in the market-place of Corunia, and doubtless in other places also. In one hollow among the dunes the surface of the sand was covered with pieces of broken pottery, most of which appeared to have been rudely engrared. A short search resulted in the finding of five bronze coins. very much abraded and corroded. One of them showed the impression of a head and some letters of an inscription. and all were apparently Roman. The most curious feature about these dunes is the extraordinarily abrupt fashion in which they terminate and hang suspended, as it were, orer the country below.

The foot of the steep slope of sand may reach. perhaps. for a foot or a couple of feet up the stem of a pine-tree, while half-way up other trees are seen to be buried up to half their height and some only have the top branches visible: these show by their green foliage that they are still alive 
and struggling for existence in the death-like grip of the all-deroming sand. A few more years and their dead branches will protrude in the midst of a sandy desert, withered and bleached with exposure until they are finally engulfed and lost completely to sight. If in finture ages this covering of sand should be removed, the sight would be rery weird and curious, and would no doubt afford endless speculation and give rise to many ingenions theories among the learned of those days.

In one of the pine-trees at the foot of one of these threatening slopes we found a Raven's nest. 'This was at the summit of the tree and strongly compacted of sticks, and the deep hollow rery thickly and comfortably lined with red cow-hair. It contained five eggs, as did also another nest not rery far away. In the same forest was a Stork's nest on the extreme summit of one of the pine-trees. and on it, against the sky, we could plainly see two young birds and both the parents. 'These forest-building Storks are always rery shy, and much more difficult to approach than those which frequent the towns and houses.

There was another nest in a large dead cork-tree not far from the house, which overlooked a small muddy areek or marsh, in which we generally noticed in passing many Storks feeding, and an ocoasional Purple Heron or Figret. Crawling into position one evening, and hiding among the bracken, which was about six feet high. I had the treat of watching a flock of about fifty Storks feeding. 'The great birds solemuly stalked through the shallow pools. feeding 
like a Hock of geese. Sometines two of them would quarrel and spar up to one another with their great red beaks. making a great clattering.

In the midst of a patch of reeds between me and them I saw the long thin neck and the bright eye of a I ittle Eigret looking warily around. as if to make sure there was no danger near. Seeing nothing. it stepped slowly and gracefully into the open, and commenced to feed. But suddenly all the birds looked up. though I could neither see nor hear anything to alarm them. All the Storks took to flight. and the Wgret retired into cover as quietly and noiselessly as he had emerged. The stampede was presently explained by the sight of a mounted herdsman. " garrocha" in hand. homeward bound. A picturesque figure he looked. but a rery umwelcome one to me.

'The herds of cattle are tended throughout the day by mounted herdsmen. armed with a heary iron-tipped club. or with the " garrocha." a kind of short. blunt lance. I never knew the bulls to interfere with amybody. I have often ridden throngh them and walked close past them. carrying the camera. without attracting any unwelcome attentions. But one evening. as Benitez and I were riding home. he pulled up his mule suddenly and motioned me to stop. saving "El toro" (the bull), as a small herd of cows and calves. followed by a magnificent black-and-white bull. crossed the track a few yards in front of us. Whether this particular bull was known to be of a bad character I do not know. but on this occasion. at any rate. he trotted quietly 
after his seraglio without deigning to take the slightest notice of 11 s.

(On the level plains Bee-caters were constantly to be seen. 'Their modns operamdi appears to be something similar to that of the Flycatchers. Instearl of keeping comstantly on the wing like the Swallows, they sit on some bare twign

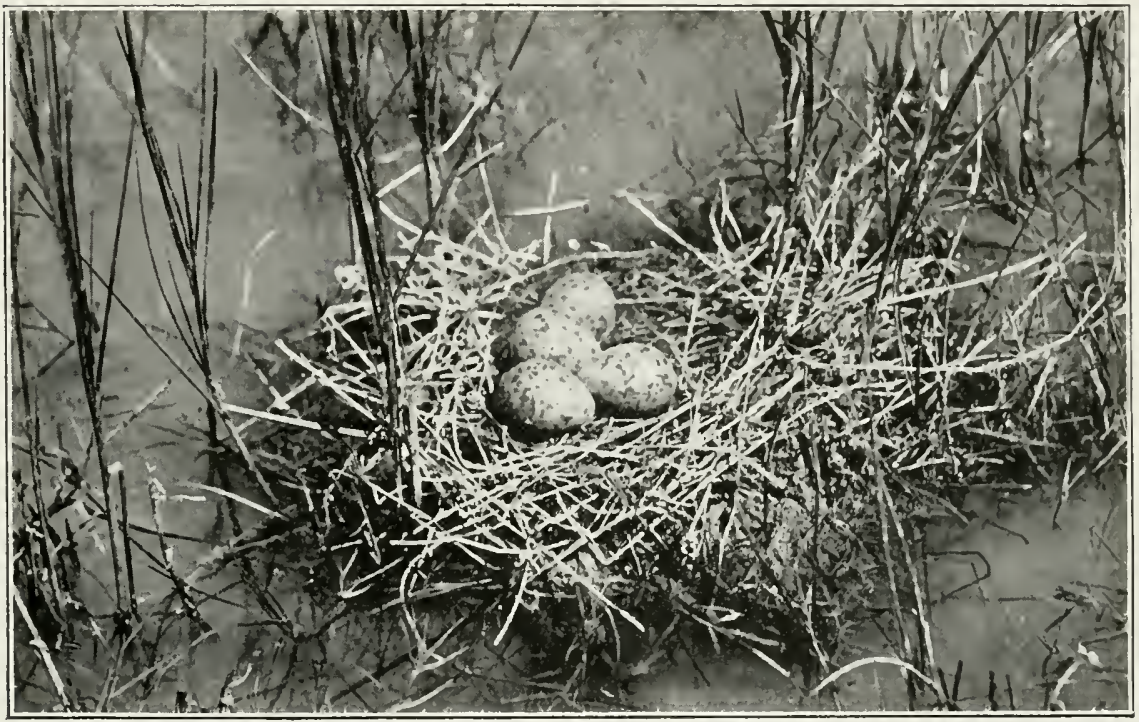

Nest of Stilt (Himantopus candidus).

or branch, on the look-out for passing insects, and dash out after them, retuming either to the same or to some other perch. 'Their burrows are to be found in banks such as at the side of a river or road, and also on the level ground. One day we borrowed a spade from a herdsman's cottage and dug out several holes. 'The soil was a rery light, sandy earth. covered with scanty turf. 'l'he burrows were 
about four feet long: and the egg-chamber--for they make no nest. but lay four round. shining white eggs on the earth at the end of the hole-was generally about two feet below the surface. 'The holes may be easily found by the heap of freshly excarated soil at the entrance, from the anomint of which a rough guess may be made of the length of the hole, and whether it is worth digging out. 'Three or four of the birds were caught in the burrows: two I released: the others, on dissection. proved to be males.

Fincircled by the shallow water of the marismas are mumerous small islets. on which grow sometimes a scanty (rop of thistles and samphire. 'To these desolate spots in the month of May myriads of wading-birds resort to lay their eggs on the baked and sum-dried mud. In such places the Pratincoles deposit their curiously coloured eggs under a tuft of samphire or in the footprint of some horse or ox. 'They are very rounded, and thickly spotted with rich, dark markings, and have an almost velvety appearance. which makes them utterly unlike the eggs of any other bird. 'There is no attempt at any nest.

'These birds have a habit of settling on the ground in front of anybody. While riding. I have known twenty or thirty of them to settle repeatedly in front of my horse, rising with a strange cry on a close approach, and settling again farther on, and repeating the performance over and orer again. On the dried mud they are practically invisible, unless the white chest can be seen. for the upper parts are the exact eolour of the ground. 'The gape of the mouth is a bright sealing- 
wax red. (On May 4th they had just commenced to lay and a few days later we could have taken hundreds of their egogs.

In the tufts of samphire and coarse grass were many Redshanks' nests, and with these there was much more attempt at concealment, the egass being more or less hidden by the canopy of green above them.

In company with the Redshanks were invariably many Stilts. the two species nearly always being found together, both while nesting and feeding. In their habits. too. they are very similar. except that the Stilt is a much quieter bird when breeding. I have seen with them none of the noisy excitement which is so conspicuous when the breedingground of Redshanks is invaded.

The Stilt is a particularly beautiful bird. As Sechohm truly says, "they look the perfection of beanty and grace"; and it was one of the most interesting experiences of this expedition, to watch them rumning orer the mud and watding in the shallow water. 'They were exceedingly numerons I should say the most abundant species in this locality. so prolific of bird life.

On May 3rd, before we had ridden more than a mile, Manuele. who was riding somewhat in advance, pulled up and hailed me with the shout, " Un nido" (a nest). ( )n reaching the spot, I saw my first Stilt's nest. It was a solid construction of tamarisk stalks and small twigs. built up from the bottom of the water. albout ten inches deep. 'This was spangled with numerous delicate white blossoms like water-erowfoot, and thinly grown orer with a spiky 
grass or rush. It held four rery richly coloured eggs, pointed like Redshanks:

After photographing the nest in situ, I attempted to wait for the old bird: but there wass no eover whatever, and I did not succeed-more especially as the three Spanialds were riding about searching for more eggs. I could never

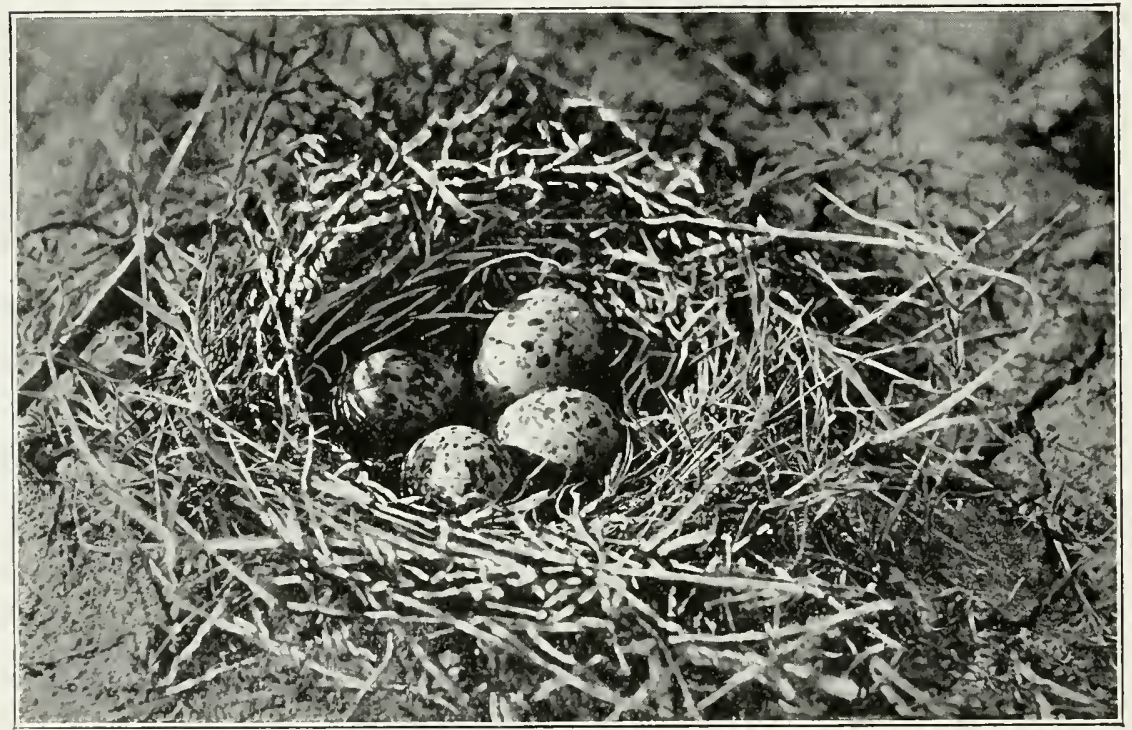

Nest of Situt (Humantopus candielus).

make them molerstand that the photographs were more important than the egoss. 'The egoss were, I suppose, more tangible objects to then, and they were certainly indefatigable in assisting ne to the utmost of their powers.

Curionsly enough, this first nest was the only one secm in the water. All the others-and we found hundreds of then-were on the mud, and the nests were rery much 
slighter. In any small hollow in the sun-cracked surface the birds would make a neat lining with al few stalks. and on these the eggs would be laid. In one we found five eggs, but four was the usual number. The nests were always in small colonies, not necessarily close together, but scattered over a limited area of ground.

The birds are tame and fairly casy to approach. When mounted, you can ride close to them without their showing any alarm: but they do not allow a man on foot to take such liberties. However, if you remain quiet, they do not mind conning quite close.

A male bird dissected by me had in its stomach some green caterpillars. 'The measurements of this bird coincide exactly with those recorded by Gilbert White of one shot near Selborne:

'Total length, beak to tail . $133 \frac{1}{2}$ inches.

Beak

Bare part of tibia

T'ursus

Frequently, when exploring this waste of waters, we would come on a colony of Whiskered and Black Terms, nesting in company together. Overhead the birds wonld gyrate, with the harsh scolding remonstrance usual with all the 'íms under similar circumstances. Seen thus from below, the Whiskered 'Tern appears of a peculiar leaden tinge.

'Their nests are very slight, mere floating rafts of green 
rushes, laid flat on the water, so that the eggs are half awash. 'These are of a decided green colour, rery darkly and richly spotted: and rery pretty they look on their green raft. surromded by the white crowfoot blossoms. 'Three eggs are laid. The colour tades very much after the egos have been blown and kept a short tine.

I dissected one male bird, and found in it an entire green caterpillar, two inches long, and the remains of another' one. 'The irides of this bird were brown, the legs and feet dark red.

'The nests of the Black 'Tems, which were not nearly so numerous as those of the larger species, were much more solidly and substantially made. built up firom the bottom, and rising higher above the surface of the water.

Both the Caspian and Gull-billed 'Terns are recorded as nesting in Spain, but no nests of either were met with.

Arocets, thomgln they had been so numerous on the Guadalquivir, were not met with at any distance away from its banks, and appear to nest later than the other species. I particularly enjoyed the opportunity of renewing acoumintance with this (hamming wader, the most elegant of an elegant family. whose dainty ways, graceful attitudes, and beantiful phumage I had so much admired on my risit to Holland the previous year.

While feeding on the mud-flats of the Guadalquivir, we found Aroeets very tame and easy to approach. In the small electric lannch belonging to the yacht we could almost get near enough to touch them with a boat-hook, as they ran 


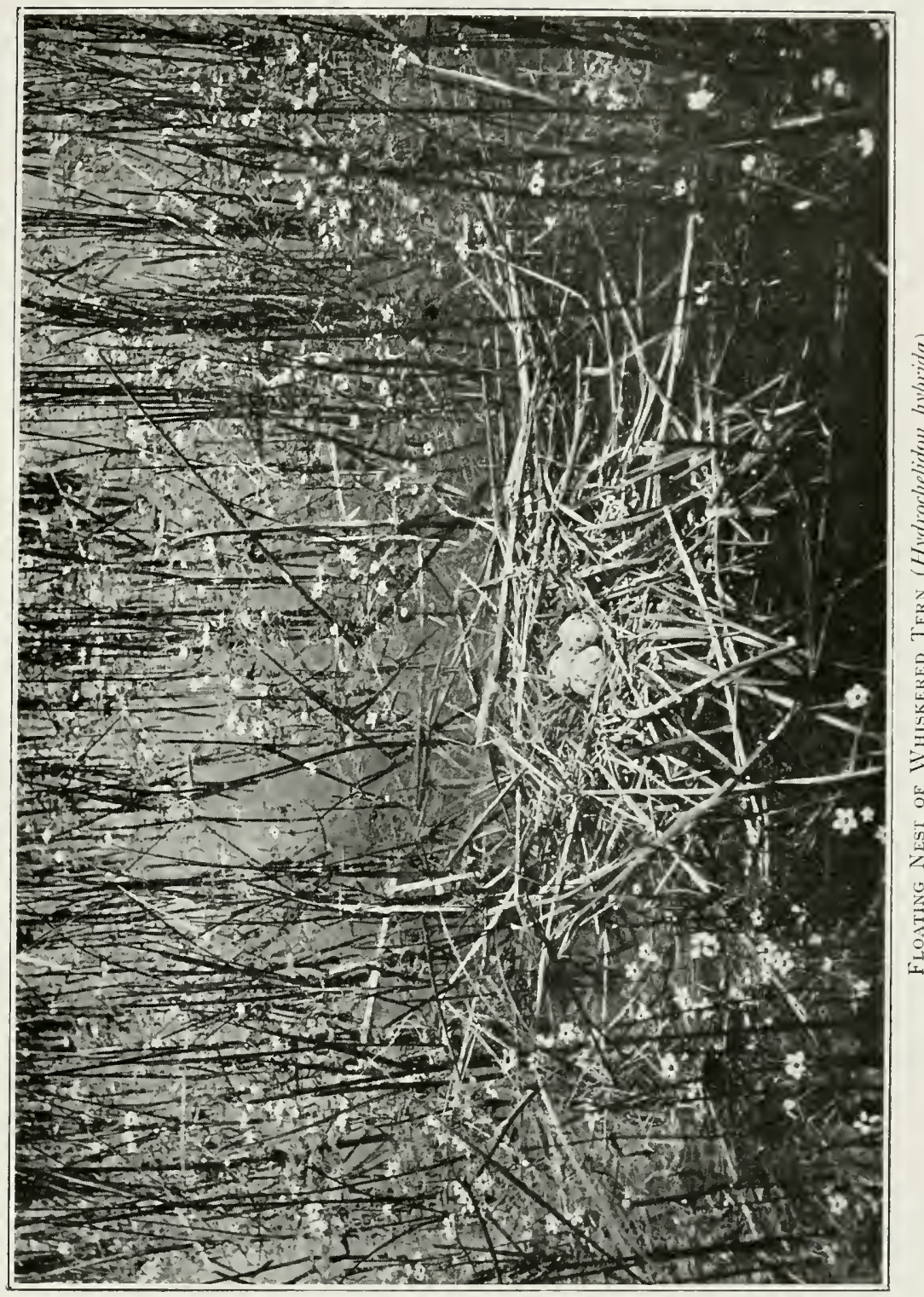


orer the shining surface of the tidal ooze. We noticed that they eonstantly hop about on one leg. as if lame.

Intil the close of our stay there appeared to be no indications of their having begun to nest. In fact, not before May 15th, the very last day I set foot in Spain, did we find any of their eggs; and then it was quite at the end of a long day's search that Benite ealled out to me that he lad at last found a nest. 'There were altogether, in this spot of quite a limited area, abont a dozen nests. Most of them were made of the beautiful rosy feathers of the Flamingoes. A large flock of these birds had been feeding elose to the spot, and numbers of their feathers were lying about and floating on the water. 'This beautiful and mique nesting material gave them a rery striking and effective appearance.

Only one nest contained four eggs, which was the usual clutch in the Duteh nests: the rest of them held but three. 'The eggs are somewhat larger than those of the Stilt and Redshank, and are of a duller clay colour. Numbers of the birds were wading in every direction, but were not so easy of approach as those on the river-banks. and I did not do much good with them.

'The Flaningoes we had seen in the morning: but these long-legged and long-necked fowl are exceedingly difficult to approach. Wading slowly, in a crouching attitude. and holding the muffled camnera in front, so as to appear as little human as possible, I found it a matter of difficulty to get within two hundred yards of their ranks. Any attempt to 


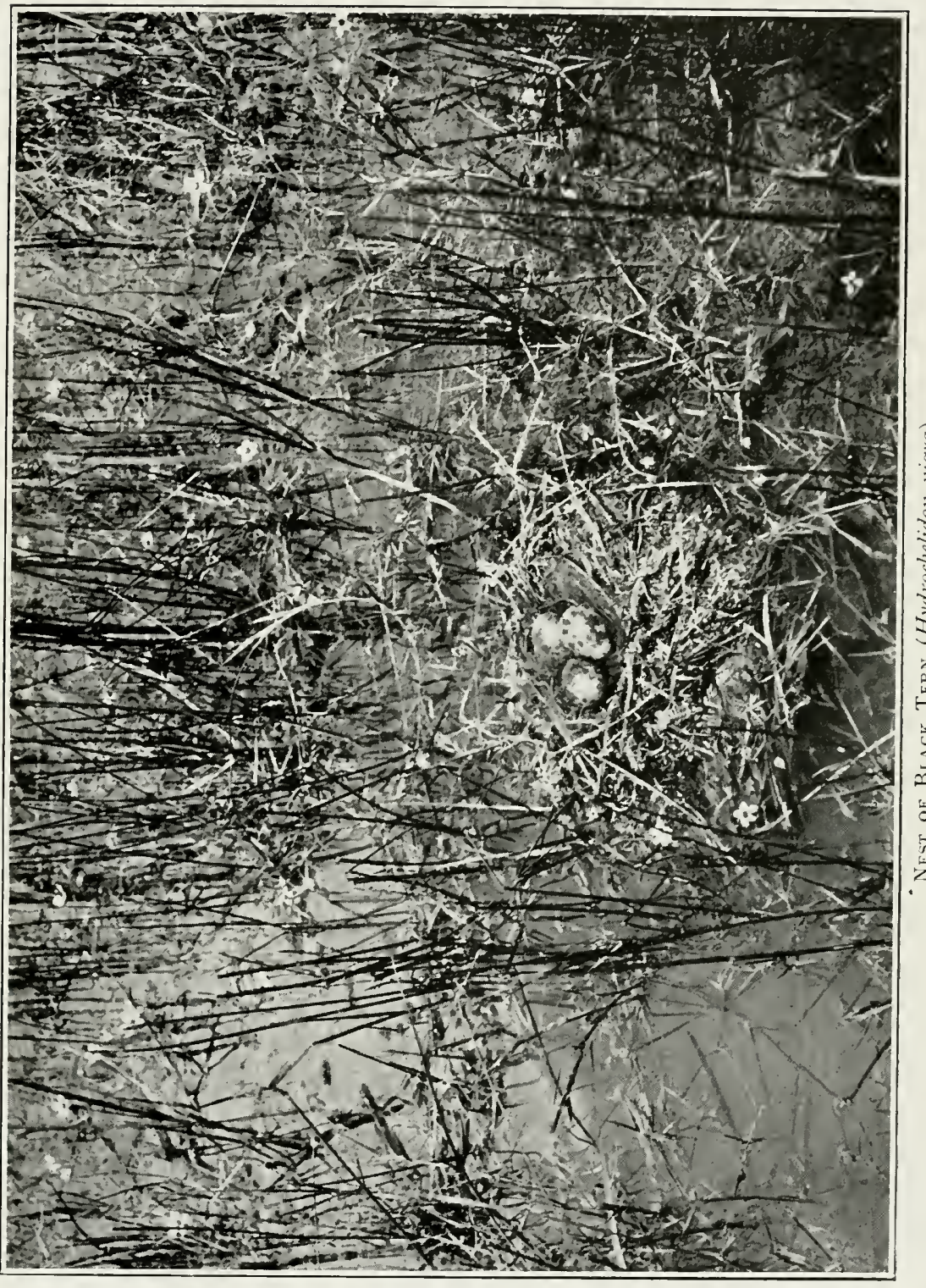


decrease this distance invariably disturbed them. and after the second such disturbance they left the place altogether. It was a fine sight to see their serried lines break up in confusion. with much flapping of thousands of scarlet wings. and a great uproar of gagging roices.

( )ne of the ambitions of the trip had been to photograph a Flamingo on its nest. but this was doomed to disappointment. No sign of any nest did we see in the whole of the immense district explored by us. The place where they were net with was merely a feeding-place: and if they were nesting at all. it was certainly at a great distance possibly on the islands where the Guadalquivir divides its chammels. Isla Menor or Isla Mayor. 'They are. howerer. always rery late nesters. Chapman. who was the first to describe the bird's real nesting habits from personal observation. gives the end of .Jume. and says that in some rears they do not breed in Spain at all.

Vultures also were not net with so frequently as I had expected. 'The (iriffon breeds exclusirely in the sicras. but none were seen while on the wing in search of food. in which search they range orer an immense area at a high altitude. until a carcase is discorered. when the descent of one hird becomes the signal to all the other Vultures within sight. The ligyptian Vulture was often seen. but not at rery close quaters.

(O) the wing this bird looks rery gland. and its power of Hight is superb. Once I stalked one on the gromed. using the pack-mule as a "stalking-horse": but the shutter of 
my camela had become rusted from its haring been blown over into the water while photographing Herons, and I was mable to work it. While tinkering at it, the bird Hew off slowly. and settled on a dead tree at a short distance. After a long and careful stalk through the brushwood, it took alarm long before anything like a close enough approach

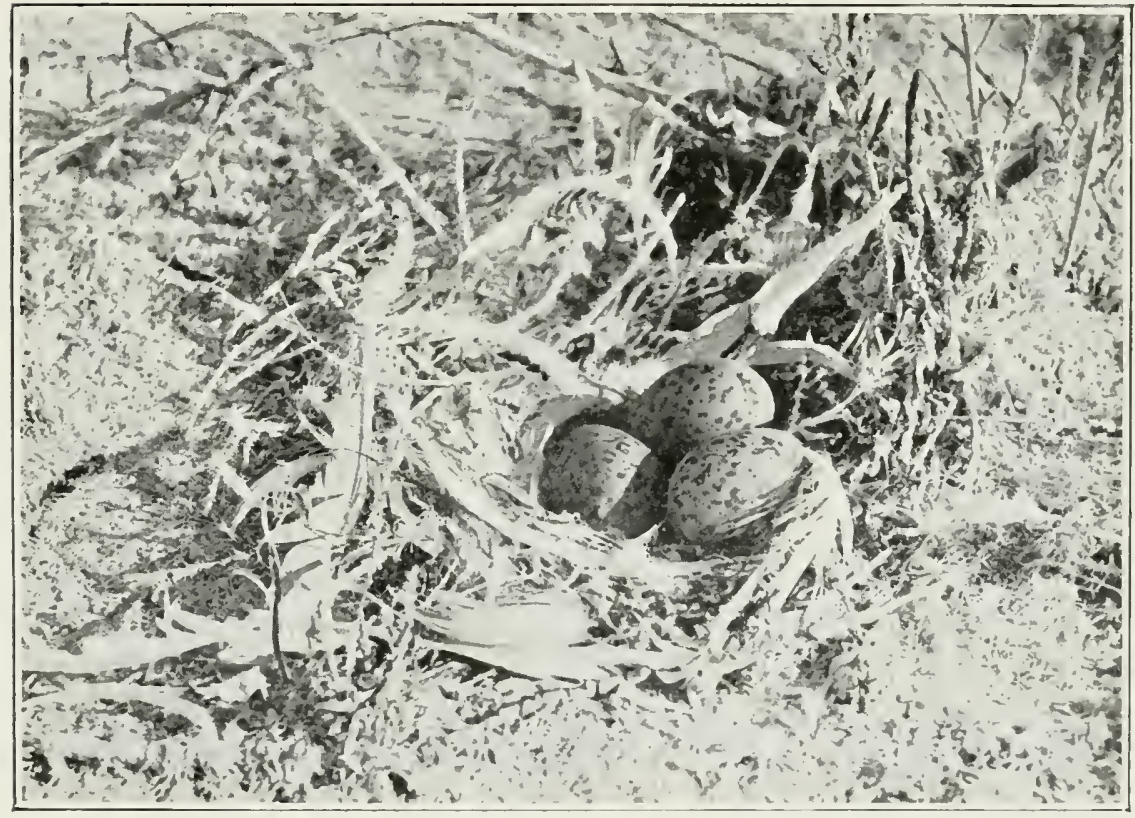

Nest of Avocet (Recurvirostra avocetta) MAdE of Flamingoes' Feathers.

had been made: and. to my surprise, it was followed by serenteen others, which had been in the same tree. but invisible through the bushes. This was the most intimate acquaintance made with the Vultures during the whole of our risit-much to my disappointment: for these large birds, despite their repulsive labits, are. by their size and 
their pieturesque appearance, interesting subjects for the camera.

The hope of an opportunity of visiting some of the breeding-places of both Griffons and Egyptian Vultures was not realised, though both species breed in the sierras not far from Gibraltar.

The Harriers, too, were a failure, though the sight of an "Aguilucho" was a daily ocemrence. 'Though always on the look-out for a nest, and systematically beating through in line several likely looking swamps, we never succeeded in finding one. If at any time we marked down a bird, it was only to find it had been regaling itself on Purple Herons' or Coots' eggess.

In fact, none of the larger Hawks or raptorial birds were found breeding. though we did get several clutches of Kestrels' eggs from old Kites' nests. or rather what we took to be Kestrels'. 'The birds, howerer. were not seen: and on comparison with eggs of Kestrels taken in England. these eggs are decidedly smaller, and rery round-some exeedingly richly coloured, and other's blotehed with reddish orer a pale gromud-colour. 'They hare been pronounced not to be I esser Kestrels' by a competent authority. Possibly they are Hobbies: but, in the absence of identification of the birds, they are not of much value or interest.

I pair of Peregrines were subsequently seen apparently breeding in the cliff's near Coruna, though no nest could be found. I Kestrel was also disturbed from a hole in the cliff-ficce, which contained bones and pellets. These 


\section{Bird Life in the Spanish Marismas}

cliff's would doubtless have rewarded a better and more prolonged seareh if we had had more time to spare. As it was. we only put in for two or three days on our run home after leaving Lisbon.

In Lisbon we saw nothing ornithologically interesting. A few Kites hovering over the 'T'agus, and an apparently wild Stork in the Zoological Gardens, which flew down and began to walk about the paths close to us in a most familiar manner, were the only things seen.

The end of this most enjoyable expedition came all too soon, but the memory of it will last for the rest of my life. The only drawback to my complete enjoyment of such a unique opportunity was that I was alone during the best part of it the stay in the marisma itself: and that the health of my friend, whose guest I had been from England, and to whose generous kindness I was indebted for the whole of the expedition, would not permit him to leave his yacht. I ittle did I think that, after my return to England, I should only see him once again.

Spain is a most interesting country for the naturalist, and would well repay a much more prolonged trip. But not many discoreries can be expected. It is ill gleaning after such experieneed workers as Chapman, Lord Lilford, Colonel Irby, Howard Saunders. and the late Prince Rudolf have been over the ground. And though so near and easily reached, the conditions of life, away from the hotels of the large towns, are entirely different from anything that might be expected, and travellers ignorant of the 
comntry would probably find themselves rery ill prepared for roughing it among the wilds.

The heat in May was terrific. appearing to scorch through my clothes. and even through my boots. We never stirred out without a large earthenware jar. or chattie. in the packsaddles. full of water. In spite of this. I have often been

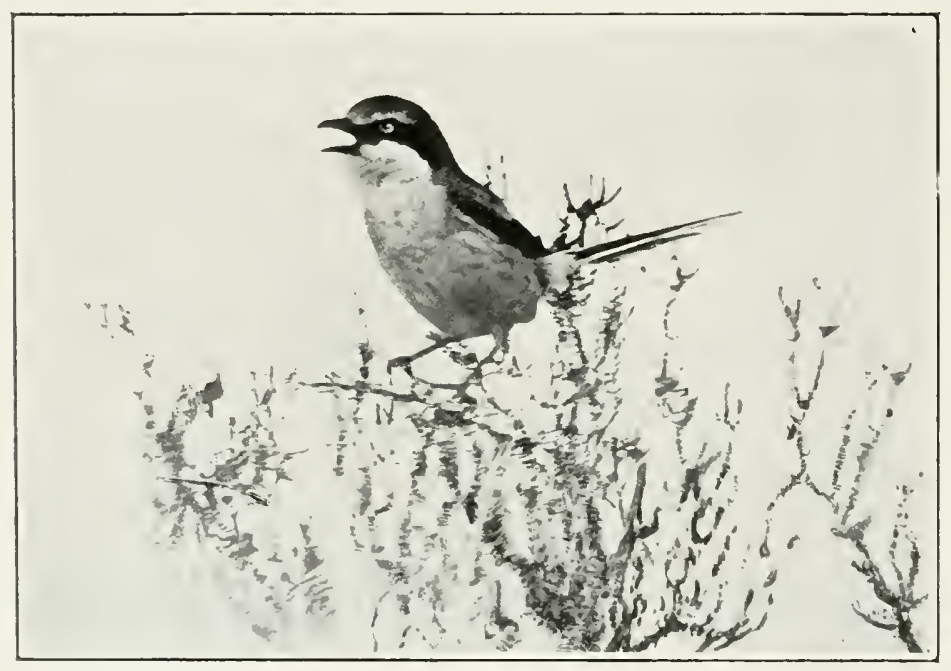

GREY SHRIKE (Lamms moridomalis).

glad of a drink from the store of a charcoal-burner or herdsman.

No wonder the natives look so dried up and coppereoloured. 'The little blood left in their rems by the mosquitoes must be entirely parched up by the intense and fiery heat of the long smmmer months-a heat which completely dries up the water from the whole of an immense area. With the exception of the deeper lagoons. what was 
11p) to March a valst inland sea becomes in time an arid desert. Ideagues of tawny mud stretch to the horimon. unbroken by tree or shrub. and baked by the heat into the hardness of brick.

'The natives suffer rery much from ferer, but the population is exceedingly scanty. 'These comsist of a few " guardas" to protect the red-deer. wild boars. and other game of the "cotos": some herdsmen in charge of the herds of semi-wild horses and attle: and a shifting gypsy-like population of charcoal-burners and timber-fellers. who live in huts made of pine-bonghs. grass, and mud. 'These huts they will erect in a day. I have passed in the evening an inhabited hut of this description where there was none in the morning.

'The Spanish peasant, whether herdsman, charcoal-burner. or what not, is a very good fellow and a keen sportsman, with the manners of a gentleman: and I thoroughly enjoyed my stay anong them.

I ife in the marismas is enjoyable enough during the day. but the ardent ornithologist has to pay for his pleasure at night. 'Then the hosts of mosquitoes come forth in their thousands and take their revenge. I have met mosquitoes in rarious parts of the world. and thought they were bad enough in the Mest Indies and in Newfoundland. but never hare I seen them in such numbers or of such bloodthirsty ferocity. 'Towards the end of the time they were daily. or rather nightly. getting worse. until the only way to get any sleep at all was to muftle my head in a puggaree sufficiently porous to breathe through. and to draw my 
stockings orer my amms. 'That puzzled them, but the heat was simply awful. 'The first necessary of life in this region is mosquito-curtains, the second being perhaps a horse.

Is not this the country where a " man" and a " horseman" are synonymous a land of ". caballeros" !

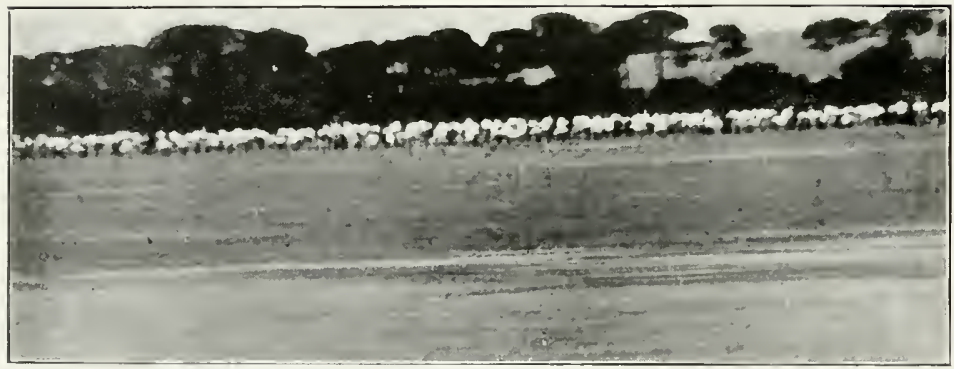

Distant View of Flamingoes in the Marisma. 


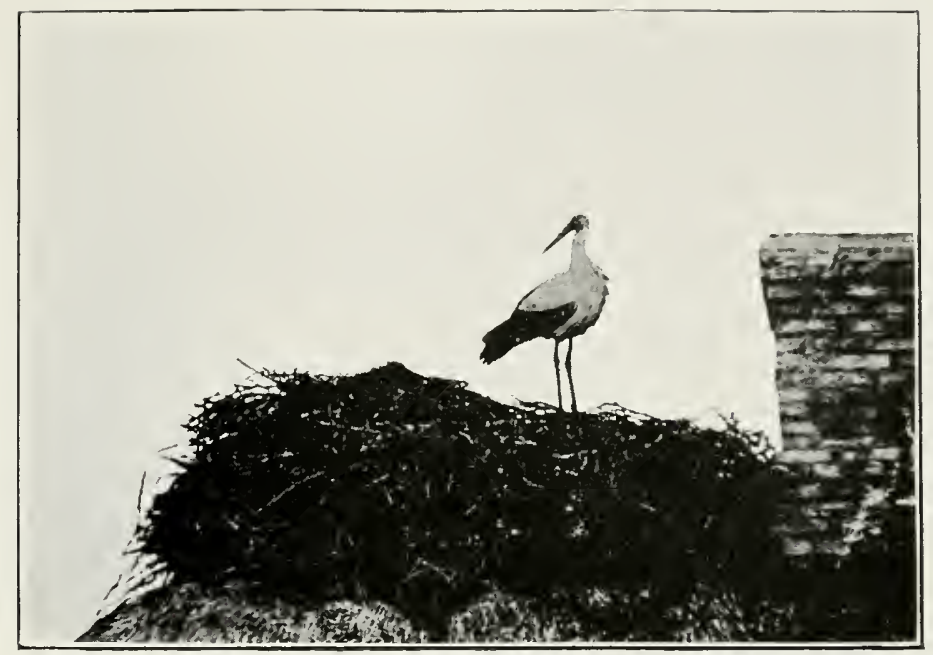

White Stork (Ciconia alba).

\section{CHAP'TER X}

\section{Bird Life in Denmark-On the Fjord}

Fon many years, to risit Denmark, and to see for myselt some of the episodes of mansh bird life, as described by Secbohm. has been a great but impossible ambition. 'This rear, however (1903), the wish has been at last fulfilled: and though I did not actually see the 'T'arm marshes described by him. yet I rather fancy I must have gone orer some of the ground risited by him in the immediate neighbourhood. Since his time, howerer, things have altered somewhat, and fresh restrictions have been made. by which a Goremment permit is necessary before one is allowed even to set foot on the best part of the ground. 
'The fact is that these restrictions have arisen in consequence of the unreasonable looting of eggs by English visitors, and. the place belonging to the I)anish Govermment. it has been constituted a national preserve, owing to the representations by Danish ornithologists. who became alamed at such systematic robbery. From what I (an see, however. these restrictions either do not apply to natives or

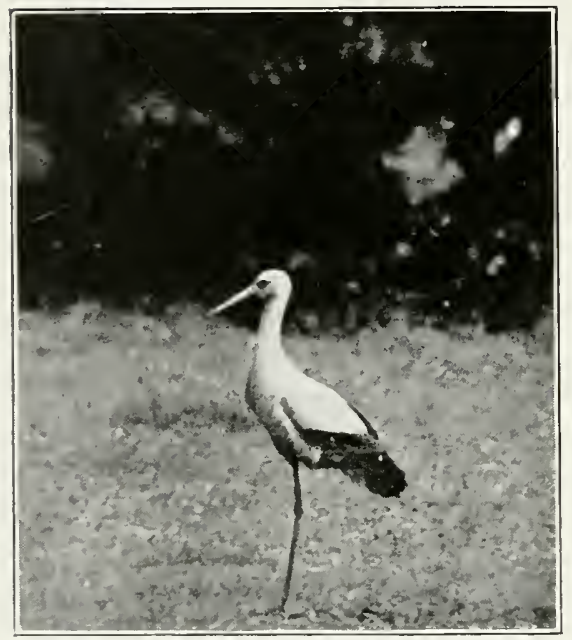

White Stork (Crecnia alba). are more difficult to enforce in their ase. for both shooting and taking of eggrs are done with more or less inpunity on their part. And it must be remenbered that in many arses the doings of visitors, especially foreign visitors, are often exaggerated by the natives to serve their own purposes.

After due consultation of anthorities and majes. and obtaining the necessary permission, my friend .J_- and myself left I,ondon on Mạ 4th, arriving at Esbjerg early oll May (itl.

All this west coast of . Jutland is extremely barren, and the scenery monotonous in the extreme. 'Travelling ornithologists. howerer. can always find beanties in the most arid and desolate countries. as long as they are not quite devoid of bird life. and even trarelling by train is not 


\section{Bird Life in Denmark On the Fjord}

quite lost time. By keeping a good look-out. it is wonderful what a lot one may see from the train-window. One does not have to go far in Demmark to discover what inmense numbers of Skylarks there alre in every direction. The songs of inmmorable Iallks are incessant the whole day.

'The next discovery is the great abundance of the White Stork. It is far and away more numerous here than in H o l l a n d d, where it is not by :111y III Call s so miniversally to be found als is popularty supposed. Here, howerer-or, at all events, throughout

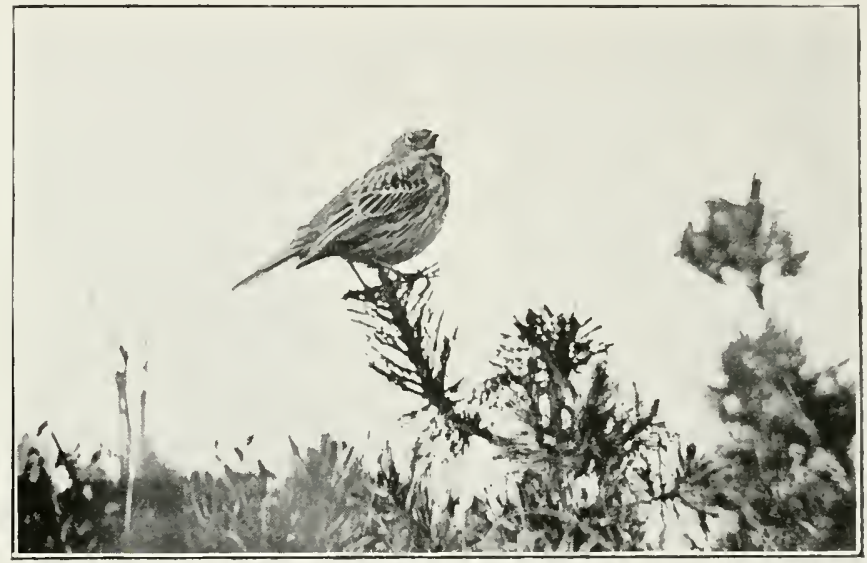

Buxtsag (Emberan miliaria).

Jutland-nearly every fammouse (and. outside the towns. almost erery house is a fammouse) hals a place reserved on the arable-end of its thatched roof' for a Stork's nest. Besides these, there are in the towns also very many nests on the honse-roof's: and to see the stately form of a White Stork frog-hunting in the meadows close to the street is so common that it ceases to be noticeable.

'To give some idea of their numbers it may be 
mentioned that on the barns and outbuildings belonging to the house of a Ianish nobleman there were, at the time of our visit, no fewer than twenty oecupied nests of the White Stork. Most interesting it was to see so many of these great, handsome birds standing on their nests. and flying orerhead with great beaksful of dry grass to line them with, or carrying a bonne-bonche in the shape of a fine fat frog for their wires, busily engaged in family duties.

Another bird almost as much faroured by the Dames is the Starling. Nearly every house, and even many of the railway-stations, put out bird-boxes for their accommodation. Some had a small house, with painted windows and doors and red chimmeys, mounted on a pole outside: while the larger houses sometinnes provided free lodgings for sixty or a hundred pairs of Starlings, with a separate entraneehole and a perch outside for each pair. It was very fumy to see rows and rows of Starlings all jabbering away at once, like so many old women.

Driving along the sandy roads of Jutland, a very conspicuous bird is the Common Bunting. Uttering its simple and monotonons song while perched on the telephone- and telegraph-wires at the roadside, a Bunting is passed so frequently that one begins to think it the commonest bird in Denmark.

Another roadside bird is the Crested Iark; but it seems actually to prefer the village street to the eountry road, and here it runs about under one's feet close to the houses in the familiar way one expects from a Sparrow 
rather than a Latrk. The arest is most conspicuous, being carried as a rule rery upright: and the bird is a striking and interesting one on first acquaintance.

(n) one by-day, when it was almost too windy to set up a camera. I walked about three or four miles on purpose to see something of the Crested Iark, and cer-

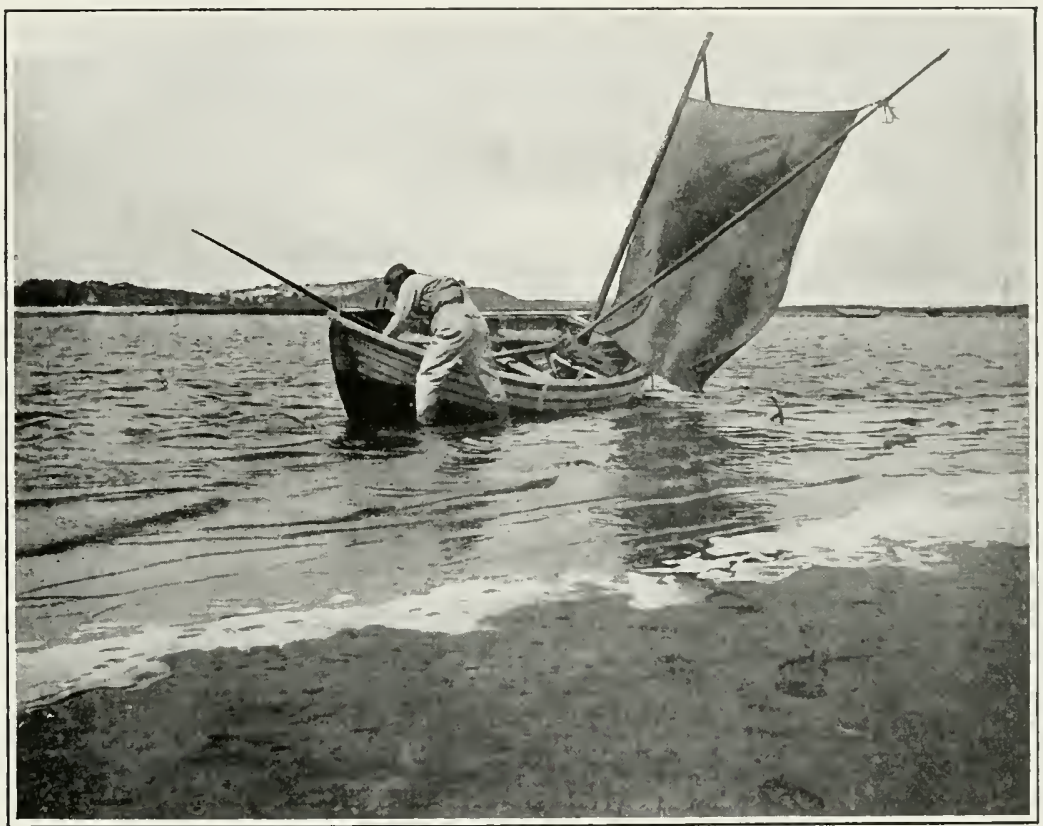

Stowing the Cameras IN THE BOAT.

tainly did see a few birds. but quite failed in discovering any nest. On reaching the small village im, however, where we were staying. there were two Crested Larks running about the road just in front of the door: and I really believe. if I had stayed in, I might lave been able to photograph them out of my window. 
()n first arrival in .Jutland, to our great disappointment we saw at once that we were nearly a fortnight too early. In exceptionally late and cold spring had so delayed matters that some of the hirds had only just arrived, and had barely commenced to nest. the first day's work only resulting in finding a few Redshanks and Peewits" egos.

The forord. which rms inland for nearly thirty miles through a narrow entrance, is very shallow and studded with mumerous islets only a few inches above high water. and surromeded by sand-dmes and salt marshes. It is an ideal spot for 'l'erms. Ciulls. Plovers. and marsh-birds ecenerally, and is in springtime resorted to by many thousands of birds. which find here a congenial spot in which to nest and bring up their young broods. Running down under sail in a small boat belonging to one of the fishermen-who spoke, by the way. excellent English-we found, on May 7 th. that, if egges were scarce, the birds themselves were present in immense numbers. Fieldonlasses in hand. we were hard at work identifying the various species. Our destination was some distant islands up the fjord, to reach which necessitated. after sailing six or eight miles, walking orer a marshy promontory, carrying the cameras (foum miles each way), and then wading to the islands in question. where we hoped to find the birds a little more adranced than on the mamband. (On our way we saw numbers of Kentish and Ringed l'lovers on the shingly shores and sandy islets. Wading in the shallow water were munerous Arocets. Redshanks. and Domlins : 


\section{Bird Life in Denmark-On the Fjord}

and orerhead were comntless Arctic. I.esser, and Sandwich 'lerns. and Black-headed. Common, Lesser Black-backed, and Herring Gulls. In the distance, mangnitied and distorted by the mirage, which plays such anious pranks with the sight in these shallow, sandy seas, were immense flocks of Brent Geese, and smaller ones of Scoters. 'Terns sat on all the

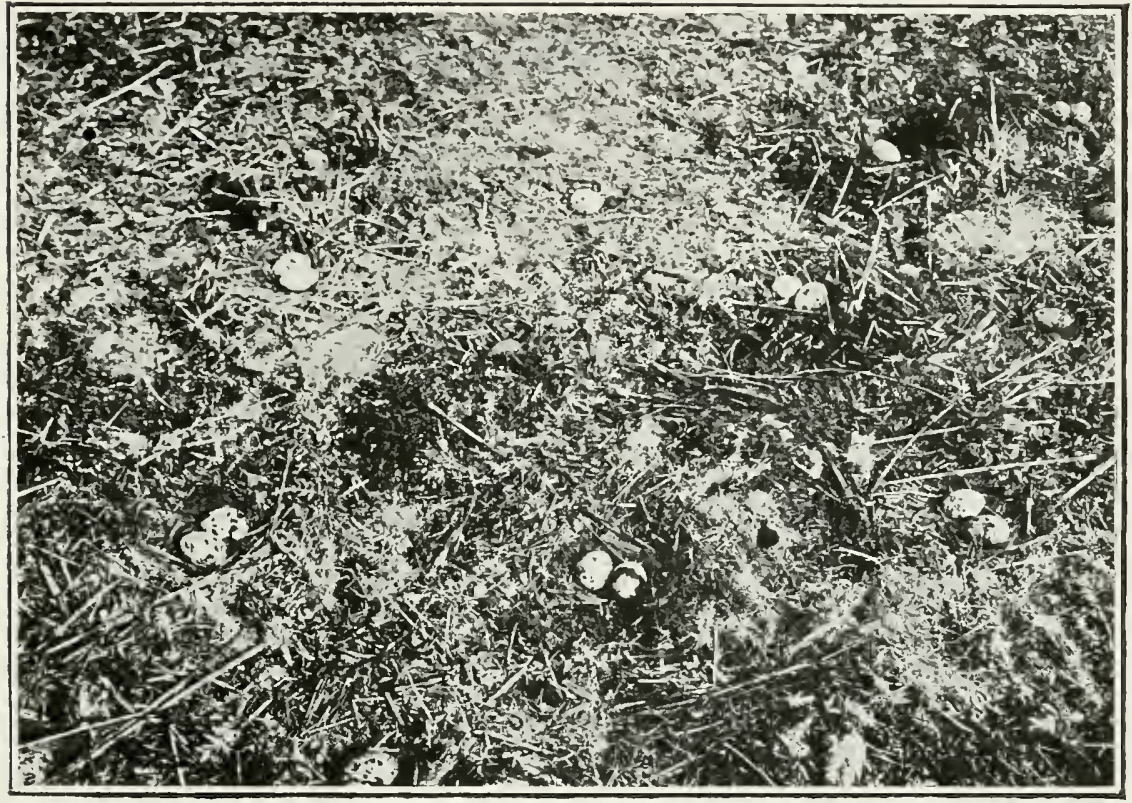

Nests of Sandwich TERN (Stema cantiaca).

stakes of the salmon-nets which bar the passage in every direction the whole length of the fjord. and l'intails and other Ducks Hew past in the distance.

After landing, our progress across the marsh was accompanied by a perfectly incessant babel of harsh and angry protests from thousands of indignant birds. Circling 
Redshanks, with their ". 'Tip-tip," the Arocets' " Whit-whitwhitter-whitter-whitter," and the " Kree-ee" of thousands of 'Terns gyrating unceasingly overhead. would make anybody think that the whole marsh was full of their eggs. But not a bit of it: there was hardly an egg to be seen. A few Redshanks' nests held one and two eggs, and the others were almost without exception empty.

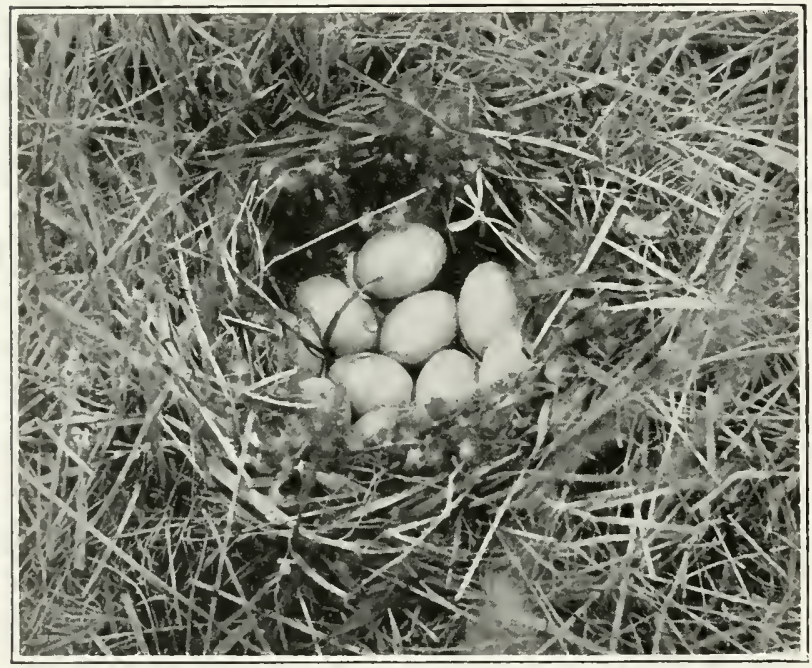

Nest of Pintall (Dafile acuta).
Many Dunlins in pairs ran abont in their nsual tame and familiar manner only a few yards away. but had not eren then begun to nest. Some days later we found numbers of nests like

Redshanks, each in a small tuft of grass, only very much smaller; but they had not begun to lay when we left. Blue-headed Wagtails were also numerous, and they also had apparently not begun to nest.

'The walking was bad-soft and slippery mud, bright yellow in colour firm the iron, I believe, when undisturbed. but black as ink when trodden on. 'The whole 
mansh was intersected with creeks, some shallow. others much deeper, all of which had to be waded: so that by degrees we got wetter and wetter. M $\mathrm{C}$ had started carring a pair of wading-trousers: but between two of us it would have taken a week to have crossed that

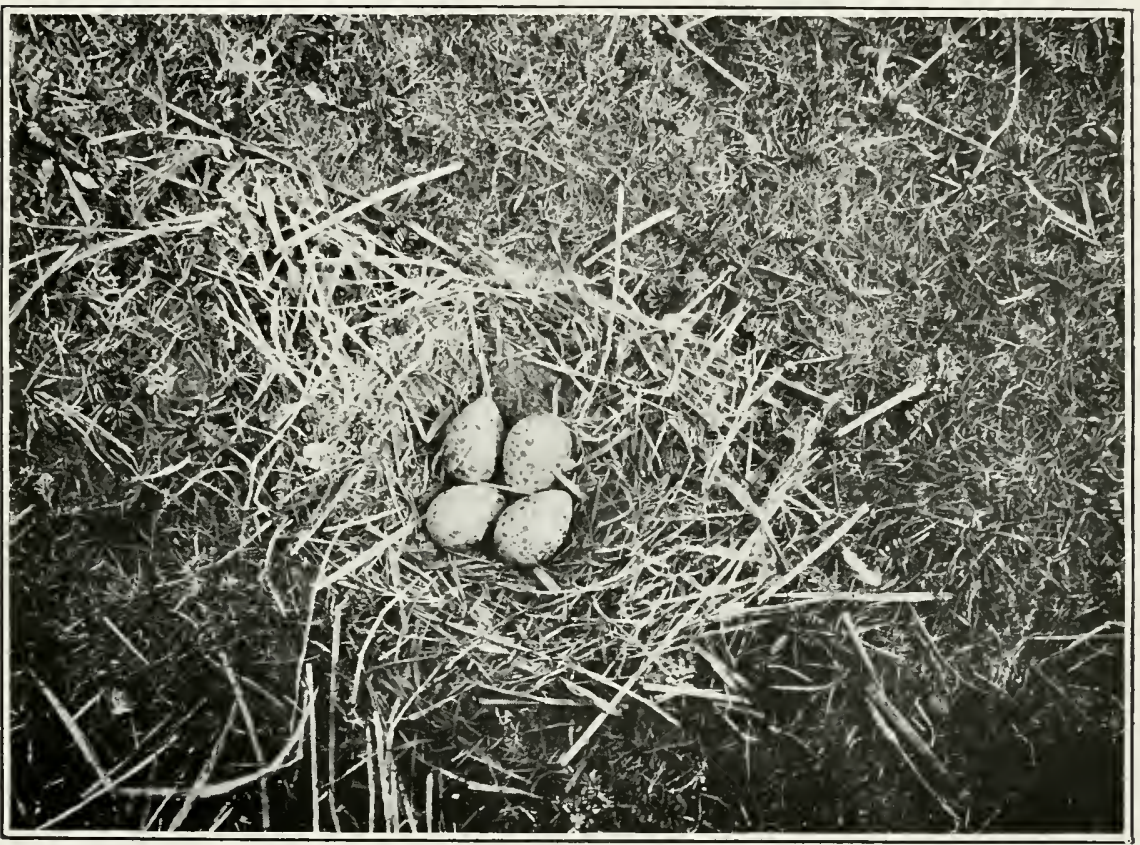

Nest of Avocet (Recurvirostia avocetta).

marsh dry, so we put them down half-way to be picked up on our return, and from being wet up to our knees we were soon wading mp to our waists, off to the island we had come to investigate.

The first island, a narrow strip about a hundred yards long, as my friend tersely expressed it, "farirly stank of 
birds" that peculiar smell so fimmiliar to both of us, which is so noticable wherever large numbers of sca-birds are nesting in a confined space. At each end was a strong colony of Sandwich 'Terns. Their extremely handsome eggs were thickly scattered orer the ground, so rlose together that I was able. a few days later, to photograph fifteen nests on one whole plate, in doing which I broke several eggs by trading on them. The eggs were curiously different (in no case were there more than two egess in a nest): but in very many instances one egg would be heavily blotched or zoned romd with dark markings, while the other was uniformly spotted all orer. 'There were three very handsomely marked eggs, but in each alse they were odd. not nuatching the other egg.

On approaching the island, the 'Terns rose ch masse in the air, and humg like a dense cloud orer their nests, returning to them as soon as we moved on a little. There were two or three Arocets' nests, with four eggs each : and a colony of Black-headed Gulls, each with three eggs.

This island seemed to verify our expectation that the islands would be carlier than the mainland, and we determined to go off to the second island, rather a larger one. It was a good long way round, howerer, and we had to negotiate some deep creeks on om way. IIalf-way we saw a big lot of Ruffis on a hill, evidently just arrived: but, unfortunately, two men with gums were working up to them. and afterwads we heard them fire sereral times.

By this time we had waded off to the other island. 


\section{Bird Life in Denmark On the Fjord}

where soon after landing we found a small colony of Arocets' nests, with three and two egg's in each, a few with four, and a Redshank's nest or two. After which, a low range of sandhills, covered with dry curly grass, raised our expectations: for .J__ said at once it exactly

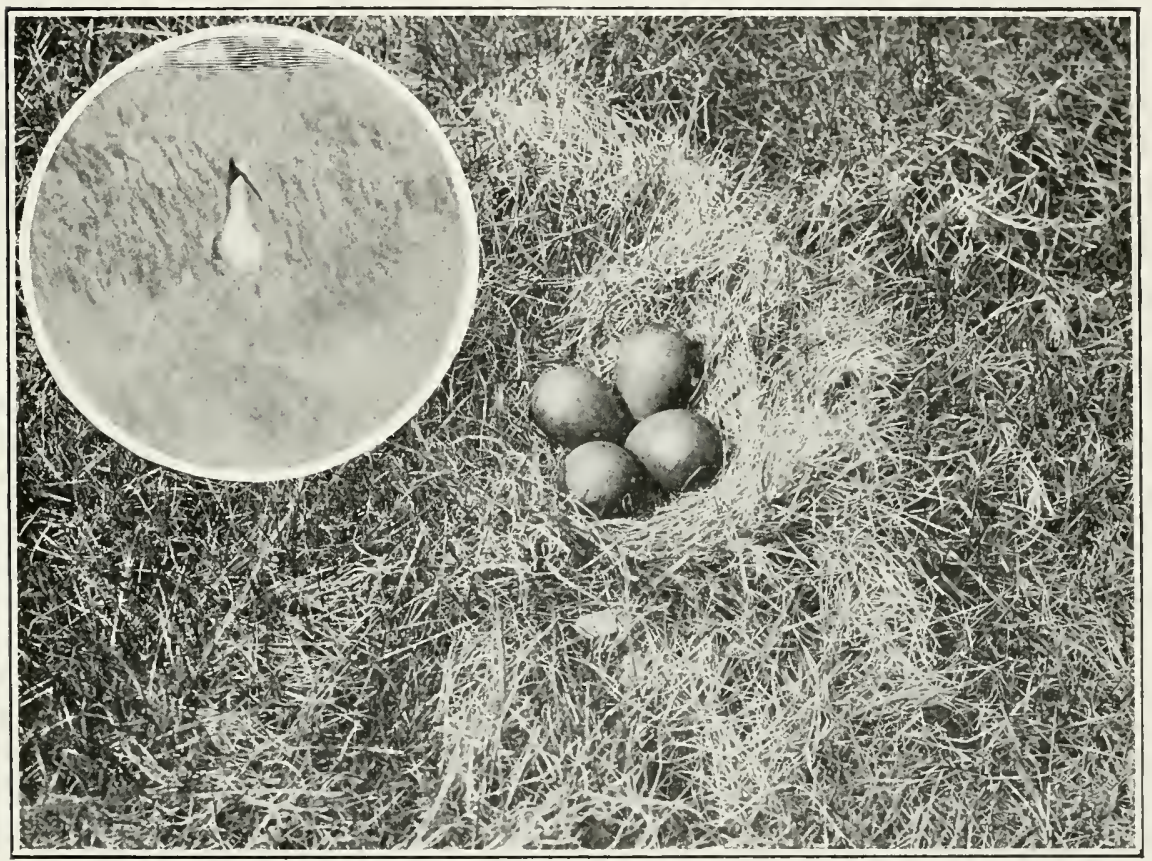

Black-talled Godwit (Limosa belgica) AND Nest.

answered Chapnanis description of where he found the l'intail breeding. $\quad 11 \mathrm{e}$ gave it, therefore, a close and thorough search, and had not proceeded far when I saw at my feet a Durk's nest, the egrss in which. ten in number. were entirely hidden and (*overed orer with down.

'This wass a puzzle. We expected l'intails' nests, and 
the eggs and down appeared to be Pintails: but without seeing the birds we felt we had no proof. Iackily a few steps farther I put a duck off her nest of twelve eggs. which appeared to be a Pintail. though I could not be quite eertain she was not a Shoveller: and close at hand was ret another nest, apparently deserted. with a broken egg. three nests. all close together. with the same type of egg and the same down. But. to make quite certain. J___. who had waded a deep creek on ahead, put off' another duck from a nest, an nmmistakable Pintail. which was joined by a I'intail drake, which had been seen about: and the two went off together. As all the eggs were alike. we now felt quite satisfied that they were really Pintails. and were rather pleased with our luck.

'The worst of it was that I now wanted badly the whole-plate camela. which our boatman had campied. while I had the tele-photo lens and another camera. 'The said boatman had left us in the lurch, and was calmly lying down a mile away. on the other side of a deep creek. which had baulked him. Instead of a whole-plate photograph. which was wanted to do justice to a nest like a Pintail's. I had to make the best of al quarter-plate, by substituting a short-focus lens I had with me for the tele-photo lens in the bird-amera. I was rather sore orer this, and took care to let onr man know how he had hindered us: but he wals afterwards so willing, and always so ready to help and obliging. that I easily forgare him.

Our return home, against a bitterly strong head-wind. 
was an unpleasant experience in our saturated condition. We did not reach our inn until late that erening, in a wretched state-wet, cold, and more or less miserable; and we must have presented a funny appearance on our way from the boat to our headquarters. 'Two mad Englishmen enjoying themselves in their own peculiar way was probably the opinion of the natives.

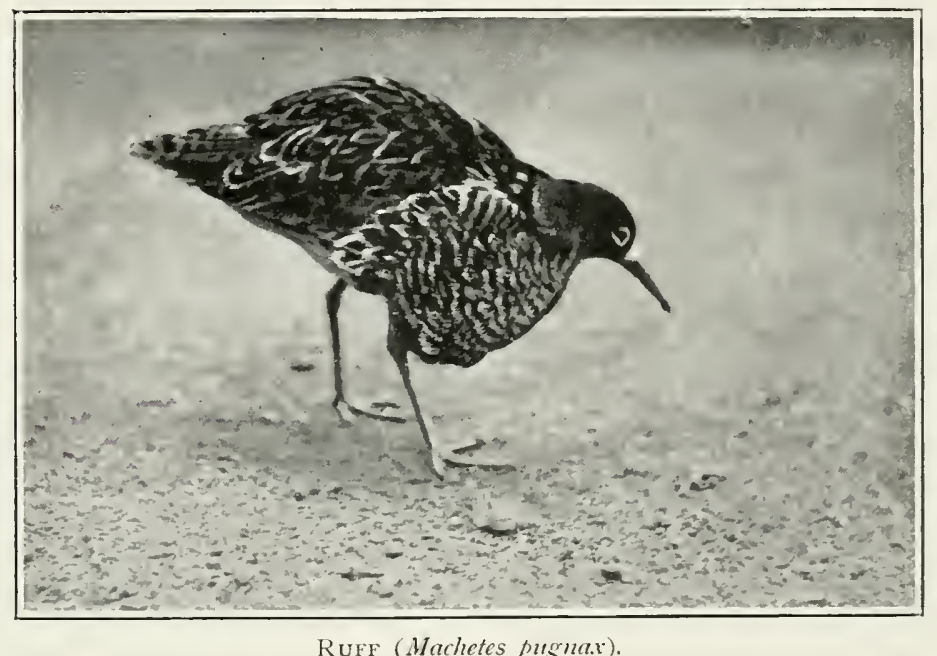

This wetting and exposure brought on, a few days later, a bad attack of rhemmatism, for the first time in my life; and I was compelled to wear wading-trousers for the remainder of my visit. And walking even such a distance as seven or eight miles, which was the minimmm, in wet wading-trousers and heary brogues, carrying a big load of camerals, is rery hard and slow work, especially as it had to be done on one leg. the other being practically useless. 
These two dars convinced us that our best plan was to go off to a distant forest. to the proprietor of which we had introductions, and return in two or three days. by which time we hoped that some of the other birds would have begun to lay.

After an interval of four days. we revisited both these islands. finding many more egges in them. and a few on the mainland. 'The patch of grass on the second island was then fiull of nests. but even then many were still emptr.

(On May 11th a Reeve was Hushed from her nest of four eggs. and a Black-tailed Godwit's nest was found with three pointed egass of a greenish brown: the first I had seen-as in Holland. where these birds are very common in the meadows. I had always been too late for eggs.

On the 1:3th another Reere's was found, also with four eggs. in the same patch: and the same day a second nest of the Black-tailed Godwit. with four eggs. was seen on the mainland on short grass. on which the nest and egges were as open as a Iapwing nest.

'The marsh now held a fair number of nests, Arocets and Redshanks chiefly. with full clutches of egos. Here also we got two nests of the Common Gull. with two eggs eaccl. 'These were on the ground at the edge of a broad ereek. studded with numbers of circular islands of turf. on which the culls were sitting about: but though I waded out to nearly all of them, no more nests were to be tound. 


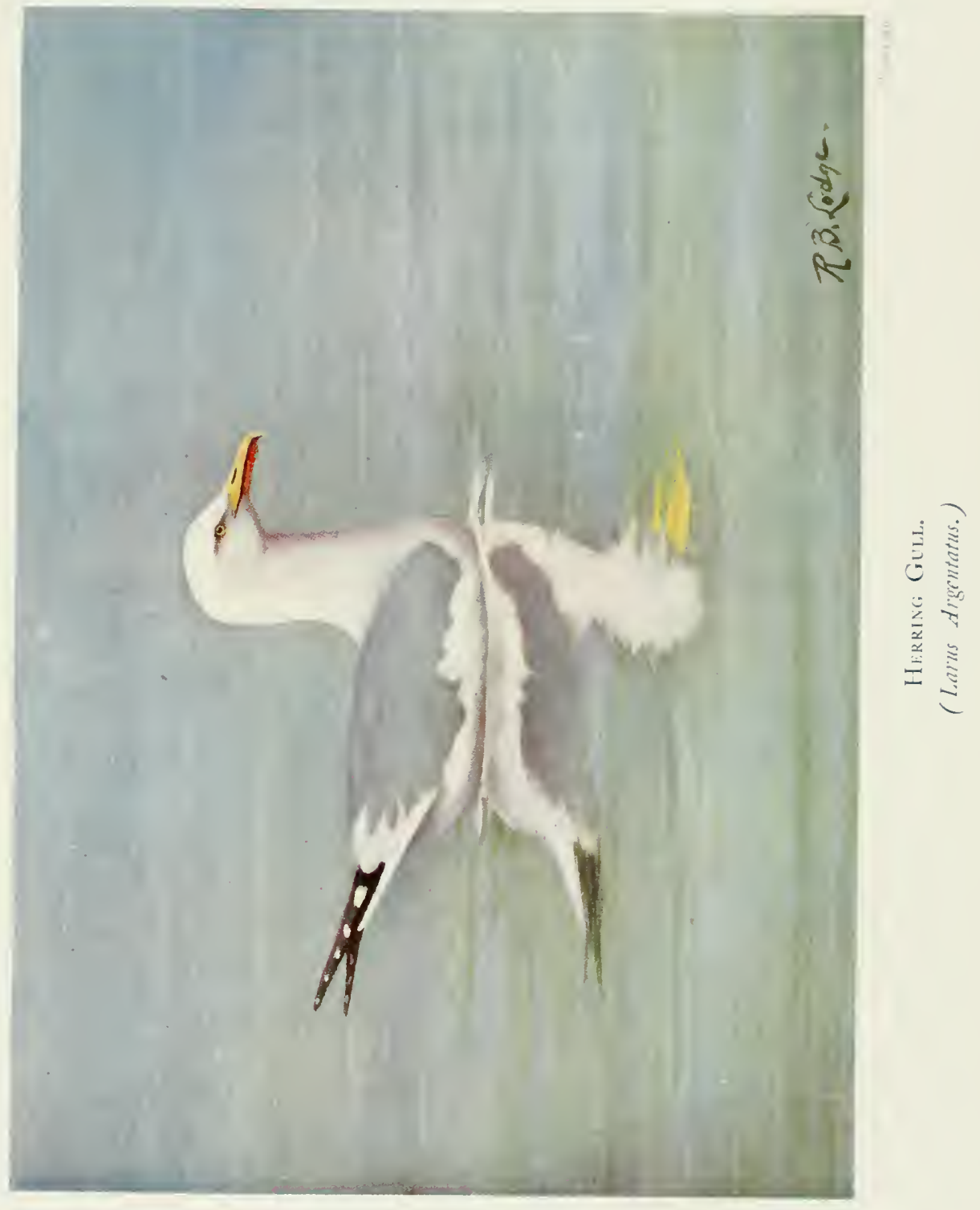



Some of the little sandy islands in the fjord by now began to have a few egas- Ringed l'lovers' and Arctic 'Terns' and a few Black-headed Gulls.

On a long day's work the question of food is a difficulty. With so many photographic things to carry, the

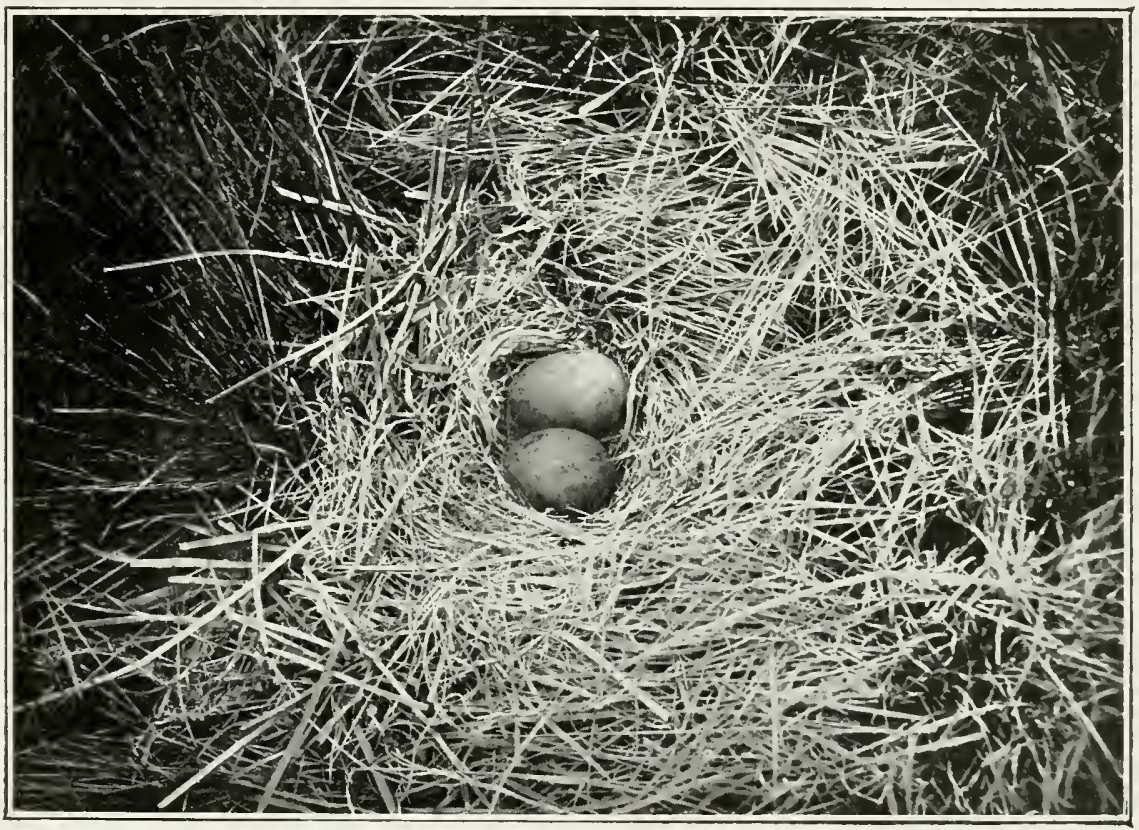

Nest of Common Gull (Lamis camus).

supplies were cut down to the minimum, and no drinkables were taken at all. At the same time. the work is exhausting, and one's appetite is apt to beconne insatiable. I was often glad to devour raw the eggs of Gulls. Redshanks, and 'Terms, and found them very refieshing indeed.

'Towards the end of our stay the numbers of birds 
seemed daily on the increase. and we could see that a little later all this neighbourhood would be indeed a " paradise for ornithologists."

Many thousands of Brent Geese still lingered, postponing their departure for their Arctic breeding-grounds. 'The whole expanse of marsh traversed by us was covered with the eridence of their recent abundance. It resembled, in fact, a hnge farmyard, and it was difficult to find a clean spot large enough to sit down on. The fishermen in the antumn and winter shoot great numbers of them from hiding-places, in which they lay prone on the watch. I heard of one man haring killed twenty-one wild Swans from one of these in one day list autumn.

'The place is evidently a faroured resort of birds the whole rear round. As soon as the smmmer visitors depart with their families, their place is taken by winter birds which have spent the smmmer in distant northern latitudes. 


\section{CHAP'TER XI}

\section{Bird Life in Denmark - In the Forest}

Not the least pleasant of our experiences in Denmark was the visit to a certain forest under the gnidance of the owner. Armed with introductions, we had called on him one morning early in May. 1903, after telegraphing our intended arrival the night before, in the hope that he would let us have the freedom of the forest in charge of a keeper or forester for a couple of days. We had not reckoned. however, on Danish hospitality. 'Though our telegram had not been received. we were welcomed with the utmost geniality and kindness, and pressed to stay for at least a week. In the meantime our luggage was sent for from the station: and after a good dinner, to which we were able to do ample justice after our long journey. our host drove us orer himself to the forest.

On the way thither we saw a Lapwing drive off" a passing Raven from the vicinity of her nest, in spite of the angry, barking protests of the sable marauder: and we had barely entered the outskirts of the forest when we saw a Burzard leave a spruce-fir on the summit of a small hill.

Then, learing the carriage. we were taken a short distance 
to the last year's nest of a Kite. near to which was a fresh nest in a beech-tree. This nest. howerer. had palpably been climbed to. and we did not trouble to ascend. I ceaning agrainst the beech was a felled spruce-fir. on which bootmarks could plainly be seen all the way up. Subsequent erents showed that this suspicion was only too true. and we were able eventually to open the eves of the owner to what had been going on in his forest. probably for years. without his knowledge or permission. His foresters had been tempted to take the eggs of the rarer birds. breeding in the forest under their charge, and sell them to a dealer in Copenhagen.

I had hoped to have been able to obtain some Kites eggs to help restock the hills of Wales. where the last pair of Kites in England are now lingering. The idea was to put a clutch of fresh Kite's egges in a Buzard's nest. as this bird is still fairly plentiful in Males, and their egoss and labits are very similar. I was quite muprepared to find that the Kites in this remote 1)anish forest were in much the same plight as the $\mathbf{W}$ elsh Kites. and from the same cause. 'The greed of egorollectors and dealers has much to answer for in exteminating rare birds. For when once a bird begins to get scarce and its egors to be in demand. the systematic robbery of them year after year for the dealers soon ends in extemmation, as it gives them no chance of recovering.

Far more important than the Kite's nest in an ornithological semse was the nest of a Black Stork. 'This was 


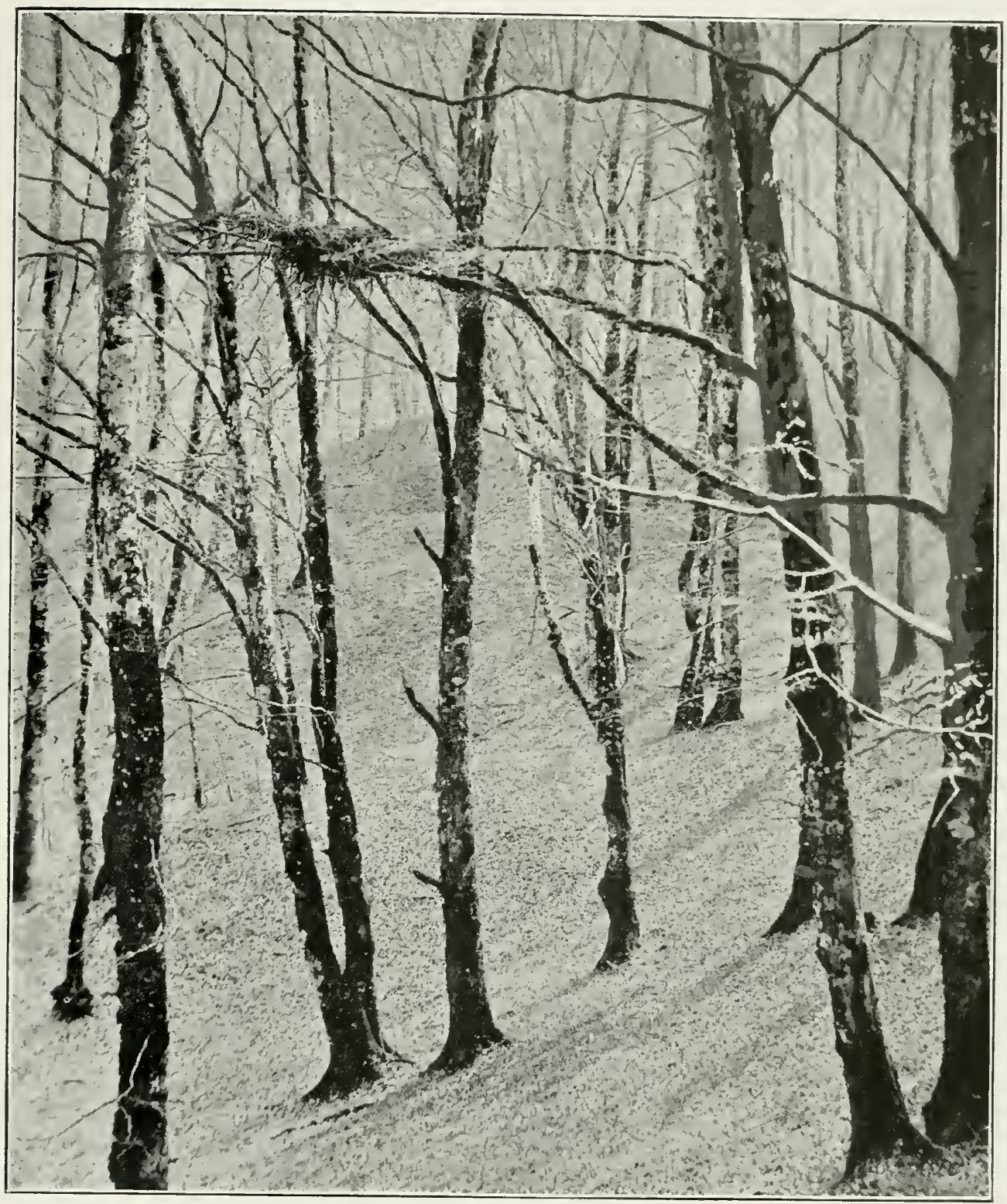

Nest of BLACK Stork (Ciconia nisra). 
also empty, probably robbed. as was a Burzard's nest close to it.

'There was a second nest of the Black Stork not rery far from the first. belonging to the same pair of birds. 'This also was empty: and our theory was that, the first clutch of eggs having been taken. the birds had nested again, but had not yet had time to lay again. 'This second nest was

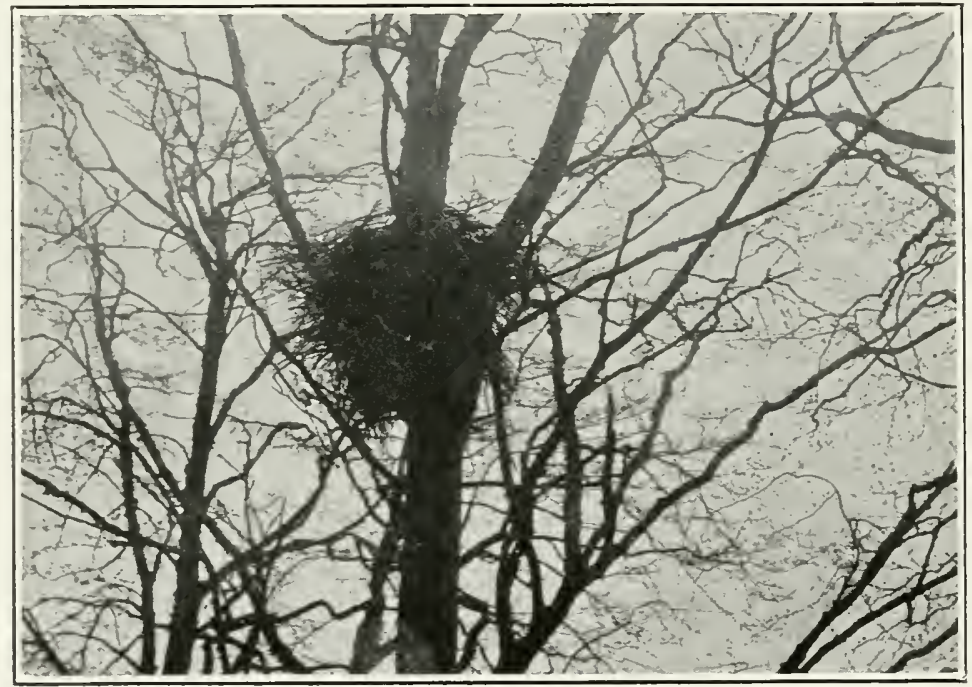

Nest of Black Stork (Ciconia nigra).

half-way up a very large beech. in a fork on the main trunk. 'The first nest was at the extremity of some horizontal boughs of a small beech-tree. and was not more than twenty feet from the gromd. overhanging the hollow of a hillside. 'The ground was covered with a russet layer of last year's leares. and the trees were just begimning to open out into leaf. and were clothed sparingly in the brightest of green. 
'The nest was a rough Hat platform of sticks, lined, as was also the other nest, with a layer of soft green moss. () n risiting the spot the second day, we were fortunate enough to see one of the Black Storks soaring on broad wings orer the ralley, where it made a most impressive picture.

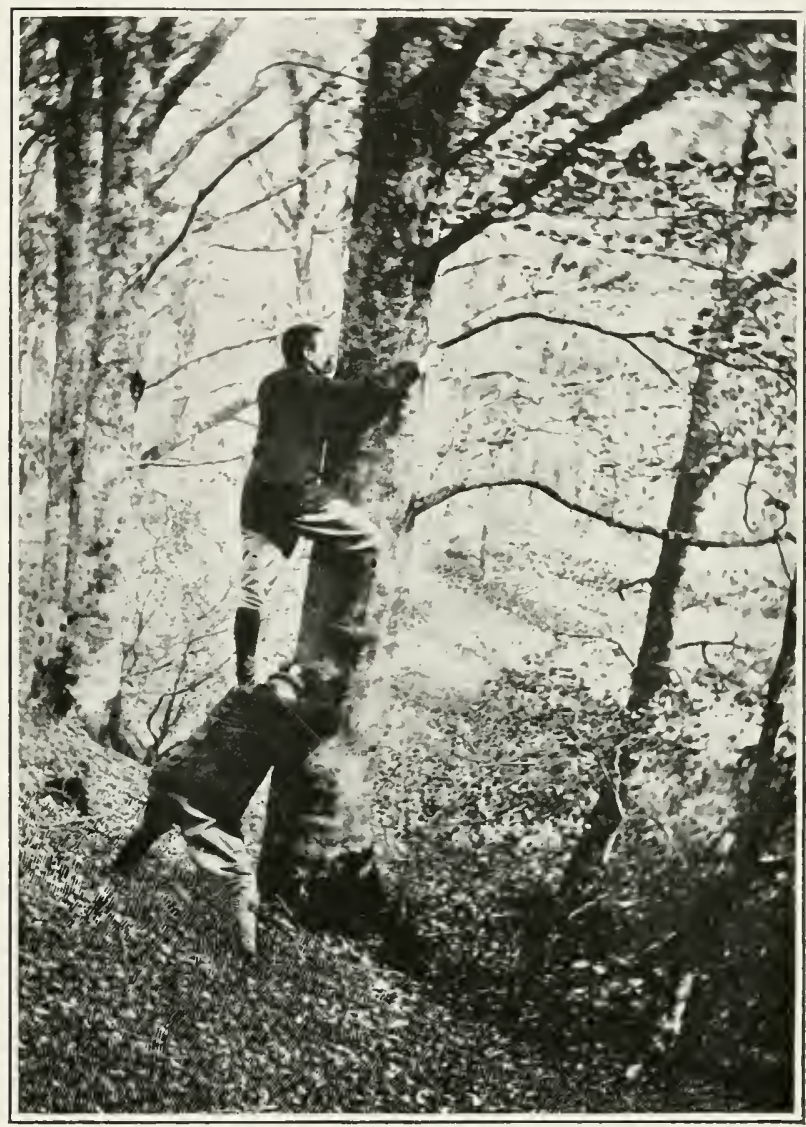

Giving a Back up a Tree.

'This was the first Black Stork ever seen by either of' us in a wild state, this bird being of extremely shy and solitary labits, and entirely restricted to the most remote and secluded forests in Europe, and is nowhere an abundant and familiar bird like the White Stork. which simply swarms in 1)emmark, nesting abundantly both in the towns and on the farmhouses. 
Some of the beech-trees in this forest. especially those in the sheltered valleys. were of enormous size, and extremely difficult to climb. owing to the growth of moss and lichen which encrusted their trunks. 'This comes off' directly it is grasped, and we found any swaming simply impossible. One immense tree defied our utmost efforts, though there was a Buzard's nest nearly at the top. We spent an hour in marailing efforts to throw a rope orer the lower branches, and were finally compelled to give it up. Enfortunately we had omitted to bring any climbing-irons. The whole time we were there the two Buzards were sailing round in circles. and the hillsides resounded with their plaintive. mewing aries. After some time a Coshawk. which proved to be nesting in the ricinity. dashed out in pursuit. and with sharp and angry ery and menacing attitude fairly drove away for a while the Buzalrds from the neighourhood of their own nest.

This Goshawk's nest we afterwards visited. and found it empty. It had also been robbed: for we saw the eggdestined for Copenhagen with the rest. 'The culprit in this business was the son of the head forester, who. born and bred in the forest. could climb like any cat.

No wonder the larger birds are getting sarce the Black Storks reduced to one or, at the most, two pairs for the whole of Denmark, the Sea-eagle to one pair, and the Kites. Ospreys. and Coshawks gradually diminishing in numbers : for 1)enmark has few extensive forest districts, except on some of the numerous islands. 


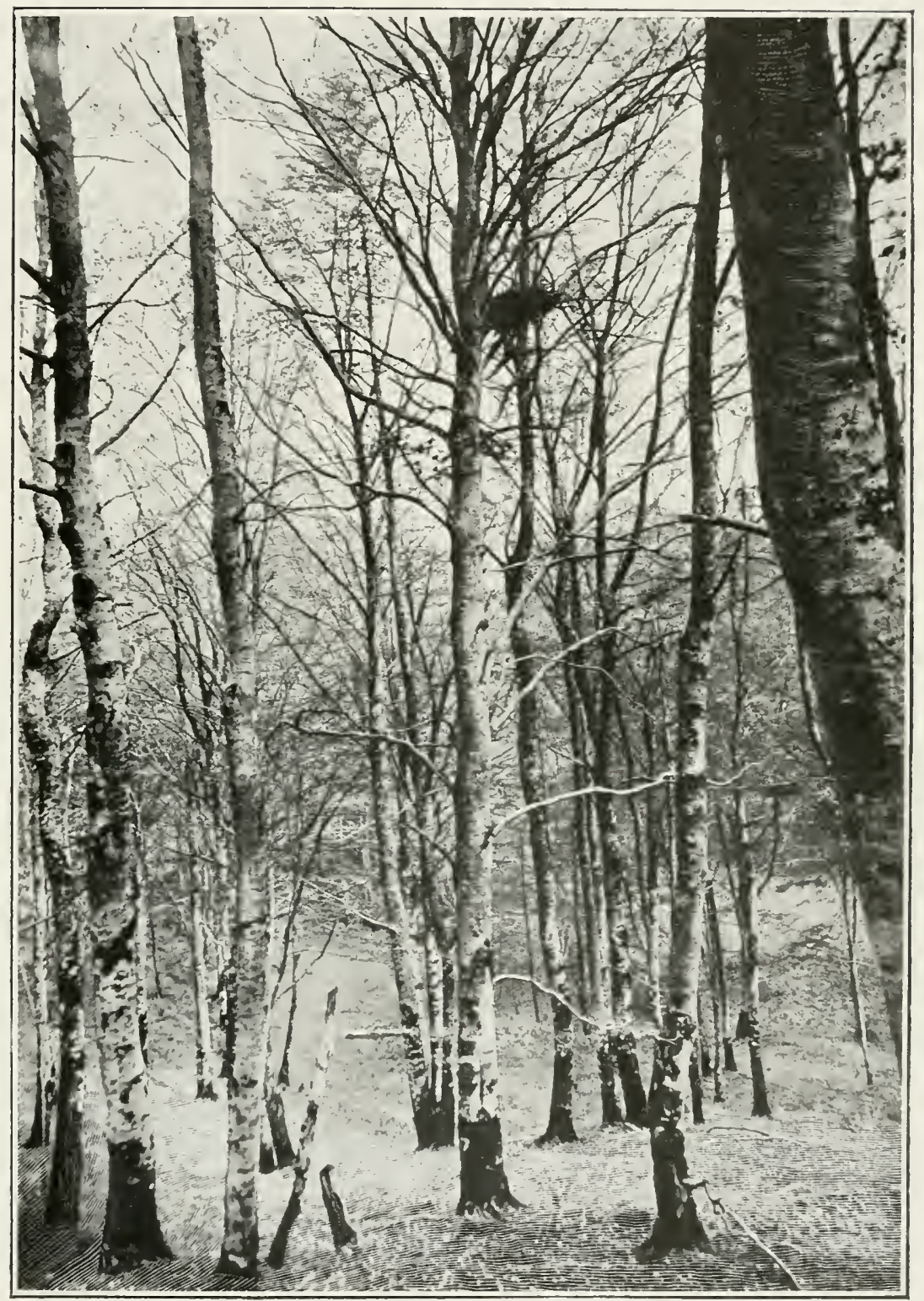

Nest of Buzzard (Butco iulgaris) 
A Ravenis nest. Which probably contained young, we did not trouble to go up to: and one of several Hooded Crows contained fire sat-on eggs-other nests being empty and holding young birds: ugly. mnamy-looking little wretches they were too. 'The Hoodie is here extremely abundant and rery familiar. 'Though so shy and wary when in Fingland during the winter montlis. here. in 1)enmark. the Hoodies nest along the roadsides. sometimes in ridiculously small trees: and round the farmhouses. in the little belt of trees which serve as a shelter from the cold winds. there is generally a nest of either the Magpie or Hooded Crow. In every direction the bird's burly figure is a conspicnous object in the landscape that is. in the wooded parts. Some parts of I Denmark. partienlarly in W est Jutland. are almost deroid of trees: and there the Hooded Crow is not to be seen.

'Two days. or really two half-days. were not enough for' this most interesting forest. We saw a good deal in the time. considering how short it was: but a week would not have been tos much to do justice to it. However. our short stay in Denmark-ten days would not allow us to stop any longer. and we were compelled reluctantly to tear ourselves away all too soon. leaving many things moisited. Eagle-owls, for instance. nest here-probably some of the smaller (Owls also: but we saw nothing of them. In the forester's house we saw a stuffed Nutcracker and Crypfalcon, but ascertained that these had been shot in the winter. 'There were also many heads of roe- and red-deer. with a 
picturesque gromp of gums, rifles. and co $11+c a d x-9 t-$ rhasses. 'The horns. howerer, scemed small. Foxes. batgers. and hares arealsotairly common.

In another fifty yearls or less I)enma l k will be covered witl forests of spruce-fir. All the sandy and batren waste-land is being extensively planted in every direction by the Govermment. 'This far-secing policy should make a great difference to the country: for much of it is at present perfectly unproductive. and incapable of grow-

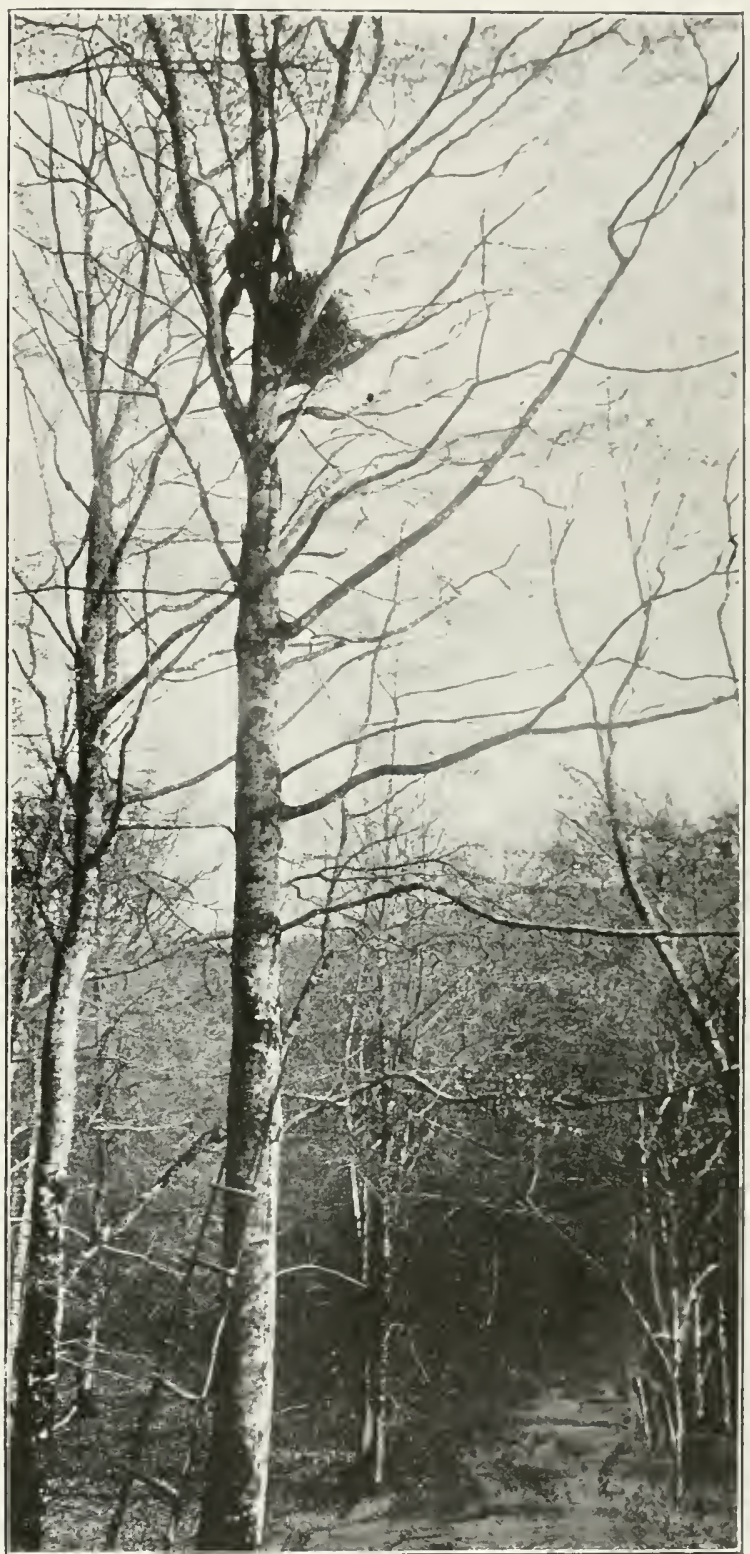

Nest of Goshawk (Astm palmmbarits). 
ing anything better than coarse grass and low shrubs-such as sallows or willows a few inches high.

On some of the hillsides, exposed to the prevailing westerly winds, trees were seen with every appearance of great age. but most curiously stunted and deformed from the eonstant struggle with the elements. Some were blown perfectly flat against the hillside. so that nowhere were they more than a foot above the ground, and not more than ten or fifteen feet in length. It is impossible to inagine a more eloquent testimony to the bleak nature of the country during the greater part of the year. 


\section{CHAP'IER XII}

\section{A Week in Derbyshire}

Ax invitation from an enthusiastic ornithologist to spend a few days under his guidance among the birds of Derbyshire was too good a chance to miss, and accordingly one day early in .June, 190:3, I stepped out of the train, and found my friend waiting for me, with the intelligence that he thought he could take me to a 'Tufted Duck's nest that aftemoon.

After a hasty meal, off we started to some large ponds about three miles away; and sure enough, on nearing our destination, a pair or two of these ducks were seen about the neighbourhood of a small island. Haring on our way procured the key of the boathouse from the keeper, we soon found ourselves afloat in a small and remarkably crank boat, in shape not unlike a tub. Shoving our craft in between the overhanging alder-branches. we stepped out very gingerly. for caution was much needed to aroid eapsizing. We commenced our search among the dry grass which covered the small island, each of us taking one side till we met again, having found nothing but a fine specoimen of a Coot's nest, a bulky mass of sticks at the base of an alder-tree a couple of feet out in the water. As we felt 
convinced the Duck's nest was there, notwithstanding our failure to discover it, we went round again; and this time with better suecess. for .J _ _ at last fomnd it right under the stem of the boat. If we had driven her ashore a little farther, we must have smashed every egg. 'The nest was

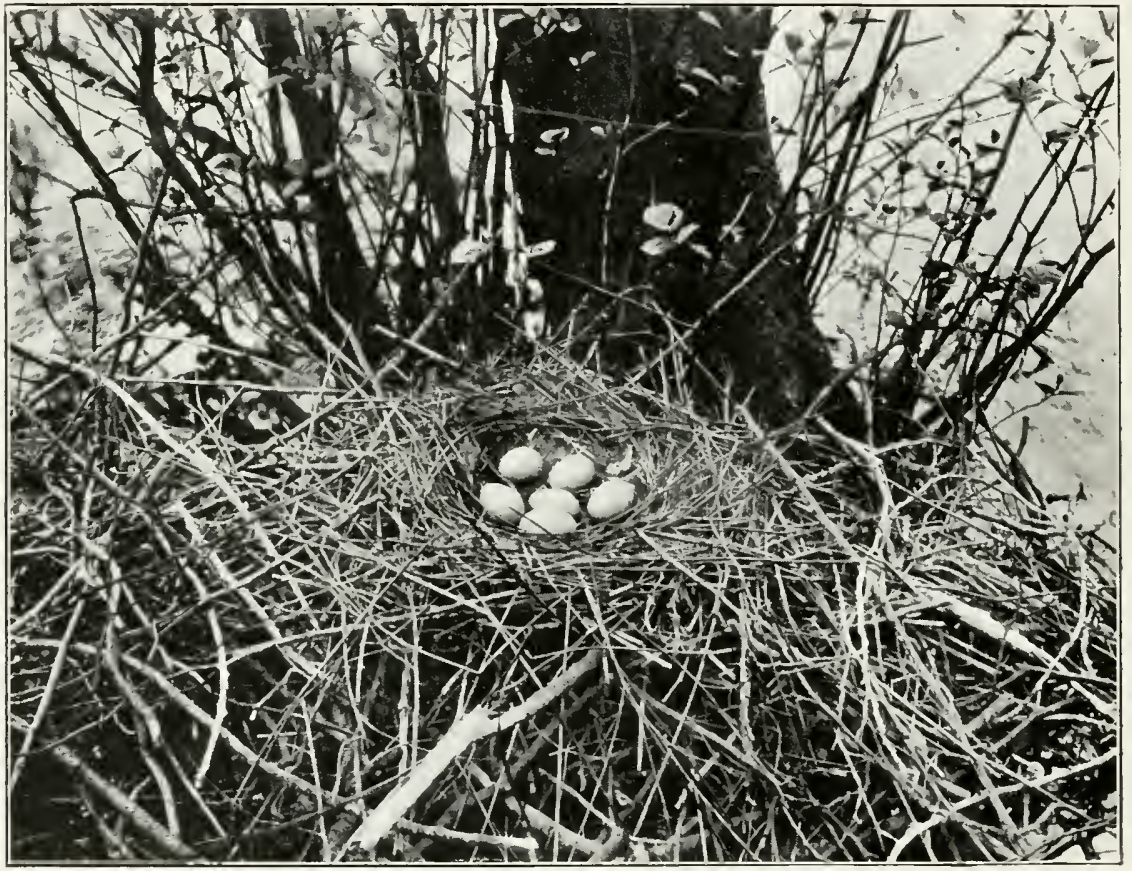

Nest of Coot (Fulica atra).

quite concealed under a tuft of dry grass, and contained eight egrs. with very little down. For the size of the 'Tufted Duck. her eggs are distinctly large-appreeiably larger than the eggs of the Pintail we had found but a few weeks before together in .Jutland. though the Pintail must be a far heavier bird. 
On another pond on the same estate we salw quite four pairs of 'Tufted Ducks, which were doubtloss nesting on some small islands round which they were swimming: but there being no boat. we did not investigate farther.

A pair of Sandpipers were seen on a grassy bank at the end of the lake, but our search for the nest was finitless. So late in the season, there was a probability of their having been hatched. Howerer, next day I was able to photographl a nest of these interesting little birds. Snugly lidden under a drooping leaf, the nest was by no means easy to find: but with the richly spotted pear-shaped egos it made a pretty picture beneath the tall burdocks, which must appoar a reritable forest to the slender forms of the Sandpipers. Such plants afford excellent covert, of which these birds are very fond of arailing themselves. more especially as they grow luxuriantly along the edges of these I)erbyshire rivers. and on the small islands which are the farourite resort of the Sandpipers. 'They are charming little hirds. Whose acquaintance I had long much desired to make, and their wild, shrill note is a fit accompaniment to the lorely scenes amid which they are so exclusively found.

One day was spent in a lalge wood on an estate which had been neglected in the way of game prescrvation. and was in consequence better stocked than usual with Hawks and Owls and other birds not usually allowed to exist by keepers. A Kestrel's nest was one inducement for the long tramp, but unfortunately it was found impossible to photograph it. 'The situation was remarkable. (On the summit 
of a steep hill. covered with bracken and oak-trees, up whose slippery slopes we toiled in a breathless condition, were two bold and isolated pinnacles of rock. and in a crevice halfway up the perpendicular fare of one of these peaks the Kestrels had five eggs. But .J _._. who had descended it by a rope, reported the eggs perfectly out of sight. quite at armislength down a very narrow fissure evidently not within the range of possibility for a photograph, and an attempt at a riew of the rock was not entirely a success.

'The wooded sides of the hills were full of Wood-wrens: and as the nest of this bird was wanted badly. we tried to watch the female bird to it. But in rain: for while the hen was plaintively whining in the tree-top orerhead. among

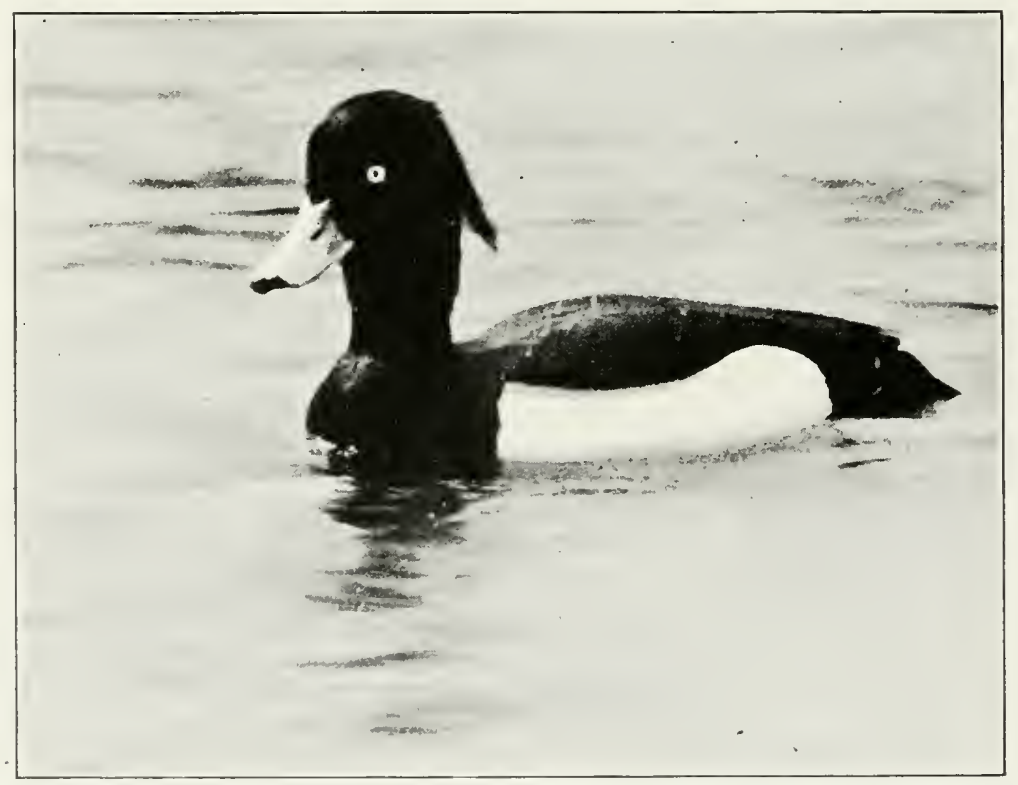

TuFted Duck (Fuligula cristata). 


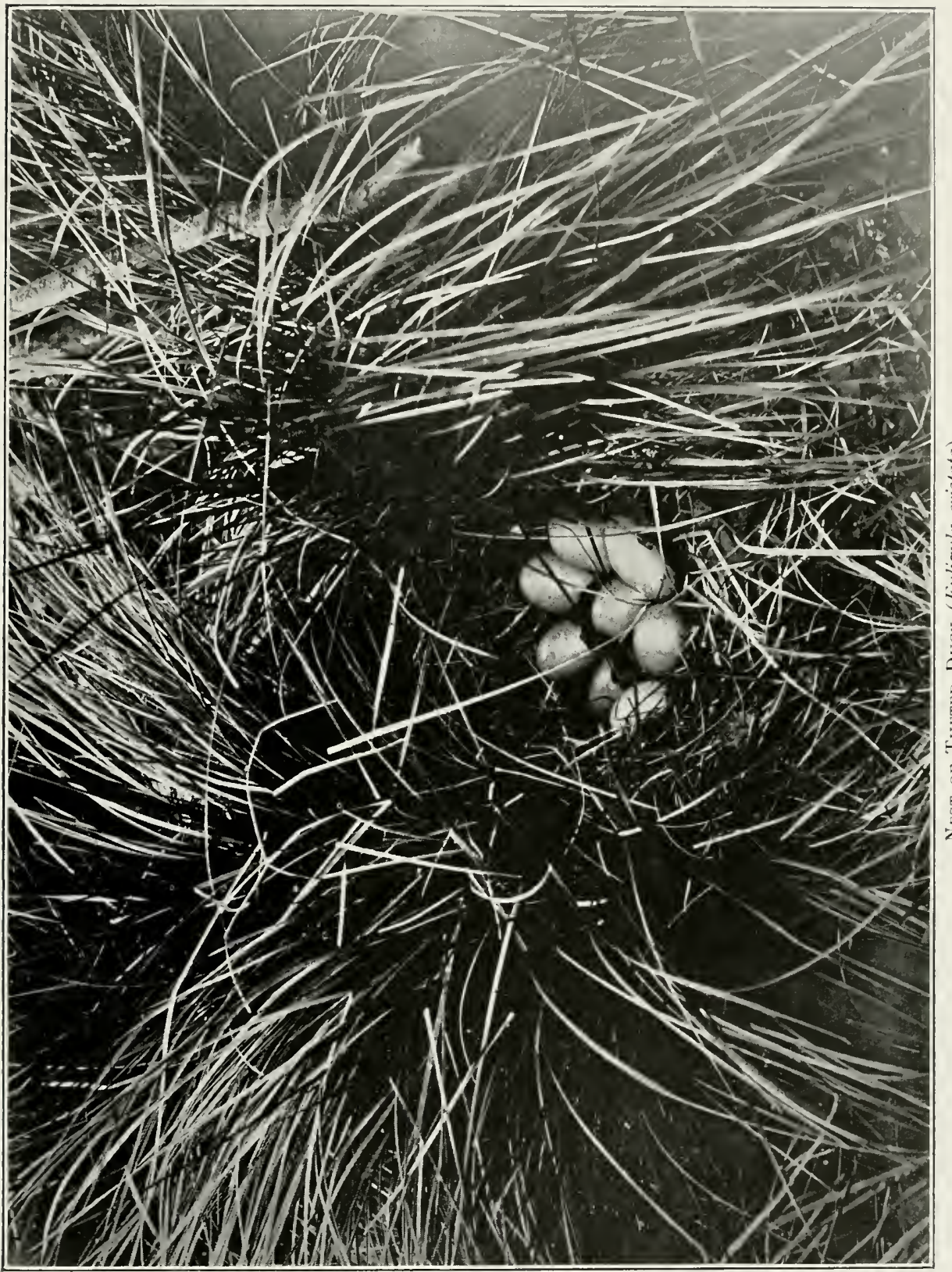


whose luxuriant foliage it was by no means easy to see the slender form, thousands of bloodthirsty midges made our lives a burden to us below. and finally we gare up the attempt.

Passing a large pond surrounded by a perfect jungle of undergrowth and large trees. we were attracted by the wild note of the I)ipper : and on field-glasses being directed to the spot, we could see the white breast of a I)ipper on a stmmp at the farther end. Fxamination of a dannp moss-grown wall by a small waterfall soon revealed the nest. amid a tangle of pendent regetation. From the dampness of the situation, the moss, of which the nest was composed. was quite green and fresh-looking-in fact, it had sprouted, and grass was growing on the top of it. It held young birds nearly fledged. 'The nest, though so large, is very casily passed over mmoticed by an inexperienced eye. It is particularly solid and thickly felted together. the heary penthouse-looking roof overhanging the cup-like receptacle. which holds the eggs. The following day. in lovely Doredale, we were fortumate in finding a late clutch of eggs, pure white and rery pointed, but only four in number, though they were hard sat on -in all probability a second laying. 'This nest was on the rock-face, about eight feet from the surface of the water, which swirled below orer a small weir of moss-grown stones. In close proximity were two old and disused nests, all amid tufts of dandelions and tassels of hanging glass, among which the nests were rery inconspicuous from the farther bank. 


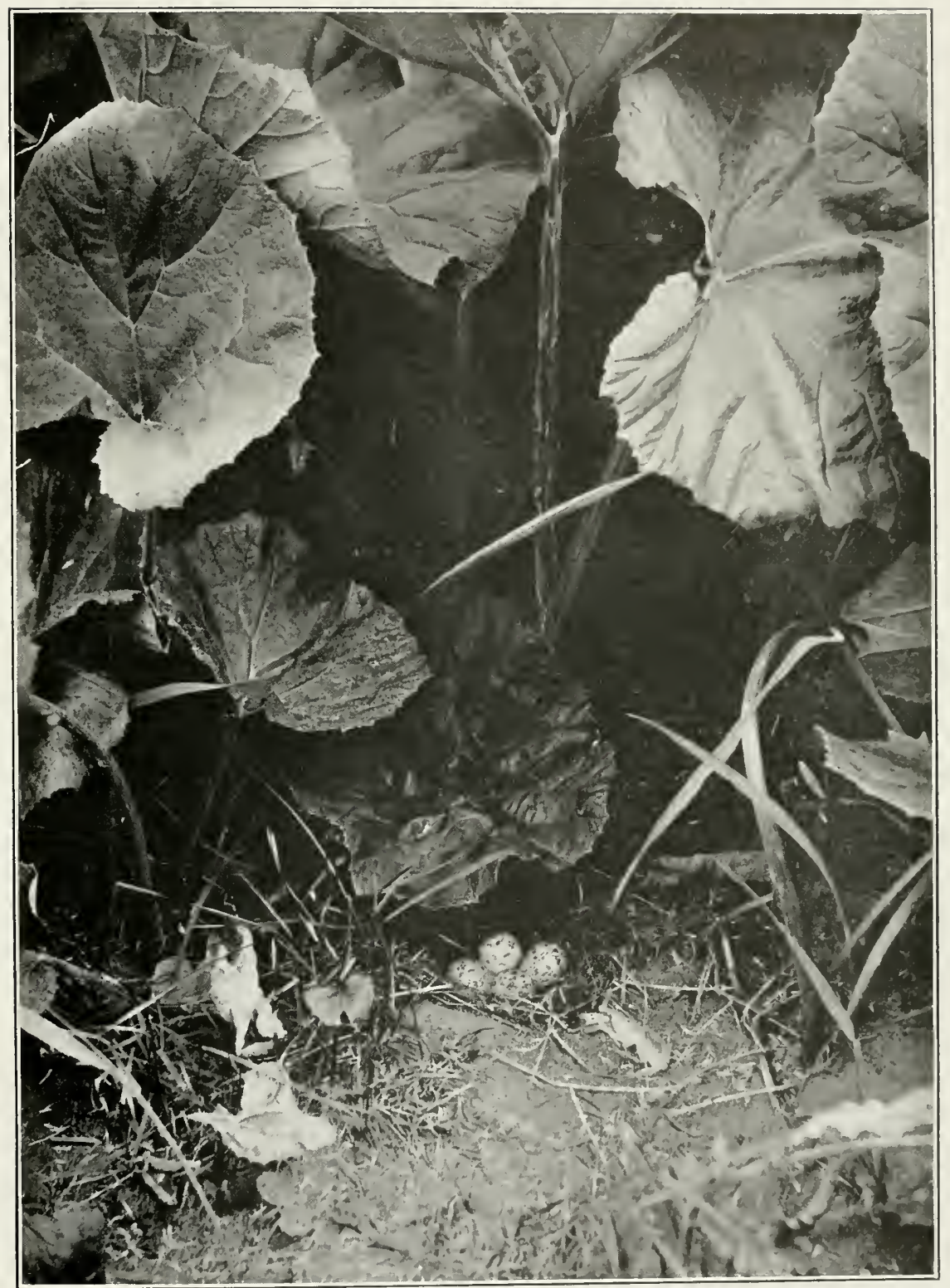

Nest of Comion SANDPIPER (Totanus hypolcucus). 
'The bird here was rely uneasy about our presence: and after Hitting up and down, actually went into the nest while we were watching it, remaining in all the time I

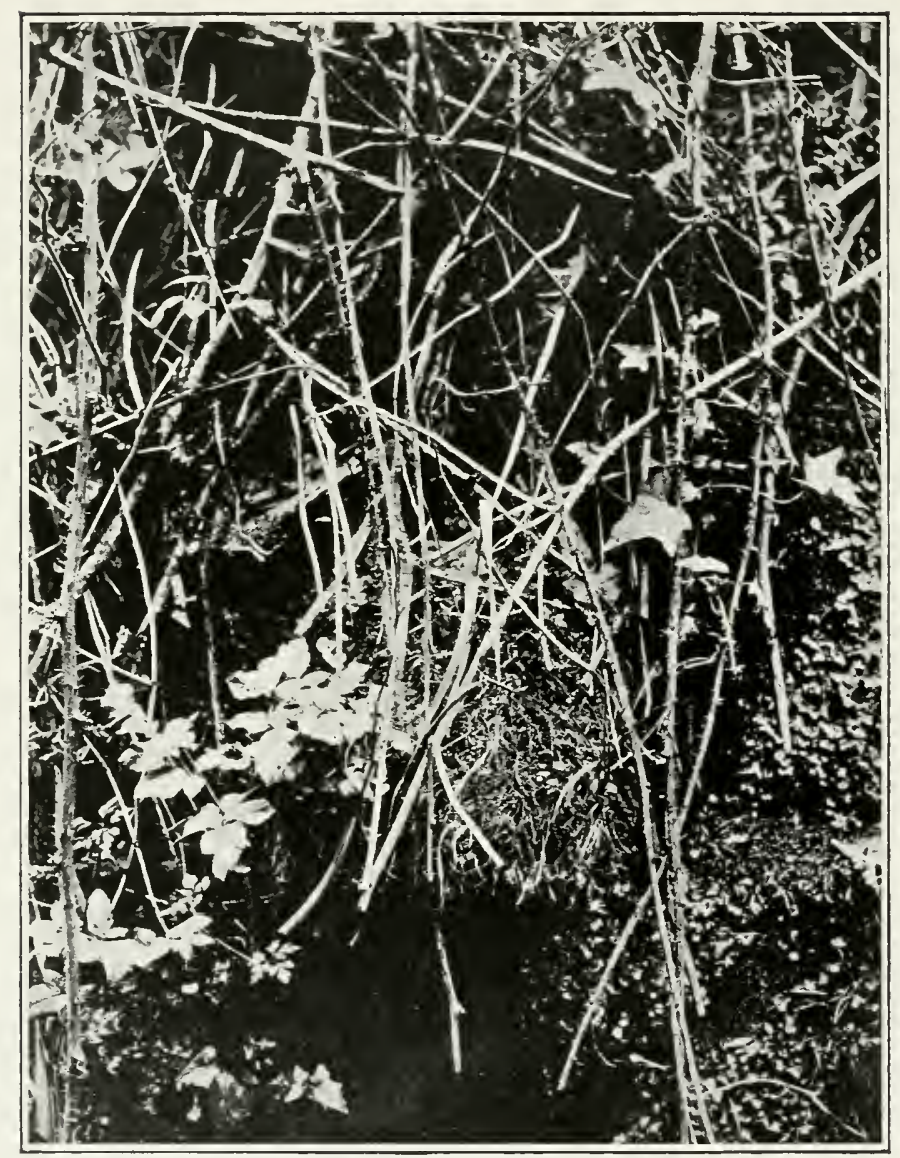

NEST OF DIPPER (Cinclus aquaticus).

was wading the river, and only left it at last while I was getting the camera into position below her. 'The white breast of the bird is a rery conspicuous object among 


\section{A Week in Derbyshire}

the stones and boulders, and is visible from a considerable

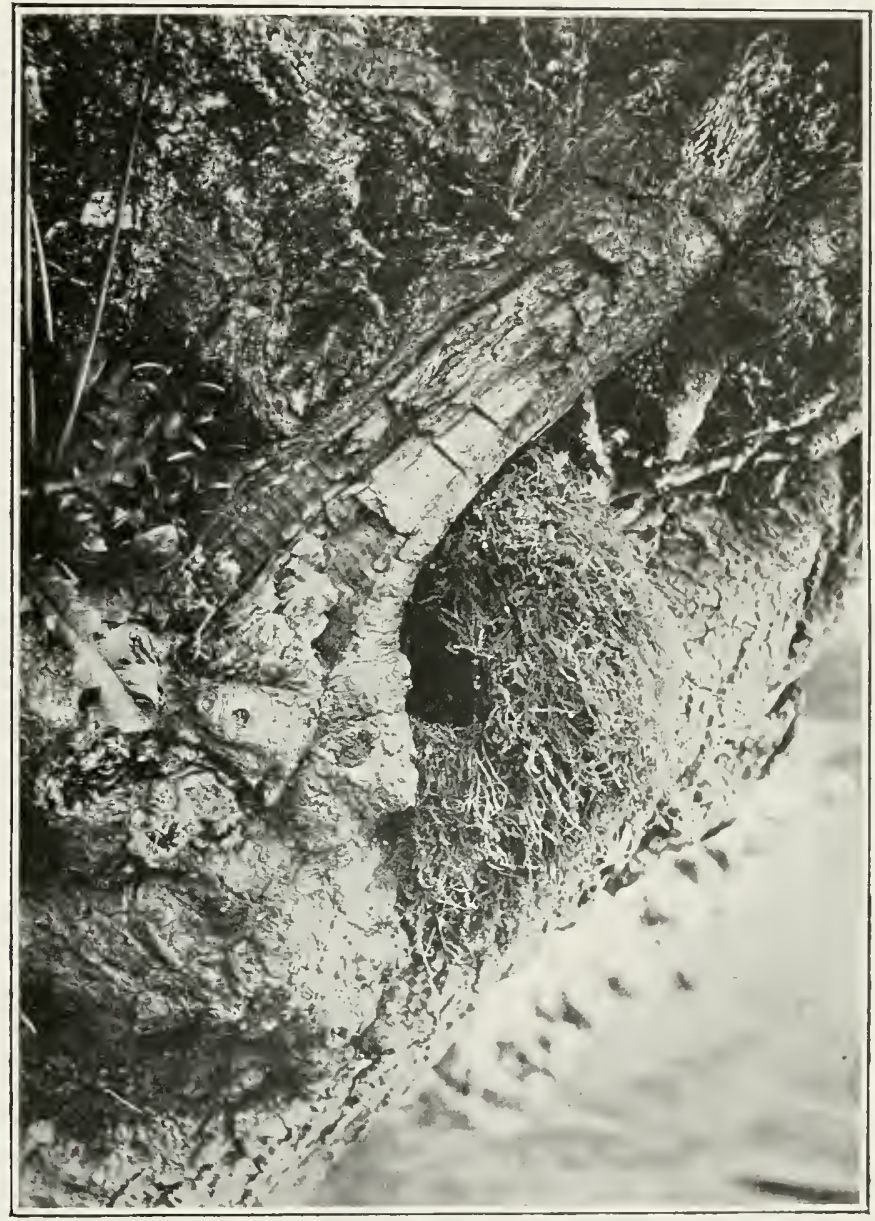

NEST of DIPPER (Cinclus aquaticus) IN A TREE-STUMP.

distance. 'The flight is rery Kingtisher-like, swift and arrowy. with quick beats of the short rounded wings.

Its chosen haunts are certainly the loreliest and most 
picturesque spots to be found in Britain, being restricted as they entirely are to the wild rocky glens and dales of Deronshire. Derbrshire. Wales, Yorkshire, and the North. In such places the Dipper is a resident. living amid the swirl and dash of the rumning stream and the spray of the waterfall, in company with the Sandpiper and the Kingtisher.

Bridges possess a great attraction for the I)ipper, and I was shown one nest among the iron girders which supported a small roadside bridge, close to the village. ()rerhanging banks and amid the roots of trees are also probable sites for their nests.

IThile I was engaged in photographing one nest on an old tree-stump orerhanging a small islet. just below the junction of the Dore and the Manifold, my friend was seated on the bank watching with his Goerz prismatic glass a Sandpiper, which was calling on the farther bank between sixty and a hundred yards away. It says a good deal for the power of this glass that he was able. at such a distance. to watch such a slender form as a crouching Sandpiper areep through the long grass and finally settle on her nest. Walking round to the nearest bridge a quarter of a mile downstream, we ame back up the opposite bank and went right to the nest, from which the bird flew. It contained three young birds and an egg on the point of hatching.

Another bird which haunts these rocky streams is the Grey Wagtail. the most elegant, perhaps, of a particularly elegant family. It may be distinguished from the other 


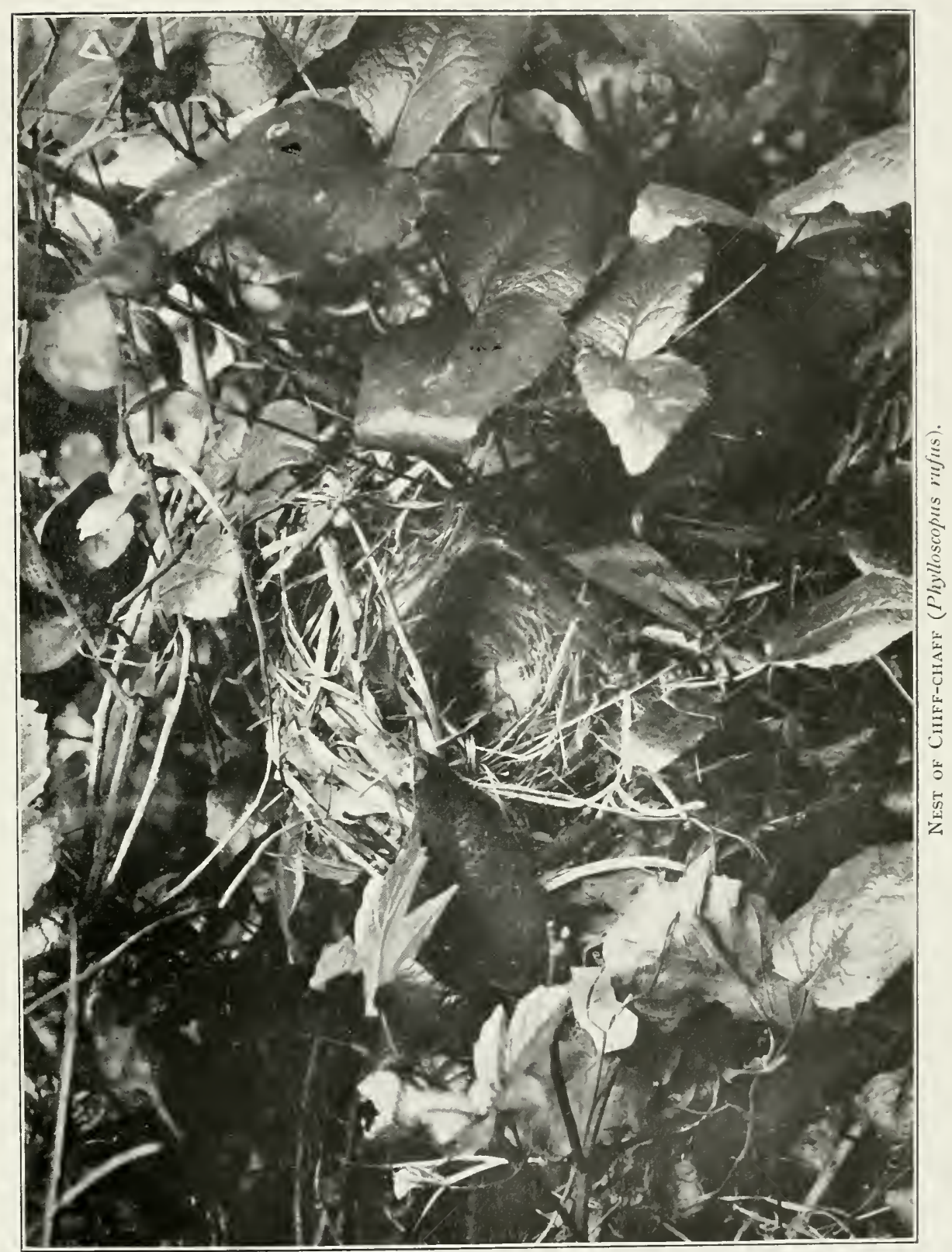


Wagtails by the greater length of its tail. Inder the glass the crey Wagtail is of quite exceptional beauty : but it breeds early, and I did not meet with any nests.

Among the rocky towers and pinnaces which orerhang 1)ovedale. and add so much to its beanty. Kestrels breed in comparative safety. Climbing on hands and knees up a narrow gorge in search of their nest, we heard some young Kestrels chatter loudly, as one of the parents sailed round into view: and though they were evidently. firom the sound. quite close to us, shut in as we were between two rockwalls, it was impossible to locate exactly the position of the nest. We worked our way up to the top. coming down on the other side of the most probable rock. but failed to discover it. In all probability we should have been mable. without a rope. to ascend the extra twenty or thirty feet which separated us from the nest. Jackdaws also chustered round the rocks, some of which resemble spores. while others take the semblance of rumed towers: and over the ralleys may nearly always be seen the sable form of a Carrioncrow.

In the cares at the entrance to Doredale from Milldale. known as the Doveholes, a pair of Dippers have for many years nested in security from any hmman foes: for their chosen retreat is in a chimney-like aperture in the roof of the largest are, quite out of all reach.

My friend's garden. as befits an ardent ornithologist. was well fitted up with bird-boxes. mostly inlabited by Starlings. Great 'lits, and the usual inhabitants of such 


\section{A Week in Derbyshire}

retreats. 'The Starlings and Blackbirds regatrd this garden als their own private estate: and while they tolerate with more or less equanimity the presence of the oceoppice and his family, they resented my appealrance with a cameral in quite ontrageous langmage.

While a Chiff'-chaff"s nest nealr the gromend in one concer was being photographed. the hen bird went in freely to feed her yomg within a yald or two of the "amerat. All the time her husband "chipped" rigoronsly orerhead. but appeared to leare all the work to his wife. Two pairs of Flycatchers built on the house. and another nest was placed on the hinge of an onthouse door. Both were in such awkward positions for the cameral that my attempts were spoilt by insufficient exposme. 


\section{N D E X}

Africa, 17.5, 184, 266\%

, South, 11

Algeciras, 276

Almoraima, $: 76$

Ameriea, 182

Antalucia, $2660,2-202$

Aretir (ircle, 184

Artistic beanty of hirls, $3 t$

Ashiford stame, :37

1.ia, 18:

Auk, Little, 18:2

Antomatic pluotograpliy hy electrieity, $12,24-3.5,244,: 246,248$

Arocet in Denmark, :3:36, 3:38

,, in Norfolk, 207

.. nesting in Demmark, :340, 341

.. ., in Itollant, 260

. .. in marisma, 8:00, 3:202

., oи Gualalquivir, 284, 29!:3

Baits, :31, :32

Barbarity of pole-trap, $1+8$

Bee-eater. $27: 2,278,31.5,316$

Bittern, $207, .2 .24, .256,311$

.. Little, 311

Blackluirl, 4!), (62-24, 1:20, $27(j$

Black("ap), 8.;

Bonanza, :-94

Bramblefinch, 116;

Bray, 176;

Breydon Broat, :07

Broxbourue, 8.7, 100

Bucklanul, Frank, !

Bullfiuch, .5:3, 116, 15!) 13unting, corn- or ('ommon, 116, :334

., Lapland, 181

. Reel-, 118, 119, 2.2.2

.. Siberian Mearlow-, 104

., Yellow, 118

Bustard, Great, 1:2, 207, :268

.. little, $\because 07$

Butcher-bird, :33

Carlett plates, $: 38$

Camera, electrie,

. reflecting, : $: 7$

('ambridge-lise, :-2:)

('astings. Kentrels', 1.50)

$$
\text { ()wls, } 147,14 \text { !) }
$$

(anvey lskunl, :-2.)

Caton-Haigh, Mr., 18:2

('haffiuch, 110, 111, :276

('hapmat1, لllr. Abel, 108, 324, 3227, :341

('hickens as bait for Kestrels, 1.50

('hift-elhatf', 4.), 88, 89), 3699

(')ili, 184

(limbing, 4:2, :204, 286, 352, 368

('limbing-iroms, $4 \cdot 2,: 3.50$

(uot at (iibraltar,

.. in Derbyhire, 3.5

, in Enfireld, 16:3

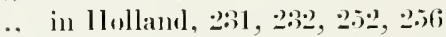

, in Lineolushire, 2.24

., in Norfolk, 2.2.2

.. in șiain, $80 \%$

C'oncealing couneres, :2!)

Conlemuation of killing. 9

Cortleaux, $\mathrm{Mr}$.. 86, 106, 148, 182 
Cormorant, $197,: 20: 3,: 04$

Corncrake, 1(i;)

Copenhagen, :3 48

Crane, 12, 268

Creeper, 'Trese-, 108

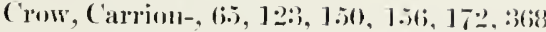

, Ilouled or cirey, in Enfield, let

., ., ,, nesting in Jutlaud, sist

,. $\quad$,. ., on the Wrish, 178, 17 !)

,, , , , photographing, :31

('urkoo, :92, 6.5, 91, 14:-145)

, Ameriean, 14t

,, (ireat spottel, 142, :30:;

, in spain, 278

,. migrating, 107

., nests faroured ly, $14 t$

, yoming, 1tt, 14.)

", powerful notre of, ]3:2

(imlew, 171, 17.), 179, :?::)

,. Exkimo, 18:;

Dilhelick, 17:3

Dallmeyer, $M r ., 17,86$

Damaralaud, 184

Daumbe, 1.5, :30\%

Demmark, :2:25, :3:31

.. horl life in fjorl, 331 :346;

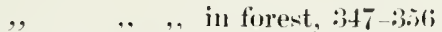

Derbyshire, a week in, :3.57-36:9

Destruction of Larks' nests by ('rows and Jackilaws, $1: 8$

levonshire, 80

1)ipper, :36i2:36i;, :368

Disguise, :2(), 2!)

Dixom, Mr., 10:3

Ditek, Eider-, :201, 2(1):

., Tufted, in Norfolk, 2-20

,, ,, nesting in Derhyshire, :35, 3.58

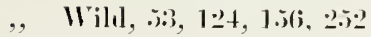

Ducks, 51

Dumlin in Demmark, :3:36, :3:38
Dunlin in Eutield,

.. in Limolushire, 175, 17(i, 17!

". in Spain, 282.2,284

Dutrh marshes, bird life in, 2-24-21it

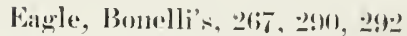

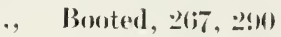

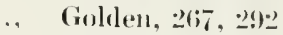

.. lmperial, :2(i⿰, 206$)$

.. Teit, :3.:-

". Slort-tom or Suake- 2(iT, $27 !)$

Wagles, 1i), 204, :296;

Natr of (1wl, 218

Eugr-shells as bait for ofackilatrs, :31

Eigyet, Little, $298,: 307,: 310,: 31: 3,: 114$

Eider, 201

klectrie photography, :24-3i.;

Eutield, 4!), 1:-7

, sewage-farm, $.71,170$

Epping Forest, 50, 8!

Esbjerg, :3:3:-

Europe, south, 175

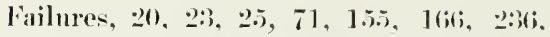
$2: 38,2+1,-246,-2.50,806$

Faleon, Perengrine, $178,: 267,: 326$

Fame lslands, sea-birds of, 186 -20.)

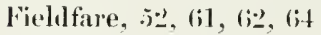

Firecrest, 181

lilamboromgh, 104

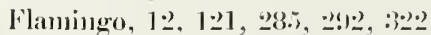

Flycatcher, spotted, :3:3, 70, 100, :3(6:)

$$
\begin{gathered}
. . \quad \text { photographing nest } \\
\text { of. } 70
\end{gathered}
$$

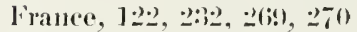

Friskney, 17+17

(iadwall, :-2.)

(iamuet, 187

Gargeney, 208

Gatke, Herr, 104, 107

Geese, Brent, :3:37, :34ti

, Wild, 17?

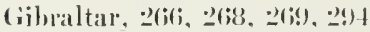


(Blass, field-. :38, 40. 366t;

Gorwit, Bar-tailed, :-81

.. Black-tailed, in Ilolland, :21i1

. $\quad$., in Norfolk, 207

.. $\quad$.. nesting in Denmark. $3+4$

(iodwits, 17.5, 176, 179. 2.57, 28.5

fioerz, glass, t0, $36 ; 6$

(ioldlerest, 85), 36, 88, 181

(iolltiuch, 111, 11:2, 15!)

Gosllawk, :35)

(irebe, Eared, 257

.. Great ('resterl, 17:3, :2:0, 2:3:2

.. Little. 17:?, :311

(ireenfinch, 10:), 110)

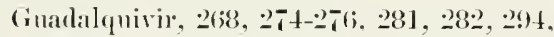
$: 3: 0$

Ginillemot. 187, 188-191, 1!

(inll, Black-hearled, 17:2, 17!), 2032, 20.5. $3: 37,840$

.. C'ommon, 179), 3:37, 344

.. Herring-, $197,1518,3: 37$

.. Les-er 13lack-hacked, 197. 1!18, 20.5. :3:37

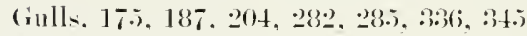

(iun camera, 17. 68

(iumey, Mr., 18:2, ำ18

(iyrfiticon, :3.54

Hagne, The, :-5!

Ilammer. Yellow- 118

Iland eamera, nselessness of, 12, 14

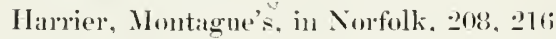

Harriers, $: 167,: 326$ in spain, :29:3

.. Ile11-, 207,2016

.. Mark-, in Holland, $2+8,200$

.. $\quad . \quad$ in Norfolk, 208,216

.. ., in spain, $280,29: 3$

Harvie-Bown. Mr. 14 nest in Hollaurl, :-51

IIawfinch. 111

Ilawk, sparrow-, 1.5:)

Heligoland, 104, $10 \overline{-}$
Heron, 5.2. 1.5t, 1.5, 241,240

.. Butt-backed, :298, :307. 310

.. Night-, :307, :310

.. Purple, in Holland, :-20. :-241, ㄴ4, $\therefore 46$

.. $\quad$.. in spain. 2998, 306, :31:3

.. $\quad$.. photographing ly electricity, : -48

.. $\quad$.. yommg. $-4: 3$

.. Siflaceo, $: 307,: 310$

IHirmidines, 100

Hobly, :3:6;

Hollanil, 2.2.5

Horve, spanish. :3!n

Hoopoe, 30:3

IIungary, 1.)

Ibis, Glos-y. $29.98,807$

Imperial plates, :3

Irby, colonel. :3:-

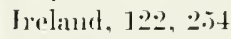

Isla Mayor, 292

.. Menor, ::2:4

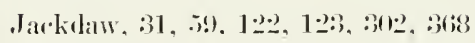

Jay, 1리, 1르르

Jutlimel, :3:3:3

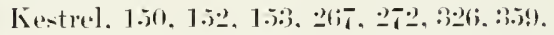
3638

,. at (iibriltar, $2-7$

.. release of 1.53

Kingfi-her, 11!9, 1:3! 1 1.2

.. in spaill, 280

Kingsley, (harles, 2.24

Kite, Black, :283, :900

.. Common, climbing to nest of. -asti. $-288$

.. $\quad$.. in Demmark, :3+8

.. $\quad . . \quad$ in Lincoluthire, .2.2.5

. $\quad . \quad$ in spain, $26 \overline{7}, 28 \cdot 2,204$,

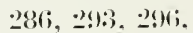

$3:-7$

.. $\quad$.. $\quad$.. .. $\quad$ nest of. $288, .29$ (1)

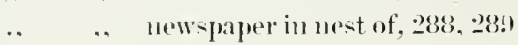


Kite in Walew, ::48

Littiwalee, 1!1-1!)4

Kinowledge. 104

Kinca, 104

Lammerneyer, 1른

Lipliand, 15, 108, 18:2. 20 (i)

Lalpwing, 나, 28, :31, 167, 168, 1699, 170, 20.2., $2966,3+7$

Lark, (rested, :3:34, :3:3.5

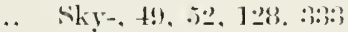

Lens, tele-photo, 17, :36;

Lilford. Lord, 14, :9-5

Limicolie, 18:-

Lincolnshire, 80, 104 .. mullflat, 17t-18.5

Li:borl, $28: 2,: 327$

London, 1.7\%, 170, 17:3

Madrid, $: 200$

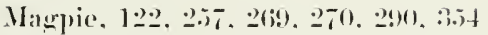

Maliaga, ent

Mallatrol, $2-5 ;$

Manchuria, 104

Martin, Ifomor-, (it, 10:-2, 10:3, 115, 足-

Siand-, 160. 2!):

Martins and sparroms, 11 ;

Meal-worms as bait for Nightingales and Robins, :i:-

Migration, 41-46i, $10: 3$

Mongolia. 104

Mule, spanish pack-, 2!!4, 2!!!

Nightingale, 1!), :30, 5:3, it, 74-81, . 276

Nightingales and Meal-worms, ::0

Nightjar, .54, .5!, 8!9, 1:00-1:3:3, 1.5!)

Nighlitjas, young, 1:?!

Norfolk, 17t, 130, 182, , 206, 2.2.5

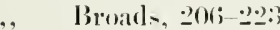

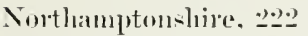

Northumberland, 186;

Nudd. Joshua, :216

Number of birds-seen in Enfield, t3

Nutcracker, 3.54

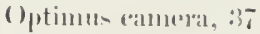

$$
\text { , limen, :36; }
$$

()riole, fiolden, 25:1, :21;1)

()-prey, $,-76,3.5) \cdot$

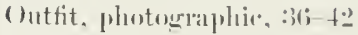

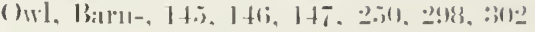

, .. in 1lollanr, :-5!)

, ., in spati1, $2098,: 3(1) 2$

., ("astings. 1+7. 14!), 2.)!

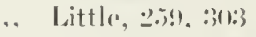

.. I I

.. Si(co) 1 r-, $20 ! 9 !$

,. Short-rined. 14!9, 17!!, 1831, 1831, -2118

, $\quad$..

,. $\quad$., 110-t, 017

., Tawny, 147, 148, 1.;2. .2.5!

., .. in Ilollatul, :-5!

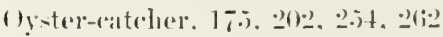

Partridge, (6.). 1601, 16i1, :-71

,, Red-lexgerd, (6.), 158, .07

Paitilgmial. 184

Petrele ti

l'igeon, Wood-, .4. 1.56, 1.58, 1.59) 17:3

Pheasint, 16:-

l'hotugralphic outfit, :is to

Plontongaphing at (iiblaltar, $2-74$

Blacke'alp, 85

.. Blue lit, !):?

.

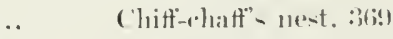

.. Com1111011 Tern and limlAlank, :.5t

('ormoraluts. 204

( )

bitbehick. 17:3

Dipper'- ner-t, :36if

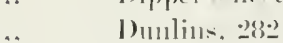

^.

.. $\quad . \quad$ in mari-nlat-. 286 i

.. Virler. 201

.. Flanninerers, :30.2

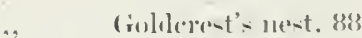

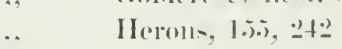


Photographing Kestrel's nest, :860

Kingfisher, $1+1$.

$$
\begin{array}{ll}
. . & \text { Kingfisher, } 14 \\
, . & \text { Lapwiıg, } 170
\end{array}
$$

.. Lome-tailed 'T'it's nest, 9.j

.. Marsh-harrier, …j

.. nest of Montague's llarrier. 216

.. of Short-eared owl,

$$
217
$$

.. nests and birkls, 4 !

.. Nightingales, 78

.. Nightjar, 1::1

.. Pheasint, $16: 2$

.. Pintail's nest, $3+2$

.. P'urple Herons, :-41, -246. 248

.. Ringed Ploser, 171

,. Robius, 7:, 74

.. Sandpiper's nest, :35!

.. Sanelwich Terr's nest, 200

.. Sinipe, $17: 2$

., Southern Mlerons, :808

,, Tpoonbills, 2:38, 244, 30.;

., ., il marismas, 304

.. Stilt's nest, :318

., Swallow, 10.2

.. Turtle-dove, 1600

.. nu a ladder, 7

.. $\quad$ up a tree, 70

.. Vulture, :32-4

., Water-hen, 160 ;

,. Whinehats with gum eamera, 68

.. Whitethroits, 82

.. Wood-pigeon, 1.28

,. . Yellow Wigtail, !S

,. $\quad$ youmg spombills, $2: 36$

Photography, antomatie, hy electricity, $24: 3.5$

,. for naturalists, $9-23$

Pinmates, 187

l'intail, :3:37, 341, 34:2

Pipit, Meaclow-, (6.), $98, .2 .23$

$\therefore$ Rock-, 20.5 .
Pipit, Trees-, (s!)

Plates, dry. 38

Plover, Grey, 15, :9:3

.. (i)lilen, .j.) 110

.. lieutish, :3:30;

.. Kill-rleer, 18:3

, Lesser Golden. 18:3

, Riugerl, 170, 171, 201), 2884, :3:36, 34.7

, Stone-or Norfolk, :311

Pochard, :2:-2.

Pole-trap, 1+8, 1+!)

Pratincole, 20!:3, :296, :316;

P'ıffin, 187, 194 196;

lyrentes, :269), :-71

(2nant, 212

Rabbit as bait for Hoonled ('rows, :1

Raven in Demmark, 347. 3.5t

,. in Estifielı, $1: 27$

., in Sipain, :31:3

Redbreast and meal-worm, :3:

.. Robin, :32, (it, 7ㄹ, 7:3, 76, 1.i9

Rerlpole, Lesser, 116

Redshank, Denmark, :3:36, :3:38, :3+1

.. Eutielı, 171

,. Ilolland, 2.54, .0(i)

.. Lineolnslire. 17.;

,. Norfolk, :2:2.2

,. Tpain, $284,289,2993,296,317$

Redstart, 7

Redwing, 5:2, 61

Richmond l'ark, 1.jt, 173, :-20

Roller, :30:2, :30:3

Rook, 76, 1:24 1:27, 179

Rudolph, Prinee, 14, : $: 2-7$

Rutf, Reeve, $26: 2,: 340,: 344$

St. James's P'ark, 17:3

Sin Lucar de Barrameda, :81

Simd-grouse, Pallas's, 181

Simdpiper, Bartram's, 18:)

, Bonaparte's, 18:3 
Samdpiper, Buff-hreasted, 18:3

, ('m)

.. (ireen, 171,2800

.. Pertoril, 183

., Solitary, 18:3

, Sipotterl, 18:3

Silumlers, IIowaml, 86, 104, 1:3.2, 184, 2!00. $3: 27$

Seaulinavia, 174, 18:9, 2018

Sicoter, $3: 37$

Sirotland, 181

Sea-binds at the Fame Islands, 186-00.)

Searrhing for nests, Beimoled 'Tits', :21:

Seebolm, Mr., 14. 1\%, 10\%, :307, :317. 3:31

Seville, $28: 2,09 ! 2,29: 3$

Sewage-firm, 170

Shellilake, Ruldy, 181

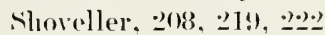

Shrikr, (ireat Grey, 18:

.. Rerl-barked, !9, 100

.. Wordehat, 278

Siberia, 14, 104, 174, 18:

snipe, 51, 171, 17:?

.. Rerl-lineasted, 18:3

sonthwell, Mr., 18:

spain, 1.5, 108, 1:2-1:88, 2365

spanis-lo marismas, 184

$$
\text { .. } \quad . . \quad \text { lird life in, } 296.5-33: 30
$$

Sparrow, Herlge-, 6.5, 91, 10.5

.. IJume-, 11:2, 11:3, 114, 11.)

. Tree-, 116

Siparrow-lawk, 1.5:3

spombill, 2.;

.. feedinar yomme, 246

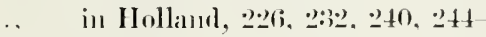
246

., in Norfolk, $207, .208$

.. nesting in spain, :304 :306;

.. photographing ly electricity in

Itolland. :-44

Staple Islamrl, 188

Starling, 10耳, 11!) 1:1, 299.2, 3334, :368

. Sardinian, 299

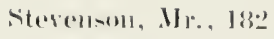

Stilt, $: 4 ! 6,: 317-319$

.. measmerments, :31!!

Stint, Ameririn, 18:3

,, little, 1.5, 17!)

Strock-rlove, 1600

Stomerlat, (i.;

Stork, Black, :348:3.il

.. Whitr, in Denutar, :3333

.. $\quad$.. in forest, :113

., ., in lislmu, :3:2-

.. .. in unarisma, 2!98

.. $\quad$., in seville, 2 (!):3

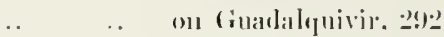

.. , in Holland, $257,0.58$

Suburban parish, hird life in, 4:3-17:3

Swallow, (it, $76,10 \cdot 0,108, .031, .070$

Nwan, Wild, :\$4t;

sweden, 1:20

sivift, 1:0

Tagus, 3:307

Tangiers, $: ? ! 4$

Teal, . $11,15(1,2.2 .2-2$

Tele-photo lons, 17. :36, :37

Temuyson, 76

Tem, Amtic, at Farne 1slands, 1!18, 1!:!, 200

..$\quad$.. in Denmark, 337, 34.5

.. Black, in Nolfolk, 2007

.. ., in Ilullind, $2.31,-2.52,-2.54$

.. . in spain, $294(;,: 31 !)$

.. .. young, ,.5.5

.. (aspiall, 9:00)

.. (ommom, at Farnes, 1!)

., .. in Holland, …5i). …4

., Gull-billerl, :3:0

.. Lescer, 198, 룽.?. 387.

. Roseate, 1!38

.. Samdwirl, at Farnes, 1!93, 199, 200

. $\quad$.. in Denmalk, 337,340

., Whiskelet, :2!:?, :2!46, :31!)

Terns, 187, :20:3, :28.; , 3336. 338, :34.; 
'Texel, -2.5.t

Thruslt, Misel-. it in;

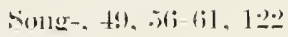

'Thuringra Walel, 1:6;

Tit, Bhe. (1). !):?

.. .. in 5pain, 280

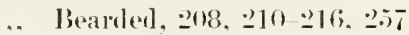

.. (val-. 9):

. Cresterl. 280

.. (ireat. !). (13, 3648

.. Long-tailed, (2), (1:3, !)-4. 9.)

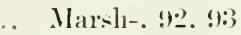

'litmice, !), .70

Turkestan, 104

'Turtle-rlove, $28,5: 3,159,160$

Inamula, 11

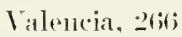

Vole plagne, 180, 181

Voles and Rowks. 1:26, 1:3

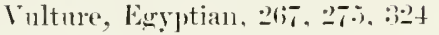

$$
\text { (irifforl, :3:4 }
$$

Vultures, 1.5, 贯(i.), :3:-4

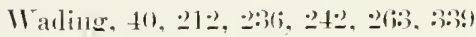

Wagtail. Blue-hearled, :3:38

(irey. :366;

Pietl. 916. (48)

Yellow, !18, :-2:!

Wrating at ne-ts. -1

Wille.s. 348

Winistearl Park, 1.it

Warbler. Larden1-, 8.;

(Grashopuer-. $90, .210 .25$
11 arbler, (ireat Reed-, :2:31, :095, :311

.. leterile. 200

.. Rardile's Bush- 104

.,$\quad$ Reerl-, $90 ., 212.02 .20,311$

.. Savi's. 20

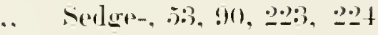

Warwich plates, 38

II: 1 , 17:;

Witter-heu, :3:3, .33. 104, 15is. 16it. 16is.

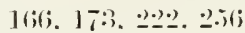

Water-rail. :2:-1

Whestear, De-ert-. 101

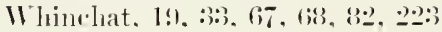

Whitethroat, (ireater, 19. 81, 82

Lessere, 84, 8.5

Wilom, Mr. W., 1:2;

Wiuchmore llill, l6;3

IVolley. 1.;

Morularek, 17!)

Wromlpertier, (ireen, 1:34-1:38

$$
\begin{aligned}
& \text {.. } \quad \text {. } \quad \text { tomerue of. } 13 ; \text {; } \\
& \text {.. Les-er siputterl. 1:33 } \\
& \text {.. Spation (ireen. 31). }
\end{aligned}
$$

Woolpeckers, !). 1:36, 1:38

IV ren. (96. 1.5!)

. Willow-. 8:- 8:1

.. Wimel-. 89), :360

Wryteck. 1:3:3. :?:):?

Tellowshank, $18: 3$

Yorkitile, 80

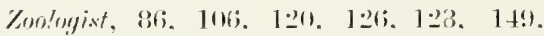
176. .20(;. 283

Zuyilere Zees, 2601 




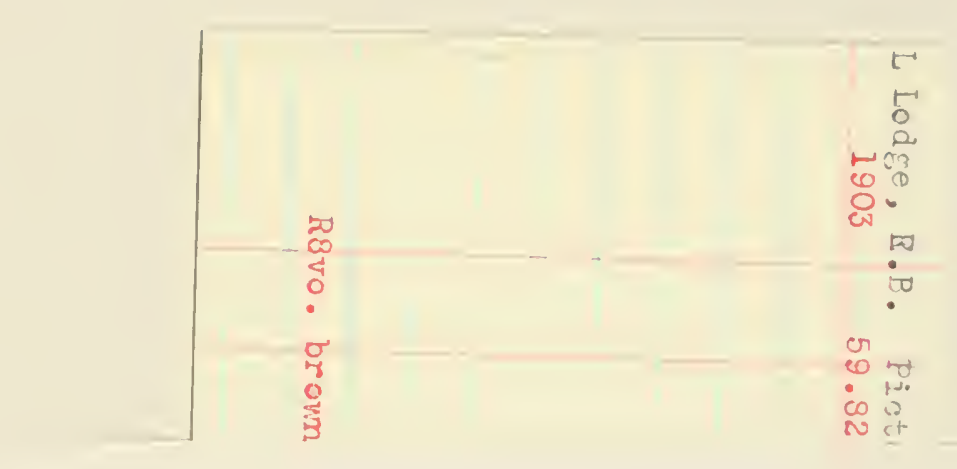


